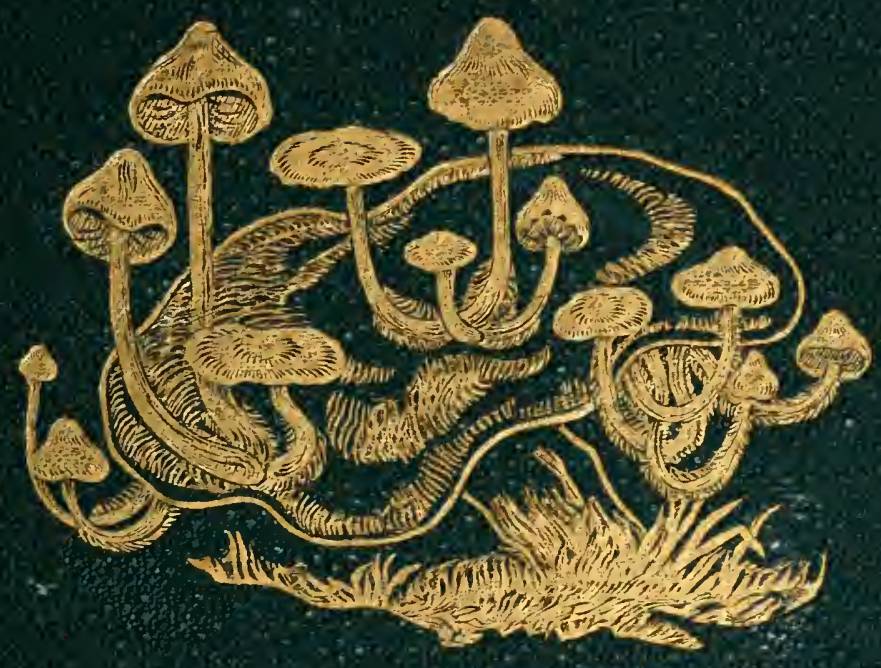




\section{MARINE BIOLOGICAL LABORATORY.}

Received Sumc / 96.35 Accession No. $226 \%$

Given by

Place,

** No book or pamphlet is to be removed from the Laboratory without the permission of the Trustees. 


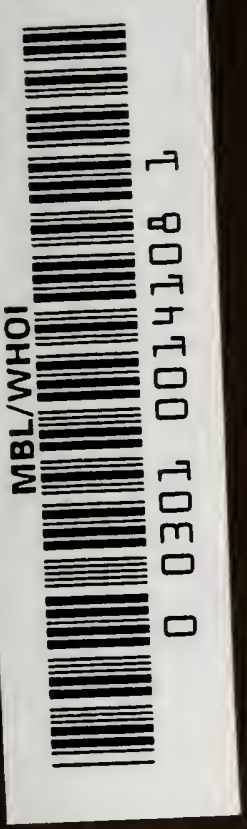




"Pleniorem dabit lucem futura ætas." 


\title{
Fumenomucetes diritamníci
}

\section{B R I T I S H F U N G I (HYMENOMYCETES)}

\author{
BY \\ REV. JOHN STEVENSON \\ AUTHOR OF 'MYCOLOGIA SCOTICA' \\ HON. SEC. CRYPTOGAMIC SOCIETY OF SCOTLAND
}

WITH ILLUSTRATIONS

IN TWO VOLUMES

VOL. II. CORTINARIUS-DACRYMYCES

WILLIAM BLACKWOOD AND SONS EDINBURGH AND LONDON

MDCCCLXXXVI 


$$
2392
$$




\section{HYMENOMYCETES.}

\section{ORDER I.-AGARICINI.}

Genus V.-Cortinarius (cortina, a veil). Fr. Epicr. p. 255.

Veil arachnoid, distinct from the cuticle of the pileus, superficial. Hymenophore continuous with the stem. Gills persistent, arid, changing colour, pulverulent with the spores which fall off slowly. Trama fibrillose. Spores globose or oblong, here and there apiculate, somewhat ochraceous on white paper. Growing on the ground in woods, putrefying. Fr. Hym. Eur. p. 335 .

The most natural of the genera of Agaricini, but not easily defined by artificial characters. The veil and the gills present the chief marks of distinction. The gills generally become cinnamon-coloured. Very rare or, altogether wanting in hot countries, but generally abundant in northern woods. All autumnal. They present a very different appearance in clifferent stages of growth, and in the various stages according as they are moist or dry. It is necessary, therefore, to examine species both in their earlier and later stages. Some Flammulae resemble them, but can scarcely be confounded with them.

Tribe I. PHLEGMACIUM ( $\phi \lambda \epsilon ́ \gamma \mu \alpha$, clammy moisture). Par- Phlegmatial veil arachnoid. Pileus equally fleshy, viscous. Stem firm, cium. dry. Fr. Hym. Eur. p. 336.

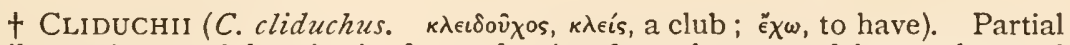
veil superior, pendulous in the form of a ring from the apex of the nearly equal or clavate stem.

* Gills pallid then clay-colour.

VOL. II. 
Phlegma- $\quad$ ** Gills violaceous or purplish then cinnamon.

cium.

*** Gills yellow, cinnamon, ferruginous (not at first whitish or violaceous).

**** Gills olivaceous.

\# Scauri (C. scaurus, club-footed). Bulb depressed or turbinate, marginate. Stem fleshy, fibrous, cortina commonly inferior, arising from the

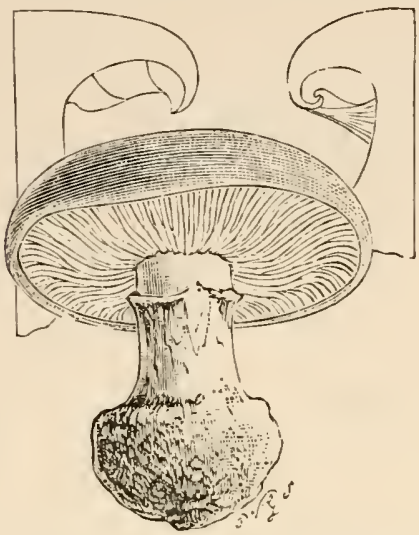

$X L$. Cortinarius (Phlesmacium) fulgens. One-third nat ural size. margin of the bulb. Pileus equally fleshy. Gills somewhat sinuate.

The margin of the bulb is a kind of circularly split volva. In many instances it has been observed conjoined with the covering of the pileus, in others free and volvaceous. Hence the stem is never sheathed with the universal veil, nor at the first, as in the next group, extended, and scarcely ever farinaceous or clothed at the apex, but like group ** of Amanitæ at first enclosed within the pileus and bulb, which are applied to each other like two small balls. The impression on the bulb around the stem arises from the margin of the pileus pressing upon it at first. There are a few species which are intermediate between Scauri and Cliduchii, the pileus at first embracing the stem to the very base, whence the bulb is nearly wanting, but the base itself is marginate.

* Gills whitish, then clay-coloured or pale cinnamon.

** Gills violaceous, dark blue, purplish, at length cinnamon.

*** Gills ferruginous, tawny or yellow.

**** Gills olivaceous.

t十† Elastici. Cortina simple, thin, fugacious, medial or inferior. Stem at the first extended, somewhat thin, never marginato-bulbous or sheathed, but rigid-elastic, externally somewhat cartilaginous, polished, shining, naked at the apex, at length most frequently hollow. Pileus thin, often hygrophanous.

* Gills whitish, then clay-coloured or dirty-cinnamon.

** Gills violaccous, purplish, flesh-coloured.

*** Gills pure ochre, tazuny, or ferruginous.

**** Gills olivaceous, fuliginous.

\section{+ Cliduchir.}

\section{* Gills pallid then clay-coloured.}

1. C. triumphans Fr.-Pileus $7.5-12.5$ cent. ( $3-5$ in.) broad, yellow with a tinge of brown or ochraceous when moist, yellow when dry, variegated at the disc with minute adpressed spot-like scales or wholly naked, fleshy, not very thick, convexo-plane, obtuse, regular, margin even, not bent inwards; flesh alike of pileus and stem compact, white. Stem 7.5-12.5 cent. (3-5 in.) long, 12 $\mathrm{mm}$. ( $1 / 2 \mathrm{in}$.) and more thick, solid, firm, attenuated from the ovato-bulbous base, striate, yellowish-white, adorned with tawny scales arranged in many circles (or rings); the partial cortina superior, woven, somewhat ringed. Gills emarginate, crowded, 
$6 \mathrm{~mm}$. (3 lin.) broad, with a small decurrent tooth which ends Phlegma. determinately in a continuous mealy white zone, densely reined cium. at the sides, plane, whitish or inclining to very pale bluish grey, at length clay-colour and somewhat cinnamon.

Large, splendid, from its zones of scales recalling A. Vittadinii. The scales readily fall off. A smaller form occurs in dry birch woods.

In grassy ground. Rare. Sept.

Spores ellipsoid or oblong-ellipsoid, I2-16 $65^{-6} \mathrm{mk} . K$. ; pruniform, punctate, I2-I3 nik. $Q$. Name-from the stem resembling a triumphal column. Fr. Monogr. ii. p. 4. Hym. Eur. p. 336 . Icon. t. I4I.f. I. B. \& Br. $n$. I263. S. lyycol. Scot. n. +45. A. sublanatus Huss. ii. t. 22.

2. C. claricolor Fr.-Pileus 7.5-10 cent. (3-4 in.) and more broad, yellow, unchangeable, wholly fleshy, convexo-flattened, and at length depressed, at the first everywhere, soon only round the margin veiled with superficial, silky-pruinose, villous down, then wholly smooth, even, for the most part however broken into scales. Stem solid, hard, white, wholly clothed as far as the superior cortina (above which it is white-mealy) with white scaly flocci or lax down, but when full grown the cortina and scales alike disappear, otherwise sometimes curt, bulbous, sometimes elongated and conico-attenuated or cylindrical ; flesh of the pileus and stem white. Gills sometimes emarginate, almost free, sometimes adnate, crowded, at the first whitish then clay-colour, the edge unequal.

Very changeable in form, but always very robust and compact. Intermediate between $C$. triumphans and $C$. turmalis. In a var. the gills are at first slightly bluish-grey.

In mixed woods. Glamis, \&c. Sept.-Nov.

Spores pruniform, nucleate, II-I $2 \times 6-8 \mathrm{mk}$. C.B.P. ; I $2 \times 6 \mathrm{mk}$. W.P. Name-clarus, clear; color, colour. Of pure colour. Fr. Monogr. ii. p. 5 . Hym. Eur. p. 336 . Icon. t. I4I. f. 2. B. \& Br. n. I54I. S. Mycol. Scot. $n$. 446. Quel. Grev. t. I02. f. I.

3. C. turmalis Fr.-Pileus yellow-tan, most frequently darker at the disc, not changeable, compact, convex then plane, very obtuse, even, smooth (sometimes obsoletely piloso-virgate), when young veiled with pruinate but very fugacious villous down, soon naked, viscid; flesh white. Stem sometimes 7.5 cent. (3 in.), sometimes $\mathrm{I} 5$ cent. ( 6 in.) long, 2.5 cent. ( $\mathrm{I}$ in.), thick, solid, very hard, rigid, cylindrical, here and there attenuated at the base, shining white whendry, when young sheathed with a white woolly veil, naked when full grown. Cortina entirely fibrillose, superior and persistent in the form of a ring, at length ferruginous with 
Phlegma- the spores. Gills variously adnexed, rounded or emarginate, even cium. decurrent with a tooth, crowded, serrated, white then clay-colour.

Densely crowded in large heaps. Dependent on the weather. The flesh is not so hard and compact as that of C. claricolor, wherefore the pileus is never broken into scales. The gills never turn bluish-grey. The mealy and floccose covering is a universal veil; in C. triumphans it is concentrically tawnyscaly, in C. claricolor, white-woolly-scaly, in C. turmalis, white-woolly, soon naked.

In mixed woods. Glamis, \&c. Sept.-Oct.

Spores $8-9 \times 5$ mk. K.; $8 \times 5$ mk. W.P. Name-turma, a troop. From its habit of growth. Fr. Monogr. ii. p. 5. Hym. Eur. p. 336. B. \& Br. n. I774. S. Mycol. Scot. n. 447 .

4. C. sebaceus Fr.-Pileus $6-12.5$ cent. $\left(2 \frac{1}{2}-5\right.$ in.) broad, unicolorous, pale, of the colour of tallow, equally fleshy, convex then rather plane, commonly very repand, viscid, smooth, but at the first covered over with a whitish pruinose lustre; flesh white. Stem 7.5-10 cent. (3-4 in.) long, 12 mm.-2.5 cent. ( $1 / 2-1$ in.) thick, solid, stout, compact, never bulbous, often twisted and compressed, slightly fibrillose, pale white. Cortina delicate, fugacious, adhering only to the margin of the pileus. Gills emarginate, not crowded, connected by veins, $8 \mathrm{~mm}$. (4 lin.) broad, clay-colour or pallid cinnamon, paler at the sides.

The flesh of the pileus is not compact at the disc and abruptly thin at the circumference, but equally attenuated towards the margin. The flesh of the stem is white. The gills never turn bluish-grey. Taste mild.

In mixed woods. Glamis, \&c. Sept.-Nov.

Spores pale cinnamon, Fr. Name-sebum, tallow. From the colour. Fr. Monogr. ii. p. 7. Hym. Eur. p. 337. Icon. t. I43. f. I. B. \& Br. n. I5t2. S. Mycol. Scot. n. 448 . Grevillea, t. 83.

$$
\text { ** Gills violaceons, ENC. }
$$

5. C. varius Fr.--Pileus 5 cent. ( 2 in.) and more broad, bright fermuginous-tawny, compact, hemispherico-flattened, very obtuse, regular, slightly viscid, even, smooth, the thin margin at first incurved, appendiculate with the cortina; flesh firm, white. Stem curt, 4-6 cent. ( $1 / 2-21 / 2$ in.) long, 2.5 cent. ( $\mathrm{I}$ in.) and more thick, bulbous, absolutely immarginate, compact, shining white, adpressedly flocculose, the superior veil pendulous. Gills emarginate, thin, somewhat crowded, at first narrow, violaceous-purplish, then broader and ochraceous-cinnamon, always quite entire.

Variable in stature, but the habit and colours are always unchangeable. It varies with the stem taller and somewhat equal, the pileus yellow-tawny, and the gills dark blue. 
In woods. Uncommon. Sept.-Nov.

Phlegma. cium.

Name-varius, changeable. Fr. Monogr. ii. p. 8. Hym. Eur. p. 338. Berk. Out. p. 183. C. Hbk. n. 487. Ag. Schef. t. $4^{2}$.

6. C. cyanopus Fr. - Pileus 6 cent. $\left(2 \frac{1}{2}\right.$ in.) broad, at first date-brown-livid, then $\tan$ and opaque, fleshy when unfolded, flattened, obtuse, regular, viscid in rainy weather, in fine weather dry opaque and even, smooth. Stem 5-7.5 cent. (2-3 in.) long, I $2 \mathrm{~mm}$. ( $1 / 2 \mathrm{in}$.) thick, solid, firm, ventricoso-bulbous, but always immarginate, above the bulb attenuated upwards, naked (neither fibrillose nor mealy) and white, violaceous above. Gills at first adnate, then emarginate, broad (6-8 mm., 3-4 lin.), not much crowded, in the same cluster intensely violaceous and pallid bluish-grey, soon changing colour to cinnamon, edge unequal.

The pileus when young is hemispherical, not embracing the bulb but the apex of the stem, the cortina extending from the closely involute margin to the apex of the stem. The stem when young is ovato-bulbous, when full grown depressed and oblique (somewhat rhomboid) at the base, more than 2.5 cent. ( $\mathrm{i}$ in.) thick, soft and spongy. The gills are less crowded than those of its allies. The flesh of the stem in its earliest stage is dingy white, variegated purple-violaceous above, that of the pileus dingy white, when full grown wholly white.

In woods. Frequent. Sept.-Nor.

Spores ro $\times 5 \mathrm{mk}$. W.P. Name-кúavos, dark blue; $\pi$ oús, a foot. From the colour of the stem. Fr. Monogr. ii. p. 9. Hym. Eur. p. 338. Berk. Out. p. I84. C. Hbk. n. 488. S. Mycol. Scot. n. 449. Quel. Grev. t. 102. f. 2. A. glaucopus Sow. t. 223 .

7. C. largus Fr.-Pileus 10-15 cent. ( $4-6$ in.) broad, commonly date-brown-tawny, fleshy, compact at the broad disc, thin at the circumference, convexo-flattened, very obtuse, slightly viscid on the surface, aclpressedly silky-fibrillose when dry, commonly rivuloso-squamulose, sometimes fibrillose towards the margin; flesh wholly fibrous, firm, whitish-bluish-grey, becoming white when exposed to the air. Stem solid, sometimes shorter, slightly bulbous, 6 cent. ( $2 \mathrm{I} / 2$ in.) long, commonly elongated, IO-I2.5 cent. (4-5 in.) long, almost 2.5 cent. ( 1 in.) thick and equal, often curved and ascending, wholly fibrillose, the superior cortina penululous, above which the stem is pruinose, white tinted violaceous; flesh same as that of pileus. Gills sometimes adnate, sometimes emarginate, crowded, $12 \mathrm{~mm}$. ( $1 / 2 \mathrm{in}$.) broad, at first bluish-grey-clay-colour, then cinnamon.

Somewhat cespitose. The pileus when young is sometimes violet such as is here and there observed round the margin of full-grown specimens. When bruised the stem is sometimes bloody. 
Phlegma* cium

In pine woods. Herefordshire. Sept.-Oct.

Name-largus, large. Fr. Monogr. ii. p. Iо. Hym. Eur. p. 339. Grevillea, vol. viii. p. 76 . Quel. Grev. t. 1о3. f. г.

8. C. Riederi Fr.-Pileus 7.5 cent. ( 3 in.) broad, ochraceous, compact, campanulato-expanded, obtusely umbonate, even, glutinous, shining when dry; flesh watery. Stem 10-12.5 cent. (4-5 in.) long, solid, clavate, lilac-silky and tawny-fibrillose. Gills adnate, rather thick, eroded, Jilac then cinnamon.

Pileus slimy when moist, obsoletely streaked. Allied to the Myxacia.

In pine woods. Herefordshire. Sept.-Oct.

Name-After Rieder. Fr. Hym. Eur. p. 339. Grevillea, vol. viii. p. 76 . Quel. Grev. t. ro4.f. r.

*** Gills yellow, cinnamon, Ecc.

9. C. saginus Fr.-Pileus Io- 12.5 cent. ( $4-5$ in.) broad, yellow, fleshy, plano-convex, irregular, repand, viscous; flesh soft, white. Stem 7.5 cent. ( 3 in.) long, 2.5 cent. ( $\mathrm{I}$ in.) and more thick, solid, somewhat bulbous, fibrillose, light yellowish, naked at the apex: Cortina fibrillose, fugacious, not very conspicuous. Gills truly decurrent, 8-10 mm. (4-5 lin.) broad, attenuated at both ends, dingy pallid then cinnamon, eroded at the edge.

Very gregarious, somewhat cæspitose.

In woods. Hereford, \&c.

Name-sagina, corpulence. From its size. Fr. Monogr. ii. p. 12. Hym. Eur. p. 340. Grevillea, vol. v. p. 56, vi. t. 92. S. Mycol. Scot. Supp. Scot. Nat. $1882, p .216$.

10. C. russus Fr. -Pileus io cent. (4 in.) broad, unicolorous, rufous, fleshy, convex then flattened, obtuse, viscid, smooth at the (lisc, innately fibrillose round the margin. Stem 7.5 cent. (3 in.) long, scarcely 2.5 cent. ( $\mathrm{i}$ in.) thick, stuffed then hollow, attenuated upwards, not bulbous, often curved-ascending, soft, adpressedly fibrillose, pale-white, delicately pruinate at the apex. Cortina very tender, fugacious. Gills obtusely adnate (scarcely perceptibly rounded), 8-10 $\mathrm{mm}$. (4-5 lin.) broad, crowded, connected by veins, rufous-ferruginous.

Well distinguished by its coppery-rufous pileus, bitter nauseous taste, and by the soft flesh being whitish-fiesh-colour.

In woods. Uncommon. Sept.-Oct.

Spores $8 \times 6$ mk. W.G.S. Name-russus, red. Fr. Monogr. ii. p. I3. Hym. Eur. p. 34r. C. Hbk. n. 489. S. Mycol. Scot.n.450. Worth. Smith, Trans. Woolh. Cl. 1870, t. I. 
11. C. anfractus Fr.-Pileus $5-7.5$ cent. (2-3 in.) broad, dark olivaceous, becoming fuliginous-tawny, equally fleshy, but at length very irregular at the thin bent in margin, even, smooth. Stem 5 cent. ( 2 in.) or a little more long, $12 \mathrm{~mm} .(1 / 2 \mathrm{in}$.) and more thick, clavate, immarginate, ascending, fibrillose, very dingy, violaceous at the apex, here and there hollow within. Cortina superior, but not in the form of a ring. Flesh whitish, obsoletely violaceous at the apex of the stem. Gills emarginate, distant, 6-8 mm. (3-4 lin.) broad, crisped, olivaceous-fuliginous.

The pileus is always zoneless, but it varies fuliginous when moist, when dry yellowish-olivaceous, with tiger-spots. It is often pitted and depressed round the margin, which is at length lobed. It varies regular.

In woods. Rare. King's Cliffe, \&c.

The whole plant when young is covered with a white volva. M.F.B. Spores $6 \times 4$ mk. WV.P. Name-anfractus, bent, waved, repand. Of the margin of the pileus. Fr. Monogr. ii. p. I4. Hym. Eur. p. 34. Berk. Out. p. 184. C. Hbk. n. 496 . Quel. Grev. t. 104. f. 3.

\section{+† SCAURi.}

* Gills whitish, then clay-coloured, Esc.

12. C. multiformis Fr.-Pileus unicolorous, light-yellow, clayyellow, tawny, \&c., fleshy, regular, convex then flattened, very obtuse and at length depressed, for the most part very viscous, even, smooth. Stem 5-10 cent. (2-4 in.) long, about $12 \mathrm{~mm}$. $(1 / 2$ in.) thick, solid, equal or attenuated, somewhat smooth or adpressedly fibrillose, naked (not pruinose), white then yellowish, with a somewhat marginate bulb. Cortina fibrillose, fugacious, white. Flesh white, at first compact then soft, that of the pileus at length slightly yellow. Gills emarginate, free or with a small decurrent tooth, very thin, crowded, tense and straight, not broad, serrulated, at first white, then clay-colour.

Very changeable. Odour and taste mild. It is distinguished by the colour being by no means violet and not hygrophanous, by the white flesh, and by the crowded serrulated gills being at the first whitish. According to the state of the atmosphere it is very viscid or somewhat dry, then often sprinkled with the universal white veil, the thin margin deflexed. The pileus often varies spotted, and when taller streaked with fibrils; moreover lacunoso-sulcate, \&c. The bulb is about 2.5 cent. ( $\mathrm{I}$ in.) thick.

In woods. Uncommon. Aug.-Oct.

I have seen the bulb so margined as to give the impression of a volva like that of A. pantherinus. M.F.B. Spores ochraceous, Fr.; pruniform, nucleate, punctate, 5-6×2-3 mk. C.B.P.; $7 \times 4 \mathrm{mk} . W . P$. Name-multus, 
Phlegma- forma. Very various in shape. Fr. Monogr. ii. p. 15. Hym. Eur. p. 343. cium. Berk. Out. p. 184. C. Hbk. n. 49r. S. Mycol. Scot. n. 45I. Quel. Grev. . 104. f. 4. A. turbinatus Sore. t. IO2.

13. C. napus Fr.-Pileus $5-7.5$ cent. (2-3 in.) broad, fuliginous, then date-brown-tawny, fleshy, convexo-plane, obtuse, even, smooth, glutinous, the regular margin bent inwards; flesh compact, white, with a horny line (hymenophore) next the gills. Stem 5 cent. ( 2 in.) long, $12 \mathrm{~mm}$. ( $1 / 2$ in.) thick, solid, equal, ascending, smooth, firm, white, at length becoming yellow at the base, inserted in an obconic, acutely and obliquely marginate bulb. Gills emarginate, somewhat distant, broad, crisped, whitishfuliginous, hyaline at the sides.

It differs conspicuously from species near to it in the broad, crisped, somewhat distant, whitish-fuliginous gills.

In pine woods. Hereford. Oct.

Name-napus, a turnip. From the bulb. Fr. Monogr. ii. p. i6. Hym. Eur.p. 3+3. Grevillea, vol. xii. p. 41.

14. C. talus Fr.-Pileus 5-7.5 cent. (2-3 in.) broad, of a yellowish dirty colour, becoming pale, margin somewhat olivaceous, yellowish, fleshy, thin, equal, convexo-plane, even, smooth, viscous; flesh watery, dingy pallid-whitish, with hyaline spots, and variegated with a horny line next the gills. Stem 7.5 cent. (3 in.) long, $12 \mathrm{~mm}$. ( $\mathrm{r} / 2 \mathrm{in}$.) thick, solid, equal, cylindrical (not oblique), becoming smooth, marginato-bulbous at the base, pale. Gills emarginate, somewhat crowded, beautiful straw-colour or ochreypallid, scarcely changing colour.

Very pretty, very much allied to $C$. turbinatus, but quite distinct in its colours. The bulb is small, somewhat round, marginate.

In woods. Epping Forest. Oct.

Name-talus, an ankle bone. From the swelling at the base of the stem. Fr. Monogr. ii. p. 17. Hym. Eur. p. 344. Icon. t. 145. f. 2. Grevillea, vol. xiv. p. $3^{8}$.

\section{** Gills violaceous, Ecc.}

15. C. glaucopus Fr.-Pileus dingy yellow, tan-tawny or claycolour, very fleshy, at first bent inwards, then flattened and unequal, somewhat repand, slightly viscid, rarely even, commonly floccoso-scaly, often marked with a raised fuscous-blackish zone round the margin; flesh compact, white. Stem solid, very stout, at first in the form of a bulb ( 2.5 cent., I in.), and marginatobulbous, fibrillose, woolly, chiefly at the apex, at length elongated (7.5 cent., 3 in.), the bulb vanishing, but the base remaining 
marginate, more than 2.5 cent. (I in.) thick, azure-blue-pallid; Phlegmainternally pale azure-blue, becoming yellow at the base. Gills rounded and emarginate, crowded, sometimes crisped, azure-blue, at length cinnamon.

Very changeable and variable. The above is the earlier form. Later it appears in great troops and is very robust. Pileus compact, very large, undulated and tiger-spotted, ochraceous or becoming tawny, when young regular and convex, 7.5-10 cent. (3-4 in.) broad, at length flattened and depressed, 20 cent. ( 8 in.) broad. Stem somewhat equal, marginate at the base, white or yellowish, fibrillose and striate, naked at the apex. Flesh alike of the pileus and stem yellowish, that of the stem dark yellow below. Gills sinuate, with a small decurrent tooth, I2 $\mathrm{mm}$. ( $1 / 2 \mathrm{in.}$ ) broad, somewhat crowded, bluish-grey then clay-colour and somewhat cinnamon.

In pine woods. Frequent. Aug.-Oct.

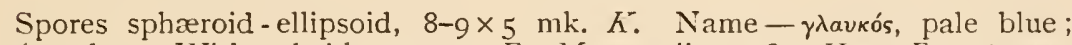
movis, a foot. With pale blue stem. Fr. Monogr. ii. p. 18. Hym. Eur. p. 344. Berk. Out. p. 184. C. Hbk. n. 492. S. Mycol. Scot. n. 452. Quel. Grev. t. 104. f. 5. Ag. Schaff. $t .53$.

16. C. calochrous Fr.-Pileus tawny, yellow round the margin, compact, convex, then plane, obtuse, viscid, guttate, commonly stained with soil; margin short, regularly involute, when unfolded often flexuous; flesh very white. Stem curt, 4-5 cent. ( $1 / 2-2$ in.) long, solid, firm, marginato-bulbous, bulb very depressed, otherwise equal, fibrillose, yellowish, never becoming dark blue. Cortina marginal, fugacious, yellow. Gills emarginate, crowded, serrated, of a beautiful dark blue-purple.

In woods and pastures. Frequent.

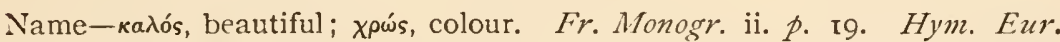
p. 345. Berk. Out. p. 185. t. 12. f. 3. C. Hbk. n. 493. Quel. Grev. t. 105. f. I. S. Mycol. Scot. n. 453 .

17. C. cærulescens Fr.-Pileus 5 cent. (2 in.), and more broad, dingy yellow, somewhat clay-colour, but varying fuscousyellowish, \&c., equally fleshy, convex, at length plane, obtuse, regular, even, rather smooth, but often streaked with fibrils, viscid, when dry shining or opaque; flesh violaceous, growing white. Stem 5 cent. ( 2 in.) long, I $2 \mathrm{~mm}$. ( $1 / 2$ in.) thick (the bulb more than 2.5 cent., I in. thick), solid, equally attenuated upwards from the marginate bulb, firm, at first fibrillose, of a charming violet colour, then naked, becoming pale, whitish. Cortina fibrillose, fugacious. Gills somewhat adnate, slightly rounded, thin, very crowded, $4 \mathrm{~mm}$. (2 lin.) broadl, at first beautifully and intensely azure-blue, then purplish, at length clingy-cinnamon.

When young the plant is here and there wholly azure-blue. The bulb is here 
Phlegma- and there obliterated with age, always white beneath. Neither the gills when cium. bruised nor the flesh when broken ever change colour (intensely azure-blue), but the gills become purple and at length cinnamon. Odour scarcely any.

In mixed woods. Frequent. Aug.-Nov.

Spores subellipsoid, 9-10 $\times 5^{-6} \mathrm{mk}$. $K$. Name-caruleus, azure. Fr. Monogr. ii. p. 19. Hym. Eur. p. 345. Berk. Out. p. 185. C. Hbk. n. 494. S. Mycol. Scot. n. 45+. Quel. Grev. t. 105. $f$. 3. A. calochrous b. Letell. t. 651.-Schreff. t. 34 (not good). Vent. t. 32. f. 1-3.

18. C. purpurascens Fr.-Pileus IO-I 2.5 cent. (4-5 in.) broad, bay-brown or date-brown-olivaceous, then tawny-olivaceous, tigerspotted, and often depressed round the margin, which is at first inflexed then repand, marked with a raised fuscous zone, fleshy, compact at the disc, obtuse, repand, variable, smeared with dense gluten, but opaque when dry; flesh wholly azure-blue. Stem solid, thick, bulbous, wholly fibrillose, intensely pallid azure-blue, darker when touched, bulb somewhat marginate. Gills broadly emarginate, $6 \mathrm{~mm}$. ( 3 lin.) and more broad, crowded, azure-blueclay, then cinnamon, violaceous-purple when bruised.

Readily distinguished from species near to it (especially $C$. glaucopus) by its gills soon changing colour and becoming spotted with purple when touched. The primary form is curt, robust, very compact, juicy, azure-blue-purplish when touched. There is another form, in dense beech woods, somewhat cæspitose, the longer stem somewhat twisted, pileus undulated, as much as 20 cent. ( 8 in.) broad, toast-brown then clay-colour and at length cinnamon with the spores. Gills at first bluish-grey-purplish; otherwise as above.

In mixed woods. Common. Sept.-Nov.

The marginal zone is not constant. M. F.B. Name-from the gills becoming purple when bruised. Fr. Monogr. ii. p. 20. Hym. Eur. p. 345. Berk. Out. p. 185. C. Hbk. n. 495. S. Mlycol. Scot. n. 455. Quel. Grev. t. 105. f. 2 .

* C. subpurpurascens Fr.-Pileus tawny-fuliginous, becoming pale, not compact, obtuse, at length very much dilated and undulato-flexuous, viscous, obsoletely streaked with fibrils, somewhat spotted; flesh soft, whitish (very faint azure-blue), unchangeable. Stem $7.5-10$ cent. (3-4 in.) long, $12 \mathrm{~mm}$. ( $1 / 2 \mathrm{in}$. thick, at length hollow, somewhat cylindrical, marginato-bulbous at the base, fibrillose below, naked above, smooth, slightly striate, pale azure-blue or whitish. Gills sometimes emarginate, almost free, sometimes decurrent, pallid then cinnamon, becoming purple when bruised.

In woods. Epping Forest. Oct. Fr. Monogr. ii. p. 21. Hym. Eur.p. 346. Grevillea, vol. xii. p. 42. Batsch f. 74 . 
19. C. dibaphus Fr.--Pileus 7.5-1o cent. (3-4 in.) broad, purplish, disc yellowish, and at length variegated with lilac, Heshy, convex then plane, at length depressed, somewhat repand, viscous, smooth; flesh yellow, variegated under the pellicle with a violet line. Stem 7.5 cent. ( 3 in.) long, $12 \mathrm{~mm}$. ( $1 / 2$ in.) thick, marginato-bulbous, stuffed, fibrillose, yellow, shining, purplish at the apex, light yellowish within. Gills adnate, slightly rounded, somewhat crowded, $6 \mathrm{~mm}$. (3 lin.) broad, quite entire, purplishferruginous.

Odour and taste mild.

In woods, beech and oak. Fordingbridge, Hants.

Spores $8 \times$ I I mk. WV.G.S. Name- $\delta$ - $\beta a \phi o s$, twice dipped or dyed. Of two colours. Fr. Monogr. ii. p. 21. Hym. Eur.p. 346. B. \& Br.n. I265. Saund. E Sin. t. 10. Quel. Grev. t. 105.f. 4.

20. C. turbinatus Fr.-Pileus znicolorous, dingy yellow or green, becoming pale, hygrophanous, opaque when dry, fleshy, convex then flattened, obtuse, at length depressed, orbicular, even, smooth, viscid; flesh soft, white. Stem commonly curt (5 cent., 2 in.), but varying elongated, yellowish, springing from a globosodepressed distinctly marginate bulb, otherwise equal, cylindrical, stuffed then hollow. Gills attenuato-adnate, thin, crowded, broad, quite entire, at first pallid light-yellowish, at length somewhat ferruginous.

The typical form is regular, distinct from its allies in the hygrophanous pileus, in the gills being isabelline-ferruginous and quite entire, and in being without any durk blue or purple colour. Easily distinguished by its turbinate bulb.

In woods. Uncommon.

Pileus variable in width. Margin of the bulb so strongly developed as to appear volvate like $A$. pantherinus. M.F.B. Name-tur-bo, a spinning-top; conical. Of the bulb. Fr. Monogr. ii. p. 22. Hym. Eur. p. 346. Berk. Out.p. 185. C. Hbk. n. 497. Quel. Grev. t. 107.f. I. Ag. Vent. t. 38.f. 5, 6. Bull. t. 1 го.

21. C. fulgens Fr.--Pileus $5-7.5$ cent. ( $2-3$ in.) broad, orangetawny, very fleshy, convexo-plane, obtuse, viscid, occasionally punctate as with drops, at length silky-fibrillose or squamulose; flesh very compact, white-yellow, at length spongy and tan-colour. Stem solid, curt, equal above the depressed and obliquely, at the first acutely, marginate bulb, woolly with the yellow, densely fibrillose (in wet weather viscid) cortina, when full grown elon- 
Phlegma. gated to 7.5 cent. ( 3 in.). Gills emarginate, $6 \mathrm{~mm}$. (3 lin.) broad, cium. somewhat crowded, quite entire, at first bright yellow, at length somewhat distant, tawny or ferruginous with the spores.

Very handsome, robust. The colour of the pileus is deeply and persistently orange-tawny. The spores tinge even the wool on the stem.

In pine woods. Rare. Sept.

Spores $9 \times 6 \mathrm{mk}$. W.G.S. Name-fulgeo, to shine. Of its bright colour. Fr. Monogr. ii. p. 23. Hym. Eur. p. 347. C. Hbk. n. 498. Saund. \& Sm. t. I2.

22. C. fulmineus Fr.-Pileus about 7.5 cent. (3 in.) broad, tawny, variegated with dense irregular agglutinated scales, very fleshy, at first hemispherical and attached to the bulb, then convex, very viscous, margin regular, at first involute; flesh thick, white, often yellow at the circumference or wholly yellowish. Stem when young enclosed in the bulb, apparently awanting, then extended but scarcely more than 2.5 cent. ( $\mathrm{I}$ in.), solid, obese, yellow, naked, white-cortinate at the apex. Bulb very depressed, marginate, rooting, wider than the young pileus. Gills rounded, thin, very crowded, golden-yellow at length tawny.

The bulb and the scales on the pileus resemble the volva of the Amanita of the group represented by $A$. rubescens. The whole plant is robust, very hard. Mild. The pileus is tawny, almost brown, margin orange. Stem not filamentous, at first slightly viscid.

In shady woods. Ledbury.

Name-fulmen, lightning. Shining. Fr. Monogr. ii. p. 23. Hym. Eur. p. 347. Grev. xii. p. 42. Ag. Schaff. t. 24 .

23. C. orichalceus Batsch.-Pileus 7.5 cent. (3 in.) broad, normally blood-red or liver-rufescent, with the margin livid, or bay-brown-ferruginous, and cinereous-olive round the margin, fleshy, convex, soon flattened, at length depressed, with a viscous pellicle or glutinous, the disc spotted with scales. Stem 7.5 cent. ( 3 in.) long, I $2 \mathrm{~mm}$. ( $1 / 2$ in.) thick, solid, equal, but springing from a marginate somewhat volvaceous bulb, very fibrillose (the fibrils viscid in wet weather from the gluten of the pileus flowing down), yellow-green or dingy yellow-pale. Gills adnate, broad, crowded, sulphur-yellow becoming green.

The flesh alike of pileus and stem white, but lemon-yellow at the circumference, at length wholly greenish-yellow. Easily distinguished by its dark dirty colours, which are nevertheless variable (the pileus sometimes olivaceous). The gills are very broad behind.

Under trees. Lyndhurst, New Forest.

Name-orichalchum, yellow copper ore, or brass. Of the colour. Fr. 
Monogr. ii. p. 24. Hym. Eur.p. 348. Grevillea, vol. xii. p. 42. Batsch f. Phlegma184. Quel. Grev. t. I06. f. I.

\section{**** Gills olivaceous.}

24. C. prasinus Fr.-Pileus sometimes æruginous, sometimes tawny-fuliginous, tiger-spotted, as if scaly, compact, convexoplane, very obtuse, regular, viscid, the margin regularly involute; flesh dingy white. Stem curt, very thick, solid, greenish-pallid, not becoming violet; flesh greenish-white. Cortina scanty, whitish or pallid-green. Gills emarginate, not crowded, when full grown rather distant, somewhat crisped, yellow-olivaceous or somewhat olivaceous, darker and cinereous-olivaceous at the base.

Commonly sporadic. Taste mild.

In beech woods. King's Cliffe.

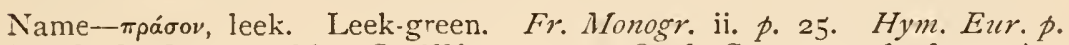
348. Berk. Out. p. 186. C. Hbk. n. 500. Quel. Grev. t. 106. f. 2. Ag. Schaff. t. 218.

25. C. scaurus Fr.-Pileus commonly 5-7.5 cent. (2-3 in.), very rarely io cent. ( 4 in.) broad, tiger-spotterl, of a peculiar tawnyfuliginous colour, when dry more tawny, fleshy, convex then plane, depressed when old, viscous, smooth, the thin margin at length slightly striate; flesh thin, soft. Stem solid, soft and spongy (especially the bulb) with age, equally attenuated upwards from the marginato-bulbous base (more than 2.5 cent., I in. thick at the base, $8 \mathrm{~mm} ., 4$ lin. at the apex), fibrillose or striate, azureblue or olivaceous then becoming white, and also yellowish when old. Cortina fibrillose, somewhat green. Gills attenuato-adnexed, rounded, thin, very crowded, 2-4 mm. ( $\mathrm{I}-2$ lin.) broad, broader $(6 \mathrm{~mm} ., 3 \mathrm{lin}$.$) in front, normally purplish-olivaceous,$ but varying pure olivaceous and even fuliginous.

Odour and taste mild. It differs from all neighbouring species in the very crowded and very narrow gills. The bulb here and there vanishes.

In woods. Rare. Oct.-Nov.

Stem purplish in my specimens with a red tinge on the edge of the bulb. M.F.B. Name-scaurus, with projecting ankles. Of the bulb. Fr. Monogr. ii. p. 25. Hym. Eur. p. 349. Iton. t. 146. f. r. Berk. Out. p. 186. C. Hbk. n. 499. S. Mycol. Scot. n. 456. Quel. Grev. t. 107. f. 2.

t† Elastici.

* Gills whitish, then clay-coloured, Ecc.

26. C. cumatilis Fr.-Pileus 7.5 cent. ( 3 in.) broad, of a very charming violet or purple-violet colour, convex, obtuse, not de- 
Phlegmacium.

pressed, often irregular, with a viscous pellicle, even, smooth; flesh both of pileus and stem hard, shining white, unchangeable. Stem 5-7.5 cent. ( $2-3$ in.) long, $12 \mathrm{~mm}$. ( $1 / 2 \mathrm{in}$.) thick, but variable and often curved, solid, firm, wholly shining white, furnished with a cortina only at the apex, but not pulverulent ; the universal veil, which serves as a pellicle of the pileus, ruptured at the base and adnate to it, as a separable agglutinated membrane of the same colour as the pileus. Gills attenuato-adnexed, almost free, crowded, narrow, scarcely $4 \mathrm{~mm}$. (2 lin.) broad, with a small decurrent tooth, acute at the apex, white then clay-colour.

Handsome, distinguished, not allied to any. The colours of the pileus and base of the stem depend upon the universal veil, which on being ruptured forms the pellicle of the former, and the sheathing membrane of the latter. Yellow spots are left where these are rubbed off. It varies sometimes solitary and larger, compact, sometimes somewhat cæspitose with the stems equal and ascending.

In woods. Honningham, Norfolk. Oct.

The colour agrees better with the name and with Fries's fig. than with his description. Spores $7 \times 4 \mathrm{mk}$. WW.P. Name-cumatilis, sea-coloured, blue. Fr. Monogr. ii. p. 27. Hym. Eur. p. 349. Icon.t. I 6.f. 2. C. cærulescens Saund. E Sm. t. 22.

27. C. decoloratus Fr.-Pileus 5-Io cent. (2-4 in.) broad, claycolour, disc darker, thin, but equally fleshy, campanulate then convex, obtuse, soft, viscous, soon dry, smooth, corrugated when old; flesh soft, white, watery. Stem 7.5 cent. (3 in.) long, 12 $\mathrm{mm}$. ( $1 / 2 \mathrm{in}$.) or less thick, stuffed, thin, somewhat equal, slightly thickened at the base, ascending, fibrillose, silvery, often curved, smooth and naked at the apex. Cortina inferior, fibrillose. Gills emarginate, adnate or decurrent according to situation, not much crowded, $6 \mathrm{~mm}$. (3 lin.) broad (broader than the flesh of the pileus), clay-colour then cinnamon.

Taste slightly acrid. Very protean. The above is the typical form found in beech woods. The habit and stature are quite those of $C$. tabularis, but the pileus is viscous, never silky-veiled, stem never scaly, \&c. In birch woods: pileus a little darker, floccoso-scaly or rivuloso-granulose when dry; bulb at the first present, small and somewhat round, but soon vanishing, soft, stem attenuated from it, sometimes yellowish; gills at the first bluishgrey-whitish. In pine woods: smaller and thinner, pileus even; gills pallid clay-colour.

In woods. Epping. Edinburgh Fungus Show. Oct.

Name-de, and coloro, to colour. Changing colour. Fr. Monogr. ii. p. 30. Hym. Eur. p. 35r. B. E Br.n. 154r. S. Mycol. Scot. n. 457. Quel. Grev. t. 107.f. 4 . 
28. C. decolorans Fr.-Pileus $4-6$ cent. ( $1 \frac{1}{2}-2 \frac{1}{2}$ in.) broad, wholly persistently yellow, fleshy, convex then flattened, somewhat gibbous, equal, even, smooth, viscous; flesh thin, firm, white. Stem 5-7.5 cent. (2-3 in.) long, 6-8 mm. (3-4 lin.) thick, stuffed, equally attenuated, shining white, smooth above the somewhat persistent medial cortina. Gills sinuato-adnexed, crowded, thin, $6 \mathrm{~mm}$. (3 lin.) broad, juiceless, purplish then soon cinnamon.

The gills are unchangeable when bruised. Easily mistaken for a thin form of $C$. varius, differing, however, in the thinner unicolorous pileus, in the stem being more slender, externally rigid, polished, without a bulb, and smooth with exception of the cortina.

In fir woods. Epping Forest. Oct.

Name-de, and coloro, to colour. From the gills changing colour. Fr. Monogr. ii. p. 3r. Hy'm. Eur. p. 35r. Grevillea, vol. xiv. p. $3^{8}$.

29. C. porphyropus Fr.-Pileus $4-7.5$ cent. ( $1 / 2-3$ in.) broad, livid-light yellowish or clay-colour, unchangeable when touched, fleshy, very thin at the margin, convexo-plane, obtuse, even, innately streaked, viscid; flesh thin, soft, whitish, soon becoming purple-lilac when broken. Stem 5-10 cent. (2-4 in.) long, about $6 \mathrm{~mm}$. (3 lin.) thick, stuffed, at length hollow, somewhat bulbous or rather equally attenuated from the thickened base (sometimes equal), fragile, externally and intemally violaceous-lilac, soon becoming pale, even whitish, but soon becoming violaceous-lilac again when touched. Cortina inferior, fibrillose. Gills rounded or emarginate, somewhat crowded, rather broad (4-8 mm., 2-4 lin.) purplish then watery cinnamon, becoming purple again when touched.

It approaches $C$. purpurascens, but the gills are crowded in that species.

In woods. Coed Coch, i87i. Oct.

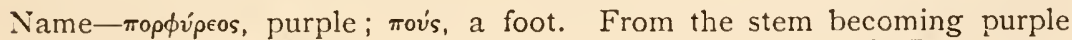
when touched. Fr. Monogr. ii. p. 3I. Hym. Eur. p. 35I. B. \& Br.n. 135 r.

30. C. croceo-cæruleus Fr.-Pileus 2.5 cent. ( $\mathrm{I}$ in.), or a little more broad, lilac or faintly violaceous, fleshy but thin, convex then plane, obtuse or gibbous, even, smooth, viscous; flesh watery, pallid. Stem 5 cent. ( 2 in.) long, hollow, somewhat equal (sometimes attenuated downwards), 4-6 mm. (2-3 lin.) thick, even, smooth, naked, fragile, whitish. Cortina white, fibrillose, fugacious. Gills attenuated or broadly emarginate, with a small very thin decurrent tooth, plane, somewhat distant, lilac then clay-saffron. 
Phlegma. Spores saffron, cinnamon. The flesh is unchangeable in colour, but othercium. wise the plant becomes very slightly purple when touched or broken.

In woods. Laxton Park, Norths. Oct.

Name-croceus, saffron; caruleus, azure. Fr. Monogr. ii. p. 32. Hym. Eur. p. 352. B. \&o Br. n. 1543. Ag. Pers. Ic. and descr. t. 1. f. 2. Bucknall, Brist. Nat. Soc. Proc. vol. iv. t. 3. f. 3.

\section{** Gills pure ochre, tainy, Eoc.}

31. C. papulosus Fr. -Pileus $6-9$ cent. $\left(2 \frac{1}{2}-3^{1 / 2}\right.$ in.) broad, honey-tan-colour at the circumference, always darker (ferruginous or fuscous) at the disc, fleshy, at first convex, obtuse, then plane and at length depressed (disc here and there gibbous), smooth, viscid; the cuticle breaking up into minute, gramular, fuscous patches when dry; flesh white, thick at the disc, thin at the margin. Stem 7.5 cent. (3 in.) long, $I-2.5$ cent. ( $1 / 2-I$ in.) or a little more thick, solid, firm, wholly fleshy within, equal or thickened at the base, densely fibrillose, but quite naked at the apex, white. Cortina inferior, very fugacious, white. Gills adnato-decurrent, crowded, slightly joined behind, but at length separating from the stem in older specimens and forming a spurious collar, $4-6 \mathrm{~mm}$. (2-3 lin.) broad, at the first pallid, soon ochraceous, at length very pale yellow-cinnamon.

There are forms with the stem longer, here and there flexuous and hollow.

In woods. Durdham Down, Bristol. Glamis. Oct.-Nov.

Name-papula, a pimple. From the minute granular patches on the pileus. Fr. Monogr. ii. p. 33. Hym. Eur. p. 352. Bucknall, Brist. Nat. Soc. Proc. vol. iv. t. 3. f. I.

\section{**** Gills olivaceous, fuliginous.}

No British species.

Myxacium.

Tribe II. MYXACIUM ( $\mu \dot{v} \xi \alpha$, mucus). Universal veil glutinous, hence the scarcely bulbous stem is also viscous. Pileus fleshy, somewhat thin. Gills adnate, decurrent. (Certain Phlegmacia having the fibres of the cortina slightly viscid by gluten from the pileus must not be confounded with the Myxacia.) Fr. Hym. Eur.p. 354 .

+ Colliniti (C. collinitus, besmeared). Stem floccoso-peronate, the flocci at first covered with gluten. 
+† Delibuti ( $C$. delibutus, besmeared). Veil entirely viscid, hence the Myxacium. stem is not floccoso-peronate but only viscid, acquiring a varnished appearance when dry.

* Gills whitish, then clay-coloured.

** Gills at first violaceous, dark blue, or reddish.

*** Gills at first ochraceous or cinnamon.

\section{+ Colliniti.}

32. C. arvinaceus Fr.-Pileus $7 \cdot 5$-10 cent. (3-4 in.) broad, orange-tawny, fleshy, soft, convex then soon flattened, at length reflexed and undulated, even, smooth, viscous (not glutinous), glistening when dry, margin slightly striate when in full vigour. Stem tall, as much as 20 cent. ( 8 in.) long, 12 $\mathrm{mm}$. ( $1 / 2 \mathrm{in}$.) thick, solid, equal, silkyviscous, never broken up into scales, white. Cortina soon fibrillose and fugacious. Gills adnato-decurrent, very broad (12-I $8 \mathrm{~mm} ., 1 / 2-3 / 4 \mathrm{in}$.), even at the sides, somewhat distant, crenulated at the edge, at first straw-colour then bright ochraceous.

Spores plentiful, of the same colour as the gills. Cortina not in the form of a ring. Perhaps too nearly allied to $C$. collinitus.

In beech woods. Blaize Castle, Bristol. Oct.

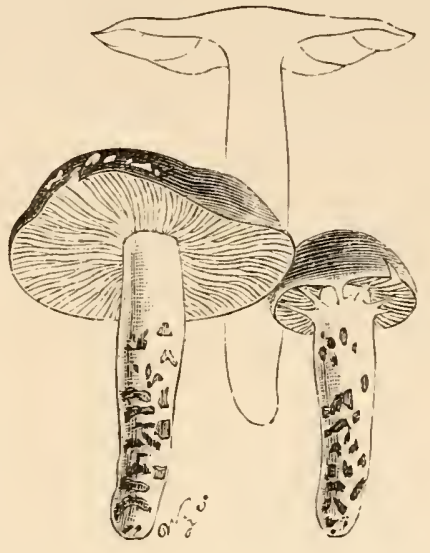

XLI. Cortinarius (Myxacium) collinitus. One-fifth natural size.

Name-arvina, grease. Greasy, viscid. Fr. Monogr. ii. p. 36. Hym. Eur. p. 354. Grevillea, vol. xii. p. 42. Bucknall, Brist. Nat. Soc. Proc. vol. iv. t. 5.f. r. Ag. Krombh. t. 73. f. x6-18.

33. C. collinitus Fr.-Pileus orange-tawny, fleshy, not compact, convex with the margin bent inwards then expanded, obtuse, clothed with a thick cuticle, which in wet weather swells into persistent orange-tawny gluten, shining when dry, margin even. Stem solid, firm, elongated, exactly cylindrical, at length soft, for the most part covered over with a floccose and glutinous veil, which is commonly broken up into concentric scales; near the apex the gluten is continuous with the glutinous cuticle of the pileus and forms an entirely viscous fugacious ring, colour variable, violaceous, white, even yellowish. Gills adnate, somewhat crowded, whitish-bluish-grey or clay-colour then cinnamon.

There are numerous forms departing from the type : b) pileus repand, stem inclining to fuscous: Batsch $f$. I97. c) small, pileus pallid yellow or straw-

VOL. II. 
Myxacium. colour, stem concentrically light yellow-scaly, gills white. d) very small, pileus date-brown-fuscous, stem scarcely 2.5 cent. ( $x$ in.)

In woods. Common. July-Nov.

Spores ferruginous, Fr.; $9 \times 6 \mathrm{mk}$. W.G.S.; I2-I4 $46-7 \mathrm{mk} . K$. Namecollino, to besmear. From the gluten. Fr. Monogr. ii. p. $3^{6 . H y m}$. Eur. p. 354. Berk. Out. p. 186. C. Hbk. n. 501. S. Mycol. Scot. n. 458. Ag. Bull. t. 549, 596. Ventur. t. 32. f. 4-6 (abnormal). Buxb. C. iv. t. 9.

34. C. mucifluus Fr.-Pileus livid-clay, when dry tan, opaque, somewhat fleshy, campanulato-expanded, smeared with separating hyaline gluten, margin striate. Stem attenuated downwards, soft, viscid with the floccoso-scaly fugacious veil, white or inclining to azure-blue. Gills adnate, distinct, clay-colour then watery cinnamon.

Odour sweet. Intermediate between $C$. collinitus and $C$. elatior, so allied to the former that it was long considered a variety. It differs especially as follows : I) stem spongy, attenuated downwards, white: 2) pileus thinner, campanulate then expanded, at length reflexed and repand, the membranaceous margin striate: 3 ) colour of pileus livid-clay, when dry tan, opaque: 4) the gluten of the pileus thin, hyaline, fluid, not forming a thick persistent brightly coloured pellicle: 5) odour sweet. Gills clay then cinnamon. There is nothing of a violaceous tint in the whole plant.

On the ground. Hereford, \&c. Oct.

Name-mucus, fuo, to flow. From its being covered with mucus which flows off and disappears. Fr. Monogr. ii. p. 37. Hym. Eur. p. 355. Icon. t. I48. f. I. Grevillea, vol. xi. p. 70. Quel. Grev. t. I08. f. 4. S. Mycol. Scot. Supp. Scot. Nat. I881, p. 35.

35. C. elatior Fr.-Pileus about 7.5-10 cent. (3-4 in.) broad, commonly livid-light yellow when damp, dingy ochraceous when dry, slightly fleshy only at the disc, cylindrical or bullate then campanulate, afterwards flattened and somewhat reflexed, the disc above the stem obtuse, even, otherwise membranaceous and longitudinally plicato-zurinkled at the sides, fragile, slightly viscous. Stem $12.5-17.5$ cent. (5-7 in.) long, I $2 \mathrm{~mm}$. ( $1 / 2 \mathrm{in}$.) and more $(5$ cent., 2 in.) thick, commonly attenuated at both ends (especially at the base), longitudinally fibrous, clothed with somewhat viscous, whitish, torn up scales, rarely becoming violet. Cortina viscous, fugacious. Gills adnate, linear, at first $6 \mathrm{~mm}$. (3 lin.) broad, at length broader (as much as 2.5 cent., I in.), somewhat distant, connected by veins or wrinkled at the sides, always dark, brown-cinnamon.

The colour of the pileus varies whitish, tan-fuscous, date brown, violaceousbrown, black, whitish round the margin, grey with the margin violaceous. Gills violet-brown in Sowerby's fig.

In mixed woods. Common. Sept.-Nov. 
Name-elatus, tall. Fr. Monogr. ii. p. 37. Hym. Eur.p. 355. Icon. t. Myxacium. I 49. f. I. Berk. Out. p. 186. C. Hbk. n. 502. S. Mycol. Scot. n. 459. Sow. t. 9 .

36. C. grallipes Fr.-Pileus 7.5 cent. ( 3 in.) broad, ferruginous when moist, when dry ochraceous-tan, opaque, almost membranaceous with exception of the disc, with a prominent often acute $u m b o$, campanulate then flattened, even, hygrophanous, slightly viscid (not glutinous). Stem 10-1 5 cent. (4-6 in.) long, 4-6 mm. (2-3 lin.) thick, stuffed then hollow, wholly equal, but flexuous, tough, fibroso-striate, viscous, yellowish-tawny, ochraceous when dry, naked at the apex. Gills wholly adnate, with a decurrent tooth, $12 \mathrm{~mm}$. ( $1 / 2 \mathrm{in}$.) broad, plane, attenuated in front, crowded, even at the sides, clay-colour then ferruginous.

The habit is that of $C$. hinnuleus, but it is viscous not torn.

Among grass near trees. Ashton Park, Bristol. Oct.

Pileus very slimy when wet; veil fugacious, cobweb-like, pale, whitish brown; spores dark ferruginous. W.G.S. Name-gralla, stilts; pes, a foot. Longstemmed as if on stilts. Fr. Monogr. ii. p. 38. Hym. Eur. p. 355. Saund. \& Sm. t. 27 .

37. C. livido-ochraceus Berk.-Pileus 2.5 cent. ( $\mathrm{I}$ in.) broad, livid-ochre, somewhat membranaceous, plane, viscid, margin not striate. Stem 2.5 cent. (I in.) high, $3 / 8$ thick in the middle, beautiful violet, ochraceous at the base, stuffed with cottony fibres, attenuated at either end, somewhat scaly, striate above the fugitive veil. Gills somewhat adnexed, broad in front, moderately distant, cinnamon, the extreme margin pale.

Pileus quite smooth, shining, covered with a thick subcartilaginous skin, the margin very thin; edge with a few indistinct fragments of the veil. Inodorous. Nearest to the smooth-stemmed form of $C$. collinitus.

In woods. Uncommon. Sept.-Oct.

An undoubted specimen has been gathered with the margin of the pileus striate. Spores lemon-shaped, $1_{3}-15 \times 6-8 \mathrm{mk}$. C.B.P. Name-livid-ochre in colour. Berk. Out. p. I86. Eng. Fl. v. p. 89. Fr. Hym. Eur. p. 356. C. Hbk. n. 504. S. Mycol. Scot. n. 460.

\section{t† Delibuti. \\ * No British species. \\ * Gills at first violaceons, \&oc.}

38. C. salor Fr.-Pileus grey, bright violaceous round the inflexed margin, at length of the same colour, when young obtusely conical or parabolic, soon campanulate and at length flattened with a broad umbo on account of the compactly fleshy disc, thin 
Myxacium. towards the circumference, small in comparison with the stem, even, smooth, thinly viscous, fibrillose towards the margin when dried ; flesh continuous, white, becoming yellow (or faintly azureblue). Stem $4-7.5$ cent. ( $1 / 2-3$ in.) long, 2.5 cent. ( 1 in.) thick at the base, $12 \mathrm{~mm}$. ( $1 / 2 \mathrm{in}$.) at the apex, solid, conico-attenuated from the bulbous base, gradually elongated, white, but when young covered to the apex with the azure-blue glutinous veil, when old becoming pale, softer. Gills adnate, distant, distinct, 4-6 $\mathrm{mm}$. (2-3 lin.) broad, quite entire, at first pale grey with the edge violaceous or bluish-grey, when full grown grey-clay-colour or cinnamon.

In proportion as the stem becomes more elongated, the bulb becomes less in size. The stem is white externally and internally, but when young it is blue with the glutinous veil. Very distinguished, firm.

In woods. Coed Coch.

Name-salum, sea. Sea-colour. Fr. Monogr. ii. p. 40. Hym. Eur. p. 357. Icon. t. I50. f. I. B. \& Br. n. 1878. Quel. Grev. t. 108. f. I.

39. C. delibutus Fr.-Pileus 5-7.5 cent. (2-3 in.) broad, lightyellowish, fleshy, thin, especially towards the margin, convex then flattened, obtuse, at length somewhat depressed, viscid with hyaline gluten, and slightly silky-fibrillose when the gluten disappears. Stem 5-Io cent. (2-4 in.) long, 6-8 mm. (3-4 lin.) thick, stuffed or hollow upwards, equally attemuated from the slightly bulbous base or somewhat equal, elastic, viscous as far as the scanty, fibrillose, fugacious cortina, when dry even, smooth, varnished, yellowish white, snow-white at the apex. Gills adnate, at length rounded or slightly emarginate, more or less distant, 4-6 mm. (2-3 lin.) broad, servulated pallid or often crisped at the edge, at the first dark blue, or violaceous-dark blue, then clay, cinnamon.

The pileus and especially the gills vary in the colour being more or less intense. Taste at first watery, then slightly pungent. It loves grassy and rather damp places.

On the ground. King's Lynn.

Spores $7 \times 5 \mathrm{mk}$.W.P. Name-delibuo, to besmear. From the gluten. Fr. Monogr. ii. p. 41. Hym. Eur. p. 357. Grevillea, vol. viii. p. 97. Quel. Grev. t. 108. f. 2. S. Mycol. Scot. Supp. Scot. Nat. 1882, p. 216.

40. C. illibatus Fr.-Pileus $2.5-5$ cent. ( $\mathrm{I}-2$ in.) broad, yellow, disc darker, slightly fleshy, campanulate then convex, at length plane and somewhat umbonate, with a viscous pellicle, even, smooth; flesh white, very thin at the circumference. Stem 7.5 cent. ( 3 in.) long, only $4 \mathrm{~mm}$. ( 2 lin.) thick, stuffed then soon hol- 
low, soft, slightly attenuated upwards, smooth, viscid, white, com- Myxacium. monly with reddish dots upwards. Cortina superior, fibrillose, very fugacious. Gills adnato-decurrent, arcuate, $4 \mathrm{~mm}$. (2 lin.) broad, thin, crowded, quite entire, flesh-colour then clay, cinnamon with the spores.

Much smaller and thinner than $C$. delibutus, \&c., and without any violet colour.

\section{In woods. Coed Coch.}

Name-illibatus, unimpaired, entire. Perhaps from the gills. Fr. Monogr. ii. p. 42. Hym. Eur. p. 358. B. E Br. n. 1879.

\section{*** Gills at the first ochraceous or cinnamon.}

41. C. stillatitius Fr.-Pileus scarcely 5 cent. (2 in.) broad, slightly fleshy, convex then plane, somewhat umbonate, even, smooth, clothed with azure-blue gluten, which is at first continuous with that of the stem, fuscous-livid when the gluten separates in the form of drops, and at length grey-white; flesh soft, watery, hygrophanous. Stem 5 scarcely 7.5 cent. (2, 3 in.) long, 6-8 mm. (3-4 lin.) thick, hollow, very soft, wholly equally attenuated, at first sheathed with thick azure-blue gluten which is extended into the cortina, naked at the apex. Gills emarginate, scarcely crowded, distant rather, $6 \mathrm{~mm}$. (3 lin.) broad, dark cinnamon.

Odour none. The gluten disappears with age. Rather aliied to the Colliniti, but the veil is by no means floccose. The gills are almost those of $C$. elatior.

\section{Among dead leaves. Uncommon.}

Pileus striate near the margin. Gills with a whitish ragged margin. W.G.S. Spores sphæroid-ellipsoid, uniguttate, yellowish, $8 \times 6 \mathrm{mk} . K$. Name-stillo, to drip. Dripping. Fr. Monogr. ii. p. 42. Hym. Eur. p. 358. C. Hbk. n. 503. S. Mycol. Scot. Supp. Scot. Nat. 1882, p. 216. Saund. E Sm. t. 3.

42. C. pluvius Fr.-Pileus $I-2.5$ cent. ( $1 / 2-I$ in.) broad, pale yellow - tawny when moist, ochrey-tan and opaque when dry, slightly fleshy, at first somewhat globose, then convex, commonly gibbous, when more fully grown and moist slightly pellucidstriate, hygrophanous, viscid and shining in rainy weather; flesh thin, of the same colour. Stem more or less elongated to as much as 7.5 cent. ( 3 in.), 4-6 mm. (2-3 lin.) thick, at first stuffed, then hollow, soft, equal or slightly attenuated upivards, even, naked or obsoletely viscid with whiter silky spots. Cortina white and entirely fibrillose, slightly covered over with slime, soon fugacious. Gills adnexed, separating, ventricose, crowded, light yellowish or at the first whitish, then ochraceous. 
Myxacium. The pileus in the earliest stage is covered over, especially round the margin, with a very thin, silky, white film. Taste at first watery, then acrid and pungent.

In woods. Lea, Gainsborough. Glamis. Sept.-Oct.

Name-pluo, to rain. From being viscid in rainy weather. Fr. Monogr. ii. p. 43. Hym. Eur. p. 359. B. E Br. n. 1267. S. Mycol. Scot. n. $46 \mathrm{r}$. Ag. Batschf. 190.

Inoloma.

Tribe III. INOLOMA (ไ้ $\sigma$, a fibre; $\lambda \hat{\omega} \mu a$, a fringe). Fr. Syst.

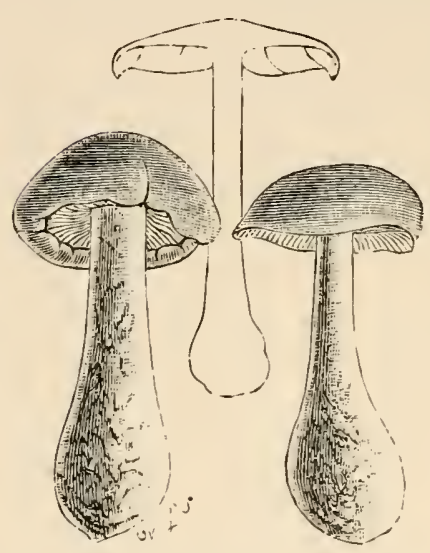

XLII. Cortinarius (Inoloma) callisteus. One-fourth natural size. Myc. i. p. 216. Pileus equally fleshy, dry, at first silky with innate scales or fibrils, flesh continuous, not hygrophanous. Veil single. Stem fleshy, somewhat bulbous. Species very distinguished. There are Telamonice which resemble Inolomata, but they differ from them by having the pileus smooth, moist, then torn (whereas the Inolomata become smooth), or by being sprinkled over with white superficial fibrils, and by possessing a double veil. Fr. Hym. Eur. p. 359.

* Gills at first white or pallid.

** Gills, as well as the veil and stem, violaceous.

*** Gills or veil cinnamon, red, or ochraceous.

(C. subferrugineus and C. armillatus are apt to be sought for here.)

**** Gills or veil dark, fuscous, olivaceous.

\section{* Gills at first white or pallid.}

43. C. argentatus Fr.-Pileus ro cent. (4 in.) broad, silveryshining, disc becoming pale, at the first silky-lilac round the margin then dun-coloured, fleshy, convexo-plane, at length broadly gibbous, silky-even becoming smooth; flesh whitish. Stem Io cent. (4 in.) long, $12 \mathrm{~mm}$. ( $1 / 2 \mathrm{in}$.) and more thick, solid, attenuated from the (scarcely bulbous) base, smooth, silverywhite, at length becoming yellow at the base, internally white. Cortina fibrillose, fugacious, adhering only to the margin of the pileus, pallid. Gills emarginate, crowded, slightly serrated, $6 \mathrm{~mm}$. (3 lin.) broad, pallid then watery cinnamon.

Odour weak. There is a smaller form in pine woods. The stem is bulbous when short. 
In woods. Epping Forest. Oct.

In 'Hym. Eur.' Fries describes the smell as somewhat strong, but not fœtid. Spores pruniform, dotted, ro-r r mk. Q. Name-argentum, silver. Silvered. Fr. Monogr. ii. p. 46. Hym. Eur. p. 36o. Grevillea, vol. xiv. $p$. 38. Ag. Krombh. t. 2. f. 27.

\section{** Gills, as well as the veil and stem, violaceous.}

44. C. violaceus Fr.-Pileus $7.5-15$ cent. (3-6 in.) broad, dark violaceous, sometimes purplish-violet, truly fleshy, convex, then flattened, regular, obtuse, villous, the innate persistent villous down for the most part rimoso-squamulose, margin at first involute; flesh soft, deeper in colour. Stem 7.5-10 cent. (3-4 in.) long, 2.5 cent. ( 1 in.) thick, solid, stout, remarkably bulbous, spongy, soft, at first tomentose, then fibrillose, dark violaceous, internally violaceous-cinereous. Cortina woolly, azure-blue, then ferruginous with the shed spores. Gills somewhat adnate, firm, distant, connected by veins, broader than the flesh of the pileus, dark almost black violaceous, then coloured with the cinnamon spores, but again violaceous when these are rubbed off.

Inodorous. Very handsome. It is easily distinguished from its allies by the colour being always dark azure-blue externally and internally, by the villous-scaly pileus, and by the distant gills.

In woods and open ground. Frequent. Sept.-Nov.

Spores sphæroid-ellipsoid, I2-I3 $\times$ 7-8 mk. $K$. Edible, excellent, resembling Agaricus campestris in flavour. Name-violaceous, of a violet colour. Fr. Monogr. ii. p. 46. Hym. Eur. p. 360. Sv. ätl. Sv. t. 58. Berk. Out. p. 187. C. Hbk. n. 505. S. Mycol. Scot. n. 462. Hussey i. t. I2. Ag. Sv. Bor. t. 288. Hedw. fil. Obs. t. 4. Bull. t. 250?

45. C. cyanites Fr.-Pileus $7 \cdot 5-12.5$ cent. ( $3-5$ in.) broad, at first dark blue, soon becoming pallid azure-blue or livid-fuscous, fleshy, soft, convex then flattened, obtuse, silky, becoming even and smooth, never floccoso-squamulose; flesh azure-blue then whitish, here and there reddish when broken. Stem 7.5-12.5 cent. (3-5 in.) long, more than 2.5 cent. (I in.) thick at the base, $12-18 \mathrm{~mm}$. $(1 / 2-3 / 4$ in. $)$ at the apex, solid, very bulbous, fibrillose, azure-dark blue, lilac when touched, also azure-blue within, but reddish blood-colour on contact with the atmosphere, and when compressed pouring out a watery vinous-reddish juice. Cortina fibrillose, azure-blue. Gills rounded, crowded, thin, $6 \mathrm{~mm}$. (3 lin.) and more broad, commonly beautifully dark blue.

A magnificent species. Var. major: pileus and stem compact, turning red more slowly, gills somewhat distant, cinereous-dark blue.

In wood. Reading. 
Inoloma. Name-кv́avos, dark blue. Fr. Monogr. ii. p. 47. Hym. Eur. p. 36o. Icon. t. I52. f. I. B. \& Br. n. I544.

46. C. albo-violaceus Fr.-Pileus $5-7.5$ cent. (2-3 in.) broad, violaceous-white, fleshy, convex, broadly umbonate or rather gibbous, dry, not moist, beautifully innately silky and becoming even; flesh juicy, azure-blue-white. Stem 5-10 cent. (2-4 in.) long, solid, firm, clavato-bulbous or conico-attenuated, $1-2.5$ cent. $(1 / 2-I$ in.) thick, externally and internally white-violaceous, whitevillous, fibrillose above with the cortina, and often with the white veil in the form of a zone at the middle. Gills adnate, scarcely emarginate, 4-6 mm. (2-3 lin.) broad, somewhat distant, somewhat serrulated, of a peculiar cinereous-violaceous colour, at length cinereous-cinnamon with the spores.

Inodorous, insipid. The fibrils on the stem are longitudinally adpressed as in $A g$. geophyllus. There is a larger form with the well-formed pileus obtuse.

In woods. Forres, \&c. Sept.-Oct.

Spores sphæroid-ellipsoid, $6-9 \times 4-5 \mathrm{mk}$. $K$. ; pruniform, ro mk. Q. Name -albus, white; violaceus, violet. Fr. Monogr. ii. p. 49. Hym. Eur. p. 36r. Icon. t. I5 . f. 3. S. Mycol. Scot. Supp. Scot. Nat. 1883, p. 31. Grevillea, vol. xii. $p .55$.

47. C. camphoratus Fr.-Pileus $5-7.5$ cent. ( $2-3$ in.) broad, at first lilac, then changing colour (becoming white, yellow, \&c.) but not hygrophanous, truly fleshy, convex then flattened, obtuse, at first silky then becoming smooth; flesh azure-blue. Stem $7.5-12.5$ cent. ( $3-5$ in.) long, $I-2.5$ cent. $(1 / 2-1$ in.) thick, solid, soft, bulbous or obclavate, when young with a woolly sheath, violet, but internally white at the base. Cortina fibrillose, azureblue, at length cinnamon with the spores. Gills at first arcuate, commonly adnato-decurrent, but varying emarginate, thin, crowded, at the first intensely azure-blue, then becoming purple.

Odour fatid and exceedingly penetrating, wholly peculiar, and different from the goat smell of $C$. truganus.

In woods. Fine shade.

Spores ochraceous-cinnamon, Fr.; $9 \times 6 \mathrm{mk}$. $K$. Name-camphoratus, strong-scented. Fr. Monogr. ii. p. 50. Hym. Eur. p. 362. Icon.t. I52.f. 2. B. E Br.n. II28. C. Hbk, n. 506.

\section{*** Gills or veil cinnamon, E.c.}

48. C. traganus Fr.-Pileus about 7.5 cent. (3 in.) broad, very fleshy, convex then flattened, obtuse, dry, at first silky, becoming even, lilac-purplish, soon becoming pale, at length becoming smooth and yellowish internally and externally. Stem 7.5-12.5 
cent. (3-5 in.) long, $I-2.5$ cent. ( $I / 2-I$ in.) thick, the villous base Inoloma. however very bulbous, $2.5-5$ cent. ( $\mathrm{I}-2$ in.) thick, solid, spongy, at first silky, then fibrillose, violaceous then whitish, internally dcep saffron-ochraceous. Cortina continuous with the silky covering of the pileus, pallid violaceous, then cinnamon with the spores. Gills emarginate, broad, distant, distinct, firm, saffron-ochraceous, at length cinnamon, somewhat crenate at the edge.

Readily distinguished by its very fotid odour, and by its thick distant gills being at the first saffron-ochraceous.

In pine woods. Forres, \&c. Aug.-Sept.

Spores sphæroid-ellipsoid, 8-1o $\times 5-6 \mathrm{mk} . K$. Name-tragus, a goat. With goat smell. Fr. Monogr. ii. p. 51. Hym. Eur. p. 362. B. \& Br. n. 1499. S. Mycol. Scot. n. 463. Ag. Schaff. t. $5^{6}$.

Var. finitimus Weinm.-Pileus silky, at length smooth, lilac, as is the stem, which is yellowish and mottled within, but not saffron-coloured nor brown. Smell not at all that of the typical form, but pleasant though peculiar, resembling that of gum just beginning to ferment.

Forres. Name-finitimus, nearly related. Weinm. p. 155. B. \& Br.n. I499. S. Mycol. Scot. sub. n. 463 .

49. C. tophaceus Fr.-Pileus about 7.5 cent. (3 in.) broad, golden-tawny, opaque, not becoming pale, compactly fleshy, thin towards the margin, hemispherical, everywhere villoso-squamulose, varying slightly silky and shining; flesh soft, white, strongsmelling. Stem solid, bulbous, villoso-squamulose, tawny, the fibrillose veil of the same colour. Gills broadly emarginate, I2 $\mathrm{mm}$. ( $1 / 2 \mathrm{in}$.) and more broad, distant, of the same colour, at length tawny-cinnamon.

Commonly springing up in a dense band, somewhat crespitose, but also solitary and then larger, in form, stature, and villoso-squamulose covering of pileus, appearing like $C$. violaceus, only that species is of an entirely different colour. Odour not remarkable. It glitters from its golden colour.

In woods. King's Lynn.

Spores ellipsoid or subglobose, 6-8 mk. C.B.P. ; $7 \times 5 \mathrm{mk}$. W.P. Name -tophus, tufa, a volcanic rock of an earthy texture. Of the colour. Fr. Monogr. ii. p. 52. Hym. Eur. p. 363. Quel. Grev. t. Iog.f. 2.

* C. redimitus Fr.-Pileus thinner, obtusely umbonate, shining, golden, streaked with innate fibrils; flesh white. Stem 2.5-5 cent. ( I-2 in.) long, slightly thickened at the base, I $2 \mathrm{~mm}$. ( $1 / 2 \mathrm{in}$. ) thick, solid, internally soft, fibroso-striate, yellowish. Gills adnate, with a small decurrent tooth, light yellow then tawny.

In mixed wood. Glamis, 1875 . Oct. Name-redimio, to wreathe round, 
Inoloma. encircle. Perhaps of the fibrillose streaking. Fr. Monogr. ii. $p .52$. Hym. Eur. p. 363. Icon. t. 153.f. 1. B. E Br. n. 1545. S. Mycol. Scot. n. 464.

50. C. callisteus Fr.-Pileus 5 cent. ( 2 in.) broad, yellowtawny, not hygrophanous and not becoming pale, fleshy, thin, especially at the bent-in margin, convexo-expanded, scarcely umbonate, rather smooth, silky towards the margin, but commonly broken up into minute innate squamules; flesh yellowishwhite. Stem 7.5-12.5 cent. (3-5 in.) long, clavato-bulbous, equally attenuated upwards, $12 \mathrm{~mm}$. ( $1 / 2 \mathrm{in}$.) and more thick at the base, solid, remarkably fibrillose or striate, externally and internally firm and yellow, rhubarb-colour, soft and spongy only at the base. Cortina marginal, fibrillose, fugacious, yellowtawny. Gills wholly adnate, adnexed behind mutually and to the stem with flocci, plane, somewhat distant, distinct, $8 \mathrm{~mm}$. (4 lin.) broad, thin, quite entire, yellow-tawny.

Odour none. Very remarkable. The figure of Saunders and Smith represents it admirably as regards stature and characters, but departs from it in the ferruginous colour.

In woods. Rare. July.

The colours are nearly those of $A$. aureus. $M . \mathcal{F} . B$. Spores $8 \times 6 \mathrm{mk}$. W.G.S. Name-кádos, beautiful. Very beautiful. Fr. Monogr. ii. $p .53$. Hym. Eur. p. 363. Berk. Out. p. 187. C. Hbk.n.507. S. Mycol. Scot. n. 455. Saund. \&ू Sm. t. 3. A. validus Berk. Eng. Fl. v. p. 84.

51. C. Bulliardi Fr.-Pileus $5-7.5$ cent. (2-3 in.) broad, dark rufescent, bay-brown-blood-colour becoming pale, fleshy, convex then expanded, obtuse, dry, commonly smooth, but also wholly fibrillose. Stem 5-7.5 cent. (2-3 in.) Iong, $12 \mathrm{~mm}$. ( $1 / 2 \mathrm{in}$.) thick, solid, fibrillose, variegated blood-red downwards as is also the ovate bulb, white at the apex. Cortina fugacious, whitish. Gills adnexed, with a decurrent tooth, $6 \mathrm{~mm}$. (3 lin.) broad, somewhat crowded, purplish then ferruginous, crenulated at the (whitish) edge.

Flesh whitish, but that of the stem rufescent at the base. Readily distinguished by its cinnabar bulb. Stature small but firm. Strong smelling.

In mixed woods. Bristol, \&c. Sept.

Name-after Bulliard. Fr. Monogr. ii. p. 53. Hym. Eur. p. 363. Berk. Out. p. 187. C. Hbk. n. 508. S. Mycol. Scot. n. 466. Quel. t. 9. f. 3 (departing from type). Ag. Bull. t. 43т. f. 3 .

52. C. bolaris Fr.-Pileus $2.5-5$ cent. ( $1-2$ in.) and more broad, light yellow-red, or pale, smooth or variegated with innate, adpressed, spot-like, red scales, rarely of one colour with continuous scales, fleshy, convexo-plane, obsoletely umbonate; flesh very 
firm, white. Stem 5-7.5 cent. (2-3 in.) long, 6-10 mm. (3-5 lin.) Inoloma. thick, stuffed, sometimes hollow, hard, equal, pale, beautifully variegated with saffron-red, adpressed, fibrillose scales, white at the apex, sometimes continuously scarlet. Cortina fibrillose, fugacious, saffron-red. Gills commonly decurrent, arcuate, sometimes adnate, even emarginate, crowded, at first pale then dark cinnamon.

The stem varies straight, curved and elongated and flexuous. Very elegant. Sometimes solitary, sometimes somewhat cæspitose.

In beech woods. Uncommon. Sept.-Nov.

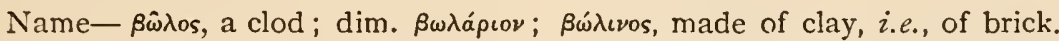
Perhaps in allusion to the red colour. When young like a red clod. Fr: Monogr. ii. p. 54. Hym. Eur. p. 364. Berk. Out. p. 188. t. I9. f. I. C. Hbk. n. 509. S. Mycol. Scot. n. 467. Grevillea, t. 79. Ag. Pers. Ic. Pict. t. I4. f. I.

\section{**** Gills or veil dark, fuscous, olivaceous.}

53. C. pholideus Fr.-Pileus 5-Io cent. (2-4 in.) broad, fawncolour, becoming pale, at length somewhat cinnamon, fleshy but thin, convex then flattened, somewhat umbonate and depressed round the umbo, scaly and squarrose with innate, piloso-fasciculate, crowded, fuscous-blackish fibres, which are fewer towards the margin; flesh pallid. Stem 7.5-10 cent. (3-4 in.) long, 6-12 mm. (3-6 lin.) thick, solid, attenuated upwards (sometimes shorter and clavato-bulbous), scaly as far as the somewhat annular cortina with fibrillose, crowded, somewhat concentric, fuliginous-black scales; above the universal cortina even and pallid violaceous, furnished with a spider-web cortina (double veiled). Gills somewhat emarginate, crowded, thin, 4-8 $\mathrm{mm}$. (2-4 lin.) broad, at first violaceous then clay-colour, at length dark cinnamon with the spores.

Very distinct and very beautiful; readily recognised by the gills being at the first violaceous, and by the pileus and stem being squarrose with fuliginousblackish scales.

In woods. Frequent. Sept.-Oct.

Spores subsphæroid, 6-7 $\times$ 5-6 mk. $K$. Name - podis, a scale. Scaly. Fr. Monogr. ii. p. 55. Hym. Eur. p. 364. Berk. Out. p. 188. C. Hbk. n. 510. S. Mycol. Scot. n. 468. Ag. Alb. \& Schw. t. I2.f. r.

54. C. sublanatus Fr.-Pileus 7.5-10 cent. (3-4 in.) broad, fawn-colour, then becoming tan-fuscous, at length becoming ferruginous, slightly fleshy, campanulate then expanded, umbonate, clothed with innate, floccose, fuscous squamules; flesh comparatively thin, whitish. Stem 7.5 cent. (3 in.) long, solid, 
Inoloma. conico-elongated or clavato-bulbous, as much as 2.5 cent. (I in.) thick at the base, clothed to the middle with fuscous down continued into a fibrillose cortina which does not form a zone, at the apex slightly violaceous, naked. Gills adnate, broader behind, scarcely crowded, $6 \mathrm{~mm}$. (3 lin.) broad, olivaceous-yellowish, at length cinnamon.

The squamules on the pileus are less compact and not so much crowded as those of $C$. pholideus.

In woods. Rare. Oct.

Spores ovoid-pruniform, dotted, ro mk. $Q$. Name-lana, wool. Somewhat woolly. Fr. Monogr. ii. p. 55. Hym. Eur. p. 364. Berk. Out. p. 188. C. Hbk. n. 511. Ag. Sow. t. 224. Hussey ii. t. 22.

55. C. arenatus Fr.-Pileus pale yellowish-fuscous, fleshy, convex, at first gibbous, granulose with floccose squamules. Stem clavato-attenuated, sheathed beyond the middle, fuscous-squamulose, even at the apex, pallid. Gills emarginate, ventricose, somewhat crowded, yellowish-cinnamon.

Closely related to $C$. sublanatus; when young also olive, not easily distinguished from forms of $C$. pholideus which have changed their colour, but the gills are never violaceous.

In woods. Uncommon. Aug.-Oct.

Spores 6-7 $\times 4-5 \mathrm{mk}$. W.P. Name-arena, sand. ${ }_{\text {F }}$ From the granulose pileus. Fr. Hym. Eur. p. 365. Berk. Out. p. 188. C. Hbk. n. 512. S. Mycol. Scot. n. 469. Hussey i. t. 72. Ag. Bull. t. 586.

56. C. penicillatus Fr.-Pileus 2.5 cent. ( $\mathrm{I}$ in.) or little more broad, ferruginous-fuscous, becoming tawny when dry, thin, slightly fleshy, convex, minutely umbonate, dry, densely floccososcaly, scales innate, dark, ferruginous-fuscous; flesh very thin, of the same colour as the pileus. Stem 5-7.5 cent. (2-3 in.) long, 4-6 mm. (2-3 lin.) thick, stuffed, equal, fragile, squamose almost to the apex with adpressed, fuscous-ferruginous, concentric scales, paler than the pileus, paler and adpressedly silky at the very apex. Gills separating, plane, somewhat crowded, $6 \mathrm{~mm}$. (3 lin.) broad, dark brown.

Placed here on account of the innately squamulose pileus and its affinity with species in this section, but its stature is quite that of the Dermocybe.

In pine woods. Cabalva. Sept.-Oct.

Spores pruniform, rough, 7-8 mk. $Q$. Name-penicillum, a painter's brush. Pencilled. Fr. Monogr. ii. p. 56. Hym. Eur. p. 365. Grevillea, vol. viii. p. 77 . 
Tribe IV. DERMOCYBE ( $\delta \dot{\epsilon} \rho \mu \alpha$, skin; ки̌ß̧́, a head). Pileus Dermocybe. thinly and equally fleshy, at first silky with somewhat innate villous down, but becoming smooth when old, dry and not hygrophanous. Flesh watery when moist or coloured. Stem equal or attenuated, externally more rigid, elastic or brittle, internally stuffed or hollow. Veil single, fibrillose, forming a zone in C. caninus. A natural group, easily distinguished from Inolomata by the thinness and substance of the pileus and by the stem; and from the following subgenera by the pileus not being moist or hygrophanous, and by its short floccose or atomate covering, its brighter colour, \&ce. Fr. Hym. Eur.p. 366.

The species of this subgenus are very changeable, and not easily de-

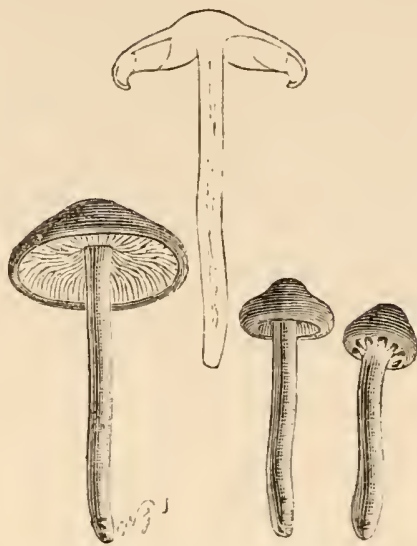

XLIII. Cortinarius (Dernocybe) cinnamomeus. One-third natural size. fined on account of the changeable colour of the gills. It comprehends two primary types; first that of $C$. anomalus with the flesh of the pileus white, and secondly that of $C$. cimnamomeus with the flesh scissile and coloured. Fr. Monogr. ii. $p .57$.

* Gills at first whitish or pallid.

* Gills at first violaceous, becoming purple.

** Gills brightly cinnamon, red, yellow. coloured. Elegant.

**** Olivaceous, veil dingy pallid or fuscous. Pileus not torn into scales.

* Gills at first whitish or pallid.

57. C. ochroleucus Fr.-Pileus 5 cent. ( 2 in.) broad, pale-white, fleshy, especially at the disc, broadly campanulate then expanded and somewhat gibbous, delicately and slightly silky, then becoming smooth, even; flesh firm, white. Stem 7.5 cent. (3 in.) long, $12 \mathrm{~mm}$. ( $1 / 2 \mathrm{in}$.) thick, solid, ventricose, naked, white, fibrillose at the apex with the cortina. Gills broader behind, adnexed, then separating-free, $6 \mathrm{~mm}$. (3 lin.) broad, crowded, clay-colour then ochraceous.

Odour none, taste remarkable, bitterish, not unpleasant. B. larger and more robust. Pileus 5-7.5 cent. ( $2-3$ in.), somewhat obtuse, ochrey-white. Stem as much as 2.5 cent. (I in.) thick, attenuated upwards. Gills adnate, pallid clay then cinnamon. 
Dermocybe. In mixed woods. Rare. Oct.

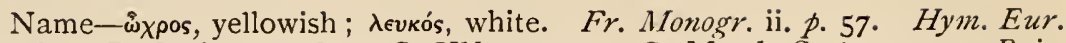
p. 366. Berk. Out. p. 189. C. Hbk. n. 513. S. Mycol. Scot.n. 470. Brig. t. 31. f. 1-4. Ag. Schaeff. t. 34 .

58. C. decumbens Fr.-Pileus 2.5-4 cent. ( $1-1 / 2$ in.) broad, sometimes entirely white, sometimes yellowish, shining, by no means hygrophanous, fleshy, firm, convex then plane, gibbous then obtuse, even, smooth. Stem $2.5-5$ cent. ( $1-2$ in.) long, about $6 \mathrm{~mm}$. (3 lin.) thick, stuffed, at length hollow, ascending, clavatobulbous downwards, smooth, white. Cortina fugacious, white. Gills adnexed, crowded, $4 \mathrm{~mm}$. ( 2 lin.) broad, thin, white then clay-colour, and at length ochrey-cinnamon with the spores.

Pileus silky-shining with a fibrillose pellicle, though smooth.

In woods. Epping.

Name-from the decumbent stem. Fr. Monogr. ii. p. 57. Hym. Eur.p. 366. B. \& Br.n. 1775 .

59. C. tabularis Fr.-Pileus 7.5 cent. ( 3 in.) and more broad, clay or fuscous-clay becoming pale, equally fleshy, not compact, convexo-plane, broadly gibbous, at length becoming remarkably plane, at first veiled with very thin, white flocci, silky near the margin, then wholly smooth; flesh white. Stem 5-7.5 cent. (2-3 in.) long, $6 \mathrm{~mm}$. (3 lin.) and more thick, stuffed, at length hollow, tough, elastic, attenuated from the base or equal, erect, sometimes floccoso-scaly, sometimes even, somewhat smooth, white, becoming pale. Cortina white, fugacious. Gills somewhat emarginate, crowded, thin, $6 \mathrm{~mm}$. (3 lin.) broad, whitish then clay-colour.

Sometimes the pileus is slightly concave, retaining water, and then the flocci are broken up and collected in the form of a zone round the margin. At the first the gills more rarely but slightly and very fugaciously incline to bluish-grey. A form has occurred with the gills at length ferruginous. Larger, paler, and smoother than $C$. anomalus to which it approaches.

In woods. Common. Sept.-Oct.

Name-tabula, a flat board or tablet. From the flat pileus. Fr. Monogr. ii."p. 58. Hym. Eur. p. 366. Berk. Out. p. 189. C. Hbk. n.514. S. Mycol. Scot.n. 47r. Bull. t. 43r.f.5.

60. C. camurus Fr.-Pileus $5-7.5$ cent. ( $2-3$ in.) broad, pallid fuscous-hoary, not hygrophanous, but becoming pale, pallid yellowish, umbo deeper in colour, very unequally fleshy, somewhat compact at the disc, but membranaceous almost to the middle, with a broad, obtuse, often oblique umbo, when dry rimosely incised; flesh white. Stem 7.5 cent. (3 in.) long, 8 mm. (4 lin.) 
thick, somewhat hollow, equal, always ascending or twisted, even, Dermocybe. smooth or fibrillose below, externally and internally white, naked and silvery-shining at the apex. Gills variously adnexed on account of the oblique pileus, sometimes broader behind and wholly adnate, sometimes almost free, crowded, $6 \mathrm{~mm}$. (3 lin.) broad, thin, grey-clay-colour, then watery cinnamon and somewhat fuscous, quite entire and of the same colour at the edge.

Odour somewhat rancid, but taste not remarkable. Different from all neighbouring species in being remarkably fragile.

In mixed woods. England. Glamis. Oct.

Name-camurus, crooked. Of the stem. Fr. Monogr. ii. p. 59. Hym. Eur. p. 367. Icon. t. I54. f. I. B. \& Br. n. I546. S. Mycol. Scot. n. 472. Bull.t. 43 I. $f .4$.

61. C. diabolicus Fr.-Pileus 2.5 cent. ( $\mathrm{I}$ in.) and more broad, at first fuscous and crusted with grey, then smooth and fuscousyellowish, fleshy, thin, hemispherical, obtuse, then gibbous, dry, fragile, at length cracked. Stem 7.5 cent. (3 in.) long, commonly thin, $4 \mathrm{~mm}$. (2 lin.) (but occurring as much as Io mm., 5 lin.) thick, stuffed, attenuated downwards, smooth, pale, bluish-grey at the apex. Cortina fugacious. Gills adnate, separating, somewhat emarginate, somewhat crowded, $4 \mathrm{~mm}$. (2 lin.) and more broad, firm, very pale bluish-grey then soon whitish, at length clay-colour.

Inodorous. A singular species, placed here on account of its colours. When old it might be readily taken for $C$. raphanoides.

In mixed woods. Uncommon. Aug.-Oct.

Name-"Called diabolicus because it holds a doubtful place among all the sections of this subgenus." Fr. Fr. Monogr. ii. p. 6o. Hym. Eur. p. 367. Berk. Out. p. I89. C. Hbk. n. 515. S. Mycol. Scot.n. 473 .

** Gills at first violaceous, becoming purple.

62. C. caninus Fr.-Pileus 7.5-1o cent. (3-4 in.) broad, variable in colour, fuscous, brown, \&c., equally fleshy, not compact, firm, not cracked, convex then becoming plane, obtuse, at first incrusted or hoary with silky villous down round the margin; when full grown becoming smooth; flesh white, at length somewhat yellowish. Stem 7.5 cent. ( 3 in.) and more long, $12 \mathrm{~mm}$. ( $1 / 2 \mathrm{in}$.) thick, stuffed, spongy internally, at length hollow, thickened at the base, somewhat bulbous, often white-villous, pale-white, violaceous at the apex. Gills emarginate, somewhat distant, thin, 6-8 mm. (3-4 lin.) broad, bluish-grey or purplish then cinnamon.

The pileus is commonly brick.rufescent when old even becoming tawny 
Dermocybe. when dry. The veil in the perfect state is double, the inferior one fibrillose or scaly clothing the greater part of the stem, and terminating near the apex in an annular (white or fuscous) zone, above which the stem is slightly villous and cortinate. Allied to $C$. tabularis as to stature, and distinct from C. anomalus in the stem being sheathed, veiled and adpressedly fibrous, somewhat annularly zoned above, and in the pileus being fuscous then rufescent.

In mixed woods. Common. Sept.-Nov.

Spores subsphæroid, 8-Io $\times 7-8 \mathrm{mk} . K$. Name-canis, a dog. Of doubtful meaning. Applied to various common plants. Fr. Monogr. ii. p. 6o. Hym. Eur. p. 368. Berk. Out.p. 189. C. Hbk. n. 516. S. Mycol. Scot. n. 474. Saund. EN Sm. t. 15. Ag. Buxb. C. 4. t. 22. Bull. t. 544.f. I.

63. C. myrtillinus Fr.-Pileus $5-7.5$ cent. (2-3 in.) broad, pure fuliginous, hoary-silky with dense fibrils, never rufescent, fleshy, thin, tough, gibbous then becoming plane; flesh when moist watery fuscous, when dry white, violaceous at the apex of the stem. Stem 5 cent. ( 2 in.) or a little more long, 6-8 mm. (3-4 lin.) thick, stuffed, externally tough, slightly bulbous, white-silky, whitish. Cortina scarcely manifest. Gills adnate, somewhat distant, of a beautiful amethyst-azure-blue, scarcely changing colour, never becoming purple.

The pileus is not at the first so convex as that of $C$. anomalus. The colour and habit are so like those of $A g$. nudus, that those who say that that species is furnished with a veil seem really to have had this before them.

In mixed woods. Glamis, 1875. Rannoch. Sept.

Name-myrtus, myrtle. Of colour (myrteus), chestnut-brown. Fr. Monogr. ii. p. 6r. Hym. Eur. p. 368 . B. \&o Br. n. 1547. S. Mycol. Scot. n. 475 . Bolt. $t$. I47.

64. C. anomalus Fr.-Pileus 2.5 cent. (I in.) and more broad, fuliginous then rufescent, becoming hoary with separating fibrils, at length yellowish, but not hygrophanous, fleshy, thin, remarkably convex, then expanded and gibbous; flesh watery when moist, white when dry, not scissile. Stem $5-7.5$ cent. (2-3 in.) and more long, $6 \mathrm{~mm}$. (3 lin.) thick, stuffed then hollow, attenuated from the base, slightly sheathed, fibrillose or somewhat scaly, violaceous above, whitish below, of the same colour internally; at length becoming pale, somewhat yellow. Gills sometimes adnate, sometimes emarginate, with a decurrent tooth, crowded, thin, more or less violaceous, bluish-grey-purplish, at length cinnamon.

Very thin, inodorous, more or less gregarious. Cortina coloured. There is a more slender variety in pine woods, with the stem thin, equal, smooth, and flexuous.

In woods. Common. Aug.-Oct. 
The colour (even of the gills) is very changeable. Spores ellipsoid-sphæroid, Dermocybe. 8-9 $\times 6-7 \mathrm{mk}$. $K$. Name $-\dot{\alpha}$, ómadós, even. Irregular, anomalous. Fr. Monogr. ii. p. 62. Hym. Eur. p. 369. Icon. t. 154.f. 2. Berk. Out. p. I90. C. Hbk. n. 517. S. Mycol. Scot. n. 476. Ag. Bull. t. 43r.f. 2.

65. C. spilomeus Fr.-Pileus 2.5 cent. (I in.) broad, rufescent or clay-colour, not hygrophanous, somewhat fleshy, convex then expanded, gibbous, becoming smooth. Stem 5 cent. (2 in.) long, thin, 2-4 mm. ( $\mathrm{I}-2$ lin.) thick, fistulose, somewhat equal, whitelilac and beautifully variegated with rufous or tawny scales, furnished with a white cortina at the apex. Gills adnate or emarginate, crowded, narrow, thin, quite entire, bluish-grey or violaceous, becoming pale, at length watery cinnamon.

Very elegant, commonly cæspitose. The scales on the stem are like those of $C$. pholideus but with the colour of those of $C$. bolaris.

In woods. Uncommon.

Spores subsphæroid, 8-9 $\times 7-8 \mathrm{mk}$. $K$. Name- $\sigma \pi \hat{\imath}$. Nos, a spot. From the variegated marking of the stem. Fr. Monogr. ii. p. 63. Hym. Eur. p. 369. Icon. t. 154. f. 3. Berk. Out. p. 190. C. Hbk. n. 518. Ag. Brig.t. 28. f. $4^{-6 .}$

\section{*** Gills brightly cinnamon, \&oc.}

66. C. miltinus Fr.-Pileus $2.5-4$ cent. ( $1-1 / 2$ in.) broad, baybrown-cinnamon or when moist dark cinnamon, when dry shining, brick-colour, disc somewhat bay-brown, fleshy, thin, convex or lens-shaped then expanded, obtuse or broadly gibbous, even, polished-smooth, scissile at the disc; flesh watery when moist, tan when dry. Stem 5-7.5 cent. (2-3 in.) long, 4-6 mm. (2-3 lin.) thick, fistulose, very tough, somewhat cartilaginous, equally attenuated upwards, often twisted, white-tomentose at the base, cinnamon or reddish, with red fibrils, often villous at the apex with the red cortina. Gills adnate, $2-3 \mathrm{~mm}$. ( $\mathrm{I}-\mathrm{I} \mathrm{I} / 2 \mathrm{lin}$.) broad, almost linear, plane, crowded, thin, beautiful reddishcinnamon then ferruginous.

Odour none. Although the pileus is moist in rainy weather and becomes pale when dry, it cannot be called hygrophanous. An elegant and remarkable species, the type of the group. The habit is that of preceding species, but the colours are those of C. cinnamomeus.

In mixed woods. Ledbury.

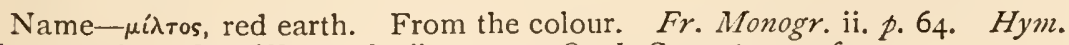
Eur. p. 369. Grevillea, vol. xii. p. 42. Quel. Grev. t. I10.f. 3.

67. C. cinnabarinus Fr.-Pileus $5-7.5$ cent. $(2-3$ in.) broad, scarlet-red, truly fleshy, campanulate, then flattened, obtuse or very obtusely umbonate, silky, then becoming smooth and shin-

VOL. II. 
Dermocybe. ing, or obsoletely scaly; the firm flesh paler. Stem 4-5 cent. ( $1 \frac{1}{2}-2$ in.) long, 6-8 mm. (3-4 lin.) and more thick, solid, equal, sometimes however bulbous, fibrillose or striate, scarlet-red, reddish-brick-colour internally. Cortina fibrillose, lax, cinnabar. Gills wholly adnate, somewhat decurrent, $6 \mathrm{~mm}$. (3 lin.) broad, somewhat distant, connected by veins, unequal and darker at the edge, dark blood-colour when bruised.

Odour of radish. Readily distinguished from all others by its splendid scarlet colour, and from $C$. sanguineus by its short solid and firm stem, its broad pileus, and somewhat distant gills. Stem never becoming yellow.

In beech woods. Street, \&c. Oct.

Name-cinnabaris, dragon's blood. From the colour. Fr. Monogr. ii. p. 64. Hym. Eur. p. 370. Icon. t. I54. f. 4. S. Mycol. Scot. Supp. Scot. Nat. 1882, p. 217. Quel. Grev. t. I 10. f. 4 .

68. C. sanguineus Fr.-Pileus $2.5-4$ cent. ( $\mathrm{I}-\mathrm{I} 1 / 2$ in.) broad, blood-colour, becoming slightly pale when dry, fleshy, thin, convex then plane, obtuse, occasionally depressed, silky or squamulose; flesh reddish, paler. Stem 5-7.5 cent. ( $2-3$ in.) long, 4-6 mm. (2-3 lin.) thick, stuffed then hollow, equal (rather attenuated than thickened at the base), here and there flexuous, with fibrils of the same colour, almost darker than the pileus. Cortina arachnoid, fugacious, red blood-colour. Gills adnate, crowded, 4-6 mm. (2-3 lin.) broad, quite entire, dark bloodcolour.

Wholly dark blood-colour, the stem when compressed pouring forth bloody juice. Odour of radish. Thinner than species nearest to it. The spores are ochraceous on a white ground, somewhat ferruginous on a black ground.

In woods, chiefly pine. Frequent. Sept.-Oct.

Spores $6 \times 4 \mathrm{mk}$. W.G.S. Name-sanguis, blood. From the colour. Fr. Monogr. ii. p. 65. Hym. Eur. p. 370. Berk. Out. p. 190. C. Hbk. n. 519. S. Mycol. Scot. n. 477. Ag. Wulf. in Facq. Coll. 2. t. 15. f. 3. Sow. t. 43. Bolt. t. 36. Klotsch Bor. t. 385. Krombh. t. 2. f. 28-30.

69. C. anthracinus Fr.-Pileus dark chestnut or brown-fuscous, fleshy at the umbonate disc, otherwise thin, convex then expanded, umbo persistent, becoming fibrillose-even or smooth; flesh very dark, of the same colour as the pileus. Stem 5 cent. ( 2 in.) long, $4 \mathrm{~mm}$. ( 2 lin.) thick, fistulose, equal, fibrillose, of an intense blood-colour, fuscous towards the base. Gills adnate, crowded, deep red or fiery in colour, blood-red when bruised.

Very elegant and most distinct; smaller in all its parts than those nearest to it.

In woods. Coed Coch. 


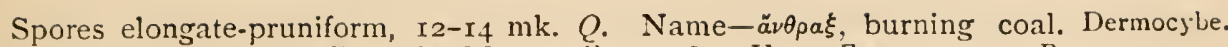
From the colour of the gills. Fr. Monogr. ii. p. 308. Hym. Eur. p. 370. B. \& Br.n. I269. Quel. Grev. t. in . f. i.

70. C. cinnamomeus Fr.-Pileus I-Io cent. ( $1 / 2-4$ in.) broad, somewhat cinnamon, fleshy, thin, obtuse, umbonate, silky or squamulose, with innate yellowish fibrils, at length becoming smooth. Stem stuffed then hollow, thin, equal, yellowish as well as the flesh and veil. Gills adnate, broad, crowded, shining.

There are innumerable forms sufficiently constant; the essential marks which are common to all are these: I) Pileus thin, when flattened obtusely umbonate, silky with yellowish villous down, but when more fully grown often becoming sinooth and then bright cinnamon, but the colour is variously changed. 2) Stem wholly equal, stuffed then hollow, yellowish, fibrillose with the cortina, which is of the same colour. 3) Flesh scissile, yellowish. 4) Gills adnate, crowded, thin, broad, always shining. 5) Spores dark ochraceous. The colour of the gills varies blood-red, red cinnamon, saffron-tazuny, golden, light yellow, \&c.

In mixed woods. Common. Aug.-Nor.

Name-cinnamomum, cinnamon. From the colour. Fr. Monogr. ii. $p .65$. Hym. Eur. p. 370. Berk. Out. p. 190. C. Hbk. n. 520. S. Mycol. Scot. n. 478. Ag. Krombh. t. 7 r. f. I2-15. Letell. t. 618. Brigant. t. 30. f. 1-4. Bolt. t. I50. Sow. t. 205 .

71. C. uliginosus Berk.-Pileus not exceeding 5 cent. ( 2 in.) in diameter, bright red-brown (almost bx̧ick-red), campanulatoconical, then expanded, very strongly umbonate, silky, sometimes streaked; flesh yellow-olive then cinnamon. Stem flexuous, paler than the pileus. Gills distant, adnate, with a tooth, yellow then olive, then cinnamon.

Remarkable for its very strong, but scarcely acute umbo.

In boggy woods among Sphagnum. King's Cliffe, \&c.

Name-uligo, marshy ground. From its habitat. Berk. Out. p. Igo. C. Hbk. n. 521. S. Mycol. Scot. n. 479. Fr. Hym. Eur. p. 371.

72. C. orellanus Fr.-Pileus orange-tawny, fleshy, obtusely umbonate, villoso-squamulose or fibrillose, the flesh, which is similar in colour to the pilens, reddening. Stem solid, firm, somewhat equal, striato-fibrillose and, as well as the cortina, tawny. Gills adfixed, broad, somewhat distant, at length opaque.

It differs from $C$. cinnamomeus: I) stem solid, firmer, striato-fibrillose, and, as well as the cortina, tawny; 2) the ground colour of the firmer pileus also tawny, the fibrillose covering orange; 3) the similar flesh reddening; 4) gills broader, firmer, and somewhat distant. C. cinnabarinus, with which it has been confounded, is quite different in colours, and especially in that of the stem being the same as the pileus, not yellowish.

In mixed woods. Coed Coch, \&c. Sept.-Oct. 
Dermocybe. Spores pruniform, Io $\times 4-5 \mathrm{mk}$. C.B.P. $; 7 \times 4 \mathrm{mk}$. W.P. Name-meaning not apparent. Fr. Monogr. ii. p. 66. Hym. Eur. p. 371. B. E Br.n. 1270. S. Mycol. Scot. n. 480. Ag. Bull. t. 598. Perhaps Fungh. Linn. v. t. 6. f. 19.

73. C. infucatus Fr.-Pileus $2.5-4$ cent. ( $I-I / 2$ in.) broad, yellow, not hygrophanous, fleshy, comparatively small, convex, obtuse, silky when dry, even; flesh whitish. Stem 7.5 cent. (3 in.) long, equally attenuated upwards from the clavate base (I2 $\mathrm{mm}$., $1 / 2$ in. thick), 4-6 mm. (2-3 lin.) thick at the apex, solid, even, fibrillose, externally and internally pallid light-yellow. Cortina manifest, yellow, then darkened with the cinnamon spores. Gills adnate, crowded, thin, $2 \mathrm{~mm}$. ( $\mathrm{I}$ lin.) broad, almost linear, tawny then cinnamon.

Remarkable for its bright yellow colour. It approaches $C$. percomis and $C$. callisteus; the former is readily distinguished by its viscous pileus and yellow flesh, the latter with more difficulty by its robust stature, by the pileus being smooth then slightly cracked with minute squamules, but especially by its firmer broad distant gills.

In woods. Haywood Forest, Hereford. Oct.

Name-fuco, to paint. From its bright colour. Fr. Monogr. ii. $p$. 309. Hym. Eur. p. 372. Icon. t. I55.f. 2. Grevillea, vol. xii. p. 42.

**** Olivaceous, veil dingy pallid, \&c.

74. C. cotoneus Fr.-Pileus 7.5 cent (3 in.) broad, everywhere clothed with a velvety, dense, beautifully olivaceous covering, fleshy, but not compact, lax, campanulate then expanded, obtuse, somewhat repand, fragile when old; flesh thin for its breadth, soft, olivaceous-pale. Stem 7.5 cent. (3 in.) long, $12 \mathrm{~mm}$. ( $1 / 2 \mathrm{in}$.) thick, solid, stout, soft, bulbous, somewhat fibrillose, olivaceouspallid. Veil persistent, woven into a fuscous zone towards the apex of the stem. Gills adnate, separating, somewhat crowded, 4-6 mm. (2-3 lin.) broad, olivaceous then cinnamon, of the same colour and quite entire at the edge.

Handsome, soft to the touch, opaque.

In oak woods. Clifton.

Name-кótcvos, wild olive. From the colour. Fr.Monogr. ii. p. 68. Hym. Eur.p. 372. B. \& Br.n. 1960. Quel. Grev. t. IrI.f. 5 .

75. C. raphanoides Fr.-Pileus $2.5-5$ cent. ( $1-2$ in.) broad, fuscous-olivaceous, when fuller grown changing colour, becoming tawny, slightly fleshy, campanulate then expanded, obtusely umbonate, often undulated, silky-fibrillose, when fuller grown becoming smooth, flesh pallid, almost of the same colour. Stem about 
5-7.5 cent. ( $2-3$ in.) long, equally attenuated upwards, 6-10 mm. Dermocybe. (3-5 lin.) thick, rarely equal, stuffed, but in no wise furnished with a hark, fibrillose, opaque, pale. Veil filamentous, pallid olive. Gills adnate, slightly ventricose, scarcely crowded, somewhat olivaceous, at length cinnamon and somewhat ferruginous, edge paler.

Odour of radish, taste bitter. Protean like C. cinnamomens. It varies with the stem elongated and twisted. The gills change colour with the state of the atmosphere, so that it is often difficult to recognise it.

In beech and fir woods. Frequent. Sept.-Oct.

Name-raphanus, radish. From the smell. Fr. Monogr. ii. p. 69. Hym. Eur. p. 373. Berk. Out. p. I9r. C. Hbk. n. 522. S. Mycol. Scot. n. 48 r. Mich. t. 75.f. 2? Quel. Grev. t. III. f. 6.

76. C. venetus Fr.-Pileus $4-5$ cent. $(1 / 2-2$ in.) broad, when young green, then greenish-yellow, when dry more yellow, but not hygrophanous, fleshy, hemispherical, obtuse, equal, velvety or tomentose, the very thin erect down persistent; flesh yellowishpallid. Stem 5-7.5 cent. (2-3 in.) long, 6-8 mm. (3-4 lin.) thick, stuffed or hollow upwards, equal, firm, curved, of the same colour as the pileus or a little paler, externally remarkably fibrillososilky, greenish-yellow. Cortina fibrillose, green. Gills adnate, connected by veins, somewhat distant, very broad, in the form of a segment, darker than the pileus, olivaceous.

Gregarious. Most distinct. The stem is often yellow-villous at the base. The yellow covering of the pileus readily distinguishes it from former species.

In woods. Rannoch. Oct.

Spores ovoid, punctate, ro mk. Q. Name-venetus, sea-coloured. Fr. Monogr. ii. p. 70. Hym. Eur. p. 374. Icon. t. I55. f. 4. B. \& Br.n. 1548. S. Mycol. Scot. n. 482 .

Tribe $V$. TELAMONIA ( $\tau \in \lambda a ̆ \mu \omega ́ \nu$, lint). Fr. Syst Myc. i. p. Telamonia. 2 Io. Pileus moist, hygrophanous, at the first smooth or sprinkled with superficial whitish fibres of the veil. Flesh thin throughout or becoming so abruptly at the margin (not equally attenuated), scissile. Stem anmulate below from the universal veil or peronate with scales, somewhat cortinate at the apex, hence the veil is somewhat double. To this subgenus are referred some species, intermediate between this and the preceding one, on account of their double veil, the universal one forming a slight ring, and their pilens not being silky, \&c. Fr. Hym. Eur.p. 374. 
Telamonia. I. Platyphylli ( $\pi \lambda \alpha \tau u ́ s$, broad; $\phi u ́ \lambda \lambda o \nu$, a leaf). Gills very broad, rather

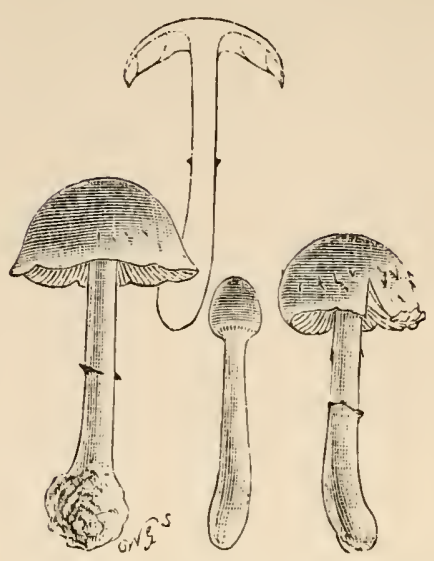

XLIV. Cortinarus (Telamonia) armillatus. One-fifth natural size.

**** Stem floccoso-scaly, and, as well as the pileus, fuscous.

\section{I.-Platyphylli.}

* Stem and cortina white or whitish.

77. C. macropus Fr.-Pileus 7.5 cent. ( 3 in.) broad, brickcolour, at length becoming ferruginous, fleshy, comparatively thin, convex then flattened, margin at the first inflexed, obtuse, dry, hoary with very small squamules, then becoming smooth; flesh cinereous. Stem 7.5-I5 cent. (3-6 in.) long, I-2.5 cent. $(1 / 2-I$ in.) thick, solid, somewhat equal, stout, fibrillose, dingy whitish, then of the same colour as the pileus. Veil distant from the pileus, woven into a narrow ring, white. Gills adnexed, very broad ( $\mathrm{I}-2.5$ cent., $1 / 2-\mathrm{I}$ in.), distant, even at the sides, sometimes crenated, sometimes quite entire, pallid then watery cinnamon.

Pileus not compact.

In woods. Leigh Wood, Bristol. Oct.

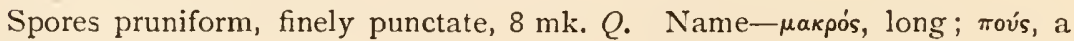
foot. Long-stemmed. Fr. Monogr. ii. p. 7r. Hym. Eur. p. 374. Bucknall, Brist. Nat. Soc. Proc. vol. iv. t. 4 .

78. C. bivelus Fr.-Pileus 5-1o cent. (2-4 in.) broad, tawnyferruginous, here and there spotted or darker at the disc, not truly hygrophanous, somewhat equally fleshy, convexo-plane, always obtuse, soft, bibulous, smooth or slightly silky only round the 
margin, commonly shining, rarely opaque, sometimes rimulose. Telamonia. Stem solid, fleshy-spongy, sometimes bulbous, sometimes longer, equally attenuated, more frequently curt, thick, dingy white, internally somewhat ferruginous. The exterior veil villous, sheathing, white, terminating in a spurious and fugacious ring, above which the thin cortina is vanishing. Gills adnate or somewhat emarginate, at first somewhat crowded, then somewhat distant, more or less broad, bright tawny-cinnamon.

The pileus is pierced as with pores, a feature which is peculiar to most of the Telamonice, and which seems to have its origin in larvæ. Growing in troops, strong smelling, taste pleasant. The stem is in no wise more rigid externally like that of the somewhat similar $C$. subfermigineus. There is a variety in which the pileus is campanulate and lax.

In woods. Coed Coch. Glamis. Sept.

Spores ellipsoid-sphæroid, 8-1o $\times 5^{-6} \mathrm{mk} . K$. Name-bis, velum, with double veil. Fr. Monogr. ii. p. 72. Hym. Eur.p. 375. Icon. t. I56. $f$. I. B. \& Br.n. I27I. S. Mycol. Scot. n. 483. Quel. Grev. t. III.f. 7 .

79. C. bulbosus Fr.-Pileus about 7.5 cent. ( 3 in.) broad, datebrown when moist, fuscous-brick when dry, unequally fleshy, campanulato-expanded, obtuse or broadly gibbous, even, or fibrilloso-squamulose towards the margin from the torn epidermis; flesh of the same colour when damp, only pallid, whitish when dry, more compact at the disc. Stem 5-7.5 cent. (2-3 in.) long, solid, bulbous, paler than the pileus, thinly sheathed and fugaciously ringed with the white veil. Gills adnate, somewhat distant, broad, at the very first dark, then brown-cinnamon, but never becoming violet.

The pileus is generally smooth, but here and there torn into fibrils towards the margin, like $C$. armillatus with which it is remarkably analogous. Stem somewhat saffron-yellow at the base and internally. It differs from the Inolomata in the hygrophanous pileus, and from the Hygrocybes in the gills.

In woods. Rare.

Name-bulbus, a bulb. From the bulbous stem. Fr. Monogr. ii. $p .73$. Hym. Eur. p. 375. Berk. Out. p. I91. C. Hbk. n. 523. S. Mycol. Scot. u. 484. Ag. Sow. t. гзо.

80. C. urbicus Fr.-Pileus 5 cent. ( 2 in.) broad, clay-whitish, fleshy, convexo-plane, obtuse, always smooth, but pitted when larger; flesh firm, whitish. Stem 5-7.5 cent. (2-3 in.) long, as much as $12 \mathrm{~mm}$. ( $1 / 2$ in.) thick, solid, equal, zoned above the middle with a narrow white ring, when young villous above the ring. Gills emarginate, crowded, thin, broad, watery ferruginous. 
Telamonia. Manifestly allied to $C$. bivelus, \&c. The gills are not of the bright tawny colour of these. Easily distinguished from $C$. bivelus by its smoothness and colour; especially remarkable for the clay-whitish colour of the pileus.

In grassy places. Cabalva. Sept.-Oct.

Name-urbs, city. Found in frequented places. Fr. Monogr. ii. p. 72. Hym. Eur. p. 375. Grevillea, vol. viii. p. 77. Quel. Grev. t. II2.f. I.

81. C. licinipes Fr.-Pileus $5-7.5$ cent. ( $2-3$ in.) broad, very pale yellow, tan-pallid when dry, fleshy-membranaceous, campanulate then convex and flattened, obtusely umbonate, and at length depressed round the umbo, even, smooth; flesh hygrophanous. Stem ro cent. ( 4 in.) and more long, 6-8 mm. (3-4 lin.) thick, stuffed then hollow, at length fragile, equal, often flexuous, pale-white, white-villous at the base, otherwise clothed with shining floccoso-plumose scales which fall off with age, even above the distant membranaceous ring. Gills adnate and very broad behind, as much as $12 \mathrm{~mm}$. ( $1 / 2 \mathrm{in}$.), somewhat crowded, quite entire, watery cinnamon.

Fragile. Odour none. Var. short-stemmed, growing in drier places. Bull. t. 6oo. f. X.W.T.

In woods. Locality not recorded.

Name-licinium, lint; pes, a foot. Woolly-stemmed. Fr. Monogr. ii. p. 83. Hym. Eur. p. 376. B. \& Br.n. 1549.

** Stem and gills violaceous, Eoc.

82. C. torvus Fr.-Pileus 7.5-10 cent. (3-4 in.) broad, brickcolour, fleshy but thin with exception of the disc, convex, margin at first bent inwards, then wholly flattened, obtuse, somewhat fragile, even or broken up when dry, pierced with dotted points when old, at first sprinkled with hoary squamules and fibrils, and marbled with the same hoariness when it becomes smooth; flesh whitish when dry, dingy. Stem 7.5-12.5 cent. (3-5 in.) long, $I-2.5$ cent. $(I / 2-I$ in.) thick, solid, pierced by larvæ, and at length spongy, when young short and bulbous, then elongated and somewhat equal, when perfect sheathed to the middle and ringed with the ainate veil, above which it is more equal and pale violaceous, when young furnished with a villous cortina, then fibrillose; below the white spreading ring whitish, fibrillose and in fullest vigour floccoso-scaly, white-villous at the base. Gills somewhat adnate, thick, distant, plane, fragile, very broad (6-I2 mm., 3-6 lin.), at first violaceous, soon purplish-umber, at length dark cinnamon, edge quite entire, at length veined at the base.

Striking, commonly robust. It is difficult to describe the ground colour of 
the pileus; date-brown, brick-colour, copper-brown. There is a variety (in Telamonia. drier weather) with the gills rufescent-flesh-colour. Small forms changed in colour occur. The pileus like that of $C$. scutulatus, elatior, \&c. varies pitted. wrinkled and ribbed from the centre.

In mixed woods. Frequent. Aug.-Oct.

Name-torvus, savage. Growing in wild places. Fr. Monogr. ii. p. 74 . Hym. Eur. p. 376. Icon. t. I57.f. I. B. \& Br.n. I353. C. Hbk. n. 524. S. Mycol. Scot. n. 485. Bull. t. 600.f. Q.R.S. Kalch. t. 21.f. r.

83. C. impennis Fr.-Pileus 5-1o cent. (2-4 in.) broad, at first almost umber, then brick-colour, changing colour and dingy, somewhat equally fleshy, very obtuse, convex; smooth, when young silky only round the margin, at length cracked; flesh pallid. Stem 5-10 cent. (2-4 in.) long, $I-2.5$ cent. $(1 / 2-1$ in.) thick, solid, cylindrical, scarcely bulbous, not clothed with scales, pale, becoming violet at the apex and internally azure-blue, girt towards the apex with a white zone formed of the veil, and furnished with a cortina (of the same colour). Gills at first adnate, then emarginate, distant, rather thick, at first intensely and brightly violaceous and somewhat purplish, but immediately changing colour and becoming watery ferruginous.

The pileus does not become hoary. Approaching $C$. torvus in colours, but much inferior, certainly different in the stem not being sheathed with the veil, in the pileus being smooth, \&c. In a young state the colour is almost that of Ag. butyraceus.

\section{Among dead leaves. Bomere.}

Name-penna, a feather. Without feathers. Smooth, contraster with C. plumiger. Fr. Monogr. ii. p. 75. Hym. Eur. p. 376. Icon. t. I57.f. 2. B. E Br. $n$. 1880 .

84. C. plumiger Fr.-Pileus fuscous, somewhat olivaceous when moist, brick-tan when dry, hygrophanous, slightly fleshy, conical when young, then campanulate, with a broad obtuse very prominent umbo, when more expanded as much as 7.5 cent. (3 in.), and often cracked, dry, clothed with dense white floccosoplumose scales, which are sometimes erect and squarrose, sometimes (after showers) adpressed and silky. Stem 7.5-IO cent. (3-4 in.) long, 2.5 cent. ( 1 in.) thick at the base, Io $\mathrm{mm}$. (5 lin.) at the apex, solid, remarkably clavate, pale, internally watery whitish. Veil floccoso-scaly on the stem, somewhat in the form of a ring at the apex, shining white. Gills adnate, scarcely crowded broad, at first violaceous, soon of a watery then of a pure cinna. mon, edge quite entire, of the same colour or clay.

Handsome. 
Telamonia. In mixed woods. Glamis, 1875. Sept.

Name-plumiger, feather-bearing. From the scales. Fr. Monogr. ii. $p$. 76. Hym. Eur. p. 377. B. \& Br. n. 1550. S. Mycol. Scot. n. 486. Quel. Grev. t. I12. f. 2.

85. C. scutulatus Fr.-Pileus comparatively small, at first turple-umber or brick-fuliginous, very hygrophanous, brickcolour when dry, somewhat fleshy, at first ovato-globose, then campanulato-hemispherical, obtuse, at first white-silky round the margin, then naked, but rivulose in the form of innate squamules, varying lacunose-wrinkled; flesh thin, violaceous. Stem sometimes $5-7.5$ cent. (2-3 in.) long, 4-6 mm. (2-3 lin.) thick, sometimes $12.5-15$ cent. (5-6 in.) long, I $2 \mathrm{~mm}$. ( $1 / 2 \mathrm{in}$.) thick, solid and rigid, cylindrical or bulbous at the very base, externally and internally intensely violaceous, at length becoming fuscous, whitevillous at the base, somewhat rooted, occasionally ascending, sheathed and somewhat ringed with the white veil. Gills adnate, rarely emarginate, more or less distant, $6 \mathrm{~mm}$. (3 lin.) broad, violaceous then purple, white-serrated at the edge when young, at length cinnamon.

Odour strong of radish. Assuming various fornis. Veil white; when in fullest vigour there is not only a superior ring, but there are also many zones from the floccose scales being arranged concentrically as in $C$. triumphans; commonly with a simple ring above and clothed with sparse fibrils, occasionally quite denuded. There are, moreover, variations with the stem hollow at the apex and the pileus umbilicate-with the pileus umbonate, more even, \&c.

In moist woods. Foxley, Cabalva. Sept.-Oct.

Name-scutula, diamond, lozenge-shaped. From the markings on the pileus. Fr. Monogr. ii. p. 76. Hym. Eur. p. 377. Icon. t. 158. f. 2. Grevillea, vol. xii. p. 77 .

86. C. evernius Fr.-Pileus 5-1o cent. (2-4 in.) broad, purplebay-brozun, brick-colour when dry and becoming isabelline-hoary when old, very hygrophanous, thin, almost fleshy-membranaceous, conico-campanulate then flattened, obsoletely umbonate, when young here and there adpressedly silky with the fibrillose white veil, but commonly smooth, at length rimosely incised and torn into fibrils, very fragile; flesh very thin, of the same colour. Stem $7.5-15$ cent. (3-6 in.) long, $12 \mathrm{~mm}$. ( $1 / 2 \mathrm{in}$.) and more thick, stuffed, soft, equal or attenuated downwards, slightly striate, violaceous, becoming pale, squamulose and obsoletely zoned with the adpressed veil. Gills adnate, ventricose, very broad (I-2.5 cent., $1 / 2-1$ in.), distant, violaceous-purple, becoming pale, at length cinnamon.

Odour not remarkable. Changing colour very much. It is analogous with 
$C$. elatior in stature, but there is plainly no affinity between them from the Telamonia. absence of a glutinous veil, and from the very different colours.

In mixed woods. Frequent. Sept.-Oct.

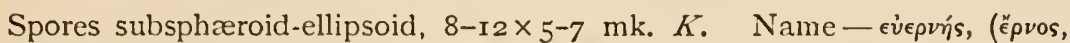
sprout) sprouting. Growing tall. Fr. Monogr. ii. p. 77. Hym. Eur. p. 377. Berk. Out. p. 191. C. Hbk. n. 525. S. Mycol. Scot.n. 487. Sow. t. 125 (departing very much from the type). Quel. Grev. $t$. II2. f. 3 .

87. C. quadricolor Fr.-Pileus $5-7.5$ cent. (2-3 in.) broad, pallid yellow, then somewhat tawny, shining when dry, slightly fleshy, conical then flattened, umbonate, smooth, at length pierced or spotted, radiato-striate at the margin; flesh thin, of the same colour. Stem 7.5 cent. ( 3 in.) long, thin, 4-6 mm. (2-3 lin.) thick, stuffed then hollow, equal, flexuous, slightly rigid, fibrillosostriate with the adpressed veil, violaceous-whitish, the veil above collapsing in the form of a zoned oblique white ring, at length vanishing. Gills adnate, distant, broad, $6-8 \mathrm{~mm}$. (3-4 lin.), but thin, white-serrated at the edge, sometimes dark violaceous, sometimes purplish then cinnamon.

Very much allied to $C$. hinnuleus, but the colours are different.

In woods. Coed Coch. Blaize Castle, Bristol. Oct.

Name-quadricolor, of four colours. Fr. Monogr. ii. p. 84. Hym. Eur. p. 378. B. \&o Br.n. 1663. Bucknall, Brist. Nat. Soc. Proc.vol. iv. t. 5. f. 2. Ag. Schaff. t. 303 .

\section{*** Stem and reil reddish or yellow.}

88. C. armillatus Fr.-Pileus $7.5-12.5$ cent. (3-5 in.) broad, red-brick-colour, truly fleshy, but not very compact, at first cylindrical, soon campanulate, at length flattened, dry, at first smooth, soon innately fibrillose or squamulose; flesh dingy pallid. Stem $7 \cdot 5-15$ cent. (3-6 in.) long, I $2 \mathrm{~mm}$. ( $1 / 2 \mathrm{in}$.) thick, solid, firm, remarkably bulbous (bulb 2.5 cent., $\mathrm{I}$ in. thick, villous, whitish) and fibrillose at the base, when old striate and rufescent-pallid, internally isabelline. Exterior veil woven, red, arranged in 2-4 distant cinnabar zones encircling the stem; partial veil continuous with the upper zone, arachnoid, reddishwhite. Gills adnate, slightly rounded, distant, at first pallid cinnamon, at length very broad ( $12 \mathrm{~mm}$., $1 / 2 \mathrm{in}$.), dark ferruginous, almost bay-brown.

Odour of radish. A very striking species. From the pileus not being hygrophanous, at the first smooth and at length torn into fibrils or squamulose, it might easily be taken for a species of Inoloma. The cortina itself is paler than the zones. It differs from all others in these zones.

In mixed woods. Frequent. Aug.-Oct. 
Telamonia. The rings are usually somewhat oblique. Spores ellipsoid, Io-12 $\times 6-7 \mathrm{mk}$. $K$. ; pruniform, nucleate, rough, 10-12 $\times 5-7 \mathrm{mk}$. C.B.P. Name-armilla, a ring. Ringed, Fr. Monogr. ii. p. 78. Hym. Eur. p. 378. Icon.t. 158. f. I. Berk. Out. p. I92. B. \& Br. n. 1354. C. Hbk. n. 526. S. Mycol. Scot. n. 488 .

89. C. hæmatochelis Fr.-Pileus fuscous-brick-colour (pallid), fleshy, thin, gibbous, silky-fibrillose. Stem solid, thickened but not bulbous, attenuated upwards, encircled with a rufous zone, becoming fuscous internally. Gills adnate, crowded, somewhat narrow, pallid cinnamon.

In woods. Coed Coch. Oct.

Name-aira, blood; $\chi \chi^{\prime} \dot{\lambda} u s$, the chest. Girt with a red zone. Fr. Hym. Eur. p. 378. B. \&o Br. n. 1273, 1354. Hussey i. t. 19. Ag. Bull. t. 527. f. I. Paul. t. III.

90. C. limonius Fr.-Pileus 7.5-10 cent. ( $3-4$ in.) broad, but often smaller, tawny-lemon-yellow, ochraceous yellow and opaque when dry, very hygrophanous, truly fleshy, convexo-plane, obtuse, even and smooth when moist, rimosely incised when dry; flesh of the same colour, not scissile. Stem 7.5 cent. (3 in.) long, 12 $\mathrm{mm}$. ( $1 / 2$ in.) thick, fleshy, solid (but often pierced by larvæ), equal or sometimes attenuated, sometimes slightly thickened, at the base, where it is at length deep saffron, floccoso-scaly with the light-yellow veil, and here and there with a floccose ring at the apex, of the same colours as the pileus. Gills adnate, more rarely emarginate, distant, for a long time yellow to light-yellow, at length tawny-cinnamon.

Odour none. There is scarcely a manifest affinity with any other species than $C$. psammocephalus. The floccose ring is often awanting, but from the scales of the stem it is manifestly a species of Telamonia.

In pine woods. Rare.

Name-lemon-coloured (Citrus Limonum). Fr. Monogr. ii. p. 80. Hym. Eur. p. 379. Icon. t. I59. f. I. Berk. Out. p. 192. C. Hbk. n. 527. S. Mycol. Scot. n. 489. Quel. Grev. t. II2. f. 4. Ag. Holmsk. Ot. 2. t. 4 O.

91. C. helvolus Fr.-Pileus 5-7.5 cent., $2-3$ in. (in smaller specimens $2.5-5$ cent., I-2 in.) broad, dark tawny-cinnamon, very pale yellow when dry, slightly fleshy, convexo-plane, obtuse or obtusely umbonate, smooth, becoming even, margin, which is at the first fumished with a cortina, regularly bent inwards. Stem 5-20 cent. (2-8 in.) long, firm, solid, rarely pierced, somewhat equal, not tense and straight, fibrillose, girt above with an annular, narrow, ferruginous-margined zone formed of the woven veil. Gills remarkably emarginate, $8 \mathrm{~mm}$. (4 lin.) broad, distant, 
thick, somewhat veined at the base, opaque, tawny, then dark Telamonia. cinnamon.

The stem in the largest form is 20 cent. ( 8 in.) long, almost 2.5 cent. ( $\mathrm{r}$ in.) thick, attenuated at the base; intermediate, 7.5 cent. ( 3 in.) long, $8 \mathrm{~mm}$. ( 4 lin.) thick; smaller, 5 cent. ( 2 in.) long, attenuated from the base, $4-6 \mathrm{~mm}$. $(2-3$ lin.) thick at the apex. Flesh slightly tawny. Stem at length fuscousferruginous externally and internally.

In mixed woods. Coed Coch. Glamis. Sept.-Oct.

Name-helvolus, pale yellow. Fr. Monogr. ii. p. 85. Hym. Eur. p. 379. B. E Br. n. 1355. S. Mycol. Scot. n. 490. Bull. t. 53I.f. I (except white flesh).

92. C. hinnuleus Fr.-Pileus pallid tawny-cinnamon, becoming pale, shining when dry, fleshy-membranaceous, campanulatoexpanded, obtuse or obtusely umbonate, sometimes depressed in the centre, even, smooth, often pierced with dotted points; flesh of the same colour. Stem 2.5-IO cent. (I-4 in.) long, stuffed, but commonly pierced by larvæ, equal or attenuated downwards, rigid, dingy tawny and sometimes fuscous, but white-silky with the adpressed silky veil and white-zoned above with the woven veil. Gills more or less emarginato-adnexed, distant, but thin, the edge, which is of the same colour, acute and quite entire, $8-10 \mathrm{~mm}$. (4-5 lin.) broad (semiovate when smaller), connected by veins, plane, saffron-tawny.

Varying much in stature. Stem sometimes short 2.5 cent. (I in.) long, sometimes 5 cent. ( 2 in.) long, 4-6 mm. (2-3 lin.) thick, sometimes elongated 7.5-10 cent. (3-4 in.) and flexuous. It departs from all the others in this group in the white veil. The above is the earlier form in birch wood. B. later anong poplar. Stem at length hollow, wholly fibrous, internally dark tawny, externally pale with the silky fibrils, ring obsolete; but the pileus (somewhat membranaceous, conico-expanded, acutely or obtusely umbonate, darker, yellowish when dry and at length rimosely torn) is silky round the margins. Gills adnate, distinct, opaque, slightly tawny then cinnamon. Very small form, stem $\mathbf{2} \mathbf{m m}$. ( $1 / 2$ in.), gills very broad.

\section{In mixed woods. Common. Sept.-Oct.}

Name-hinnuleus, fawn. Fawn-coloured. Fr. Monogr. ii. p. 86. Hym. Eur. p. 380. Berk. Out. p. I92. C. Hbk. n. 528. S. Mycol. Scot. n. 49 I. Sow. t. I73. Quel. Grev. t. I13.f. I.

93. C. gentilis Fr.-Pileus $I-2.5$ cent. ( $1 / 2-I$ in.) broad, tawnycinnamon, yellow when $d r y$, very hygrophanous, slightly fleshy, conico-expanded, then flattened, acutely umbonate, rimosely incised, varying somewhat silky; flesh thin and of the same colour. Stem 7.5 cent. ( 3 in.) and more long, $2-4 \mathrm{~mm}$. ( $1-2$ lin.) thick, stuffed then hollow, slender, equal or attenuated at the base, often curved, fibrillose, of the same colours as the pileus when moist and dry, never becoming pale. Veil forming an anmular zone, 
Telamonia. oblique, sometimes arranged in many zones, sometimes floccososcaly below the ring, yelloze. Gills adnate, thick, very distant, plane, connected by veins, quite entire, tawny-cinnamon.

Gregarious. The stem is commonly more tense and straight than others of the same stature. The gills are of the same colour as the pileus in the primary state; they do not change colour when dry, like the pileus and stem, wherefore the fungus is remarkably of the same colour when moist, but when dry of different colours, the pileus and stem being yellow. Spores have been observed somewhat clay-coloured on a black ground.

In woods, chiefly pine. Frequent. Aug.-Oct.

Spores subsphæroid-ellipsoid, 8-9 $\times 5-6 \mathrm{mk}$. $K$.; pruniform, nucleate, slightly rough, ro $\times 6 \mathrm{mk}$. C.B.P. Name-gentilis, national, as opposed to exotic. Fr. Monogr. ii.p. 87. Hym. Eur. p. 380. Icon.t. I59.f. 2. Br. Bath Transact. 1870, p. 72. C. Hbk. n. 529. S. Mycol. Scot. n. 492. Grevillea, t. 84. f. 3 .

94. C. helvelloides Fr.-Pileus $\mathrm{I}-2.5$ cent. ( $1 / 2-\mathrm{I}$ in.) broad, ferruginous, becoming tawny when dry, somewhat membranaceous, convex then flattened, umbonate (obtusely or acutely), smooth, somewhat striate when moist, when more fully grown cracked and squarrose. Stem 5-7.5 cent. (2-3 in.) long, $2-4 \mathrm{~mm}$. ( I-2 lin.) thick, fistulose, equal, very much undulated and flexuous, somewhat ferruginous and without any whiteness. Veil yellowish, silky round the margin of the pileus, and somewhat in the form of a ring at the apex of the stem, above which the stem is white-silky and glittering. Gills adnate, very thick and exceedingly distant, rather broad, distinct, at first violaceous-umber (never purplish), edge white-floccose, soon however of one colour umber-cinnamon, at length ferruginous.

Quite inodorous. The pileus varies fibrillose when young; sometimes bullate, rarely conical: it varies also in colour.

In mixed woods. Uncommon. Aug.-Oct.

Name-Helvella-like. Fr. Monogr. ii. p. 87. Hym. Eur. p. 380. Icon. t. 139.f. 3. B. \& Br.n. 929. C. Hbk. n. 530. S. Mycol. Scot. n. 493.

**** Stem becoming fuscous, ENC.

95. C. punctatus Fr. - Pileus hoary-umber (tan), somewhat membranaceous, conico-convex, smooth, at length even, pierced. Stem somewhat fistulose, equal, slender, undulated, fibrillosostriate, yellow-fuscous, girt with a pallid fuscous zone from the fugacious veil. Gills adnate, very distant, quite entire, browncinnamon.

Primary form : pileus $12 \mathrm{~mm}$. ( $1 / 2$ in.) broad; stem $5-7.5$ cent. (2-3 in.) long, scarcely beyond $2 \mathrm{~mm}$. (I lin.) thick; gills almost $6 \mathrm{~mm}$. (3 lin.) broad. Very 
much allied to $C$. gentilis, distinct in the colour of all its parts, and in the Telamonia. convex, obtuse or obtusely umbonate pileus. Commonly also thinner, very flexuous, like $C$. helvelloides. In pine woods it occurs larger, somewhat cinnamon, pileus at length fibrillose, gills sinuato-adnexed and less distant.

In woods. Locality not recorded.

Name-punctus, a puncture. Pierced. Fr. Hym. Eur. p. 382. Monogr. ii. p. 9 I. B. \& Br. n. 155 I.

\section{II.-LEPTOPHYLLI. \\ * Stem whitish, pallid, \&oc.}

96. C. triformis Fr.-Pileus $5-7.5$ cent. (2-3 in.) broad, remarkably hygrophanous, farun-colour when young, then yellowish or honey-colour, isabelline when dry, unequally fleshy, thin at the margin, convex then plane, obtuse or slightly gibbous, superficially fibrillose or becoming smooth, at length pierced-dotted, always even, opaque. Stem 7.5 cent. ( 3 in.) long, $12 \mathrm{~mm}$. ( $1 / 2$ in.) thick, somewhat bulbous, stuffed, spongy internally, fragile, rather smooth, pallid, ringed upwards with the woven veil, the ring distant and white. Gills adnate, ventricose, somewhat emarginate, $8 \mathrm{~mm}$. (4 lin.) broad, connected by veins, somewhat distant, thin, watery honey-colour, then watery cinnamon.

The pileus varies in colour, at first brownish or livid-yellowish, dingy tan when dry. The gills are of one colour.

In woods. Alresford, Hants.

Name-tres, three; forma, form. From its assuming three distinct forms, of which the above (Schafferi) is the type. Fr. Monogr. ii. p. 73. Hym. Eur. p. 382. Schaff. t. 247 ? Grevillea, vol. xiv. p. $3^{8 .}$

\section{** Stem inclining to violet, Eoc.}

97. C. periscelis Fr.-Pileus 5 cent. (2 in.) broad, lilac, whitesilky, hygrophanous, campanulate then convex, umbo fleshy, otherwise somewhat membranaceous. Stem 7.5-10 cent. (3-4 in.) long, 4-6 mm. (2-3 lin.) thick, equal, straight, fibrillose, of the same colour as the pileus, somewhat ringed with the woven fuscous veil, becoming fuscous when dry, white-villous at the base. Gills adnate, crowded, narrow, pallid then dark ferruginous.

Peculiar, rather perhaps belonging to the fuscous series.

In bogs and under beech. Bowood.

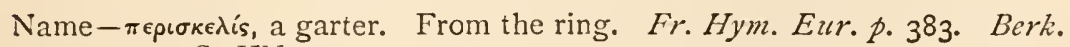
Out.p. 193. C. Hbk.n. 531.

98. C. flexipes Fr. -Pileus $I-2.5$ cent. ( $1 / 2-I$ in.) broad, at first 
Telamonia very dark date-brown-fuscous, also inclining to violaceous, but becoming pale, very pale yellow in dry weather, tan when old, slightly fleshy, at first conical and acute, then expanded and acutely umbonate, at length depressed round the umbo, hoaryfibrillose, at length denuded, torn when old; flesh thin, of the same colour as the pileus. Stem ro cent. (4 in.) long, $4 \mathrm{~mm}$. (2 lin.) thick, stuffed, then pierced, equal, flexuous, floccoso-scaly below the woven sufficiently manifest white ring, pallid, violaceous throughout or at least at the apex. Gills adnate, slightly distant, broad, purple or umber-violaceous, then at length cinnamon, whitish at the edge.

When old almost like $C$. evernius, with which it agrees in the variation of colour.

In woods. Frequent. Sept.-Oct.

Name--Aexus, bent; pes, a foot. From the flexuous stem. Fr. Monogr. ii. p. 84. Hym. Eur. p. 384. S. Mycol. Scot. Supp. Scot. Nat. 1881, p. 36. Grevillea, t. I13. $f \cdot 3$.

99. C. flabellus Fr.-Pileus $18 \mathrm{~mm}$. ( $3 / 4$ in.) broad, olivaceous. fuscous, tan when dry, somewhat membranaceous, commonly acutely umbonate, at first conical, then flattened, at first covered with white superficial separating scales, silky when dry, and at length rimosely incised, torn into fibrils; flesh very thin, paler. Stem 2-4 mm. (I-2 lin.) thick, sometimes short, 5 cent. (2 in.) long, in the typical form elongated (7.5-10 cent., 3-4 in.), stuffed then hollow, equal, undulated and flexuous, floccoso-scaly, pallid, becoming violet at the apex. Veil white, inferior, giving rise to the scales on the stem, terminating in a ring, which is sometimes perfect and entire, sometimes woven and oblique. Gills adnate, crowded, linear, narrow, dark violaceous, then cinnamon, at length ferruginous.

Growing in troops. Odour strong, somewhat of radish. Ring often awanting.

In woods. Coed Coch.

According to Fries's earlier description the umbo is commonly obtuse and vanishing. Name-fabellus, a small fan. Meaning not apparent. Fr. Monogr. ii. p. 85. Hym. Eur. p. 384. B. \& Br.n. 1881 .

\section{*** Stem and pileus tawny, ferruginous.}

100. C. psammocephalus Fr. Wholly tawny-cinnamon.-Pileus 2.5 cent. ( $\mathrm{i}$ in.) broad, fleshy, thin, convex then plain and at length umbonate and revolute, broken up into minute furfuraceous squamules. Stem 2.5 cent. (I in.) long, $4 \mathrm{~mm}$. (2 lin.) thick, stuffed, at 
length hollow, somewhat attenuated, sheathed with the continuous Telamonia. squamulose veil, from which proceeds a fibrillose cortina. Gills sinuato-adnate, crowded, $4 \mathrm{~mm}$. (2 lin.) broad, at length darker, umber-cinnamon.

Odour none. Internally it is of the same colour (not white as in Bulliard's fig.); the pileus and stem become pale and somewhat golden when dry. No distinct ring.

\section{In mixed woods. Frequent. Sept.-Oct.}

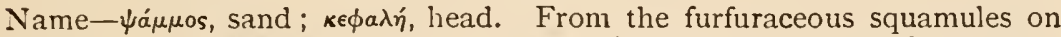
the pileus. Fr. Monogr. ii. p. 80. Hym. Eur. p. 384. Berk. Out. p. I93. C. Hbk. n. 532. S. Mycol. Scot. n. 494. Bull. t. 53r.f. 2.

101. C. incisus Fr.-Pileus tazony-ferruginous, opaque, slightly fleshy, variable in form, sometimes very acutely, sometimes obsoletely umbonate, convexo-expanded, naked when young, then (especially in dry weather) torn into fibrils or scales, but even and shining when scorched by the sun. Stem sometimes curt, 2.5 cent. ( $\mathrm{I}$ in. long), $2-4 \mathrm{~mm}$. ( $\mathrm{I}-2$ lin.) thick, sometimes elongated 5-Io cent. (2-4 in.), somewhat stuffed, flexuous, wholly fibrous in moist places, fibrillose, not polished externally. Gills adnate, somewhat distant, cinnamon-ferruginous.

Not much smell. Growing in trnops, somewhat cæspitose. The pileus is commonly tawny-ferruginous, hut when young also date-brown, olivaceousfuscous, \&c. It differs from G. gentilis, \&c., in the colour being darker, ferruginous, and especially in the somewhat zoned white veil.

In woods. Loughborough.

Spores ellipsoid or sphæroid-ellipsoid, uniguttate, $9-12 \times 6 \mathrm{mk} . K$. Name -incido, to cut into. From the cracked pileus. Fr. Monogr.ii.p.88. Hym. Eur. p. $3^{84}$. Icon. t. I60. f. I. B. \& Br. n. I272. Ag. Bull. t. 586. f. 2.

102. C. iliopodius Fr.-Pileus $2.5-5$ cent. ( $\mathrm{I}-2$ in.) broad, cinnamon, tan when dry, slightly fleshy, conical then expanded and for the most part acutely umbonate, at the first silky with hoary fibrils, becoming smooth when full grown. Stem here and there short, commonly elongated, stuffed, flexuous, equal, elastic, sheathed to the middle with the white veil which becomes even and silky, and cortinato-ringed where the sheathing ends, naked and fibrilloso-striate at the apex, internally saffron-cinnamon. Gills adnate, slightly distant, thin, cinnamon.

Very protean, and there are individual forms which can scarcely be defined. It is distinguished, however, from others by its opaque cinnamon colour, that of the stem often becoming fuscous, by the stem being externally somewhat cartilaginous and paler, by the white veil, and by the gills being more crozided and thin.

In mixed woods. Common. July-Nov. VOL. II. 
Telamonia. Name-idús, mud; moús, a foot. From the dirty stem. Fr. Monogr. ii. $p$. 88. Hym. Eur. p. 385. Berk. Out. p. 193. C. Hbk. n. 533. S. Mycol. Scot. n. 495. Ag. Bull. t. 586. f. 2. A.B., t. 578 partly.

\section{**** Stem floccoso-scaly, \&oc.}

103. C. hemitrichus Fr.-Pileus $2.5-7.5$ cent. ( $1-3$ in.) broad, dark fuscous, fuscous-tan when dry, umbo commonly persistently dark, somewhat fleshy, convexo-expanded, sometimes acutely, sometimes obtusely umbonate or wholly obtuse (in largest specimens even umbilicate on account of the hollow apex of the stem), sometimes wholly, sometimes round the margin elegantly whitefibrilloso-curled with erect flocci, the fibrils however superficial, even, never torn. Stem $4-6$ cent. ( $1 \frac{1}{2}-21 / 2$ in.) long, at the very first hollow, equal, thick, firm, scarcely ever flexuous, pallid fuscous, white-flocculose below the medial ring which is woven, shining white, not rarely membranaceous and reflexed. Gills adnate, but ventricose at the base, hence they appear rounded, very crowded, $6 \mathrm{~mm}$. (3 lin.) broad, quite entire, clay-colour, at length cinnamon.

Odour none, taste not unpleasant. Pileus stiff, scissile. It becomes adpressedly fibrillose when the flocci are flattened, and becomes smooth when these are wiped off by showers. The colour resembles that of $C$. castaneus when dry. In smaller forms the fibrils of the pileus are shorter, and the ring less conspicuous.

In mixed woods. Uncommon. Sept.-Oct.

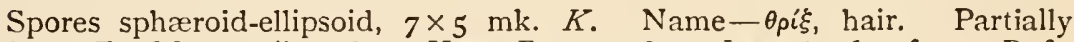
hairy. Fr. Monogr. ii. p. 89. Hym. Eur. p. 385. Icon. t. 160. f. 2. B. \& Br.n. 930. C. Hbk. n. 534. S. Mycol. Scot. n. 496.

104. C. stemmatus Fr.-Pileus $4-5$ cent. ( $1 / 2-2$ in.) broad, date-brown when moist, becoming pale when dry, slightly fleshy, convex then flattened, obtuse, fragile, hoary-silky round the margin when moist, fibrillose when dry. Stem 5-7.5 cent. (2-3 in.) long, stuffed then fistulose, equal or slightly attenuated at the base, often curved, soft, externally and internally ferruginousdate-brown, paler and becoming silky-even at the apex. Gills adnate, crowded, $4 \mathrm{~mm}$. (2 lin.) broad, narrower behind, datebrown, opaque.

Distinguished by the pileus being hoary-silky round the margin, and by the very crowded, narrow, date-brown gills. It occurs under two forms: the earlier with the stem floccoso-squamulose and somewhat ringed; and the later with the stem naked, the veil being wiped off. Allied to C. uraceus, but in that species there is no trace of a woven veil even in its earliest stages.

In moist woods. Lyne, Sussex.

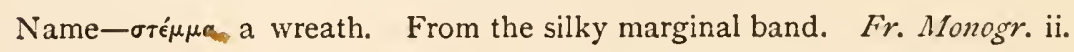


p. 89. Hym. Eur. p. 385. Icon. t. I6o. f. 3. Grevillea, vol. xii. p. 68 Telamonia. (ringless form).

105. C. paleaceus Fr.-Pileus fuscous when damp, dingy when dry, very hygrophanous, somewhat membranaceous, conical then expanded, acutely or obtusely umbonate, at first silky with superficial squamulose white villous down (veil), becoming smooth, opaque; flesh of the disc of the same colour, almost none at the sides. Stem 7.5 cent. ( 3 in.) long, $2 \mathrm{~mm}$. (I lin.) thick, fistulose, slender, toughish, undulated on the surface, externally and internally fuscous, paler when young, white-villous at the base, here and there squamulose with white flocci, and white-ringed at the apex. Gills adnate, broad, crowded, at first pallid-whitish, at length cinnamon.

Odour weak. Commonly acutely umbonate. It differs from $C$. iliopodius in the stem not being tawny within, and in the veil being floccoso-scaly not becoming even.

In beech woods. Cabalva. Sept.-Oct.

Name-palea, chaff. From the scales. Fr. Monogr. ii.p.92. Hym. Eur. p. 386 . Icon. t. I60. f. 4. Grevillea, vol. viii. p. 77. S. Mycol. Scot. Supp. Scot. Nat. I883, p. 31. Quel. Grev. t. I13. f. 5, t. I I4.f. 4 .

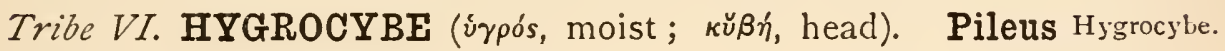
smooth or only covered with white superficial fibrils, not viscous, but moist when fresh, changing colour when dry, flesh very thin or scissile; rarely more compact at the disc. Stem slightly rigid, not sheathed; cortina thin, fibrillose, rarely collapsing and forming an irregular zone on the stem. Quite distinct from Telamonia, but only by the veil. Fr. Hym. Eur. p. 386.

I. Firmores. Pileus somewhat fleshy, convex or campanulato-convex then expanded, obtuse or at length gibbous, mar. gin at first incurved. Stem (for the most part) attenuated upwards.

* Stem white, cortina of the same colour.

** Stem and gills commonly inclining to violet. In various species of the former sec-

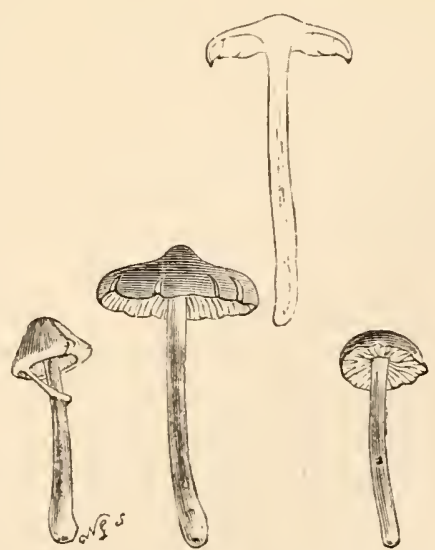

$X L V$. Cortinarius (Hygrocybe) sastanezs. One-third natural size. tion there is a fugitive tinge of violet at the apex of the stem.

*** Stem and somewhat obsolete veil yellow or rufous. 
Hygrocybe. **** Stem inclining to fuscous; cortina of a pallid dirty colour or white (not yellow); gills dark.

II. Tenuiores. Pileus somewhat membranaceous, conical then expanded, umbonate, umbo acute or more rarely obtuse and vanishing (the opposite is the way of the Firmiores), margin at first straight. Stem somewhat equal or attenuated at the base. (The thinness of the pileus is only relative to its size.)

* Stem white.

** Stem inclining to violet or reddish.

*** Stem yellowish, commonly becoming pale.

**** Stem inclining to fuscous.

\section{I.-FIRMIORES. \\ * Stem white, cortina of the same colour.}

106. C. subferrugineus Fr.-Pileus about 7.5 cent. (3 in.) broad, ferruginous or watery cinnamon, more or less hygrophanous, when dry sometimes shining and tawny, sometimes becoming pale, unequally fleshy, abruptly more compact at the disc, convex then expanded, obtuse, here and there flexuous, firm but not rigid, even, smooth; flesh scissile, dingy, isabelline-white. Stem variable in stature, commonly 7.5 cent. (3 in.) long, $12 \mathrm{~mm}$. ( $1 / 2$ in.) thick, solid, more or less bulbous, attenuated upwards, adpressedly fibrillose, externally rigid and somewhat cartilaginous, pallid, internally soft, saffron-yellow at the base. Veil entirely fibrillose and marginal only, not sheathing, very fugacious. Gills remarkably emarginate, $6 \mathrm{~mm}$. (3 lin.) broad, more or less crowded, opaque, at first pallid, soon watery then dark ferruginous.

Among heaped rotting pine-leaves the stem is stout, very inflated, spongy. Odour that of the Inolomata, taste unpleasant. There are many forms definite as to colour, but scarcely to be defined by description. It differs from $C$. $a r$. meniacus in the opaque colour, in the fleshy obtuse pileus, in the stem not being elastic, in the veil not collapsing, \&c., and from $C$. bivelus in the simple veil, the smooth and hygrophanous pileus (watery ferruginous when moist, becoming tan-ferruginous when dry), \&c.

In woods. Coed Coch. Sept.

Name-ferrugo, rust-colour. Somewhat ferruginous. Fr. Monogr. ii. p. 93 . Hym. Eur. p. 387. B. E Br. n. 1275. Quel. t. I13. f. 6. Ag. Batschf. 186 (not good).

107. C. armeniacus Fr.-Pileus 5-Io cent. (2-4 in.) broad, tawny-cinnamon when moist, ochraceous when dry, rigid, slightly fleshy, campanulate then convex and flattened, broadly and obtusely umbonate, even, smooth, not viscid, here and there slightly striate at the margin; flesh somewhat of the same colour, scissile. Stem commonly 5-7.5 cent. ( $2-3$ in.) long, $12 \mathrm{~mm}$. ( $1 / 2$ in.) thick, stuffed, conico-attenuated, fibrillose, white, externally rigid and 
somewhat cartilaginous, internally spongy, hence elastic, wholly $\mathrm{H}_{y g r o c y b e}$ white. Cortina simple, white, somewhat sheathing, collapsing and commonly leaving an adpressed (not annular) zone on the stem. Gills adnate, at length slightly rounded, always crowded, rather broad, at first pallidly then tawny cinnamon, shining.

Handsomest in pine woods. Firm, bright, changeable. Pileus soon destitute of white fibrils. There is a remarkable variety (falsarius) in which the pileus is paler, light yellowish, white when dry. On heaped rotting leaves in noist places the stem becomes very much swollen, among damp mosses it is longer and more slender.

In pine woods. Uncommon. Oct.

Spores ellipsoid, nucleate, $4-5 \times 2-21 / 2 \mathrm{mk}$. C.B.P. Name-from likeness in colour to Apricot (Prunus Armeniaca). Fr. Monogr. ii. p. 94. Hym. Eur. p. 387. Berk. Out. p. 193. C. Hbk. n. 535. S. Mycol. Scot. n. 497. Ag. Schaff. $t$. 8I.

108. C. privignus Fr.-Pileus about 5 cent. ( 2 in.) broad, the ground colour fuscous, but becoming hoary-pale with a very thin white film, pallid-tan when dry, slightly and unequally fleshy, convex then flattened (even reflexed and undulated), obtusely umbonate, without striæ, dry, but remarkably hygrophanous; flesh hygrophanous. Stem about 7.5 cent. (3 in.) long, $6 \mathrm{~mm}$. ( 3 lin.) thick, stuffed then hollow, sometimes attenuated from the base, sometimes equal, most frequently twisted, silvery-pale, here and there white-silky with the veil. Gills adnate, broad, not crowded, distinct, at first watery, then opaque cinnamon, serrated and white-fimbriate at the edge when perfect.

Very fragile, strong smelling, but scarcely acrid. The most remarkable of the group.

In pine woods. Woolhope Foray, i 885 . Oct.

Spores pruniform, punctate, $8 \mathrm{mk}$. Q. Name-privignus, a step-son. Relation not apparent, but the plant being fragile occupies a singular position in the group. Fr. Monogr. ii. p. 95. Hym. Eur. p. 388. Grevillea, vol. xiv. p. $3^{8}$.

109. C. duracinus Fr.-Pileus 5 cent. ( 2 in.) and more broad, when moist watery brick-colour, tan when dry, always opaque, fleshy, plane with a broad obtuse umbo, and with a singular elevated ridge round the margin caused by the margin being at first sharply and regularly bent inwards to the breadth of half a line, at which stage it is clothed with white silkiness, and afterwards becoming flattened, when it is naked and even; cuticle hard, rigid, fragile. Stem 7.5 cent. (3 in.) long, $12 \mathrm{~mm}$. ( $1 / 2$ in.) thick, solid, hard, somewhat bulbous but rooted at the attemuated stem-like base, externally even, smooth, and rigid, with a thick cartilaginous rigid separable cuticle (the fragments of 
Hygrocybe. which when it breaks up become revolute), pale-white. Cortina appearing only as a silky narrow white zone round the very margin of the pileus. Gills adnate, moderately crowded, 4-6 $\mathrm{mm}$. (2-3 lin.) broad, watery cinnamon, even at the sides.

No trace of a fibrillose cortina has been observed in any stage of its growth. In pine woods the stem is not bulbous, but attenuated downwards. Oct.

In old pastures beside stumps. Dun, I876. Scone, I 877.

Name-durus, hard; actnus, berry. Hard. From the coating of the pileus and stem. Fr. Monogr. ii. p. 96. Hym. Eur. p. 388. B. \& Br. $n$. 1776. S. Mycol. Scot. n. 498. Quel. Grev. t. II5.f. I.-Schaff. t. 221.

110. C. dilutus Fr.-Pileus about 5 cent. ( 2 in.) broad, at first bay-brown, even watery brick-colour, tan when $d r y$, in either state opaque, somewhat fleshy, convex then expanded, umbonate (umbo thin, vanishing), smooth when the veil is rubbed off. Stem 5-7.5 cent. (2-3 in.) long, 4-8 mm. (2-4 lin.) thick, stuffed then hollow, slightly attenuated from the base, externally not cartilaginous-polished, white-silky, then becoming smooth, opaque, whitish. Gills deeply emarginate, very ventricose, 6-8 $\mathrm{mm}$. (3-4 lin.) broad, crowded, pale cinnamon, not shining.

Inodorous. Veil white, often collapsing into spots on the stem or forming spurious zones, and on the pileus forming a white-silky zone round the margin. Wholly soft and fragile, and thus readily distinguished from the much more robust $C$. armeniacus with which it agrees in colours, so that it was formerly taken for a thinner form of that species.

In woods. Rare.

Not recorded since the time of Bolton. Name-dilutus, diluted, watery. Of the colour. Fr. Monogr. ii. p. 98. Hym. Eur. p. 389. Berk. Out. p. I94. C. Hbk. n. 536. Grevillea, t. 85. f. 2. var. Ag. Bolt. t. Io.

\section{** Stem and gills commonly inclining to violet.}

111. C. saturninus Fr.-Pileus $5-7.5$ cent. (2-3 in.) even IO-I2.5 cent. ( $4-5$ in.) broad, dark bay-brown somewhat umber when damp, soon becoming pale, brick-colour, changing colour very much, unequally fleshy, campanulate when young, then expanded, obtuse, even, smooth (or when young superficially silky round the margin with the veil); flesh violaceous then whitish, thin at the circumference. Stem 5-7.5 cent. (2-3 in.) long, I-2.5 cent. ( $1 / 2-1$ in.) thick, occasionally shorter and bulboso-ventricose, firm, stuffed, internally spongy, thickened downwards, fibrillose, deep violet, but becoming white. Cortina inferior, abundant, white. Gills rounded-adfixed, very broad ( $8 \mathrm{~mm} ., 4$ lin.), crowded, thin, fragile, purplish when young, at length watery ferruginous. 
Somewhat cæespitose. It varies in stature, sometimes much smaller. Cor- Hygrocyle. tina remarkably fibrillose, lax, not forming a zone. Manifestly allied to $C$. armeniacus; they might be easily confounded when this is old and changed in colour.

In grassy places. Woolhope Foray, 1885. Oct.

Name-saturnine, gloomy. Of the dark colour. Fr. Monogr. ii. p. 99. Hym. Eur. p. 390. Grevillea, vol. xiv. p. 39.

112. C. imbutus Fr.-Pileus 7.5 cent. ( 3 in.) broad, toast-brown then pale yellowish, somewhat unequally fleshy, convex, obtuse, even, smooth, obsoletely hoary - fibrillose towards the margin. Stem 7.5 cent. ( 3 in.) long, not 2.5 cent. (I in.) thick, solid, equal, sometimes twisted, becoming even, scarcely fibrillose, whitish, pale violaceous at the apex, of the same colour internally. Cortina white, adhering to the margin of the pileus and to the apex of the stem, fugacious. Gills rounded, somewhat distant, $6 \mathrm{~mm}$. (3 lin.) broad, with narrower and shorter ones intermixed, at the first dark bluish-grey or violaceous-cinereous, never purplish, then watery cinnamon.

Flesh dingy, manifestly violaceous only at the apex of the stem. It approaches $C$. subferrugineus in the same way as $C$. saturninus approaches $C$. armeniacus.

In woods. Dinmore.

Name-imbuo, to soak, stain. Perhaps from the dyed flesh. Fr. Monogr. ii. p. гоo. Hym. Eur. p. 390. Grevillea, vol. viii. p. Iog.

113. C. castaneus Fr.-Pileus fuscous-chestnut, scarcely becoming pale when dry, but shining, umbo becoming black, paler at the circumference, slightly fleshy, but firm, almost pliant, campanulate then flattened, not or only obtusely umbonate, often irregular, even, smooth. Stem about 2.5 cent. (I in.) long, 4-6 $\mathrm{mm}$. (2-3 lin.) thick, somewhat fistulose (when young also stuffed), tough, externally cartilaginous, slightly fibrillose with the veil, otherwise smooth, even, somewhat equal, pallid violaceous or pallid rufescent, unchangeable when dry. Cortina entirely fibrillose, scanty, white. Gills adnate, but varying emarginate, crowded, thin, $4-6 \mathrm{~mm}$. (2-3 lin.) broad, edge whitish, violaceous then ferruginous.

Gregarious, even cæspitose, polymorphous, always very small. The pileus is often obsoletely white-silky round the margin with the cortina. Spores dark ferruginous.

In woods, \&c. Common. July-Oct.

Odour none; taste like Marasmius oreades. M.F.B. Name-castaneus, chestnut. Fr. Monogr. ii. p. Ior. Hym. Eur. p. 39r. Berk. Out. p. I94. C. Hbk.n. 537. S. Mycol. Scot. n. 499. Ag. Bull. t. 268. 
114. C. colus Fr.-Pileus $2.5-5$ cent. ( $1-2$ in.) broad, brownrufescent, brick-colour paler and shining when dry, somewhat fleshy, small in comparison with the tall stem, campanulate when young, then convex, obtusely umbonate or wholly obtuse, wellformed; flesh of the same colour, dingy whitish when dry. Stem Io cent. ( 4 in.) long, $6-8 \mathrm{~mm}$. (3-4 lin.) thick below, only $4 \mathrm{~mm}$. (2 lin.) at the apex, stuffed, almost solid, equally attenuated upwards, encircled with the blood-red mycelium at the base, which is sometimes rooted, stiff, naked, not cartilaginous but remarkably fibrillose longitudinally and throughout, scissile, tense and straight, coloured with fibrils of the same colour as the pileus, but paler than the pileus. Cortina entirely fibrillose, tawny-reddish. Gills adnate, scarcely sinuate, $6 \mathrm{~mm}$. (3 lin.) broad, plane, firm, tough, rather thick, scarcely crowded, veined, dark cinnamon, paler when young.

Spores ochrey-cinnamon. Mycelium fiery-saffron-yellow. Hym. Eur.

In woods. Blaize Castle, Bristol. Oct.

Spores pruniform, 8-9 mk. Q. Name-colus, a distaff. From the remarkably fibrillose stem. Fr. Monogr. ii. p. 102. Hym. Eur.p. 391. Bucknall, Fung. Bristol, pt. vii. $p \cdot 3$.

115. C. renidens Fr.-Pileus $2.5-5$ cent. ( $1-2$ in.) broad, ferruginous-tawny when damp, ochraceous when dry, here and there becoming pale only at the disc, slightly fleshy, firm, convexoplane, obtuse or gibbous, very smooth, shining; flesh thin, scissile, paler. Stem $4-7.5$ cent. ( $1 / 2-3$ in.) long, $6-8 \mathrm{~mm}$. (3-4 lin.) thick, firm, stuffed, exactly equal, externally somewhat cartilaginous, wholly dissolvable however into fibrils, of the same colour as the pileus, yellowish-pale, then tawny. Cortina laxly fibrillose, fugacious, yellow. Gills adnate, but also separating-free, somewhat crowded, entire, about $6 \mathrm{~mm}$. (3 lin.) broad, at first pallid cinnamon then tawny.

Spores dark ochraceous. Odour weak, by no means that of radish. Remarkably hygrophanous. Its nature is that of $C$. armeniacus, but it is smaller, and is readily distinguished by its brighter colour, and especially by the yellow cortina. The pileus is sometimes umbilicate from the hollow apex of the stem.

In shady woods. Highbeach, Epping.

Name-renideo, to shine back. Glistening. Fr. Monogr. ii. p. I03. Hym. Eur. p. 392. Icon. t. I62.f. I. Grevillea, vol. xi. p. 70.-Paul. t. 54.f. 1, 2? 
116. C. uraceus Fr.-Pileus $2.5-5$ cent. ( $\mathrm{I}-2$ in.) broad, when moist nmber or brown, sometimes inclining to olive, somewhat shining, when dry (when young brick-colour) commonly tan or isabelline, slightly fleshy, conical then campanulate, then expanded and umbonate or obtuse, when moist even, smooth, when dry at length somewhat fibrillose; flesh fuscous, darker in the stem. Stem 5-Io cent. (2-4 in.) long, 4-8 mm. (2-4 lin.) thick, slightly tubular, stuffed then hollow, cylindrical, exactly equal, firm, fibrilloso-striate (the striæ paler), but becoming even, fuscous, naked and becoming pale at the apex, sometimes inclining to olive, at length becoming wholly fuscous-black, internally of the same colour. Cortina superior, fibrillose, fuscous, but rarely conspicuous. Gills adnate, ventricose, firm, $6 \mathrm{~mm}$. (3 lin.) and more broad, distant, cinnamon-brown, the edge sometimes quite entire and of the same colour, sometimes white and fimbriato-serrated.

The slight margin of the pileus is incurved. There are variations which cannot be noted.

In pine woods. Dinmore.

Spores pruniform, granulated, 8-9 mk. $Q$. Name-ĩpa $\xi$, a mouse. Mousecoloured. Fr. Monogr. ii. p. II2. Hym. Eur. p. 393. Icon. t. I62. f. 3. Grevillea, vol. viii. $p .77$.

117. C. jubarinus Fr.-Pileus $4-7.5$ cent. ( $1 / 2-3$ in.) broad, splendidly tawny-cinnamon and shining, somewhat fleshy, campanulato-flattened, obsoletely umbonate, when larger and old depressed in the centre, often repand and undulated, at length reflexed, fragile, even and smooth at the disc, when young silky towards the margin with the veil, when old innately fibrillose under a lens. Stem 5 cent. ( 2 in.) long, when larger $12 \mathrm{~mm}$. ( $1 / 2$ in.), when smaller 4-6 $\mathrm{mm}$. (2-3 lin.) thick, at first stuffed, then hollow, fibrilloso-striate, externally and internally pale tawny, paler at the base and (naked) apex. Gills adnate, somewhat distant, 2-6 mm. ( $\mathrm{I}-3$ lin.) broad, distinct, tawny-cinnamon, the edge which is quite entire of the same colour.

At first sight very like $C$. cinnamomeus, but differing in the fugacious, fibrillose, white veil. The pileus is not velvety-villous as in $C$. cinnamomeus. It may also be confounded with $C$. incisus on account of its colours, but it differs from that species in the surface being scarcely hygrophanous, always polished and entire, although the pileus is rimoso-incised at the margin.

In woods. Coed Coch.

Name-jubar, radiance. Shining. Fr. Monogr. ii. p. 105. Hym. Eur. p. 393. B. SB Br.n. I883.-Bull. t. 431. f. I. 
Hygrocybe.

\section{II.-TENUIORES. \\ * Stem white.}

118. C. rigens Fr.-Pileus $2.5-5$ cent. (I- 2 in.) and more broad, opaque and tan-clay-colour when damp, tan-whitish when dry, fleshy, thin, when young campanulate and lax, then convex, obtuse or broadly gibbous, even, smooth; flesh slightly firm, white. Stem 5-10 cent. (2-4 in.) long, 4-10 mm. (2-5 lin.) thick, stuffed, furnished with a remarkably cartilaginous bark, elastic, rigid and tough, rooted, smooth, even, naked, pale when moist, white when dry. Cortina scarcely manifest. Gills adnate, somewhat decurrent, distant, very broad (6-10 mm., 3-5 lin.), distinct, watery clay-colour, then pallid cinnamon.

The stem varies much in stature, sometimes equal, thickened sometimes downwards sometimes towards the apex, which is then hollow, even fusiform.

In mixed woods. Uncommon. Oct.

Spores pruniform, granulated, 8-9 mk. Q.; $7 \times 5 \mathrm{mk}$. W.P. Name-rigeo, to be stiff. Stem rigid. Fr. Monogr. ii. p. I07. Hym. Eur.p. 395. B. \& Br. n. 39r. C. Hbk.n. 539. S. Mlycol. Scot. n. 500.

119. C. Reedii Berk.-Pileus 2.5 cent. (I in.) broad, persistently brown, conical then expanded and strongly umbonate, smooth, shining, disc areolate, margin splitting; flesh pallid. Stem 4-5 cent. ( $1 / 2-2$ in.) long, solid, fibrilloso-striate, slightly bulbous, white. Veil fibrillose, evanescent. Gills ascending, attenuated behind, free, broad, ventricose, white or pallid, then cinnamon.

Tasteless and scentless. Allied to C. leucopus.

Among moss and beech mast. Hayes, Surrey. May.

Name-after Reed. Berk. Out.p. 194. C. Hbk.n. 538. Fr. Hym. Eur. p. 395. Hussey ii. t. 45 .

120. C. leucopus Fr.-Pileus scarcely reaching 2.5 cent. ( $\mathrm{I}$ in.) broad, very pale yellow, tan when dry, somewhat fleshy, conical then expanded and umbonate, even, smooth, moist but not viscous. Stem $2.5-5$ cent. (I-2 in.) long, 4-8 mm. (2-4 lin.) thick, stuffed then hollow, rather thick, equal or slightly attenuated upwards, soft, shining white, furnished with a cortina at the middle. Gills adnexed, separating, crowded, ventricose, thin, pallid then cinnamon, the edge which is quite entire of the same colour.

With the habit of $C$. pluvius, but not viscid.

In mixed woods. Frequent. Sept.-Oct. 


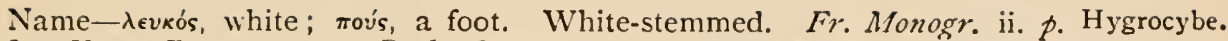
ro8. Hym. Eur. p. 395. Berk. Out. p. r94. C. Hbk. n. 540. S. Mycol. Scot.n. 501. Ag. Bull. t. 533.f. 2.

121. C. scandens Fr.-Pileus when moist at first tawny-ferruginous, then honey-colour, tan when dry, umbo becoming tawny, somewhat membranaceous, slightly fleshy at the umbo, which is sometimes acute sometimes obtuse, conical when young, $12 \mathrm{~mm}$. ( $1 / 2$ in.) broad, broader ( 2.5 cent., I in. and more) when flattened, smooth, slightly striate at the margin; flesh yellowish. Stem 7.5-10 cent. (3-4 in.) long, $4 \mathrm{~mm}$. (2 lin.) thick, fistulose, thickened at the apex, always attenuated at the base, very thin, somewhat awl-shaped, flexuous, soft, even, yellowish, but at first sight, from the adpressed fibrils, and when dry shining whitish. Cortina thin, fibrillose, white. Gills adnate, thin, somewhat distant, narrow, 2-4 mm. ( $\mathrm{I}-2$ lin.) broad, attenuated in front, tawnycinnamon, the edge which is quite entire of the same colour.

The colour varies in intensity with the age of the plant. The umbo is sometimes obsolete. The base of the stem is always white. Like C. obtusus.

In pine wood. Forres. Oct.

Name-scando, to climb. From the long-drawn wavy stem. Fr. Monogr. ii. p. I08. Hym. Eur. p. 396. Icon. t. I63.f. I. S. Mycol. Scot. Supp. Scot. Nat. $1883, p .31$.

\section{* Stem inclining to violet or reddish.}

122. C. erythrinus Fr.-Pileus $2.5-4$ cent. ( $1-1 / 2$ in.) broad, bay-brown-rufous when moist, becoming tawny when dry, slightly fleshy, conical then convex, regular, umbonate, the obtuse or obsolete umbo darker, even, smooth; flesh when moist somewhat of the same colour. Stem $4-7.5$ cent. ( $1 / 2-3$ in.) long, 4-6 mm. (2-3 lin.) thick, stuffed then hollow, equal, rarely thickened at the base, straight or ascending, smooth, but striate with the adpressed fibrils, shining, silvery-white, violaceous and of ten pruinate upwards. Cortina superior, fibrillose, white. Gills slightly adnexed, thin, somewhat distant, ventricose, at first pallid, then pale cinnamon.

\section{In woods. Coed Coch. Oct.}

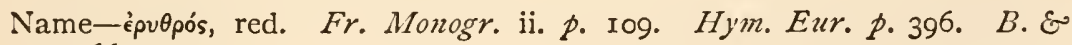
$B r . n .1665$.

123. C. decipiens Fr.-Pileus 2.5 cent. (I in.) or a little more broad, shining, not very hygrophanous, bay-brown, shining and brick-colour when dry, umbo always darker, fleshy-membranaceous, campanulato-expanded, acutely umbonate, at length depressed round the umbo, smooth, margin when full grown slightly 
Hygrocybe. striate and at length innately torn. Stem 5-Io cent. (2-4 in.) long, 2-4 mm. (I-2 lin.) thick, stuffed, then fistulose, exactly equal, sometimes tense and straight, sometimes flexuous, but the surface not undulated, fibrillose, pallid, pale rufescent or with brickcoloured spots, somewhat brick-colour internally, externally covered over with a pallid separable cuticle. Cortina fibrillose, white, very fugacious. Gills adnate, more or less crowded, thin, 4-6 mm. (2-3 lin.) broad, brick-colour-ferruginous.

It approaches $C$. castaneus. It belongs to this series though the stem does not incline to violet, but is only reddish-white. There is a remarkable variety with paler pileus, flexuous and smooth stem, and less crowded gills.

In mixed woods. Frequent. Sept.

Name-decipio, to deceive. Beguiling, cheating. Fr. Monogr. ii. p. rog. Hym. Eur. p. 396. B. \& Br. n. II29. C. Hbk. n. 541. S. Mycol. Scot. n. 502. Hoffm. Ic. t. 9. f. 2. Grevillea, t. 114.f. 3 .

124. C. germanus Fr.-Pileus almost 2.5 cent. ( $\mathrm{I}$ in.) broad, remarkably hygrophanous, fuscous when moist, clay-colour when dry, opaque, somewhat membranaceous, campanulate, obtusely umbonate when expanded, fragile, somewhat silky, but not torn into squamules and not striate. Stem 7.5 cent. (3 in.) long, $2 \mathrm{~mm}$. (I lin.) thick, somewhat fistulose, equal, but often twisted, smooth, silvery-pale, somewhat lilac. Cortina fibrillose, fugacious. Gills adnate, somewhat distant, broad, watery cinnamon.

Strong-smelling.

In pine woods. Logie, Forfarshire. Oct.

Name-germanus, full brother. Closely related to those next it. Fr. Monogr. ii. p. 1o9. Hym. Eur. p. 397. S. Mycol. Scot. Supp. Scot. Nat. 1882, p. 217 . Quel. Grev. t. I14. f. 2.

\section{*** Stem yellowish, commonly becoming pale.}

125. C. detonsus Fr.-Pileus 2.5-5 cent. ( $1-2$ in.) broad, bright yellowish when moist, tan when dry, somewhat membranaceous, conical then expanded, somewhat umbonate, slightly silky then rather smooth, striate to the middle when moist, even and slightly silky when dry; flesh thin, whitish. Stem 5-7.5 cent. (2-3 in.) long, about $4 \mathrm{~mm}$. ( 2 lin.) thick, stuffed then fistulose, equal or attenuated upwards, soft, smooth, pale, the yellowish colour deeply struck into the flesh. Gills adnate, ventricose, distinct, somewhat distant, quite entire, unicolorous, at first bright yellowish then brick-cinnamon.

Fragile. The umbo is at first acute, gradually vanishing, sometimes darker. Stature almost that of $C$. decipiens. It occurs much larger with the stem yellowish-brick-colour. 
Among moss in woods. Glamis, I875. Sept.

Hygrocybe.

Name-detondeo, to shear. Shaven, smooth. Fr. Monogr. ii. $p$. IIo. Hym. Eur. p. 397. B. \& Br.n. I552. S. Mycol. Scot. n. 503 .

126. C. obtusus Fr.-Pileus $1-4$ cent. $(1 / 2-11 / 2$ in.) broad, at the first bay-brown-ferruginous, soon cinnamon, when dry either (according to age) becoming pale-ochraceous or tan-whitish, somewhat membranaceous, conical then campanulate, at length expanded and obtusely umbonate, smooth, striate at the margin. Stem 5-1o cent. (2-4 in.) long, at first spongy-stuffed, soon hollow, comparatively thick, curved, flexuous (not undulated), attenuated at the base, fragile, sprinkled with adpressed white silky fibrils, otherwise rather smooth, tan-yellowish when moist, whitish when dry. Gills adnate, ventricose, somewhat distant, very broad, rather thick, the shorter ones narrower, connected by veins, tawny-cinnamon, white-fringed at the edge.

Spores somewhat ochraceous. Gregarious. Strong-smelling. Cortina entirely fibrillose, whitish; pileus when young here and there rendered hoary silky by the cortina, commonly smooth, but torn when dry. Umbo vanishing. It is very changeable in stature, but the colour is constant, though it changes so much with age and the state of the atmosphere that it requires long familiarity with the plant to enable one to distinguish individual specimens in different conditions.

In woods, chiefly pine. Frequent. Oct.

Name-obtusus, obtuse. From the umbo. Fr. Monogr. ii. p. III. Hym. Eur. p. 397. Icon. t. 163.f. 3. B. Eo Br. n. 1274. S. Mycol. Scot. n. 504.

127. C. acutus Fr.-Pileus honey-colour to very pale yellow and somewhat shining, tan or white when dry, with a silky appearance, somewhat membranaceous, conical then campanulate, then expanded, umbo acute and of the same colour, at length depressed round the umbo, striate when moist, obsoletely fibrillose round the margin when young, smooth when full grown; flesh very thin, of the same colour. Stem 7.5 cent. $(3$ in.) and more long, 2-4 mm. (I-2 lin.) thick, fistulose, slender, equal, flexuous, white-fibrillose, at length smooth, of the same colours as the pileus when moist and dry. Cortina adhering to the margin, fibrillose, white. Gills adnate, thin, crowded, more distant as the pileus becomes more expanded and sometimes free, lanceolate, ochraceous-cinnamon.

Sometimes scattered, sometimes growing in troops. The habit is that of Galera, but remarkable for its acute umbo.

In fir and mixed woods. Frequent. Sept.-Nov.

Spores ellipsoid-oblong, nucleate, $8-9 \times 3-4 \mathrm{mk}$. C.B.P. Name-acutus, acute. From the umbo. Fr. Monogr. ii. p. II2. Hym. Eur. p. 398. Berk. 
Hygrocybe. Out. p. 195. C. Hbk. n. 542. S. Mycol. Scot. n. 505. Quel. Grev. t. I12. f. 5 .

\section{**** Stem inclining to fuscous.}

128. C. Junghuhnii Fr. - Pileus about 2.5 cent. (I in.) broad, shining cinnamon when damp, tawny when dry, slightly fleshy at the disc, otherwise thin, convexo-plane, umbonate with a papilla, when damp striate to the middle, under a lens somewhat velvety with thin, sparse, white, persistent fibrils. Stem 5-7.5 cent. (2-3 in.) long, $4 \mathrm{~mm}$. (2 lin.) thick, stuffed then hollow, externally pale brick-colour, internally darker, externally shining and adpressedly fuscous-fibrillose, quite equal or attenuated and whitish at the base. Veil obsolete, inclining to fuscous. Gills adnate, ventricose, $4 \mathrm{~mm}$. ( 2 lin.) broad, thin, veined at the base, saffronbrick-colour.

Odour none.

In woods. King's Cliffe. Aug.

Spores $8 \mathrm{mk}$. B. \& Br. Name-after Junghuhn. Fr. Monogr. ii. p. Ir3. Hym. Eur. p. 398. B. \& Br. n. 1130. C. Hbk. n. 543 .

129. C. milvinus Fr.-Pileus $\mathrm{I}-2.5$ cent. ( $1 / 2-\mathrm{I}$ in.) broad, olivaceous-fawn-colour, becoming hoary-tan and opaque when dry, membranaceous with exception of the disc, conical then convex, obtusely or obsoletely umbonate, when full grown striate to the middle and beautifully wreathed at the margin with white squamules, somewhat silky when dry; flesh very thin, of the same colour, not scissile. Stem 5-7.5 cent. (2-3 in.) long, equal, $4 \mathrm{~mm}$. (2 lin.) thick, somewhat fistulose, curved, but never flexuous, even, somewhat naked (not scaly), pallid fuscous, here and there with white silky spots. Veil obsolete, except in the form of the wreath encircling the margin of the pileus. Gills adnate, connected by veins, somewhat distant, very thin, scarcely ventricose, watery ferruginous, becoming olive.

Scented. A marked species, growing in troops after heavy rain.

In woods. Wrotham, Kent. Oct.

Name-milvus, a kite. Of the colour of a kite's back. Fr. Monogr. ii. $p$. 114. Hym. Eur. p. 399. B. E Br. n. I553. Quel. Grev. t. II4. f. 6.

130. C. fasciatus Fr.-Pileus I cent. ( $1 / 2$ in.) broad, somewhat membranaceous, conical then expanded, the acute umbo blackish, brick-colour at the circumference, smooth, slightly silky and becoming pale when dry. Stem sometimes 5 cent. ( 2 in.) long, $2 \mathrm{~mm}$. (I lin.) thick, straight, sometimes elongated 7.5-10 cent. 
(3-4 in.) and flexuous, fistulose, undulated on the surface, smooth, Hygrocybe not furnished with a cuticle but wholly fissile into fibrils, pallid fuscous, at length cinnamon-fuscous. Gills adnate, slightly ventricose, thin, but truly distant, distinct, $3 \mathrm{~mm}$. ( $1 \frac{1}{2} \mathrm{lin}$.) broad, cinnamon.

Spores cinnamon. On account of its colours it is like $C$. flexipes, but in its whole nature it is nearest to $C$. acutus.

In pine woods. Dinmore, \&c. Sept.-Oct.

Umbo very acute. M.F.B. Name-fascia, band; fillet. From the stem splitting into bundles of fibres. Fr. Monogr. ii. p. II4. Hym. Eur. p. 399. Grevillea, vol. viii. p. 78. B. Eo Br. n. 1884. Quel. Grev. t. I14.f. 5.

Genus VI.-Gomphidius (ró $\mu$ os, a wooden bolt or nail). Fr. Epicr. p. 31 q.

Hymenophore decurrent on the stem. Gills composed of a mucilaginous membrane, scissile, continuous at the acute edge, pruinate with the blackish fusiform spores. Veil viscoso-floccose. Grow. ing on the ground, fleshy, putrescent, pileus at length turbinate; gills decurrent, distant, soft.

A small genus, with great differences among the species, intermediate by its habit between Cortinarius and Hygrophorus. Fr. Hym. Eur. p. 399 .

Universal veil glutinous, at first terminating on the stem in a floccose ring or fugacious cortina. The gills often admit of being detached and stretched out into a continuous membrane. Fr. Monogr. ii. p. I49.

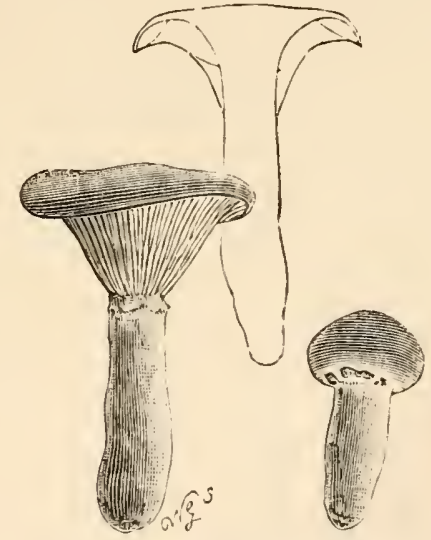

$X L V I$. Gomphidius viscidus. One-fifth natural size.

1. G. glutinosus Fr.-Pileus 5-12.5 cent. (2-5 in.) broad, purple-fuscous, often mottled with black spots, fleshy, convex, obtuse, at length plane, even depressed, even, smooth, very glutinous; flesh thick, about $12 \mathrm{~mm}$. (1/2 in.), soft, white. Stem 5-7.5 cent. ( $2-3$ in.) and more long, about $12 \mathrm{~mm}$. ( $1 / 2 \mathrm{in}$.) thick, solid, whitish, thickened and externally and internally yellow at the base, viscid with the veil, fibrillose or varying with black 
Gomphidius. scales. Cortina often woven in the form of a ring, but soon fugacious. Gills deeply decurrent, distant, distinct, branched, quite entire, mucilaginous, 6-8 mm. (3-4 lin.) broad, at first whitish, then cinereous, clouded with the spores.

Trama none, wherefore the gills easily separate from the pileus. Taste watery, mouldy. Odour not marked.

In woods, chiefly pine. Common. July-Nov.

Spores oblong, uniguttate, $18-23 \times 6-8 \mathrm{mk} . K . ; 16-17 \times 6 \mathrm{mk}$. W.G.S. Name -gluten. Glutinous. Fr. Monogr. ii.p. 149. Hym. Eur.p. 399. Berk. Out. p. 196. C. Hbk. n. 579. S. Mycol. Scot. n. 506. Ag. Schaff. t. 36. Sow. t. 7. Fl. Dan. t. 1247. Letell. t. 547. Krombh. t. 62. f. 18-20. Corda ap. Sturm. xi. t. 51.

Var. roseus.-Pileus rose-colour. Stem white, attenuated and rosy flesh-colour internally at the base.

Very distinguished, constant, always smaller. Spores oblong, 20-22 $\times 6 \mathrm{mk}$. K. Fr. Monogr. ii. p. 150. Hym. Eur. p. 400. C. Hbk. n. 579. S. Mycol. Scot. n. 506. Krombh. t. 63. f. 13-17. Saund. \& Sm. t. 8.

2. G. viscidus Fr. - Pileus $5-7.5$ cent. (2-3 in.) and more broad, fuscous-rufous, compact, at first campanulate, then expanded, umbonate, slightly viscous, shining when dry; flesh yellowish. Stem 7.5-10 cent. (3-4 in.) and more long, $12 \mathrm{~mm}$. ( $1 / 2$ in.) thick, solid, equal or attenuated at the base which is rhubarb-coloured internally, scaly-fibrillose, not very viscous, yellowish. Cortina very evidently floccose, not glutinous, woven in the form of a ring, but readily falling off. Gills deeply decurrent, distant, the shorter ones adnexed to the longer, not truly branched, at first paler, somewhat olive, at length fuscouspurple, clouded with the spores.

Hymenophore descending between the gill plates. Odour not unpleasant.

In woods, chiefly pine. Frequent. July-Oct.

In Hym. Eur. Fries describes the gills as truly branched, while in Monogr. they are described as above. Name-viscidus, viscid. Spores $16-17 \times 6 \mathrm{mk}$. W.G.S. Fr. Monogr. ii. p. 150. Hym. Eur. p. 400. Berk. Out. p. I96. C. Hbk. n. 580 . S. Mycol. Scot. n. 507. Ag. Linn.-Schaff. t. 55. Krombh. t. 4. f. 5-7. Pers. Ic. E descr. t. 13.f. $\mathbf{x}-3$.

3. G. gracilis B. \& Br.-Pileus 2.5 cent. ( $\mathrm{I}$ in.) broad, pale vinous brown, clothed with dingy fuliginous gluten, at length spotted with black. Stem 5 cent. ( 2 in.) long, $3 \mathrm{~mm}$. (I $1 / 2 \mathrm{lin}$.) thick, slender, flexuous, pale, sprinkled with minute white scales above, virgate below (with the remains of the slime), yellow at the base. Gills decurrent, arched, forked, thick, obtuse, of a watery dingy white. 
The gluten on the pileus dries especially round the margin into black spots, Gomphidius. or forms a narrow irregular black border. The gills are clothed under a lens with short tomentose hairs. Distinguished from other species by its slender, thin, and delicate habit.

In fir woods. Frequent. July-Oct.

Spores oblong, elliptic, $24 \times 9 \mathrm{mk}$. with a nucleus at either end. $B$. $\& B r_{\text {. ; }}$ fusiform ellipsoid, $15 \mathrm{mk}$. Q. Name-gracilis, slender. B. \& Br. $n .698$. Berk. Out. p. 196. t. 12.f. 7. S. Mycol. Scot. n. 508. Fr. Hym. Eur. p. 400. G. stillatus C. Hbk. $n \cdot 5^{8 \mathrm{r}}$.

Genus VII.-Paxillus (paxillıs, a small stake). Fr. Gen. Paxillus. Hymenom. p. 8.

Hymenophore continuous with the stem, decurrent. Gills membranaceous, scissile, somewhat branched and here and there anastomosing behind, distinct from the hymenophore and readily separating from it. Spores dingy whitish or ferruginous. Fleshy, putrescent, pileus at first with the margin involute then continuously and gradually unfolded and dilated, indeterminate.

A natural genus, but its extent is not yet properly determined. There are several species of Tricholoma and Clitocybe, which apparently ought to be transferred to it. It is analogous to Boletus in respect of its gills easily separating from the pileus, but to Polyporus in respect of its indefinite growth. Most of the species seem to

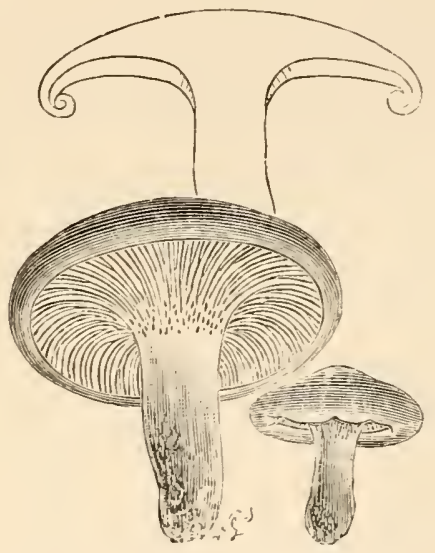

XLVII. Paxillus involutus.

One-fourth natural size. be edible. Fr. Hym. Eur. p. 400.

It comprehends two typical sections which are manifestly distinct, the one that which has $P$. lepista for its type, the other (Tapinia) that which has $P$. involutus tor its type. The former always grow on the ground, but the Tapiniæ occur both on the ground and on trunks; the former have the pileus entire, the latter more or less dimidiate, or altogether lateral and sessile. Fr. Monogr. ii. p. II 5 .

Trib. I. Lepista ( $P$. lepista). Pileus entire, central. Spores dingy, only in $P$. panceolus with a tendency to ferruginous.

Trib. II. Tapinia ( $\tau a \pi \epsilon t v^{\prime} \omega$, , to depress). Pileus commonly excentric or resupinate. Spores ferruginous.

VOL. II. 
1. P. giganteus Fr.-Tan-white. Pileus fleshy, comparatively thin, depressed then plano-infundibuliform, soft, margin involute, then spreading, smooth, sulcate in the form of small channels. Stem solid, obese, smooth. Gills somewhat decurrent, very crowded, here and there branched and anastomosing, whitish then tan-colour.

Large. The pileus is smooth when moist, flocculose or rivulose when dry, easily splitting from the margin to the stem. Hymenophore not horny. Very remarkable, very distinct from $A$. maximus.

\section{In meadows and woods. Uncommon. Sept.-Oct.}

Pileus 4-I4 inches broad, fleshy, often splitting at the margin, broadly infundibuliform, the base of the funnel sunk into the stem with no trace of an umbo, dirty white with an ochraceous tinge, minutely adpresso-squanulose to the naked eye, sometimes guttate; the whole surface under a lens clothed with a fine matted silkiness; margin grooved, the grooves shallow. Gills close, forked, yellow-white, as broad as the flesh of the pileus. Stem $21 / 2-3$ inches high, nearly 2 thick at the base, firm, fleshy, elastic, quite solid, subbulbous, sometimes attenuated upwards, minutely but conspicuously pubescent, when bruised dirty rufescent. Odour strong like that of $M$. oreades. M.F.B. Name-giganteus, of gigantic size. Fr. Hym. Eur. p. 40u. S. Mycol. Scot. n. 509. Ag. Sow. t. 244. Fr. Monogr. i. p. i18. Sv. ätl. Sv. t.86. Berk. Eng. Fl.v. p. 33. Out.p. I 1о. Letell. t.682. Quel.t.3.f.3. A. maximus C. Hbk. n. 95 .

2. P. lepista Fr.-Pileus 7.5-Io cent. (3-4 in.) and more broad, dingy whitish, sometimes (young) compactly fleshy, sometimes (full grown) thin, plano-depressed, obtuse, without stria, but rimuloso-squamulose tozvards the circumference, dry, the involute margin commonly undulato-flexuous; flesh white. Stem sometimes curt, 2.5 cent. ( 1 in.) or little more, attenuated downwards, sometimes elongated to 7.5-Io cent. (3-4 in.), equal, always blunt at the base, about $12 \mathrm{~mm}$. ( $1 / 2 \mathrm{in}$.) thick and more, solid, compact, spongy-elastic, and at length pierced by larvæ and hollow, whitish, sometimes rufescent or inclining to fuscous, white-villous at the base. Gills deeply decurrent, somewhat branched but simple at the base, 4-6 mm. (2-3 lin.) broad, very crowded, quite entire, dingy white, at length darker.

The cuticle of the stem is somewhat horny, continuous with the hymenophore and similar to it. Solitary and sporadic, very changeable. Odour mealy, somewhat rancid, approaching that of $A$. prunulus, to which it is somewhat allied.

\section{In woods. Slough.}

Spores reddish, then becoming fuscous-pallid. Fr. Name-lepista, a pan. From its shape. Fr. Monogr. ii. p. iा6. Hym. Eur. p. 402. Icon. t. I64. f. I. B. Eo Br.n. I554. Ag. Sterb. t. I9. C. 
3. P. paradoxus Berk.-Pileus $5-7.5$ cent. ( $2-3$ in.) broad, deep Paxillus. rufous-umber or yellowish-brown, fleshy, compact, in some cases subexcentric, convex or pulvinate then plane, scarcely depressed, often lobed and sinuate at the margin, dry, adpressedly tomentose, not shining. Stem 4 cent. ( $1 / 2$ in.) and more long, $\frac{3}{10}-\frac{4}{10} \mathrm{in}$. thick and when bulbous thicker, solid, bulbous or attenuated at the base, fusiform, somewhat rooted, adpressedly fibrillose, otherwise even and smooth, the cuticle most frequently breaking up into squarrosely revolute flaps, yellow, sometimes with a dingy purplish tinge. Gills truly decurrent, distant, the alternate ones broader, $\frac{1}{10}-\frac{3}{10}$ in., entire at the edge, connected by veins at the base and in some cases anastomosing to form pores towards the margin, yellow then golden, reddish when bruised.

Stem variable in stature. No trace of a veil. Flesh soft, juicy, dingy white, slightly rufous under the cuticle of the pileus, becoming yellow at the base of the stem. Taste and odour scarcely any.

In woods. Wrekin, Salop, I875. Sept.

Spores ovate, oblong, of medium size, lurid ochraceous. Kalchb. 16-17 66

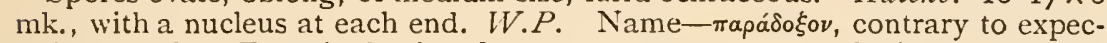
tation or rule. From its having features contrary to normal Agaricus, under which Kalchbrenner placed it. Berk. Ag. Kalchb. Fung. Hung. t. I6. f. r. Fr. Hym. Eur. p. 244. Grevillea, vol. iv. p. I18.

4. P. panæolus Fr.-Pileus $2.5-5$ cent. ( $I-2$ in.) broad, whitish, fleshy, thin, convexo-plane then somewhat depressed, even, smooth, moist, the thin margin involute; flesh becoming black. Stem 2.5 cent. ( $\mathrm{I}$ in.) or little more long, $6 \mathrm{~mm}$. (3 lin.) thick, stuffed, striato-fibrillose, rufescent, thickened downwards. Gills slightly decurrent, crowded, narrow, at length watery-ferruginous.

The whole plant is at first whitish, then the stem is rufescent, and the gills in the end become cinnamon. The gills are separated from the hymenophore by a horny line, and readily separate from the pileus. Spores watery ferruginous, in which it approaches the Tapiniæ.

* spilomæolus.-Pileus spotted as with drops, and, as well as the slender stem, yellowish-white. Gills at length watery ferruginous, horny-grey at the base.

\section{Among fir-leaves. Stoke Poges.}

The spotted pileus and dingy spores at once distinguish it from any Tricholoma with which it might be confounded. The stem is sometimes incrassated at the base, sometimes quite equal. $B$. \& $B r$. The var. only is British.

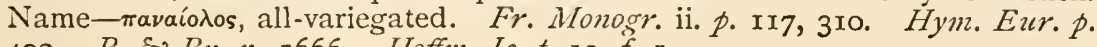
402. B. \& Br. n. т666. Hoffm. Ic. $t$. го. $f$. . 
5. P. involutus Fr.-Pileus $7.5-12.5$ cent. ( $3-5$ in.) broad, ochrey-ferruginous, fleshy, firm, convexo-plane then depressed, for the most part central, at the first pubescent, soon becoming smooth, somewhat viscid when moist, shining when dry, obtuse and villous round the margin which is at first closely involute, when more fully grown extenuated and acute; flesh compact, pallid. Stem 5-7.5 cent. (2-3 in.) long, I-2.5 cent. ( $\mathrm{I} / 2-\mathrm{I}$ in.) thick, fleshy, solid, firm, thickened upwards, more rarely at the same time bulbous at the base, naked, dingy yellowish, commonly spotted. Gills decurrent, rather broad, branched and forming pores behind, when young arcuate, crowded, pallid, at once spotted when touched, at length extended, ferruginous.

Commonly large, obese, readily distinguished by the pileus being villous round the very involute margin, by the gills anastomosing and forming pores at the base and being dingy-spotted when touched. Pileus more rarely excentric, darker in colour in wet, and paler in dry weather. It varies lobed and scaly.

In woods. Very common. June-Nov.

Edible; highly esteemed in Russia. Spores ferruginous, Fr. ; ellipsoid or sphæroid-ellipsoid or oblong-ellipsoid, $8-16 \times 6 \mathrm{mk}$. K., $5 \times 6 \mathrm{mk}$. W.G.S. Name-involutus, rolled inwards. From the involute pileus. Fr. Monogr. ii. p. I18. Hym. Eur. p. 403. Sv. ätl. Sv. t. 75. Berk. Out. p. 195. t. 12. f. 5. C. Hbk. n. 547. S. Mycol. Scot. n. 510. Hoffm. Ic. t. 10. f. 2. Ag. Batschf. 61. Ventur. t. 42. f. 6, 7. Schaff. t. 72. Bull. t. 240, 576. f. 2. -Klotsch. Bor. t. 391 .

6. P. leptopus Fr.-Pileus $4-7.5$ cent. ( $1 \frac{1}{2}-3$ in.) broad, fuscous-yellowish, always excentric or lateral, at length depressed but gibbous in the middle, fleshy, thin, dry, covered with dense down, soon torn up into dense villous scales, which are fuscous or yellowish; flesh yellow. Stem very short, scarcely reaching 2.5 cent. ( $\mathrm{I}$ in.), somewhat incurved, attenuated downwards, yellow within. Gills simple behind, decurrent but not anastomosing, tense and straight, crowded, very narrow, yellowish, then darker, but not spotted when touched.

Changeable in stature and form. A remarkable species, with the habit of $P$. involutus, from which it is readily distinguished by having the gills simple (not anastomosing) at the base.

On the ground about stumps, \&c. Forres. Glen Tilt. Kenmore. Aug.

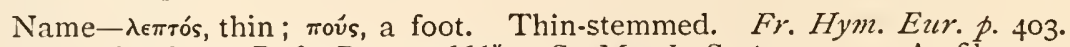
Icon. t. I64. f. 3. B. \& Br.n. 1666*. S. Mycol. Scot. n. 5II. A. filamentosus Fr. Monogr. ii. II8, 3II. B. \& Br.n. 1276.

7. P. atrotomentosus Fr.-Pileus 5-Io cent. (2-4 in.) and more 
broad, ferruginous, compactly fleshy, excentric, plano-infundibuli- Paxillus. form and sometimes wholly lateral and ascending, dry, rivulosogranular on the surface, sometimes also slightly tomentose, the thin margin involute; flesh white. Stem 5-7.5 cent. (2-3 in.) long, I-2.5 cent. ( $1 / 2-1$ in.) thick, solid, elastic, somewhat equal, not tuberous, curved-ascending, rooting, covered over with dense, soft velvety down, which is umber-blackish or inclining to violaceous. Gills adnate, scarcely decurrent, branched at the base, somewhat anastomosing, crowded, $6 \mathrm{~mm}$. (3 lin.) broad, yellowish, easily separating from the sulcate hymenophore.

Commonly solitary. Robust, firm, often very large. The pileus is variable in form. The gills do not form pores like those of P. involutus. Sometimes lateral, but marginate behind.

On pine-stumps. Rare. Aug.-Nov.

Spores somewhat clay-colour, paler than those of $P$. involutus. Fr.; ellipsoid-sphæroid, subhyaline, $4-6 \times 3-4 \mathrm{mk}$. $K$. Name-ater, black; tomentum, down. Fr. Monogr. ii. p. II9. Hym. Eur. p. 403. Berk. Out. p. I95. C. Hbk. n. 548. S. Mycol. Scot. n. 512. Ag. Batsch f. 32. Paul. t. 33. f. 2, 3. Nees. f. I75.

8. P. panuoides Fr. Wholly dingy yellow.-Pileus about 4 cent. ( $1 \frac{1}{2}$ in.) long, fleshy, sessile or extended behind and at the first resupinate, soon conchate dimidiate and obovate, at length broadly expanded undulato-lobed and often imbricated, surface pubescent then becoming smooth, somewhat rivulose; flesh equal but thin. Gills decurrent to the base, anastomosing behind, branchea, crowded, crisped, yellow.

Very variable in size and changeable in form.

On sawdust, \&c. Uncommon. Aug.-Oct.

Spores ellipsoid-sphæroid, $4-6 \times 3^{-4}$ mk. $K$. $; 3 \times 4$ mk. W.G.S. NamePanus; eíos, appearance. Panus-like. Fr. Monogr. ii. p. ı 20. Hym. Eur. p. 404. Berk. Out. p. Ig6. t. I2.f. 6. C. Hbk. n. 549. S. Mycol. Scot. n. 513. Merulius Sow. t. 403 .

9. P. fagi B. \& Br.-Crisped, pallid upwards, orange beneath. Gills crisped, orange.

Remarkably gregarious. Forming a wide crisped mass of great beauty, very different in appearance from $P$. panuoides, which is confined to fir or sawdust.

On a beech-stump. Coed Coch.

Name-fagus, beech. B. \& Br.n. Ig6r. 
Hygrophorus.

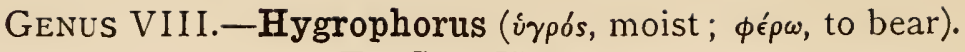
Fr. Gen. Hymen.

Hymenophore continuous with the stem and descending unchanged as a trama into the gills. Gills acute at the edge, clothed with the hymenium which

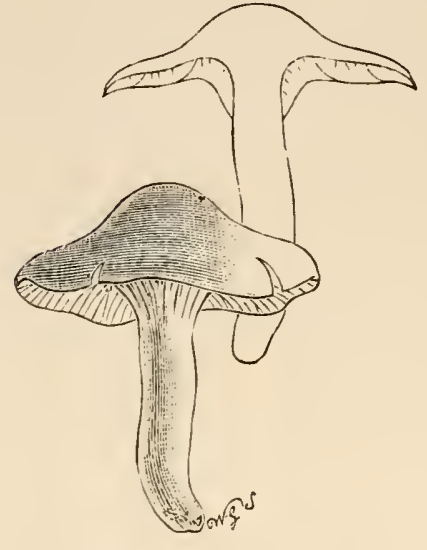

XLVIII. Hygrophoruspratensis. One-third natural size. turns into a waxy mass, and not membranaceous. Spores globose, white. Growing on the ground, putrescent; pileus viscid or watery, gills often branched. Fr. Hym. Eur. $p$. 405 .

This genus differs from the central one of Agaricus in the manifest trama, the substance of which is similar to that of the pileus; from Lactarius and Russula by the trama not being vesicular, but somewhat floccose with granules intermixed; from Cantharellus, its nearest ally, by the sharp edge of the gills. The Cortinarii, Paxilli, and Gomphidii are at once distinguished from it by their coloured spores and the changing colour of their gills, as well as by other marks. From all the other genera of Agaricini it is distinguished by a mark peculiar to itself-viz., by the hymeneal stratum of the gills changing into a waxy mass, which is at length removable from the trama. This altogether singular character is specially remarkable in $H$. caprinus, coccineus, murinaceus, \&c. Hence the gills seem full of watery juice, but they do not become milky like those of the Lactarii. Monogr. ii. p. I2I.

I. Limacium (limax, a slug; slimy). Fr. Syst. Myc. p. 3I. Universal veil viscid, with occasionally a floccose partial one, which is annular or marginal. Stem clothed with scales, or more frequently rough with dots above. Gills adnato-decurrent.

* White or yellozvish white.

** Reddish.

*** Tawny or light yellow.

**** Olivaceous $-u$ mber.

***** Fuscous-cinereous or livid.

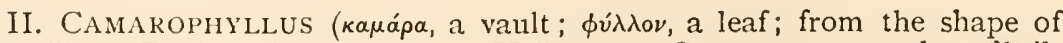
the gills). Fr. Syst. Myc. i. p. 98. Veil none. Stem even, smooth or fibrillose, and not rough with dots. Pileus firm, opaque, moist in rainy weather, not viscous. Gills distant, arcuate.

* Gills deeply and at length obconically decurrent.

** Gills ventricose, sinuato-arcuate, or plano-adnate. 
III. HygRocybe (v́ypós, moist; кǔßń, a head). Fr. Syst. Myc. i. p. ror. HygroVeil none. Whole fungus thin, watery succulent, fragile. Pileus viscid phorus. when moist, when dry shining, rarely floccoso-scaly. Stem hollow, soft, not punctate. Gills soft. Most of the species brightly coloured and shining.

This group presents the type of the genus, and clearly differs from the Agarici; from the rest of the Hygrophori it might easily be separated as a genus by itself.

* Gills decurrent.

** Gills adnexed, somewhat separating.

\section{I.-Limacium.}

* White or yellowish white.

1. H. chrysodon Fr.-Pileus 5-7.5 cent. (2-3 in.) broad, white, shining when dry, but commonly yellowish with minute adpressed squamules at the disc, light yellow-flocculose at the involute margin, fleshy, convex then plane, obtuse, viscid; flesh white, sometimes reddish. Stem 5-7.5 cent. (2-3 in.) long, about $12 \mathrm{~mm}$. ( $1 / 2$ in.) thick, stuffed, soft, somewhat equal (sometimes, however, irregularly shaped or thickened at the base), white, with minute light yellow squamules, which are more crowded and arranged in the form of a ring towards the apex. Gills decurrent, distant, $6 \mathrm{~mm}$. (3 lin.) broad, thin, white, somewhat yellowish at the edge, sometimes crisped.

Odour not unpleasant. There is a manifest veil, not woven into a continuous ring, but collected in the form of floccose squamules at the apex of the stem and the margin of the pileus. Var. leucodon with white squamules.

In woods. Rare.

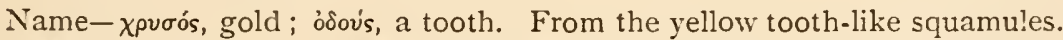
Fr. Monogr. ii. p. 123. Hym. Eur. p. 405. Berk. Out. p. 197. C. Hbk.n. 550. Ag. Batsch f. 212. Gonn. \& Rab. viii.-ix. t. Io. f. I. Var. with shining white pubescence $B$. \& $B r . n$. 1 $356^{\%}$.

2. H. eburneus Fr. Wholly shining white-Pileus fleshy, sometimes thin, sometimes somewhat compact, convexo-plane, somewhat repand, even, very glutinous in rainy weather, margin soon naked. Stem sometimes short, sometimes elongated, stuffed then hollow, unequal, glutinous like the pileus, rough at the apex with dots in the form of squamules. Gills decurrent, distant, reined at the base, $6-\delta \mathrm{mm}$. (3-4 lin.) broad, tense and straight, quite entire.

Odour mild, not unpleasant. Very changeable. The veil is absent, unless the very plentiful gluten which envelops the stem be regarded as a universal veil; margin of the young pileus involute, only at the first pubescent, soon naked. The stem is soft internally, at length hollow, attenuated towards the base.

In woods and pastures. Frequent. Sept.-Oct. 
Hygro- Edible. Spores subsphæroid, irregular, 5-6 mk. K. ; $4 \times 5 \mathrm{mk}$. W.G.S.; phorus. subellipsoid, $6 \times 4 \mathrm{mk}$. C.B.P. Name-ebur, ivory. Ivory - white. Fr. Monogr. ii. p. I23. Hym. Eur. p. 406. Berk. Out. p. I97. t. I5. f. 4. C. Hbk. n. 55т. S. Mycol. Scot.n. 514. Gonn. E Rab. t. II. f. 5. Ag. Bull. t. 551. f. 2. Viv. t. I7. Schaff. t. 39. Krombh. t. 6I. f. II-I4. Buxb. iv. t. 3o.f. 2.

3. H. cossus Fr.-Pileus 4 cent. ( $1 / 2$ in.) broad, yellowishwhite, disc somewhat ochraceous, fleshy, convexo-plane, obtuse, smooth, glutinous, shining when dry, margin naked; flesh white. Stem 5-7.5 cent. (2-3 in.) long, varying elongated, $4-10 \mathrm{~mm}$. $(2-5$ lin.) thick, varying thin, stuffed, soft, somewhat equal, furfuraceous and rough with dotted points upwards, white or becoming tinged with yellow. Gills adnate, decurrent, distant, connected by veins, firm, white.

Veil none. It differs from H. eburneus in the pileus being yellowish, in the margin being at the first naked, and especially in its unpleasant odour of goatmoth.

In woods. Frequent. Sept.-Oct.

Name-from its odour of goat-moth (Phalana cossi). Fr. Monogr. ii. $p$. 124. Hym. Eur. p. 406. Berk. Out. p. I97. C. Hbk. n. 552. S. Mycol. Scot.n. 5I6. Ag. Sow. t. I2 ז.

4. H. penarius Fr.-Pileus tan-colour, opaque, fleshy especially when young, at first umbonate, then very obtuse, hemispherical then flattened, even, smooth, commonly dry, margin at first involute, exceeding the gills, undulated when flattened; flesh thick, hard, whitish, unchangeable. Stem curt, 4 cent. (I $1 / 2$ in.) or more long, about $12 \mathrm{~mm}$. ( $1 / 2 \mathrm{in}$.) thick at the apex, solid, compact, hard, attenuated at the base into a fusiform root, ventricose to the neck, again attenuated upwards or wholly fusiform-attenuated, palewhite, smeared with tenacious easily dried slime, scabrous; flesh firm, but externally more rigid, cuticle somewhat fragile. Veil not conspicuous. Gills adnato-decurrent, acute behind, distant, thick, $6-8 \mathrm{~mm}$. (3-4 lin.) broad, veined, tan inclining to pale.

Odour pleasant, taste sweet. The fusiform root is as long as the stem.

In mixed woods. Stoke Poges.

Edible. Name-penus, food. For food. Fr. Monogr. ii. p. 124. Hym. Eur. p. 406. Sv. ätl. Sv. t. 48. B. \& Br. n. 1778. Ag. Schaff. t. 238. Sow. $t .7 \mathbf{r}$.

5. H. pulverulentus B. \& Br.-Pileus about $8 \mathrm{~mm}$. ( $1 / 3 \mathrm{in}$.) broad, shining white, pulvinate, viscous, the involute margin tomentose. Stem I $8 \mathrm{~mm}$. ( $3 / 4$ in.) $2-4 \mathrm{~mm}$. ( $\mathrm{I}-2$ lin.) thick, stuffed, nearly equal, attenuated at the very base, wholly powdered 
with rose-coloured meal. Gills decurrent, thick, obtuse at the Hygroedge, whitish.

Allied to $H$. eburneus, but the rose-coloured meal with which the stem is covered separates it from all other species.

Among pine-leaves. Glamis, 1876. Nov.

A small but very beautiful species. Name-pulvis, dust; pulverulent. B. \& Br. n. 1667. S. Mycol. Scot. n. 515 .

\section{** Reddish.}

6. H. erubescens Fr.-Pileus 5-Io cent. (2-4 in.) and more broad, white becoming everywhere red, fleshy, gibbous then convexo-plane, viscid, adpressedly dotted with squamules or be. coming smooth, sometimes wholly compact, sometimes thin towards the margin which is at the first naked; flesh firm, white. Stem sometimes short, robust, 5 cent. (2 in.) long, 2.5 cent. (I in.) thick and attenuated upwards, sometimes elongated, Io cent. ( 4 in.) long, equal or attenuated at the base, solid, flexuous, with red fibrils, dotted with red upwards. Gills decurrent, distant, soft, white, with red spots.

Veil none. The ground colour is white, as it is also internally, but it everywhere becomes red and the pileus often rosy-bloud-colour. Handsome, growing in troops, commonly forming large lax circles.

In pine woods. Hereford.

Spores ellipsoid, very obtuse at both ends, 8-ro $\times 4-5 \mathrm{mk} . K$. Nameerubesco, to become red. Fr. Monogr. ii. p. 125. Hym. Eur. p. 407. Sv. ätl. Sv. t. 65. Quel. t. Ix.f. x. Grevillea, vol. vi. p.7x. Ag. Kalchbr. Ic. t. I8. $f .2$.

7. H. glutinifer Fr. - Pileus rufescent, whitish round the margin, fleshy, convexo-expanded, thin with exception of the disc which is at length broadly gibbous, with a glutinous pellicle, disc wrinkled-dotted. Stem stuffed, somewhat elastic, ventricose downwards, with a viscous vill, of the same colour as the pileus, white-squamulose at the apex. Gills arcuato-decurrent, rather thick, shining white.

Gregarious, mild, variable in stature.

In woods. Penzance.

Fries considers it different fron 1 A. aromaticus Sozv. $t$. 144. Berkeley ( $B$. \&o $B r . n$. 2019) thinks it is probably the same. Name-gluten, fero, to carry. Gluten-bearing. Fr. Hym. Eur. p. 407. Epicr. p. 322. B. Eo Br. n. 2019. Ag. Bull.t. 258, 539.f. B.

\section{*** Tawny or light-yellow.}

8. H. arbustivus Fr.-Pileus 5 cent. ( 2 in.) broad, slightly tawny-brick-colour, paler round the margin, opaque, fleshy, con- 
Hygro- vexo-plane, obtuse, somewhat repand, viscid, streaked with innate phorus. fibrils, but wholly smooth, even. Stem 4 cent. ( $1 / 2$ in.) long, I2 $\mathrm{mm}$. ( $1 / 2$ in.) thick, solid, equal, incurved, with white mealy granules at the apex, smooth at the base, pale white, externally more rigid and polished, internally somewhat spongy, hence elastic. Gills adnate, scarcely decurrent, distant, thick, white.

Odour and taste not unpleasant. It differs from all neighbouring species in the mealy free (not innate) white granules at the apex of the stem. In structure it is nearest to $H$. pratensis.

In woods. Colleyweston, \&c. Dec.

Perhaps edible. Name-arbustum, a plantation. Found under trees. Fr. Monogr. ii. p. 126. Hym. Eur. p. 408. B. \& Br.n. 932, тог3. C. $H b k . n \cdot 556$.

9. H. discoideus Pers.-Pileus $2.5-5$ cent. ( $1-2$ in.) broad, pale yellowish inclining to pale, the disc alwuays darker somewhat ferruginous, slightly fleshy with exception of the firmer disc, on its first appearance campanulato-convex, margin inflexed, then rather plane and somewhat obtuse, and at length depressed at the disc, even, smooth, very glutinous; flesh of the same colour as the gills. Stem $4-5$ cent. ( $1 / 2-2$ in.) long, 6-1o mm. (3-5 lin.) thick, stuffed, equal or attenuated upwards, very soft (texture fibrous, separable), flocculose, viscid, pale-white, with white dots at the apex. Veil entirely glutinous, rarely terminating somewhat in the form of a ring on the stem. Gills at first adnate, somewhat crowded, then decurrent, distant, moderately thin, soft, pale, yellowish-white.

Gregarious, here and there forming rings. In later autumn it occurs with the pileus clay-coloured, disc ferruginous, stem elongated, at length hollow.

In grassy places. Laxton Park, Norths. Oct.

Stem dotted all over with viscid granules. $B . \& B r$. Spores ellipsoid-

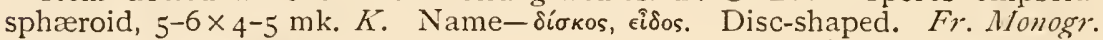
ii. p. 127. Hym. Eur. p. 408. B. E Br.n. I558. Ag. Pers.—Gonn. \& Rab. viii.-ix. $t$. Io $f .4$.

\section{**** Olivaceous-umber.}

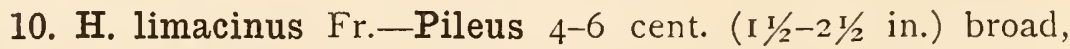
disc umber then fuliginous, paler round the margin, fleshy, convex then flattened, obtuse, smooth, viscid; flesh rather firm, white. Stem $5-7.5$ cent. (2-3 in.) long, I $2 \mathrm{~mm}$. ( $1 / 2$ in.) thick, solid, firm, ventricose, viscous, flocculose, fibrilloso-striate, roughened with squamules at the apex. Gills adnate then decurrent, somewhat distant, thin, white inclining to cinereous.

Veil entirely viscous, not floccose. Intermediate between $H$. olivaceo-albus 
and $H$. agathosmus, differing from the former in the stem being squamulose at Hygro. the apex, and from the latter in the manifest veil being cortinate.

In woods among damp leaves. St Leonards. Oct.

Name-limax, a slug; slimy. Fr. Monogr. ii. p. 129. Hym. Eur. p. 409. B. \& Br.n. 1277. Saund. \& Sm. t. 28. Ag. Scop.

11. H. olivaceo-albus Fr.-Pileus $2.5-5$ cent. ( $\mathrm{I}-2$ in.) broad, olivaceous-fuscous, becoming pale, especially towards the margin, which is at the first naked, fleshy, at first acorn-shaped, then expanded, umbonate, and at length depressed round the uinbo, wholly even, smooth, glutinous; flesh thin, white. Stem about 7.5 cent. (3 in.) long, $6 \mathrm{~mm}$. (3 lin.) thick, solid, equal or attenuated at the very base, squamulose and spotted with the fuscous veil, which is in the form of an adnate sheath, viscid, but the ground colour is white; veil terminating near the apex in the form of a ring above which the stem is even, shining white. Gills decurrent, distant, broad, simple, connected by veins at the base, always shining white.

Margin somewhat striate when old. Scattered throughout the summer in rainy weather, not enduring cold, and hence very different in its nature from H. hypothejus, which is allied.

In woods, chiefly pine. Frequent. Aug.-Oct.

Spores $4 \times 7$ mk. W.G.S. Name-from the olivaceous pileus and white gills. Fr. Monogr. ii. p. 128. Hym. Eur. p. 4 I0. Berk. Out. p. 198. C. Hbk. n. 558. S. Mycol. Scot. n. 517. Ag. Brig. t. 5. f. I-3.

12. H. hypothejus Fr.-Pileus $2.5-5$ cent. ( $\mathrm{I}-2$ in.) broad, at first smeared with olivaceous gluten, cinereous, when the gluten disappears, becoming pale and yellowish, orange or rarely (when rotting) rufescent, fleshy, thin, convex then depressed, obtuse, even, somewhat streaked; flesh thin, white then becoming light yellow. Stem 5-Io cent. (2-4 in.) long, 4-6 mm. (2-3 lin.) and more thick, stuffed, equal, even, viscous, but rarely spotted with the veil, at length hollow. Partial veil floccose, at the first cortinate and anmular, soon fugacious. Gills decurrent, distant, distinct, at first pallid (even whitish), soon yellow, sometimes flesh-colour.

Very protean, changeable in colour and variable in size. Stem not scabrous. There is no trace of the veil when the plant is full grown. Appearing after the first cold autumn nights, and lasting even till snow.

In pine woods. Frequent. Sept.-Nov.

Spores subellipsoid, 8-9 $\times 4-5$ mk. K.; $12 \times 4$ mk. IV.G.S. Name-v́mó ; $\theta \in i o \nu$, sulphur. From the sulphur-colour under the gluten. Fr. Monogr. ii. p. 128. Hym. Eur. p. 4 10. Berk. Out. p. 198. C. Hbk. n. 557. S. Mycol. Scot.n. 518. Ag. Krombh. t. 72. f. 24, 25. Gonn. \& Rab. t. 10.f.5. Sow. $t$. 8. Alb. ES Schw. t. го. f. 4. Buxb. C. iv. t. 2 I. 
Hygro- 13. $H$. cerasinus Berk.-Pileus $4-6$ cent. ( $1 / 2-21 / 2$ in.) broad, phorus. pale umber then grey, fleshy, convex, broadly umbonate, often more or less wavy, sometimes depressed, viscid, shining when dry, margin minutely tomentose. Stem $2.5-5$ cent. (I-2 in.) long, solid, white, attenuated below, punctato-squamulose above. Gills decurrent, broad, white, tinged with pink, sometimes forked, very distant.

Smell like that of cherry-laurel leaves. Somewhat gregarious. The minute white down at the margin of the pileus is divided into little linear heaps by the pressure of the gills in the early stage of growth.

In woods, fir, \&c. Rare. Oct.

Name-from its smell of cherry-laurel (Prunus laurocerasus). Berk. Eng. Fl. v. p. 12. Out. p. 197. C. Hbk. n. 553. S. Mycol. Scot. n. 519. Fr. Hym. Eur. p. 410.

\section{**** Fuscous-cinereous or livid.}

14. H. fusco-albus Fr.-Pileus about 5 cent. (2 in.) broad, fuscous then cinereous, fleshy, moderately firm, convexo-plane, even, smooth, viscous, margin white-floccose. Stem 5-7.5 cent. (2-3 in.) long, 8-I2 mm. (4-6 lin.) thick, solid, equal, when dry white-floccose at the apex. Gills decurrent, broad, rather thick, snow-white.

Stature and veil those of $H$. chrysodon, but the veil is somewhat annular, floccose not squamulose.

Among moss. Gwrwch, I88I.

Remarkable for its distinct floccose veil. M.F.B. Name-from the fuscous pileus and white gills. Fr. Hym. Eur. p. 410. B. \& Br.n. 1962. Ag. Fung. Linn. v. t. 6. f. . .

15. H. agathosmus Fr.-Pileus $4-6$ cent. ( $1 / 2-21 / 2$ in.) broad, livid-grey, unicolorous, dotted with minute, raised, crowded, viscous, pellucid, whitish papilla, fleshy, convex then plane, gibbous, viscous, margin at first involute and villous, soon unfolded and naked, at length reflexed and undulated ; flesh soft, watery, whitish. Stem 5-7.5 cent. (2-3 in.) long, 6-Io mm. (3-5 lin.) and more thick, solid, firm, at length soft (also hollow), equal or slightly thickened downwards, somewhat fibrilloso-striate, not viscous, roughened as if mealy upwards with white punctiform squamules, which at length become cinereous. Partial veil not conspicuous. Gills decurrent, distant, soft, $6-8 \mathrm{~mm}$. (3-4 lin.) broad, quite entire, somewhat veined at the base, shining white.

A very remarkable species. Odour chiefly when older sweet, of anise. Lasting into late autumn. The pileus when luxuriant is much larger and 
flexuous. The stem varies curved, flexuous, \&c. The squamules take the place Hygroof the veil.

In fir woods. Forres. Glamis. Sept.-Nov.

Spores sphæroid-ellipsoid, hyaline, $8 \times 5 \mathrm{mk} . K$. Name-ảyatós, good; o $\sigma \mu \dot{\eta}$, scent. From the agreeable scent. Fr. Monogr. ii. p. I29. Hym. Eur. p. 4II. S. Mycol. Scot. n. 520. Gonn. \& Rab. viii.-ix. t. II.f. 4 .

16. H. mesotephrus B. \& Br.-Pileus about 2.5 cent. ( $\mathrm{I}$ in.) broad, white, disc brown, convex, somewhat hemispherical, viscid, striate, the extreme margin often remaining quite even; flesh white, hygrophanous. Stem about 5 cent. (2 in.) long, $4 \mathrm{~mm}$. (2 lin.) thick, stuffed with a fibrillose pith, slender, flexuous, attenuated at the base, white, viscid, floccoso-granulated at the apex. Gills shortly decurrent, moderately broad, ventricose, rather distant, pure white.

A very delicate species, allied to $H$. fusco-albus, but with a very different habit. In age the lower part of the stem is slightly stained, but by no means squamose.

In woods. Rare. Bowood.

Spores $9 \mathrm{mk}$. long. $B$. \& $B r_{\text {. ; }}$ elliptical, pruniform, Io-I2 mk. $Q$. Name

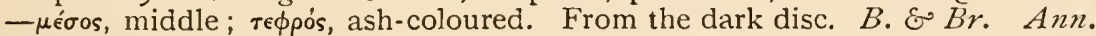
Nat. Hist. ser. 2. vol. xiii. t. I5.f. 2. Berk. Out. p. x98. C. Hbk. n. 555. Fr. Hym. Eur. p. $4 \mathrm{II}$.

17. H. livido-albus Fr.-Pileus livid, anicolorous, fleshy, thin, obtuse, even, smooth, viscid, margin naked. Stem stuffed, slender, equal, rather even. Gills decurrent, distant, distinct, shining white.

It differs from $H$. eburneus not only in the livid colour but also in the slightly viscous pileus as well as stem being even, smooth. It approaches the Camarophylli.

In woods. Street. Oct.

Name-from the livid pileus and white gills. Fr. Hym. Eur. p. 4 I2. Monogr. ii. p. г31. B. \& Br. n. I357. Ag. Fl. Dan. t. I907. f. 2.

\section{II.-Camarophyllus.}

* Gills deeply and at length obconically decurrent.

18. H. caprinus Fr.-Pileus 5-Io cent. (2-4 in.) and more broad, at first blackish-fuliginous, or blackish, at length cinereousfuliginous, but varying azure-blue, \&c., fleshy, at first conicoconvex, often with a prominent acorn-shaped umbo, then flattened or depressed, obtuse, somewhat repand, at the first slightly viscid, streaked with fibrils; flesh soft, fragile, thin towards the margin which is at length repand. Stem 7.5-10 cent. (3-4 in.) long, 4 
Hygro- cent. ( $1 / 2$ in.) and more thick, solid, equal or attenuated downphorus. wards, at length soft, often hollow and fragile at the apex, externally in a remarkable degree longitudinally fibrillose, fuliginous, pubescent and whitish at the base. Veil none. Gills remarkably decurrent, exceedingly distant, very broad, thick, quite entire, at first white, at length waxy-soft, becoming glaucous.

A most distinct species, in habit to be compared only with Ag.elixus. The gills are sometimes altogether eaten away by slugs.

In pastures. Bath. Glamis. Oct.

Spores ellipsoid-sphæroid, $6-8 \times 4-5 \mathrm{mk} . K$.; ellipsoid, guttate, ro mk. $Q$. Name-caper, a goat. From the streaking of the fibrils. Fr. Monogr. ii. $p$. I31. Hym. Eur. p. 4 12. B. \&o Br. n. 1278. S. Mycol. Scot. n. 521. Ag. Scop.-Krombh.t.72.f. 21-23.

19. H. leporinus Fr.-Pileus $2.5-5$ cent. ( $1-2$ in.) broad, yellowrufescent, varying fuscous, equally fleshy, convex, gibbous, equal, fibrilloso-floccose, opaque. Stem short, stuffed, firm, rigid, attenuated commonly downwards, more rarely upwards, fibrillose, pallid. Gills decurrent, pale yellowish.

Its appearance is wholly that of $H$. pratensis.

In wookls and on downs. Rare. Sept.-Oct.

Spores pale umber. M.F.B. Name-lepus, a hare. From the colour. Fr. Hym. Eur. p. 412. Berk. Out.p. ig9. C. Hbk. n. 559. S. Mycol. Scot.n. 522. Ag. Schaff. t. 313.-Batt. t. 9. f. B.

20. H. nemoreus Fr.-Pileus somewhat orange, equally fleshy, convex then expanded, gibbous and at length depressed, somewhat smooth. Stem stuffed, firm, squamulose, fibroso-striate, attenuated at the base. Gills decurrent, thick, distant, somewhat of the same colour.

In woods. Stoke Poges. Dec.

Spores white. $B . \& B_{0}$; ovate-spherical, punctate, 5-6 mk. $Q$. Namenemus, a grove. Found in wooded groves. Fr. Hym. Eur. f. 4r3. B. \& Br. n. $\mathrm{x} 668$.

21. H. pratensis Fr.-Pileus $2.5-5$ cent. ( $I-2$ in.) and more broad, somewhat pale yellowish, compactly fleshy especially at the disc, thin towards the margin, convex then flattened, almost turbinate from the stem being thickened upwards, even, smooth, moist (but not viscous) in rainy weather, when dry often rimosely incised, here and there split regularly round; flesh firm, white. Stem $4-5$ cent. ( $1 / 2-2$ in.) long, $12 \mathrm{~mm}$. ( $1 / 2 \mathrm{in}$.) and more thick, stuffed, internally spongy, externally polished-evened and firmer, attenuated downwards, even, smooth, naked. Gills remarkably 
decurrent, at first arcuate, then extended in the form of an inverted $\mathrm{Hygro}$. cone, very distant, thick, firm, brittle, connected by veins at the phorus. base, very broad in the middle, of the same colour as the pileus.

Very protean. Veil none. The flesh of the pileus is formed as it were of the sten dilated upwards. The typical form resembles the Cantherelli. Everywhere becoming light yellow-tawny, but varying with the stem and gills palewhite.

In pastures. Common. Aug.-Nov.

Edible; very little distinctive flavour. Spores sphæroid-ellipsoid, 6-Iox 4-6 mk. K. $5 \times 4$ mk. IV.G.S. Name-pratum, meadow. Found in meadows. Fr. Monogr. ii. p. 132. Hym. Eur. p. 41з. Sv. ätl. Sv. t. 30. Berk. Out. p. 199. C. Hbk. n. 560. S. Mycol. Scot. n. 523. Hussey ii. t. 90. Ag. Pers.-Fl. Dan.t. I735. f. I. Grev.t.91. Krombh. t. 43. f. 7-10. Bull. t. 587. Forms departing from the type: Bolt. $t .{ }_{56}$. Sozv. $t$. I4I. Pers. Myc. Eur. t. 28.f. x. Brig. t. 22.

* H. cinereus Fr.-The thinner pileus and gills cinereons, margin at length striate. Stem white.

Otherwise as in $H$. pratensis. Spores ovoid-spherical, $6 \mathrm{mk}$. Q. Namefrom the cinereous colour. Fr. Hym. Eur. p. 413. Sv. ätl. Sv. t. 30 (two upper fig.) B. \& Br.n. I56I. S. Mycol. Scot. n. 523 .

* H. pallidus B. \& Br.-Pileus pallid, infundibuliform, margin undulated, deflexed. Stem dilated upwards, fibrilloso-striate. Gills distant, decurrent, branched, pallid.

Coed Coch. Oct. B. \& Br.n. 1356*. Fr. Hym. Eur. p. 41 3 .

22. H. fotens Phill.-Pileus about 2.5 cent. (I in.) broad, dark brown, somewhat fleshy, convex then becoming plane, smooth, at length broken up into squamules. Stem $2.5-7.5$ cent. (I-3 in.) long, $4 \mathrm{~mm}$. (2 lin.) thick, stuffed, attenuated downwards, shining, clothed with transversely arranged fibrous scales, paler than the pileus. Gills decurrent, distant, rather thick, somewhat of the same colour as the pileus or paler, somewhat glaucous-pruinose.

Fragile. Very foetid, nauseous. The odour is very similar to that of Thelephora fastidiosa. Not at all viscid.

On the ground. Shrewsbury, I878, I884. Nov.

Nearly related to H. micans. B. \& Br. Name-fetens, stinking. Phill. Grevillea, vol. vii. p. $74 . B$. \& $B r . n$. 1780 .

23. H. virgineus Fr. Wholly white.-Pileus fleshy, convex then plane, obtuse, moist, at length depressed, cracked into patches, floccose when dry. Stem curt, stuffed, firm, attenuated at the base, externally becoming even and naked. Gills decurrent, distant, rather thick.

Flesh sometimes equal, sometimes abruptly thin. Commonly confounded 
Hygro- with $H$. niveus, but it is more difficult to distinguish it from white forms of $H$. phorus. pratensis. It is distinguished chiefly by its smaller stature, by the colour being constantly white, sometimes becoming pale, by the obtuse pileus being scarcely turbinate, at length cracked into patches and floccose when dry, and by the gills being thinner, \&c.

In pastures. Common. Aug.-Nov.

Taste like Marasmius oreades. M.F.B. Edible; delicious when broiled or stewed. Name-virgo, a virgin. From the purity of the colours. Fr. Monogr. ii. p. 133. Hym. Eur. p. 413. Berk. Out.p. I99. C. Hbk. n. 56r. S. Mycol. Scot. $n$. 524. Price f. 4 I (ochrey-white). Ag. Wulf. in Facqu. Miscell. 2. t. 15. f. 1. Sow. t. 32. Grev. t. 166. Gonn. E Rab. t. Io. f. 3. Bull. t. I88. Batt. t. 12.f. H.-Batsch f. 200 (a very small form).

24. H. ventricosus B. \& Br. White.-Pileus $5-7.5$ cent. (2-3 in.) broad, fleshy, unequal, convex. Stem 6 cent. (2 $1 / 2$ in.) long, I $2 \mathrm{~mm}$. ( $1 / 2 \mathrm{in}$.) thick in the middle, solid, at length partially hollow, attenuated at the base and apex. Gills deeply decurrent, narrow, sometimes forked.

Often tinged with red from the growth of a little Fusisporium.

Among grass. Coed Coch.

Name-venter, the belly. From the ventricose stem. $B . \mathcal{E} B r . n$. I777.

25. H. niveus Fr. Wholly white.-Pileus scarcely reaching 2.5 cent. (I in.) broad, somewhat membranaceous, and without a more compact disc, hence truly umbilicate, campanulate then convex, smooth, striate and viscid when moist, not cracked when dry; flesh thin, everywhere equal, white, hygrophanous. Stem 5 cent. ( 2 in.) or a little more long, $2-4 \mathrm{~mm}$. ( $1-2$ lin.) thick, fistulose, equal, even, smooth, tense and straight. Gills decurrent, distant, thin, scarcely connected by veins, arcuate, quite entire.

Thinner, tougher, and later than $H$. virgineus, \&c. Being hygrophanous the pileus is shining white when dry. Very tender forms occur.

In pastures. Common. Sept.-Oct.

Name-niveus, snow-white. Fr. Monogr. ii. p. I33. Hym. Eur. p. 4 I4. Berk. Out. p. I99. C. Hbk. n. 562. S. Mycol. Scot. n. 525. Ag. Scop.Schaff. t. 232. Krombh. t. 25. f. I-3.

26. H. Wynniæ B. \& Br. Lemon-yellow, hygrophanous.Pileus thin, umbilicate, or somewhat infundibuliform, striate. Gills decurrent, narrow, thin.

Fœtid when decayed, losing much of its lemon colour when it parts with its moisture. Resembling $A g$. mollis Bull., but on a smaller scale.

On chips, old stumps, \&c. Coed Coch, \&c.

Name-after Mrs Lloyd Wynne. B. \& Br. n. 178r, I962*. Sm. Gard. Chron. Oct. 1878, p. 476. fig. Clitocybe xanthophylla, Bresadola Fung. Trid. $f i g$. 
27. H. russo-coriaceus B. \& Br.-Pileus about $12 \mathrm{~mm}$. ( $1 / 2 \mathrm{in}$.) Hygrobroad, ivory-white, fleshy, convex, slightly viscid. Stem $18 \mathrm{~mm} .-$ phorus. 2.5 cent. (3/4-I in.) long, not $2 \mathrm{~mm}$. (I lin.) thick, slender, solid, thickened upwards, smooth, pure white. Gills decurrent, arched, broad, thick, very few and distant, with a few shorter ones intermixed.

Known at once by its persistent delightful odour, like that of Russian leather or Potentilla atro-sanguinea.

In pastures. Rare. Oct.

Spores II $\times 6 \mathrm{mk}$. W.G.S. Name-from its odour of Russian leather. $B$. \& Br. n. 332. Berk. Out. p. 199. C. Hbk.n. 563. S. Mycol. Scot. n. 526. Fr. Hym. Eur. p. 414. Saund. Eo Sm. t. 28. f. 2.

28. H. micaceus B. \& Br.-Pileus $12-8 \mathrm{~mm}$. ( $1 / 2-1 / 3$ in.) broad, hemispherical, at first light yellow then becoming cinereous, wrinkled, micaceous. Stem is $\mathrm{mm}$. ( $3 / 4 \mathrm{in}$.) long, $2 \mathrm{~mm}$. (I lin.) thick, solid, granulated, light yellow then brown downwards. Gills decurrent, pallid umber.

Mycelium white. The whole plant turns dark brown when dry. When young it looks like a small specimen of Leotia lubrica.

On clayey soil. Coed Coch, i878. Oct.

Name-mica, grain, granule. From the micaceous pileus. $B$. \& $B r . n$. I779.

* Gills ventricose, sinuato-arcuate or plano-adnate.

29. H. fornicatus Fr.-Pileus 2.5 cent. ( $\mathrm{I}$ in.) high and broad, white or pallid livid, fleshy, but thin, campamulate then expanded, obsoletely umbonate, somewhat repand, viscid, even, smooth. Stem 5-7.5 cent. (2-3 in.) long, 6-8 mm. (3-4 lin.) thick, solid or hollow at the very apex, compact, firm, tough, equal, somewhat undulated, smooth, shining white. Gills sometimes almost free, sometimes slightly adnexed with a small decurrent tooth (sinuatoadnexed), thick, ventricose, distant, distinct, exceeding the margin, white.

The structure of the stem and pileus is that of $H$. pratensis, but it is wholly white, and the attachment of the gills is plainly different. It has occurred with the stem fuscous-squamulose at the base.

In pastures. Holme Lacy, Herefordshire. Batheaston. Oct.

Name-fornix, a vault. Arched. Fr. Monogr. ii. p. 133. Hym. Eur. p. 414. B. \& Br. n. x420. Krombl. t. 25. f. 4,5 .

30. H. distans Berk.-Pileus about 5 cent. ( 2 in.) broad, white, with a silky lustre, here and there stained with brown, somewhat fleshy, plane or depressed, viscid. Stem white above, cinereous

VOL. II. 
Hygro- below, and attenuated, not spotted. Gills decurrent, few, very phorus. distant, somewhat ventricose, pure white then tinged with cinereous, interstices obscurely rugose.

Often umbilicate. Remarkable for the few and distant gills.

In woods. Rare. King's Cliffe.

Name-from the distant gills. Berk. Out. p. 200. t. I3.f. r. C. Hbk.n. 564. Fr. Hym. Eur. p. 415 .

31. H. Clarkii B. \& Br.-Pileus livid-cinereous, convex, somewhat umbonate, viscous, margin even. Stem hollow, of the same colour as the pileus. Gills adnate, broad, when larger nearly I2 $\mathrm{mm}$. ( $1 / 2$ in.) broad, distant, thick, white.

Fragile.

In pastures. Street. Perth Fungus Show. Sept.-Oct.

Name-after J. A. Clark. B. \& Br. n. 1358. S. Mycol. Scot.n. 527. Fr. Hym. Eur. p. 4I 5 .

32. H. metapodius Fr.- Pileus $4-7.5$ cent. ( $1 / 2-3$ in.) broad, cinereous-fuscous, compactly fleshy, convex then plane, obtuse, at first even and slightly shining, then silky and squamulose, irregular; flesh $12 \mathrm{~mm}$. ( $1 / 2 \mathrm{in}$.) thick, pallid-grey, reddish when broken and at length becoming black. Stem $2.5-5$ cent. ( $1-2$ in.) long, I $2 \mathrm{~mm}$. ( $1 / 2 \mathrm{in}$.) and more thick, stuffed, attemated downwards, unequal, ascending, smooth, cinereous, reddish internally. Gills variously adnate (for the most part arcuato-decurrent behind, or broadly emarginate), distant, thick, veined, about $6 \mathrm{~mm}$. (3 lin.) broad, grey-white.

Odour of new meal, taste mild. In respect of its flesh being compact, reddish when broken and at length becoming black, and its thick juicy gills, it is very analogous with Russula nigricans. There is a var. paradoxa appearing among taller mosses; stem elongated to ro cent. (4 in.), wholly fusiform, pileus smaller, regular and villous, gills obconico-decurrent as in $H$. pratensis.

In old pastures. Street, I871. Glamis, i876. Aug.-Nov.

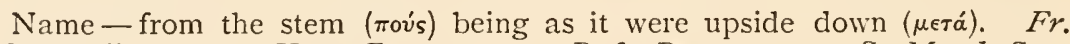
Monogr. ii. p. 135. Hym. Eur. p. 415. B. \& Br.n. 1359. S. Mycol. Scot. n. 528 .

33. H. ovinus Fr.-Pileus 5 cent. (2 in.) broad, fuscous, slightly fieshy, campanulate then expanded, somewhat umbonate, at first slightly viscid and even, then dry and squamulose, at length revolute, undulated, rimosely incised; flesh only $4 \mathrm{~mm}$. (2 lin.) thick, rigid-fragile. Stem about 5 cent. (2 in.) long, $6 \mathrm{~mm}$. (3 lin.) thick, somewhat stuffed, somewhat equal or slightly thickened at both ends, curved or twisted, compressed, smooth, slightly shin- 
ing, pallid. Gills arcuato-adnate, decurrent with a tooth, distant, Hygrothick, as much as $6 \mathrm{~mm}$. (3 lin.) broad, connected by veins and phorus. occasionally divided, grey then rufescent, the thin edge quite entire.

Very much allied to $H$. metapodius, odour almost the same. The flesh is the same except in being thinner and rigid-fragile. In a larger var. the pileus becomes black and the stem fuscous-black.

In pastures. Uncommon. Sept.

Name-ovis, a sheep. Woolly, squamulose. Fr. Monogr. ii. p. 135. Hym. Eur. p. 415. Berk. Out. p. 200. C. Hbk. n. 565. S. Mycol. Scot. n. 529. Hussey ii. t. 50 . Ag. Bull. t. 580.

34. H. subradiatus Fr.-Pileus varying in colour, white, livid, disc fuscous, \&c., somewhat membranaceous, slightly fleshy at the disc from the apex of the stem being dilated, otherwise quite membranaceous, but moderately tough and somewhat irregularly shaped, convex then expanded, obsoletely umbonate, hygrophanous when moist, radiato-striate from the translucent gills. Stem 5 cent. ( 2 in.) long, $4 \mathrm{~mm}$. ( 2 lin.) thick, fistulose, equal, attenuated at the base, twisted, ascending, smooth, pale, white at the base. Gills plane but deeply decurrent with a tooth, ventricose, someruhat thin, distant, connected by veins, white.

Allied to the thinner forms of $H$. pratensis, but differing very widely in the attachment of the gills.

In old pastures. Glamis, I874. Sept.

Name-sub, and radiatus, rayed. From the character of the striæ. Fr. Monogr. ii. p. г36. Hym. Eur. p. 416. B. \& Br. n. 1670. S. Mycol. Scot. n. 530. Ag. Schum.

* H. lacmus Fr.-Pileus 2.5 cent. (I in.) broad, lilac then becoming pale, fragile, slightly fleshy at the disc, otherwise membranaceous, plano-depressed, occasionally at the same time umbonate, unequal at the circumference, radiato-siriate when moist, when dry even, shining, commonly smooth, but occasionally fibrillose or squamulose on the disc. Stem elongated to 5 cent. ( 2 in.) and more, stuffed then hollow, often twisted, smooth, somewhat shining, narrowed at the base and apex. Gills plano-decurrent, thin, $2 \mathrm{~mm}$. (I lin.) broad, connected by veins, somewhat distant, cinereous.

In the same habitats as $H$. subradiatus. In pastures and heathy places. Coed Coch. Loch Maree, \&c. Sept.-Oct. Name-lac, varnish. Shining. Fr. Monogr. ii. p. 136. Hym. Eur. p. 416. B. \& Br. n. 1780. S. Mycol. Scot.n. 530. Fl. Dan. t. I73. f. I.

35. H. irrigatus Fr.-Pileus $2.5-5$ cent. ( $1-2$ in.) broad, livid, 
Hygro- becoming dingy white as the gluten separates, slightly fleshy, phorus. fragile, campanulate, expanded, obtuse, even, smooth, viscous. Stem 5-7.5 cent. (2-3 in.) long, 2-4 mm. ( $1-2$ lin.) thick, fistulose, flexuous, tough, equal, smooth, very viscous, livid. Gills adnate, with a decurrent tooth, somewhat distant, distinct, fragile, rather thick, scarcely connected by veins, either wholly white or grey.

Very variable, sometimes much larger. The gills are less juicy than those of $H$. unguinosus, with which it must not be confounded.

In grassy places and fir woods. Laxton, Norths. Glamis. Oct.-Nov.

Name-irrigo, to wet. From its watery texture. Fr. Monogr. ii. p. I37 (irriguus). Hym. Eur. p. 4 r6. Icon. t. 168. f. 3. B. \& Br. n. I280. S. Mycol. Scot. n. 53i. Ag. Pers.

36. H. Houghtoni B. \& Br.-Pileus $4-5$ cent. ( $11 / 2-2$ in.) broad, bright coloured, convex, at length depressed in the centre, striate, very viscous. Stem 5 cent. ( 2 in.) and more long, $6 \mathrm{~mm}$. ( $1 / 4$ in.) thick, transversely undulated, very viscous, tawny-light yellow. Gills decurrent, thin, pale yellowish.

Odour foxy. The stem is sometimes tinged above with blue. The gelatinous coat is extremely thick, and at length separates and forms a cup in the centre.

Among grass. Preston, Salop, I872. Oct.

Name-after Rev. William Houghton. B. \& Br.n. 1360. Fr. Hym. Eur. p. 416 .

I I I. - H Y G OCYBE.

* Gills decurrent.

37. H. Colemannianus Blox.-Pileus $2.5-5$ cent. ( $\mathrm{I}-2$ in.) broad, reddish umber, paler when dry except in the centre, somewhat fleshy, at first somewhat campanulate, at length expanded, strongly umbonate, when moist striate and slightly viscid. Stem 2.5 cent. (I in.) or more long, 2-4 mm. ( $1-2$ lin.) thick, brittle, fibrous, nearly equal, somewhat silky, white, very slightly tinged with umber. Gills deeply decurrent, rather broad, distant, interstices veined and rugose, umber but paler than the pileus.

In grassy places. Twycross, Warwickshire.

Spores $6 \times 8 \mathrm{mk}$. B. \& Br. Name-from W. H. Coleman. Blox.-Berk. Out.p. 200. B. \&o Br. n. 701. C. Hbk. n. 566. Fr. Hym. Eur. p. 417.

38. H. sciophanus Fr.-Pileus $I-4$ cent. ( $1 / 2-I \frac{1}{2}$ in.) broad, very hygrophanous with a peculiar deep tawny or rather vivid 
brick but opaque colour, becoming pale when dry, becoming white Hygrowhen older, thin, slightly fleshy at the disc, otherwise membran- phorus. aceous, hemispherical or obtusely campanulate then expanded, always obtuse, slightly viscid, even at the disc, remotely and pellucidly striate to the middle, regular, torn when older. Stem $4-7.5$ cent. ( $1 \frac{1}{2}-3$ in.) long, hollow, wholly equal, always thin, scarcely more than $2 \mathrm{~mm}$. (I lin.) thick, flexuous, even, smooth, slippery, never tense and straight, tawny yellowish, but paler than the pileus, even becoming white. Gills attenuato-adnate, at the first slightly ascending, then plano-decurrent, distant, commonly distinct, of the same colour as the pileus, or sometimes inclining to rose-colour.

Very elegant, densely gregarious, fragile. In habit and opaque tawny colour it is like $H$. pratensis, but is thin, fragile, juicy, with the pileus somewhat repand, and the gills thin and plano-decurrent. The stem is never tense and straight as in $H$. conicus. There is a var. with the pileus date-brown.

In mossy places. Perth.

Spores very pale clay-coloured. $B$. \& $B r$. Name- $\sigma \kappa \iota$, shade; $\phi a i v \omega$, to appear. From its shaded colour. Fr. Monogr. ii. p. I37. Hym. Eur. $p$. 4 17. Icon. t. 167. f. r. B. \& Br. n. I560. S. Mycol. Scot. n. 532. Ag. Fl. Dan.t. $1845 \cdot f$. 2.

39. H. lætus Fr.-Pileus reaching 2.5 cent. (I in.) broad, tawny, shining, not becoming pale, slightly fleshy, almost membranaceous at the margin, convex then flattened, obtuse, slippery, even or slightly pellucid-striate round the margin; flesh thin, of the same colour as the pileus and paler. Stem 5-7.5 cent. (2-3 in.) long, thin, about $4 \mathrm{~mm}$. (2 lin.) thick, hollow or rather fistulose, equal, tough, even, very smooth, slippery, tawny. Gills somewhat decurrent, distant, thin, somewhat connected by veins, for the most part flesh-coloured, but varying whitish, fuliginous, Sc.

The stem is here and there undulated and darker at the apex, in which it approaches $H$. psittacinus. It departs from all the others in this group in the toughness, especially of the stem. Appearing in troops.

In pastures. Frequent.

Spores nearly globose, $8 \mathrm{mk}$. $B$. \& $B r_{0}$; ovoid pruniform, $8 \mathrm{mk}$. $Q$. Name-latus, joyful, pleasing. From the bright colour. Fr. Monogr. ii. p. 138. Hym. Eur. p. 4r7. Icon. t. I67.f. 2. B. \& Br.n. 702. Berk. Out. p. 200. C. Hbk. n. 567 . S. Mycol. Scot. n. 533. Ag. Pers.

40. H. vitellinus Fr.-Pileus $I-2.5$ cent. ( $\mathrm{I} / 2-\mathrm{I}$ in.) broad, citron-egg-yellow, becoming white when dry, very thin, slightly fleshy only at the disc, otherwise almost membranaceous, smooth, viscid, margin plicato-striate. Stem 5 cent. (2 in.) long, scarcely 
Hygro- $2 \mathrm{~mm}$. (I lin.) thick, fistulose, equal, even, smooth, pallid light phorus. yellow, becoming white when dry, very fragile, here and there flexuous. Gills deeply decurrent, somewhat distant, egg-yellow.

It is certainly different from $H$. ceraceus, which is somewhat like it, in the colour being wholly bright citron-yellow, whitish when dry, in the margin of the pileus and in the deeply decurrent gills.

In pastures. Penzance.

Name-vitellus, yolk of egg. Egg-yellow. Fr. Monogr. ii.p. 312. Hym. Eur. p. 417. Icon. t. I67.f. 3. B. E Br. n. 2020.

41. H. ceraceus Fr.-Pileus about 2.5 cent. ( $\mathrm{I}$ in.) broad, waxy-yellow, shining, slightly fleshy, thin, but slightly firm, convexo-plane, obtuse, slightly pellucid-striate, viscid. Stem 2.5-5 cent. ( $\mathrm{I}-2$ in.) and more long, about $4 \mathrm{~mm}$. (2 lin.) thick, hollow, often unequal, flexuous and at length compressed, even, smooth, of the same colour as the pileus, never darker at the apex. Gills adnato-decurrent, broad, almost triangular, distinct, yellow.

Fragile; easily distinguished from others by its waxy (not changeable) colour. Growing in troops. The gills are by no means emarginato-adnexed and ventricose as in the similar, but more watery and sulphur-coloured $H$. chlorophanus. Like neighbouring species it varies very much in stature.

In woods and pastures. Common. Sept.-Oct.

Spores sphæroid-ellipsoid, $7 \times 4$ mk. K. ; $6 \times 4$ mk. W.G.S. Name-cera, wax. From the colour. Fr. Monogr. ii. p. 138. Hym. Eur.p. 417. Berk. Out. p. 201. C. Hbk. n. 568. S. Mycol. Scot. n. 534. Ag. WVulf, in Facqu. Coll. ii. t. 15. f. 2. Sow. t. 20.

42. H. coccineus Fr.-Pileus $2.5-5$ cent. ( $\mathrm{I}-2$ in.) and more broad, at first bright scarlet, then soon changing colour and becoming pale, slightly fleshy, convex, then plane and often unequal, obtuse, at first viscid and even, smooth, not floccoso-scaly; flesh of the same colour as the pileus. Stem 5 cent. (2 in.) long, 6-8 mm. (3-4 lin.) thick, hollow, then compressed and rather even, not slippery, scarlet upwards, always yellow at the base. Gills wholly adnate, decurrent with a tooth, plane, distant, connected by veins, watery-soft as if fatty, when full grown purplish at the base, light yellow in the middle, glaucous at the edge.

Flesh of the pileus descending into the gills and forming a trama of the same colour. Fragile. Varying in stature, easily mistaken for some of the following species which are of the same colour. Pileus at length becoming yellow.

In pastures. Very common. Aug.-Nov.

Spores sphæroid-ellipsoid, 6-8 $\times 4-5 \mathrm{mk} . K . ; 4 \times 8-7 \mathrm{mk}$. W.G.S. Name -coccineus, of scarlet colour. Fr. Monogr. ii. p. 139. Hym. Eur. p. 4I7. 
Berk. Out.p. 201. C. Hbk. n. 569. S. Mycol. Scot. n. 535. Hussey i. t. Hygro61. Price f. 57. Ag. Schaff. t. 302. Bull. t. 570. f. 2 partly. Fl. Dan. phorus. t. 7 15. Sow. $t .3^{81}$ (scarlet fig.) Batt. t. I9. f. B.

43. H. miniatus Fr.-Pileus scarcely reaching 2.5 cent. ( $\mathrm{I}$ in.) broad, at first vermilion then becoming pale and opaque, slightly fleshy, convex, obtuse, then umbilicate, at first even and smooth, then squamulose. Stem about 5 cent. ( 2 in.) long, $2 \mathrm{~mm}$. (I lin.) thick, someruhat stuffed, equal, round, even, smooth, shining, vermilion. Gills adnate, not decurrent, plane, distant, distinct, rather thick, yellow or sometimes light yellow-vermilion.

Very fragile. The gills are frmer than in H. coccineus. Intermediate between $H$. coccineus and $H$. turundus.

In open places, pastures, \&c. Common. July-Oct.

Spores $5 \times 8 \mathrm{mk}$. IV.G.S. Name-minium, vermilion. Fr. Monogr. ii. $p$. 139. Hym. Eur. p. 418. Berk. Out. p. 201. C. Hbk. n. 570. S. Mycol. Scot. n. 536. Quel. t. ro.f. 5. Ag. Fl. Dan. t. Ioog. Harz. t. 4. f. I.

44. H. turundus Fr. - Pileus $\mathrm{I}-2.5$ cent. ( $1 / 2-\mathrm{I}$ in.) broad, yellow or tawny, variegated with cinereous-fuscous squamules, slightly fieshy, fragile, convex then expanded, umbilicate or depressed, often elegantly crenate at the margin. Stem 5-7.5 cent. (2-3 in.) long, about $4 \mathrm{~mm}$. (2 lin.) thick, rigid-fragile, stuffed then fistulose, round, equal, even and polished, tawnyreddish. Gills at first slightly then deeply decurrent, distant, juicy, distinct, at first white then becoming yellow, the acute edge of the same colour.

Very protean. The pileus is commonly dry, soon broken up into fuliginous flocci, but it occurs during rain at the first viscid and even, and in this condition it must be carefully distinguished (by the colour of the golden pileus and of the gills) from $H$. miniatus, to which it is allied though very dissimilar. It varies with the somewhat veined gills of the Cantharelli.

On peat soil. Farragon, Perthshire, I877. Aug.

2000 feet. Name-turunda, lint. Flocculose. Fr. Monogr. ii. p. I39. Hym. Eur. p. 418. B. \& Br. n. 1670. S. Mycol. Scot. n. 537.

Var. mollis B. \& Br. Golden.-Pileus $12-18 \mathrm{~mm} .(1 / 2-3 / 4 \mathrm{in}$.) broad, nearly plane, at length slightly depressed, clad with soft, short, radiating hairs of the same colour. Stem 2.5-3 cent. ( I-I I/4 in.) long, 2-4 mm. (I-2 lin.) thick, stuffed, equal. Gills decurrent, arcuate, narrow, distant.

In moist mossy ground. Rare. July-Sept. B. \& Br.n. 1279. S. Mycol. Scot. n. 537. Fr. Hym. Eur. p. 418 .

45. H. mucronellus Fr.-Pileus 6-8 mm. (3-4 lin.) broad, when moist a) scarlet b) yellow, when dried changing colour 
Hygro- $\quad$ very much, becoming hoary, slightly fleshy, when smaller acutely phorus. conical, when larger campanulate and obtuse, then expanded, when moist pellucidly striate, when dried somewhat silky, but never squamulose. Stem about 5 cent. (2 in.) long, $2 \mathrm{~mm}$. (I lin.) thick, fistulose, thin, somewhat attenuated and white at the base, otherwise yellow, even, smooth, flexuous. Gills ascending, distant, very broad and adnate behind with a very broad base, somewhat decurrent, yellow.

Fragile. The smallest of species of the same nature.

In grass field. King's Lynn. Dec.

In 'Hym. Eur.' Fries describes the stem as somewhat silky. Namemucro, a sharp point. From its acute form. Fr. Monogr. ii. p. I40. Hym. Eur. p. 4 18. Grevillea, vol. iv. p. I18.

** Gills adnexed, somewhat separating.

46. H. puniceus Fr.-Pileus 5-Io cent. (2-4 in.) broad, glittering blood-scarlet, in dry weather and when old becoming pale especially at the disc, slightly fleshy for its breadth, at first campanulate, obtuse, commonly repand or lobed, very irregular, even, smooth, viscid; flesh of the same colour, fragile. Stem 7.5 cent. ( 3 in.) long, $I-2.5$ cent. ( $1 / 2-1$ in.) thick, solid when young, at length hollow, very stout (not compressed), ventricose (attenuated at both ends), striate, and for the most part squamulose at the apex, when clry light yellowish or of the same colour as the pileus, always white and often incurved at the base. Gills ascending, ventricose, $4-8 \mathrm{~mm}$. (2-4 lin.) broad, thick, distant, white-light yellow or yellow and often reddish at the base.

The largest of the group, and very handsome. It certainly differs from H. coccineus, for which it is commonly mistaken, in stature, in the adnexed gills, and in the white base of the striate stem. The attachment of the gills varies, but from the form of the pileus they ascend to the base of the cone and appear free.

In pastures. Frequent. July-Nov.

Name-puniceus, blood-red. Fr. Monogr. ii. p. I41. Hym. Eur.p. 4 I9. Sv. ätl. Sv. t. 77. Berk. Out.p. 201. B. \& Br.n. 1281. C. Hbk. n. 57 I. S. Mycol. Scot. n.538. Ag. Fl. Dan. t.883. Bolt. t. 67.f. 2.

47. H. obrusseus Fr.-Pileus $5-7.5$ cent. ( $2-3$ in.) broad, golden-sulphur-yellow, shining, not becoming pale, very thinly fleshy, rigid-fragile, campanulate then expanded, flexuous, somewhat lobed and often torn, obtuse, dry, even, smooth. Stem 7.5 cent. ( 3 in.) and less in length, $12 \mathrm{~mm}$. ( $1 / 2$ in.) thick or when compressed still broader, but scarcely ventricose, stout, ascending, compressed and commonly unequal, quite smooth, even, sulphur 
yellow, becoming tawny at the base. Gills adnexed, ventricose, Hygrobut at length separating, free, very broad (12 mm., $1 / 2 \mathrm{in}$.), thick, phorus. distant, almost white.

The stem is hollow and hence flattened, but the walls are slightly firm and somewhat cartilaginous, fragile however and easily splitting into crisped fibres. The gills are much more rigid and firm than in allied species. A. laceratus Bolt. t. 68 which is referred to this species by Secretan is rather a luxuriant form of $\mathrm{H}$. conicus.

In woods. Mossburnford. Oct.

Name-obrussa, the testing of gold. From the pure golden colour. Fr. Monogr. ii. p. I4I. Hym. Eurr. p. 419. Berk. Out. p. 202. C. Hbk.n. 572. S. Mycol. Scot. n. 539. Ag. Batt. t. 19. f. D.

48. H. conicus Fr.-Pileus commonly light yellow, becoming black, somewhat membranaceous, conical, acute, smooth, often lobed, then expanded and cracked. Stem hollow, cylindrical, tense and straight, fibroso-striate. Gills attenuato-free, ventricose, thin, somewhat crowded, varying white, light yellow, \&c.

Very easily distinguished from all neighbouring species by its juicy and fragile substance, \&c. Viscid when moist, shining when dry. It is smooth even when dry. The primary colour depends upon the weather. It has the singular character of the flesh becoming black when broken, but in some forms (springing in dry weather) it is unchangeable. The following forms may be noted : a) coccinea, scarlet and shining, gills yellow, often reddish at the base: b) lutea, pileus and gills yellow-neither becoming black: c) pileus reddish or tawny, gills yellow : d) sulphurea, pileus bright light yellow-sulphurcolour, sometimes greenish, gills often whitish-both becoming black when broken: e) squalida, pileus livid or fuliginous-light yellow: f) tristis, pileus at the first fuliginous, soon shining black-both of their own accord becoming wholly black.

\section{In pastures. Very common. July-Nov.}

Pileus $2.5^{-6}$ cent. ( $I-2 \mathrm{I} / 2$ in.) Stem varying very much in length and thickness. Spores sphæroid-ellipsoid, Io-I r $\times 6-8 \mathrm{mk}$. K. ; I I $\times 6 \mathrm{mk}$.W.G.S. Name-from its conical shape. Fr. Monogr. ii. p. I42. Hym. Eur. p. 4I9. Berk. Out. p. 202. C. Hbk. n. 573. S. Mlycol. Scot. n. 540. Ag. Scop.Schaff. t. 2. Fl. Bat. t. 310. Bull. t. 50 (524. f. 3. var. tristis). Batsch f. 28 .

49. H. calyptræformis B. \& Br. - Pileus about 2.5 cent. (I in.) high, $18 \mathrm{~mm}$. ( $3 / 4 \mathrm{in}$.) broad at the base, pink, becoming pallid, thin, acutely conical, lobed below, moist when unexpanded, striate under a lens, minutely innato-fibrillose. Stem 2.5 cent. (I in.) or more long, hollow, the walls fibrous within, remarkably smooth, slightly striate, brittle, often splitting longitudinally, white. Gills acutely attenuated behind, very narrow, distinct, rose-coloured at length pallid.

The gills are often almost evanescent behind. The stem is pure white, except within the pileus where it has often a roseate tinge. Very distinct from $H$. conicus. It does not turn black when bruised. 
In pastures. Uncommon. Aug.-Oct.

I have found several specimens larger than described by Berkeley, quite as large as full-sized $H$. conicus which it resembles very much in shape. Spores $3 \times 4$ mk. W. G.S. Name-calyptra, a hood; forma, form. From its shape. Berk. Out. p. 202. Trans. Woolh. Club, t. 2I. f. 4-6. C. Hbk.n. 576. S. Mycol. Scot. n. 54r. Fr. Hym. Enr.p. 420.

50. H. chlorophanus Fr.-Pileus 2.5 cent. (I in.) broad, commonly bright sulphur-yellow, sometimes however scarlet, not changing colour, somewhat membranaceous, very fragile, at first convex, then plane, obtuse, orbicular and lobed, and at length cracked, smooth, viscid, striate. Stem 5-7.5 cent. (2-3 in.) long, 4-6 mm. (2-3 lin.) thick, hollow, equal, round, rarely compressed, wholly even, smooth, viscid when moist, shining when dry, wholly unicolorous, rich light yellow. Gills emarginato-adnexed, very ventricose, with a thin decurrent tooth, thin, distant, distinct.

Very much allied to $H$. conicus, but never becoming black, and otherwise certainly distinguished by its convex, obtuse, striate pileus, by its even and viscous stem, and by its emarginato-free, thin, somewhat distant, whiter gills. Like $H$. ceraceus in appearance.

\section{In grassy and mossy places. Common. Aug.-Oct.}

Spores pruniform, $8 \mathrm{mk}$. $Q$. Name- $\chi \lambda$ woós, greenish-yellow; of colour generally, pale; $\phi$ iivw, to appear. From the pale yellow colour. Fr. Monogr. ii. p. 143. Hym. Eur. p. 420. Icon. t. I67. f. 4. B. E Br.n. 933. C. Hbk. n. 574. S. Mycol. Scot. n. 542. Hoffm. Ic. t. 5.f. I.

51. H. psittacinus Fr.-Pileus about 2.5 cent. ( $\mathrm{I}$ in.) broad, for the most part yellow tinged with green; slightly fleshy, campanulate then expanded, umbonate, smooth, very glutinous when young, slightly viscid when more fully grown, becoming pale but not changing colour and not torn. Stem 5 cent. ( 2 in.) long, 4-6 mm. (2-3 lin.) thick, hollow, equal, but often bent, even, toughish, greenish, at least at the apex. Gills adnate, but very ventricose, rather thick, broad, somewhat distant, most frequently green.

The colour of the pileus and stem is very variable, when full grown for the most part yellowish, but varying brick-colour, reddish, whitish, most frequently with a greenish tinge. In the toughness of the stem it approaches $H$. latus. Easily distinguished by the greenish gluten with which it is smeared, and which persistently tinges the apex of the stem. It varies very much in size.

\section{In pastures. Common. Aug.-Oct.}

In some stages of growth it is exceedingly tough. Spores ellipsoid-sphæroid, $7-8 \times 5^{-6} \mathrm{mk} . K$. ; $6 \times 7 \mathrm{mk}$. WW.G.S. Name-psittacus, the ringed green parrot. From the colours. Fr. Monogr. ii. p. I43. Hym. Eur. p. 420 . Berk. Out. p. 202. C. Hbk.n. 575. S. Mycol. Scot. n. 543. Hussey i. t. 4I. Ag. Schaff. t. 301. Sow. t. 82. Grev. t.74.-Bull.t. 545. f. I. Ventur. t. 42. f. I-3. Batt. t. 21. f. E. 
52. H. unguinosus Fr.-Pileus about 5 cent. ( 2 in.) broad, Hygrosmeared zuith dense fuliginous gluten, slightly fleshy, campanulate phorus. then convex, obtuse, even, or at length rimosely incised. Stem 5 cent. ( 2 in.) long, $6 \mathrm{~mm}$. ( 3 lin.) thick, hollow, commonly attenuated at the base and apex, unequal, somewhat compressed, glutinous, of the same colour as the pileus. Gills adnate, but very ventricose, distant, thick, broad, connected by veins, shining white, becoming glaucous, soft.

Inodorous, very fragile, appearing chiefly in later autumn. The fuliginous colour is unchangeable. The tough fuliginous gluten on the pileus distils in drops. It differs sufficiently from $H$. irrigatus in its larger stature, in its watery substance, in the gluten, and in its ventricose separating gills.

In woods and pastures. Frequent. Aug.-Oct.

Name-unguinosus, oily. From the gluten. Fr. Monogr. ii. p. 144. Hym. Eur. p. 42r. Icon. t. 168. f. 2. Berk. Out. p. 202. C. Hbk. n. 577. S. Mycol. Scot. n. 544 .

53. H. nitratus Fr. Fuscous-cinereous.-Pileus 5 cent. (2 in.) broad, becoming pale, scarcely fleshy, very fragile, convex, obtuse or depressed in the centre, at the first slightly viscid, soon flocculose, then squamulose and rimosely incised, irregularly shaped, somewhat revand. Stem $5-7.5$ cent. (2-3 in.) long, 6-1o mm. (3-5 lin.) thick, hollow, equal, but often twisted, and at length somewhat compressed, fragile, externally polished, smooth, whitish, woven with thick crisped fibres. Gills broadly emarginate, very broad, as much as $18 \mathrm{~mm}$. ( $3 / 4$ in.) broad (obliquely ovate), distant, thick, mucid-soft, connected by veins, whitish then becoming glaucous.

The above is the larger and rarer form. B. The smaller form is the commoner. Pileus $I-2.5$ cent. ( $1 / 2-\mathrm{I}$ in.) broad, viscous when young and moist, even, fuscous, but soon dry and rimoso-squamulose, cinereous. Stem 2.5 cent. ( $\mathrm{r}$ in.) and mure long, 2-6 mm. ( $\mathrm{I}-3$ lin.) thick, unequal, commonly compressed and undulated, sometimes yellowish. Gills at first wholly adnate, even with a decurrent tooth, then ventricose and glaucous, but broad and thick, as if smeared.

Widely removed from all others by its strong nitrous odour, and by the colour being by no means bright. As regards substance and structure it agrees well with $H$. coccineus, and affords the best example of the generic character; the gills are thick, juicy, and the hymenium, which is waxy soft as if composed of fat, is as easily rubbed off from the trama as if it were fat. Very changeable in stature according to locality.

In pastures. Uncommon. Aug.-Sept.

Name-nitrum, nitre. From its nitrous odour. Fr. Hym. Eur.p. $42 \mathrm{r}$. S. Mycol. Scot. n. 545. H. murinaceus Fr. Monogr. ii. p. 145. Berk. Out. p. 203. C. Hbk. n. 578 .

* H. glauco-nitens Fr.-Pileus olivaceous-black or fuliginous, 
Hygro- becoming pale, streaked with fibrils. Stem equal, shining. Gills phorus. becoming glaucous.

Stiff. It seems to be a young state of $H$. nitratus, scorched by the sun, but it is reckoned distinct by Persoon and others. Odour the same, but weaker.

In mixed woods. Pass of Killiecrankie. I877. Aug.

Name-glaucus, glaucous; nitens, shining. Fr. Hym. Eur. p. 421. B. \& Br.n. 1671. S. Mycol. Scot.n. 546. Ag. Batschf. 192.

Lactarius.

Genus IX.-Lactarius (lac, milk). Fr. Epicr. p. 333.

Hymenophore continuous with the stem. Gills unequal, membranaceous-waxy, slightly rigid, milky, acute at the edge. Spores globose, white, rarely yellowish. Fleshy fungi, growing on the

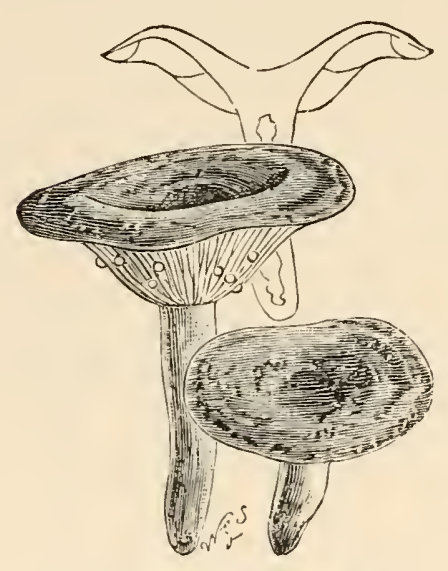

$X L I X$. Lactarius subdulcis.

One-third natural size. ground (with two exceptions), putrescent, pileus depressed, gills adnatodecurrent and often branched.

A very distinct genus and easily recognised. Pileus in some species zoned which is peculiar to this genus. Watery milk is never a normal feature of the genus, but where it does occur it is owing to the dampness of the station where the specimens have grown. Fr. Hym. Eur.p. 421.

The nearest allies to the Lactarii are the Russula, which are at once distinguished by their want of milk. The genus includes some species which are edible and delicious, while others are exceedingly poisonous.

The best mark of distinction of species is the nature of the milk.

Tribe I. PipertTes (piperitis, pepper-wort). Stem central. Gills unchangeable, naked, not changing colour and not pruinose. Milk at the first white, (commonly) acrid.

* Tricholomorder. Pileus viscid when moist, margin at first involute, tomentose.

** Limacini. Pileusviscid when moist, pelliculose, margin naked.

*** Piperati. Pileus without a pellicle, hence absolutely dry, most frequently unpolished.

Tribe II. Dapetes (daps, food). Stem central. Gills naked; milk at the first deeply coloured. 
Tribe III. Russulares. Stem central. Gills pallid then changing colour, Lactarius afterwards darker, glancing when turned to the light, at length white-pruinose. Milk at the first white, mild or from mild turning acrid.

* Pileus at the first viscous.

** Pileus unpolished, squamulose, villous or pruinose.

*** Pileus polished, smooth.

Tribe $I V$. Pleuropus. Stem excentric or lateral. Growing on trunks.

\section{TRIBE I.-Piperites.}

* Tricholomoidei. Pileus viscid when moist, Esc.

1. L. scrobiculatus Fr. - Pileus io cent. (4 in.) and more broad, yellow, commonly zoneless, fleshy, but not compact, at first convex, umbilicate, at length infundibuliform, obtuse, with agglutinated villous down, very viscid when moist, margin involute, bearded, at length when old unfolded and almost naked; flesh lax, whitish, but commonly becoming yellow when broken. Stem 4-6 cent. ( $1 / 2-21 / 2$ in.) long, as much as 2.5 cent. (I in.) and more thick, stout, often stuffed when young, but soon remarkably hollow, equal, light yellow, pitted with broad roundish spots, smooth, somewhat viscid, pubescent at the base. Gills adnatodecurrent, thin, crowded, quaternate, whitish. Milk plentiful, at first white, soon sulphur-yellow when exposed to the air.

Very acrid, odour not unpleasant. Pileus sometimes as much as 30 cent. (I2 in.) broad. The pileus becomes pale in open places, and is sometimes zoned. In very watery places when broken it occasionally becomes azure-blue-purple, milk white, soon serous.

On the ground. Bristol.

Spores subsphæroid, echinulate, II-I2 $\times 8$-Io mk. $K$.; subglobose, 6-8 mk. C.B.P. Name-scrohis, a trench. From the pitted stem. Fr. Monogr. ii. p. I52. Hym. Eur. p. 422. Grevillea, vol. xii. p. 42. Ag. Schaff. t. 227. Krombh. t. 58. f. I-6. B. milk watery white becoming violet. Barla t. I8. f. $3-6$.

2. L. torminosus Fr.-Pileus 7.5 cent. ( 3 in.) and more broad, pallid flesh-colour, laxly fleshly, somewhat fragile, obtuse, depressed, becoming even, viscid when moist, somewhat zoned, with a white-fibrillose beard at the margin and towards the margin which is at first involute; flesh pallid. Stem 6-9 cent. $\left(2 \frac{1}{2}-31 / 2\right.$ in.) long, $18 \mathrm{~mm} .-2.5$ cent. ( $3 / 4-\mathrm{I}$ in.) thick, stuffed soon hollow, equal or attenuated downwards, delicately adpressedly tomentose or becoming smooth, even or obsoletely pitted, dry. Gills adnato-decurrent, $2-3 \mathrm{~mm}$. ( $\mathrm{I}-\mathrm{I} \mathrm{I} / 2 \mathrm{lin}$.) broad, very thin and crowded, unequal but rarely connected by branches, paler than the pileus. Milk white, unchangeable, acrid.

Inodorous. It frequently varies pale-ochraceous. It also occurs with the 
Lactarius. pileus wholly white and tomentose Sow. t. I03. In another form the pileus is smooth, zoneless, white. In a variety the pileus is at length excentric, whitish, cracked in a tesselated manner, margin spreading, naked.

In mixed woods. Common. Aug.-Nov.

Spores subsphæroid, echinulate, 6-8 mk. K.;9 6 mk. W.G.S. Nametormina, gripes. Causing gripes. Fr. Monogr. ii. p. I53. Hym. Eur. p. 422. Sv. ätl. Sv. t. 28. Berk. Out. p. 203. C. Hbk. n. 582. S. Mycol. Scot. n. 547. Ag. Schaff. t. 12. Fl. Dan. t. 1068. Sv. Bot. t. 184. Bull. t. 529. f. 2. Krombh.t. 13. f. 15-23. Ventur. t. 30. f. 2. Barla t. x8.f. 7-10. Harz. t. Ix.

3. L. cilicioides Fr.-Pileus 5-10 cent. (2-4 in.) broad, fleshcolour inclining to fuscuus, fleshy, convex then flatiened and depressed in the centre, everywhere tomentose, viscous, zoneless, margin involute, fibrilloso-woolly ; flesh not very compact, yellowish-white. Stem 5-7.5 cent. (2-3 in.) long, 2.5 cent. (I in.) thick, firm, stuffed, somewhat hollow only when old, equal, even, pruinato-silky under a lens, pallid, never pitted or spotted. Gills decurrent, crowded, branched, white inclining to yellow. Milk acrid, white or light yellow-white.

The stem is dingy, not of a pure colour as in L. torminosus, \&c. Intermediate between L. torminosus and L. turpis.

In woods. Frequent. Sept.-Nov.

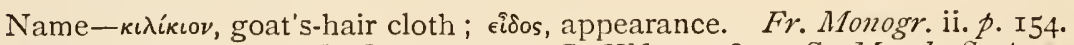
Hym. Eur. p. 422. Berk. Out. p. 203. C. Hbk. n. 583. S. Mycol. Scot. n. 548. Ag. Schaff. t. 228. Krombh. t. 58. f. II-I3 var. B. \& Br. n. 1887.

4. L. turpis Fr.-Pileus large, as much as 30 cent. ( 12 in.) broad, olivaceous inclining to umber, fleshy, rigid, convex becoming plane, disc-shaped or umbilicate, at length depressed, innato-villous at the circumference or wholly, covered over with tenacious gluten, zoneless, sometimes tawny towards the margin, at length entirely inclining to umber; margin for a long time involute, at the first villous, olivaceous-light-yellow, then more or less flattened, at length often densely rivuloso-sulcate; flesh compact, white, then slightly rufescent. Stem $4-7.5$ cent. $(1 / 2-3$ in.) long, $\mathrm{I}-2.5$ cent. $(\mathrm{I} / 2-\mathrm{I}$ in.) and more thick, solid, hard, equal or attenuated downwards, even or pitted and uneven, but not spotted, viscid or dry, pallid or dark olivaceous, ochraceous-whitish at the apex. Gills adnato-decurrent, thin, 2-4 mm. ( $1-2$ lin.) broad, much crowded, forked, white straw-colour, spotted fuscous when broken or bruised. Milk acrid, white, unchangeable.

Gregarious, rigidly and compactly fleshy; habit almost that of Paxillus involutus. It varies with the stem hollow, and the pileus somewhat zoned.

In woods, roadsides, \&c. Common. Sept.-Nov. 
The pileus varies in size from about $7 \cdot 5-30$ cent. (3-12 in.) Spores Lactarius. spliæroid or subsphæroid, uniguttate, echinulate, $6-8 \mathrm{mk} . K$. Name-turpis, base. From its ugly appearance. Fr. Monogr. ii. p. I54. Hym. Eur.p.423. Sv. ätl. Sv. t. 6o. Berk. Out. p. 203. C. Hbk. n. 584. S. Mycol. Scot. n. 549. Ag. Weinm.-Fl. Dan. t. 1913. Krombh. t. 69. f. I-6. Harz. t. 60.

5. L. controversus Fr.-Pileus 7.5 cent. ( 3 in.) and more broad, fleshy, compact, rigid, at the first convex, broadly umbilicate, when fuller grown somewhat infundibuliform, oblique, on emerging from the ground dry, flocculose, whitish, then with rain smooth, viscid, reddish, with blood-coloured spots and zones (especially towards the margin), margin acute when young, closely involute, more or less villous; flesh very firm. Stem commonly 2.5 cent. (I in.) long and thick, sometimes however 5 cent. ( 2 in.) long and then manifestly attenuated towards the base and often excentric, solid, obese, even but pruinate and as if striate at the apex from the obsoletely decurrent tooth of the gills, wholly white, never pitted. Gills decurrent, thin, very crowded, 2-4 $\mathrm{mm}$. (I-2 lin.) broad, with many shorter ones intermixed, but rarely branched, pallid-white-flesh-colour. Milk white, unchangeable, plentiful.

Odour weak but pleasant, taste very acrid. Allied to L. piperatus.

In woods. Uncommon. Aug.--Oct.

Spores echinulate, $8 \times 6 \mathrm{mk}$. W.G.S. Name-contra, against; verto, to turn. From its becoming at length infundibuliform. Fr. Monogr. ii. p. I55. Hym. Eur. p. 423. Sv. ätl. Sv. t. 29. B. \& Br. n. I282. C. Hbk. n. 585. S. Mycol.Scot. n. 550. Trans. Woolh. Club, 1868, fig. Ag. Pers.-Vittad. t. 37. Ventur. t. 51. f. I-4. Barla t. I8.f. I, 2. Bull. t. 538. Batschf. 20 I. Krombh. t. 56.f. 5-7 (var.)

6. L. pubescens Fr. - Pileus about 5 cent. ( 2 in.) broad, whitish passing into flesh-colour, fleshy, rather plane, depressed in the centre, then broadly infundibuliform, quite zoneless, even, dry, becoming smooth at the disc, shining, margin involute, fibrilloso-pubescent; flesh thin but firm, pliant, white, or fleshcoloured in the cuticle, unchangeable. Stem short, scarcely 2.5 cent. (I in.) long, I $2 \mathrm{~mm}$. ( $1 / 2$ lin.) thick at the apex, attenuated downwards and sometimes compressed, stuffed, soit internally, even (not pitted), commonly pruinato-pubescent when young, but commonly becoming smooth, flesh-colour then whiie. Gills adnate or slightly decurrent, crowded, quaternate, narrower than the flesh of the pileus, pallid, slightly flesh-coloured. Milk white, unchangeable, not plentiful.

Inodorous, taste very acrid. It is like a poor form of $L$. controversus, but is very distinct. 
Lactarius. Among pebbles. Loch Kenord, Aberdeenshire.

Name-from the pubescent margin of the pileus. Fr. Monogr. ii. $p$. I 55 . Hym. Eur. p. 424. B. E Br. n. 1282. S. Mycol. Scot. n. 551. Grevillea, $t$. 76. f. 2. Ag. Krombh. t. I3. f. I-14.

Var. margine-tomentoso B. \& Br.-Pileus clothed with fine matted down, margin tomentose. Stem nearly equal, 3 cent. ( $1 / 1 / 4$ in.) long, about $10 \mathrm{~mm}$. (5 lin.) thick.

Odour pungent. In pastures. Aboyne. Aug. B. \& Br. n. IoI5. C. Hbk. n. 586. S. Mycol. Scot. n. 551. Krombh. t. 13. f. т, 2.

\section{** Limacini. Pileus viscid when moist, pelliculose, Eoc.}

7. I. insulsus Fr. - Pileus 7.5-Io cent. (3-4 in.) broad, yellowish-brick-colour, fleshy, not very compact, deeply umbilicate and at length infundibuliform, rigid, zoned (especially round the margin), smooth, with a somewhat separable viscid pellicle, margin naked; flesh firm, pallid, somewhat zoned under the pellicle. Stem stuffed when young, but varying hollow when old, most frequently curt and attenuated downwards, 4 cent. ( $\mathrm{I} / 2 \mathrm{in}$.) long, as much as 2.5 cent. ( $\mathrm{I}$ in.) thick, rarely lengthened to 7.5 cent. (3 in.) and then equal, thinner, smooth, even or more rarely pitted-spotted. Gills decurrent, very crowded, forked at the base, $2 \mathrm{~mm}$. (I lin.) or little more broad, whitish, becoming pale. Milk white, unchangeable, acrid.

Its stature and size are those of $L$. deliciosus, but the colours are paler; the milk when the plant is old is often watery (not coloured); otherwise when wounded it does not change colour as $L$. deliciosus does.

In mixed woods. Common. Aug.-Oct.

Spores globose, pallid. Fr. Name-insulsus, insipid, tasteless. Fr. Monogr. ii. p. 157. Hym. Eur. p. 424. Berk. Out. p. 204. t. 13. f. 2. C. Hbk. n. 587. S. Mycol. Scot. n. 552. Krombh. t. 12. f. 1-6. Hussey, i. t. 59 .

8. L. zonarius Fr.-Pileus 5-10 cent. (2-4 in.) broad, pallid orange or pale yellowish to deeper yellow, fleshy, convex becoming plane, then depressed, somewhat umbilicate, margin thin, naked, long involute, at first even, smooth, with a closely. adnate pellicle, viscid, beautifully zoned most frequently towards the margin, at length - and at the first at the circumference-minutely ruguloso-flocculose; flesh compact, white. Stem 5-7.5 cent. (2-3 in.) long, equal, or 2.5 cent. ( $\mathrm{I}$ in.) and attenuated downwards, $\mathrm{I}-2.5$ cent. $(1 / 2-\mathrm{I}$ in.) thick, firm, solid, elastic, spongysoft internally, even, smooth, dry, white then yellowish, unspotted, pale upwards. Gills rounded-adnate and adnato-decurrent, 
arcuate, thin, narrow, somewhat crowded, branched, scarcely Lactarius. broader than $2 \mathrm{~mm}$. ( 1 lin.), whitish, at length becoming dingy yellowish, becoming dingy or even somewhat æruginous when bruised. Milk white, unchangeable, acrid.

Pileus sometimes deeply umbilicate. Like $L$. insulsus, but well distinguished from it by its compact substance, \&c. It varies in having the stem hollow, the walls of the cavity at first white, then ochraceous-tawny, and also in the pileus being flexuous, smooth, zoneless.

In woods. Rare. Aug.-Oct.

Spores minutely echinulate, almost globular, $7 \mathrm{mk}$. W.G.S. Name-zona, a zone. Zoned. Fr. Monogr. ii. p. 158. Hym. Eur. p. 425. Berk. Out. p. 204. C. Hbk. n. 588. S. Mycol. Scot. n. 553. Fl. Bat. t. 825 middle fig. Ag. Bull.t. 104. Vaill. Par. t. 12.f.7.

9. L. blennius Fr.-Pileus 5-10 cent. (2-4 in.) broad, pallid olivaceous or cruginous-grey, fleshy, plano-depressed, glutinous, often concentrically guttate or somewhat zoned, the margin, which is at the first bent inwards, slightly downy when young, soon naked; flesh rigid, white. Stem $4-5$ cent. ( $1 / 2-2$ in.) long, I $2-18 \mathrm{~mm}$. ( $1 / 2-3 / 4$ in.) thick, stuffed then hollow, somewhat equal or attenuated downwards, even, viscid, pallid olive or pallid-grey. Gills adnato-decurrent, thin, crowded, about $2 \mathrm{~mm}$. (I lin.) broad, white, becoming cinereous when wounded. Milk white, unchangeable.

Firm, acrid. Dry in fine weather. When young it must not be confounded with $L$. turpis. It varies with the disc of the pileus rufescent : Fl. Dan. $t$. Ig6r. $f$. I.

In woods. Common. Aug.-Nov.

Spores sparingly echinulate, $6 \times 8 \mathrm{mk}$. W.G.S. Name- $\beta \lambda \epsilon \nu \nu o ́ s$, mucous matter. Slimy. Fr. Monogr. ii. p. 159. Hym. Eur. p. 425. Berk. Out. p. 204. C. Hbk. n. 589. S. Mycol. Scot. n. 554. Krombh. t. 69. f. 7-9. Krapf. t. 4. f. II-I3. Sterb. t. 5. E. B. disc rufescent. Fl. Dan. t. I6gI. f. 2 .

10. L. hysginus Fr.-Pileus $6-10$ cent. $(2 x / 2-4$ in.) broad, redflesh-colour or reddish brown, fleshy, not thick, umbilicate, becoming plane, the thin margin inflexed, even, viscous, zoneless or somewhat zoned, often shining; flesh white, somewhat rigid. Stem 5-10 cent. ( $2-4$ in.) long, $8 \mathrm{~mm} .-2.5$ cent. ( $3 / 4-1$ in.) thick, stuffed then hollow, often inflated, constricted at the apex, attenuated at the base, smooth, here and there pitted or somewhat spotted. Gills adnato-decurrent, thin, crowded, $2-4 \mathrm{~mm}$. (I-2 lin.) broad, white then light yellow-ochraceous. Milk white, unchangeable.

Taste acrid; rigid-fragile, pileus somewhat repand. The gills are not pruinose as in the Russulares. It varies with the stem curt, firm, even, the

VOL. II. 
Lactarius. pileus at length darker in the centre, becoming pale, tan-flesh-colour, round the margin.

In woods. Rare. Aug.-Oct.

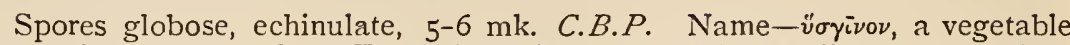
dye, crimson or scarlet. From the colour. Fr. Monogr. ii. p. r6o. Hym. Eur. p. 426. Icon. t. 169. f. 2. Berk. Out. p. 204. C. Hbk. n. 590. S. Mycol. Scot. n. 555. Ag. Krombh. t. I4. f. I5, I6.

11. L. trivialis Fr.-Pileus IO-I7.5 cent. (4-7 in.) broad, at first dark lurid, becoming pale when full grown, pallid yellowish, tan-flesh-colour, zoneless, convex then soon depressed, at length infundibuliform, margin at first involute, then flattened, at length the pellicle of the margin only inflexed, even, smooth, viscous; flesh equal, somewhat rigid, white. Stem stout, $2.5-15$ cent. ( $\mathrm{I}-6$ in.) long, 2.5 cent. ( $\mathrm{I}$ in.) and more thick, commonly inflatedhollow, even, smooth, slippery, unspotted, almost paler than the pileus. Gills somewhat decurrent, tense and straight, rather broad, 4-S mm. (2-4 lin.), somewhat thin, crowded, whitish, becoming pale. Milk white, unchangeable.

Acrid, large, fleshy, rigid-fragile. The stem is shorter and firmer in drier situations.

In woods, chiefly pine. Uncommon. Aug.-Oct.

Name-trivialis, common. Occurring everywhere in Northern Europe. Fr. Monogr. ii. p. r6o. Hym. Eur. p. 426. B. \& Br. n. 934. C. Hbk. n. 591. S. Mycol. Scot. n. 556. Ag. Krombh. t. I4. f. I7, I8.

12. L. circellatus Fr. - Pileus $5-7.5$ cent. ( $2-3$ in.) broad, rufous inclining to fuscous in wet weather, but becoming pale, variegated with darker zones, fleshy, umbilicato-convex then becoming plane, depressed in the centre, for the most part repand when older, even, smooth, very viscous in wet weather; flesh grumous-compact, white. Stem $4-5$ cent. ( $1 / 2-2$ in.) long, I 2 $\mathrm{mm}$. ( $1 / 2 \mathrm{in}$.) and more thick, solid, equal or attenuated downwards and often ascending, even, smooth, pale. Gills horizontal (not arcuate), somewhat decurrent with a tooth, very thin and crozuded, narrow, often forked, whitish, at length becoming yellow. Milk white, unchangeable.

Stature curt and firm; odour not unpleasant; taste acrid, stinging.

In woods. Rare.

Spores spherical, echinulate, ro $\mathrm{mk}$. Q. Name-circellus, a small ring. Ringed. From the zones. Fr. Monogr. ii. p. I6r. Hym. Eur. p. 426. Berk. Out. p. 204. C. Hbk. n. 592. Ag. Batt. t. I3. D. Sow. t. 203. Ventur. t. 34. f. 4,5 .

13. L. uvidus Fr.-Pileus 5-10 cent. (2-4 in.) broad, hoary- 
whitish, grey-flesh-colour-livid, becoming fuscous, fleshy, somervhat Lactarius. thin, convex, plane, then depressed, margin at first involute, very soon almost straight, even, smooth, viscous, zoneless; flesh rather lax, white then lilac when broken. Stem $4-9$ cent. (I $1 / 2-31 / 2$ in.) long, I $2-1 S \mathrm{~mm}$. ( $1 / 2-3 / 4 \mathrm{in}$.) thick, soon hollow, even or somewhat pitted, smooth, viscous, whitish becoming light yellow, sometimes with yellowish-ferruginous spots. Gills adnate and somewhat decurrent, somewhat arcuate, $2-4 \mathrm{~mm}$. ( $\mathrm{I}-2$ lin.) and more broad, thin, crowded, very unequal, here and there connected by branches and anastomosing with veins, shining white to dead white, soon spotted with lilac when wounded, at length here and there pallid ochraceous-ferruginous, even tinged with pallid brick-colour. Milk white then lilac.

Soft-fragile; somewhat insipid, at length slowly acrid; odour weak, some what nauseous-pungent, somewhat aromatic. It varies with the pileus obsoletely zoned, slightly pellucid-striate when old, and with the gills sometimes yellowish. The milk rarely remains white or at length turns dingy tan-colour; commonly it becomes lilac.

In woods. Uncommon. Aug.-Sept.

Spores globose, echinulate, 5-6 mk. C.B.P. Name-uvidus, moist. Fr. Monogr. ii. p. 162. Hym. Eur. p. 426. Berk. Out. p. 205. C. Hbk. n. 593. S. Mycol. Scot. n. 557 .

\section{*** Piperati. Pilens without a pellicle, Eoc.}

14. L. flexuosus Fr.-Pileus 5-Io cent. (2-4 in.) broad, leadgrey or violet-grey, becoming pale, zoned or zoneless, fleshy, convex, becoming plane, depressed, somewhat repand, margin at first and for a long time bent inwards, at length spreading, erect, $d r y$, at the first smooth, somewhat shining, then rivulososcaly, unpolished, opaque; flesh hard, grumoso-compact, white. Stem 5-9 cent. ( $2-3 \frac{1}{2}$ in.) long, 2.5 cent. ( $\mathrm{I}$ in.) and more thick upwards, solid, obese or equally attenuated downwards, not rarely excentric, here and there somewhat lacunose, not however pitted, pallid grey, the apex whitish, the base somewhat yellowish. Gills adnate, somewhat horizontal, thick, distant, 2-3 mm. (II $1 / 2$ lin.) broad, connected by branches, light yellowish, at length becoming whitish-flesh-colour. Milk white, unchangeable.

Remarkable; hard, firm, very acrid. Under a lens the stem is clothed with very delicate adpressed down. There is a form roseo-zonatus Post, approaching L. flexuosus alınost as Gomphidius roseus approaches Gomphidius glutinosus. Fr. Icon. t. 169.f. 3 .

In pine woods, \&c. Haywood Forest. Rothiemurchus. Glamis. Oct. 
Lactarius. Edible according to some, but doubtful from its very acrid taste. Spores sphæroid or subsphæroid, uniguttate, $6-8 \mathrm{mk}$. $K$. Name-flexus, a bending. Flexuous. From the margin of the pileus. Fr. Monogr. ii. p. I63. Hym. Eur. p. 427. Grevillea, vol. x. p. 45. S. Mycol. Scot. Supp. Scot. Nat. 1885, p. 73. Ag. Schaff. t. 235. Harz. t. 43.

15. L. pyrogalus Fr. - Pileus $5-7.5$ cent. ( $2-3$ in.) broad, cinereous-grey, at length becoming dingy yellow, firm, fleshy, convex becoming plane, margin very soon spreading, depressed, under a lens delicately grumoso-uneven, smooth, in rainy weather moist but not viscid, somewhat zoned; (flesh somewhat thin, but grumoso-firm, white). Stem 4 cent. ( $1 / 2$ in.) and more long, 6-1o mm. (3-5 lin.) thick, stuffed then soon hollow, often attenuated downwards, even or here and there delicately grumosotubercular under a lens, smooth, pallid-white, somewhat dingy. Gills adnato-decurrent, thin, somewhat distant, $2 \mathrm{~mm}$. (I lin.) and more broad, light yellow-wax-colour, the colour rich, inclining to ochraceous. Milk plentiful, white, unchangeable, very airid.

Pileus dry in fine weather. Allied to L. Aexuosus, but smaller and thinner. There is a var. like $L$. fuliginosus with the pileus zoneless and tan-colour, not fuliginous, and the gills yellow and distant.

In woods and pastures. Frequent. Aug.-Oct.

Poisonous. Spores sphæroid or subsphæroid, echinulate, 6-Io mk. $K$.; sparingly echinulate, white or with a suggestion of ochre, almost globular, $6 \mathrm{mk}$. W.G.S. Name- $\pi \hat{v} \rho$, fire; $\gamma \alpha$ áda, milk. From the milk being extremely acrid. Fr. Monogr. ii. p. 163. Hym. Eur. p. 427. Berk. Out. p. 205. C. Hbk. n. 594. S. Mycol. Scot. n. 558. Ag. Bull. t. 529. f. I. Krombh. t. I4. f. I-9.

16. L. squalidus Fr.-Pileus pallid lurid, compact, convexoplane, umbilicate, dry, smooth, zoneless; flesh white, sprinkled at the margin with saffron-yellow dots. Stem solid, equal, smooth, pallid brown. Gills adnate, narrow, yellowish. Milk whitish, sweet.

Its affinity is not clear. Krombholz compares it with L. fuliginosus, but its stature is that of $L$. pyrogalus, \&c., and the pileus is smooth.

In moist places. Scotland, I875; locality not recorded.

Name-squalidus, dirty. From the dingy colour. Fr. Hym. Eur. p. 428. B. \& Br. n. I556. S. Mycol. Scot. n. 559. Ag. Krombh. t. 40. f. 23-25.

17. L. capsicum Schulz.-Pileus 7.5 cent. ( 3 in.) broad, chestnut, paler at the disc, compact, pulvinate, dry, margin closely involute; flesh yellowish, becoming fuscous on exposure to the air. Stem about 2.5 cent. (I in.) thick, solid, firm, whitish, striate with tawny or rufescent fibres. Gills adnato-decurrent, somewhat crowded, tawny, somewhat orange. Milk white, acrid. 
Very robust. The gills are described as anastomosing.

Lactarius.

In wood. Dumfries, I884. Sept.

Name-probably from the taste being hot like that of Capsicum. Schulz.Fr. Hym. Eur.p. 428. S. Mycol. Scot. Supp. Scot. Nat. 1885, p. 73.

18. L. chrysorheus Fr.-Pileus $5-7.5$ cent. (2-3 in.) broad, somewhat flesh-colour, with darker zones or spots, fleshy, firm, umbilicate then infundibuliform; flesh white, bright sulphur-yellow when broken. Stem $5-7.5$ cent. (2-3 in.) long, I-2.5 cent. $(1 / 2-1$ in. $)$ thick, rigid, stuffed then soon hollow, equal, even, delicately pruinate under a lens, dry, white, changing colour only when old. Gills decurrent, very thin and crowded, narrow, $4 \mathrm{~mm}$. (2 lin.) broad, pallid-yellowish, not truly changing colour and not pruinose. Milk white then bright sulphur-yellow (golden), very acrid.

It is easily distinguished from all neighbouring species by the change of colour in the flesh and milk. Pileus when dry sprinkled with thin, whitish lustre, at length darker.

In mixed woods. Frequent. Sept.-Oct.

Margin of pileus wavy, involute, and minutely downy when young; flesh firm, crisp ; gills slightly forked; stem downy at the base. M.F.B. Name-

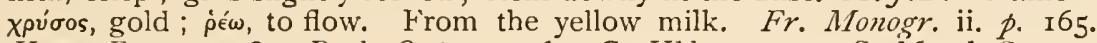
Hym. Eur. p. 428. Berk. Out. p. 206. C. Hbk. n. 597. S. Mycol. Scot.n. 560. Ag. Bolt.t. I44. Krombh. t. I2. f. 7-14.

19. I. acris Fr.-Pileus 7.5 cent. ( 3 in.) broad, cinereous-fuliginous, sometimes darker sometimes paler, fleshy, firm, rigid, irregular, often excentric or emarginate on one side, at first convex then plane, at length obliquely infundibuliform, moist rather than viscous, scarcely zoned, here and there spotted; flesh white. Stem about $4-5$ cent. ( $1 / 2-2$ in.) long, $12 \mathrm{~mm}$. ( $1 / 2$ in.) or a little more thick, stuffed then hollow, attenuated downwards, often oblique, ascending or curved, pallid, at length fragile. Gills somewhat decurrent, thin, somewhat crowded, somewhat divided behind, at first pallid, then yellow-flesh-colour. Milk white, soon reddish, plentiful.

Strong-smelling, acrid. Very different from L. fuliginosus, which is of the same colour, but approaching L. pyrogalus.

In woods. Rare. Aug.-Nov.

Spores echinulate, yellow, $6 \times 8 \mathrm{mk}$.W.G.S. Name-acer, sharp. From the acrid taste. Fr. Monogr. ii. p. I64. Hym. Eur. p. 428. Berk. Out.p. 207. C. Hbk. n. 596. S. Mycol. Scot. n. 561. Ag. Bolt. t. 60. Batsch f. 68. Batt. t. 13. E.

20. L. pergamenus Fr. White.-Pileus fleshy, pliant, convex 
Lactarius. then plano-depressed, repand, zoneless, slightly wrinkled, smooth. Stem stuffed, smooth, changing colour. Gills adnate, very narrow, horizontal, very crowded, branched, white then straw-colour. Milk white, acrid.

Very much allied to $L$. piperatus, but differing in the stem being stuffed, at length softer internally, elongated ( 7.5 cent., 3 in.), unequal, attenuated downwards and here and there ascending, guite smooth; in the pileus being thinner, pliant, elastic, most frequently irregular and excentric, for the most part flexuous, at first convex (not umbilicate), then rather plane, the surface very smooth, but unpolished and wrinkled in a peculiar manner; and in the gills being adnate, not decurrent, very crowded, very narrow (scarcely $2 \mathrm{~mm}$., I lin. broad), always straight and horizontal, not arcuate or extended upwards, soon straw-colour. The flesh is very milky, but the gills are sparingly so.

In woods. Haywood Forest, \&c. Oct.

Spores subglobose, rather irregular, 6-8 mk. C.B.P. Name-pergamenus, pergamena, parchment. From its toughness and parchment-like appearance. Fr. Monogr. ii. p. г66. Hym. Eur. p. 430. Grevillea, vol. xi. p. 7x. Ag. Swartz.-Krombh. t. 57.f. x-3. Batsch f. 59 .

21. L. piperatus Fr.-Pileus 10-22.5 cent. (4-9 in.) broad, white, fleshy, rigid, umbilicate when young, reflexed (margin at first involute) at the circumference, when full grown wholly infundibuliform, for the most part regular, even, smooth, zoneless; flesh white. Stem 2.5-5 cent. (I-2 in.) long, $2.5-5$ cent. ( $1-2$ in.) thick, solid, obese, equal or obconical, even, obsoletely pruinose, white. Gills decurrent, crowded, narrow, scarcely broader than $2 \mathrm{~mm}$. (I lin.), obtuse at the edge, dichotomous, arcuate then all extended upwards in a straight line, white, here and there with yellow spots. Milk white, unchangeable, plentiful and very acrid.

Compact, firm, dry, inodorous. The pileus becomes obsoletely yellow when old. Although the gills are spotted with yellow, they do not change to strawcolour like those of L. pergamenus.

In mixed wood. Common. Aug.-Oct.

When bruised changing to umber. M.F.B. Said to be edible, but very acrid. Spores not echinulate, generally with an apiculus, $5 \times 6 \mathrm{mk}$. W.G.S. Name-piper, pepper. From the acrid taste. Fr. Monogr. ii. p. x66. Hym. Eur. p. 430. Sv. ätl. Sv. t. 27. Berk. Out. p. 205. C. Hbk.n. 598. S. Mycol. Scot. n. 563. Ag. Scop.-Fl. Dan. t. I132. Barla t. 22. f. I-5. Harz. t. 39. Krombh. t. 56. f. I-4. Bull. t. 200. Paul. t. 68. f. 3-4.

22. L. vellereus Fr.-Pileus $12.5-17.5$ cent. (5-7 in.) broad, white, fleshy, compact, convexo-saucer-shaped, the margin for a long time sloping downwards, innato-pubescent, dry, zoneless. Stem 5-7.5 cent. ( $2-3$ in.) long, $2.5-4$ cent. ( $1-1 / 2$ in.) thick, stout, solid, equal, covered over with innate, very thin pubescence. Gills arcuate, adnato-decurrent, rather thick, acute at the edge, some- 
what distant, rather broad ( $4 \mathrm{~mm} ., 2$ lin. and more), connected by Lactarius. branches (but not dichotomous), pallid, watery white. Milk white, scanty, very bitter.

Large, hard, rigid. The pileus tends to become pallid reddish-tan. Very much allied to $L$. piperatus. On being broken it sometimes changes to pallid sulphur-yellow, but after a time becomes white again. Easily confounded with Russula delica.

In woods. Common. Sept.-Dec.

Spores hardly echinulate, $4 \times 8 \mathrm{mk}$. W.G.S. Name-vellus, fleece. From the pubescence. Fr. Monogr. ii. p. I67. Hym. Eur.p. 430. Berk. Out.p. 206. C. Hbk. n. 599. S. Mycol. Scot. n. 565. Hussey i. t.63. Ag. Klotsch Fl. Bor. t. 469. Barla. t. 22. f. 6.8. Krombh. t. 57.f. 10-13. Sow. t. ro4.

23. L. exsuccus Smith.-Pileus clothed with adpressed down, fleshy, depressed, with an involute margin. Stem very short, white, clothed with adpressed down. Gills decurrent, connected by veins, and forked, white, shaded with verdigris.

Whole plant rigid and brittle, milkless.

In woods. Uncommon.

Considered by some to be a var. of $L$. vellereus. It must be regarded as a distinct species, but I retain it among Lactarii only in deference to the opinion of others. Spores covered with spines, almost globular, $9 \mathrm{mk}$. W.G.S. Name-ex, succus, juice; juiceless. Sm. Fourn. Bot. 1873, p. 336. S. Mycol. Scot. $n .566$. L. vellereus var. exsuccus. Fr. Hym. Eur. p. 430. Berk. Out. p. 206. C. Hbk. n. 599. Ag. Berk. Eng. Fl. v. p. 31.

24. L. scoticus B. \& Br.-Pileus depressed-tomentose then smooth, the involute margin tomentose; flesh firm. Stem somewhat unequal, smooth, somewhat flesh-colour. Gills thin, scarcely branched. Milk persistently white, acrid.

Odour pungent.

Among moss. Aboyne. I862.

Name-Scottish. B. \& Br.n. r783. S. Mycol. Scot. n. 564.

TRIBE II.-DAPETES.

Milk at first deeply coloured, \&oc.

25. L. deliciosus Fr.-Pileus 5-1 5 cent. (2-6 in.) broad, orangebrick-colour, becoming pale, fleshy, when quite young depressed in the centre, margin naked, involute, then plano-depressed or broadly infundibuliform with the margin unfolded, smooth, slightly viscid, zoned (zones sometimes obsolete); flesh soft, not compact, pallid, coloured at the circumference only by the juice. Stem 2.5-5 cent. (I-2 in.) and more long, about 2.5 
Lactarius. cent. ( $\mathrm{I}$ in.) thick, stuffed then hollow, at length fragile, equal or attenuated at the base, spotted in a pitted manner, of the same colour as the pileus or paler. Gills somewhat decurrent, crowded, narrow, arcuate, often branched, typically saffronyellow, but becoming pale and always becoming green when wounded. Milk aromatic, from the first red brick-saffron.

The pileus becomes pale in various degrees, often greenish; it occurs also cinereous, fuscous-zoned, \&c. Nov.

In woods, chiefly pine. Common in some localities. July-

Edible; when young and fresh one of the most delicious of fungi, and from its orange-coloured milk it cannot be mistaken for any other. Spores white. Fr.; sphæroid, echinulate, 7-8 mk. $K . ; 6 \mathrm{mk} . W . G . S . \quad$ Name-from its delicious flavour. Fr. Monogr. ii. p. I68. Hym. Eur. p. 431. Sv. ätl. Sv. t. 6. Berk. Out. p. 206. C. Hbk. n. 600. S. Mycol. Scot. n. 567. Hussey i. t. 67. Ag. Schaff. t. Ir. Fl. Dan. t. 1751. Sv. Bot. t. 173. Letell. t. 632. Viv. t. I3. Barla t. I9. Vittad. t. 42. Krombh. t. II. Hara. t. Io.

\section{TRIBE III.-RUsSUlares. \\ * Pileus at the first viscous.}

26. L. pallidus Fr.-Pileus $7 \cdot 5-15$ cent. (3-6 in.) broad, fleshcolour or clay-colour to pallid, somewhat tan, fleshy, umbilicatoconvex, depressed, obtuse, margin broadly and for a long time involute, smooth, viscous, zoneless; flesh pallid. Stem 5 cent. (2 in.) and more long, about $18 \mathrm{~mm}$. (3/4 in.) thick, somewhat equal, stuffecl then hollow, even, smooth, of the same colour as the pileus. Gills somewhat decurrent, arcuate, rather broad (3-4 mm., I $1 / 2-2$ lin. and more), somewhat thin, crowded, somewhat branched, whitish at length of the same colour as the pileus. Milk white, unchangeable.

Taste somewhat mild. Stature that of $L$. deliciosus, but more lax in texture and always pallid. There is a var. with the pileus inclining to fuscous.

In mixed woods. Uncommon. Sept.-Oct.

Spores echinulate, almost round, $8 \mathrm{mk}$. W.G.S. Name-from the pallid colour. Fr. Monogr. ii. p. 169. Hym. Eur. p. 431. Sv. ätl. Sv. t. 6I. Berk. Out. p. 207. C. Hbk. n.601. S. Mycol. Scot. n. 568. Ag. Pers.Krombh. t. 56.f. I0-12?

27. L. quietus Fr.-Pileus 7.5 cent. (3 in.) broad, fleshy, depressed, obtuse, margin deflexed, smooth, at the first viscid, somewhat cinnamon, flesh-colour, disc darker, somewhat zoned, soon dry, somezuhat silky, opaque, becoming pale; flesh white then rufescent. Stem $5-7.5$ cent. (2-3 in.) long, $12 \mathrm{~mm}$. ( $1 / 2$ in.) and more thick, stuffed, spongy, smooth, rufescent, at length 
beautifully rubiginous. Gills adnato-decurrent, somewhat forked Lactarius. at the base, 3-4 mm. (I $1 / 2-2$ lin.) broad, white then soon brickrufescent. Milk white, unchangeable, sweet.

Abounding in milk. Soft, not so obese and fleshy as L. pallidus. The pileus is sometimes of one colour, rufescent.

In woods. Common. Aug.-Nov.

Margin of pileus delicately downy. Stem bearing strong pressure without breaking, when old less firm. Odour oily, and somewhat like that of bugs. M.F.B. Spores papillose, $8 \times 5 \mathrm{mk}$. IV.G.S. ; spherical, echinulate, I I mk. Q. Name-quietus, mild. From the taste. Fr. Monogr. ii. p. 169. Hym. Eur. p. 43r. Berk. Out. p. 207. C. Hhk. n. 602. S. Mycol. Scot. n. 56g. L. pallidus Saund. E Sm. t. 16. Ag. Krombh. t. 40. f. 5-7.

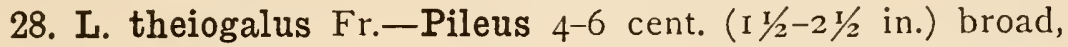
rufous-tawny, fleshy, thin, convex when young, then depressed, at length infundibuliform in the centre, margin more or less thin, rather broadly deflected, even, smooth, visious, shining when dry, zoneless; flesh whitish. Stem $2.5-5$ cent. (I-2 in.) long, 4-8 mm. (2-4 lin.) thick, stuffed then hollow, equal, even, of the same colour as the pileus. Gills adnato-decurrent, about $2 \mathrm{~mm}$. (I lin.) broad, thin, crowded, pallid then rufescent. Milk white then sulphur-yellow.

Slowly acrid, inodorous. Var. B. pileus zoneless, dry, gills becoming intensely yellow. Bolt. t. 9 .

In mixed woods. Frequent. Sept.-Oct.

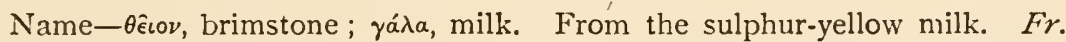
Monogr. ii. p. 170. Hym. Eur. p. 432 . Berk. Out. p. 206. C. Hbk. n. 603. S. Mycol. Scot. n. 570 . Ag. Bull. t. 567.f. 2. Krombh. t. I. f. $23,24$. Barla t. 20. f. I4-16. Paul. t.7I.

29. I. vietus Fr.-Pileus $4-6$ cent. ( $1 / 2-21 / 2$ in.) broad, fleshcolour or livid-grey, becoming pale, somewhat papillate becoming plane, then umbilicate, at length somewhat infundibuliform, margin somewhat deflexed, even, smooth, at the first viscid, opaque, slightly silky when dry; flesh whitish. Stem 4-6 mm. (2-3 lin.) thick, attenuated upwards or somewhat equal, stuffed then hollow, even, smooth, dry, somewhat of the same colour as the pileus. Gills adnato-decurrent, thin, somewhat crowded, somewhat flaccid, scarcely broader than $2 \mathrm{~mm}$. (I lin.), whitish. Milk white then somewhat grey.

Small, thin, soft, fragile, changeable in form. Slowly acrid, odour weak, somewhat pungent. The gills become at length yellowish.

In grassy woods. Stoke Poges. Glamis. Oct.

Name-vietus, shrunken, withered. From its appearance. Fr. Monogr. 
Lactarius. ii. p. I7 I. Hym. Eur. p. 432. Icon. t. I7o. B. \& Br. n. I672. S. Mycol. Scot. Supp. Scot. Nat. 1882, p. 217.

30. L. cyathula Fr.-Pileus $2.5-5$ cent. ( $1-2$ in.) broad, slightly fleshy, convexo-plane, umbonate, at length plano-depressed, umbo often vanishing, viscid in wet weather, soon dry, always very opaque, when in full vigour even, rufescent-brick or flesh colour, somewhat zoned, when dry becoming pale, livid or flesh-claycolour, hoary-tan, rimoso-rivulose; flesh white-flesh-colour. Stem about 5 cent. ( 2 in.) long, 2-Io $\mathrm{mm}$. ( $1-5$ lin.) thick, stuffed, internally spongy-soft, equal, round, even, smooth, pale, at length whitish. Gills decurrent, very crowded, thin, scarcely reaching $2 \mathrm{~mm}$. (I lin.) in breadth, linear, white-flesh-colour then yellowish. Milk white, unchangeable, acrid.

Growing in troops, for the most part very thin and very small, but larger, firmer, and darker specimens occur. Allied to $L$. vietus, but remarkable for its stature, thinness, and mode of growth; easily distinguished by the white milk being unchangeable when the gills are wounded, by its having at the first scarcely any odour, but a strong smell of bugs when withering or halfdried. It varies with the pileus zoneless, not umbonate.

In woods. Rare. Aboyne, \&c. Aug.-Nov.

Name-cyathula, a little cup. From its shape. Fr. Monogr. ii. p. I72. Hym. Eur. p. 433. B. \& Br. n. ror6. C. Hbk. n. 604. S. Mycol. Scot. n. $57 \mathrm{r}$.

* Pileus unpolished, squamulose, Eoc.

31. L. rufus Fr.-Pileus 7.5-10 cent. (3-4 in.) broad, baybrown-rufous, fleshy, umbonate when young, soon depressed with an umbo, and at length infundibuliform, wholly zoneless, dry, at the first flocculoso-silky, but soon polished, smooth, somewhat shining, margin involute when young, somewhat whitish-tomentose; flesh not compact, pallid. Stem 5-7.5 cent. (2-3 in.) long, about $12 \mathrm{~mm}$. ( $1 / 2$ in.) thick, stuffed, somewhat fragile, equal, obsoletely pruinate or wholly smooth, rufescent, but paler than the pileus, white-pubescent at the base. Gills adnato-decurrent, crowded, about $3 \mathrm{~mm}$. ( $1 / 2 \mathrm{l}$ lin.) broad, quaternate, scarcely branched, ochraceous or pallid then rufescent. Milk white, unchangeable.

Odour none. Taste very acrid, stinging. The colour of the pileus when older or dried passes into cinnamon-rufous. There is a smaller var. which must be carefully distinguished from $L$. subdulcis; very bitter.

In pine woods. Common. June-Nov.

The umbo is remarkably persistent and distinct even when most deeply infundibuliform. Very poisonous. Spores globose, white. Fr.; subsphæroid, $8 \mathrm{mk} . K$. ; scarcely echinulate, almost round, $5 \mathrm{mk}$. W.G.S. Name-rufus, 
red. Fr. Monogr. ii. p. 173. Hym. Eur. p. 433. Sv. ätl. Sv. t. II. Berk. Lactarius. Out. p. 208. C. Hbk. n. 605. S. Mycol. Scot.n.572. Hussey i. t. 15. Ag. Scop.-Krombh. t. 39. f. 12-15.-Paul. t. 22 bis.

32. L. helvus Fr.- Pileus 5-10 cent. (2-4 in.) broad, pale yellowish-brick-colour, becoming pale, fleshy, fragile, at first convex, then flattened, somewhat umbonate, the surface wholly broken up into gramuloso-squamulose flocci; flesh soft, of the same colour as the pileus but paler. Stem 5-7.5 cent. (2-3 in.) long, I $2 \mathrm{~mm}$. ( $1 / 2$ in.) and more thick, stuffed, or stuffed then hollow, moderately firm but soft, equal, brick-colour inclining to pale, everywhere slightly pruinate, and somewhat tomentose at the base. Gills decurrent, crowded, in groups of 8 , often dichotomous, 2-3 $\mathrm{mm}$. ( $\mathrm{I}-\mathrm{I} \mathrm{I} / 2 \mathrm{lin}$.) broad, fragile, at first whitish, then somewhat flesh-colour, at length yellowish. Milk scanty, somewhat acrid, white.

Odour weak, sweetish; taste commonly mild. It occurs most frequently in marshes with watery juice, not coloured. Very much allied to L. rufus.

In fir wood. Grantown, Morayshire. Aug.

Spores sphæroid, echinulate, 6-7 mk. $K$. Name-helvus, pale yellowish; dun-colour. Fr. Monogr. ii. p. I74. Hym. Eur. p. 433. S. Mycol. Scot. Supp. Scot. Nat. 1881, p. 36. Ag. Krombh. t. 40. f. I7, I8.

33. L. mammosus Fr.-Pileus grey-fuscous, truly fleshy, at the first convex, acutely umbonate, depressed on the umbo at length vanishing, soft, everywhere clothed with depressed down, dry, zoneless, the margin involute, white-pubescent. Stem moderately short and thick, stuffed then hollow, firm, pubescent, white inclining to pale. Gills adnate, crowded, whitish, then pallid ferruginous. Milk white, slowly acrid.

Small, firm, inodorous.

In woods. Holme Lacy, I879.

Name-mamma, a breast. Breast-shaped. Fr. Monogr. ii. p. I74. Hym. Eur. p. 434. Icon.t. 170.f. 2. Grevillea, vol. viii. p. 98. Quélet t. r1.f.6.

34. L. glyciosmus Fr.-Pileus $2.5-5$ cent. ( $\mathrm{I}-2$ in.) broad, grey, brick-colour, fuscous, most frequently passing into violet, zoneless, convex becoming rather plane, acutely papillate, then depressed, the papilla vanishing, delicately innato-squamulose or unpolished, opaque; flesh white, acquiring at last a slight tinge of the external colour. Stem $2.5-5$ cent. (I-2 in.) long, 4-8 mm. (2-4 lin.) thick, stuffed, somewhat equal, even, pubescent, light yellowish, becoming tawny when bruised, sometimes somewhat silvery-whitish, especially at the apex. Gills arcuate becoming 
Lactarius. rather plane, adnato-decurrent, $\mathrm{I}-2 \mathrm{~mm}$. ( $1 / 2-\mathrm{I}$ lin.) broad, thin, often connected by branches, crowded, straw-colour, becoming in the end tawny-flesh-colour or somewhat ochraceous. Milk white, somewhat mild, at length acrid.

Strong-smelling, with a sweet-spirituous pungent odour, which distinguishes it from all others; rigid, fragile, variable in stature, resembling $L$. vietus, but sufficiently distinguished from it by the pileus being absolutely dry, and by the gills being very crowded, straw-colour-ochraceous, and not spotted when wounded. The mill is sometimes unchangeable, sometimes becoming bright straw-colour-green when dried on the broken flesh, but it does not change colour on the gills. Var. stem elongated, hollow; pileus at first silky, even; also umbilicate, repand, zoned.

In woods, chiefly pine. Uncommon. Sept.-Nov.

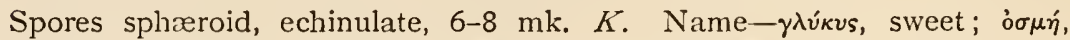
smell. Sweet-scented. Fr. Monogr. ii. p. I75. Hym. Eur. p. 434. Icon. t. I70. f. 3. Berk. Out. p. 209. C. Hbk. n. 6o6. S. Mycol. Scot. n. 573. Ag. Krombh. t. 39. f. I6-18?

35. L. fuliginosus Fr.-Pileus 2.5 -Io cent. ( $\mathrm{I}-4$ in.) broad, fleshy, spongy-compact, at length softer, becoming plane, somewhat repand, not rarely uneven, margin at first inflexed, but very soon spreading, flexuous, somewhat erect; depressed, very dry, at first even, tan-whitish, zoneless, sprinkled with innate, fuliginous pruina, somewhat velvety to the touch, rather hard, somewhat slippery when wetted, at length naked, pelliculose, now and then somewhat rugulose, soapy-livid, fawn-brick-colour, the disc sometimes at last brown; flesh almost equally attenuated towards the margin of the pileus, moderately thick in the centre. Stem 4-7.5 cent. ( $1 / 2-3$ in.) long, 6-1o mm. (3-5 lin.) thick, spongystuffed, somewhat equal, even or at length obsoletely rugulose, smooth, dead white to shining white then dingy, tan, somewhat rufescent-brick-colour, fuliginous. Gills at the first rounderadfixed, soon decurrent, 2-6 mm. ( $1-3$ lin.) broad, somewhat thin, somewhat distant, white at length light yellow-ochraceous, connected by branches and veins, the intermediate ones at length crisped. Milk and flesh when broken white, soon rose-colour, at length saffron-yellow.

Taste mild, soon acrid, again after a time, and when old, mild, pleasant. Odour weak, somewhat nauseous, somewhat pungent. Slightly firm, somewhat elastic; when full grown and seen from above somewhat resembling $A$. (Clitocybe) clavipes. The milk sometimes remains white; it occurs also thin and watery.

In woods. Frequent. Aug.-Oct.

The colour of the pileus is exactly that of coffee and milk. M.F.B. The change of colour in milk and flesh is remarkable. Spores yellowish. Fr.; sphæroid, echinulate, uniguttate, 6-1o mk. $K$.; almost globular, $7 \mathrm{mk}$. 
IV.G.S. Name-fuligo, soot. From the smoky colour. Fr. Monogr. ii. p. Lactarius. 178. Hym. Eur. p. 4.34. Berk. Out. p. 209. C. Hbk. n. 608. S. Mycol. Scot. n. 574. Ag. Krombh. t. 14. f. ro-12. Barle t. 21. f. 6, 7. Harz. t. 19. Bull. t. $567 \cdot f \cdot 3$.

36. L. picinus Fr.-Pileus 7.5 cent. ( 3 in.) broad, umber or blackish-umber, zoneless, fleshy, convex becoming plane, umbonate, orbicular, dry, even, at first everywhere villous, somewhat velvety (the down innate, not depressed or silky) then when the disc has become smooth wholly continuous on the surface (not rivuloso-flocculose or squamulose); flesh firm, but not very thick, pallid. Stem 5-7.5 cent. (2-3 in.) long, comparatively thin, scarcely more than I2 $\mathrm{mm}$. ( $1 / 2$ in.) thick, stuffed, internally spongy, equal, even, smooth, paler than the pileus. Gills adnate, thin, very crowded, straight, plane, ochraceous. Milk white, unchangeable, acrid.

Very distinguished, rigid, regular.

In pine woods. Foxley, Hereford. Rothiemurchus. Sept.-Oct.

Spores round, ochraceous. Fr.; sphæroid, echinulate, 5-6 mk. C.B.P. Name-picinus, pitch-black. Fr. Monogr. ii. p. 176. Hym. Eur. p. 435. Grevillea, vol. viii. p. r 10. S. Mycol. Scot. Supp. Scot. Nat. 1885, p. 74. Ag. Krombh. t. 40.f. 20-22 (f. 19 rather L. acris).

37. L. lilacinus Lasch.-Pileus 5 cent. ( 2 in.) broad, rosy-lilac, becoming pale, zoneless, fleshy, thin, convex then depressed, papillate, floccose when dry, granular. Stem stuffed then hollow, white-mealy, pallid. Gills adnate, somewhat distant, pallid fleshcolour. Milk white, acrid.

Fragile. Milk plentiful.

In woods. Hawthornden. Sept.

Spores sphæroid or sphæroid-ellipsoid, echinulate, uniguttate, 7-ro mk. K. Name-from the lilac colour. Lasch.-Fr. Hym. Eur. p. 435. Grevillea, vol. viii. p. 98. S. Mycol. Scot. Supp. Scot. Nat. r885, p. 74 .

\section{*** Pileus polished, smooth.}

38. L. volemus Fr.-Pileus 7.5 cent. ( 3 in.) and more broad, rufous-tawny, golden, becoming pale, zoneless, compact, rigid, obtuse, plano-convex, with the margin at the first bent inwards, at length depressed, even, at length rimoso-rivulose, dry. Stem 5-6 cent. $(2-21 / 2$ in.) long, $18 \mathrm{~mm} .-3$ cent. $(3 / 4-1 / 4$ in.) thick, obese, hard, solid, somewhat equal or attenuated upwards, even, pruinose, of the same colour as the pileus. Gills adnato-decurrent, 2-4 mm. ( I-2 lin.) broad, thin, crowded, white to yellowish. Milk white, sweet, plentiful. 
Lactarius. The largest and most robust of the Russularie. The milk sometimes becomes yellow. Wounds on the gills become dingy.

In mixed woods. Frequent. Sept.-Oct.

Stem sculptured longitudinally. M.F.B. Edible, delicious; savoury even when raw. Name-volema pira, a kind of large pear. From the shape. Fr. Monogr. ii. p. 178. Hym. Eur. p. 435. Sv. ätl. Sv. t. 1o. Berk. Out. p. 207. C. Hbk. n. 609. S. Mycol. Scot. n. 575. Hussey i. t. 87. Ag. Ventur. t. 34. f. I-3. Letell. t. 624. Fl. Bat. t. 874. Krombh. t. 39. f. I-4.

39. L. ichoratus Fr.-Pileus 7.5-10 cent. (3-4 in.) broad, tawnybrick-colour, disc often brown, brick-colour and zoned, fleshy, thin, at first rigid, then softer, obtuse, plano-depressed, often unequal, excentric, occasionally repand, even (not pruinate), very dry, opaque; flesh pallid. Stem $4-7.5$ cent. (I $1 / 2-3$ in.) long, 6-1o mm. (3-5 lin.) thick, solid, at first hard, then softer, internally spongy, equal or fusiform downwards, even, smooth, at first tawny, then rufescent. Gills adnate, decurrent with a tooth, scarcely crowded, white then ochraceous, never spotted. Milk white, unchangeable, sweet.

Allied to $L$. volemus, but thinner, very compact when young, then softer, strong-smelling. The stem is not so obese as that of $L$. volemus.

In woods. Hereford. Oct.

Name-ixwp, lymph. From the colour of the milk. Fr. Monogr. ii. p. I79. Hym. Eur. p. 436. Grevillea, vol. viii. p. 98. Ag. Batsch f. 60 .

40. L. serifluus Fr.-Pileus brown-tawny, zoneless, fleshy, plane then depressed, somewhat flexuous, dry, smooth, margin inflexed. Stem solid, yellowish, paler than the pileus, somewhat incurved. Gills crowded, of the same colour as the stem. Milk scanty, somewhat insipid, of the colour of serum.

In mixed woods. Frequent. Aug.-Nov.

Pileus $2.5-5$ cent. ( $I-2$ in.) broad. It must be carefully distinguished from L. camphoratus to which it is similar in appearance and in the nature of the milk. The scent of L. camphoratus distinguishes it. Name-serum, whey; fluo, to flow. From the nature of the milk. Fr. Hym. Eur. p. 436. Berk. Out. p. 207. t. I3. f. 4. C. Hbk. n. 607. S. Mycol. Scot. n. 576. Ag. Krombh. t. 4 o.f. $15,16$.

41. I. mitissimus Fr.-Pileus $2.5-7.5$ cent. ( $\mathrm{I}-3$ in.) broad, golden-tawny, zoneless, fleshy, thin, somewhat rigid, convex, papillate, clepressed, papilla vanishing, even, smooth, somewhat slippery when moist; flesh pallid. Stem elongated, $2.5-7.5$ cent. (I-3 in.) long, $8-12 \mathrm{~mm}$. ( $1 / 3-1 / 2$ in.) thick, stuffed then hollow, even, smooth, of the same colour as the pileus. Gills adnatodecurrent, somewhat arcuate, then tense and straight, $2-3 \mathrm{~mm}$. 
( $I-I \frac{1}{2}$ lin.) and more broad, thin, crowded, a little paler than the Lactarius. pileus, most frequently stained with minute rufous spots. Milk white, mild, plentiful.

Thin ; very much allied to $L$. subdulcis, but distinguished by the taste being mild then somewhat bitterish, and especially by the bright, golden-tawny', resplendent colour of the pileus and stem.

In mixed and pine woods. Common. Aug.-Nov.

Spores sphæroid, echinulate, 6-7 mk. C.B.P. Name-mitis, mild. Very mild in taste. Fr. Monogr. ii. p. I80. Hym. Eur. p. 437. Sv. ätl. Sv. t. 78. Berk. Out. p. 208. C. Hbk. n.6ro. S. Mycol. Scot. n. 577. Hoffm. Ic. t. 2. Ag. Krombh. t. 39.f. r9-20.

42. L. subdulcis Fr.-Pileus $5-7.5$ cent. (2-3 in.) broad, rufescent, zoneless, fleshy, thin, papillate, at length depressed, even, smooth, dry. Stem $2.5-5$ cent. (I-2 in.) long, 4-8 mm. (2-4 lin.) thick, stuffed then hollow, equal, somewhat pruinate, of the same colour as the pileus. Gills adnate, crowded, paler. Milk somewhat mild, white.

Inodorous. Slightly rigid. The colour is variable, rufous-cinnamon, baybrown-rufous, \&c., but not becoming pale. Flesh rufescent, compact although thin. Gills sometimes dark ferruginous-rufous, sometimes paler. All the forms agree in the slender growth, in the pileus being even, smooth, dry, zoneless, and, as well as the equal stem, rufescent, in the gills being somewhat rigid, crowded, somewhat rufescent, in the taste being somewhat mild, and in the milk being white, unchangeable.

In woods, mixed and pine. Common. July-Nov.

The substance of the stem is looser than in L. quietus. M.F.B. Spores between papillose and echinulate, $7 \mathrm{mk}$. IV.G.S. Name-sub, and dulcis, sweet. Somewhat sweet in taste. Fr. Monogr. ii. p. 180. Hym. Eur. p. 437. Berk. Out.p. 208. C. Hbk. n. 6I I. S. Mycol. Scot.n. 578. Ag. Bull. t. 227. Sow. t. 204. Bolt. t. 3. Harz. t. 53. Barla t. 20. f. 4-10. Quel. t. Ir. f. 3. Lenz.f. II.

43. L. Terrei B. \& Br.-Pileus $12 \mathrm{~mm}$. ( $\mathrm{t} / 2 \mathrm{in}$. ) broad, baybrown, corrugated, depressed. Stem 18 mm.-2.5 cent. (3/4-I in.) long, $4 \mathrm{~mm}$. (2 lin.) thick, hollow, thickened at the base, of the same colour as the pileus, with orange down. Gills decurrent, pallid.

Cæspitose. Odour sweet. Allied to L. subdulcis.

On the ground. Stoke Poges, i876. Nov.

Name-after Michael Terry. B. \& Br. n. I673.

44. L. camphoratus Fr.-Pileus brown-brick-red, somewhat zoned, fleshy, thin, depressed, dry, smooth. Stem stuffed, somewhat undulated, of the same colour as the pileus. Gills adnate, crowded, yellowish-brick-colour. Milk mild, white. 
Lactarius. Strong-smelling. So like L. subdulcis, that it can be distinguished safely only by its odour of Melilot when dried.

In woods, chiefly pine. Frequent. Aug.-Nov.

Pileus about $2.5-5$ cent. ( $\mathbf{I}-2$ in.) broad. Stem short. The pileus is sometimes quite zoneless. The milk is scarcely white as described by Fries, rather pale watery like that of $L$. serifuus. The unmistakable odour is slight when the plant is fresh, but very strong when dried, nor does it lose its scent with years. The milk, as well as the scent, distinguishes it from L. subdulcis. Spores spherical, echinulate, 6-7 $\mathrm{mk}$. Q. Name-camphorated, strongscented. Fr. Hym. Eur. p. 437. Berk. Out. p. 208. C. Hbk. n. 6r2. S. Mycol. Scot. n. 579. Quel. t. II. f. 5. Ag. Bull. t. 567. f. I. Ventur. t. 55 . f. 3. Barla t. 20. f. II-13. Krombh. t. 39. f. 2I-24.

45. L. obnubilus Lasch.-Pileus scarcely 2.5 cent. ( $\mathrm{I}$ in.) broad, brown-fuliginous, zoneless, fleshy, thin, convex then umbilicate, smooth, somewhat striate. Stem stuffed then hollow, thin, paler than the pileus. Gills somewhat crowded, yellowish. Milk white, somewhat sweet.

Small, fragile; pileus at first papillate; varying in colour like L. subdulcis, of which it was commonly taken to be a subspecies.

In damp places below alder and in pastures. Greeshop, Morayshire. Glamis. Sept.-Nov.

Name-obnubilo, to overcloud, obscure. Dark. Lasch Linn. n. 7r. under Agaricus. Fr. Hym. Eur. p. 438 . B. \& Br. n. I784. S. Mycol. Scot. n. 580. A. obscuratus Lasch. Fr. Monogr. ii. p. I8I. Ag. Fl. Dan. t. I674. Compare Ag. tristis Krombh. t. 40. f. 26-29.

46. L. minimus Smith.-Pileus $1 / 4-5 / 8$ in. broad, pallid claycolour, fleshy, pulvinate, rounded or slightly umbonate, margin incurved. Stem very short, generally excentric, of the same colour as the gills. Gills somewhat decurrent, arcuate, branched, moderately distant. Milk abundant, white, mild.

Very small.

In pastures. Abergavenny, I87 I. Forres. Oct.

Spores echinulate, $8 \mathrm{mk}$. Name-smallest in size. Smith Fourn. Bot. 1873, p. 2C5. B. E Br.n. 1557. S. Mycol. Scot. n. 581. Fr. Hym. Eur. p. $43^{8}$.

Tribe IV.-Pleuropus.

No British species. 
Genus X.-Russula (russulus, reddish). Pers.

Russula.

Fr. Epicr. i. p. 349.

Veil none. Hymenophore descending unchanged and forming a vesicular trama. Gills rigid, fragile and not milky, acute at the edge. Spores rounded, often echinulate, white or yellowish. Growing on the ground, fleshy, putrescent, with polished stem, and pileus at the first or at length depressed.

The Russulæ constitute a very natural group, allied to the Lactarii, but very easily distinguished from them by their want of milk. Various Russulæ however exude watery drops, especially in rainy weather. The gills of most of them are equal in length or furcate, but in the tribe of the Compacte they are quite unequal. The species are for the most part striking in appearance: the

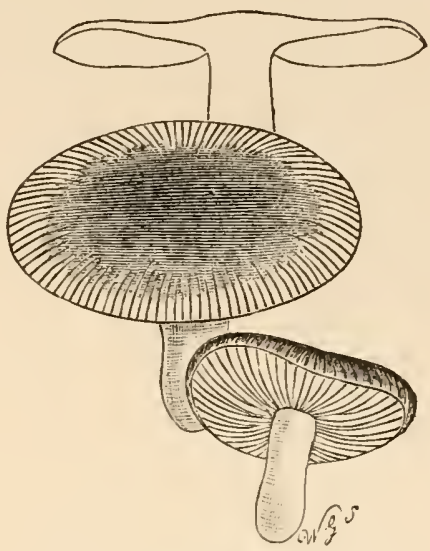

L. Russula aurata. One-fourth natural size.

Fragiles, the most common tribe, are difficult to determine on account of the variations of their colour. Fr. Hym. Eur. p. 439.

The most protean species is $R$. integra. Fries warns beginners to beware of making out new species in the neighbourhood of this, and of ascribing forms of it to truly distinct species which are of comparatively rare occurrence.

On account of the danger of mistaking noxious species for the few which are edible, their use as food is not to be commended.

I. COMPACTE (compingo, to put together: compact). Pileus fleshy throughout, hence the margin is at first bent inwards and always without striæ, without a distinct viscous pellicle (in consequence of which the colour is not variable, but only changes with age and the state of the atmosphere). Flesh compact, firm. Stem solid, fleshy. Gilis unequal.

II. Furcat \& (furca, a fork. With forked gills). Pileus compact, firm, covered with a thin, closely adnate pellicle, which at length disappears, margin abruptly thin, at first inflexed, then spreading, acute, even. Stem at first compact, at length spongy-soft within. Gills somewhat forked, with a few shorter ones intermixed, commonly attenuated at both ends, thin and normally narrow.

III. RIGIDÆ (rigidus, rigid). Pileus without a viscid pellicle, absolutely dry, rigid, the cuticle commonly breaking up into flocci or granules. Flesh thick, compact, firm, vanishing away short of the margin which is straight (never involute), soon spreading, and always without strice. Stem solid, at

VOL. II. 
Russula. first hard, then softer and spongy. Gills, a few dimidiate, others divided, rigid, dilated in front, and running out with a very broad rounded apex, whence the margin of the pileus becomes obtuse and is not inflexed. Exceedingly handsome, but rather rare.

IV. HeTEROPHyLla: (R. heterophylla, the typical species of the section). Pileus fleshy, firm, with a thin margin which is at first inflexed, then expanded and striate, covered with a thin adnate pellicle. The gills consist of many shorter ones mixed with longer ones, along with others which are forked. Stem solid, stout, spongy within.

V. FRAGILES (fragilis, fragile or brittle). Pileus more or less fleshy, rigidfragile, covered with a pellicle which is always continuous, and in wet weather viscid and somewhat separable; margin membranaceous, at first convergent and not involute, in full-grown plants commonly sulcate and tubercular. Flesh commonly floccose, lax, friable. Stem spongy, at length wholly soft and hollow. Gills almost all equal, simple, broadening in front, free in the pileus when closed. Several doubtful forms occur. $R$. integra is specially fallacious from the variety of its colours.

* Gills and spores white.

** Gills and spores white, then light yellowish or bright lemon-yellow.

*** Gills and spores ochraceous.

\section{I.-СомРАСТæ.}

1. R. nigricans Fr.-Pileus 5-10 cent. (2-4 in.) and more broad, olivaceous-fuliginous, at length black, fleshy to the margin which is at first bent inwards, convex then flattened, umbilicatodepresssed, when young and moist slightly viscid and even (without a separable pellicle), at length rimoso-squamulose; flesh firm, white, when broken becoming red on exposure to the air. Stem 2.5 cent. (I in.) thick, persistently solid, equal, pallid when young, at length black. Gills rounded behind, slightly adnexed, thick, distant, unequal, paler, reddening when touched.

Compact, obese, inodorous, within and without at length wholly black, in which it differs from all others. The flesh becomes red when broken because it is saturated with red juice, although it does not exude milk. Sometimes a very few of the gills are dimidiate.

In woods. Common. June.-Nov.

Spores papillose, $8 \mathrm{mk}$. W.G.S. Coarse in habit. Name-nigrico, to be blackish. Fr. Monogr. ii. p. I84. Hym. Eur. p. 439. Berk. Out. p. 209. C. Hbk. n. 6гі. S. Mycol. Scot. n. 582. Hussey i. t. 73. Ag. Bull. t. 579. f. 2, t. 212. K̈rombh. t. 70. f. I., 15. Barla t. 17. Sow. t. $3^{6 .}$

2. R. adusta Fr.-Pileus pallid or whitish, cinereous-fuliginous, equally fleshy, compact, depressed then somewhat infundibuliform, margin at first inflexed, smooth, then erect, without striæ; flesh unchangeable. Stem solid, obese, of the same colour as the pileus. Gills adnate then decurrent, thin, crowded, unequal, white then dingy, not reddening when touched.

It can only be compared with $R$. nigricans, but is sufficiently distinct; 
stature commonly smaller, flesh juiceless, not reddening, \&c. The pileus does Russula. not become black, but only of a scorched appearance.

In woods. Frequent. Aug.-Oct.

Well distinguished by its comparatively thin, crowded gills, \&c. M.F.B. Spores spharoid, echinulate, $7-9 \mathrm{mk} . K . ;$ globose, rough, $8 \mathrm{mk}$. C.B.P. Name-aduro, to scorch. From its scorched appearance. Fr. Monogr. ii. p. 184. Hym. Eur. p. 439. Berk. Out. p. 209. C. Hbk. n. 6r4. S. Mycol. Scot.n.583. Ag. Pers.-Krombh. t. 7o. f. 7-Ir. Batt. t. I3.

3. R. semicrema Fr. - Pileus persistently white, compactly fleshy, convex then plane, even, smooth, dry, disc umbilicate, margin at first involute, always even; flesh juiceless, white, unchangeable. Stem sometimes curt, sometimes 5-7.5 cent. (2-3 in.) long, almost 5 cent. ( 2 in.) thick, fleshy, solid, firm, white, but when broken becoming cinereous internally, and at length becoming black. Gills decurrent, crowded, thin, persistently white.

Odour none, taste mild. Intermediate between $R$. adusta and $R$. delica, but easily distinguished from both.

In mixed woods. Glamis. Aug.

Name-semi, half; crĕmo, to burn. From the blackening stem. Fr. Monogr. ii. p. 185. Hym. Eur. p. 440. Icon. t. 172. f. I. B. \& Br. n. I674. S. Mycol. Scot. n. $5^{84}$.

4. R. delica Fr. White.-Pileus $7.5-12.5$ cent. ( $3-5$ in.) broad, fleshy throughout, firm, umbilicate then infundibuliform, regular, everywhere even, smooth with a whitish lustre, the involute margin without striæ; flesh firm, juiceless, not very thick, white. Stem curt, $2.5-5$ cent. ( $1-2$ in.) long, $12 \mathrm{~mm}$. ( $1 / 2 \mathrm{in}$.) and more thick, solid, even, smooth, white. Gills decurrent, thin, distant, very unequal, white, exuding small watery drops in wet weather.

The stature and unchangeable colonrs are wholly those of L. vellereus and L. piperatus, but it is readily distinguished by the gills being juiceless, though they exude watery drops when young.

In mixed woods. Uncommon. Sept.-Oct.

Name-delicus, weaned; without juice or milk in the gills, as distinguished from L. vellereus, \&c. Fr. Mlonogr. ii. p. 185. Hym. Eur. p. 440. Berk. Out. p. 2 го. C. Hbk. n. 615. S. Mycol. Scot. n. 585. Vent. t. 48. f. 3, 4. Batt. t. 17. A. Paul. t. 73.f. г.

5. R. elephantina Fr.-Pileus 7.5 cent. ( 3 in.) broad, fuscoustan, paler round the margin, but not changeable, equally fleshy, firm, at first convexo-umbilicate; margin bent inwards, smooth, undulated, and almost exceeding the gills, but never striate, covered with a pellicle which is not separable; flesh equal, 
Russula. compact, but comparatively thin. Stem $5-7.5$ cent. (2-3 in.) long, 2.5 cent. ( $\mathrm{i}$ in.) thick, solid, obese, very hard, even, smooth, externally and internally shining white. Gills obtuse or somewhat simuato-adnate, arcuate, somewhat crowded, thin, divided behind, unequal in front, white, spotted pale yellowish when touched.

Habit that of $R$. fotens, but inodorous.

In woods. Stoke Poges. Sept.

Name-elephantinus, of ivory. From the white ivory-like stem. Fr. Monogr. ii. p. 186. Hym. Eur. p. 440. B. \& Br.n. 1785-not Bolt.

\section{II.-FuRCATÆ.}

6. R. furcata Fr.-Pileus about 7.5 cent. ( 3 in.) broad, sometimes æruginous-greenish, sometimes umber-greenish, fleshy, compact, gibbous then plano-depressed or infundibuliform, even, smooth, but often sprinkled with slightly silky lustre, pellicle here and there separable, margin thin, at first inflexed, then spreading, always even; flesh firm, somewhat cheesy, white. Stem 5 cent. ( 2 in.) or a little more long, solid, firm, equal or attenuated downwards, even, white. Gills adnato-decurrent, rather thick, somewhat distant but broad, attenuated at both ends, frequently forked, shining white.

Taste bitterish. The structure is that of $R$. sanguinea or rubra, not of $R$. virescens, with which it agrees in colour, but from which it differs in the form of the pileus, in the acute and at first inflexed margin, in the pellicle being separable and not dividing into warts, and in the entire type of the gills.

In woods. Common. Sept.

Poisonous. Spores globose, echinulate, $6-7 \mathrm{mk}$. C.B.P. Name-furca, a fork. With forked gills. Fr. Monogr. ii. p. 187. Hym. Eur. p. 44I. Berk. Out. p. 210. C. Hbk. n. 6r6. S. Mycol. Scot. n. 586. Ag. Pers.-Krombh. t. 62. f. I, 2, t. 69. f. I8-22. Bull. t. 26. Schaff. t. 94. f. I. Barla t. I6. f. I-9. Harz. t. 54, t. 63.f. 5. Paul. t. 74. f. I. Buxb. C. v. t. 47. f. 2.

7. R. sanguinea Fr.--Pileus $5-7.5$ cent. (2-3 in.) broad, bloodred or becoming pale round the even, spreading, acute margin, fleshy, firm, at first convex, obtuse, then depressed and infundibuliform and commonly gibbous in the centre, polished, even, moist in damp weather; flesh firm, cheesy, white. Stem stout, spongy-stuffed, at first contracted at the apex, then equal, slightly striate, white or reddish. Gills at first adnate, then truly decurrent, very crowded, very narrow, connected by veins, fragile, somewhat forked, shining white.

Taste acrid, peppery. Often confounded with $R$. rubra, which is of the 
same colour, but entirely different from it in the firm solid flesh, in the gills Russula. being adnate, then deeply decurrent, and acuminate in front.

In woods, chiefly fir. Uncommon. Aug.-Sept.

Poisonous. Name-sanguis, blood. Blood-coloured. Fr. Monogr. ii. p. 188. Hym. Eur. p. 442. Berk. Out. p. 210. C. Hbk. n. 6r7. S. Mycol. Scot. n. 587. Ag. Bull. t. 42 .

8. R. rosacea Fr.-Pileus 5-10 cent. (2-4 in.) broad, somewhat flesh-coloured varying in intensity, becoming whitish when the pellicle disappears, often variegated with darker spots when dry, compactly fleshy, at first convex, then expanded, obtuse, commonly unequal, repand, even incised, covered with a pellicle which is viscid and separable in wet weather, margin acute, even; flesh firm, cheesy, white. Stem about 5 cent. (2 in.) long, solid, firm, at length spongy internally, even, smooth, occasionally ventricose, white or reddish. Gills in every stage of growth adnate, thin, crowded, fragile, forked behind, with dimidiate ones intermixed, always persistently white.

Taste slowly acrid. Allied to $R$. sanguinea but irregular, often excentric with the pileus somewhat repand, scarcely depressed, and the gills less crowded, broader, less divided, scarcely connected.

In mixed woods. Frequent. Sept.-Oct.

Spores papillose, almost globose, $7 \mathrm{mk}$. IV.G.S. Name-rosa, a rose. Rose-coloured. Fr. Monogr. ii. p. I88. Hym. Eur. p. 442. Berk. Out. p. 210. C. Hbk. n. 6r8. S. Nycol. Scot. n. 588. Ag. Bull. t. 509. f. Z.

9. R. sardonia Fr.-Pileus $5-7.5$ cent. ( $2-3$ in.) broad, reddish, \&c., fleshy, compact, convex then plane, rarely depressed, but here and there repand, with an adnate pellicle which is viscid in wet weather and soon changes colour-and then often spotted, margin even. Stem $4-5$ cent. ( $1 / 2-2$ in.) long, almost 2.5 cent. (I in.) thick, solid, firm, but at length spongy within, even, white or reddish. Gills adnate, crowded, broad, somewhat forked, white, exuding watery drops in wet weather, whence arise yellowish spots when dry.

Robust, firm. The colour is very changeable, sometimes reddish, sometimes pallid with yellow spots, sometimes dingy yellow, opaque. Flesh same as in $R$. rosacea, \&c. Intermediate between $R$. rosacea and $R$. expallens, but distinct from both in the colour becoming yellow.

In woods, chiefly fir. Uncommon. Sept.

Name-from its acrid taste. Herba Sardonia (probably Ranunculus sceleratus), screwing the mouth with its bitterness. Fr. Monogr. ii. p. r89. Hym. Eur. p. 442. Berk. Out. p. 21 I. C. Hbk. u. 6Ig. S. Mycol. Scot.n. 589. Ag. Krombh. t. 68. f. I-4.-Scheff. t. I6. f. 5, 6.

10. R. depallens Fr.-Pileus pallid reddish or inclining to 
Russula. fuscous, \&c., fleshy, firm, convex then plane, more rarely depressed, but commonly irregularly shaped and undulated, even, the thin adnate pellicle presently changing colour especially at the disc, the spreading margin even, but slightly striate when old; flesh white. Stem about 4 cent. ( $1 \frac{1}{2}$ in.) long, solid, firm, commonly attenuated downwards, white, becoming cinereous when old. Gills adnexed, broad, crowded, distinct, but commonly forked at the base, often with shorter ones intermixed.

Inodorous, taste mild. The colour of the pileus is at first pallid reddish or inclining to fuscous, then whitish or yellowish, opaque in every stage of growth. It approaches nearest to the Heterophylla.

In beech woods, pastures, \&c. Uncommon. Aug.-Sept.

Name-de, and palleo, to be pale. Becoming pale. Fr. Monogr. ii. p. r89. Hym. Eur. p. 442. Berk. Out. p. 211. C. Hbk. n. 620. S. Mycol. Scot.n. 590. Krombh. $t .66 . f .12,13$.

11. R. drimeia Cke.-Pileus 5-Io cent. (2-4 in.) broad, bright purple, compact, firm, convex then depressed, scarcely viscid when moist, opaque when dry, margin somewhat incurved, even. Stem $5-7.5$ cent. (2-3 in.) long, $12-18 \mathrm{~mm}$. ( $1 / 2-3 / 4$ in.) thick, solid, firm, cylindrical, equal, tinged with purple. Gills adnexed, scarcely crowded, narrow and furcate at the base, at first pale sulphur-yellow, then deeper yellow, never white.

Acrid, peppery. Spores pale ochre. The colour and habit similar to $R$. Queletii, but distinguished by the yellow gills, ochraceous spores, and intensely peppery taste.

On the ground among larch. Black Park, I881, \&c. Sept.Nov.

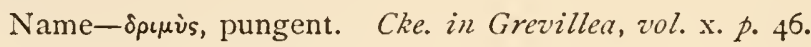

$$
\text { III.-RIGIDÆ. }
$$

12. R. lactea Fr.-Pileus 5 cent. ( 2 in.) broad, at the first milkwhite, then tan-white, throughout compactly fleshy, campanulate then convex, often excentric, without a pellicle, always dry, at the first even, then slightly cracked when dry, margin straight, thin, obtuse, even; flesh compact, white. Stem $4-5$ cent. ( $1 \frac{1 / 2-2}{2}$ in.) long, 4 cent. ( $\mathrm{I} / 2$ in.) thick, solid, very compact, but at length spongy-soft within, equal, even, always white. Gills free, very broad, thick, distant, rigid, forked, white.

Mild. The gills are at length adnate, forked at the base and apex. Care must be taken not to confound it with other Russule which have changed colour and become white.

In mixed woods. Uncommon. Aug.

Edible, but not commended for use. Name-lac, milk. Milk-white. Fr. 
Monogr. ii. p. I90. Hym. Eur. p. 443. B. \& Br. I133. C. Hbk. n. 621. Russula. S. Mycol. Scot. n. 591. Ag. Pers.-Krombh. t. 6r.f. I-2. Barla t. I5. f. 1-13. Paul. t. 74.f. 2.

13. R. virescens Fr.-Pileus green, compactly fleshy, globose then expanded, at length depressed, often unequal, always dry, not furnished with a pellicle, wherefore the flocculose cuticle is broken up into patches or warts, margin straight, obtuse, even; flesh white, not very compact. Stem solid, internally spongy, firm, somewhat rivulose, white. Gills free, somewhat crowded, sometimes equal, sometimes forked, with a few shorter ones intermixed, white.

Taste mild. It varies in size and colour of pileus, which is sometimes deep sometimes pallid green, sometimes yellowish then green. The gills are not so broad in front as those of neighbouring species. It is very easily distinguished from all others by the green pileus being without a pellicle and innatoflocculose, then rivulose, and scaly in the form of patches.

In woods. Frequent. July-Sept.

Stem variable in form, slightly reticulated with raised lines. M.F.B. Pileus sometimes as much as Io cent. (4 in.) broad. Edible. Spores scarcely echinulate, almost globular, $6 \mathrm{mk}$. W.G.S. Name-vireo, to be green. Fr. Monogr. ii. p. Igo. Hym. Eur. p. 443. Berk. Out. p. 212. t. I3.f. 6. C. Hbk. n. 622. S. Mycol. Scot. n. 592. Hussey ii. t. I r. Ag. Schaff. t. 94 excluding f. 1. Vittad. t. 31. Sturm Deutschl. Fl. iii. 3. t. 31. Barla t. I6. f. rо-г2. Ventur. t. I7. f. I, 2. Krombh.t.67.f. I-Iо.

14. R. Du Portii Phill.-Pileus $4-6.5$ cent. ( $1 / 2-23 / 4$ in.) broad, centre rufous or flesh-red, margin bluish, compact, fleshy, firm, convexo-plane, depressed, smooth, dry, margin even, obtuse. Stem 2.5 cent. (1 in.) or more high, 10-16 mm. (5-8 lin.) broad, spongy-stuffed, minutely striate, glabrous, white. Gills rounded behind, broad, distant, white.

The flesh turns reddish-brown when cut, and the odour is that of the common crab.

In wood. Mattishall, Norfolk.

Spores globose, asperate, 9 mk. W.P. Name-after Rev. J. M. Du Port. Phill. Grevillea, vol. xiii. p. 49.

15. R. lepida Fr.-Pileus 7.5 cent. ( 3 in.) broad, blood-red-rose, becoming pale, whitish especially at the disc, somewhat equally fleshy, convex then expanded, scarcely depressed, obtuse, opaque, unpolished, with a silky appearance, at length often rimososquamulose, margin spreading, obtuse, without striæ. Stem as much as 7.5 cent. ( 3 in.) long, often 2.5 cent. ( 1 in.) thick, even, white or rose-colour. Gills rounded behind, rather thick, somewhat crowded, often forked, connected by veins, white, often red at the edge. 
Russula. Taste mild; wholly compact and firm, but the flesh is cheesy not somewhat grumous. The gills are often red at the edge chiefly towards the margin, on account of the margin of the pileus being continuous with the gills.

In mixed woods. Frequent. Sept.-Oct.

Edible. Name-lepidus, neat, elegant. Fr. Monogr. ii. p. I91. Hym. Eur. p. 444. Sv. ätl. Sv. t. 59. Berk. Out. p. 212. C. Hbk. n. 623. S. Mycol. Scot. n. 593. Hussey ii. t. 32. Hogg \& Fohnst. t. 4. Ag. Krombh. t. 64. f. 19, 20. Batsch t. 13 (very small).

16. R. rubra Fr.-Pileus unicolorous, cinnabar-vermilion, but becoming pale ( $\tan$ ) when old, disc commonly darker, compact, hard but fragile, convex then flattened, here and there depressed, absolutely dry, without a pellicle, but becoming polished-even, often rivuloso-rimose when old, margin spreading, obtuse, even, always persistent; flesh white, reddish under the cuticle. Stem 5-7.5 cent. (2-3 in.) long, about 2.5 cent. ( $\mathrm{I}$ in.) thick, solid, even, varying white and red. Gills obtusely adnate, somewhat crowded, whitish, then yellowish, with dimidiate and forked ones intermixed.

Very acrid, very hard and rigid, most distinct from all the others of this group in the pileus becoming polished-even, although without a pellicle, in the fesh being somezhat grumous, and in the very acrid taste. Gills often red at the edge.

In mixed woods. Frequent. Aug.-Nor.

Poisonous. Spores whitish. Fr.; sphæroid, 8-ro mk. $K$. Name-ruber, red. Fr. Monogr. ii. p. I91. Hym. Eur. p. 444. Sv. ät. Sv. t. 49. Berk. Out.p. 212. C. Hbk. n. 624. S. Mlycol. Scot. n. 594. Ag. Decand.-Barla t. I5.f. r-Io. Krombh. t. 65. Vitt. Mang. t. 38.f. 2, not Bull. Schaff.t. I5. $f \cdot 4-6$.

17. R. Linnæi Fr. - Pileus $7 \cdot 5$-1o cent. (3-4 in.) broad, unicolorous, dark purple, blood-red or bright rose, opaque, not becoming pale, everywhere fleshy, rigid, plano-depressed, sometimes repand, even, smooth, dry, without a separable pellicle, margin spreading, obtuse, without striæ; flesh thick, spongycompact, white. Stem 4 cent. ( $1 \frac{1}{2}$ in.) and more long, 2.5 cent. (I in.) and more thick, stout, firm, but spongy-soft within, somewhat ventricose, obsoletely fibrilloso-reticulate, intensely bloodred. Gills adnate, somewh at decurrent, rather thick, not crowded, broad (more than $12 \mathrm{~mm}$., $1 / 2 \mathrm{in}$.), fragile, sparingly connected by veins, white, becoming yellow when dry, with a few dimidiate ones intermixed, somewhat anastomosing behind.

Taste mild. The habit is exactly that of $R$. emetica; the substance also is floccose, but very compact, firm, and thick. The stem according to v. Post is hollow.

In woods. Stoke Poges. 
Spores wholly white. Fr.; ellipsoid-sphæroid, echinulate, Ir mk. Q. Russula. Name-after Linnæus. Fr. Mlonogr. ii. p. I92. Hym. Eur. p. 444. Icon. t. 172. f. 3. B. \& Br.n. I786.

18. P. xerampelina Fr.-Pileus 7.5 cent. ( 3 in.) and more broad, rosy-purple, \&c., disc becoming pale, fleshy, compact, convex then flattened, at length depressed, without a distinct pellicle, wherefore always dry, opaque, even, but when older commonly very thinly rimulose, so that the cuticle under a lens is very thinly granulated or punctate, margin spreading, without striæ; flesh compact, white inclining to yellowish. Stem 5-7.5 cent. (2-3 in.) long, 2.5 cent. ( $\mathrm{I}$ in.) thick, stout, firm, internally at length soft, spongy, even hollow, commonly thickened at the base, even, white or reddish. Gills adnexed, somewhat crowded, broader in front, forked behind, whitish, then yellowish.

Taste mild. The colour of the pileus is changeable, commonly rosypurple, with the disc becoming pale, yellowish-white, sometimes inclining to olivaceous. The stem is redder when moist. It approaches $R$. integra, but differs in the pileus not having a distinct pellicle, \&c.

\section{In Scotch fir wood. Glamis, I876. Oct.}

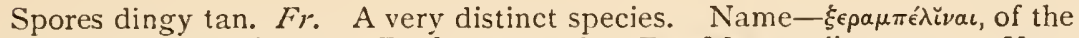
colour of dry vine-leaves. Dark rosy red. Fr. Monogr. ii. p. Ig2. Hym. Eur. p. 445. B. \& Br. n. 1675. S. Mycol. Scot.n. 595. Ag. Schaff. t. 214, 2 I5.

19. R. olivacea Fr.-Pileus dingy purple then olivaceous or wholly fuscous-olivaceous, fleshy, convexo-flattened and depressed, slightly silky and squamulose, margin spreading, even; flesh white, becoming someruhat yellow. Stem firm, ventricose, rose-colour to pallid, spongy-stuffed within. Gills adnexed, wide, yellow, with shorter and forked ones intermixed.

Mild. Near to R. rubra, but certainly distinct in the stem being definitely spongy, in the pileus being unpolished, and in the gills being soft and brightly coloured; corresponding with $R$. alutacea.

In woods. Slough.

Spores light yellow. Fr.; sphæroid, punctate, ro mk. $Q$. Name-oliva, an olive. Olivaceous in colour. Fr. Hym. Eur. p. 445. B. \& Br. n. ${ }_{5} 62$. Ag. Schaff. t. 204. Krombh. t. 68. f. 13.

20. R. cutefracta Cke.-Pileus $7 \cdot 5-10$ cent. (3-4 in.) or more broad, green, purple, dull red, \&c., fleshy, firm, dry, opaque, convex then a little clepressed in the centre, cuticle cracking from the margin inwards into minute firm adnate areolæ, otherwise even; flesh beneath the cuticle tinged with purple. Stem 7.5 cent. ( 3 in.) long, often 2.5 cent. ( $\mathrm{i}$ in.) thick, firm, solid, nearly equal, or a little attenuated above, smooth, slightly tinged 
Russula. with purple. Gills somewhat crowded, narrowed behind, furcate, adnexed or nearly free, white.

Mild. Allied to $R$. virescens which it resembles in the cracking of the cuticle, but differs in the purple tint beneath even in green specimens, and in the tinted stem, as well as in the colour of the pileus, which is of a darker and different shade of green, and sometimes of a deep bluish-purple, as well as of a madder-red.

On the ground in woods. Epping, \&c.

Name-cutis, skin; frango, to break. From the cracked cuticle. Cke. in Grevillea, vol. x. p. 46 .

\section{IV.-HETEROPHYLLE.}

21. R. vesca Fr.-Pileus red-flesh-colour, disc darker, fleshy, slightly firm, plano-depressed, slightly wrinkled with veins, with a viscid pellicle, margin at length spreading; flesh cheesy, firm, shining white. Stem solid, compact, externally rigid, reticulated and wrinkled in a peculiar manner, often attenuated at the base, shining white. Gills adnate, crowded, thin, shining white, with many unequal and forked ones intermixed, but scarcely connected by veins.

Of middle stature. Taste mild, pleasant.

In mixed woods. Frequent. Sept.-Oct.

Reckoned edible. Name-vesco, to feed. From its edible qualities. Fr. Monogr. ii. p..193. Hym. Eur. p. 446. Sv. ätl. Sv. t. 63. Berk. Out. p. 211. C. Hbk. n. 625. S. Mycol. Scot. n. 596. (Hussey i. t. 89.)

22. R. cyanoxantha Fr.-Pileus $5-7.5$ cent. $(2-3$ in.) and more broad, lilac or purplish then olivaceous-green, disc commonly becoming pale often yellowish, margin commonly becoming azureblue or livid-purple, compact, convex then plane, then depressed or infundibuliform, sometimes even, sometimes wrinkled or streaked, viscous, margin deflexed then expanded, remotely and slightly striate; flesh firm, cheesy, white, commonly reddish beneath the separable pellicle. Stem $5-7.5$ cent. ( $2-3$ in.) long, as much as 2.5 cent. (I in.) thick, spongy-stuffed, but firm, often cavernous within when old, equal, smooth, even, shining white. Gills rounded behind, connected by veins, not much crowded, broad, forked with shorter ones intermixed, shining white.

Allied to $R$. vesca in its mild, pleasant taste and in other respects, but constantly different in the colour of the pileus, which is very variable, whereas in $R$. vesca it is unchangeable. The peculiar combination of colours in the pileus, though very variable, always readily distinguishes it.

In mixed woods, \&c. Common. Aug.-Oct.

Sometimes considerably larger than Fries describes. Name-кviavos, blue ; 


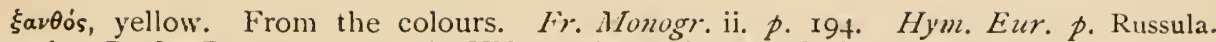
446. B. \& Br. n. гізг. C. Hbk. n. 626. S. Mycol. Scot. n. 597. Ag. Schaff. t. 93. Krombh. t.67.f. 16-19. Paul. t. 76.f. I-3.

23. R. heterophylla Fr.-Pileus very variable in colour, but never becoming reddish or purple, fleshy, firm, convexo-plane then depressed, even, polished, the very thin pellicle disappearing, margin thin, even or densely but slightly striate; flesh white. Stem solid, firm, somewhat equal, even, shining white. Gills reaching the stem in an attenuated form, very narrow, very crowded, forked and dimidiate, shining white.

Taste always mild, as in $R$. cyanoxantha, from which it differs in its smaller stature, in the pileus being thinner, even, never reddish or purplish, with a thin closely adnate pellicle, in the stem being firm and solid, and in the gills being thin, very narrow, very crowded, \&c. The apex of the stem is occasionally dilated in the form of a cup, so that the gills appear remote.

In woods. Common. July-Oct.

Edible, of a sweet nutty flavour. Spores echinulate, $5 \times 7 \mathrm{mk}$. W.G.S.

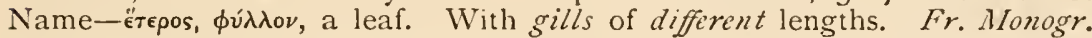
ii. p. I94. Hym. Eur. p. 446. Berk. Out. p. 2 I r. t. I3.f. 5. C. Hbk. n. 627. S. Mycol. Scot. n. 598. Hogg \&o Fohnst. t. 9. Hussey i. t. 84. Badh. i. t. ı. f. 3 ; ii. t. 3.f. 3, 4. Ag. Fl. Dan. t. I909. f. x. Paul. t. 75. f. x-5.

* R. galochroa Fr. Smaller.-Pileus at the first milk-white, then greenish, rather plane, viscid in wet weather, commonly dry, even, sometimes sprinkled with white floccose spots, slightly striate at the margin. Stem 2.5-5 cent. (I-2 in.) long, $12 \mathrm{~mm}$. ( $1 / 2$ in.) thick, solid, firm, never becoming red. Gills very thin, more or less forked and unequal.

The flocci at the disc in the form of spots or warts are not like those of

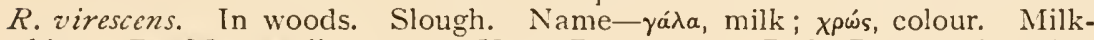
white. Fr. Monogr. ii. p. 195. Hym. Eur. p. 447. B. \& Br. n. 1563. Ag. Bull.t. 509.f. L.M. Batt. t. xii. f. E.

24. R. consobrina Fr.-Pileus 7.5 cent. ( 3 in.) broad, dark cinereous or fuscous olivaceous, fleshy, fragile, campanulate then expanded, at length depressed, margin spreading, even, though membranaceous; flesh white, cinereous under the thich, viscous, separable pellicle. Stem 5-7.5 cent. (2-3 in.) long, almost 2.5 cent. (I in.) thick, solid, but soft, equal, even, smooth, shining white, at length becoming cinereous. Gills at the first free, then appearing adnate when the pileus is flattened, broad, crowded, shining white, very many of them dimidiate and forked.

Taste very acrid. Not fœtid. Stature in general that of R. emetica, but differing in the colour of the pileus, and in the very unequal gills.

In mixed woods. Glamis, I876. Oct. 
Russula. Spores granular, ro mk. $Q$. Name-consobrinus, cousin. Distantly related to neighbouring species. Fr. Monogr. ii. p. I95. Hym. Eur. p. 447. B. E Br. n. I676. S. Mycol. Scot.n. 599.

* R. sororia Larbr.-Pileus convex then plane or depressed, striate at the margin. Gills somewhat distant, connected by veins.

The habit and colour are the same, but it differs by many marks. Stem white. Many of the gills dimidiate, but scarcely forked. Name-soror, a sister. From its relation to $R$. consobrina. In fir woods. North Wooton. Aug. Larbr.t. 19.f. 7. Fr. Hym. Eur. p. 447. Icon. t. I73.f. I. Grevillea, vol. x. p. 67 .

25. R. fœtens Fr.-Pileus IO-I2.5 cent (4-5 in.) and more broad, dingy yellow, often becoming pale, thinly fleshy, at first bullate, then expanded and depressed, covered with a pellicle which is adnate, not separable, and viscid in wet weather, margin broadly membranaceous, at the first bent inwards with ribs which are at length tubercular; flesh thin, rigid-fragile, pallid. Stem 5 cent. ( 2 in.) and more long, $I-2.5$ cent. ( $1 / 2-I$ in.) thick, stout, stuffed then hollow, whitish. Gills adnexed, crowded, connected by veins, with very many dimidiate and forked ones intermixed, whitish, at the first exuding watery drops.

Fotid. Taste acrid. Very rigid, most distinct from all others in its very heavy empyreumatic odour. In very dry weather the odour is of ten obsolete. The margin is more broadly membranaceous and hence marked with longer furrows than in any other species. It differs from all the preceding ones in the gills at the first exuding watery drops. The gills become obsoletely light yellow, and dingy when bruised.

In woods, \&c. Very common. July-Sept.

Sten ruggedly hollow within as if eaten by snails. M.F.B. A very coarse and easily recognised species. Reckoned poisonous, though eaten by slugs. Spores minutely echinulate, almost globular, $8 \mathrm{mk}$. W.G.S. Name-fotens, stinking. Fr. Monogr. ii. p. 195. Hym. Eur. p. 447 . Sv. ätl. Sv. t. 40. Berk. Out. p. 213. C. Hbk. n. 628. S. Mycol. Scot. n. 600. Ag. Pers.-Krombh. t. 70. f. I-6. Viv. t. 41. Bull. t. 292. Ventur. t. 33. f. I-3.

26. R. subfœtens Smith.-Pileus bullate, somewhat viscid, disc fleshy, margin somewhat membranaceous. Stem not stout. Gills thick, distant, branched.

Odour somewhat disagreeable, taste slightly acrid. Smaller than $R$. foctens, stem not so stout, margin different. This is the plant referred to by Fries Syst. Myc. i. p. 58. as a var. of $R$. fragilis.

On the ground. Various localities.

Name-sub, and foctens, somewhat stinking. Worth. Smith Fourn. Bot. $1873, p .337$.

27. $\mathrm{R}$. fellea Fr.-Pileus $2.5-5$ cent. ( $1-2$ in.) broad, straw- 
colour often with a deeper yellowish tinge, lisc darker, thinly fleshy, Russula. convex then plane, polished, smooth, margin even, slightly striate when old; pellicle closely adnate, thin; flesh firm, of the same colour as the gills. Stem 5 cent. (2 in.) long, $12 \mathrm{~mm}$. ( $1 / 2$ in.) thick, spongy-stuffed then hollow, fragile, equal, even, white then straw-colour. Gills adnate, crowded, thin, narrow, obsoletely connected by veins, intermixed with a few which are dimidiate or bifid behind, straw-colour.

Distinguished, very acrid, odour none. The gills exude watery drops in damp weather.

In beech woods. Common. Aug.-Nov.

Easily distinguished from all others by its unchangeable persistent yellowish straw-colour. The gills vary more distant. Name-felleus, full of gall. Bitter. Fr. Monogr. ii. p. ig6. Hym. Eur. p. 447. Icon. t. I73. f. 2. B. \& Br.n. 1787. S. Mycol. Scot. Supp. Scot. Nat. I881, p. 36. Paul.t. 76. $f .4$.

28. R. Queletii Fr.-Pileus violaceous-black or fuscous, purplelilac at the margin which is slightly striate, compact, campanulato-convex then plane, even, viscous; flesh firm, white, redpurple under the pellicle. Stem spongy, mealy, violaceous- purple. Gills attenuated, unequal or forked, exuding drops, white.

Acrid. When the drops on the gills are dried, they leave azure-bluecinereous or pallid olivaceous spots.

In woods. Common. Aug.-Nov.

Pileus commonly about 7.5 cent. ( 3 in.) broad; stem about same in length and 2.5 cent. ( 1 in.) thick. Easily distinguished from $R$. integra by the white gills. Name-after L. Quélet. Fr. in Quél. Fur. p. 185. t. 24. f. 6. Hym. Eur. p. 448 . B. \& Br.n. 1888. S. Mycol. Scot.n. 6or.

\section{V.-Fragiles.}

* Gills and spores white.

29. $\boldsymbol{R}$. emetica Fr.-Pileus $7 \cdot 5^{-10}$ cent. (3-4 in.) broad, at first rosy then blood-colour, tawny when old, sometimes becoming yellow and at length (in moist places) white, at first campanulate then flattened or depressed, polished, margin at length sulcate and tubercular; flesh white, reddish under the separable pellicle. Stem spongy-stuffed, stout, elastic when young, fragile when older, even, white or reddish. Gills somewhat free, broad, somewhat distant, shining white.

Handsome, regular, moderately firm, but fragile when full grown, taste very acrid. The gills are never dusty. There is one form taller, with the pileus campanulate then expanded, and the gills persistently free, another with the pileus convex then expanded, and gills appearing adfixed. 
Russula. In woods and open ground. Common. July-Dec.

Spores shining white, Fr.; sphæroid, echinulate, 8-10 mk. K.; $7 \mathrm{mk}$. $W . G . S$. Stem longitudinally rugulose. M.F.B. Easily distinguished by the flesh remaining red under the cuticle when peeled off. Poisonous. Said to act as its name implies as an emetic; certainily dangerous. Name-emetica, a vomit. Fr. Monogr. ii. p. 197. Hym. Eur. p. 448. Sv. ätl. Sv. t. 21. Berk. Out. p. 212. C. Hbk. n. 629. S. Mycol. Scot. n. 602. Ag. Harz. t.63. Barl.t. I4.f. 4. Lenzf. $5_{5}$.

30. R. pectinata Fr.-Pileus 7.5 cent. ( 3 in.) broad, at first viscous, toast-brown, then dry, becoming pale, tan, with the disc always darker, fleshy, rigid, convex then flattened and depressed or concavo-infundibuliform; margin thin, pectinato-sulcate, here and there irregularly shaped; flesh white, light yellowish under the pellicle, which is not easily separable. Stem curt, 5 cent. ( 2 in.) long, I $8 \mathrm{~mm} .-2.5$ cent. ( $3 / 4-\mathrm{I}$ in.) thick, rigid, spongystuffed, longitudinally slightly striate, shining white, often attenuated at the base. Gills attenuato-free behind, broader towards the margin, somewhat crowded, equal, simple, white.

Odour weak, but nauseous, approaching that of $R$. foetens. The gills are narrower than those of neighbouring species, but dilated from the stem to the margin, not exuding drops, and not changeable when touched.

In mixed woods. Glamis, 1874. Aug.

Name-pecten, a comb. From the furrows at the margin being like the teeth of a comb. Fr. Monogr. ii. p. 197. Hym. Eur. p. 449. B. E Br. $n$. 1564. S. Mycol. Scot. n. 603. Ag. Bull. t. 509. f. N.

31. R. ochroleuca Fr.-Pileus yellow, becoming pale, fleshy, flattened or depressed, polished, with an adnate pellicle, the spreading margin becoming even. Stem spongy, stuffed, firm, slightly reticulato-urinkled, white becoming cinereous. Gills rounded behind, united, broad, somewhat equal, white becoming pale.

Odour obsolete, but pleasant. The pileus is never reddish. It agrees wholly with $R$. emetica in structure and stature, as well as in the acrid taste; it differs however in the stem being slightly reticulato-wrinkled, white becoming cinereous, in the adnate pellicle of the pileus, in the margin remaining for a long time even (remotely striate, but not tubercular, only when old), and in the gills being rounded behind and becoming pale. The colour of the pileus is constant. The gills remain free and do not exude drops.

In woods, chiefly fir. Frequent. Aug.-Nov.

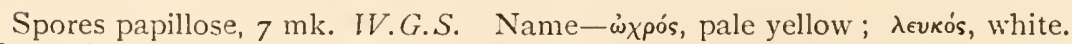
From the yellow pileus and white stem and gills. Fr. Hym. Eur. p. 449. Monogr. ii. p. 197. Berk. Out. p. 212. C. Hbk. n. 630. S. Mycol. Scot. n. 604. Ag. Pers. -Krombh. t. 64.f. 7-9. Buxb. C. v. t. 45. f. 2.

32. R. fragilis Fr.-Pileus $2.5-4$ cent. ( $\mathrm{I}-\mathrm{I} / 2 \mathrm{2}$ in.) broad, rarely 
more, flesh-colour, changing colour, very thin, fleshy only at the Russula. disc, at the first convex and often umbonate, then plane and depressed, pellicle thin, becoming pale, slightly viscid in wet weather; margin very thin, tuberculoso-striate. Stem 4-5 cent. ( $1 / 2-2$ in.) long, spongy within, soon hollow, often slightly striate, white. Gills slightly adnexed, very thin, crowded, broad, ventricose, all equal, shining white.

Very acrid. Smaller and more fragile than the rest of the group, directly changing colour. The colour is variable, often opaque, typically flesh-colour, when changed in colour white externally and internally, often with reddish spots. Among varieties of colour is to be noted a livid-flesh-coloured form, with the disc becoming fuscous.

It is not easy to define it from fragile forms of $R$. emetica, but the gills are much more crowded, thinner, and often slightly eroded at the edge, ventricose ; the pileus thinner and more lax, \&c.

In woods. Common. Aug.-Oct.

Name-fragilis, fragile or brittle. Fr. Monogr. ii. p. 198. Hym. Eur. p. 450. Berk. Out. p. 213 . C. Hbk.n.63r. S. Mycol. Scot.n. 605. Ag. Pers. -Krombh. t. 64. f. 12-18. Bull. t. 509. $f . T, U$. Barla t. 14. f. I0-12. Corda ap. Sturm xi. t. 53. Vent. t. 33. f. 4,5 .

\section{** Gills and spores white then light yellowish, Eoc.}

33. R. veternosa Fr.-Pileus 5 cent. ( 2 in.) broad, rose or flesh-colour, soon becoming pale, commonly whitish or yellowish at the disc, slightly fleshy, plane when full grown, depressed in the middle, covered with a thin, adnate, somewhat viscid pellicle, margin even, scarcely membranaceous; flesh soft, white. Stem 5-7.5 cent. (2-3 in.) long, $12 \mathrm{~mm}$. ( $1 / 2$ in.) thick, soft, spongy then hollow, fragile, equal, even, white. Gills adnate, crowded, narrow, becoming broader in front, with shorter ones intermixed, white then straw-colour.

Taste acrid.

On the ground. Chatteris.

Name-veternosus, drowsy, languid. Fr. Monogr. ii. p. zor. Hym. Eur. p. 450. B. \& Br. n. 1132. C. Hbk. n. 635. Ag. Krombh. t. 66. f. 18, 19. Paul. t. 74.f. 3 .

34. R. integra Fr.-Pileus typically red, changing colour, fleshy, campanulato-convex then expanded and depressed, fragile when full grown, with a viscous pellicle, at length sulcate and somewhat tubercular at the margin; flesh white, sometimes yellowish above. Stem at first short, conical, then clavate or ventricose, as much as 7.5 cent. (3 in.) long, spongy-stuffed, commonly stout, even, shining white. Gills somewhat free, very broad, equal or bifid at the stem, somewhat distant, connected 
Russula. by veins, pallid-white, at length light yellow, somewhat ochraceouspulverulent with the spores.

Taste mild, often astringent. The most changeable of all species, especially in the colour of the pileus which is typically red, but at the same time inclining to azure-blue, bay-brown, olivaceous, \&c. Sometimes the gills are sterile and remain white.

In woods, chiefly pine. Common. Aug.-Nov.

Pileus 7.5-Io cent. $(3-4$ in. ) broad. The white stem and yellow-pulverulent gills distinguish it. Spores ellipsoid-sphæroid or sphæroid, echinulate, ro $\times 8$ or $7 \times 9 \mathrm{mk} . K . ;$ globose, rough, 8-9 mk. C.B.P. Name-integer, whole, entire. Perfect in form. Fr. Monogr. ii. p. I99. Hym. Eur. p. 450. Berk. Out. p. 213. C. Hbk. n. 632. S. Mycol. Scot. n. 606. Ag. Schaff. t. 92. Vittad. t. 21. Vent. t. 63. f. 5, 6. Harz. t. 59. Krombh. t. 66. f. 14, 15, and 16, I7? Batt. t. 16. C.

35. R. decolorans Fr.-Pileus 7.5 cent. (3 in.) broad, unicolorous, at first orange-red, then light yellow and becoming pale, fleshy, spherical then expanded and depressed, remarkably regular, viscid when moist, thin and at length striate at the margin; flesh white, but becoming somewhat cinereous when broken, and more or less variegated with black spots when old. Stem elongated (I o cent., 4 in.) cylindrical, solid, but spongy within, often rugoso-striate, white then becoming cinereous especially within. Gills adnexed, often in pairs, thin, crowded, fragile, white then yellowish.

Taste mild. Colours changeable according to a fixed rule, but not variable. The gills are not ochraceous-pulverulent as in $R$. integra, nor shining and pure yellow as in $R$. aurata, \&c.

\section{In woods. Uncommon. Aug.-Sept.}

Spores pallid ochraceous Fr. Name-de, and coloro, to colour. Changing colour. Fr. Monogr. ii. p. 199. Hym. Eur. p. 451. Berk. Out. p. 214. C. Hbk. n. 633. S. Mycol. Scot. n. 607.

36. R. aurata Fr.-Pileus $5-7.5$ cent. (2-3 in.) broad, varying lemon-yellow, orange and red, disc darker, fleshy, rigid, brittle however, hemispherical then plane, disc not depressed, pellicle thin, adnate, viscid in wet weather, margin even, and slightly striate only when old, but sometimes wrinkled; flesh lemon-yellow under the pellicle, white below. Stem 5-7.5 cent. (2-3 in.) long, solid, firm, but spongy within, cylindrical, obsoletely striate, white or lemon-yellow. Gills rounded free, connected by veins, broad, equal, shining, never pulverulent, whitish inclining to light yellow, but vivid lemon-yellow at the edge.

Taste at first mild, then slightly acrid, odour pleasant. It is among the most beautiful and most easily recognised species by the colours alike of the pileus and of the flesh and gills. 
In woods. Uncommon. Aug.-Sept.

Russula.

The bright yellow edge of the gills is a very distinctive mark. Nameaurum, gold. From its colour. Fr. Monogr. ii. p. 200 . Hym. Eur. p. 452. Berk. Out. p. 213. C. Hbk.n. 634. S. Mycol. Scot.n.608. Ag. With. Krapf. t. 5. Schaff. t. 15.f. I-3. Krombh. t. 66. f. 8-1 1.

37. R. nitida Fr.-Pileus about 5 cent. ( 2 in.) broad, commonly bay-brown-purplish, disc darker, shining, fleshy, stiff, convex then plane or slightly depressed, covered with a pellicle which is viscid in wet weather, margin striate, somewhat tubercular; flesh white. Stem 5-7.5 cent. ( $2-3$ in.) long, $12 \mathrm{~mm}$. ( $1 / 2$ in.) thick, spongy-stuffed, soft, somewhat equal or attenuated downwards, even, white inclining to pale. Gills adnexed, separating, crowded, pallid then bright sulphur-yellow, not pulverulent.

Taste mild, at length nauseous; said to be somewhat fotid. Distinguished at first sight from all others by the gills being bright lemon-yellow, shining, and never ochraceous-pulverulent.

In woods. Uncommon. Aug.-Sept.

Name-nitidus, shining. Fr. Monogr. ii. p. 201. Hym. Eur. p. 452. Berk. Out. p. 214. t. I3. f. 7. C. Hbk. n. 636. S. Mycol. Scot. n. 609. Ag. Pers.-Krombh. t. 66. f. I-3. -Schaff. t. 254.

\section{*** Gills and spores ochraceous.}

38. R. alutacea Fr.-Pileus 5-Io cent. (2-4 in.) broad, commonly bright blood-colour or red, even black-purple, but becoming pale, especially at the disc, fleshy, campanulate then convex, flattened and somewhat umbilicate, even, with a remarkably viscous pellicle, margin thin, at length striate, tubercular; flesh snow-white. Stem 5 cent. (2 in.) long, solid, stout, equal, even, white, most frequently variegated-reddish, even purple. Gills at first free, thick, very broad, connected by veins, all equal, somewhat distant, at first pallid light yellow, then bright ochraceous, not pulverulent.

Handsome. Taste mild, pleasant; at length soft and very fragile. Changeable in colour; in shady beech woods a form occurs with the pileus aruginous. In one form the stem is wholly dark blood-colour, and the gills are rounded behind and remote from the stem. It is distinguished from $R$. integra by its gills not being pulverulent.

In mixed woods. Common.

Edible and very good. Name-aluta, tanned leather. From the yellowish gills. Fr. Monogr. ii. p. 202. Hym. Eur. p. 453. Berk. Out. p. 214. t. ${ }_{3}$. f. 8. C. Hbk. n. 637. S. Mycol. Scot. n. 6ro. Price f. 36. Ag. Vittad. t. 34. Krombh. t. 64.f. 1-3. Barla t. 14.f. I-3.

39. R. lutea Fr.-Pileus $2.5-5$ cent. ( $1-2$ in.) broad, yellow, VOL. II. 
Russula. at length becoming pale, and occasionally wholly white, thinly fleshy, soon convexo-plane or plano-depressed, viscous when moist, even or when old obsoletely striate at the margin; flesh white. Stem 4 cent. (I $1 / 2$ in.) long, $6-8 \mathrm{~mm}$. (3-4 lin.) thick, stuffed then hollow, soft, fragile, equal, even, white, never reddish. Gills somewhat free, connected by veins, crowded, narrow, all equal, ochraceous-egg-yellow.

Always small, very regular; taste mild. When young the pileus is always of a beautiful yellow.

In woods. Uncommon. July-Oct.

Spores yellow, echinulate, $8 \mathrm{mk}$.W.G.S. ; globose, rough, 6-7 mk. C.B.P. Name-luteus, yellow. Fr. Monogr. ii. p. 203. Hym. Eur. p. 454. Berk. Out. p. 214. C. Hbk. n. 638. S. Mycol. Scot.n.6ri. Ag. Huds.

40. R. nauseosa Fr. - Pileus variable in colour, typically purplish at the disc, then livid, but becoming pale and often whitish, laxly fleshy, thin, at first plano-gibbous, then depressed, viscid in wet weather, sulcate and somewhat tubercular at the somewhat membranaceous margin; flesh soft, white. Stem short, about 2.5 cent. ( $\mathrm{I}$ in.) long, $8 \mathrm{~mm}$. (4 lin.) thick, spongystuffed, slightly striate, white. Gills adnexed, ventricose, somewhat distant, here and there with a few shorter ones intermixed, light yellow then dingy ochraceous.

The taste is mild, but also nauseous, as the odour often is. The habit is that of $K$. nitida, of the same colour of pileus, but differing in the colour of the gills.

In woods, chiefly pine. Coed Coch, \&c. Oct.

Name-nauseosus, nauseous. Fr. Monogr. ii. p. 204. Hym. Eur. p. 454. B. \& Br. n. 1283. Ag. Sihreff. t. I6. f. 4 .

41. R. vitellina Fr.-Pileus 2.5 cent. ( $\mathrm{I}$ in.) broad, unicolorous, light yellow then wholly pallid, somewhat membranaceous, at length tuberculoso-striate, somewhat dry, disc very small, slightly fleshy. Stem thin, scarcely exceeding 2.5 cent. ( 1 in.) long, $4 \mathrm{~mm}$. (2 lin.) thick, equal. Gills separating-free, equal, distant, rather thick, connected by veins, saffron-yellow.

Pretty, very fragile, strong-smelling, mild.

In fir and mixed woods. Uncommon. Aug.-Sept.

Name-vitellus, yolk of egg. Egg-yellow. Fr. Hym. Eur. p. 454. Berk. Out. p. 2r5. C. Hbk. n. 639. S. Mycol. Scot. n. 6r2. Ag. Pers.-Batsch f. 72 .

42. R. chamæleontina Fr.-Pileus $2.5-5$ cent. ( $1-2$ in.) broad, thinly fleshy, soon flattened, sometimes oblique with a thin, 
separable, viscid pellicle, which is at first flesh-colour, then Russula. presently changing colour, becoming yellow at the disc and at length wholly yellow, margin even, then slightly striate. Stem as much as 7.5 cent. ( 3 in.) long, but thin, somewhat hollow, slightly striate, white. Gills more or less adnexed, thin, crowded, equal, narrow, somewhat forked, light-yellow-ochraceous.

Mild, inodorous, very fragile. Pileus rosy-blood-red, purplish lilac, \&c. Sometimes even at the first yellowish at the disc.

In woods. Rare. Sept.

Name-from its changing colours like the chamaleon. Fr. Monogr. ii. $p$. 204. Hy'm. Eur. p. 455. B. \& Br.n. Ior4. C. Hbk.n.640. S. Mycol. Scot. n. 6rз.

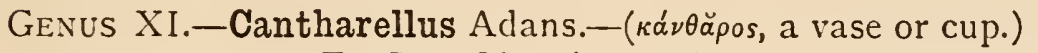
Fr. Syst. Myc. i. p. 316.

Cantharellus.

Hymenophore continuous with the stem, descending unchanged into the trama. Gills thick, fleshy-waxy, fold-like, somewhat branched, obtuse at the edge. Spores white. Fleshy, membranaceous, putrescent fungi, without a veil. Fr. Hym. Eur. p. 455 .

The distinguishing character of the genus consists in the fold-like gills. The Mesopodes commonly grow on the ground; the rest commonly on mosses, very rarely on wood. Intermediate between $A g a-$ ricus and Craterellus. Some are edible, others reckoned poisonous.

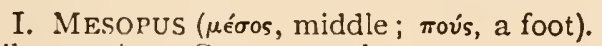
Pileus entire. Stem central.

* Pileus and solid stem fleshy.

** Pileus somewhat membranaceous, stem tubular and polished.

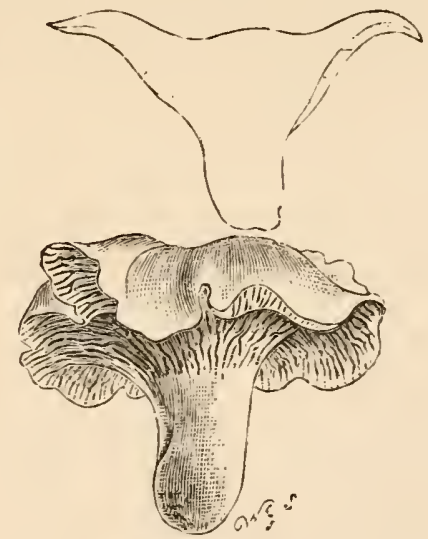

LI. Cantharellus cibarius. One. third natural size.

II. Merisma ( $\mu \in \rho i \zeta \omega$, to divide). Stems very numerous, united into an elongated column or branched.

III. Pleuropus ( $\pi \lambda \epsilon u p o v$, the side; $\pi$ oús, a foot). Dimidiate, stem exactly lateral.

IV. Resupinatus (resupinatus, lying on the back). Pileus entire, at first cup-shaped, adfixed by the vertex, then somewhat reflexed.

* Bryophili (moss-loving).

** Lignatiles (growing on wood), doubtful species. 
Canthar. ellus.

I.-Mesopus.

* Pileus and solid stem fleshy.

1. C. cibarius Fr. Egg-yellow.-Pileus truly fleshy, firm, at first convex, then plane or somewhat depressed, repand, always smooth. Stem solid, thickened upwards. Gills decurrent, thick, distant, branched, narrow, fold-like.

Taste pleasant. Growing in troops. The stem passes into the pileus which is hence turbinate. The gills are more swollen than those of the other species. It varies wholly white.

In woods, especially beech. Common. July-Dec.

Berkeley records a var. white, here and there tinged with pink. The smell, especially when the plant is old, is that of ripe apricot. Edible, delicious. It must have four hours' slow cooking. Spores sphæroid-ellipsoid, 8-9 $\times 5-6$ mk. K.; $6 \times 8 \mathrm{mk}$. W.G.S.; pruniform, nucleate, I I mk. Q. Name-cibaria, food. Fr. Monogr. ii. p. 206. Hym. Eur. p. 455. Sv. ätl. Sv. t. 7. Berk. Out. p. 215. C. Hbk. n. 641. S. Mycol. Scot.n.614. Harz. t. 18. Grev. t. 258. Badh. i. t. 9. f. 2 ; ii. t. 8. f. I. Pricef. 94. Krombh. t. 45. f. I-II. Vittad. t. 25. f. 1. Barla t. 28. Ag. Fl. Dan. t. 264. Sow. t. 46.

2. C. Friesii Quel.-Pileus somewhat orange, fleshy, thin, convex then depressed, villous. Stem solid, slender, villous, at the base white, attenuated. Gills narrow, fold-like, branched, yellow.

Exactly intermediate between $C$. cibarius and $C$. aurantiacus, but smaller than either.

In woods. Sydenham Hill.

Name-after Elias Fries. Quél. Fur. p. 191. t. 23. f. 2. Fr. Hym. Eur. p. 455. B. \& Br.n. I782. Apparently Krombh. t. $46 . f \cdot 3^{-6}$ and perhaps Paul. t. 51. f. 3-4.

3. C. aurantiacus Fr.-Pileus $5-7.5$ cent. (2-3 in.) broad, orange-ochraceous, fleshy, soft, depressed, often excentric and undulated, somewhat tomentose, involute at the margin. Stem 5 cent. ( 2 in.) long, stuffed at length hollow, somewhat incurved and unequal, ochraceous. Gills decurrent, tense and straight, repeatedly dichotomous and crowded, often crisped at the base, deep orange.

Taste unpleasant. The pileus is not firm, and the stem is not so much diffused into the pileus as in C. cibarius. The stem, especially in marshy places, becomes at length black. Bull. t. 505. It varies with light yellow pileus and white gills, and is sometimes wholly white.

In woods, especially pine. Common. Aug.-Nov.

Reckoned poisonous. Spores ellipsoid or sphæroid-ellipsoid, $5-6 \times 3 \mathrm{mk} . K$. Name-aurantiacus, orange-yellow. Fr. Monogr. ii. p. 206. Hym. Eur. p. 455. Sv. ätl. Sv. t. 79. Berk. Out. p. 215. t. 14. f. 1. C. Hbk. n. 642. S. Mycol. Scot. n. 6r5. Ag. Wulf. Facqu. Coll. ii. t. I4.f. 3. Batschf. 37. Sorw. t. $4 \mathrm{r} 3$. 
4. C. Brownii B. \& Br. Ochraceous-white or cream-coloured. Canthar- Pileus about $12 \mathrm{~mm}$. ( $1 / 2 \mathrm{in}$.) broad, thin, convex, somewhat ellus. umbonate, obscurely silky. Stem $4-5$ cent. ( $1 / 2-2$ in.) long, stuffed, slender, tough, nearly equal, somewhat furfuraceous. Gills (folds) obtusely decurrent, rather distant, linear, extremely narrow, sometimes forked, interstices smooth.

Hymenium nearly white. Stem furnished with a little white fibrillose myce. lium at the base, which sometimes forms a small earthy ball. A very distinct species.

Among grass. Hitchin.

Name-after J. Brown. Berk. Out. p. 215. C. Hbk.n.643. Fr. Hym. Eur. p. 456 .

5. C. carbonarius A. \& S.-Pileus date-brown then black, somewhat fleshy, striato-squamulose, umbilicate. Stem paler. Gills tense and straight, white.

Rooted, fasciculate. The following seem to be the same: B. C. anthracophilus, solitary, black, tough, pileus fleshy-membranaceous, naked, depressed ; stem stuffed, slender, smooth, slightly rooted; gills distant, dichotomous. Leveill. Ann. Sc. Nat. 1841, p. 236. t.14.f. 2.-C. C. radicosus, slender, pileus $x 8 \mathrm{~mm} .-2.5$ cent. ( $3 / 4-\mathrm{I}$ in.), deeply umbilicate, floccose, black; stem rooting, pallid; hymenium white, gills narrow. Two or three pilei often grow from the same obconical root, which is white and spongy.

On charcoal heaps, \&c. Rare. Sept.-Nov.

Spores $9 \times 6 \mathrm{mk}$. W.G.S. Name-carbo, charcoal. From its habitat. A. \& S. Fr. Hym. Eur. p. 456. C. radicosus B. \& Br. n. II34. C. Hbk. n. 647. Saund. \& Sm. t. r.

6. C. umbonatus Fr.-Pileus 2.5 cent. ( $\mathrm{I}$ in.) and more broad, cinereous-blackish, slightly fleshy, convex when young, umbonate, at length depressed, even, dry, flocculoso-silky on the surface, shining brightly especially under a lens; flesh soft, white, often becoming red when wounded. Stem 7.5 cent. ( 3 in.) long, about $8 \mathrm{~mm}$. (4 lin.) thick, stuffed, equal, elastic, villous at the base, cinereous, but paler than the pileus. Gills decurrent, thin, tense and straight, crowded, repeatedly dichotomous, shining white.

Odour and taste scarcely notable. Gregarious. Among the taller mosses the stem is longer. Often overlooked from its habit being that of an Agaric. It varies with the pileus squamulose and blackish.

In woods. Rare. April-Aug.

Name-umbo, the boss of a shield. Umbonate. Fr. Monogr. ii. p. 207. Hym. Eur. p. 457. Berk. Out. p. 216. C. Hbk. n. 644. S. Mycol. Scot.n. 616. Hofm. Ic. t. 22. f. 2. Ag. Wulf. Facqu. Coll. 2. t. 16. f. 1.

7. C. albidus Fr.-Pileus $\mathrm{I}-2.5$ cent. ( $1 / 2-\mathrm{I}$ in.) broad, whitish, 
Canthar. inclining to yellowish or rufescent, fleshy, very thin, somewhat ellus. infundibuliform, irregular, somewhat repand and torn, smooth, somewhat zoned. Stem 2.5-4 cent. (I-I $1 / 2$ in.) long, $4 \mathrm{~mm}$. (2 lin.) thick, solid, tough, equal or at length compressed, smooth, white or rarely yellowish. Gills decurrent, thin, somewhat crowded, repeatedly dichotomous, white.

Tough but not coriaceous. It approaches near to the Clitocyba among Agarics, clearly showing the affinity of these with the Cantharelli (C. cibarius, aurantiacus, umbonatus, and albidus).

In mossy places. Coed Coch. Sept.-Oct.

Name-albus, white. Whitish. Fr. Monogr. ii.p. 207. Hym. Eur. p. 457. B. \& Br.n. 1421. Fl. Dan. t. I293.f. I.

8. C. Houghtoni Phill.-Pileus 2.5 cent. ( $\mathrm{I}$ in.) or more broad, dirty white with a tinge of flesh-colour, thin, convex, umbilicate, smooth. Stem 5 cent. ( 2 in.) long, $2 \mathrm{~mm}$. (I lin.) thick, stuffed, slender, thickened at the apex, at first delicately fibrillose, rooting at the base which is more or less cottony. Gills somewhat decurrent, narrow, scarcely forked, pallid flesh-colour.

Sometimes 5 cent. ( 2 in.) broad. Allied to $C$. albidus.

On the ground. Hereford.

Name-after Rev. William Houghton. Phillips.-B. \& Br.n. 1565 .

\section{* Pileus somewhat membranaceous, stem tubular and polished.}

9. C. tubæformis Fr.--Pileus fuscous when moist, becoming pale when dry, fleshy-membranaceous, infundibuliform, repand and lobed, flocculose. Stem hollow, at length compressed and lacunose, smooth, orange-tawny. Gills thick, distant, branched with many clefts, yellow or fuliginous, naked.

It differs widely from all the preceding species in the somewhat membranaceous, infundibuliform, flocculose pileus, and in the tubular stem. Intermediate between $C$. infundibuliformis, to which it is like in the hymenium, and Craterellus lutescens, which is more like it in the entire habit.

Var. lutescens, pileus convexo-umbilicate, rather even, somewhat regular; stem more equal, attenuated upwards; gills less divided. Bull. t. 473. f. 3 .

In woods. Common. Aug.-Oct.

Spores $8 \times 4$ mk. W.G.S. Name-tuba, a trumpet; forma, form. Trumpet-shaped. Fr. Monogr. ii. p. 208. Hym. Eur. p. 457 . Berk. Out. p. $2 \mathrm{r} 6$. C. Hbk. n. 645. S. Mycol. Scot. n. 6r7. Fl. Dan. t. 2080. f. 1. Merulius Pers. Ic. descr. t. 6. f. I. Dittm. Sturm. t. 30. Batt.t. 23. f. I.

10. C. infundibuliformis Fr.-Pileus $2.5-5$ cent. ( $1-2$ in.) broad, rarely more, yellowish-cinereous or fuliginous when 
moist, becoming pale when dry, somewhat membranaceous, Cantharumbilicate then infundibuliform, here and there pervious to the ellus. base, floccoso-wrinkled on the surface, at length undulated at the margin. Stem 5-7.5 cent. ( $2-3$ in.) long, about $4 \mathrm{~mm}$. (2 lin.) thick, fistulose, somewhat thickened at the base, even, smooth, always light yellow. Gills decurrent, thick, distant, dichotomous, tense and straight, sometimes light yellowish, sometimes cinereous, especially when old and then pruinate.

Gregarious, somewhat cæspitose. Often not easily distinguished from $C$. tubeformis. It does not approach Crat. lutescens. The colours are less intense, moderately persistent when dried.

In woods. Common. July-Oct.

Spores sphæroid-ovoid, 9-II $\times 7-8 \mathrm{mk} . K$. Name-infundibulum, a funnel; forma, form. Funnel-shaped. Fr. Monogr. ii. p. 208. Hyn. Eur. p. 458. Berk. Out. p. 2 16. C. Hbk. n. 646. S. Mycol. Scot. n. 618. Merulius Scop.-Sow. t. 47. Krombh. t. 46. f. 7-9. Fl. Dan. t. 1617.

11. C. cinereus Fr.-Pileus $2.5-5$ cent. ( $\mathrm{I}-2$ in.) and more broad, hoary-fuliginous, somewhat membranaceous, infundibuliform, pervious as far as the base of the stem, villoso-squamulose. Stem 5-7.5 cent. (2-3 in.) long, 4-8 mm. (2-4 lin.) thick, hollow, manifestly attenuated downwards, smooth, fuliginous-blackish. Gills decurrent, thick, very distant, connected by veins but not much branched, cinereous.

As $C$. tubaformis resembles Crat. lutescens this entirely resembles Crat.cornucopioides, but is very easily distinguished from it by the hymenium being in the form of gills.

In woods. Rare. Halifax, \&c.

Spores ${ }_{15} \times 8 \mathrm{mk}$. B. \& $B r$. Name-cinis, ashes. From the cinereous gills. Fr. Monogr. ii. p." 209. Hym. Eur. p. 458. Berk. Out. p. 216. B. Eo Br.n. Iо16*, I1 $39^{*}$. C. Hbk. n. 648. Krombh. $t$. 45.f. I2. Merulius Pers. - Bull. t. $465 . f .2$.

12. C. cupulatus Fr.-Pileus $12 \mathrm{~mm}$. ( $1 / 2$ in.) broad, pallid fuscous when damp, becoming pale, somewhat rufescent, when dry, membranaceous, plano-infundibuliform (exactly cup-shaped), repand, not zoned, when moist smooth, striate at the margin, when dry even, flocculose. Stem scarcely 2.5 cent. ( $\mathrm{I}$ in.) long, I $\mathrm{m}$. ( $1 / 2$ lin.) thick, stuffed, equal, tense and straight, tough, smooth, paler than the pileus. Gills decurrent, very distant, branched with many clefts, with some simple ones intermixed, broad, but obtuse at the edge, grey.

The branches on the gills ramify in a fasciculate manner. It must not be confounded with Xerotus degener.

In waste places. Rare. Oct. 
Canthar- Name-cupa, a cup. Shaped like a little cup. Fr. Monogr. ii. p. 209. ellus. Hym. Eur. p. 458. Merulius Pers. Syn. t. 5. f. 2. Ag. helvelloides Bull. $t$. 6о1.f. 3. Berk. Out. p. 132. C. Hbk. n. 226.

13. C. Stevensoni B. \& Br.-Pileus about $4 \mathrm{~mm}$. (2 lin.) broad, pallid, orbicular, umbilicate, smooth, margin inflexed. Stem $6 \mathrm{~mm}$. ( $1 / 4 \mathrm{in}$.) long, I m. ( $1 / 2$ lin.) thick, cylindrical, delicately pulverulent, white then darker. Gills decurrent, pallid, becoming fuscous in front.

Stem with a little white mycelium at the base. Very near to C. cupulatus; but that is very strongly umbonate when young, and the umbo is always visible at the bottom of the umbilicus; the habit, moreover, is different.

On rotten stump among moss. Glamis, i 874 . March, April.

Name-after Rev. John Stevenson. B. \& Br. n. 1422. S. Mycol. Scot. n. 619.

$$
\text { II.-MERISMA. }
$$

No British species.

\section{III.-PlEUROPUS.}

14. C. muscigenus Fr.-Pileus fuscous when moist, cinereouswhitish when dry, somewhat zoned, membranaceous, tough, spathulate, smooth, rather plane, slightly undulated when full grown. Stem short, $2-4 \mathrm{~mm}$. (I-2 lin.), round, exactly lateral, villous at the base, horizontal as well as the pileus with which it is continuous. Gills slightly swollen, diverging from the apex of the stem, distant, branched, not anastomosing, of the same colour as the pileus.

The whole plant from the base of the stem to the apex of the pileus scarcely reaching 2.5 cent. ( $\mathrm{I}$ in.), commonly smaller.

On mosses. Uncommon. June.

Name-muscus, moss; gigno, to bear. Growing on mosses. Fr. Monogr. ii. p. 2 10. Hym. Eur. p. 460. Berk. Out. p. 217. C. Hbk. n. 649. S. Mycol. Scot. n. 620. Ag. Bull. t. 288, 498.f. 2. Merulius Nees Syst.f. 236.

\section{IV.-Resupinati. \\ * Bryophili (moss-loving).}

15. C. retirugus Fr.-Pileus 6-1o mm. (3-5 lin.) broad, whitishcinereous above, darker, cinereous-fuliginous, beneath, membranaceous, expanded, repando-lobed, very tender, somewhat round, at first entire at the margin then variously split. Gills radiating from the centre, very tender, reticulated. 
Easily distinguished from $C$. lobatus by the thinner, reticulated gills; Cantharwithout the rudiment of a stem, adfixed to mosses by fibrils at the vertex. ellus. It approaches the Cyphella in many respects.

On mosses. Uncommon. May.

Name-rete, a net; ruga, a wrinkle. From the reticulated gills. Fr. Monogr. ii. p. 212. Hym. Eur. p. 460. Berk. Out. p. 217. t. 14. f. 2. Helvella Bull. i. 498. f. I. Sow. t. 348 .

16. C. lobatus Fr.-Pileus scarcely 2.5 cent. (I in.), dark fuscous when in full vigour, becoming pale when dry, sessile, horizontal, membranaceous, somewhat round, at first adfixed, entire, then somewhat lateral and lobed. Gills fold-like, somewhat distant, distinct, branched, of the same colour as the pileus.

On mosses in bogs. Uncommon. Autumn.

When old often very much lobed and crisped, and then the wrinkles, especially at the base, are reticulated, though towards the margin they continue distinct. M.F.B. Spores ovoid-pruniform, ro mk. $Q$. Name-lobatus, lobed. Fr. Monogr. ii. p. 21 r. Hym. Eur. p. 46r. Berk. Out. p. 217. C. Hbk. n. 650. S. Mycol. Scot.n. 622. Fl. Dan. t. Io77. Bolt. t. 177.

\section{** Lignatiles (growing on wood). \\ No British species.}

Genus XII.-Arrhenia Fr. Summ. Veg. Scand. p. 3 I 2.

Membranaceous, very tender, hymenium inferior and striate with few, delicate, slightly raised, simple, straight veins, which take the place of gills. Spores pallid. Minute, moderately persistent, variable in form. Stria not decurrent. Compare Cantharellus Brownii. Fr. Hym. Eur. p. 461.

No British species.

Genus XIII.-Nyctălis ( $\nu u ́ \xi$, night. From inhabiting dark Nyctalis. places.) Fr. Syst. Orb. Veg. p. 203.

Hymenophore continuous with the stem. Gills fleshy, thick, juicy, obtuse at the edge, not decurrent on the stem nor fold-like. Veil (in species which have been fully observed) floccoso-pruinose. Fleshy fungi, not reviving, of uncertain and irregular occurrence, differing in many respects from ons another and from the rest of the Agaricini. Fr. Hym. Eur. p. 462.

I. SPELEÆ (spelaum, a cave). Gills crowded, somewhat coalescent. In 
Nyctalis. hollow places. There is scarcely any doubt that these species are forms of others, changed in appearance and disguised owing to their place of growth. fungi.

II. Parasite (parasita, a parasite). Gills distinct, distant. On putrid

\section{I.-SPELEÆ.}

1. N. caliginosa Smith.-Pileus white when dry, marked with colours (as in Ag. butyraceus) when

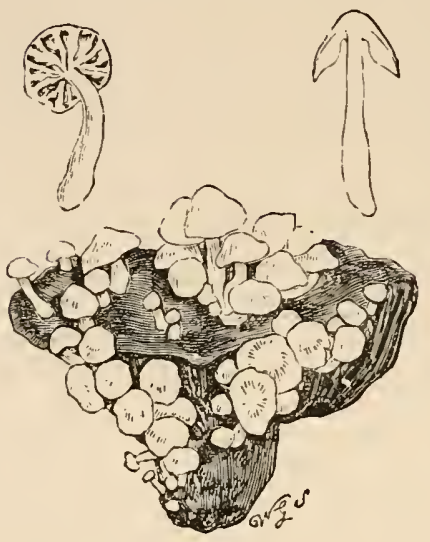

LII. Nyctalis parasitica. One. half natural size. wet, very fleshy, floccoso-pruinose when dry, margin involute, slightly exceeding the gills. Stem solid, floccoso-pruinose, base naked. Gills decurrent, thick, branched.

Odour and taste rank and disagreeable like Polyporus squamosus. Closely allied to $N$. parasitica, but at once distinguished by its truly decurrent gills and other characters.

Amongst earth and dead leaves in dense dark wood. Bishop's Wood, Highgate.

Name-caligo, darkness. From its ha. bitat. Worth. Smith Fourn. Bot. 1873 . $p \cdot 337$.

\section{II.-PARASIT}

2. N. asterophora Fr.-Pileus white when young, then fawncolour, fleshy, conical then hemispherical, often papillate when young, then splitting open, floccoso-pulverulent. Stem scarcely exceeding $12 \mathrm{~mm}$. ( $1 / 2 \mathrm{in}$.) long, $\mathrm{I}-2 \mathrm{~mm}$. ( $1 / 2-1$ lin.) thick, stuffed, equal, but often twisted, at first whitish and pruinose, then becoming fuscous. Gills adnate, distant, thick, tense and straight, somewhat forked, dingy.

Very abnormal. Gregarious. The dust covering the pileus represents stellate spores under the microscope. B. even underneath and without gills.

On dead Russula nigricans, \&c. Frequent. Sept.-Nov.

Spores $2 \times 3$ mk. W.G.S. Name-aster, a star; fero, to bear. From the stellate bodies in the dust on the pileus. Fr. Monogr. ii. p. 214. Hym. Eur. p. 463. Berk. Out.p. 217. C. Hbk. n. 652. S. Mycol. Scot. n. 623. Ag. Bull. t. 516. f. I. Asterophora Lycop. Dittm. Sturm t. 26.

3. N. parasitica Fr.-Pileus $I-2.5$ cent. ( $1 / 2-I$ in.) broad, whitish-fuscous, then becoming pale, whitish, slightly fleshy, when young conico-campanulate then convex, soon plane and obtuse 
or obsoletely umbonate, unequal, with a persistent, pruinose, grey Nyctalis. pellicle; flesh dingy. Stem 2.5-5 cent. (I-2 in.) long, $3 \mathrm{~mm}$. ( $1 / 2$ lin.) thick, delicately fistulose, equal or slightly attenuated upwards, straight or curved from oblique position, pubescent, white. Veil manifest, fibrillose. Gills adnate, thick, distant, with alternate shorter ones intermixed, becoming fuscous, at length contorted and anastomosing.

Gregarious, even cæspitose. The pileus is often irregular-(angular, repand and rimose).

On dead Russula, adusta and fotens. Common. Aug.-Nov.

Odour like Polyporus squamosus. MI.F.B. Name-from its parasitic growth. Fr. Monogr. ii. p. 214. Hym. Eur. p. 464. Berk. Out. p. 218. t. 19. f. 2. C. Hbk. n. 653. S. Mycol. Scot. n. 624. Ag. Bull. t. 574.f. 2. Sow. $t$. 343 .

Genus XIV.-Marasmius ( $\mu a \rho a i \nu \omega$, to wither or shrivel). Marasmius. Fr. Gen. Hymen. Epicr. p. 372.

Tough, arid fungi; shrivelling (and not putrescent), reviving when wet. Hymenophore continuous with the stem, but heterogeneous, descending into the trama; veil none with one exception. Stem cartilaginous or horny. Gills pliant, somewhat distant, edge acute and quite entire.

This begins a new series of pliant and arid Agaricini. They are commonly epiphytal. Like other plants they may be dried and preserved in herbaria. Marasmius is a very natural genus, although it be principally distinguished by biological marks. Many of the species have a strong smell and peculiar taste (all the Agaricini with the smell of garlic seem to belong to this genus, but no one of the species has the smell

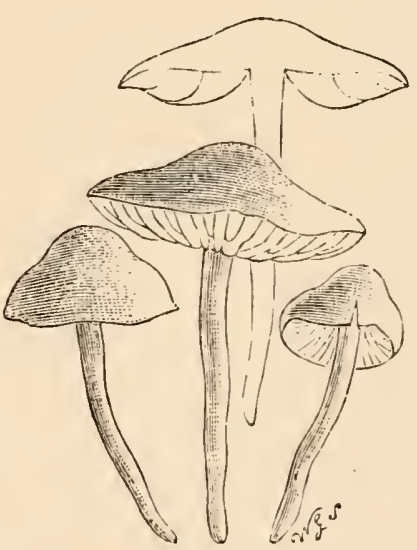

LIII. Marasnizics oreades. Onehalf natural size. of new meal). Fr. Hym. Eur.p. 464.

Marasmius is closely allied to Collybia. Their biological character of shrivelling, and reviving with moisture is of the utmost importance in the determination of the true Marasmii. Fries refers (Monogr. ii. p. 215) to two species which hold a doubtful 
Marasmius. place between the genuine Agarics and the Marasmii-viz., Ag. (Collybia) stipitarius and Marasmius oreades. One species (not British) M. subannulatus has a veil.

The species are mostly small, thin, and commonly epiphytal; those which are found on the ground are generally on putrid leaves or roots of grasses. They are too thin to be of much use for food, but some are esteemed for flavouring.

I. Collybia. Fr. Syst. Orb. Veg. i. p. 73. Pileus fleshy-pliant, at length somewhat coriaceous, sulcate or wrinkled, margin at first involute. Stem somewhat cartilaginous, mycelium floccose in a very few not manifest.

A. Scortei (scorteus, coriaceous). Stem solid, or stuffed with a pith then hollow, internally fibrous, externally with villous down (pruina, 'Monogr.') that is easily wiped off covering the cartilaginous cuticle. Gills separating-free.

* Stem woolly or strigose at the base.

** Stem naked at the base, often composed of twisted fibres.

B. Tergini (tergum, hide, skin, leather). Stem rooting, definitely tubular, not fibrous, manifestly cartilaginous. Gills separating-free. Pileus thinner than in the former section, hygrophanous, sometimes even, sometimes striate at the margin.

* Stem woolly downwards, smooth upwards.

** Stem (at least when dry) everywhere pruinato-velvety.

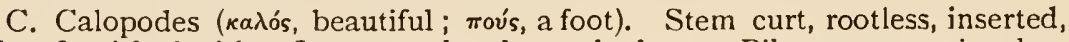
often furnished with a floccose tubercle at the base. Pileus convexo-involute then plane and depressed; in this state the gills, which are typically adnate, are somewhat decurrent. On stipules, branches, \&c., gregarious, arid.

* Stem very smooth and shining upwards, with a simple base.

** Stem velvety or pruinate, with a somewhat tubercular base.

II. Mycena. Stem horny, fistulose, but here and there with a pith, tough, arid, mycelium rhizomorphoid corticate and not floccose. Pileus somewhat membranaceous, campanulate then expanded, margin at the first straight and adpressed to the stem.

A. Chordales (chorda, a gut. $M$. chordalis). Stem rigid, rooting, or adnate by a dilated base. Pileus campanulate or convex. Type manifestly that of Mycena.

B. Rotulæ (rotula, a little wheel). Stem filiform, flaccid, inserted at the base. Pileus soon rather plane or umbilicate. Growing on leaves, declining from the common type of Mycena.

* Stem very smooth, shining.

** Stem velvety or pilose.

III. ApUs ( $a$, and noús, a foot. Stemless). Pileus sessile, resupinate.

$$
\text { I. - C O L L Y B I A. }
$$

A. Scortei.

* Stem woolly or strigose at the base.

1. M. urens Fr.-Pileus $5-7.5$ cent. ( $2-3$ in.) broad, unicolorous, pale yellowish becoming pale, slightly fleshy, moderately compact at the disc, even, but here and there squamulose or rimoso- 
rivulose when dry, smooth, the thin margin involute. Stem 5-7.5 Marasmius. cent. (2-3 in.) long, $6 \mathrm{~mm}$. (3 lin.) thick, solid, composed of crisp tough fibres, rigid, equal, sometimes however ventricose, $12 \mathrm{~mm}$. ( $1 / 2$ in.) thick, everywhere clothed with white flocci, pale, whitevillous at the base. Gills free, united behind, at length remote from the stem, distant, tough, at first pale-wood colour, then brown.

Gregarious, somewhat cæspitose. Taste very stinging. The stem is not strigosely sheathed at the base.

In mixed woods. Frequent. June-Sept.

A curious form has occurred with the pileus turning very dark when full grown. $B$. \& $B r$. Poisonous. Worthington Smith has tested it by accident. It produced headache, swimming of brain, burning in throat and stomach, followed by severe purging and vomiting. Spores $3 \times 4 \mathrm{mk}$. W.G.S. Nameuro, to burn. From its burning taste. Fr. Monogr. ii.p. 216. Hym. Eur. p. 465. Berk. Out. p. 218. t. I4.f. 3. B. \& Br. n. I889. C. Hbk. n. 654. S. Mycol. Scot. n. 625. Gonn. \& Rab. t. 8.f. I. Ag. Bull. t. 528.f. I. Fl. Dan. t. 2018. f. I.

2. M. peronatus Fr.-Pileus $2.5-5$ cent. ( $\mathrm{I}-2$ in.) and more broad, light yellowish or pallid brick-rufescent, then becoming pale, wood-colour or tan, at first fleshy-pliant, then coriaceo-membranaceous, convex then plane, obtuse, flaccid, slightly wrinkled, even at the disc, at length lacunose, striate at the margin; flesh white. Stem 5-7.5 cent. (2-3 in.) long, $2-4 \mathrm{~mm}$. (I-2 lin.) thick, stuffed, fibrous, tough, attenuated upwards, at length hollow and compressed, furnished with a bark, light yellow then pallid, caticle villous but separating and rufescent when rubbed, somewhat incurved at the base, where it is clothed with dense, somewhat strigose, yellowish or white villous down. Gills adnexed then separating, free, moderately thin, and crowded, when young whitish, pallid wood-colour, at length somewhat remote, rufescent.

B. Woolly-sheathed at the base. Taste acrid like that of M. urens, odour none.

In woods. Common. July-Dec.

Spores pip-shaped, $7 \times 4$ mk. W.G.S. Name-pero, a kind of boot; peronatus, sheathed. From the strigose sheathing at the base of the stem. Fr. Monogr. ii. p. 2 16. Hym. Eur. p. 465. Berk. Out. p. 218. t. 14. f. 4. C. Hbk. n. 655. S. Mycol. Scot. n. 626. Ag. Bolt. t. 58. Sow. t. 37. Fl. Dan. t. $2018 . f .2$.

3. M. porreus Fr.-Pileus $2.5-5$ cent. ( $\mathrm{I}-2$ in.) broad, dingy yellowish, pallid when dry, coriaceo-membranaceous, flaccid, convex then flattened, obtuse, even at the disc, striate at the margin, opaque; flesh pallid, almost of the same colour as the pileus. Stem 7.5 cent. ( 3 in.) long, stuffed then hollow, tough, juiceless, pubescent, somewhat thickened at both ends, red-fuscous, paler at the apex, slightly villous at the base. Gills separating-free, 
Narasmius. distant, rather thick, tough, broadly linear, at length coriaceous, light yellowish then becoming pale.

Odour of garlic, but fugacious when the plant is dried.

In woods, especially among oak-leaves. Frequent. Sept.Nov.

Spores pip-shaped, $4 \times 6 \mathrm{mk}$. W.G.S. Name-porrum, the leek. From its smell of garlic. Fr. Monogr. ii. p. 217. Hym. Eur. p. 466. Berk. Out. p. 219. C. Hbk.n.656. S. Mycol. Scot.n. 627. Ag. Pers.-Sow. t. 8r.

\section{** Stem naked at the base, \&c.}

4. M. oreades Fr.-Pileus $2.5-5$ cent. ( $1-2$ in.) broad, rufescent then becoming pale, hygrophanous, whitish when dry, fleshy, pliant, convex then plane, somewhat umbonate, even, smooth, slightly striate at the margin when moist. Stem 5-7.5 cent. (2-3 in.) long, $3 \mathrm{~mm}$. ( $1 / 2 \mathrm{lin}$.) thick, solid, very tough, equal, tense and straight, everywhere clothed with a villous-woven cuticle which can be rubbed off, pallid; bluntly rooted at the base, naked, not villous or tomentose. Gills free, broad, distant, the alternate ones shorter, at first soft, then firmer, pallid-white.

Odour weak, but pleasant, stronger when dried, taste mild. Commonly growing in circles or rows.

In lawns and pastures. Common. May-Oct.

Edible, delicious when broiled with butter. It may be pickled or dried for future use. Carefully distinguish $M$. urens (poisonous) from it. Spores ellipsoid-sphæroid, 6-7 $\times$ 5-6 mk. $K$. Name-'Opєı́s, a mountain-nymph. Forming fairy rings. Fr. Monogr. ii. p. 218. Hym. Eur. p. 467. Sv. ätl. Sv. t. 31. Berk. Out. p. 219. t. 14. f. 5. C. Hbk. n. 657. S. Mycol. Scot. n. 628. Ag. Bolt. t. I51. Grev. t. 323. Sow. t. 247. Pricef. II. Badh. i. t. 8. f. 3, ii. t. 7.f. 4. Vittad. t. Io.f. I. Krombh. t. 43.f. 11-16. Fl. Bat. t. 830. Gonn. E Kab. t. 8. f. 3. Schaff. t. 77. Bull. t. 144, 528. f. 2.

5. M. scorteus Fr. Wholly whitish.-Pileus 6-1o mm. (3-5 lin.) broad, becoming pale when dried, slightly fleshy, convex, scarcely umbonate, even (not striate at the margin), but slightly wrinkled when dried. Stem 2.5 cent. (I in.) long, obsoletely fistulose, thin, filiform, equal, not rooted, smooth, delicately pruinose towards the apex, contorted and becoming fuscous when dry. Gills quite free, remarkably broad, rounded behind, ventricose, white.

Inodorous, mild. Habit that of very small $M$. oreades.

In grass among trees. Moncreiffe. Aug.

Name-scortum, hide. Leathery, wrinkled. Fr. Monogr. ii. p. 219. Hym. Eur. p. 468. B. E Br. n. 1677. S. Mycol. Scot. n. 629. Batsch t. 109? 
* Stem woolly dozunwards, smooth upwards.

6. M. varicosus Fr.-Pileus $12 \mathrm{~mm}$. ( $1 / 2$ in.) or a little more broad, fuscous-purple, becoming darker when dry, somewhat membranaceous, pliant, campanulate then convex, plane, umbonate, even. Stem 5-7.5 cent. (2-3 in.) long, thin, fistulose, rubiginous, among mosses villoso-tomentose beyond the middle, the down rubiginous, blackish when dry, smooth above, filled with dark blood-coloured juice, which drops when it is broken. Gills separating-free, very crowded, linear, wery narrow, of the same colour as the pileus, but becoming dark, umber-fuscous when dry.

Solitary, inodorous. In places which are not mossy the stem is only 2.5 cent. ( $\mathrm{r}$ in.) long, wholly smooth, becoming black. It is very singular in the juicy stem, and quite exceptional in the gills being darker when dry. It cannot be compared with $A$. hematopus.

In damp mossy places. Apethorpe. Sept.

Name-varix, dilated vein. Full of veins, which yield a bloody juice. Fr. Monogr. ii. p. 220. Hym. Eur. p. 469. Icon. t. I74. f. I. B. \& Br. $n$. I788.

7. M. fusco-purpureus Fr.-Pileus $I-2.5$ cent. ( $1 / 2-I$ in.) broad, dark purple when in vigour, becoming pale (tan) when dry, slightly fleshy, at first hemispherical, then plane, obsoletely umbilicate, slightly wrinkled. Stem $2.5-7.5$ cent. ( $1-3$ in.) long, 2-4 mm. ( I-2 lin.) thick, fistulose, smooth, at first pallid, then rufous or dark purple, sheathed towards the base with strigose, rubiginous down. Gills adnexed in the form of a ring, then free, distant, narrow, rufescent.

Inodorous, juiceless. There are two forms, one larger, solitary, with the stem (longer) decumbent, another smaller, cæspitose, with the stem (shorter) tense and straight.

In woods, on sticks, \&c. Frequent. Aug.

Name-fuscus, fuscous; purpureus, purple. Fr. Monogr. ii.p. 220. Hym. Eur. p. 469. Berk. Out. p. 219. C. Hbk. n. 658. S. Mycol. Scot. n. 630. Ag. Pers. Ic. descr. t. 4. f. I-3.

8. M. terginus Fr.--Pileus about 2.5 cent. ( $\mathrm{I}$ in.) broad, fleshcolour when moist, whitish when dry, shining, tough, slightly fleshy, convex then plane, obtuse, at length soinewhat depressed, margin striate when moist. Stem 5-7.5 cent. (2-3 in.) long, 2-4 mm. ( $1-2$ lin.) thick, fistulose, slightly attenuated upwards, longitudinally fissile, smooth, shining, and pallid upwards, and 
Marasmius. not somewhat pruinate when dried, reddish downwards, whitevillous at the rooting base. Gills separating-free, somewhat crozuded, narrow, pallid.

Inodorous and juiceless, always solitary.

Among leaves, beech, \&c. Dursley. Nov.

Name-tergum, hide, leather. Fr. Monogr. ii. p. 221. Hym. Eur. p. 469. Icon. t. 17t.f. 4. B. \& Br.n. 136r. C. Hbk. n. 66r. M. Stephensii Berk. Out.p. 220.

\section{** Stem (at least when dry) everywhere pruinato-velvety.}

9. M. Wynnei B. \& Br.-Pileus 2.5-4 cent. ( $\mathrm{I}-\mathrm{I} / \mathrm{T} / 2$ in.) broad, lilac-brown, tardily changing colour, fleshy, convexo-plane, somewhat umbonate. Stem 5 cent. ( 2 in.) long, $3 \mathrm{~mm}$. ( $1 \mathrm{I} / 2 \mathrm{lin}$.) thick, fistulose, furfuraceous, somewhat of the same colour as the pileus. Gills adnexed, thick, distant, bright-coloured, beautifully tinged with lilac; interstices even.

Inodorous. Gregarious or cæspitose. The stem springs from a white mycelium, but is by no means strigose or tawny at the base. Quite distinct from $M$. fusco-purpureus.

Among leaves, twigs, \&c. Coed Coch.

Name-after Mrs Lloyd Wynne. B. \& Br.n. 802. Berk. Out. p. 2 19. $t$. 19. f. 3. C. Hbk. n. 659. S. Mycol. Scot. n. 631. Fr. Hym. Eur. p. 470. Gonn. \& Rab. viii.-ix. t. 8. f. 2.

10. M. erythropus Fr.-Pileus about 2.5 cent. (I in.) broad, hygrophanous, pale, almost whitish when dry, slightly fleshy, convex then plane, obtuse, slightly wrinkled when dry. Stem 5-7.5 cent. ( $2-3$ in.) and more long, $4 \mathrm{~mm}$. (2 lin.) thick, fistulose, firm, tough, round or at length compressed, dark red, smooth above, at the first paler, somewhat pruinate when dry, whitestrigose below, internally villous at the sides. Gills separatingfree, broad, lax, connected by veins, not crowded, quite entire, whitish.

Inodorous, juiceless, single or somewhat cæspitose. The pileus varies in colour with the moisture of the atmosphere. It varies with the stem decumbent, even contorted. In habit it approaches nearest to Ag. (Collybia) confuens and acervatus; in these, however, the gills are very narrow and very crowded.

\section{Among leaves near stumps. Frequent.}

Pileus pallid, somewhat shaded with pink. M.尹.B. Name-épvepós, red;

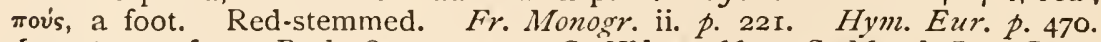
Icon.t. 174.f. 2. Berk. Out. p. 220. C. Hbk. n. 66o. S. Mycol. Scot. Supp. Scot. Nat. r885, p. 74 . 
11. M. archyropus Fr.-Pileus 2.5 cent. ( $\mathrm{I}$ in.) broad, tan-Marasmius. colour, becoming pale, slightly fleshy, convex then plane or depressed, smooth. Stem very long, but scarcely $2 \mathrm{~mm}$. (I lin.) thick, stuffed then hollow, rigid, tense and straight, pallid rufescent under the white tomentose pruina which forms an outer covering, similar at the base. Gills adnexed, separating, crowuded, linear, pallid.

Inodorous. Fasciculato-cæspitose. Analogous with M. terginus. The covering of the stem is almost that of $M$. oreades.

Among leaves. Rare. Bristol.

Name-From the very tall stem. Fr. Hym. Eur. p. 471. Berk. Out.p. 220. C. Hbk. n. 663. Gonn. Eo Rab. t. 8.f. 6. Ag. Pers. Myc. Eur. 3. p. I35. t. 25. f. 4 .

12. M. torquescens Quel.-Pileus pallid, disc tawny, membranaceous, thin, convexo-plane, rugoso-striate. Stem somewhat filiform, delicately velvety, brown, smooth, and whitish at the apex, twisted and sulcate when dry. Gills free, thin, rentricose, distant, white or reddish.

\section{Among oak-leaves. Glamis, 1877.}

The gills are finely serrulated. In the very young plant, when the pileus is conical, there is a slight indication of a veil. $B$. \& Br. Name-torqueo, to twist. From the twisted stem. Quél. p. 198. t. 22. f. 3. Fr. Hym. Eur. p. 471. B. \& Br.n. 1678. S. Mycol. Scot.n.632.

13. M. impudicus Fr.-Pileus $I-2.5$ cent. ( $1 / 2-I$ in.) broad, bay-brown-rufous, becoming pale when dry, slightly fleshy at the disc, convex then plane, often depressed in the centre, soft; membranaceous, striato-plicate, and paler from the circumference to the middle. Stem 5 cent. ( 2 in.) long, $2 \mathrm{~mm}$. (i lin.) thick, fistulose, equal, but broader in becoming compressed, rooting at the attenuated base, tough, flexile; when moist rufous or rufous-fuscous, sometimes violaceous-purple, naked, but wholly covered over with white villous down (pruinato-velvety) when dry. Gills at first reaching the stem, then free, truncate behind, connected by veins, ventricose, at first crowded, then distant, whitishflesh-colour.

Gregarious, odour strong, disgusting, of the same kind as that of $M$. fretens or perforans, but very heavy.

On and about pine-trunks. Hanham. Sept.

Name-impudicus, disgusting. Of the odour. Fr. Monogr. ii. p. 222. Hym. Eur. p. 47 I. Br. Bath. Trans. 1870, p. 77. B. \& Br. n. 1789. C. Hhk. n. 662 .

VOL. II. 
* Stem very smooth and shining upwards, with a simple base.

14. M. scorodonius Fr.-Pileus $12 \mathrm{~mm}$. ( $1 / 2$ in.) and more broad, rufous when young, but soon becoming pale, whitish (not hygrophanous), slightly fleshy, pliant, convex then soon plane, obtuse, always arid; even when young, at length wrinkled and crisped. Stem 2.5 cent. (I in.) long, scarcely $2 \mathrm{~mm}$. (I lin.) thick, horny, tough, fistulose, equal, very smooth throughout, shining, nufous, inserted and naked at the base. Gills adnate, often separating, connected by veins, at length crisped in drying, whitish.

Commonly gregarious. Readily distinguished from neighbouring species by its strong odour of garlic.

Heaths and dry pastures on twigs, \&c. Rare.

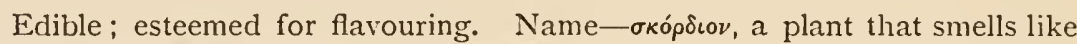
garlic. Fr. Monogr. ii. p. 223. Hym. Eur. p. 472. Sv. ätl. Sv. t. $3^{2}$. Berk. Out. p. 220. C. Hbk. n. 644. Ag. Schaff. t. 99. Paul. t. 122 bis f. 2, 3. Lenzf. 17. Sv. Bot. t. 173?

15. M. calopus Fr.-Pileus about $8 \mathrm{~mm}$. (4 lin.) broad, whitish, slightly fleshy, tough, convex then flattened, obtuse, rarely depressed, even, smooth, slightly wrinkled when dried. Stem 2.5 cent. ( $\mathrm{I}$ in.) long, $2 \mathrm{~mm}$. ( $\mathrm{I}$ lin.) thick, fistulose, slightly attenuated upwards, even, smooth, tough, rufous or bay-brozun-rufous, shining, somewhat rooted. Gills slightly emarginate, in groups of 2-4, thin, white.

Inodorous. Almost smaller than $M$. scorodonizs, but the stem is longer, otherwise very like it.

On twigs, \&c. Bristol.

In 'Hym. Eur.' the stem is described as not rooted. Name-kadós, beautiful ; $\pi$ oús, a foot. With beautiful stem. Fr. Monogr. ii. p. 223. Hym. E.ur. p. 472. B. \& Br. 1. 1790. Quel. t. 13. f. 5. Ag. Pers.-Bull. t. 550. f. I.

16. M. Vaillantii Fr.-Pileus $12 \mathrm{~mm}$. ( $1 / 2 \mathrm{in}$.) and more broad, whitish, somewhat membranaceous, pliant, soon flattened and depressed in the middle, plicato-rugose. Stem 2.5 cent. (I in.) long, stuffed, thickened and paler upwards, here and there obsoletely pruinate; otherwise smooth, date-brown, bright shining, inserted at the base, where it is naked and blackish. Gills adnate, somewhat decurrent on account of their triangular form, broad, clistant, distinct, simple, white.

Very remarkable. Inodorous, tough, arid. The pileus is plicate as in the Rotula. 
On dead wood. Royal Botanic Garden, Regent's Park. Sept. Marasmius.

Perhaps imported. B. \& Br. Name-after Vaillant. Fr. Monogr. ii. $p$. 223. Hy'm. Eur. p. 472 . Berk. Out. p. 221. C. Hbk. n. 665. Ag. Fr. l'aill. t. II. f. $21-23$. Bus.t. iv. t. 36. f. 2 .

17. M. angulatus B. \& Br.-Pileus fuscous-whitish, somewhat membranaceous, hemispherical then flattened, at length plicatoangular. Stem 2.5 cent. (I in.) and more long, thin, rufescentgrey, thickened at both ends, hairy at the base. Gills distant, whitish.

Very different from .\%. Vaillantii.

On grass. Cefn, Denbighshire, above Bone-cave.

Name-angulus, an angle. From the angular pileus. B. \& Br. n. ror 8 . Fr. Hym. Eur. p. 473. Ag. Pers. Myc. Eur. 3. p. 155. t. 26. f. 3, t. Michel. t. $7+\cdot f \cdot+$ (whitish vidr.)

18. M. languidus Fr.-Pileus $12 \mathrm{~mm}$. ( $1 / 2 \mathrm{in}$.) broad, white, inclining to flesh-colour or light yellow, slightly fleshy, at first convex, margin involute, then more expanded and umbilicate, flocculose, rugoso-sulcate. Stem scarcely 2.5 cent. (I in.) long, I-2 mm. ( $1 / 2-\mathrm{I}$ lin.) thick, stuffed, thickened upwards, naked, pallid, becoming fuscous and commonly white villous at the base. Gills adnate then decurrent, distant, connected by veins, narrow, white.

Gregarious, tough, pliant, inodorous, especially remarkable for its decurrent gills. Its appearance is that of Agaricus.

On dead leaves of grass. Coed Coch.

Name-langueo, to be weak, languid. Limp and tough as opposed to brittle. Fr. lonogr. ii. p. 224. Hym. Eur. p. 473. B. \& Br. n. I017. C. Hbk. n. 667. Ag. Lasch-Batt. t. 27.f. O.

** Stem velvety or priinate, with a somewhat tubercular base.

19. M. fœidus Fr.-Pileus $12 \mathrm{~mm}$. ( $1 / 2$ in.) broad, bay-browntaruny, membranaceous, somewhat pellucid, pliant, convex then expanded, at length umbilicate, striato-plicate. Stem scarcely reaching 2.5 cent. (I in.) long, I m. ( $1 / 2$ lin.) thick, horny, fistulose, equal, date-brown, and everywhere velvety, inserted with a very small floccose tubercle at the base. Gills adnexed in the form of a ring, somewhat decurrent when the disc is depressed, distant, connected by veins, yellowish-rufescent.

Odour fatid. There is another form differing in the colour being wholly umber, and in the absence of the villous tubercle at the base. This and the other plicate species differ from the Rotule in the mycelium not being rhizomorphoid, and in the margin of the pileus being at first somewhat involute. 
Marasmius. On decayed twigs, \&c. Rare. Aug-Nov.

Name-foetidus, stinking. Fr. Monogr. ii. p. 224. Hym. Eur: p. 473. Berk. Out. p. 221. C. Hbk.n. 668. S. Mycol. Scot. n.633. Ag. Sow. t. 2т.

20. M. amadelphus Fr.-Pileus 6-8 mm. (3-4 lin.) broad, pale yellowish, becoming pale, sometimes whitish, fleshy-membranaceous, convex then plane, always obtuse, at length depressed at the darker disc, somewhat pruinose, even, at length striate only at the margin. Stem curt, I2 $\mathrm{mm}$. ( $1 / 2 \mathrm{in}$.) long, scarcely reaching $2 \mathrm{~mm}$. (I lin.) thick, stuffed, equal, somewhat mealy, pallid, commonly inserted with an obsolete tubercle. Gills adnate, somewhat decurrent, broad, distant, pallicl.

Gregarious, arid, inodorous. In a var. in fir woods the gills are still more distant, swollen in the form of veins, at length separating, rufescent-woodcolour (pallid number) ; pileus thinner, whitish.

On dead branches, \&c. Rare. Sept.

Name- $\dot{\alpha} \mu, a \delta \in \lambda \phi o ́ s$, brother. From its relation to $M$. ramealis next to which Fries placed it, though differing in some respects from the group. Fr. Monogr. ii. p. 225. Hym. Eur. p. 474. Berk. Out. p. 221. C. Hbk. 669. S. Mycol. Scot. n. 634. Ag. Bull. t. 550. f. 3 .

21. M. ramealis Fr.-Pileus 6-8 mm. (3-4 lin.) broad, white, rufescent at the disc, somewhat fleshy, firm, convex then plane, obtuse or depressed in the centre, slightly wrinkled, but without strice. Stem 6-10 $\mathrm{mm}$. (3-5 lin.) long, scarcely $2 \mathrm{~mm}$. (I lin.) thick, stuffed, but commonly with a white line in the centre indicating that it is typically fistulose, often incurved, mealy (or with hairy squamules under a lens), whitish, or rufescent at the base, inserted when young at least with a very small tubercle. Gills adnate, connected behind, slightly distant, narrow, white.

Gregarious, arid, inodorous.

On dead twigs. Common. Sept.-Nor.

Under a lens clothed with minute matted silkiness. M.F.B. Nameramus, a branch. Growing on twigs. Fr. Monogr. ii. p. 225. Hym. Eur. p. 474. Berk. Out. p. 221. C. Hbk. n. 670. S. Mycol. Scot. n. 635. Ag. Bull. t. 336. Nich. t. 74. f. 7 .

\section{II.-MYCENA.}

A. CHOR D A LES.

22. M. alliaceus Fr. - Pileus $2.5-4$ cent. ( $I-I \frac{1}{2}$ in.) broad, whitish inclining to fuscous, often milk-white when young, somewhat membranaceous, campanulate then expanded, somewhat umbonate, even, at length striate and sulcate, smooth, dry. Stem 
as much as 20 cent. ( 8 in.) long, homy, rigid, fistulose, attenuated Marasmius. upwards, pruinato-velvety, blackish, rooted at the base where it is somewhat incurved and naked. Gills adnexed in the form of a ring then free, slightly ventricose, arid, slightly distant, fuscouswhitish, crisped when dry.

Odour strong, of garlic, persistent. There is nothing of a reddish tinge in the iihole plant. The stem is not tomentose at the base as in the Tergini.

Among leares and on rotten wood. Frequent. Aug.-Oct.

Name-allium, garlic. From the smell. Fr. Monogr. ii. p. 226. Hym. Enr. p. 475. Berk. Ont. p. 223. C. Hbk. n. 671. S. Mycol. Scot. n. 636. Ag. Facq. Austr. t. 82. Fl. Dan. t. 1251. llich. Gen. t. 78.f. 4. Paul. t. I22. $f$. I.

23. M. caulicinalis Fr.-Pileus $12 \mathrm{~mm}$. ( $1 / 2$ in.) and more broad, dingy yellow becoming ferruginous, then ochraceous, membranaceous, thin, pliant, campanulate then convex, obtuse, at length plane, never umbilicate, even then striato-sulcate. Stem 2.5-5 cent. ( I-2 in.) long, fistulose with a pith, rigid, tough, flocioso-villous and bay-brown below, attenuated, paler and mealy upwards, somewhat inserted at the base. Gills adnato-decurrent, somewhat distant, connected by a network of veins, pallid light yellow.

It differs widely from $A g$. campanella, with which it agrees in stature and habit. A. caulicinalis Bull. is entirely different.

Among leaves. Rare. Nov.

It occurs paler in colour. Spores $4-5 \times 2-3 \mathrm{mk} . B$. Name-caulis, a stalk, stem. Growing on stems. Fr. llonogr. ii. p. 227. Hym. Eur. p. 476 . B. E Br.n. 1136. C. Hbk, n. 672. S. 1lycol. Scot, n.637. Ag. With, -Sozu. t. 163.

\section{B. Rotul..}

* Stem very smooth, shining.

24. M. rotula Fr.-Pileus $6-8 \mathrm{~mm}$. (3-4 lin.) broad, whitish, unicolorous, or with the umbilicus becoming fuscous, arid, membranaceous, slightly convex, umbilicatc, plicate, undulato-crenulated at the margin. Stem variable in length, horny, fistulose, equal, shining, very smooth, blackish, manifestly striate when dry. Gills adnate behind to a collar encircling the stem but removed from it, broad, few (often equal), very distant, white.

Gregarious, often cæspitose, with root-like branchlets.

On dead twigs. Common. July-Nov.

Stem deep shining brown at the base. M.F.B. Name-rota, a wheel. Like a little wheel. Fr. llonogr. ii. p. 229. Hym. Eur. p. 477. Berk. Out.p. 222. t. 14.f. 7. C. Hbk. n. 673. S. Mycol. Scot. n. 638. Gonn. \& 
Marasmius. Rab. t. 8. f. 8. Ag. Scop.-Sozw. t. 95. Bull. t. 64, 569.f. 3. Fl. Dan. t. II34. Mich.t. 74.f. 5 .

25. M. graminum Berk.-Pileus scarcely exceeding $6 \mathrm{~mm}$. (3 lin.) broad, very pale rufous, the furrows paler, umbo brown, nearly plane, umbonate, sulcate. Stem quite smooth, shining, black, white above. Gills attached to a free collar, few, somewhat ventricose, even, with veiny interstices, cream-coloured.

A most elegant species, and quite distinct from $M$. rotula.

On grass. Uncommon. July-Sept.

Stem 2.5 cent. ( $\mathrm{r}$ in.) and more long. Gills 6-8 only. Fr. Name-gramen, grass. On grass. Berk. Out. p. 222. t. I4. f. 8. C. Hbk. n. 674. S. Mycol. Scot. 1.639. Fr. Hym. Eur. p. 477. Ag. Lib. exs. I19.

26. M. androsaceus Fr.-Pileus 4-6 mm. (2-3 lin.) broad, whitish or somewhat fuscous, membranaceous, arid, somewhat umbilicate, smooth, striate. Stem 4 cent. ( $1 / 2 \mathrm{in}$.) and more long, filiform, horny, fistulose, very tough, equal, very smooth, black, contorted and striate when dry. Gills adnate to the stem (without a collar), simple, distinct, distant, whitish.

There are two forms: on deciduous leaves the pileus is whitish, deeply umbilicate, plicate, the mycelium (on oak-leaves) creeping within the substance of the leaf; on perennial leaves (Pinus silvestris, Juniper, here and there on bark) the pileus is scarcely umbilicate, more even, somewhat fuscous, and the mycelium conmonly free.

On leaves, twigs, \&c. Common. April-Nov.

The umbilicus is darker. Name-androsaces, a zoophyte: madrepora acetabulum Linn. Perhaps from its form. Fr. Monogr. ii. p. 229. Hym. Eur. p. 477. Berk. Ont. p. 222. C. Hbk. 11. 675. S. Mycol. Scot. n.640. Ag. Limn.-Fl. Dan. t. 1551. f. 1. Bolt. t. 32. Sow. t. 94. Bull. t. 569. f. 2. Boce. Mus. t. I04.

27. M. splachnoides Fr.-Pileus somewhat membranaceous, convex then expanded and umbilicate, smooth, striate. Stem horny, fistulose, smooth, shining, red ("becoming fuscous"). Gills somewhat decurrent, crowded, simple and anastomosing, white.

Inodorous. Allied most closely to $M$. androsaceus; differing however in the red stem, and somewhat decurrent, more crowded gills.

Among pine-leaves. Cabalva, Foxley. Oct.

By an error in 'Hym. Eur.' it is represented as being of the habit of M. perforans. See 'Epicr.' and 'Monogr.' Name-splachmm, a moss ( $\sigma \pi \lambda \dot{a} \gamma \chi^{\nu 0 \nu}$, applied to a cryptogamic plant); eîos, appearance. Splachnumlike. Resemblance not apparent. Fr. Hym. Eur. p. 478. Monogr. ii. p. 230. Grevillea, vol. viii. p. I 10. 
28. M. Curreyi B. \& Br.-Pileus pallid rufous, furrows paler, Marasmius. umbo fuscous, somewhat plane, sulcate, somewhat radiate. Stem inserted, very smooth, shining, black, white at the apex. Gills attached to a collar, few, somewhat ventricose, creamcoloured, interstices veined, elsewhere very even.

On leaves of grasses. Fineshade, Norths. Aug.

Name-after F. Currey. B. \& Br. n. I794.

\section{** Stem velvety or pilose.}

29. M. perforans Fr.-Pileus $8 \mathrm{~mm}$. (4 lin.) broad, whitish, becoming pale-rufescent, somewhat membranaceous, rather plane, rarely depressed, not umbilicate, without strice, at length slightly wrinkled. Stem 2.5 cent. (I in.) or little more long, fistulose, not very horny, but tough, equal, even, everywhere velvety, bay-brown then black, inserted at the base. Gills adnate, numerous, simple, unequal (the alternate ones shorter), not very distant.

Odour fotid, not of garlic. In appearance like the Calopodes.

On fir-leaves. Rare. Aug.

Name-perforo, to pierce. Perforating with its stem the leaves on which it grows. Fr. Monogr. ii. p. 230. Hym. Eur. p. 478. Berk. Out. p. 223. C. Hbk. n. 676. S. Mycol. Scot. n. 641. Ag. Hoffm. Nomencl. t. 4. f. 2. Schaff. t. 239. Batsch f. 10.

30. M. insititius Fr.-Pileus $12 \mathrm{~mm}$. ( $1 / 2 \mathrm{in}$.) broad, white, membranaceous, pliant, convexo-plane, somewhat umbilicate, unpolished, even when young, then plicato-sulcate. Stem scarcely 2.5 cent. ( $\mathrm{I}$ in.) long, horny, fistulose, attenuated downwards into a simple (not tubercular) inserted base, floccosofurfuraceous, rufous inclining to fuscous. Gills broadly adnate to the stem and attenuated to the margin, distant, simple, unequal, pale to white.

Inodorous. Gregarious, arid. A very remarkable species. The habit is that of 1 . Vaillantii.

On leaves, decayed grass, \&c. Rare. Aug.

Variable. Sometimes the stem is paler and the pileus less plicate. Sometimes the disc is reticulated. M.F.B. Name-insero, to insert or graft. From the way in which the stem is engrafted on the host plant. Fr. Monogr. ii. p. 230. Hym. Eur. p. 478 . Berk. Out. p. 223. t. I4. f. 6 (white-stemmed var.) B. \&o Br. n. 1792. C. Hbk. n. 677. S. Mycol. Scot.n. 642 .

31. M. Hudsoni Fr.-Pileus scarcely $4 \mathrm{~mm}$. (2 lin.) broad, pale fuscous-rufescent, membranaceous, hemispherical, slightly 
Marasmius. wrinkled, beset with scattered purple hairs. Stem horny, filiform, dark purple, with the same hairs as the pileus. Gills adnexed, narrow, single, white, the alternate ones dimidiate.

Inodorous.

On fallen holly-leaves. Frequent in England. Rare in Scotland. June-Dec.

The whole of the outer surface of the pileus is clothed with echinulate processes. $B$. \& $B r$. Spores fusiform, II mk., with a central nucleus very different from those of any other Agaric or Marasmius. B. \& Br. Name-after Hudson, author of 'Flora Anglica.' Fr. Hym. Eur. p. 478. Berk. Out. p. 223. C. Hbk. n. 678. S. Mycol. Scot. n. 643. B. \& Br. n. 708*. t. I5. f. 3 (spores). Sow. t. 164 .

32. M. epichloe Fr.-Pileus whitish, bay-brown-fuscous in the centre, thin, plano-convex, somewhat papillate, without striæ. Stem bay-brown, opaque, sulcato-striate, the strice slightly bristly, paler at the base. Gills rounded, somewhat crowded, broader behind.

On the base of grasses. Hereford.

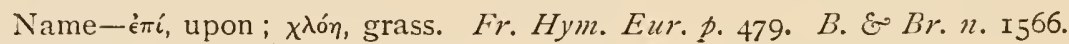
M. gramineus Leveill.

33. IM. saccharinus Fr.-Pileus wholly white, membranaceous, convex, somewhat papillate, smooth, sulcate and plicate. Stem very thin, filiform or attenuated upwards, flocculose then becoming smooth, inserted obliquely, reddish, pale at the apex. Gills broadly adnate, narrow, thick, very distant, reticulato-united, whitish.

Stem often rufous-fuscous below. Tending more to the form of 1/ycena than the rest.

On dead twigs. Rare. King's Cliffe, \&c.

Name-saccharon, sugar. Granulate. From the papillate pileus. Fr. Hym. Eur. p. 479. Monogr. ii. p. 23r. Berk. Out. p. 224. B. \& Br. n. I793. C. Hbk. n. 680. S. Mycol. Scot. 11. 644. Ag. Batschf. 83.

34. M. epiphyllus Fr.-Pileus 4-Io mm. (2-5 lin.) broad, milk-white, membranaceous, very thin, convex then plane, at length umbilicate, smooth, at length plicato-rugose. Stem I-2.5 cent. ( $1 / 2-I$ in.) long, very thin, somewhat horny, fistulose, equal, velvety under a lens, date-brown, whitish at the apex, inserted without mycelium at the base. Gills adnate, few (4-IO), very distant, entire, veined, branched, white.

Gregarious, very slender but persistent, inodorous. When dried it revives with moisture. Sometimes there are only wrinkles in place of gills. Batt. $t$. 28. D. Batsch $f .8+$ (very young). It occurs also wholly even beneath. Pers. Ic. E descr. t. 9. f. 7 . 
On dead leaves, twigs, \&c. Common. Sept.-Oct.

Marasmius.

In large specimens the gills form a close collar round the stem, margin of

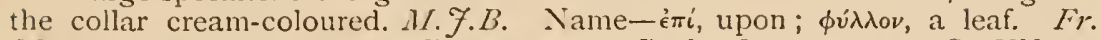
Monogr. ii. p. 23r. Hym. Eur. p. 479. Berk. Out. p. 224. C. Hbk. $n$. 679. S. Mycol. Scot. n. 645. Ag. Tratt. Austr. f. 22. Fl. Dan. t. rig4. f. I. Sori. $t .93$.

\section{III.-APUS.}

35. M. spodoleucus Berk.-Pileus $4 \mathrm{~mm}$. (2 lin.) broad, cinereous, pulverulent or slightly furfuraceous, conchate, resupinate, margin free, arched. Stem none. Hymenium white, very even. Gills few, narrow, entire, so short as to have a naked space at the base, white, interstices even.

On clead elm-twigs. Batheaston.

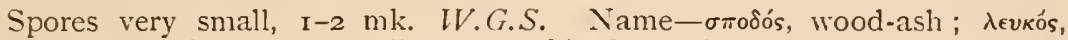
white. Fron the cinereous pileus and white hymenium and gills. $B . \& B r$. n. 803. Berk. Out.p. 224. C. Hbk. n.681.

36. M. Broomei Berk.-Half-resupinate. Pallid brown then striate black; hymenium shining white. Gills distant, veined; interstices even.

On dead twigs. Batheaston. Jan.

Name-after C. E. Broome. B. \& Br.n. I795.

Genus XV.-Lentinus (lentus, tough or pliant). Fr. Epicr. p. 387 . Lentinus.

Pileus fleshy-coriaceous, pliant, or in fleshy species becoming hard when old, persistent. Hymenophore continuous with the stem or the base of the pileus when sessile. Gills concrete with the hymenophore, thin, unequal, membranaceous, with the edge serrated or torn in a toothed manner. Spores somewhat round, even, white. With the exception of one species, growing on wood, polymorphous, somewhat irregular, very mumerous in warmer countries, decreasing in number and not becoming so hard towards the north. Fr. Hym. Eur. p. 480 .

A very natural, though very poly-

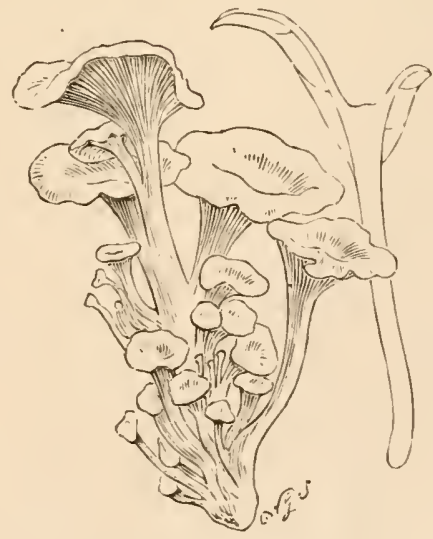

L.IV. Lentinus cochleatus. Onefourth natural size. 
Lentinus. morphic genus. The serrated or torn edge of the gills is a distinctive feature.

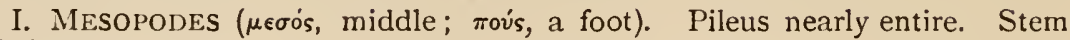
distinct.

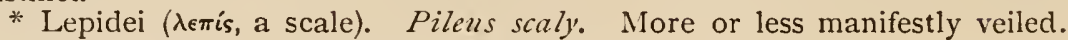
(In none of the following groups is there a veil.)

** Pulverulenti (pulvis, dust). Pileus villlous or pulvernlent.

*** Cochleati (cochlea, a snail-shell, lobed and twisted in shape). Pileus smooth.

II. Pleuroti ( $\pi \lambda \epsilon u p o ́ v$, a side; oîs, an ear). Dimidiate, sessile or furnished with a somewhat lateral stem.

\section{I.-MESOPODES. \\ * Lepiclei. Pileus scaly, \&oc.}

1. I. tigrinus Fr.-Pileus commonly 5 cent. ( 2 in.) broad, white, variegated with somewhat adpressed, blackish, hairy squamules, fleshy-coriaceous, thin, commonly orbicular and central, at first convexo-plane, umbilicate, at length infundibuliform, often split at the margin when dry. Stem about 5 cent. (2 in.) long, thin, solid, very hard, commonly attenuated downwards, minutely squamulose, whitish, often ascending and becoming fuscous at the base, at first furnished at the apex with an entire reflexed ring, which soon falls off. Gills decurrent (by no means sinuate), narrow, crowded, unequal, toothed like a saw, white.

Somewhat gregarious, even cxspitose, thinner and more coriaceous and regular than L. lepideus. B. wholly blackish with squamules.

On old stumps. Rare.

When fresh very tender and easily torn, when dry coriaceous. Sow. Smell strong, acrid, like that of some Lactarii. M.F.B. Spores $3 \times 7$ mk. W.G.S. Name-tigrinus, tiger-like. From the marking on the pileus. Fr. Monogr. ii. p. 233. Hym. Eur. p. 481. Berk. Out. p. 224. C. Hbk. n. 682. Ag. Bull.t.70. Sow. t. 68. Batt.t. 12. f. B-D.

* L. Dunalii Fr.-Pileus pallid, with adpressed, separating, spot-like scales, fleshy-coriaceous, thin, umbilicate, irregularly shaped. Stem short, somewhat silky. Gills decurrent, crowded, pallid.

When the scales separate the pileus is even. Veil scarcely manifest. Very much allied to L. tigrinus.

On ash-trees. Rare.

Crespitose. Pileus 2 in. broad, margin deflexed, sometimes variously split and sinuated, yellow-white, with brownish rather close scales, margin nearly smooth: gills dichotomous, crenate. Stem I in. high, 3 lin. thick, tough, the lower part clothed with dark, nearly square, adpressed scales, the upper half not scaly, white, resembling the under side of white kid leather. Odour sub- 
acid, farinaceous. M.F.B. Name-after Dunal. Fr. Hym. Eur. p. 48r. Lentinus. Berk. Out. p. 225. t. I5.f. 2. C. Hbk. 11.683. Batt. t. 12. A.

2. L. lepideus Fr.-Pileus 5-10 cent. (2-4 in.) broad, pallidochraceous, variegated with adpressed, darker, spot-like scales, fleshy, very compact and firm, irregular, commonly excentric, convex then depressed, but not truly umbilicate, sometimes broken up into cracks; flesh pliant, white. Stem short, commonly 2.5 cent. (I in.) long, solid, stout, very irregularly formed, almost woody, tomentoso-scaly, whitish, rooted at the base, at the first fumished with a cortina towards the apex. Gills decurrent, but sinuate behind, crowded, broad, transversely striate, whitish, edge torn into teeth.

Odour pleasant. Almost always solitary; earlier than the rest, often appearing quite in spring. Very variable in stature and size. Cortina very fugacious. Gills very remarkable in being sinuate behind while decurrent. Often pierced by larvæ when old. Sozi. t. 382 is a monstrous form of this.

On pine. Ráre. July.

Fries refers to various monstrous forms found in close places, cellars, aqueducts, \&c. I have one such from under a floor; more than 2 feet in height, the very thick woody stem springing from a dense leathery stratum, which covered yards of the wood, then branched and united in fantastic forms, like branched coral, with here and there a small infundibuliform pileus on the end

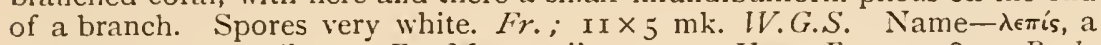
scale. From the pileus. Fr. Monogr. ii. p. 23.3. Hym. Eur. p. 48r. Berk. Out.p. 225. C. Hbk. n. 684. S. Mycol. Scot. n. 646. Ag. Schaff. t. 29, 30. $B u x b$. C. iv. t. 25 .

\section{** Pulverulent. Pileus villous or pulverulent.}

3. L. leontopodius Schulz.-Pileus tan-clay-colour, fleshycoriaceous, tough, irregular, delicately tomentose, disc depressed, the deflexed margin slightly lobed. Stem thick, woody, unpolished, pulverulent, pale chestnut, blackish downwards. Gills clecurrent, connected by veins, wrinkled at the sides, serrated at the edge.

Large, handsome, with a pleasant taste. Pileus here and there cinnamon with the down.

On clecayed willow. Menmuir, Forfarshire.

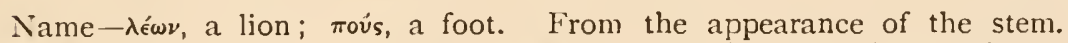
Schula.-Kalchbr. in litt. Fr. Hym. Eur. p. 482. S. Mycol. Scot. n. 647.

4. L. pulverulentus Fr.-Pileus yellow, mealy with white dust, fleshy-pliant, convex. Stem stout, elongated, equal, rigid, mealy with white dust. Gills slightly toothed, white.

Crespitose. 
Lentinus. On dead trunks. Glamis, i875. Oct.

Tufted, at first infundibuliform, then lateral flabelliform, fuliginous, floccosopulverulent, with little umber particles; stem elongated, at length smooth; gills thick, pallid, deeply decurrent, their edge crenulate but not torn. Pileus 2 inches across, stem 3 inches high. $B$. \& Br. Name-pulvis, dust. Pulverulent. Fr. Hym. Eur. p. 483. B. \& Br.n. 1567. S. Llycol. Scot. n. 648. Ag. Scop. Cam. p. 434 .

* L. resinaceus Fr.-Pileus ochraceous-cinnamon, somewhat fleshy, pliant, excentric, somewhat gummy-villous. Stem unequal, tomentose. Gills crowded, serrated, shining white.

Somewhat cæspitose. Covered with a dry, tenacious, somewhat resinous gluten arising from the quasi-glandular villous down.

On trunks. Forres.

Name-resina, resin. From the resinous covering. Fr. Hym. Eur. p. 483. B. \& Br. n. I283. S. Mycol. Scot. n. 649. Ag. Trog. Fl. 1832. p. 525.

5. L. adhærens Fr.-Pileus dingy pallid, somewhat fleshy, pliant, irregular, convexo-umbonate then depressed and infundibuliform, lacunose, somewhat pulverulent, coated with a glutinous varnish. Stem somewhat hollow, rooted, of the same colour as the pileus and like it coated with a glutinous varmish. Gills decurrent in lines, very thin, torn, white.

Small, unequal, taste at length astringent.

In pine woods. Rare.

Name-ad, and hareo, to stick. From the glutinous varnish. Fr. Hym. Eur. p. 483. C. Hbk. n. 685. S. Mycol. Scot. n. 649. Ag. A. E S.-A. adhæsivus With.

\section{*** Cochleati. Pileus smooth.}

6. L. cochleatus Fr.-Pileus 5-7.5 cent. (2-3 in.) broad, fleshcolour, but becoming pale, somewhat tan, fleshy-pliant, thin, commonly excentric, imbricated, very unequal, somewhat lobed or contorted, sometimes plane, sometimes infundibuliform-umbilicate, but not pervious, smooth. Stem solid, firm, sometimes central, most frequently excentric, sometimes wholly lateral, always sulcate, smooth, flesh-coloured upwards, rufous-fuscous downwards. Gills decurrent, crowded, serrated, white-fleshcolour.

Pliant, tough, flaccid, very changeable in form, sometimes solitary, sometimes cæespitose, imbricated, growing into each other. From very small forms, which are commonly solitary, with the stem and pileus scarcely 2.5 cent. (I in.) it ranges to 7.5 cent. ( 3 in.)

On stumps. Frequent. Aug.-Oct. 
According to Fries the odour is weak, of anise; but it is generally strong Lentinus. and very pleasant. Spores sphæeroid or ellipsoid-spharoid, uniguttate, 4-6 mk. K.; almost globular, 4 mk. IV.G.S. Name-cochlea, a snail-shell. From the shape. Fr. Mlonogr. ii. p. 235. Hym. Eur. p. 484. Berk. Out. p. 226. t. 19.f. 4. C. Hbk. n. 686. S. Mycol. Scot. n. 650. Price t. 125. Ag. Sow. t. 168 .

\section{II.-Pleuroti. Dimidiate, \&c.}

7. L. scoticus B. \& Br.-Pileus $I-4$ cent. ( $1 / 2-1 \frac{1}{2}$ in.) broad, pallid, at length brownish, hygrophanous, umbilicate, sometimes infundibuliform, at length flattened; extremely variable in form, either quite stemless and reniform, or variously stipitate, lobed at the margin and sinuate, or plicate. Stem when present varying from $4 \mathrm{~mm}$. (2 lin.) to 5 cent. ( 2 in.) long, cylindrical, darker, pulverulent, springing from a brown, fibrillose mycelium. Gills decurrent when the stem is developed, rather distant, strongly toothed.

Solitary or cæspitose; sometimes 2 pilei are joined. Inodorous, or at any rate without any odour of aniseed. The nearest ally to this curious species is L. omphalodes.

On decayed ulex, birch and spruce. Menmuir. Glamis. Nov.-Jan.

The teeth of the gills are very irregularly torn. Name-Scottish. B. \& Br. n. I+23. S. Mycol. Scot. n. 651. Fr. Hym. Eur. p. 485 .

8. L. fimbriatus Curr.-Pileus $\mathrm{I}-2.5$ cent. ( $1 / 2-\mathrm{I}$ in.) broad, fawncolour, covered with darker floccose scales, somewhat dimidiate, somewhat coriaceous, thin (not fleshy), depressed, sometimes very much so and almost cyathiform, margin slightly involute, almost strigose. Stem $1 / 8-1 / 4$ in. long, lateral, rough with somewhat reflexed scales of the same colour as the gills, or rather paler. Gills descending, but not decurrent, irregularly serrated and torn at the margin, pale brown.

In young specimens a delicate white fimbriate collar or fringe (the remains of the ruptured veil) separates the gills from the stem. Pilei two or three together, one above another in an imbricated manner. Some of the pilei tinged here and there with pink stains.

On a stump standing in a pond. Lewes. Sept.

Name-fimbrice, fringe. From the fimbriate collar. Currey in Trans. Linn. Soc. xxiv. p. I52. t. 25. f. 2. C. Hbk. n. 688. Fr. Hym. Eur. p. 485.

9. L. vulpinus Fr. Sessile, many times imbricated.-Pilei tan, fleshy, very pliant, reniform-conchate, very convex, margin deflexed and almost perpendicular, hence concave beneath ; surface wholly peculiar, with raised longitudinal ribs, which are 
Lentinus. broken up into scales or fibrous teeth towards the margin, hence entirely rough and corrugated, and white-warty behind. Gills extended to the base, broad, crowded, torn into teeth.

Pilei like steps of a ladder (the intermediate ones largest, 7.5 cent. ( 3 in.) broad), horizontal, connate behind in a dense cluster, the common base piercing the trunks of trees. Substance white. Margin thin, incurved, becoming fuscous in older specimens. When dry the pileus often gapes open in longitudinal cracks. The gills at the base are concrete with the substance of the pileus. It sheds very plentiful, white spores, hence the clusters when old are very white-mealy.

On stumps. Rare.

Smell very strong and overpowering, somewhat resembling that of field mint. M.F.B. Spores almost globular, very small, $2 \mathrm{mk}$. W.G.S. Namevulpes, a fox; foxy. Meaning obscure. Fr. Monogr. ii. p. 238. Hym. Eur. p. 486. Icon.t. I76.f. I. Berk. Out. p. 226. C. Hbk. n.687. Sow. t. 35 I.

10. L. flabelliformis Fr. Somewhat sessile.-Pileus not exceeding 2.5 cent. ( $I$ in.) broad, pallid fawn-colour, membranaceous, pliant, reniform, plane, even, smooth, margin fimbriatotoothed. Stem commonly rudimentary, thin, 4-6 $\mathrm{mm}$. (2-3 lin.) long. Gills broad, somewhat distant, rather thick, pallid or whitish, torn into teeth at the edge.

Commonly exactly lateral with a motimentary stem; much smaller and thimmer than any of the rest, at length crisped. Var. herburum very small, the membranaceous pileus becoming pale.

On stumps. Rare.

Perhaps Bolton's plant may be only Ag. salignus. M.F.B. Name-fabellum, a small fan; forma, form. From the shape. Fr. Monogr. ii. p. 239. Hym. Eur. p. 487. Berk. Out. p. 226. C. Hbk. n. 689. Ag. Bolt. t. 157?

Genus XVI.-Panus (a name given to an arboreal fungus by Pliny.) Fr. Epicr. p. 396.

Whole fungus fleshy-coriaceous, tough, drying up, of fibrous texture, which radiates into the hymenium. Gills concrete with the hymenophore, unequal, at length coriaceous, edge quite entire. Spores even, white, somewhat cylindrical in species which have been examined. Growing on wood, various in form, lasting long.

A genus which must be inserted in this series on account of its flesh which is pliant and somewhat coriaceous (even in the gills), allied to the Lentini, but differing from them in the firmer, coriaceous and very entive gills. Either poisonous, or owing to the toughness of the substance not suitable for eating. Fr. Hym. Eur.p. 487 . 
* Pilcus irregular, stem excentric.

Panus.

** Stem definitely lateral.

*** Pileus resupinate, sessile or extended bchind.

* Pileus irregular, stem excentric.

1. P. conchatus Fr.-Pileus 5-Io cent. (2-4 in.) broad, cinnamon then becoming pale, fleshy-plian t, thin, unequal, excentric, even dimidiate, flaccid, squamulose when old. Stem about $12 \mathrm{~mm}$. (1/2 in.) long, $8 \mathrm{~mm}$. (4 lin.) thick, unequal, often compressed, pubescent at the base. Gills deeply decurrent in parallel lines, by no means anastomosing, but here and there branched and unequal, at first whitish or pale flesh-colour, at length ochraceouswood-colour, crisped when dry.

Caspitose, often imbricated and growing into each other. No form is constant. So much allied to $P$. torulosus that the real difference is not apparent. It is thinner, more conchate and more lobed than that species.

On trunks. Rare. June-Oct.

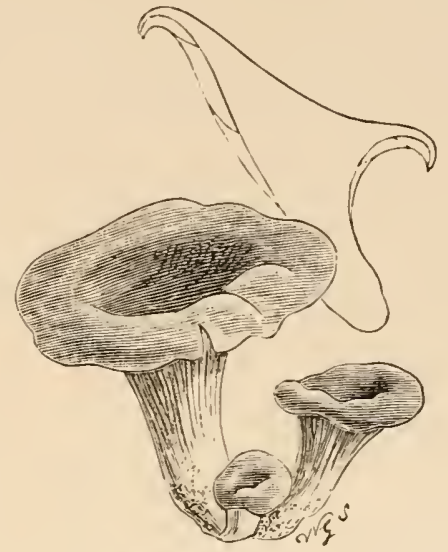

LV. Panus torulosus. One-fourth natural size.

Name-concha, a shell. Shell-shaped. Fr. Monogr. ii. p. 24o. Hym. Eur. p. 488. Berk. Out. p. 227. C. Hbk. n.691. S. Mycol. Scot. n. 652. Krombh. t. 42. f. I, 2. Schaff. t. 43, 44. Bull. t. 298, 5i7.f. O. P.

2. P. torulosus Fr.-Pileus $5-7.5$ cent. ( $2-3$ in.) broad, somewhat flesh-colour, but varying rufescent-livid and becoming violet, entire, but very excentric, fleshy, somewhat compact when young, plano-infundibuliform, even, smooth; flesh pallid. Stem short, commonly 2.5 cent. (I in.), solid, oblique, tough, firm, commonly with grey, but often violaceous down. Gills decurrent, somewhat distant, simple, separate behind, reddish then tancolour.

Very changeable in form, at first fleshy-pliant, at length coriaceous. In the covering of the stem it approaches Paxillus atro-tomentosus, but there is no affinity between them.

On old stumps. Frequent.

Spores $6 \times 3 \mathrm{mk}$. IV.G.S. Name-torulus, a tuft of hair. From the hairy down on the stem. Fr. Monogr. ii. p. 240. Hym. Eur.p. 489. Berk. Out. p. 226. C. Hbk. n. 690. S. 1lycol. Scot. Supp. Scot. Nat. I881, p. 37. Ag. Krombh. t. 42. f. 3-5. Bolt. t. I46 (var.) Gonn. \& Kab. t. 12. f. 4. Batsch f. 33. Paul. t. 26. f. 3, 4. Nees Syst.f. I76. 
3. P. stipticus Fr.-Pileus $I-2.5$ cent. ( $1 / 2-1$ in.) broad, cinnamon becoming pale, arid, thin, but not membranaceous, reniform, pruinose, the cuticle separating into furfuraceous scales. Stem not reaching 2.5 cent. (I in.) long, solid, definitely lateral, compressed, dilated upwards, ascending, pruinose, paler than the gills. Gills ending determinately (not decurrent), thin, very narrow, crowded, elegantly connected by veins, cinnamon.

Gregarious, cæespitose, remarkable for its astringent taste. The pileus sometimes has an infundibuliform appearance with lobes all round.

On stumps, \&c. Common. Aug.-Feb.

Reckoned poisonous. Spores obovoid-sphæroid, $2-3 \times 1-2$ mk. $K$.; $3 \times 4$ mk. IV.G.S. Name-stypticus, astringent. Fr. Monogr. ii. p. 2+I. Hym. Eur. p. 489. Berk. Out. p. 227. C. Hbk. 11.692. S. Mycol. Scot. n. 653. Ag. Bull. t. I40, 557, f. I. Schaff. t. 208. Sow. t. 109. Fl. Dan. t. 832. $f$. I, 1292.f. I. Tratt. Austr. t. 2. Krombh.t.44. f. 13-17. Buxb. C.v.t. 10.f. 1.

4. P. farinaceus Schum.-Pileus cinnamon-umber, somewhat coriaceous, flexuous, cuticle separating into whitish-bhuish-grey scurf. Stem short, lateral, of the same colour as the pileus. Gills determinately free, distinct, paler.

The habit is that of $P$. stipticus.

On fir pole. Glamis, I873. Dec.

Name-farina, meal. From the scurf on the pileus. Schum.-Fr. Hym. Eur. p. 490. S. Mycol. Scot. 11. 654 .

*** Pileus resupinate, sessile or extended behind.

5. P. patellaris Fr.-Pileus $12 \mathrm{~mm}$. ( $1 / 2$ in.) or a little more broad, pallid externally, resupinate, coriaceous, orbicular, planocup-shaped, adnate by the sessile vertex, the free margin involute, furfuraceo-villons externally. Gills concurrent in a central point, crowded, quite entire, arid, dark ochraceous.

Very remarkable, nearest to $P$. stipticus.

On cherry. Forres. March.

Name-patella, a small dish. Fr. Monogr. i. p. 242. Hym. Eur. p. 490. Icon. t. 176. f. 3. B. \& Br. n. 1680. S. Mycol. Scot. n. 655 .

6. P. Stevensoni B. \& Br.-Pileus olivaceous-light yellow, spathulate; flesh greenish-yellow. Stem dilated upwards, convex and golden, slightly hispid. Gills narrow, entire.

On oak. Glamis, I877. Penicuik, I878. Sept.-Oct. 
A very striking species. Name-after Rev. John Stevenson. B. E Br. $n$. 1796. S. .11ycol. Scot. n. 656 .

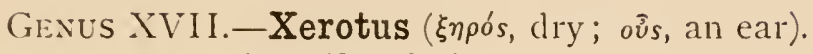

Xerotus.

Fr. Elench. i. p. 48.

Hymenophore continuous with the stem, descending into the trama which is homogeneous with the coriaceous pileus. Gills coriaceous, broadly plicæeform, dichotomous, edge quite entire, obtuse. Rigid, porsistent, analogous with the Cantharelli, but differing in the whole structure. Fr. Hym. Eur. p. 491 .

1. X. degener Fr.-Pileus datebrown-grey when moist, when dry grey, somewhat zoned, coriaceo-membranaceous, very thin, but very tough, plano-infundibuliform, striate when moist, flocculose when dry. Stem not 2.5 cent. ( 1 in.), often only $4-6$ mm. (2-3 lin.) long, $2 \mathrm{~mm}$. (I lin.) thick, very tough, solid or floccosostuffed at the apex, equal, fuscous,
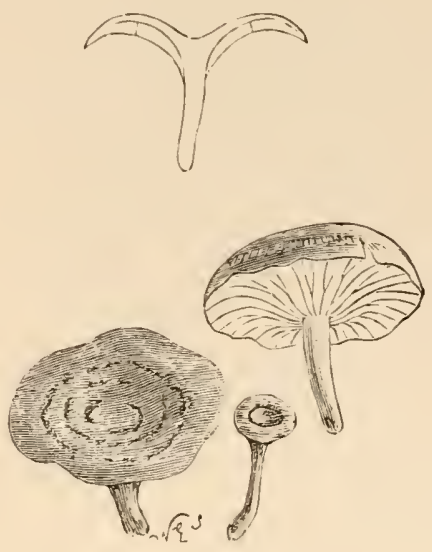

LVI. Serotus degener. Onehalf natural size.

somewhat white-velvety. Gills decurrent, few, very distant, when rightly developed thin, rather broad, whitish-grey, edge acute, flaccid.

When dry the pileus is zoneless in smaller specimens. When the gills are less fully dereloped, they resemble the ribs of Cladoderris, the edge being very obtuse. They vary, sometimes all equal, simple, sometimes simply dichotomous, with shorter alternate ones. They are the most widely distant of any of the species of Agaricini. Jan.

On peaty soil among short grass. Glamis, Warren, I 877 .

This extremely rare species has hitherto been recorded as British by Sowerby only. My specimens, in the opinion of Berkeley were nearest Schceff. $t .2+3$. Spores elliptical, irregular, 8-12 $x_{+}-6 \mathrm{mk} . B$. Name-degener, degenerate. Fr. Monogr. ii. p. 243. Hym. Eur. p. 491. Berk. Out. p. 227. C. Hbk. n. 693. S. Ilycol. Scot. 11. 657. Ag. Scheff. t. 243. A. turfosus Sow. t. 210. 
Trogia.

Genus XVIII.-Trogia (after Trog, a Swiss botanist). Fr. Epicr. p. 402.

Gills fold-like, edge longitudinally channelled (in the single

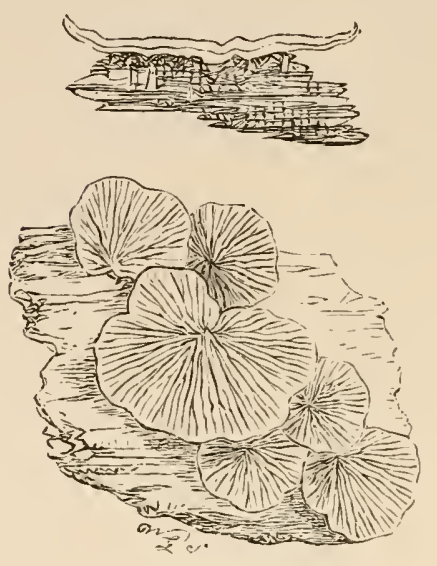

LVII. Trogia crispa.

Natural size. European species only crisped). In other respects agreeing with Xerotus. Soft, flaccid, but arid and persistent, texture fibrillose. Fr. Hym. Eur. p. 49I.

Reviving when wet. Spores white.

1. T. crispa Fr. - Pileus I-2.5 cent. ( $1 / 2-\mathrm{I}$ in.), light yellow-rufescent behind, whitish at the margin, sessile with or without a vertical stem, then reflexed, horizontal, very irregularly shaped, lobed, delicately villous. Gills in the form of reins, dichotomous, narrow, crisped, very much swollen, edge very obtuse but not channelled, whitish or bluish-grey.

Substance and texture as described in the generic characters. Very gregarious, commonly imbricated. When young pezizoid or cup-shaped.

On logs, birch, \&c. Uncommon. Oct.-Nov.

It occurs almost white. Spores elongated or cylindrical, $4 \times I \mathrm{mk} . K$. Name-crispus, crisped or curled. Fr. NTonogr. ii. p. 244. Hym. Eur. p. 492. C. Hbk. n. 694. S. Mycol. Scot. n. 658. Merulius Pers. Ic. descr. $t$. 8. f. 7. Cantharellus Fl. Dan.t. 1759. B. So Br. n. II35.

Schizophyllum.
Gexus XIX.-Schizophyllum ( $\sigma \chi^{i} \zeta \omega$, to split; $\phi \dot{v} \lambda \lambda o v$, a leaf). Fr. Obs, i. p. IO3.

Pileus fleshless, arid. Gills coriaceous, fan-wise branched, united above by the tomentose pellicle, bifid, split longitudinally at the edge. Spores somewhat round, white. Fr. Hym. Eur. p. 492 .

The two lips of the split edge of the gills are commonly revolute. The farthest removed of all the Agaricini from the type. Growing on wood.

1. S. commune Fr.-Pileus scarcely exceeding 2.5 cent. ( $\mathrm{I}$ in.), 
very arid, pendulous, commonly extended behind into a stem-like Schizophy. base, entire or lobed, corered with whitish-grey down. Gills fuscousgrey then purplish, villous, revolute at the edge.

On dead wood, logs, \&c. Rare in Britain.

White or greyish zoned, sometimes resupinate. $M . \mathcal{F} . B$. Spores very small, almost giobular, $3 \mathrm{mk}$. IV.G.S. In Britain it is usually found and is common on foreign logs. In the 'Scottish Cryptogamic Flora' Greville records it as having been gathered on Dundas Hill, near Edinburgh. I have examined his specimen in the Edinburgh Herbarium marked "Dindas Hill." From the locality and from Greville's well-known accuracy, there can be no doubt that it was indigenous. Berkeley and Broome state that "undoubtediy indigenous specimens have occurred both in Buckinghamshire and Kent in 1878." Name-communis, common. Common in most countries. Fr. llonogr: ii. p. 2.4. Hym. Eur. p. 492. Berk. Out. p. 228. B. \& Br. n. 1796*. C. Hbk. n. 695. S. Mycol. Scot. n. 659. Grev. t. 61. Krombh. t. 4. f. I4-16. Ag. Linn.-Batschf. 126. Bull. t. 346, 581. f. г. Sow. t. I83.

Genus XX.--Lenzites (after Lenz, a German botanist).
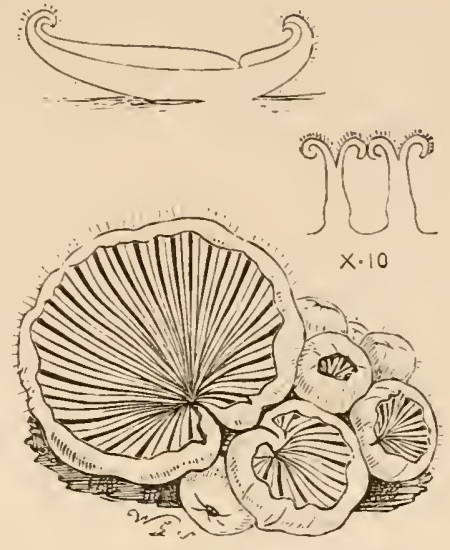

LVIII. Schizophyllum commune. Natural size. Section ten times natural size. lum.

\section{Fr. Epicr. p. 403.}

Pileus corky or coriaceous, texture arid and floccose. Gills coriaceous, firm, sometimes simple and unequal, sometimes anastomosing and forming pores behind, trama floccose and similar to the pileus, edge somewhat acute. The European species are dimidiate, sessile, persistent, growing on wood, quite resembling Dadalea. Fr. Hym. Eur. p. 492.

Allied most nearly to Trametes and Dadalea and forming as it were the transition from Agaricini to Polyporei. In tropical countries they are more woody in texture.

\section{* On wood of deciduous trees.}

1. I. betulina Fr.-Pileus $2.5-5$ cent. ( $\mathrm{I}-2$ in.) broad, pale, grey-whitish, corky-coriaceous, firm and rigid, becoming plane, tomentose, commonly obsoletely zoned, zones sometimes darker; flesh floccose, white. Gills reaching the base, straight, some- 
Lenzites. times simple, sometimes branched and often anastomosing, about $6 \mathrm{~mm}$. (3 lin.) broad, dingy white, edge acute.

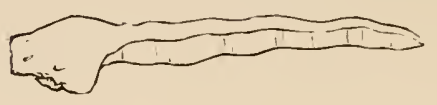

Dimidiate, sessile. It varies solitary and crespitoso-imbricated. 'The margin is of the same colour.

Stumps, logs, \&c., chiefly birch. Common in England. Rare in Scotland. Perennial.

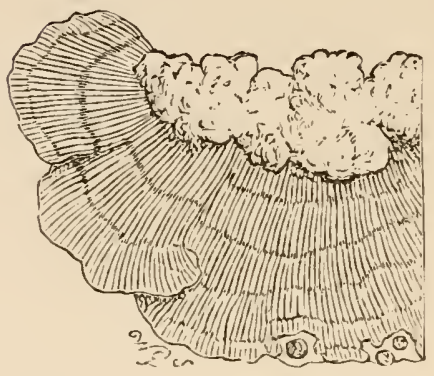

Deeply grooved concentrically. Often green with minute $A \lg a$. Often quite resupinate, and then very deceptive. II.7.B. Name-betula, birch. Fr. Mlonogr. ii. $p$. 246. Hym. Eur. p. 493. Berk. Out. p. 228. t. I5. f. 3. C. Hbk: n. 696. S. Mycol. Scot. 11. 660. Ag. Linn.-Fl. Dan. t. 1555. B. with darker gills. Sow. t. 182. Schaff. t. 57 is a handsome form.

LIX. Lenzites betulina. One-fourth

2. L. flaccida Fr.--Pileus at first natural size.

whitish, then dingy, with zones wholly of the same colour, coriaceous, thin, scarcely $2 \mathrm{~mm}$. (I lin.) thick, unequal, easily bent, strigosohairy. Gills thick, firm, straight, very broad, crowded, simple or branched, with shorter ones intermixed, at first shining white, then becoming pale.

The gills are never anastomosing, but here and there obfurcate, i.e., towards the base. Commonly taken for L. betulina, but wholly different.

On stumps. Frequent in England.

Name-flaccidus, flaccid. Fr. Monogr. p. 246. Hym. Eur. p. 493. Berk. Out.p. 228. C. Hbk. n. 697. Ag. Bull. t. 394. Bolt. t. $5_{5}^{8 .}$

* On wood of trees with leaves like needles.

3. L. sæpiaria Fr.-Pileus $2.5-7.5$ cent. ( $\mathrm{I}-3$ in.) broad, yellowtawny when young (remaining so at the margin when full grown), date brozun when full grown, becoming black when old, corkycoriaceous, hard, convex becoming plane, sometimes orbicular, more frequently extended longitudinally, zoned, strigoso-tomentose, at length squamulose and pitted; flesh tacuny. Gills extended to the base, very rigid and firm, branched, more or less anastomosing, 2-4 mm. ( -2 lin.) broad, yellowish when in vigour, but umber when old, the edge entire or slightly toothed.

Dinidiate, lateral. The gills are like those of Dadalea. It varies resupinate, forming orbicular placenta-like patches. There are many remarkable monstrous forms; occasionally the hymenium is wholly that of Polyporis.

On pine. Uncommon. Jan.-Dec. 
Name-scpis, a hedge, fence. Growing on old fences. Fr. Monogr. ii. p. Lenzites. 247. Hym. Eur. p. 494. Berk. Out. p. 228. C. Hbk. n. 698. S. Mycol. Scot. n.66I. Dxdalea-Schaff. t. 76 . Ag. Sow. t. 4 I8. Buxb. C. v. t. 6.Faill. t. I. f. I-3 (resupinate var.)

4. L. abietina Fr.-Pileus umber-tomentose,, then becoming smooth, hoary, coriaceous, thin and comparatively soft, zoneless, effuso-reflexed; flesh very thin, of the same colour as the pileus. Gills decurrent in the effused base, distant, simple, unequal, not anastomosing, but here and there interrupted, or torn into teeth, becoming glaucous with dense pruina.

Nearly always lengthened out even to as much as 30 cent. (I2 in.), but always remaining narrow, about $12 \mathrm{~mm}$. ( $1 / 2 \mathrm{in}$.) broad. Effuso-reflexed, but sometimes remaining resupinate.

Chiefly on dressed fir. Rare. Glasgow. Perennial.

Perhaps imported. Name-abies, fir. Fr. ITonogr. ii. p. 247. Hym. Eur. p. 495. Berk. Out. p. 229. C. Hbk. n. 699. S. Mlycol. Scot. n. 662. Ag. Bull. t. 442. f. 2, 54I.f. I. Ventur. t. 60.f. 3-5. 


\section{ORDER II.-POLYPOREI.}

Hymenophore inferior, facing the ground; hymenium consisting of tubes with poriform mouths which are round or angular, sometimes sinuous or torn, lined within with 4 -spored sporophores and cystidia.

Fleshy, coriaceous, or woody fungi, most abundant and luxuriant in warm conntries. Intermediate between the Agaricini and the Hydnei, connected with the former by Dadalea and Lenzites, and with the latter by Fistulina and Irpex.

Boletus. Gevus XXI.-Boletus. Dill. Fr. Obs. i.p. Io9. (The name of a fungus considered a great delicacy among the Romans, derived from $\beta \hat{\omega} \lambda$ os, a clod, probably to denote the round figure of the plant.)

Hymenium wholly composed of small tubes, connected together in a stratum the surface of which is dotted with their poriform

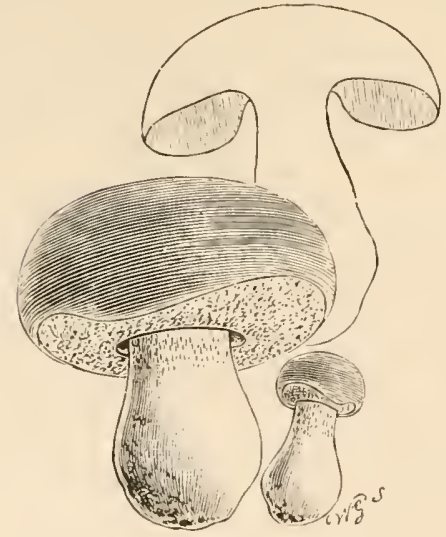

LX. Boletus edulis. One-fourth natural size. mouths, and which is distinct from the hymenophore on account of the latter not descending into a trama. Tubes packed close together, easily separating from the hymenophore and from one another. Pores or mouths of the tubes round or angular (in the subgenus Gyrodon sinuous or gyroso-plicate). Spores normally fusiform, rarely oval or somewhat round. Growing on the ground, fleshy, putrescent, with central stems. Mostly edible, and of importance as articles of food; a feru poisonons.

A well-marked and sharply defined genus, although some of the species depart so much from the type that they have been referred to distinct genera. Fr. Hym. Eur.p. 495. Compare Epicr. p. 408 and Syst. Myc. i. p. 385.

The colour of the spores of many of the species is unknown, 
and where it is known, it is found to differ in closely allied roletus. species; and hence in arranging them it is necessary to take the colour of the tubes (and not as in the Agaricini the colour of the spores) as the basis of the primary groups. Fr. Hym. Eur. $p$. 496, Sc.

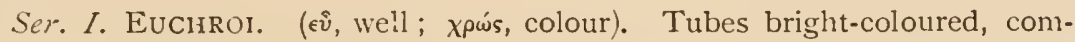
monly yellow, not white or grey.

A. Viscipelles (viscum, bird-line; pellis, a skin). Pileus covered over with ar viscous pellicle. Stem solid, not bulbous, nor reticulated with veins. Tubes adnate to the stem behind, rarely sinuate, of one colour. Spores of such as are sufficiently well known yellowish.

* Genuini, forming a continuous series.

** Dcparting from the type, of doubtful affinity.

B. Subtomentosi (sub, tomentum, down). Pileus destitute of a viscid pellicle, villous when youns, rarely at length becoming smooth. Stem at the first extended, not bulbous, nor reticulated with veins, though here and there rugose or striate. Flesh rarely changing colour. Tubes of one colour, adnate.

C. Subpruinosi (sub, pruina, hoar-frost). Tubes adnate to the stem, yellowish. Stem equal, even, not bulbous nor reticulated. Pileus smooth, but most frequently pruinose.

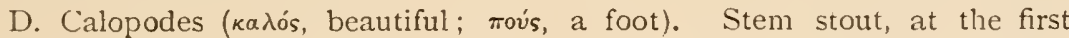
bulbous, in typical species reticulated with veins. 'Tubes adnate, pores not reddish.

* Genuini. Stem reticulated with zeins, commonly of a beautiful red.

** Departing from the type, of uncertain affinity. Stem ciavate, even.

E. Edules (edulis, edible). Stratum of tubes, which at the first are not reddish at the orifice, but have usually a white stuffing, ronnded and depressed "bout the stem, somewhat free. Stem stout, bulbous, resembling that of the Luridi, only (except in $B$. edulis) it is neither reticulated, nor dotted with small scales, nor red. Flesh scarcely changing colour, taste pleasant. Preeminent for their esculent qualities.

F. Luridi (luridus, lurid). Stratum of tubes rounded towards the stem and free; pores at the first stopped up, red. Pileus compact, then soft, pulvinate; flesh juicy, changing colour. Stem stout, at first curt, bulb-shaped, then elongated and nearly equal, somewhat reticulated or dotted. Growing chiefly in deciduous woods. Very poisonous.

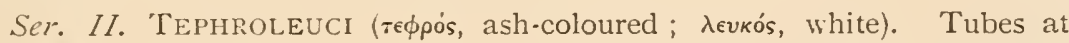
first white or grey.

G. Favosi (far'us, honeycomb. From the size and shape of the tubes). Tubes large, angular, unequal, adnate to the stem, but often shortened around it, not however forming a roundedly-free stratum. Spores, as far as known, brown.

H. Versipelles (verto, to change; pellis, a skin. From the typical species $B$. versipellis). 'Tubes minute, round, equal, crowded together in a convex stratum, which is free from the stem. Spores ferruginous.

I. Hyperhodii (inó, somewhat; jósov, a rose. From the colour of the spores). Tubes adnate to the stem, whitish; spores rosy then white-fleshcolour.

K. Cariosi (caries, rottenness). Stem externally never reticulated, internally stuffed with a spongy pith, at length commonly hollowed out. Tubes 
Boletus. at the first white, then often light yellowish; pores minute, round. Spores white.

Subg. I. Grrodon Opatowski (rupós, a circle; odoús, a tooth). Pores sinuous or gyroso-plicate; tuhes very short, scarcely $2 \mathrm{~mm}$. (I lin.) long, slightly adnate to the hymenophore.

Subg. II. Boletinus Kalchbr. Enum. p. 286. (From Boletus to denote its relation to that genus.) "Hymenophore not even as in the true Boleti, but with projecting points which descend like a trama between the tubes." Sten annulate.

Ser. I. Euchrol. Tubes bright-coloured, \&c.

A. Viscipelles. Pileus covered over with a riscous pellicle, \&.c. * Genuini, forming a continuous series.

1. B. luteus Linn.-Pileus about 5-10 cent. (2-4 in.) broad, yellowish, smeared with fuscous separating gluten, gibbous then pulvinate; flesh white. Stem about 5 cent. ( 2 in.) long, $12 \mathrm{~mm}$. ( $1 / 2$ in.) and more thick, equal, firm, whitish, rough with dots and light yellowish above the large, membranaceous, white-fuscous ring. Tubes adnate; pores minute, simple, yellow.

The pileus becomes paler and virgate-spotted when the gluten separates.

In pine woods. Common. July-Nor.

Edible and highly esteemed like other Boleti. The flesh is very tender. The tubes should be scraped away from all the species before being cooked. Spores spindle-shaped, yellowish-brown, $8 \times 3 \mathrm{mk}$. II.G.S.; 6-8 $\times 3 \mathrm{mk}$. K. Name-luteus, yellow. Linn.-Fr. Hym. Eur. p. 497. Syst. Myc. i. p. 386. Sv. ätl. Sv. t. 22. Berk. Out. p. 229. C. Hbk. n. 700. S. Mycol. Scot.n. 663. Schaff. t. I14. Fi. Dan. t. I135. Rosth. Sturm. 4. t. r. Kl. Fl. Bor. t. 377. Barla t. 3r.f. т-3. Har:. t. 6. Gomm. \& Rab. vii, t. 6. f. 2 and $t .4$. -Krombh. t. 33 .

2. B. elegans Schum.-Pileus golden or inclining to ferruginous, convexo-plane, viscous; flesh light yellowish. Stem firm, unequal, golden then rufescent, dotted above the white then light yellowish, fugacious ring. Tubes decurrent; pores minute, simple, golden-sulphur-yellow.

Gills at length darker.

In woods, especially larch. Common. June-Oct.

About the size of B. luteus. Name-elegans, elegant. Schum.-Fr. Hym. Eur. p. 497. Sv. ïtl. Sv. t. 76. Berk. Ont. p. 229. C. Hbk.n. 701. S. Mycol. Scot. n. 66. Hussey ii. t. 12. Gonn. \& Kab. t. 5. f. 2. Price f. гіо. Grev. t. 183. L'entur. t. 47. f. 1, 2. Bull. t. 332. Krombh. t. 34 . f. I. IO.

3. B. flavus With.-Pileus light yellow with fuscous separating 
gluten, pulvinate, compact. Stem yellow becoming fuscous, Boletus. reticulated above the dirty light yellow, membranaceous, fugacious ring. Tubes adnate; pores angular, yellow.

Firm. Distinguished from B. Inteus, which is like it, by the larger angular pores.

In mixed woods. Common. June-Oct.

Pileus 5-7.5 cent. ( $2-3$ in.) broad. Stem 5-7.5 cent. ( $2-3$ in.) long, 12-1 8 mm. (6-9 lin.) thich. Spores spindle-shaped, yellowish-brown, $8 \times 4 \mathrm{mk}$. II.G.S. Name-favus, light yellow. With.-Fr. Hym. Emr. p. 497. Berk. Out. p. 230. C. Hbk. n. 702. S. Mycol. Scot. n.665. Bolt. t. 169. Sow. t. 265. Kl. Linn. vii. t. I98.

4. B. flavidus Fr.-Pileus $2.5-5$ cent. ( $\mathrm{I}-2$ in.) broad, lividlight-yellowish, gibbous then plane, viscous; flesh pallid. Stem 5-7.5 cent. (2-3 in.) long, thin, $4-6 \mathrm{~mm}$. (2-3 lin.) thick, somewhat equal, pallid, sprinkled with fugacious glandules above the entirely viscous ring. Tubes decurrent; pores large, angular, compound, dirty light yellow.

Thin. Quite distinct from its allies, more slender, and differing from all of them in the veil, which is entirely glutinous.

In pine woods. Rannoch. Sept.

Spores elongato-ellipsoid, straight, subhyaline, 8-1o $\times 3.5^{-4} \mathrm{mk} . K$ : Name - favidus, light yellowish. Fr. Hym. Eur. p. 498. Syst. M.Jyc. i. p. $3^{87}$. S. Mycol. Scot. n. 666.-Pers. Myc. Eur. 2. t. 20. f. I-3. Krombh. t. 4. f. $35-37$.

5. B. collinitus Fr.-Pileus becoming pale when the fuscous gluten separates, pulvinate, even; flesh white. Stem firm, attenuated downwards, ringless, white becoming fuscous, someruhat reticulated with adpressed squamules. Tubes adnate, elongated; pores divided in two, pallid then yellow, naked.

It resembles $B$. lutens in stature and colour.

In fir woods. Ascot. Nor.

Name-collino, to besnear. From the gluten. Fr. Hy'm. Eur. p. 498. B. \& Br.n.1284.-Krombh.t.76.f. 10, ix?

6. B. granulatus Linn.-Pileus $5-7.5$ cent. ( $2-3$ in.) broad, fuscous-fermginous with the gluten with which it is smeared, yellowish when the gluten separates, convexo-expanded; flesh light yellowish. Stem 5 cent. (2 in.) and more long, 6-1 $2 \mathrm{~mm}$. (3-6 lin.) thick, ringless, light yellowish, dotted with granules upwards. Tubes aclnate, short; pores simple, granulated.

Commonly gregarious. The stem is often attenuated upwards. 
Boletus. In woods. Rare. July-Sept.

Orifices of tubes at first dripping with a milky fluid. II.F.B. This dries in the form of sugary granules. Edible. Spores spindle-shaped, yellowishorange, $8 \times 3$ mk. W.G.S.; oblong, 8-1o $\times 3$ mk. K. Name-granula, a granule. Granulated. Linn.-Fr. Hym. Eur. p. 498. Syst. Iyyc. i.p. $3^{87}$. Sv. ätl. Sv. t. 23. Berk. Out. p. 230. C. Hbk. n. 704. S. Mycol. Scot. n. 667. Lenz f. 31. Letell. t. 604. Barla t. 31. f. 4-12. Rostk. t. 3. Gonn. \& Rab. vii. t. 6. f. I.-Schaff. t. I23. Krombh. t. 34. f. II-I4. Sow. t. 420.

7. B. bovinus Linn.-Pileus 5 cent. ( 2 in.) broad, pale yellowish, rather plane, smooth, viscid; flesh white. Stem 5 cent. (2 in.) long, equal, even, unicolorous. Tubes somewhat decurrent; pores compound, grey-light-yellow becoming ferruginous.

The gluten on the pileus, which is at length repand, is thin, not of a different colour and not separating. Somewhat cæspitose.

In woods, chiefly pine. Uncommon. Sept.-Oct.

Tubes resembling the pores of Merulius lachrymans, very shallow ( $\frac{1}{5}$ in.) Smell like Marasmins oreades. M.F.B. Spores spindle-shaped, dingy greenochre, $8 \times{ }_{4} \mathrm{mk}$. WV.G.S.; oblong-ellipsoid, 8-1o $\times 3 \mathrm{mk}$. $K$. Name-bos, an ox. Perhaps from its gregarious habit; the synonym of 'Fl. Dan.' is $B$. gregarius. It might also refer to colour as vaccinus does. Linn.-Fr. Hym. Eur. p. 499. Syst. Iyy. i. p. 388. Berk. Out. p. 230. C. Hbk. 11. 705. S. Mycol. Scot. 11. 668. Lenzf. $3^{8}$ (old). Krombh. t. 75. f. I-6. Kl. Bor. t. 378. Gonn. \& Rab. vii. t. 2. f. I. Hussey i. t. 34.-Fl. Dan. t. Ior8.

8. B. badius Fr.-Pileus $7.5-15$ cent. (3-6 in.) broad, baybrown-tawny, pulvinate, soft, viscous; flesh $2.5-5$ cent. ( $1-2$ in.) thick, becoming azure-blue at the tubes. Stem 7.5 cent. ( 3 in.) long, 2.5 cent. ( $I$ in.) thick, solid, somewhat equal, even, paler, brown-prinate. Tubes long, adnate, sinuato-depressed; pores rather large, dingy, white-light-yellow becoming green, angular.

The stem is attenuated, sometimes upwards, sometimes downwards, but never bulbous. Pileus commonly glutinous, but shining when dry, or when young as if villous-riscous, always even. Very distinct.

In woods, chiefly pine. Frequent. Aug.-Oct.

Spores fusoideo-oblong, light yellow, $\mathrm{I}_{5}^{-20} \times 5^{-6} \mathrm{mk} . h$. Name-badius, bay-brown. Fr. Hym. Eur. p. 499. Elench. p. 126. Sv. ätl. Sv. t. 50. Berk. Out. p. 23I. C. Hbk. n. 706. S. Ilycol. Scot. n. 669. Rostk. t. 5. Fl. Bat. t. 804. Kl. Bor. t. 379. Lenzf. 35.-Krombh. t. 36. f. 12-I8.

9. B. sanguineus With.-Pileus blood-red, convexo-plane, even, smooth, viscid. Stem equal, even, variegated yellow and bloodred. Tubes adnate, orange-yellow; pores large, unequal.

Colour remarkably glistening. Easily confounded with forms of $B$. chrysenteron.

In woods. Rare. 
Pileus $18 \mathrm{~mm} .-3$ cent. $(3 / 4-1 \mathrm{I} / 4)$ in. broad, when old nearly 7.5 cent. ( 3 in.) Boletus. Stem $2.5^{-6}$ cent. ( $1-21 / 2$ in.) long, nearly $9 \mathrm{~mm}$. ( $3 / 8$ in.) thick. Pileus when old rich brown. Flesh white, a little tinged with crimson next to the skin, changing slowly to a bluish cast when wounded. In the larger specimens the base is bulbous, With. Name-sanguis, blood. Blood-red. With.Fr. Hym. Eur. p. 500. Berk. Out. p. 231. C. Hbk. 11. 707. Sow. t. 225. Leicill. in Paul. t. I8I. f. 3,4 .

10. B. piperatus Bull.-Pileus $2.5-7.5$ cent. ( $\mathrm{I}-3$ in.) broad, yellow to pale yellowish, convexo-plane, smooth, slightly viscid; flesh yellowish. Stem 4 cent. ( $1 / 2$ in.) long, thin, $6-8 \mathrm{~mm}$. $\left(3^{-4}\right.$ lin.) thick, even, fragile, of the same colour as the pileus, containing yellow milk at the base. Tubes decurrent, ferruginous; pores large, angular.

Smaller than the rest, occasionally rimoso-squamulose. Easily distinguished by its peppery taste.

In woods. Frequent. Aug.-Nor.

Reckoned poisonous. Spores oval, brown, $8 \times 4$ mk. W.G.S.; ellipsoidoblong, yellowish, $8-9 \times 3^{-4} \mathrm{mk}$. $K$. Name-piper, pepper. From the taste. Bull.t. 45I. f. 2. Fr. Hym. Eur. p. 500. Syst. Ilyc. i. p. $388 . \quad$ Sz: iitl. Sv. t. 67. Berk. Out. p. 231. C. Hbk. n. 708. S. Mycol. Scot. n. 670. Sow. t. 34. Fl. Dan. t. 1850. f. 2. Krombh. t. 37. f. 16-20. Rostk. t. 6. Barla t. 32. f. 5-10. Corda Sturm xi. t. 60.-Batsch t. I28.

\section{** Departing from the type, of doubtful affinity.}

No British species.

B. Subtomentosi. Pileus destitute of a viscid pellicle, Esc.

11. B. variegatus Sw.-Pileus 7.5-12.5 cent. (3-5 in.) broad, dark yellow, convex then plane, obtuse, slightly moist, sprinkled with superficial, fasciculate-hairy squamules, the acute margin at the first flocculose; flesh yellow, here and there becoming azureblue. Stem 5-7.5 cent. ( $2-3$ in.) long, I $2 \mathrm{~mm}$. ( $1 / 2 \mathrm{in}$.) thick, firm, equal, even, dark yellow, sometimes reddish. Tubes adnate, unequal, pores minute, brown then cinnamon.

The scales on the pileus are separating.

In woods, chiefly pine. Frequent. Sept.-Oct.

Smell unpleasant, taste not so. IV. F.B. Spores oval, greenish-ochre, $3 \times 2 \mathrm{mk}$. W.G.S.; oblong-ellipsoid, hyaline or very pale yellow, 8-I I $\times 3^{-4}$ mk. $K$. Name-variegated. Of the different colours. Swartz.-Fr. Hym. Eur. p. 501. Syst. Lyc. i. p. 388. Sv. ät. Sv. t. 66. Berk. Out. p. 23 I. C. Hbk. n. 7II. S. Wycol. Scot. n. 671. Lenzf. 39. Krombh. t. 34. f. 15-18, and t. 75. f. 7-14. Harz. t. I5. Rosth, t. 16.-B. Golden. Schaff. t. II5.

12. B. sulphureus Fr.-Pileus sulphur-yellow', compact, convex then plane, silky-tomentose with innate flocci; flesh light 
Boletus. yellow, becoming more or less azure-blue when broken, but golden when exposed to the air, here and there reddish under the tubes. Stem 2.5-5 cent. ( $1-2$ in.) long, 2.5 cent. ( $I$ in.) thick, firm, ventricose, even, smooth, sulphur-yellow, at length becoming dingy ferruginous. Tubes adnato-decurrent, short, 2-4 $\mathrm{mm}$. ( $1-2$ lin.) long, adhering more closely than usual, changeable on being touched, at length with ferruginous spots; pores minute, compound, sulphur-yellow, at length becoming green.

Springing from a broadly expanded, golden, woolly mycelium, it is very cæspitose, with the appearance of $A g$. spectabilis.

Among sawdust. Loch-an-Eilan, Rothiemurchus. Sept.

Spores light yellow then ochraceous. Fr. Name-sulphur, brimstone. Sulphur-yellow. Fr. Hym. Eur. p. 502. B. \& Br. n. I424. S. 1lycol. Scot. $n .672$.

13. B. striæpes Secr.-Pileus olivaceous, the cuticle fermginous within, convex then plane, soft, silky. Stem firm, curved, yellow, with fuscous-black stria, fuscous-rufescent at the base. Tubes adnate, angular, greenish; pores minute, yellow.

Flesh white, yellow at the tubes, and at the base of the stem which is externally of the same colour and velvety.

In woods. Rare.

Flesh sparingly changing to blue. M.F.B. Name-stria, a line; pes, a foot. From the striate stem. Secr.-Fr. Hym. Eur. p. 502. Berk. Out. p. 232. C. Huk. n. 712. Battur. t. 29. C.

14. B. chrysenteron Fr.-Pileus fuscous or somewhat brickcolour, convexo-plane, soft, floccoso-squamulose; flesh yellow, red beneath the cuticle. Stem somewhat equal, rigid, fibroso-striate, scarlet or light yellow. Tubes somewhat adnate; pores rather large, angular, unequal, greenish-yellow.

The pileus is often cracked into patches, and then the cracks are scarlet. Varying in stature like its allies, with the pileus becoming smooth and more brightly coloured, with the flesh becoming somewhat azure-blue, and with the tubes depressed round the stem.

In woods and open ground. Common. July-Nor.

Edible. Pileus $5-7.5$ cent. ( $2-3$ in.) or more broad. Stem 7.5 cent. ( 3 in.) long, 6-I2 mm. ( $1 / 4-1 / 2$ in.) thick, easily distinguished by the red cracks.

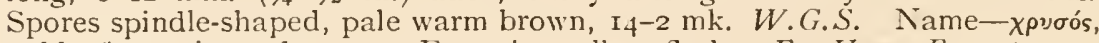
gold; 'évтepa, inward parts. From its yellow flesh. Fr. Hym. Eur. p. 502. Berk. Out. p. 232. C. Hbk. n.713. S. Mycol. Scot. n. 673. Bull. t. 490.f. 3. Hussey i. t. 5. Quel. t. I6. f. 4 .

15. B. subtomentosus Linn.--Pileus somervhat olivaceous, of the same colour beneath the cuticle, pulvinato-expanded, soft, dry, 
villoso-tomentose. Stem stout, attenuated downwards, someruhat Boletus. ribbed-sulcate, slightly rough with dots under a lens. Tubes adnate; pores large, angular, yellow.

Flesh white or pallid, not red beneath the cuticle. When the pileus is cracked the interstices become yollow. The colour of the pileus is brighter when the olivaceous down disappears.

In woods. Common. Aug.-Nov.

About same size as $B$. chrysenteron. Often growing on beech-nuts. II.F.B. Easily distinguished by its yellow cracks. Spores oval, yellowish-brown, I $4 \times 5 \mathrm{mk}$. IV.G.S.; fusoideo-oblong, hyaline or very pale yellow, I I-I $3 \times 4-5$ mk. $K$. Name-sub, and tomentosus, downy. Limn.-Fr. Hym. Eur. p. 503. Berk. Out. p. 232. C. Hbk. n. 714. S. Mlycol. Scot. n. 674. Price f. 2 Vivian. t. 37. Gonn. \& Rab. vii. t. 5. f. I. Bolt. t. 84. middle fig.-Schreff. t. II2. Krombh. t. 37. f. 8-I r. Bull. t. 393. Fl. Dan. t. Iо74. Battar. t. 30. f. F. Krombh. t. $4^{8}$. f. I-6 represents a beautiful var, somewhat aruginous.

16. B. spadiceus Schæff.-Pileus date-brown, opaque, pulvinato-expanded, moderately compact, dry, tomentose, then widely cracked; the white flesh unchangeable, fuscous reddish above. Stem firm, clavate, cven, flocculoso-furfuraceous, yellow inclining to fuscous. Tubes adnate, yellow; pores minute, somewhat round.

The sten is compact, not reddish, yellowish-white internally.

In mixed woods. Glamis, I875. Aug.

Pileus 7.5-Io cent. (3-t in.) broad. Stem very thick. Name-spadix, a palm-branch. Date-brown. Scheff.t. i26. Fr. Hym. Eur. p. 503. B. \& Br. n. I797. S. Ilycol. Scot. 12.675.-Krombh. t. 36. f. I9, 20.

17. B. radicans Pers.-Pileus olivaceous-cinereous then pale yellowish, pulvinate, dry, somewhat tomentose, the thin margin involute; flesh light yellow, becoming immediately dark azureblue. Stem attenuato-rooted, even, light yellow, flocculose with reddish pruinc, naked and dark when touched. Tubes adnate; pores unequal, large, lemon-yellow.

Taste bitterish. The pores are those of $B$. subtomentosus, the habit that of B. badius.

In woods. Epping Forest. Staplehurst, \&c.

Spores spindle-shaped, very pale ochre, almost white, $6 \times 3 \mathrm{mk}$. IV.G.S. Name-radix, a root. Rooting. Pers.-Fr. Hym. Eur. p. 503. Foum. Bot. I873, p. 337. C. Hbk. n. 7I4. Opatowski Bolet. t. I.

18. B. rubinus Smith.-Pileus $5-7.5$ cent. ( $2-3$ in.) broad, yellow - fuscous, pulvinato-gibbous then plane, dry, somewhat tomentose, slightly cracked; flesh vivid yellow, wholly unchange- 
Boletus. able. Stem 5-7.5 cent. (2-3 in.) long, yellow, smeared with crimson, irregular. Tubes somewhat decurrent, compound, of medium size, wholly carmine.

It differs from all other British species in the wholly carnine tubes, together with the vivid yellow, wholly unchangeable flesh.

\section{In mixed woods. Rare. Aug.-Sept.}

Spores oval, almost round, pale warm brown, $6 \times 5 \mathrm{mk}$. II:G.S. Nameruber, red. From the tubes. Smith Seem. Foum. 1868, p. 33. t. 75. f. I-4. Fr. Hym. Eur.p. 504. C. Hbk. n. 709. S. Mycol. Scot. n. 676.

\section{Subpruinosi. Pileus smooth, but most frequently pruinose, \&c.}

19. B. pruinatus Fr.-Pileus 5 cent. ( 2 in.) and more broad, purpiish-bay-brown, umber-pruinose, convex then plane, rigid, dry; flesh white, but also obsoletely green or azure-bluish. Stem 5 cent. ( 2 in.) long, firm, somewhat ventricose, even, smooth, variegated yellow and reddish. Tubes adnate, light yellow; pores minute, round.

On grassy ground. Kew, \&c.

Name-priina, hoar-frost. From the pruinose pileus. Fr. Hym. Eur. p. 50 . . Epicr: p. 4r4. B. \& Br.n. 1285. Scheff. t. 133?-Bull. t. 393 .
f. B. C.

20. B. parasiticus Bull.-Pileus $2.5-5$ cent. ( $1-2$ in.) broad, dingy yellow, convex then plane, silky becoming smooth, dry, soon cracked in a tesselated manner. Stem 5 cent. ( 2 in.) long, thin, rigid, incurved, externally and internally yellow. Tubes decurrent, of medium size, compound, golden.

The colour of the pileus is variable.

On species of Scleroderma. Rare. Clifton. Kew.

Tubes labyrinthiform. Not viscid in any stage of growth. $B$. \& $B r$. Spores spindle-shaped, elongated, pale brown, $\mathrm{I}_{4} \times 4 \mathrm{mk}$. II.G.S. Nameparasitus, a guest. Parasitic. Bull. t. 45I. f. I. Fr. Hym. Eur. p. 505. Syst. Myc. i. p. 389. Berk. Out.p. 231. C. Hbk. n. 7 I0. Saund. Eo Sm. t. 43. Rostk. t. 7 (monstrous).

D. Calopodes. Stem stout, at the first bulbous, Sc.

* Genuini. Stem reticulated with veins, \&.c.

21. B. variecolor B. \& Br.-Pileus olivaceous, convex, somewhat tomentose, margin involute; flesh dark purple under the cuticle. Stem bulbous, attenuated upwards, reticulated at the 
apex, yellowish downwards, rufescent and delicately pubescent Boletus. upwards. Tubes minute, free, yellow.

The flesh of the pileus and stem is pale, here and there inclining to yellow, and partially marbled. Approaching $B$. subtomentosus in habit, but with the bulbous reticulated stem of Calopodes.

In woods, \&c. Uncommon. Aug.-Sept.

Name-iarius and color. From the various colours. B. \& Br. 11.1020. t. I3.f. 3. Fr: Hym. Eur. p. 506. C. Hbk. n. 715. S. Mycol. Scot. n. 677.

22. B. calopus Fr.-Pileus olivaceous, globose then pulvinate, unpolished, somewhat tomentose; flesh pallid, becoming somewhat azure-blue. Stem firm, conical then somewhat equal, reticulated, scarlet, throughout or at the apex. Tubes adnate; pores minute, angular, yellow.

Stem at length of the same colour as the pileus downwards and elongated. Pileus not involute, somewhat repand.

In mixed woods. Frequent. July-Sept.

Spores spindle-shaped, yellowish-brown, $8 \times 3 \mathrm{mk}$. IV.G.S. Names-kadós, beautiful; mov́s, a foot. With beautiful stem. Fr. Hym. Eur. p. 506. Si'. ätl. Sv. t. 69. Berk. Out.p. 232. C. Hbk. n. 716. S. Mycol. Scot. n. 678. Frombh. t. 37.f. I-7. Rostk. t. 27. Harr. t. 69. Saund. Eo Sm. t. I4. -Schaff. $t$. 3I5.

23. B. olivaceus Schrff.-Pileus oliz'aceous-fuscous, convex, eren, becoming smooth, margin at first inflexed; flesh azure blue, then white. Stem firm, clavate, bulbous, red, yellowish at the apex; with blood-red reticulations and dots. Tubes adnate, curt; pores minute, unequal, light yellow-olivaceous.

Stature curt, robust.

In beech woods. Uncommon. Sept.

Pileus $5-7.5$ cent. (2-3 in.) and more broad. Stem short. Name-oliz'a, an olive. Olivaceous in colour. Schceff. t. ro5. Fr. Hym. Eur.p. 506. Berk. Out.p. 233. C. Hbk.n.717. S. I/ycol. Scot.n.679. I'entur. t. 36. f. 3, 4 . -Rostk. $t .32$.

24. B. pachypus Fr.-Pileus Io-20 cent. ( $4-8$ in.) broad, fuscous then pallicl-tan, pulvinate, somewhat tomentose; flesh thick, whitish, becoming slightly azure-blue. Stem 5-I2.5 cent. (2-5 in.) long, always thick, firm, curt, ovato-bulbous, then elongated, equal, reticulated, variegated light yellow and red, often wholly intensely blood-red. Tubes somewhat elongated, shortened round the stem; pores round, light yellow, at length somewhat green.

Larger than preceding species, handsomer, approaching Edules in habit.

In woods, chiefly pine. Uncommon. Sept.-Oct. 
Boletus. Monstrous forms of B. edulis are often mistaken for it. Spores oval, yel-

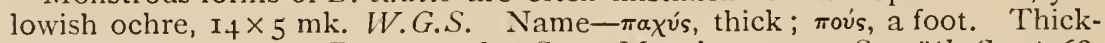
stemmed. Fr. Hym. Eur. p. 506. Syst. Myc. i. p. 390. Sv. ätl. Sv. t. 68. Berk. Out. p. 233. C. Hbk. n. 718. S. Mycol. Scot. n. 680. Lenz t. 60. Krombh. t. 35. f. 13-15.-Ventur. t. 64. f. I, 2. B. pachypus Krombh. $t .35$. f. 10-12. Saund. \& Sm. $t$. I7 (wholly white) is perhaps a new species.

** Departing from the type, of uncertain affinity, \&c.

No British species.

\section{E. Edules. Stratum of tubes rounded and depressed about the stem, \&oc.}

25. B. edulis Bull.-Pileus someruhat brown, pulvinate, smooth, moist; flesh white, reddish beneath the cuticle, compact then softer. Stem stout, reticulated, pallid-fuscous. Tubes semifree, elongated, minute, at first white, then yellow and greenish.

The pileus varies white, grey-rufescent, \&c. The stem is sometimes obsoletely reticulated, sometimes curt and bulbous, sometimes elongated'and equal, also rooting.

In woods, especially beech. Common. July-Nov.

Pileus I 5 cent. ( 6 in.) and more broad. Stem to cent. ( 4 in.) or more long. 5 cent. ( 2 in.) thick. Spores fusoideo-oblong, bright yellowish, I4-16 $\times 4-5.5$ mk. $K$. Name-edinlis, edible. Reckoned one of the most delicious, but the flesh is rather soft wlien cooked. Bull. t. 60, 494. Fr. Hym. Eur. p. 508. Sv. ätl. Sv. t. 13. Berk. Out. p. 234. C. Hbk. n. 7 I9. S. Mycol. Scot. 1. 681. Sow. t. xा . Sv. Bot.t. 197. Lenzf. 34. Tratt. Austr. f. 34. Krombh. t. 3r. Vittad. t. 22. Ventur. t. 8. Vivian. t. 25. Barla t. 34. Hussey i.t. 81. Badh. .. t. 3, ii. t. 3.f. 1, 2. Price t. 63. Hogg \& Fohnst. t. x r. Harz. t. 40, 4I. Gonn. \& Rab. vii. t. I.-Schaff. t. I34. Rostk. t. 37.

26. B. æreus Bull.-Pileus olivaceous-fuscous, somewhat blackish, pulvinate, smooth, somewhat pelliculose: flesh white, becoming yellow on exposure to the air. Stem stout, somewhat reticulated, yellowish, becoming fuscous at the base. Tubes minute, somewhat free, sulphur-yellow.

Pileus small. The stem when young is oblongate not bulbous.

In woorls. Surrey.

Spores oblong, oblique at the base, II-I $4 \times 6 \mathrm{mk}$. B. \& Br. Name- $\mathrm{Es}$, copper. From the colour. Bull. t. 321. Fr. Hym. Eur. p. 508. B. E Br. II. I425. Krombh. t. 36. f. I-7. Quel. t. 16. f. 2.-Rostk. t. 15. Bull. t. $3^{8} 5$ var.

27. B. fragrans Vitt.-Pileus fuscous-umber, pulvinate, repand, somewhat tomentose, margin inflexed; flesh yellow, sometimes unchangeable, sometimes becoming green or azure-blue, at length becoming red. Stem stout, at first ovato-bulbous, often fusiform 
at the base, even, ariegated yellowish and red. Tubes semi- Boletus. free; pores minute, round, yellow, becoming green.

The pileus varies unequal, and here and there spotted or margined with purple.

In woods, under oak, \&c. Sept.-Oct.

Spores pale yellowish-green, ovate, with an apiculus at one end, II $\times 4 \mathrm{mk}$. IV.G.S. ; elongato-prumiform, nucleate, to mk. $Q$. Edible. Name-fragrans, fragrant. Vittad. t. 19. Fr. Hym. Eur. p. 509. C. Hbk. n. 720. Ventur. t. 53.f. 3-5.-Krombh. t. 75. f. 15-21.

28. B. impolitus Fr.-Pileus tawny-brown, pulvinate, dilated, flocculose, at length granuloso-rivulose, unpolished; flesh thick, light yellowish beneath the cuticle. Stem stout, somewhat bulbous, even, pubescent, light yellow. Tubes free; pores minute, yellow.

Handsome, obese, pleasant in odour and taste. Sometimes there is a reddish zone near the apex of the stem.

In mixed woods. Rare. Sept.

Pileus ro cent. (4 in.) or more broad. Stem about 5 cent. (2 in.) long. Spores oval or spindle-shaped, pale greenish-brown, $14 \times 5 \mathrm{mk}$. W.G.S.; ellipsoid, papillate, I6-18 mk. $Q$. Edible; reckoned among the most delicious. Name-impolitus, unpolished. Fr. Hym. Eur. p. 509. Sv. ätl. Sv. t. 42. Berk. Out. p. 234. C. Hbk. n. 721. S. Mycol. Scot. n. 682.-Harz. t. 51. B. pileus areolato-rimose. Schaff. $t$. io8. Letell. t. 614. Rostk. $t$. 36.

29. B. æstivalis Fr.-Pileus whitish, pulvinate, somewhat repand, even, smooth, granular in dry weather; flesh yellow beneath, white above, reddish in the base of the stem. Stem very thick, bulbous, even, smooth, light yellow. Tubes somewhat free; pores equal, minute, yellow.

Stature almost that of $B$. impolitus, equally pleasant, tasty.

In woodland pastures. Uncommon.

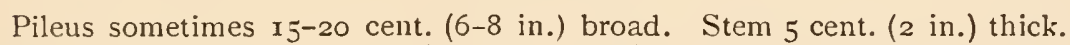
Spores elongated oval, greenisli-brown, rather dark, $12 \times 4$ mk. W.G.S. Edible. Name-astivalis, pertaining to summer. Fr. Hym. Eur. p. 5 ro. Sv. ätl. Sv. t. 43. Berk. Out. p. 234. C. Hbk. n. 722. Hussey i. t. 25. Hogg \& Fohnst. t. 13.

F. Luridi. Stratum of tubes rounded towards the stem, \&c.

30. B. satanas Lenz.-Pileus fuscous-tan then whitish, pulvinate, smooth, somewhat viscous; flesh whitish, becoming red or violet when broken. Stem obese, ovato-ventricose, with bloodred reticulations above. Tubes free, yellow; pores minute, at first blood-red-scarlet, orange when old.

VOL. II. 
Boletus. Handsome, robust, mild, not bitterish.

In woods. Rare. Aug.-Sept.

Pileus sometimes 20 cent. ( 8 in.) broad. Stem $5-7.5$ cent. (2-3 in.) long. Spores earthy-yellow. Fr.; rich brown, oval or spindle-shaped, I $2 \times 5 \mathrm{mk}$. W.G.S. Very poisonous. Name-Satan. Satanic. From its poisonous and dangerous qualities. Lenz f. 3I. Fr. Hym. Eur. p. 5 Io. Berk. Out. p. 233. C. Hbk. n. 723. S. Mycol. Scot. n. 683. Fl. Bat.t. ro4o. Hussey i. t. 7. Quel. t. 15.f. 1.-Rocq. t. 6. Krombh. t. 38. f. 1-6. Vivian. t. 40.

31. B. luridus Schæff. - Pileus often 20 cent. (8 in.) but occurring $5-7.5$ cent. ( $2-3$ in.) broad, tomentose, umber-olivaceous, then somerwat viscons, fuliginous, pulvinate; flesh yellow, becoming azure-blue when broken. Stem 5 cent. ( 2 in.) and much more long, stout, vermilion-red, marked with reticulations or dots. Tubes free, yellow, at length becoming green; pores round, vermilion then orange.

Stem somewhat orange at the apex. Taste pleasant.

In mixed woods, \&c. Common. July-Nov.

Spores oval, greenish slate-colour, $17 \times 9 \mathrm{mk}$. W.G.S. Very poisonous. Name-luridus, lurid in colour. Schaff. t. ro7. Fr. Hym. Eur. p. 51 . Syst. Myc. i. p. 391. Sv. ätl. Sv. t. I2. Berk. Out. p. 233. t. 15. f. 5. C. Hbk. n. 724. S. Mycol. Scot. n. 684. Grev. t. I21. Barla t. 33. f. I-5. Krombh. t. $3^{8}$. f. I I-I7.-Bull. t. roo. Rostk. t. 3I. B. stem curt, bulbous, scarcely reticulated Bolt. $t .85$.

* B. erythropus Pers. -Stem thinner, cylindrical, not reticulated but dotted with squamules, internally somewhat red.

The pileus is often tawny-rufescent. Smaller than preceding species. The flesh, according to Persoon, is red-blood-colour, according to Fl. Dan. $t$. I792 yellow.

In woods and shrubbery. Uncommon. July-Aug.

Name-éputpós, red; nov́s, a foot. Red-stemmed. Pers.-Fr. Hym. Eur. p. 5i I. Berk. Out. p. 233. C. Hbk. n. 725. S. Mycol. Scot. n. 685. Letell. t. 612. Barla t. 33. f. 6, 7. Harz. t. ${ }^{6}$.

32. B. purpureus Fr.-Pileus purplish-red, pulvinate, somewhat velvety, opaque, dry; flesh azure-blue only when young, then dark yellow. Stem stout, yellow, variegated with purple veins and dots. Tubes somewhat free, greenish-yellow; pores minute, purple-orange.

Very handsome. The stem varies reticulated only at the apex, becoming red internally, chiefly at the base.

In woods. Rare.

Spores somewhat spindle-shaped, green-sepia-brown, II $66 \mathrm{mk}$. W.G.S. Name-purpureus, purple. Fr. Hym. Eur.p. 511. Sv. ätl. Sv.t. 41. Berk. 
Out.p. 234. C. Hbk. n. 726. Barla t. 33. f. 8-10. Saund. E Sm. t. 43.- Boletus. Krombh.t. 37.f. 12-15. Clus. Pern. gen. xix. 3 .

Ser. II. Tephroleuci. Tubes at first white or grey.

G. Favosi. Tubes large, angular, unequal, \&c.

33. B. laricinus Berk.-Pileus $5-7.5$ cent. ( $2-3$ in.) broad, dirty white, with livid stains, covered at first with dirty-yellow or brownish evanescent slime, somewhat scaly; flesh white, very slightly tinged with yellow. Stem 5 cent. ( 2 in.) or more long, I $2-16 \mathrm{~mm} .(1 / 2-2 / 3$ in.) thick, cribrose above the ring, pitted below, dirty white. Tubes adnate, somewhat decurrent, compound, at first nearly white.

In larch woods. Frequent. Aug.-Sept.

The squamules on the pileus are the fragments of a veil. Spores oblong, brownish clay-coloured. M.F.B.; spindle-shaped, pale-brown, Io $\times 4 \mathrm{mk}$. W.G.S. Name-larix, larch. Fron habitat. Berk. Eng. Fl. v. p. I48. Out. p. 230. C. Hbk. n. 703. S. Mycol. Scot. n. 686. Fr. Hym. Eur. p. 513. Hussey i. $t .25$.

34. B. viscidus Linn.-Pileus dingy yellowish, pulvinate, soft, smooth, viscid; veil somewhat anmular, torn, white, somewhat appencliculate. Stem riscous, white becoming yellow, thickened at the base, reticulated above. Tubes adnate; pores large, unequal, livid.

Perhaps too nearly allied to $B$. laricinus. The stem often appears torn from the agglutinated fragments of the veil.

In woods. Rare.

Spores fuscous-black. Fr.; spindle-shaped, elongated, brownish green, $9 \times 3 \mathrm{mk}$. WV.G.S. Name-viscum, bird-lime. Viscid. Linn.-Fr. Hym. Eur.p. 513. Icon. t. I78.f. 3. Berk. Out. p. 235. C. Hbk. n. 727.

H. Versipelles. Tubes minute, round, equal, \&c.

35. B. versipellis Fr.-Pileus rufous, pulvinate, dry, at first compact and tomentose, then scaly and becoming even, appendiculate with the annular, membranaceous, fugacious veil. Stem solid, attenuated upwards, wrinkled-scaly. Tubes free, plane, minute, dingy white; pores grey.

Truly distinct from $B$. scaber, but it is difficult to define exactly the difference between them on account of analogy in colour and variation in stature. The colour of $B$. versipellis is more constantly rufous.

In woods and heath. Frequent. Aug.-Oct. 
Boletus. Spores spindle-shaped, pale, ochraceous, $1_{5} \times 5 \mathrm{mk}$. W.G.S. ; fusoideooblong, $17-20 \times 6-7.5 \mathrm{mk}$. $K$. Name-verto, to turn; pellis, the skin. From its changeable appearance. Fr. Hym. Eur. p. 515. Berk. Out. p. 235. C. Hbk. n. 728. S. Mycol. Scot. n. 687.-A. pileus rufescent. Schaff. $t$. ro3. Krombh.t.32. Sow. t. I 10. Rostk. t. 39. B. pileus fuliginous. Batt. t. 3०. f. $A$.

36. B. scaber Fr.-Pileus variable in colour, red or orange, \&c., pulvinate, smooth, viscid when moist, at length rugulose or rivulose, margin at first furnished with a cortina. Stem solid, attenuated upwards, roughened with fibrous scales. Tubes free, convex, white then dingy; pores minute, round.

Sometimes robust, sometimes slender. The chief varieties are as follows: A. pileus red or orange. Bull. t. 489. $f .2$. B. pileus fuliginous or cinereous. Fl. Dan. t. 833. Bull. t. 489. f. I. Sow. t. I75. Krombh. t. 35. f. I-6. C. pileus fuscous-black, stem floccoso-scaly, tubes shining white. Schreff. $t$., 104. D. pileus fuscous-olivaceous. Bolt. t. 86. E. pileus wholly white. Rostk. t. 48 .

In woods, \&c. Common. July-Nov.

Pileus $5^{-1} 7.5$ cent. (2-7 in.) or more broad. Stem ro-r 5 cent. (4-6 in.) or more long. Scales on the stem black. Spores spindle-shaped, pale brown, I $4 \times 5$ mk. W.G.S.; fusoideo-oblong, light yellowish, $x_{4}-\mathrm{r} 8 \times 6 \mathrm{mk} . K$. Edible. Name-scaber, rough. From the stem. Fr. Hym. Eur. p. 5r5. Sv. ätl. Sv. t. r4. Berk. Out. p. 235. C. Hbk. n. 729. S. Mycol. Scot. n. 688. Vittad. t. 28. Vent. t. 9, ro. Barla t. 35. f. 6-12. Rostk. t. 40. Harz. t. 2. Gonn. \& Rab. vii.t. 3. Badh. i. t.7.f. r, ii. t. 6.f. r, 2. Hussey i. t. 57. Hogg \& Fohnst. t. 22.

I. Hyporhodii. Tubes adnate to the stem, whitish, \&c.

37. B. felleus Bull.-Pileus 7.5-10 cent. ( $3-4$ in.) broad, somewhat pale yellowish, pulvinate then expanded, soft, smooth, even; flesh when broken white then flesh-colour. Stem 7.5 cent. (3 in.) and more long, solid, attenuated and reticulated upwards. Tubes adnate, convex, elongated; pores angular, white then fleshcolour.

Taste bitter. The colour of the pileus varies chestnut, pale yellowish and tawny. Stem of the same colour, here and there becoming olive, more rarely dotted with squamules as in $B$. erythropus.

\section{In woods. Uncommon.}

Spores spindle-shaped, salmon-colour, $16 \times 6 \mathrm{mk}$. W.G.S. ; fusoideo-oblong, hyaline, 12-16 6 4.5-5.4 mk. $K$. Poisonous. Name-fel, gall. Bitter. Bull. t. 379. Fr. Hym. Eur. p. 516. Syst. Myc. i. p. 394. Sv. ätl. Sv. t. 52. Berk. Out. p. 236. C. Hbk. n. 731. Rostk. t. 43. Krombh. t. 74. f. I-7.

38. B. alutarius Fr.-Pileus fuscous-tan, pulvinate then expanded, soft, velvety, becoming smooth. Stem solid, bulbous, rather even, rugged at the apex. Tubes depressed round the 
stem, short, plane; pores round, white, becoming fuscous when Luletus. bruised.

Very much allied to $B$. felleus, but easily distinguished by its somew hat unchangeable flesh, and mild watery taste.

In woodland pastures. Rare.

Name-aluta, tanned leather. From the colour. Fr. Hym. Eur.p. $5^{16 .}$ Bcrk. Out. p. 235. C. Hbk. n. 730 .

K. Cariosi. Stem externally never reticulated, \&c.

39. B. cyanescens Bull.-Pileus 5-12.5 cent. (2-5 in.) broad, somewhat fuscous or tan, convexo-expanded, adpressedly tomentose, floccoso-scaly, opaque; flesh rigid, white, soon becoming deep blue when broken. Stem stuffed with a spongy pith, at length cavernous, ventricose, villoso-pruinose, of the same colour as the pileus, constricted at the apex where it is even, white. Tubes free, white, at length light yellow; pores minute, round, when young scarcely $2 \mathrm{~mm}$. (I lin.) long.

Very remarkable; when compressed pouring out azure-blue juice.

\section{In mixed woods. Rare. Aug.-Sept.}

Spores at first milk-white, at length pale lemon-yellow. Fr.; spindle-shaped, I $4 \times 8 \mathrm{mk}$. W.G.S. Becoming instantly intense blue when broken. The down on the pileus is very matted and floccosely scaly. Name-cyanens, deep blue. From the flesh becoming deep blue. Bull. t. 369 . Fr. Hym. Eur. p. 517. Syst. Myc. i. p. 395. Sv. ätl. Sv. t. 80. Berk. Out. p. 236. C. Hbk. n. 732. S. Mlycol. Scot. n. 689. Letell. t. 654. Krombh. t. 35. f. 7-9. Barla t. 37. Rostk. t. 44. Harz. t. 71. Saund. Eo Sm. t. 47 (dark).

40. B. castaneus Bull.-Pileus $5-7.5$ cent. ( $2-3$ in.) broad, cinnamon, opaque, convexo-expanded or depressed, firm, even, velvety; flesh white, unchangeable. Stem $5-7.5$ cent. (2-3 in.) long, stuffed then hollow, attenuated from the somewhat bulbous base, even, velvety, opaque, cinnamon. Tubes free, curt, white; pores minute, round.

Smaller than $B$. cyanescens, not juicy. Pileus at first embracing the base of the stem, whence the stem when young is obsoletely somewhat marginatobulbous, not constricted at the apex as in $B$. cyanescens.

In woods. Rare.

Name-castanea, chestnut. Chestnut-coloured. Bull. t. 328. Fr. Hym. Eur. p. 517. Syst. Myc. i. p. 392. Berk. Ont. p. 236. C. Hbk. n. 733. Barla t. 32. f. II-15. Krombh. t. 4.f. 28-30. Hussey, ii. t. i7.

Subg. I. GYRODON.

No British species. 
Boletus.

Strobilomy. ces.

\section{Subg. II. Boletinus. \\ No British species. \\ Of uncertain affinity.}

41. C. carnosus Rostk. Compact.-Pileus fuscous, pulvinate, smooth; flesh pallid, dirty yellowish. Stem short, firm, somewhat striate, rufescent light yellow. Tubes adnate (according to the fig. depressed round the stem), clark yellow; pores rather large, angular, of the same colour.

According to the fig. the pileus is purplish-fuscous. In woods. Stoke Poges. Name-carnosus, fleshy. Rostk. t. I4. Fr. Hym. Eur. p. 520. B. \& Br. n. 1426 .

Genus XXII.-Strobilomyces Berk. ( $\sigma \tau \rho o ́ \beta \iota \lambda$ s, a pine-cone;

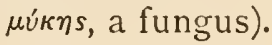

Hymenophore quite distinct from the hymenium. Pileus fleshy, at length tough. Spores glo-

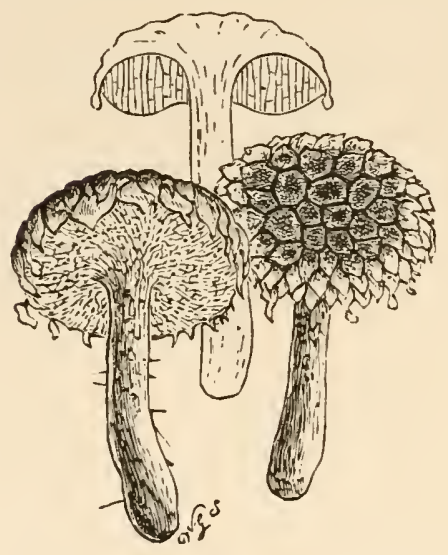

LXI. Strobilomyces strobilaceus.

One-sixth natural size. bose or broadly elliptic, minutely rough. Berk. Out.p. 236.

1. S. strobilaceus Berk. Blackishumber. - Pileus pulvinate, rough with thick floccose scales. Stem equal, veiled, sulcate above. Tubes adnate, white, angular, whitishbrown.

Pileus tesselated or cracked like the cone of the Scotch fir.

In fir woods. Very rare. Bullstrode. Ludlow. Haywood Forest, Herefordshire. Oct.

Pileus 5-1o cent. (2-4 in.) broad, brownumber, tough, pulvinate, broken up into large, thick, projecting scales, merging into a thick, floccose, ragged and pendulous, white veil at margin. Stem $7 \cdot 5^{-15}$ cent. (3-6 in.) long, I $2 \mathrm{~mm}$. ( $1 / 2 \mathrm{in}$.) or more thick, solid, equal, coarsely tibrillose, brown at the base, white at the deeply sulcato-reticulated apex, which runs gradually into the tubes. Tubes white, very large, adnate, or with a decurrent tooth, anastomosing. The whole plant turns deep sienna-red when cut or bruised. W.G.S. Spores very dark. M.F.B.; oval, nearly globose, stalked, blackishbrown, $9 \times 13 \mathrm{mk}$. W.G.S. Berk. Out. p. 236. C. Hbk. n. 734. Boletus strobilaceus Scop. Ann. Nat. Hist. iv. t. r.f. I. Berk. Eng. Fl. v. p. I54. 
Fr. Hym. Eur. p. 513. Dicks. Crypt. Brit. t. 3. f. 2. Krombh. t. 74. f. 12, 13. Rostk. t. 38. Quel. t. I6. f. I.-Vent.t. 43.f. 1, 2. Pers. Myc. Eur. 2. t. 19.

Genus XXIII.-Fistulina ( fistula, a pipe. From the pipe-like Fistulina. character of the tubes). Bull. Champ. p. 3I4.

Hymenium inferior, at the first dotted over with warts, then protruding cylindrical tubes, which are free and distinct from one another. Somewhat fleshy fungi, growing on wood, intermediate between Polyporei and Hydnei. Fr. Hym. Eur. p. 522.

1. F. hepatica Fr. Juicy-fleshy, not rooting. - Pileus entire, bloodred; flesh thick, soft, viscid above, traversed with tenacious fibres, hence variegated-red. Tubes at first pallid.

Changeable in form, sessile or extended into a lateral stem.

On living oak. Common in England. Aug.-Oct.

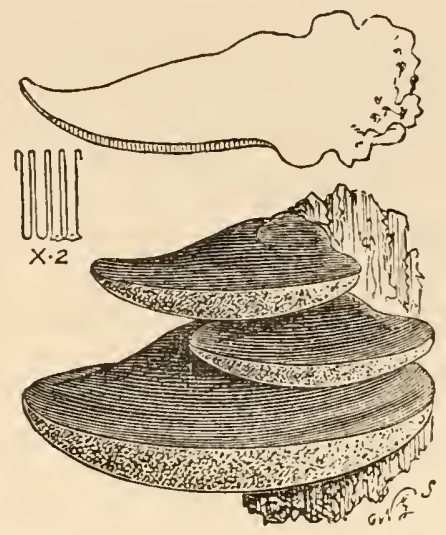

LXII. Fistulina hepatica. Onefifth natural size. Section two times natural size.

Pileus roundish, dimidiate or subspathulate. Substance thick and juicy, marbled like beet-root, distilling a red pellucid juice; hymenium convex. Taste rather acid. It attains sometimes an enormous size, even nearly $30 \mathrm{lb}$. in weight. M.F.B. Spores salmon-colour, nearly round with an oblique apiculus, $3 \mathrm{mk}$. WV.G.S. Edible and nourishing, but rather coarse, and not of a very pleasant flavour. Known as the beef-steak fungus. Slices exactly like beef-steak. Name-i் $\pi$ ăткós, of the liver; diseased in the liver. From its appearance. Fr. Hym. Eur. p. 522. Sv. ätl. Sv. t. 25. Berk. Out. p. 257.t. I7. f. I. C. Hbk. n. 84r. S. Mycol. Scot. n. 690. Grev. t. 270. Ventur. t. 36. f. 1, 2. Barla t. 30. f. 4-7. Hogg \& Fohnst. t. 7. Hussey i. t. 65. Badh. i. t. I2. f. 4 ; ii. t. I2. f. 2. Pricef: 22.-Huds. Schaff. t. I 6. 120. Bolt. t. 79. Sow. t. 58. Fl. Dan. t. 1039. Bull. t. 74, 464, 497.

Genus XXIV.-Polyporus. Fr. Obs. Myc. i. p. I2I.

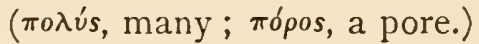

Hymenophore descending and forming a trama between the pores. Hence the pores are connate with the substance of the 
Polyporus. pileus, and not separable from one another; they are at first rudimental or altogether wanting, then round, angular, or torn. Persistent fungi, most of them
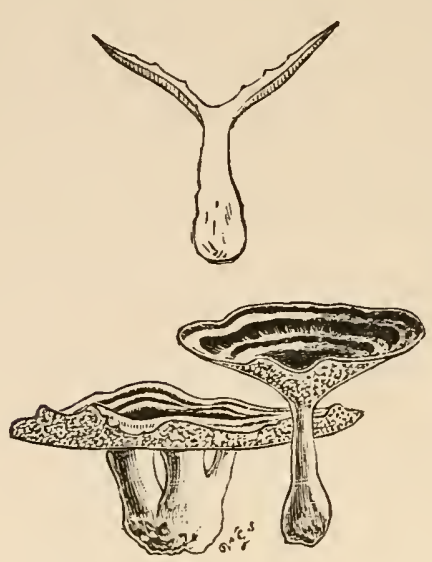

LXIII. Polyporus perennis. Onethird natural size. growing on wood, not fully formed before expansion like Boleti, but growing gradually and indefinitely. Odour, if any, slightly acid.

A genus holding the like central place in this order as Agaricus does in the former one, of immense extent, and specially abundant in the number of its species in warm countries on account of the greater variety of trees. Fr. Hym. Eur. p. 522.

A few are edible, but not recommended.

I. Mesopus ( $\mu \in \sigma o ́ s$, middle ; moús, a foot). Pileus entire or excentric. Stem distinct, vertical, simple, of the same colour at the base, and not definitely blackish.

A. Carnosi (caro, flesh). Pileus fleshy, fragile or pliant (but not coriaceous), zoneless. White-spored, growing on the ground, edible, autumnal.

* Pileus unpolished, scaly or floccose.

* Pileus polished, smooth.

B. Lenti (lentus, tough, pliant). Pileus fleshy-pliant then coriaceous, zoneless. White-spored, growing on trunks, persistent.

* Pileus unpolished, scaly or villous.

** Pileus even, smooth.

C. Spongiosi (spongia, a sponge). Pileus at first spongy-soft, absorbing water, tomentose, then corky or coriaceous. Stem curt, irregularly shaped. Pores irregularly shaped, pruinose, changing colour, but the spores (of all of them ?) white. - A very varied group, of striking appearance, mostly growing on the ground. At first they appear as a rooting, somewhat crustaceous mass, effused and encrusting, shapeless, spongy and juicy, tomentose; from this is evolved a pileus, which is sometimes remarkably regular, with a central stem, and of large size, sometimes by growing into one another irregular and lobed, nay dimidiate. They only last in a dead state to the following spring, but thereafter are covered over with a new stratum of pores. In all these respects they are analogous to Thelephore (e.g. Th. terrestris). Most of them rare, confined to certain localities.

D. Subcoriacei (corium, a hide, leather). Pileus at the first indurated, arid, when full grown corky or coriaceous. Stem definite. Pores at first sprinkled over with a white bloom. Substance of a ferruginous colour. Growing on the ground or trunks, more rigid than the Spongiosi, more regular and persistent, but not reviving.

* Pileus tomentose, velvety.

* Pileus very smooth.

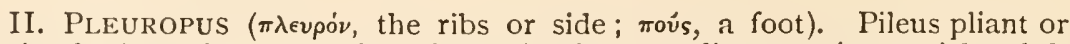
corky, horizontal, not circular. Stem simple, ascending, corticate, either defi- 
nitely lateral or excentric, always black at the base. Growing on wood, and Polyporus. not on the ground.

A well-defined group. Species with excentric stems occur both in this and in the former group, but the definitely black base at once distinguishes then.

A. Lenti. Pileus feshy-pliant, zoneless. Stem excentric, blackish at the base. Tubes short. Substance pallid, somewhat fibrous.

* Pileus scaly or floccose.

** Pileus even, very smooth.

B. Suberoso-lignosi (corky-woody). Pileus thick, hard, zoneless. Stem stout, vertical, of the same colnur at the base. Pores elongated. Species not closely allied to one another nor to the preceding group.

III. MERISMA ( $\mu \in \rho i \zeta \omega$, to divide). Syst. Myc. i. p. 354. From a common trunk or tubercle proceed very many pileoli, arising from the subdivision of the primary pileus, which are at first, at least potentially, porous all over, but the side which is turned to the light is sterile. (In dark underground places they often remain club-shaped and porous.) Very handsome fungi, becoming free, by far the largest of all fungi, composed of many small pilei cohering the one with the other.

A very distinct group, well marked off from the rest, and only verging back by imperfect forms to the Mesopodes.

A. Carnosi. Pileus fleshy, firm, flcccoso-fibrous, zoneless, not coriaceoindurated. Tufts central, stipitate, springing from a common base, more or less concrete, so that in slender forms they occasionally resemble a central, simple, lobed pileus. Pores separating from the pileus. IVhite-spored, partially growing on the ground, autumnal, all certainly edible.

B. Lenti. Pileus fleshy-pliant then somewhat coriaceous, more or less zoned, fibrous within. Pores adnate. Tufts lateral, somerwhat stipitate, in many imbricated layers, stems more or less connate, or growing from a common tuber. White-spored, not edible, fragile when old, antumnal and not lasting till the following spring, occurring at the base of trunks.

C. Caseosi (caseus, cheese). Pileus cheesy, at first soft and juicy, then arid, fragile, without a pellicle, zoneless; pores separating. Tufts sessile on the stems of trees, commonly dimidiate, but in a horizontal situation expanded on all sides, central, at the first evolved from a single shapeless tubercle into numerous pileoli. Acid. Occurring from spring through the whole summer, but soon decaying.

D. Suberosi (suber, cork). Pileus corky or coriaceous, persistent, tough ; substance floccose, somewhat soft, suitable for tinder, pores adnate. Tufts somewhat sessile, lateral or central according to situation, but the pileoli are drawn together and free at the base and not effused. On trunks close to the ground. Not edible.

IV. ApUs ( $\alpha$, without; rov́s, a foot. Stemless). Pileus sessile, normally adnate by a thickened and dilated base and dimidiate, or entire and attached behind (commonly by an umbo), more rarely attenuated and sessile (a transition to the Pleuropodes), more frequently wholly resupinate (always abnormal states; the true Kesupinati are very different having no pileus). Growing on wood, very abundant, with an endless variety of forms.

A. Anodermei (ả $\nu$ sép $\mu \alpha$, skin. Without a cuticle). Pileus without a cuticle. consequently the naked surface is broken up into flocci or fibres, zoneless, but within transversely zoned, or more or less fibrous. Always annual, somewhat fleshy, and not reviving.

I. Carnosi. Pileus cheesy, at first of a watery softness, fragile, flocculose 
Polyporus. and not bristly-hispid, pores white. When more fully grown sometimes soft, sometimes hardened, but soon putrefying and not lasting through the winter.

* Eupolypori. Pores round, entire, obtuse, without small teeth.

** Pores elongated, flexuous, acute, and torn. Species in this section do not become hard.

2. Lenti. Pileus fleshy-pliant (tough even in younger specimens), soft, elastic, villoso-tomentose on account of the fibroso-floccose texture of the substance; pores somewhat adnate, coloured. Always soft, somezhat flexile, lasting to the following spring, joined by intermediate forms to the preceding group, but manifestly presenting a different type.

* Substance coloured.

** Substance white.

3. Spongiosi. At first and while fresh moist, spongy, when dry firm, elastic, for the most part bristly-hispid, internally fibrous. The flesh commonly presents an intermediate stratum, more compact than the exterior. Firm, but annual, autumnal, the finest specimens on living trunks. Commonly mixed up with $P$. stupposi which are always dry and rigid not spongy.

* Substance coloured.

** Substance and spores white.

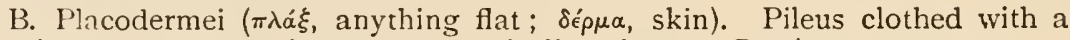
continuous crust, zoneless or concentrically sulcate. Persistent.

4. Suberosi. Pileus at the first somewhat fleshy and juicy, then hardened, covered with a rather thin crust ; pores slender, at length somewhat separating. Autumnal, in some cases lasting to the following spring, but never reviving so as to produce strata. Differing from the foregoing by the cuticle, from all the following by the pileus being at first fleshy and juicy.

* Substance coloured.

** Substance, which is not zoned, and spores white.

5. Fomentarii (fomentum, fuel. From some species, e.g., P. fomentarius, being used as tinder). Pileus floccose, of the nature of tinder, juiceless from the first, not fleshy or spongy, covered with a hard, horny crust, the pores at length stratose. Growing on wood, somewhat pulvinate, truly perennial, adding new strata year by year. In specimens from to to 20 years of age narrow zones corresponding with warm and dry years, and thick and broad ones corresponding with rainy years can be observed. Care must be taken not to be deceived by a specimen of the first season, without strata. In old specimens the cuticle is here and there broken into chinks or wasted away.

* Substance and pores umber or fuscous.

** Substance and pores somewhat fermginous.

*** Substince white or pallid.

6. Lignosi (lignum, wood). Pileus from the first hard, woody, juiceless, covered with a thin, somewhat varnished crust, which is smooth or becomes so, somewhat effused at the base; pores not stratose. Perennial (not putrefying) but not stratose, flatter than the former group or effuso-reflexed.

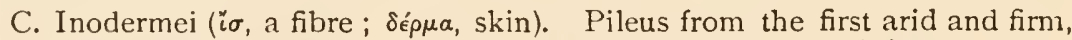
with a thin fibrous cuticle. Annual or biennial fungi, not reviving.

7. Stupposi (stuppa, flax). Pileus flocculose then smooth, or adpressedly villous, uneven, zoneless, texture fibrous.

* Substance coloured.

* Substance white.

8. Coriacei (corium, a hide). Pileus coriaceous, villous, banded with concentric zones which are generally of different colours.

V. REsUPinati. Pileus none, consequently the fungus is absolutely resupinate; pores immediately seated on wood or on the mycelium without the 
intervention of any subiculum (except in the case of $P$. medullapanis and P. Polyporus. mucidus).

'The species of this group must be cautiously examined. For many species of Apodes are found in a resupinate state when growing in a horizontal situation, e.g., P.mollis, destructor, croceus, nidulans, amorphus, adustus, igniarius, radiatus, conchatus, abietinus.

In a horizontal situation the pores in this group are straight, in a vertical one oblique, nay gaping at one side.

* Pores fuscous or blackish.

* Pores ferruginous or cinnamon.

*** Pores purple or violaceous.

**** Pores red.

***** Pores yellowish. Compare P. vulgaris.

****** Pores white then changing colour.

******* Pores persistently white, minute, crowded, in a plane situation round, equal.

******** Pores persistently white, unequal, angular, close to one another, commonly rather large.

********* Pores white, superficial, distant, punctiform.

I. Mesopus. Pileus entire, \&c.

A. Carnosi.

* Pileus unpolished.

1. P. leucomelas Fr.-Pileus $5-7.5$ cent. (2-3 in.) broad, black-fuliginous, fleshy, somewhat fragile, irregularly shaped, slightly silky-squamulose; flesh white, reddish when broken. Stem 2.5-7.5 cent. (I-3 in.) long, stout, unequal, somewhat tomentose, of the same colour as the pileus. Pores rather large, unequal, cinereous, whitish.

The stem is sometimes curt, 2.5 cent. ( $\mathrm{I}$ in.) and tuberous, sometimes 5-7.5 cent. $(2-3$ in.) and equal, also becoming black internally. 'The pores become black in dried specimens.

In fir wood. Rothiemurchus. Sept.

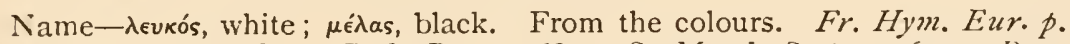
524. Icon. t. I79.f. I. B. \& Br. n. I682. S. Mycol. Scot. n. 691.-Pers. Sym. p. 515 .

** Pileus polished, smooth.

No British species.

B. Lenti. Pileus fleshy-pliant then coriaceous, \&c.

* Pileus unpolished, scaly or villous.

2. P. lentus Berk.-Pileus 4 cent. ( $1 \frac{1 / 2}{2}$ in.) broad, reddishbrown at length ochraceous, fleshy, but tough, umbilicate, minutely scaly, especially at first. Stem 12 mm.-2.5 cent. $(1 / 2-1$ in.) long, $9 \mathrm{~mm}$. ( $3 / 8$ in.) thick, rather slender, incurved, 
Polyporus. central or excentric, hispid, furfuraceous, nearly of the colour of the pileus. Pores irregular, large, decurrent, white.

The stem is covered with pores to the very base, only the lower ones are abortive. Allied to $P$. squamosus.

On Ulex, \&c. Frequent. April.

Name-lentus, tough, pliant. Berk. Out. p. 237. t. r6. f. r. Eng. Fl. v. p. 134. C. Hbk. n. 738. S. Mycol. Scot. n. 692. Lir. Hym. Eur. p. $5^{26 .}$

3. P. brumalis Fr.- Pileus 2.5 -Io cent. ( $\mathrm{I}-4$ in.) broad, fleshypliant then coriaceous, somewhat umbilicate, zoneless, in the first year villous, fuliginous, in the second squamulose becoming smooth, becoming pale; flesh white. Stem 2.5-5 cent. (I-2 in.) long, 4-8 mm. (2-4 lin.) thick, hirsute, squamulose. Pores oblong and angular, thin, acute, toothed, white, at length becoming yellow.

The margin of the pileus is somewhat fimbriato-ciliate. In hollow trunks, $\& c$. , there is a very small form, somewhat pulverulent.

On dead branches. Frequent. Oct.-March.

Pores oblong, slightly curved, hyaline, $6 \times 2 \mathrm{mk}$. $K$. Name-bruma, wirter. Fr. Hym. Eur. p. 526. Syst. Nyc. i. p. 348. Berk. Out. p. 237. C. Hbk. n. 735. S. Mycol. Scot. n. 693. Pers. Batsch f. 42 (first year). Fl. Dan. t. 1297 (second year). P. floccipes Rostk. 28. t. I3.

* Pileus even, smooth.

4. P. fuscidulus Fr.-Pileus $2.5-5$ cent. ( $\mathrm{I}-2$ in.) broad, fuscousyellowish, fleshy, pliant, somewhat coriaceous, convexo-plane, zoneless, smooth; flesh white-yellowish. Stem 2.5-5 cent. (I-2 in.) long, $4 \mathrm{~mm}$. ( 2 lin.) thick, equal or thickened at both ends, smooth, fuscous becoming yellow. Pores somewhat roundedangular, obtuse, quite entire, yellowish.

Among chips, \&c. Rare. Darlington.

Name-fuscus, fuscous, brown. Slightly fuscous. Fr. Hym. Eur. p. 528. Berk. Out. p. 237. C. Hbk. n. 736. Schrad. Bolt. t. I7o.

5. P. leptocephalus Fr. Small.-Pileus under 2.5 cent. (I in.) broad, pale then faron-colour, pliant, then coriaceous, convexoplane, thin, smooth, even, zoneless; flesh white. Stem short, scarcely 2.5 cent. ( 1 in.) smooth, pallid. Pores adnate, minute, somewhat round, obtuse, whitish.

The margin of the pileus is somewhat repand.

On trunks. Rare.

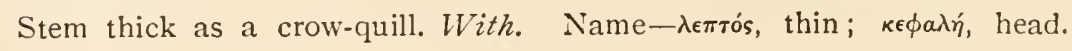


With thin pileus. Fr. Hym. Eur. p. 528. Syst. Myc. i. p. 349. Berk. Out. Polyporus. p. 237. C. Hbk. n. 737. S. Mycol. Scot. n. 694.-Facq. Misc. i. t. I2. Mici. t. 70. f. 7. Paul. t. 16+f. f. 12.

\section{Spongiosi. Pileus at first spongy-soft, \&c.}

6. P. Schweinizii Fr.-Pileus 20 cent. (8 in.) and more broad, date-brozun, thick, spongy-corky, strigoso-tomentose, rugged. Stem thick, very short or obsolete, ferruginous. Pores large, variable in size and torn, sulphur-greenish.

Very large, sometimes regular and plano-cup-shaped, sometimes irregularly shaped and dimidiate from growing into each other and incrusting, at first tawny-tomentose, soon only at the margin, then when old wholly fuscous. The substance when the plant is in fullest vigour is very soft-spongy, then hardened, fragile when dry, rhubarb-colour becoming fuscous.

In pine woods about roots. Rare. July-Oct.

It occurs with a central stem and also imbricated. B. \& Br. Spores oval, white or transparent, $3 \times 8$ mk. W.G.S. Name-after Schweinitz. Fr. Hym. Eur. p. 529. Icon. t. 179. f. 3. Berk. Out. p. 238. C. Hbk. n. 739. S. IIjcol. Scot.n. 695. Su. Bot. t. 720.

7. P. rufescens Fr. Flesh-colour.-Pileus 5-1o cent. (2-4 in.) broad, spongy, soft, unequal, hairy. Stem short, irregularly shaped. Pores large, simuated and torn, white-flesh-colour.

Its growth is quite that of $P$. Schweinizii, but it is smaller, softer, and different in colour both internally and externally.

On stumps. Frequent. Nov.

Name-rufesco, to become red. Fr. Hym. Eur. p. 529. Syst. Myc. i. p. 351. Berk. Out. p. 238. C. Hbk. n. 740. S. Mycol. Scot. n. 696.-Sow. t. $19 \mathrm{I}$.

D. Subcoriacei. Pileus at the first indurated, Sc.

* Pileus tomentose, velvety.

8. P. perennis Fr.-Pileus cinnamon then date-brown, coriaceous, tough, plano-infundibuliform, velvety becoming smooth, zoned. Stem slightly firm, thickened downwards, velvety. Pores minute, angular, acute, at first sprinkled with a white bloom, then naked, torn.

The margin when the plant is in fullest vigour is fimbriate, then entire.

On the ground and stumps. Frequent. July-Jan.

Pileus $4-5$ cent. ( $1 / 2-2$ in.) broad. Stem 2.5 cent. ( $\mathrm{I}$ in.) long, varying in thickness. II. F.B. Spores oval, white, $3 \times 2 \mathrm{mk}$. W.G.S. Name-perennis, perennial. Fr. Hym. Eur. p. 531. Berk. Out. p. 238. C. Hbk. n. 74r. S. Mycol. Scot. n. 697. Rostk. t. 6. Hussey i. t. 5r.-Linn. Schaff. t. I25. Sow. t. 192. Fl. Dan. t. 1075. Bull. t. 28, 449. f. 2. Bolt. t. 87. 
No British species.

II. Pleuropus. Pileus pliant or corky \&c.

A. Lenti. Pileus fleshy-pliant, \&c.

* Pileus scaly or floccose.

9. P. squamosus Fr.-Pileus 3 in. $-\mathrm{I} / 2 \mathrm{ft}$. broad, somewhat ochraceous, variegated with broad, adpressed, spot-like, centri-

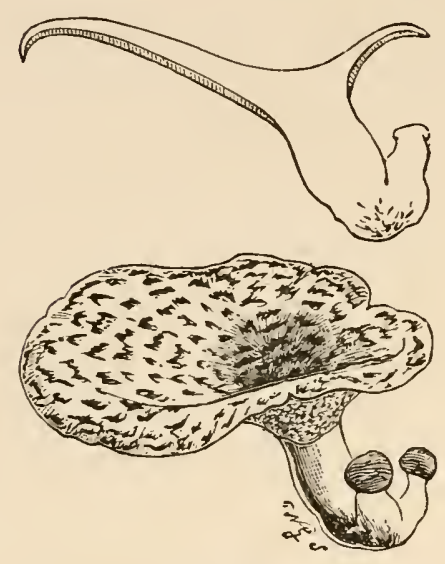

LXIV. Polypornes squamosus.

One-seventh natural size. fugal, darker scales, fleshy pliant, fanshaped, flattened. Stem excentric and lateral, obese, reticulated at the apex, blackish at the base. Pores thin, variable (at first minute), then large angular and torn, pallid.

Handsome, commonly very large, somewhat central and umbilicate when young, at length lateral, very variable in shape.

On trunks and stumps, chiefly ash. Common. May-Nov.

When young a mere swollen blackish lump. Spores oval, white, $\mathrm{I}_{4} \times 6 \mathrm{mk}$. W.G.S. Name--squama, a scale. Scaly. Fr. Hym. Eur. p. 532. Syst. Myc. i. p. 343. Berk. Out. p. 238 . C. Hbk. n. 742. S. Mycol. Scot. n. 698. Grev. t. 207. Rostk. t. 2. Ventur. t. 37. Hussey i. $t .33$. -Huds. Bolt. t. 77. Scheff. t. 101, то2. Bull. t. 19. Harz. t. 32. Fl. Dan. t. 983, I196. Paul. t. 16. Sterb. t. 13, I4. B. pileus fuliginous.

10. P. Michelii Fr. -Pileus 5-7.5 cent. (2-3 in.) broad, yellowish-white, fleshy-pliant, depressed, repand, slightly silky, somewhat squamulose. Stem 4 cent. (I $1 / 2$ in.) long, somewhat lateral, bulbous, rough, white, becoming fuscous at the base. Pores large, somewhat round-oblong, entire, white.

Allied to $P$. squamosus.

On stumps. Penzance.

Name-after Micheli. Fr. Hym. Eur. p. 533. Syst. Myc. i. p. $3+3$. B. \& Br.n. 1963. Rostk. t. I. - Mich. t. 6r. f. 2.

11. P. melanopus Fr.-Pileus $5-7.5$ cent. ( $2-3$ in.) broad, white then yellowish-fuscous, fleshy-pliant, plane then infundibuliform, at first delicately flocculose; flesh thick, white, soft, not 
becoming woody. Stem 4 cent. (1 $1 / 2$ in.) long, $6-8 \mathrm{~mm}$. (3-4 lin.) Polyporus. thick, excentric, somewhat velvety, incurved, thickened downwards, black. Pores decurrent, curt, minute, obtuse, unequal, white.

The pileus is at length, and at first sight smooth. Stem diffused into the pileus.

On dead wood and roots. Uncommon. Aug.-Sept.

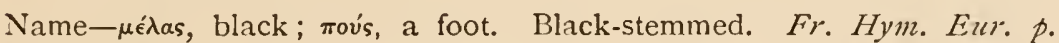
534. Syst. Myc. i. p. 543. B. \& Br. n. 1286. S. Mycol. Scot. n. 699. Rostk. t. 4. -Swartz V. A. H.

** Pileus even, very smooth.

12. P. Rostkovii Fr. - Pileus smoke-colour, fleshy-pliant, dimidiato-infundibuliform, smooth, even. Stem long, excentric, reticulated, abruptly black, thickened at the base. Pores decurrent, large, pentagonal, acute, toothed, white then dingy-yellowish.

In size it vies with $P$. squamosus to which it is allied. The stem is generally longer, incurved, connate and somewhat cæspitose at the base. The pileus inclines to yellowish. The pores are deeply decurrent on the outer side of the stem.

On stumps. Rare.

Pileus 15 cent. ( 6 in.) broad. Stem long. Pores 4 mm. (2 lin.) or more long. $B$. \& $B r$. Spores with two nuclei, $44 \times 6 \mathrm{mk}$. W.G.S. Name-after Rostkovius. Fr. Hym. Eur. p. 534. Berk. Out. p. 238 . C. Hbk. n. 743. Rostk. $t$. I7.

13. P. picipes Fr.-Pallid then chestnut, commonly pale yellowish-livid, with the disc chestnut. Pileus fleshy-coriaceous then rigid, tough, even, smooth, depressed at the disc or behind; flesh white. Stem excentric and lateral, equal, firm, at first velvety, then naked, dotted, black up to the pores. Pores decurrent, round, very small, rather slender, white, then slightly pale yellowish.

Imbricated, odour somewhat sweet. The pileus is depressed behind, com. monly emarginate, infundibuliform with lobes all round.

On trunks, especially willow. Frequent. July-Dec.

Name-pix, pitch; pes, a foot. Black-stemmed. Fr. Hym. Eur. p. 534. Berk. Out. p. 239. C. Hbk. n. 744. S. Mycol. Scot. n. 700.-Grev. t. 202. Pers. Ic. pict. t. 4. f. I, 2.

14. P. varius Fr.-Pileus commonly bay-brown, fleshy-pliant, extenuated, soon woody, smooth, somewhat virgate, irregularly shaped, depressed at the disc or behind. Stem excentric and 
Polyporus. lateral, even, smooth, gradually cinereous-blackish downwards. Pores decurrent, minute, curt, round, unequal, whitish (internally watery) then cinnamon.

In stature, form, \&c., it is not constant. The colour is commonly bay-brown (fuliginous and very evidently virgate when old) but (compare Bolt. $t$. I68) pale when young, and when full grown, as it is also internally, light yellowish. It varies sessile; also crowded in very large, irregularly shaped tufts, in habit quite as in Schaff. $t$. I09, I IO.

On trunks and stumps, especially ash. Frequent. Aug.-Oct.

Pileus $12 \mathrm{~mm}$.-ro cent. $(1 / 2-4$ in.) broad. M.F.B. Name-varius, variable (in size, form, colour, \&c.) Fr. Hym. Eur. p. 535. Berk. Out. p. 239. C. Hbk. n. 745. S. Mycol. Scot. n. 701. Batschf. 129. Ventur. t. 57.f. 2.Rostk. 28. t. 24, t. 20. Buxb. C. v. t. I5.f. 2.

15. P. elegans Fr.-Pileus 5-Io cent. (2-4 in.) broad, unicolorous, pallid ochraceous or orange, shining, equally fleshy, then soon hardened, becoming woody, flattened, even, smooth; flesh white. Stem excentric or lateral, even, smooth, pallid, at the first abruptly black and rooting at the base. Pores plane, minute, somewhat round, yellowish-white, pallid.

White when young. The pileus is not streaked, nor is it infundibuliform, scarcely depressed. The flesh is thick to the margin.

On trunks, chiefly birch. Frequent. July-Nov.

Pileus 5-10 cent. (2-4 in.) broad. Name-elegans, elegant. Fr. Hym. Eur. p. 535. Berk. Out. p. 239. C. Hbk. n. 746. S. Mycol. Scot. n. 702. Bull. t. 46. Fl. Dan. t. 1075. f. r. Rostk. t. Ix. Bolt. t. 83.

* P. nummularius Fr. Smaller, thinner.-Pileus scarcely 2.5 cent. (I in.) broad, somewhat regular. Stem equal, excentric.

It merges in $P$. elegans without definite line of demarcation. On trunks. Uncommon. Dec. Name - nummulus, a small coin. From fancied resemblance of shape. Fr. Hym. Eur. p. 536. Berk. Out. p. 239. C. Hbk. n. 746. S. Mycol. Scot. n. 702. Kostk. t. 12. Bull. t. 124.

16. P. petaloides Fr.-Pileus chestnut-fuscous, somewhat membranaceous, spathulate, rugose, smooth, zoneless, flaccid when moist. Stem lateral, ascending, compressed, smooth, not rooting, whitish, adnate at the base which is dilated in the form of a shield. Pores decurrent, very short, very small, shining white.

When dry it is involute and fragile, not becoming woody like preceding species.

On old stumps. Sibbertoft.

Name-from some fancied resemblance to the petal of a flower. Fr. Hym. Eur.p. 536. B. S Br. n. 2023. 
B. Suberosi-lignosi. Pileus thick, hard, zoneless, \&c.

17. P. lucidus Fr.-Pileus light yellow then blood-red-chestnut, corky then woody, fan-shaped, sulcato-rugose. Stem lateral, equal, varnished, shining, of the same colour as the pileus. Pores determinate, long, minute, white then cinnamon.

On and about stumps. Frequent. Summer.

Pileus 5-I5 cent. (2-6 in.) broad. Stem I5-25 cent. (6-ro in.) long, 2.5 cent. ( $\mathrm{r}$ in.) or more thick. M.F.B. Name-lucidus, bright, shining. From the stem. Fr. Hym. Eur. p. 537. Berk. Out. p. 240. t. I6.f 2. C. Hbk. n. 748. S. Mycol. Scot. n. 703. Krombh. t. 4. f. 22-24. Rostk. t. 13. Grev. t. 245. Ventur. t. 49.-Leys. Sow. t. 134. Fl. Dan. t. 1253. Schaff. t. 263. Batsch f. 225. Bull. t. 7, 459 .

\section{Merisma. Very many pileoli, \&c.}

A. Carnosi. Pileus fleshy, firm, \&c.

18. P. umbellatus Fr.-Very much branched, fibrous-fleshy, toughish. Pileoli very numerous, I-4 cent. $\left(1 / 2-I \frac{1}{2}\right.$ in.) broad, fuliginous, rufous or pallid light yellow, entire, umbilicate. Stems elongated, separate, united at the base, white. Pores minute, white.

The pileoli have occurred white.

On stump. Epping. July.

Cluster about $17.5 \times 12.5$ cent. $(7 \times 5$ in.) M.C.C. Name-umbella, a sunshade, parasol. From its spreading habit. Fr. Hym. Eur. p. 537. Syst. Myc. i. p. 354. Grevillea, vol. xii. p. 36. Krombh. t. 52. f. 3-9. Lenz f. 44. Tratten. t. T. Quel. t. 18. f. 1.-Schaff. t. iii. 265, 266. Facqu. Austr. $t$. I72. Fl. Dan. t. I I97.

19. P. frondosus Fr.-Tuft I5-30 cent. ( $1 / 2-I \mathrm{ft}$.) broad, very much branched, fibrous-fleshy, toughish. Pileoli very numerous, $\mathrm{I}-5$ cent. ( $1 / 2-2$ in.), fuliginous-grey, dimidiate, rugose, lobed, intricately recurved; flesh white. Stems growing into each other, white. Pores rather tender, very small, acute, white.

Pores commonly round, but in an oblique position gaping open and torn.

On stumps and roots. Rare. Oct.

Name-frons, a leafy branch. Branched. Fr. Hym. Eur. p. 538. Syst. Myc. i. p. 355. Sv. ätl. Sv. t. 44. B. \& Br. n. 1364. Krombh. t. 48. f. 17-20. Rostk. t. 18.-Fl. Dan. t. 952. Paul. t. 29. Sterb. t. 28.

20. P. intybaceus Fr.-Very much branched, fleshy, somewhat fragile. Pileoli very numerous, pale yellowish inclining to fuscous, dimidiate, stretched out, sinuate, at length spathulate.

VOL. II. 
Polyporus. Stems connate in a very short trunk. Pores firm, obtuse, white inclining to fuscous.

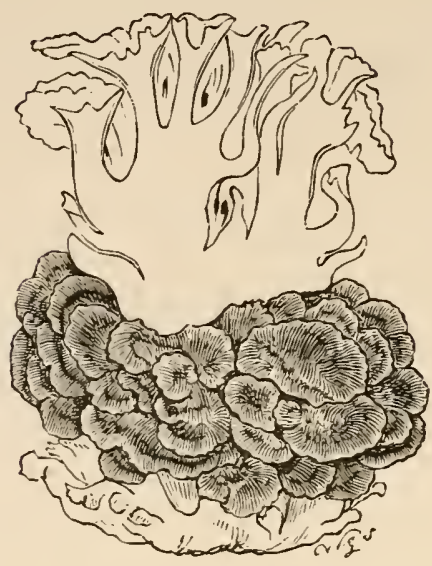

LXV. Polyporus intybaceus. One-sixth natural size.

B. truncigenus flaps elongated, conchate, extended laterally, undulated, paler. Paul. t. 130. Odour of mice.

On stumps, especially oak. Rare. Sept.

About same size as $P$. frondosus and larger. Spores oval, white, $6 \times 3 \mathrm{mk}$. W.G.S. Edible. Name-from its likeness in habit of growth to succory (Cichorium intylus). Fr. Hym. Eur. p. 538. Berk. Out. p. 240. C. Hbk. n. 749. S. Mycol. Scot. n. 704. Hussey i. t. 6.-Fl. Dan. t. x793.

21. P. cristatus Fr. - Branched, firmly fleshy, fragile. Pileoli about 7.5 cent. (3 in.) broad, rufous-greenish, entire and dimidiate, imbricated, depressed, somewhat pulverulent-villous, then rimosely scaly. Stems connate, irregularly shaped, white. Pores minute, angular and torn, whitish.

Very changeable in form, sometimes simple with an undulato-lobed, central pileus. B. flabelliformis Schaff. $t .113$.

In beech woods. Rare.

Name-crista, a crest. Crested. Fr. Hym. Eur. p. 539. Syst. Myc. i. p. 356. Berk. Out. p. 240. C. Hbk. n. 75o. S. Mycol. Scot. n. 705. K̈rombh. t. 48. f. 15-16. Barla t. 29. f. 4-7. Rostk. t. 16.-Pers. Myc. Eur. ii. p. 50.

B. Lenti. Pileus fleshy-pliant then somewhat coriaceous, \&c.

22. P. giganteus Fr.-Tuft $\mathrm{I}-2 \mathrm{ft}$. and more broad, in many imbricated layers, fleshy-pliant then somewhat coriaceous. Pilei date-brown, dimidiate, very broad, flaccid, somewhat zoned, rivulose, depressed behind. Stems connato-branched from a common tuber. Pores minute, somewhat round, pallid, at length torn.

The rigid cuticle separates into granules or fibrillose squamules. Pores becoming dark when touched. Sept.

On stumps and old roots under ground. Frequent. Aug.-

It occurs 3-4 ft. broad. Name-gigas, a giant. Gigantic. Fr. Hym. Eur. p. 540. Syst. Myc. i. p. 356 . Berk. Out. p. 240. C. Hbk. n. 75I. S. Mycol. Scot. n. 705. Hussey i. t. 82.-Pers. Schaff. t. 267. Bolt. t. 76. Var. claveformis: Holmsk. Ot. 2. t. $\mathbf{1}_{3}$. 
23. P. acanthoides Fr. - In many imbricated layers, pliant Polyporus. then coriaceous. Pileoli ferruginous, infundibuliform, incisodimidiate, somewhat zoned, longitudinally rugose. Stems connato-branched, white then rufescent. Pores lamelloso-sinuate, thin, toothed at the edge, white then rufescent.

Thinner than $P$. giganteus, pale when young. Although it is somewhat coriaceous, it very soon hardens, and becomes fragile when old. $P$. rufescens differs sufficiently in the spongy, hairy pileus, in not being undulato-lobed, \&c.

On trunks. Penzance.

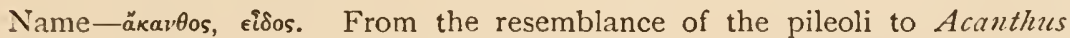
leaves. Fr. Hym. Eur. p. 540. B. \& Br. n. 1694.-Bull. t. 486. Pers. Ic. Pict. t. 6.

\section{Caseosi. Pileus cheesy, \&c.}

24. P. sulphureus Fr.-In many cæspitose layers, I-2 ft. and more, juicy-cheesy. Pilei 20 cent. (8 in.) or more broad, reddishyellow, imbricated, undulated, rather smooth; flesh light yellowish, then white, splitting open and not hardened when old. Pores minute, plane, sulphur-yellow.

Son becoming pale. Commonly sessile, but varying with a stem (Batt. t. 34. B. Paul. t. I4), lateral on standing trees, but expanded on all sides on fallen ones; also club-shaped, porous throughout, Sow. In its fullest vigour it is filled with sulphur-yellow milk.

On living trees and stumps. Frequent. Aug.-Oct.

Whole mass sometimes $2-21 / 2 \mathrm{ft}$. broad. A lovely plant, of delicate shades. Spores oval, white, minutely papillose, $8 \times 5 \mathrm{mk}$. IV.G.S. Edible. Namesulphur, brimstone. Sulphur-yellow. Fr. Hym. Eur. p. 542. Syst. Myc. i. p. 357. Sv. ätl. Sv. t. 88. Berk. Out. p. 241. t. 16. f. 3. C. Hbk. n. 752. S. Mycol. Scot. n. 707. Grez. t. II3. Ventur. t. 53. f. 6-7. Rostk. t. 20. Hussey i. t. 46.-Bull. t. 429. Sow. t. 135. Schaff. t. I3I, 132. Fl. Dan. t. 1019.

25. P. Herbergii Rostk.-Cæspitose, rather corky. Pileoli imbricated, bright bay, sulphury about the margin. Pores labyrinthiform, unequal, torn and toothed, pale cinereous.

On trunks. Edinburgh Fungus Show, i878. Oct.

Referred with doubt to $P$. spongia by Fries. Berkeley considers it clearly the plant of Rostkovius. Name-after Herbergius. Rostk. xxix. $t$. 18. $B$. E Br. n. 1805. Grevillea, viii. p. 6. P. spongia Fr. Hym. Eur. p. $5 t^{2}$. S. Mycol. Scot. n. 708.

26. P. alligatus Fr.-In many cæspitose layers, fibrous-fleshy, rigid-fragile. Pilei tan-isabelline, imbricated, unequal, zoneless, villous. Pores minute, soft, white, readily becoming stopped up with flocci. 
Polyporus. Often clavate when young. Commonly wrapping round stipules and grasses.

On roots, \&c. Rare.

Name-alligo, to bind to. From its habit of growth. Fr. Hym. Eur. p. 543. Berk. Out. p. 24I. C. Hbk. n. 753. S. Mycol. Scot. n. 709.-Sow. t. 422 .

D. Suberosi. Pileus corky or coriaceous, \&c.

27. P. heteroclitus Fr.--In many cæspitose layers, coriaceous. Pilei 6 cent. $(21 / 2 \mathrm{in}$.) broad, orange, sessile, expanded on all sides from a radical tubercle, lobed, villous, zoneless. Pores irregularly shaped and elongated, golden-yellow.

On the ground under oak. Rare.

The flat pilei extend horizontally from the tubercle. Name- $\ddot{\epsilon} \tau \rho \circ$, one of two; $\kappa \lambda i \nu \omega$, to lean. Irregular, excentric. Fr. Hym. Eur. p. 544. Syst. Myc. i. p. 344. Berk. Out.p. 241. C. Hbk.n.754--Bolt. t. I64.

28. P. salignus Fr.-Cæspitose, coriaceous-soft, elastic. Pilei whitish, dimidiate, imbricated, dilated-reniform, adpressedly villous, depresso-sulcate round the margin which is somewhat lobed and swollen. Pores thin, crowded, elongated, intricately flexuous, white.

The tufts are commonly small, inodorous.

On willows. Uncommon.

Name-salix, willow. Fr. Hym. Eur. p. 544. Berk. Out. p. 241. C. Hbk. n. 755.-Pers. Bolt. t. 78. Batt. t. 38.f. E.

IV. Apus. Pileus sessile, \&c.

A. Anodermei. Pileus without a cuticle, \&c.

I. Carnosi. Pileus cheesy, \&c.

* Eupolyporei. Pores round, entire, Eoc.

29. P. epileucus Fr.-Pileus 7.5-1o cent. (3-4 in.) broad, $2.5-5$ cent. (I-2 in.) thick, whitish, similar internally, cheesy-soft then firm, pulvinate, villous-rugged. Pores minute, round, quite entire, white.

Simple, semi-orbicular, concave beneath, not fibrous internally, scarcely zoned; pores at first scarcely discernible.

On stumps, chiefly fir and elm. Rare. Sept.-Oct.

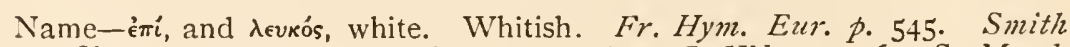
Seem. Fourn. 1868, p. 34. B. \& Br. n. 1287. C. Hbk. n. 756. S. Mycol. Scot.n. 7 10. $-F l$. Dan. t. I794. 
30. P. alutaceus Fr.-Pileus 2.5 cent. ( $\mathrm{I}$ in.) broad and thick, Polyporus. tan, fleshy, at length tough, reniform-dilated, somewhat velvety, obsoletely zoned within, margin acute, even. Pores very small, thin, somewhat round, whitish-tan-colour.

Somewhat imbricated, sometimes convex, sometimes flattened, occasionally hairy and rugose, plane beneath.

On decayed pine-stumps. Glamis, 1876. Sept.-Oct.

Tubes about $18 \mathrm{~mm}$. ( $3 / 4$ in.) long. Name-aluta, tanned leather. Tancolour. Fr. Hym. Eur. p. 545. Syst. Myc. i. p. 360. B. E Br. n. 1799. S. Mycol. Scot. n. 7II.-Rostk. t. 3 o.

31. P. pallescens Fr.-Pileus 5 cent. (2 in.) broad, yellowish, the acute margin of the same colour, fleshy then corky, even, smooth, zoneless. Pores curt, minute, round, white, then yellowish.

Somewhat cæspitose, commonly small and thin, of doubtful affinity.

On old stumps. Rare.

Name-pallesco, to grow pale. Fr. Hym. Eur. p. 546. Syst. Myc. i. p. 369. Berk. Out. p. 244. C. Hbk. n. 773.-Sozv. t. 230.

32. P. chioneus Fr. - White. Pileus 2.5 cent. (I in.) and more broad, fleshy, soft, becoming even, smooth, zoneless, often extended behind, margin inflexed. Pores curt, very small, round, equal, quite entire.

Always soft, fragile, hyaline-white when moist, shining white when dry. Odour acid. Without a cuticle.

On stumps, \&c. Uncommon. July-Sept.

Spores white, oval, $21 \times 3$ mk. W. G.S. Name- $\chi \iota \omega v$, snow. Snow-white. Fr. Hym. Eur. p. 546. Berk. Out. p. 241. C. Hbk. n. 757. S. Mycol. Scot. n. 712.-Pers. Myc. Eur. 2. t. 15. f. 2.

33. P. cerebrinus B. \& Br.-About 2.5 cent. ( $\mathrm{I}$ in.) across, snow-white, pulvinate, delicately tomentose, becoming smooth, margin crenate. Pores rouncled, entire, dissepiments thick, obtuse.

Looks like a portion of white brain.

On fir. Glamis, 1877. Aug.

Name-cerebrum, brain. Brain-like. B. \& Br. n. I8oo. S. Mycol. Scot. n. 7 1 3 .

** Pores elongated, flexuous, Ecc.

34. P. lacteus Fr.-Shining white. Pileus fleshy-fibrous, 
Polyporus. fragile, triangular, pubescent, zoneless externally and internally; margin inflexed, acute. Pores thin, acute, toothed, at length labyrinthiform, torn.

Commonly small, thin, but sometimes larger, transversely elongated, very much sloped downwards and gibbous behind, at length becoming smooth and uneven.

On dead laburnum and birch. Rare. Sept.-Nov.

Name-lac, milk. Milk-white. Fr. Hym. Eur. p. 546. Icon. t. 182. f. I. S. Mycol. Scot, n. 714. Rostk. t. 23 .

35. P. fragilis Fr.-Whitish, spotted with fuscous when touched. Pileus fleshy, fibrous, fragile, plano-depressed and reniform, rugose, convex beneath. Pores thin, elongato-flexuous, intricate.

Very distinct, although no form is constant. It varies stretched out in the form of a stem and pendulous.

On dead pine. Uncommon. Sept.-Nov.

Name-fragilis, fragile. Fr. Hym. Eur.p. 546. Icon. t. 182.f. 2. Berk. Out.p. 242. C. Hbk. n. 758. S. Mycol. Scot. n. 7I5.

36. P. mollis Fr.-Pileus flesh-colour, fleshy-fibrous, soft, effuso-reflexed, somewhat triangular, rugose, margin acute. Pores unequal, elongated, flexuous, soft, white, spotted with red when touched.

Not watery, but soft to the touch, seriato-elongated or resupinate.

On dead pine. Slough.

Name-mollis, soft. Fr. Hym. Eur. p. 547. Icon. t. 182. f. 3. B. \& Br. n. $1365 .-$ Pers. Obs. i. p. 14 .

37. P. cæsius Fr.-White, now and then tinged bluish-grey. Pileus $I-5$ cent. $(1 / 2-2$ in.) broad, fleshy, soft, tough, unequal, silky. Pores very small, unequal, elongato-flexuous and torn into teeth.

Small, variable in form, stipitate and resupinate.

On dead fir. Frequent. Sept.-Nov.

Spores pale blue, oval, $3 \times \mathrm{I}_{4} \mathrm{mk}$. W.G.S. Name-casius, bluish-grey. Fr. Hym. Eur. p. 547. Syst. Myc. i. p. 36c. Berk. Out. p. 242. C. Hbk. n. 759. S. Mycol. Scot. n. 716.-Schrad. Sozw. t. 226.

38. P. trabeus Rostk.-White. Pileus fleshy-fibrous, then firm, effuso-reflexed, transversely elongated, zoneless, pallid. Pores curt, minute, somewhat round or elongated, toothed, white.

Commonly conjoined with $P$. destructor. Both vary effused and reflexed, smooth and pubescent, but $P$. trabeus is more regular, of brighter colour, hyaline within when moist, obsoletely zoned. 
On dead pine. Den of Dun, I874. Menmuir. Feb.

Polyporus.

Name-trabs, timber, a vessel. Found in ships. Rostk. t. 28. Fr. Hym. Eur. p. 547. B. \& Br. n. I 428 . S. Mycol. Scot. n. 7 17.

39. P. destructor Fr.-Pileus fuscous-whitish, watery, Aleshy, effuso-reflexed, fragile, rugose, somewhat undulated, zoned internally. Pores elongated, somewhat round, toother or torn, white.

B. undulated, broadly expanded, marginate, whitish-date-brown. It softens and destroys wood like Merulius lachrymans.

On fir, larch and Scotch. Common. July-Dec.

Sometimes almost resupinate or effused. M.F.B. Name-destruo, to destroy. From its destroying wood. Fr. Hym. Eur. p. 547. Berk. Out. p. 242. C. Hbk. n. 760. S. Mycol. Scot. n. 718. Krombh. t. 5. f. 8.-Schrad. Rostk. t. 27.

\section{Lenti. Pileus fleshy pliant, \&c.}

\section{* Substance coloured.}

40. P. nidulans Fr.-Pileus $\mathrm{I}-2.5$ cent. ( $1 / 2-\mathrm{I}$ in.) thick, somewhat pale yellowish, of the same colour internally, fleshy, very soft, somewhat pulvinate, villous, becoming even, zoneless. Pores elongated, of medium size, unequal, angular, tawny-brick-colonr.

Fragrant when dry, remarkable for its softness. Margin spreading, somewhat obtuse. There are two forms, one pale yellowish, the other somewhat flesh-colour.

On dead wood. Uncommon. Sept.-Nov.

Name-nidus, a nest. From its shape. Fr. Hym. Eur. p. 548. Syst. Myc. i. p. 364. Berk. Out. p. 242. C. Hbk. n. 76r. S. Mycol. Scot. n. 719. -P. rutilans Saund. \& Sm. t. 45. - Bull. t. 482 .

41. P. rutilans Fr.-Pileus tawny-cinnamon becoming pale (tawny), of the same colour internally, fleshy-pliant, thin, at first villous, then becoming smooth, zoneless. Pores curt, minute, thin, equal, acute, cinnamon, somewhat shining.

Pileus at length juiceless, friable, the slight margin inflexed, but not incurved or fimbriate as in $P$. cuticularis. Variable in form, but extenuated, not pulvinate and convex on both sides like $P$. nidulans.

On fallen branches. Uncommon.

When fresh has a sweet scent like that of anise. M.F.B. Name-rutilo, to be reddish. Fr. Hym. Eur. p. 548. Berk. Out. p. 242. C. Hbk. n. 762.Pers. Ic. t. 6. f. 4 .

42. P. gilvus Schw.-Pileus pale yellowish, fleshy-pliant, effusoreflexed, soft, even, bccoming smooth, zoneless, margin spreading, thin, acute. Pores very small, naked, quite entire, pale yellowish-ferruginous, opaque. 
Polyporus. Commonly longitudinally effused, flaxy in close places, soft to the touch, properly velvety, but becoming so even as to appear smooth.

On trunks. Rare.

Fries has no doubt that Sowerby's Boletus impuber is the same plant, and therefore it must be included as British. Name-gilvus, pale yellowish. Schwein.-Fr. Hym. Eur. p. 548.-Sow. t. I95.

\section{** Substance white.}

43. P. fumosus Fr.-Pileus 5-Io cent. (2-4 in.) broad, fuliginous-pallid, fleshy-corky, firm, zoneless, silky then becoming smooth, adnate and dilated behind, internally fibrous, somewhat zoned. Pores minute, curt, round, entire, whitish-smoke-colour, darker when bruised.

Cæspitose, imbricated, moderately thick, attenuated towards the margin which becomes black. Colour more or less smoky.

On old stumps. Common. Oct.-Dec.

Smell oppressive. M.F.B. Name-fumosus, smoky. Fr. Hym. Eur. p. 549. Syst. Myc. i. p. 367. Berk. Out. p. 243. C. Hbk. n. 763. S. Mycol. Scot. n. 720. Kl. Bor. t. 392. Rostk. t. 42. Pers. Tratten. t. 3. f. 5.

44. P. adustus Fr.-Pileus cinereous-pallid, fleshy-pliant, thin, villous, effuso-reflexed behind, the margin which is tense and straight becoming black. Pores minute, curt, round, obtuse, whitish-pruinose soon cinereous-fuscous, the marginal ones obsolete.

Like $P$. fumosus, but thinner, darker; pileus spuriously zoned, slightly wrinkled. Pores at length blackish.

On old stumps. Frequent. Sept.-Jan.

Pores always leaving a whitish margin on the under side. Name-aduro, to burn. Appearing as if scorched. Fr. Hym. Eur. p. 549. Berk. Out.p. 243. C. Hbk. n. 764. S. Mycol. Scot. n. 721. Fl. Dan. t. 1850. f. I. Kl. Bor. t. 472. Rostk. t. 38. -Willd. Bull. t. 501. f. 2. Batsch f. 226.

45. P. crispus Fr.-Pileus cinereous-blackish, fleshy-pliant then coriaceous, tough, rugose, effuso-reflexed behind, margin thin, crisped, at length black. Pores rather large, unequal, at length labyrinthiform, silvery-cinereous.

Small, pileus when young fuliginous-black, floccoso-rugose, zoneless, white at the margin, when full grown thinner, flexile, becoming pale, grey, becoming smooth with a fuscous marginal zone (occasionally with many zones).

On old stumps. Uncommon. Dec.

Name-crispa, a curl. From the crisped margin. Fr. Hym. Eur. p. 550. Berk. Out. p. 243. C. Hbk. n. 765. S. Mycol. Scot. n. 722.-Pers. Obs. Myc. ii. p. 8. 
46. P. amorphus Fr.-Pileus shining zohite, fleshy-pliant, thin, Polyporus. effuso-reflexed, silky. Pores minute, unequal, golden.

Often crespitose, imbricated, very irregular, also resupinate on ground covered with pine-needles. Jan.

On fir-stumps and among pine-leaves. Uncommon. Nov.-

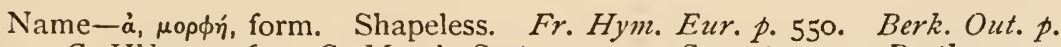
243. C. Hbk. n. 767. S. Mycol. Scot. n. 723.-Sow. t. 423. Rostk. 27. t. I2. pores reddish.

47. P. adiposus B. \& Br.-White, here and there acquiring a foxy tinge. Pileus waxy-soft, shortly reflexed, obscurely tomentose; hymenium rather thick. Pores small, obtuse at the edge.

Very variable in form, sometimes fixed by the apex, sometimes resupinate. Losing much of its substance in age. Substance not zoned within. Pores when horizontal with the edges even, but often elongated and irregular, not stratose. Turns brownish in drying. Allied to $P$. amorphus, but very distinct.

On the ground beside stumps. Uncommon. Dec.

Name-adeps, fat. From its substance. B. \& Br.n.7Ir. Berk. Out.p. 243. C. Hbk. n. 766. S. Mycol. Scot. n. 724. Fr. Hym. Eur. p. $55^{\circ}$.

48. P. Keithii B. \& Br.-Shell-shaped, stemless, decurrent behind. Pileus about $\mathrm{I} 2 \mathrm{~mm}$. ( $1 / 2 \mathrm{in}$.) across, bright red-brown, rough with rigid tooth-shaped processes; hymenium pallid; dissepiments lacerated.

On fallen sticks. Dunphail.

Name-after Rev. Dr Keith. B. \& Br. n. I430. S. Mycol. Scot. n. 725 .

3. Spongiosi. Spongy when fresh, \&c.

\section{* Substance coloured.}

49. P. hispidus Fr.-Pileus IO-I 5 cent. (4-6 in.) broad, somewhat ferruginous, compact, spongy-fleshy, dimidiate, pulvinate, hispid, internally composed of diverging fibres. Pores minute, rounded, somewhat separate, fimbriated, paler than the pileus.

Changing colour. Pores yellowish then fuscous.

On living ash, \&c. Common. July-Nov.

Pileus sometimes 30 cent. (12 in.) or more broad, ro cent. (4 in.) thick. M.F.B. Name-hispidus, hispid. Fr. Hy'm. Eur. p. 55r. Syst. My'. i. p. 362. Berk. Out. p. 243. C. Hbk. n. 768. S. Mycol. Scot. n. 726. Grev. t. 14. Krombh. t. 48. f. 7-10. Hussey i. t. 29, 3r.-Bull. t. 210,493 . Bolt. t. 161. Sow. $t .345$. 
Polyporus. 50. P. cuticularis Fr. - Pileus ferruginous-fuscous then blackish, thin, spongy-fleshy, then juiceless, becoming plane, hairy, tomentose, internally laxly composed of parallel fibres, margin fibroso-fimbriate, incurved. Pores minute, long, pallid then ferruginous.

Allied to $P$. hispidus, but much thinner, soft, the pores longer than the depth of the flesh. Spores plentiful, ochraceous.

On trunks. Burnham Beeches.

Name-cuticula, a thin external skin. Fr. Hym. Eur. p. 55r. B. \& Br. n. I137. C. Hbk. n. 769.--Bull. t. 462.

\section{** Substance and spores white.}

51. P. spumeus Fr.-Whitish. Pileus 7.5 cent. (3 in.) broad, fleshy-spongy, compact, pulvinate, gibbous, rugoso-hispid, with a stem-like base, margin incurved; flesh zoned towards the margin. Pores separating, minute, round, acute, entire.

A very distinguished species.

On trunks and stumps. Rare. July.

Oozing out from the tree in a very soft mass. M.F.B. Name-spuma, froth. Fr. Hym. Eur. p. 552. Syst. Myc. i. p. 358 . Berk. Out. p. 244. $t$. 16. f. 4. C. Hbk. n. 770. S. Mycol. Scot. n. 727.-Sow. t. 21 I.

52. P. borealis Fr.-White then yellowish, 5 cent. ( 2 in.) and more broad and thick. Pileus spongy then corky, compact, somewhat pulvinate, hairy, internally composed of parallel fibres, margin spreading. Pores adnate, unequal, sinuoso-flexuous and torn, white.

It is exceedingly distinct from those nearest to it ; fleshy indeed when young, but when full grown corky. Otherwise it is very variable; the following are to be noted. B. montanus pileus fleshy, thick, hairy, margin obtuse; pores obtuse, entire. C. spathulatus pileus thin, villous, margin acute, extended into a short lateral stem; pores thin, very much torn.

On stumps. Slough. Balnamoon, Forfarsh. Strachan, Kincardinesh.

Name-borealis, northern. Fr. Hym. Eur. p. 552. Syst. Myc. i. p. 366. B. \&o Br. n. 1429. S. Mycol. Scot. n. 728. Kostk. 4. t. 40.-Schaff. t. 314 (bad).

B. Placodermei. Pileus clothed with a continuous crust, \&c.

4. Suberosi. Pileus at the first somewhat fleshy and juicy, \&c.

$$
\text { * Substance coloured. }
$$

53. P. dryadeus Fr.-Pileus somewhat ferruginous, becoming fuscous, fleshy then corky, thick, pulvinate, cuticle thin, soft, 
rugged becoming even, smooth; flesh somewhat zoned, ferrugi- Polyporus. nous. Pores very long, thin, round, soft, ferruginous, paler at the orifice.

Among the largest and most distinguished, growing rapidly, exuding watery drops at the margin and hence confounded with $P$. applanatus.

On old oaks. Frequent. Aug.-Oct.

Pileus $7 \cdot 5^{-17.5}$ cent. ( $3-7$ in.) or more broad, 6 cent. $\left(2 \frac{1}{2}\right.$ in.) thick. Smell

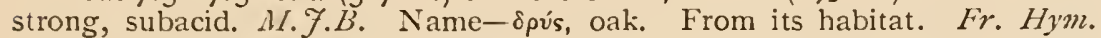
Eur.p. 553. Berk. Out. p. 244. C. Hbk. n. 77 r. S. Mycol. Scot. Supp. Scot. Nat. 1881, p. 37. Hussey i. t. 21.-Pers. Bull. t. $45^{8}$.

\section{** Substance, which is not zoned, and spores white.}

54. P. betulinus Fr.-Pileus fleshy then corky, hoof-shaped, obtuse, zoneless, smooth, the oblique vertex in the form of an umbo, pellicle thin, separating. Pores late of being developed, curt, minute, unequal, at length separating.

On living and dead birch. Common. May-Dec.

Pileus $7.5^{-1} 5$ cent. $\left(3^{-6}\right.$ in.) broad. The pileus is at first pale, then acquiring a brownish tinge. The edge is always very obtuse. Name-betula, birch. From its habitat. Fr. Hym. Eur. p. 555. Berk. Out. p. 244. C. Hbk. n. 772. S. Mycol. Scot. n. 730. Grev. t. 246. Rostk. t. 22.-Bull. t. 312. Bolt. t. 159. Sow. t. 212 . Fl. Dan. t. 1254.

55. P. quercinus Fr.-Pileus tan-pallid, now and then reddish when touched, thick, corky, texture floccose, soft then hardened, tongue-shaped, convexo-plane, even, at first floccoso-granulated, narrowed behind into a thick horizonital stem. Pores curt, minute, whitish.

A remarkable species, analogous with Fistulina.

On old oak. Rare.

Name-quercus, oak. From its habitat. Fr. Hym. Eur. p. 555. Berk. Out. p. 239. C. Hbk. n. 747. Hussey i. t. 52.-Krombh. t. 5. f. 3-5; t. 48. f. I I.14. -Schrad. Spic. p. I57.

5. Fomentarii. Pileus floccose, of the nature of tinder, \&c.

* Substance and pores umber or fuscous.

56. P. vegetus Fr.-Pileus fuscous, dilated, smooth, opaque, concentrically sulcate, the annual zone broad, texture floccose, lax, very thin, cuticle of the second season thick, separable. Pores minute, separating, umber, those of each season distinct on account of an intermediate floccose stratum formed annually.

It is among the largest, growing rapidly, attaining to $\mathrm{ft}$. in the first year, 
Polyporus. but the flesh is very thin, and from it both the cuticle and the very long pores can at length be separated. Plane beneath, at first whitish, margin very smooth, shining, barren, narrow. It has been confounded with $P$. applanatus, but differs by many marks.

On lime-trees. Rare.

Name-vegetus, of vigorous growth. Fr. Hym. Eur. p. 556. Icon. t. 183. f. 1. Berk. Out. p. 245. C. Hbk. n. 774.

** Substance and pores somewhat ferruginous.

57. P. applanatus Fr.-Pileus cinnamon becoming hoary, flattened, tubercular, obsoletely zoned, pulverulent or smooth, cuticle crustaceous, rigid, at length fragile, internally very soft, laxly floccose, margin swollen, white then cinnamon. Pores very small, somewhat ferruginous, orifice whitish, becoming fuscous when bruised.

Odour acid. When fresh much softer than $P$. fomentarizs, \&c., but not fleshy or juicy. The pores are softer and shorter.

On trunks, especially ash. Uncommon. Aug.-Oct.

Attaining a large size. Name-plano, to level. Flattened. Fr. Hym. Eur. p. 557. Berk. Out. p. 245. C. Hbk. n. 775. S. Mlycol. Scot. n. 73 r. Kl. Bor. t. 393.-Pers. Rostk. 27. t. 9. Butsch f. 130. Bull. t. 454. f. C?

58. P. fomentarius Fr.-Pileus fuliginous becoming hoary, hoof-shaped-pulvinate, thick, smooth, remotely and concentrically sulcate, smooth, opaque, internally soft, floccose, ferruginoustawny, cuticle thick, very hard, persistent, margin at first glaucous-pruinose then ferruginous. Pores very long, minute, distinctly stratose, at first glaucous-pruinose then ferruginous.

Plane beneath, attenuated towards the margin from the very thick base, hence triangular indeed, but semi-orbicular at the circumference and on all sides sloping downwards. There are two monstrous forms; one stalked, cylindrical (Batt. t. 37. E. Nees Nov. Act. Nat. Cur. x. with fig.); another effused, resupinate. It used to be gathered and sold as making excellent tinder.

On trunks. Common. Aug.-Nov.

Pileus IO-I2. 5 cent. (4-5 in.) broad. Sometimes when old, especially when growing on birch, nearly white, occasionally tinged with bright yellow. Mass of pores generally concave. M.F.B. Name-fomentum, tuel, tinder. Fr. Hym. Eur. p. 558. Sv. ätl. Sv. t. 62. Berk. Out. p. 245. C. Hbk. n. 776. S. Mycol. Scot. n. 732. Rostk. 4, t. 52.-Linn. Lenz f. 48. Sow. t. 133 (first year).

59. P. nigricans Fr.-Pileus black, pulvinate, very thick, densely and concentrically sulcate, smooth, shining, the very hard crustaceo-torn crust persistent, internally very hard, ferruginous, mar- 
gin very obtuse, ferruginous. Pores very small, plane, confluent- Polyporus. stratose, naked, ferruginous.

The typical form with the pileus even, varnished, and shining, presents a most distinct species, but with this is confounded a trivial form with the pileus triangular, rugose, opaque, which approaches $P$. igniarius. Rostk. t. 5I. Quel.t. 19.f. 3 .

On living and dead birch. Uncommon. May-Oct.

5-I5 cent. (2-6 in.) broad. Sometimes exactly the shape of a horse's hoof. Name-niger, black. Blackish. Fr. Hym. Eur. p. 558. Icon. t. I84. f. 2. Berk. Ont.p. 245. C. Hbk.n. 777. S. Mycol. Scot.n. 733.

60. P. igniarius Fr.-Pileus at first tuberculoso-globose (immarginate), even, with a thin, flocculose, adpressed, hoary covering, then hoof-shaped, ferruginous then fuscous-blackish, opaque, cuticle concrete, roughly uneven, very hard; flesh zoned, ferruginous, very hard, margin rounded. Pores very small, convex, stratose, cinnamon, when old stuffed with a white substance, at the first hoary.

It differs from preceding species in its entire nature and life-history. The new growth, which is vernal, makes smaller specimens throughout, and larger ones only at the margin and on the hymenium (which is also at first destitute of pores) floccoso-hoary, then ferruginous, at length dark. It varies resupinate: Mich. t. 62. Unsuitable for tinder, but used for burning.

On ash, poplar, willow, plane, cherry. Common. May-Nov.

Pileus narrower and thicker than $P$. fomentarius, resembling a horse's hoof. Mass of tubes in general plane or very convex. M.F.B. Name-ignis, fire. From its being used for burning. Fr. Hym. Eur. p. 559. Berk. Out. p. 246. C. Hbk. n. 778. S. Mycol. Scot. n. 73t. Lenz f. 47. Ventur. t. 6r. f. 4 . Rostk. 4. t. 54.-Linn. Bull. t. 454. Bolt. t. 80. Sow. t. I32.

61. P. fulvus Fr.-Pileus tawny, at length becoming hoary, woody-corky, very hard, exactly triangular, even (not concentrically sulcate), at first hairy or villous. Pores curt, round, minute, cinnamon, at first covered with cinereous-yellow pruina.

Pileus convex on both sides, adnate by a broad base, not very obtuse at the margin. Pores not distinctly stratose.

On decayed trunks. Rare.

Name-fulvus, tawny. Fr. Hym. Eur. p. 559. Icon.t. 184.f. 3. B. \& Br. n. I $13^{8}$. C. Hbk. n. 779 .

62. P. pectinatus Kl. - Pileus ferruginous-fuscous, corkywoody, hard, triangular, concentrically lamellato-plicate above, tomentoso-scaly; margin pale-yellowish, naked. Pores very small, curt, obtuse, pale-yellowish, naked.

It is doubtful whether the margin and pores are always naked. 
Polyporus. Habitat not recorded. Penzance.

Name-pecten, a comb. From the markings on the pileus. Klotsch.Fr. Hym. Eur. p. 559. B. \& Br. n. 1965.-Quel. t. 17. f. 5 .

63. P. conchatus Fr.-Pileus date-brown, corky inclining to the nature of tinder, thin, effused, somezwat shell-shaped-reflexed, concentrically sulcate, tomentose, margin acute. Pores curt, very small, the thin trama of the same colour.

Pileus concave beneath. It varies wholly resupinate.

On trunks, willow, \&c. Frequent.

Distinguished from $P$, ribis by its harder substance and smoother pileus. M.F.B. Name-concha, a shell. From its shape. Fr. Hym. Eur. p. 560. Berk. Out. p. 246. C. Hbk. n. 781. S. Mycol. Scot. n. 735.-Pers. Myc. Eur. ii. p. 85 .

64. P. ribis Fr.-Pileus as much as Io cent. (4 in.) broad, ferruginous then umber, corky-coriaceous, becoming plane, rather even, velvety, tawny internally and at the acute margin. Pores curt, $2 \mathrm{~mm}$. (I lin.) long, very small, naked, tawny.

Perennial. Imbricated, somewhat zoned.

On currant and gooseberry bushes. Common in England.

Name-ribis, currant. Fr. Hym. Eur.p. 56o. Syst. Myc. i. p. 375. Berk. Out. p. 24 6. C. Hbk. n. 780 . Rostk. t. 53. Fl. Dan. t. 1790.f. 2. Corda Sturm. xi. t. 62.-Schum. Bull. t. 454. f. E.

65. P. salicinus Fr.-Pileus cinnamon then hoary, woody, very hard, undulated, smooth, for the most part resupinate, margin short, obtuse, spreading. Pores very small, round, ferruginouscinnamon.

Pileus 30 cent. (12 in.) and more, often interrupted. Allied to $P$. fomentarius or igniarius, with an ebony-black crust. From its situation wholly resupinate or in vertical places encircled above with a narrow, undulated, smooth margin.

On willows. Common. Autumn.

Name-salix, willow. Fr. Hym. Eur. p. 56o. Syst. Myc. i. p. 376. Icon. t. 185.f. I. Berk. Out. p. 246. C. Hbk. n. 782. S. Mycol. Scot.n. 736.

$$
\text { ** Substance white or pallid (except } P \text {. roseus). }
$$

66. P. roseus Fr.-Pileus 5-10 cent. (2-4 in.) broad, I-2.5 cent. $(1 / 2-\mathrm{I}$ in.) thick, externally and internally rose-colour, corkywoody, hard, triangular, even, somewhat banded, externally as if blown upon with cinereous-blackish powder, internally floccosofibrous. Pores minute, round, rose-colour.

Somewhat cæspitose. 
On dressed wood in conservatory. Glamis, I877. Autumn. Polyporus.

Name-roseus, rose-colour. Fr. Hym. Eur. p. 562. Syst. Myc. i. p. 372. B. \& Br.n. I801. S. Mycol. Scot.n. 737.-A. \& S. p. 25 I.

67. P. ulmarius Fr.-Pileus 7.5-10 cent. (3-4 in.) broad, in the first season white, corky-ivoody, very hard, incrusted, tubercular, becoming smooth, substance white. Pores round, stratose, yellowish.

A. first season, pileus white. Sow. $t$. 88. B. In succeeding seasons, pileus blackish, margin tawny. Berk. Out. $t$. $16 . f$. 5. The two figures are so unlike that one would scarcely suppose them to be allied.

On old elm. Frequent. Sept.

Name-ulmus, elm. Fr. Hym. Eur. p. 552. Syst. Mvc. i. p. 365. Berk. Out. p. 246. C. Hbk. n. 783. S. Mycol. Scot. n. 738. Hussey i. t. 64. Sow. \& Berk. quoted above.

68. P. cytisinus Berk.--Large, 30 cent. ( 2 in.) or more across, imbricated. Pileus coarsely tuberculated, hard, woody, margin subacute. Pores minute, nearly white.

Dimidiate, quite smooth at least when dry; substance slightly zoned, very thick and close, but composed of velvety fibres, pale, nearly white, evidently composed of two or three successive layers.

On laburnum. Rare.

Name-cytisus, laburnum. Berk. Eng. Fl. v. p. 142. Out.p. 247. C. Hbk. n. 785. S. Mycol. Scot. n. 739. Fr. Hym. Eur. p. 562. -Soze. t. 288.

69. P. connatus Fr.-Pilei white or cinereous, corky-woody, effuso-reflexed, imbricated like the steps of a ladder, growing into each other, villous, internally white. Pores stratose, minute, somewhat round, white.

Increasing from season to season and distinctly stratose, pileus commonly covered with mosses growing upon it.

On old trunks, elm, crab-tree, \&c. Frequent. Autumn.

Running up trunks for $\mathrm{x}$ or $2 \mathrm{ft} . M . \mathcal{F} . B$. Name-con, together; natus, born. Growing together. Fr. Hym. Eur. p. 563. Icon. t. 185. f. 2. Berk. Out.p. 248 . C. Hbk.n.789. S. Mycol. Scot.n. 740. Batt. t. 37. f. G.

6. Lignosi. Pileus from the first hard, woody, \&c.

70. P. fraxineus Fr.-Pileus white then rubiginous and fuscous, corky-iwoody, smooth, somewhat plane, zoneless, at first even, then concentrically sulcato-plicate, pallid within. Pores minute, curt, rufous-fermginous, at first, as well as the margin, covered over with white greasy villous down.

Variable in form, softer when young, but not fleshy, truly perennial. 
Polyporus. On old ash. Frequent. May-Nov.

Solitary or imbricated. Smell strong and penetrating. M.F.B. Spores ovoid-sphæroid, 6-7 mk. $Q$. Name-fraxinus, ash-tree. Fr. Hym. Eur. p. 563. Berk. Out. p. 247. C. Hbk. n. 784. S. Mycol. Scot. n. 741.-Bull.t. 433. f. 2.

71. P. variegatus Secr.-Pileus variegated orange and baybrown, corky-woody, somewhat plane, even, smooth, zoneless, shining, pallid within. Pores round, minute, curt, unequal and torn, yellowish.

With the habit of $P$. varius, but decurrent at the base as is usual in this section. Sowerby compares it with $P$. lucidus as regards its substance.

On trunks. Rare.

Name-variegatus, variegated. From the colours. Secr. n. 45. Fr. Hym. Eur. p. 563. Berk. Out. p. 247. C. Hbk. n. 786. -Sow. t. 368.

72. P. carneus Nees.-Pileus flesh-colour, of the same colour internally, effuso-reflexed, woody, hard, thin, rugose, smooth, zoneless. Pores minute, round, decurrent at the base.

Smaller and thinner than $P$. fraxineus and $P$. variegatus, but hard and perennial.

On old stump. Welshpool, I87i. Nov.

Name-caro, flesh. Flesh-colour. Nees Nov. Act. Nat. Curios. xlii. t. 3. Fr. Hym. Eur. p. 563. B. E Br. n. I366.

73. P. annosus Fr.-Pileus woody, convex then becoming plane, rugoso-tubercular, in the first season brown and silky, in the second and subsequent seasons covered with a rigid, smooth, blackish crust, white within. Pores of medium size, whitish.

A. Pileus reflexed, pores obtuse. B. Pileus wholly resupinate, pores unequal. Very variable in form, but very distinct.

About roots of stumps, \&c. Very common. April-Dec.

Forming masses $3 \mathrm{in}$. $-\mathrm{r} / 2 \mathrm{ft}$. wide of imbricated, rugged, or radiato-striate brown pilei, marked with strong vaulted zones. M.F.B. Name-annus, a year. From its growing yearly. Fr. Hym. Eur. p. 564. Icon. t. I86. f. 2. Berk. Out. p. 247. C. Hbk. n. 788. S. Mycol. Scot. n. 742.-Rostk. 4. t. 29.

74. P. populinus Fr.-White. Pileus $12 \mathrm{~mm}$. ( $1 / 2 \mathrm{in}$.) broad, corky-woody, rigid, zoneless, villous, of the same colour internally, margin obtuse. Pores minute, curt, round.

Imbricated, growing into each other at the decurrent base, transversely dilated. Not stratose.

On trunks of poplar. Uffington, Lincolnshire.

Very much the habit of $P$. connatus. $B$. \& Br. Name-populus, poplar. Fr. Hym. Eur. p. 564. Syst. Myc. i. p. 367. B. \& Br. n. 1288. 
C. Inodermei. Pileus from the first arid and firm, \&c.

7. Stupposi. Pileus flocculose then smooth, \&c.

* Substance coloured.

75. P. radiatus Fr.-Pileus 2.5 cent. ( 1 in.) broad, corky, coriaceous, rigid, radiuto-nugose, at first velvety, tawny, then becoming smooth, ferruginous-fuscous, margin spreading, repand. Pores minute, pallid, silvery-glistening, at length ferruginous.

Very much imbricated, growing into each other, becoming woody, but not perennial.

On hazel, alder, \&c. Frequent. Oct.-Feb.

Name-radiatus, radiate. From the wrinkles on the pileus. Fr. Hym. Eur. p. 565. Syst. Myc. i. p. 369. Berk. Out. p. 248. C. Hbk. n. 790. S. Mycol. Scot. n. 743. Kl. t. 46r.-Sow. t. ig6. Batt. t. 39. C.

76. P. polymorphus Rostk.-Pileus umber, resupinate, effused, coriaceous, margin reflexed, crisped, smooth. Pores rather large, angular and torn, pallid.

The above description is from the figure. From the description of the author it is wholly bay-brown-pallid.

On fir in a fence. Forres. Aug.

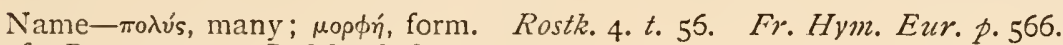
B. E Br.n. 1802. S. Mycol. Scot. n. 744 .

77. P. cryptarum Fr.-Pileus rufescent-fernginous, corkycottony, effuso-reflexed and variable, zoneless, adpressedly silky, paler internally. Pores very long, minute, round, paler than the pileus.

Exceedingly changeable in form and colour, becoming paler with the weather.

On fir-trees. Frequent.

Nearly related to $P$. fermoginosus, and perhaps a mere state of it. $B . \& B r$. Name-crypta, a vault, cellar. Probably first found in cellar. Fr. Hym. Eur.p.566. B. Eo Br. n. 180.4. Pers. Myc. Eur. 2. t. 16. f. 3.-Bull. t. 478.

\section{** Substance white.}

78. P. gossypinus Lev.-White. Pileus coriaceous, effusoreflexed, becoming plane, tomentose, zoneless, substance of the same colour. Pores at first labyrinthine, then angular, pallid cinereous, dissepiments thin, slightly toothed.

The pores are three or four times longer than the flesh of the pileus is thick.

VOL. II. 
Polyporus. On old stumps of Ulex. Sibbertoft.

Name-gossypium, cotton. Leveill. Ann. Sc. Nat. 1843, p. 124.-Fr. Hym. Eur. p. 566. B. \& Br. n. 2024 .

79. P. fibula Fr.-Whitish. Pileus coriaceous, soft, tough, velvety-hairy, zoneless, often radiato-rugose, internally snowwhite, margin entire, acute. Pores small, rounded, acute, at length torn, yellowish.

Small, adnate behind, everywhere free at the circumference, sometimes forming orbicular shields, sometimes variable in form from growing into each other.

On the door of a wine-cellar. Rare.

Name-fibula, a button. From its shape. Fr. Hym. Eur. p. 567. Berk. Out. p. $248 . \quad$ C. Hbk. n. 79r. Sow, t. 387. f. 8.

8. Coriacei. Pileus coriaceous, villous, \&c.

80. P. hirsutus Fr.-Pileus unicolorous, but zoned with concentric furrows, whitish, corky-coriaceous, convexo-plane, shaggy with rigid hairs. Pores round, obtuse, whitish, becoming somewhat fuscous.

B. Pores wholly white. C. Pores yellow at the orifice, but white within. D. Pores obtuse, angular. E. Margin of the pileus ferruginous (Fl. Dan. $t$. 2079. $f$. I). F. pileus blackish.

On dead trunks. Near Twycross.

Name-hirsutus, hairy. Fr. Hym. Eur. p. 567. B. \& Br.n. II 39 . C. Hbk. n. 792.-Wulf.Ifacq. Coll. ii. p. I49.

81. P. velutinus Fr.-Pileus about 5 cent. ( 2 in.) broad, white at length yellowish, corky-coriaceous, plane on both sides, velvety-soft, slightly zoned, the extenuated margin acute. Pores round, minute, thin, white.

Damp when young, then hardened, not shining like $P$. versicolor, the zones only a little darker.

On stumps, branches, \&c. Uncommon. Nov.

Sometimes entirely white, and not unfrequently the zones are mere depressions. M.F.B. Name-velluetum (low Latin). Velvety. Fr. Hym. Eur. p. 568. Syst. Myc. i. p. 368. Berk. Out. p. 248. C. Hbk. n. 793. S. Mycol. Scot. n. 745 .

82. P. versicolor Fr.-Pileus variegated with differently coloured zones, coriaceous, thin, rigid, becoming plane, depressed behind, becoming even, velvety, shining. Pores minute, round, acute and torn, white, becoming pale (somewhat yellowish).

Varying endlessly both in form and colour. 
On dead wood. Exceedingly common. April-Dec.

Polyporus.

More or less imbricated. Pileus $5 \mathbf{- 7 . 5}$ cent. (2-3 in.) broad. Name-versicolor, changeable in colour. Fr. Hym. Eur. p. 568. Berk. Out. p. 248. C. Hbk n. 794. S. Mycol. Scot. n. 746. Hussey i. t. 24.Linn. Bull. t. 86. Bolt. t. 81. Sow. t. 229. Fl. Dan.t. 1554. Schaff. t. 263. Sterb. t. 27. K. Batt. t. 35. A.

83. P. abietinus Fr.-Pileus cinereous-white, coriaceous, thin, effusoreflexed, villous, obsoletely zoned. Pores unequal, torn, violaceous becoming pale.

There is no species more easily distin. guished, though it is sometimes wholly resupinate, sometimes reflexed, if only once it has been rightly identified when in full vigour, and if distinct species are not sought for in old (washed out) and dry specimens.
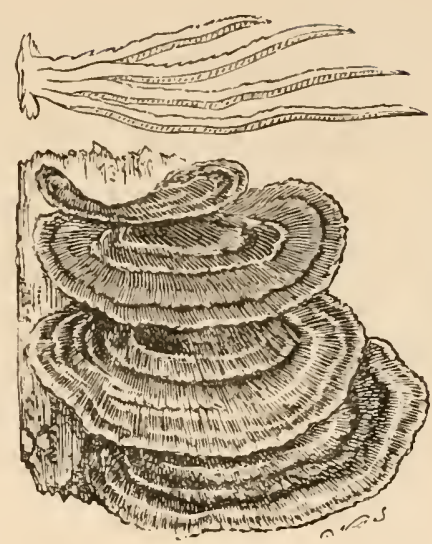

LXVI. Polyporus versicolor. One-half natural size.

On fir. Common. July-Nov.

Fries says it is "the mother of vast confusion." Pileus $2.5-5$ cent. ( $\mathrm{I}-2$ in.) broad. Often stained with minute green Algce. MI.F.B. Name-abies, fir. Fr. Hym. Eur. p. 569. Berk. Out. p. 249. C. Hbk. n. 795. S. Mycol. Scot. n. 747. Grev. t. 226. Fl. Dan. t. 2079. f. 2.-Dicks. Crypt. 3. t. 9. f. 9. Fl. Dan. t. 1298.

84. P. Wynnei B. \& Br.-Confluent, variable in form. Pileus tan-colour, adnate behind, effuso-reflexed, marked with silky raised lines. Pores small, angular, white.

Incrusting various substances, with the margin more or less broadly reflected. Pores $\frac{1}{96}$ in. across, acquiring a slight tint like that of the pileus in drying. Somewhat of the habit of $P$. amorphus, but not so fleshy in texture.

Running over twigs, grass, \&c. Coed Coch, \&c.

Name-after Mrs Lloyd Wynne. B. \& Br. n. 807. Berk. Out. p. 249. C. Hbk. n. 796. Fr. Hym. Eur. p. 569.

V. Resupinati. Pileus none, \&c.

* Pores fuscous or blackish.

No British species.

* Pores ferruginous or cinnamon.

85. P. umbrinus Fr.-Rufous-umber, resupinate, determinate, undulato-tubercular, defined by a smooth, paler margin. Pores 
Polyporus. minute, somewhat round, unequal, of the same colour as the pileus.

Clearly different from $P$. ferruginoszus and following species.

On trunks. Knowle Park, Burchell.

Name-umbrinus, umber-coloured. Fr. Hym. Eur. p. 57r. B. \& Br. n. I8go. -Rostk. 27. t. 6 .

86. P. ferruginosus Fr.-As much as 2.5 cent. ( $\mathrm{I}$ in.) thick, tazony, date-brown-ferruginous when old, effused, firm, unequal, circumference sterile. Pores of medium size, very long, somewhat round and torn, cinnamon.

Composed chiefly of the elongated pores.

On logs, posts, \&c. Common. May-Nov.

Mycelium ochraceous. At first appearing under the form of a confervoid stratum, which gradually thickens and acquires pores in the centre. M.Y.B. Name-ferrum, iron. Rust-coloured. Fr. Hym. Eur. p. 57I. Berk. Out. p. 249. C. Hbk. n. 798. S. Mycol. Scot. n. 748. Grev. t. 155.-Schrad. Spic.p. $x 72$.

87. P. contiguus Fr.-Almost 7.5 cent. (3 in.) long, 2.5 cent. ( $\mathrm{I}$ in.) broad, $\mathrm{I} 2 \mathrm{~mm}$. ( $\mathrm{I} / 2 \mathrm{in}$.) thick, cinnamon when young, effused, firm, smooth, someruhat marginate, margin at the first villous. Pores rather large, equal, obtuse, entire.

Smaller than $P$. ferruginosus; distinguished by its ochraceous mycelium from resupinate forms of $P$. igniarizes (of which the mycelium is white according to Berkeley).

On rotten wood and sticks. Uncommon.

Name-contiguus, continuous, uninterrupted. Fr. Hym. Eur. p. 57r. Syst.Myc. i. p. 378 . Berk. Out.p. 249. C. Hbk.n.797.-Pers. Syn.p. 544.

*** Pores purple or violaceous.

88. P. violaceus Fr.-Violaceous, effused, determinate, thin, short, even, smooth, closely adnate, destitute of a distinct subiculum. Pores short, cellular or veined, quite entire.

It approaches the Merulii in the curt, cellular pores.

On fir poles and stumps. Frequent. Jan.-May.

Spores ovoid, punctate, rose-yellow, $7 \mathrm{mk}$. $Q$. Name-violaceus, violetcolour. Fr. Hym. Eur. p. 572. B. E Br. n. 1021. C. Hbk. n. 803. S. Mycol. Scot. n. 749.-Rostk. 27. t. 3.

89. P. purpureus Fr.-Very broadly and widely effused, IO-30 cent. (4-I2 in.) long and broad, the mucedinous, flocculose, white mycelium creeping over the surface of rotten wood. Pores curt, 
scarcely $2 \mathrm{~mm}$. (I lin.) long, minute, unequal, interruptedly Polyporus. siattered or conglomerate, purple-lilac.

On decayed willow. Cotterstock, Norths.

Name-purpureus, purple. Fr. Hym. Eur. p. 572. Syst. Myc. i. p. 379. Berk. Out. p. 250. C. Hbk. n. 804 .

\section{**** Pores red.}

90. P. incarnatus Fr.-Flesh-colour, effused, 2.5-1o cent. (I-4 in.) long, scarcely 2.5 cent. (I in.) broad, corky-coriaceous, persistent, firm, smooth. Pores elongated, unequal, commonly oblique.

The superior margin here and there reflexed. Pores oblique from position.

On fir. Rare. June-Nov.

Sometimes small cottony protuberances occur amongst the pores which have the appearance of small pilei, with tubes underneath. Grev. Nameincarnatus, flesh-colour. Fr. Hym. Eur. p. 573. Syst. Myc. i. p. 379. Icon. t. 189. f. x. Berk. Out. p. 250. C. Hbk. n. 802. S. Mycol. Scot.n. 750.A. ES S. p. 250.

91. P. rufus Fr.-Blood-red-rufous, effused, coriaceous, thin, adnate, even, smooth, determinate. Pores very small, thin, acute.

On broom. Strachan, Kincardineshire.

Name-rufus, reddish. Fr. Hym. Eur.p.573. S. Mycol. Scot. n. 751.Rostk. 4. t. 62.

92. P. rhodellus Fr.-White-flesh-colour, effused, 5 cent. (2 in.) and more long, thin, adnate, soft, margin determinate, naked. Pores minute, somewhat round, continuous.

Thinner than preceding species, apparently nearest to $P$. vulgaris.

In Scotch fir wood. Glamis, i874. Aug.

Name-ṕóov, a rose. Slightly rose-colour. Fr. Hym. Eur. p. 573. Syst. Myc. i. p. 380. Icon. t. 189. f. 2. B. \& Br. n. 1806. S. Mycol. Scot. n. 752. -Bull.t. $44^{2}$. f. $D$.

93. P. micans Fr.-Whitish-flesh-colour, effused, thin, adnate, soft, circumference flaxy and white. Pores very thin, resembling honeycomb, angular, somewhat crenate.

Somewhat orbicular, confluent, fugacious. In the structure of the pores it approaches $P$. bombycinus.

On dead wood, ash. Leighwood, Bristol. Altyre. Nov.

Name-mico, to glitter. Fr. Hym. Eur. p. 573. B. \& Br.n. I289. S. llycol. Scot. n. 753.-Ehrenb. Silv. Berol.p. 30. 
94. P. nitidus Fr.-Yellow, effused, thin, somewhat adnate, defined, villoso-marginate at the circumference. Pores minute, curt, round, equal, shining. form.

Remarkable for its bright, almost golden colour, and somewhat regular

On dead wood. Rare. March.

Name-nitidus, shining. From the pores. Fr. Hym. Eur. p. 574. Berk. Out. p. 250. C. Hbk. n. 799. S. Mycol. Scot. n. 754,-A. \&o S. p. 258.

95. P. Læstadii Fr. \& Berk.-Substance white, hymenium here and there tubercular. Pores bright lemon-yellow.

Colour bright persistent yellow, very beautiful. Forming confluent patches, many inches in length.

On the under side of a deal board in hothouse. Coed Coch.

Name-after C. P. Læstadius. B. \& Br. n. 2025.

96. P. bombycinus Fr.-Dingy-yellowish, effused, silkymembranaceous, adhering laxly, spider-web-velvety at the circumference. Pores large, angular.

Very distinct and singular. Pores in their first stage forming only small pits, which are sunk in the mycelium, then developed, wholly formed from the tomentum, somewhat round, at length firmer, angular and here and there flexuous.

On dead wood. Rare.

Name-bombyx, silk. Fr. Hym. Eur. p. 575. Berk. Out.p. 250. C. Hbk. n. 801.-Sow. t. 387. f. 5 .

97. P. aneirinus Sommerf.-White, effused, thin, somewhat innate, flaxy at the circumference. Pores large, cell-like, waxy, angular, smooth, tawny.

The growth is at first wholly flaxy; the formation of pores is the same as in $P$. bombycinus, but they are at length waxy and often exactly hexagonal.

On dead branches. Rare. Oct.

Name-ảv, eipíveos, woolly. Not woolly. From the pores becoming waxy as contrasted with those of $P$. bombycinus, which are persistently downy. Sommerf. Lapp. p. 276.-Fr. Hym. Eur. p. 575. Berk. Out.p. 252. C. Hbk. n. 8r6. S. llycol. Scot. n. 755 .

98. P. ramentaceus B. \& Br.-Somewhat orbicular; subiculum white, tomentose, margin obsolete. Pores honey-colour, large, $\frac{1}{32}$ in. across, somewhat hexagonal, dissepiments thin, slightly rigid, acute. 
On Scotch fir. Glamis, I874. Sept. Polyporus.

Name-ramenta, shavings, chips. On chips. B. \& Br. n. 1809. S. Mycol. Scot. $n .774$.

\section{****** Pores white then changing colour.}

99. P. cinctus Berk.-White, turning pallid, forming small erect scattered tufts, each surrounded by radiating strigose fibres. Pores extremely minute, angular, dissepiments extremely thin, edge ragged.

Some of the patches are barren, and some at length become confluent. Under favourable circumstances a distinct hymenium, $3 \mathrm{~mm}$. ( $1 / 2 \mathrm{lin}$.) thick, with a free, even, abrupt, vertical circumference is formed in the centre of each tuft.

On old deal boards. Rare. King's Cliffe.

Pores at length pallid ochraceous, darker when dry. Quite peculiar in its structure. Fr. Name-cingo, to encircle. From the fibres surrounding the tufts. Berk. Out. p. 250. Mag. Zool. \& Bot. i. t. 2. f. 3. C. Hbk. n. 805. Fr. Hym. Eur. p. 575 .

100. P. armeniacus Berk.-Suborbicular, confluent, extremely thin, circumference minutely downy. Pores shallow, minute, nearly round, at first white then bright buff, often confined to the centre, the marginal portion being of a byssoid structure under a lens.

Forming broadly effused patches, composed evidently of many confluent orbicular individuals.

On fir bark. Appin.

Name-of the colour of apricot (Armeniacum). Berk. Eng. Fl. v. p. I47. Out.p. 250. C. Hbk. n. 800.

101. P. Rennyi B. \& Br.-Subiculum thick, pulvinate, pulverulent, forming a thick, at first somewhat frothy then pulverulent mass, white, turning to lemon-colour when dry. Pores sparingly produced, white, elongated, dissepiments thin.

On Scotch fir stump and running on the ground. Hereford, I873. Glamis, I873. Nov.

Name-after J. Renny. B. \& Br. n. I432. S. Mycol. Scot.n. 756 .

102. P. subfusco-flavidus Rostk.-White then light yellowfuscous, broadly effused by becoming confluent, thin, coriaceous, arid, adnate, margin thin, white-flaxy, determinate. Pores minute, irregular.

On oak planks. Roof of King's Cliffe Church.

The pores appear when viewed one way of a greyish-brown, and the other 
Polyporus. white. B. \& Br. Name-from the colours. Rostk. 27. t. II. B. \& Br. n. ro22. Fr. Hym. Eur. p. 576. P. corticola C. Hbk. n. 817.

103. P. viridans Berk.-At first white, then when dry pallid green, effused, crustaceo-adnate, thin, margin pulverulentotomentose. Pores minute, angular, dissepiments thin.

Habit that of $P$. vulgaris.

On rotten wood. Rare. Sept.

Name-virido, to be green. Greenish. B. \& Br.n.347. C. Hbk.n.810. Fr. Hym. Eur. p. 576 .

104. P. terrestris Fr.-White, effused, spider-web-flaxy, rather tender, fugacious. Pores central, extremely small, white then rufescent.

A doubtful and scarcely typical form.

On naked soil. Uncommon. Sept.-Oct.

Extremely delicate, vanishing when touched. Name-terra, earth. Growing on the soil. Fr. Hym. Eur. p. 576. Berk. Out. p. 252. C. Hbk.n. 8I4. S. Mycol. Scot. n. 757.-Dec. Fl. fr. 6. p. 39.

105. P. subgelatinosus B. \& Br.-Orbicular, forming little pulvinate masses with an obtuse raised border, which is at first tomentose and pallid, becoming black, of a somewhat gelatinous consistence. Pores pale delicate grey, with an acute even edge, about $\frac{\pi}{40}$ in. diameter.

On dead wood, parasitic on P. amorphus. Rannoch.

Name-sub-gelatinosus, somewhat gelatinous. B. \& Br. n. I569. S. Mycol. Scot. n. $75^{8}$.

******* Pores persistently white, Eoc.

106. P. medulla-panis Fr.--White, effused, determinate, somewhat undulated, firm, smooth, the naked circumference somewhat marginate, almost wholly formed of the longish, medium-sized, entire pores.

Annual, moderately large, becoming hard when dry, separating. Softer and watery-soft when on the ground.

On decaying branches. Uncommon.

Becoming yellowish when old. Name-medulla, pith, \&c.; panis, bread. From its likeness to soft crumb of bread. Fr. Hym. Eur. p. 576. Icon. $t$. 190. f. 2. Berk. Out. p. 251. C. Hbk. n. 806. S. Mycol. Scot. n. 759.Pers. Syn. p. 544 . 
107. P. mucidus Fr.-White becoming pale, effused, rather Polyporus. thick, somewhat immersed, soft, the indeterminate circumference flaxy. Pores medium-sized (seated on the crust formed of the mycelium), unequal and torn.

It varies softer and firmer according to place, but is moderately persistent. Much larger than $P$. molluscus, and not allied to it.

On decayed fir. Penzance.

Name-mucus, mucous. Mucid. From its substance. Fr. Hym. Eur.p. 577. B. \& Br. n. 1967.-Pers. Syn.p. 546.

108. P. vitreus Fr.-Whitish, somewhat hyaline, broadly and unequally effused, rather thick, somewhat undulated, indeterminate, the thin villous margin shining white; mycelium forming a woody stroma, tough and separable. Pores very small, round, long, obtuse, entire.

The pores are straight or oblique according to situation.

On dead wood, especially fir. Uncommon. Aug.-Nov.

Distinguished by its distinct xylostromatoid substratum, which separates easily from the matrix. $B$. \& $B r$. Name-vitrum, glass. Glassy. From its shining appearance. Fr. Hym. Eur. p. 577. Syst. Myc. i. p. 38I. Berk. Out. p. 25I. C. Hbk. n. 807. S. Mycol. Scot. n. 760.-Pers. Myc. Eur. 2. p. II2.

109. P. obducens Pers.-White, effuserl, incrusting, innate, firm, wholly formed of very small, crowded, equal, distinctly stratose pores, the annual strata pallid-tan.

In the first year the plant resembles $P$. vulgaris, but in succeeding years it becomes thick from the numberless strata $(2 \mathrm{~mm}$., I lin. thick) placed one above another, altogether concrete with the mouldy wood which is pervaded with the mycelium. In vertical places it puts forth rudimentary pileoli. Allied to $P$. connatus.

On rotten trunks. Rare. Bristol.

Name-ob, and duco, to lead. Covering over. Probably from the strata covering each other. Pers. Myc. Eur. 2. p. 104.-Fr. Hym. Eur. p. 577. Berk. Out. p. 25I. C. Hbk. n. 808.

110. P. callosus Fr.-White, circumference similar, widely effused, even, tough, entire, separable like soft leather. Pores firm, round, equal, quite entire, obtuse.

The pores are seated upon a skin, $2-4 \mathrm{~mm}$. ( $\mathrm{I}-2$ lin.) thick, firm, but not hard, everywhere porous. Annual and not stratose.

On dead wood. Glamis, 1874. April.

Spores pruniform, hyaline, $6 \mathrm{mk}$. $Q$. Name-callum, a hardened skin. From the skin on which the pores are seated. Fr. Hym. Eur. p. 577. B. \& Br.n. I43r. S. Mycol. Scot. n. 76r. 
Polyporus. 111. P. vulgaris Fr. - White, broadly effused, thin, I $\mathrm{m}$. ( $1 / 2$ lin.) thick, arid, closely adnate, even, soon smooth at the circumference, wholly consisting of firm, crowded, very small, round, somewhat equal pores.

The colour is sometimes light yellow. The pores vary oblique and gaping open. It cannot be separated from the wood except in fragments.

On dead wood. Common. April-Dec.

Effused sometimes to the breadth of 30 cent. (12 in.) M.F.B. Namevulgaris, common. Fr. Hym. Eur. p. 577 . Syst. Myc. i. p. 381. Berk. Out. p. 25I. t. 16. f. 6. C. Hbk. no. 809. S. Mycol. Scot. n. 762 . Rostk. t. 60.

112. P. molluscus Fr.-White, effused, thin, soft, the flaxy circumference radiating in fibrils.

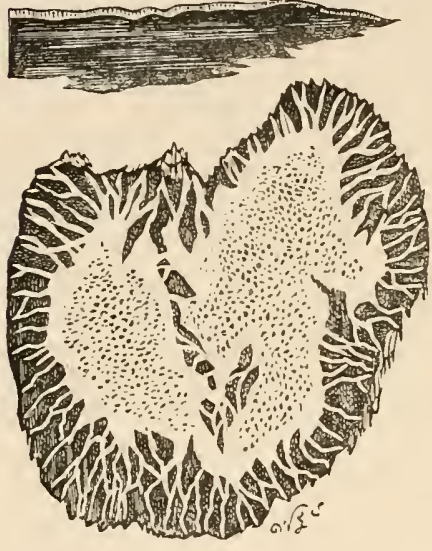

LXVII. Polyporus molluescus. Natural size. Pores collected in the centre or now and then in patches, very small, thin, round, unequal and torn, pale.

There is a variety with the circumference membranaceous sterile and continuous. Sorw. $t .387 . f \cdot 9$.

On dead wood. Uncommon. Sept. - Nov.

At first forming a mere fringed byssoid membrane. The partitions of the pores are so thin that they very generaliy become torn. M.F.B. Name - molluscus, soft. Fr. Hym. Eur. p. 578. Berk. Out. p. 25 I. C. Hbk. n. 812. S. Mycol. Scot. n. 763 . Fl. Dan. t. 1299.

113. P. collabefactus B. \& Br. - Stratum quite smooth, resembling a Corticium. Pores seem at first to arise from the mere collapsing of the substance, short, margin obtuse.

The barren parts resemble exactly a very smooth Corticium like $C$. calceum.

On dead wood. Glamis, I873. Oct.

Name-collabefio, to be brought to ruin. From the pores arising out of the collapsing of the substance. B. \& Br. n. I432. S. Mycol. Scot. n. 764 .

******** Pores persistently white, unequal, Eoc.

114. P. sanguinolentus Fr. - Whitish but bleeding when touched, nodulose, soon confluent, effused, soft, the flaxy circumference vanishing. Pores small, somewhat round, unequal, at length torn. 
Mycelium emerging and forming nodules, which are at first flaxy then Polyporus. smooth, in which the pores nestle, but it does not result in a pileus. Pores very changeable in form.

On dead branches. Uncommon. Sept.-Oct.

Name-sanguis, blood. Bleeding. Fr. Hym. Eur. p. 578. B. \& Br. n. 1290. C. Hbk. n. 811. S. Mycol. Scot.n. 765.-A. \& S. p. 257.

115. P. radula Fr.-White, effused, made up of the naked tomentose mycelium closely compacted, soft, villous beneath. Pores medium-sized, angular, toothed, pubescent when young.

Its growth is that of $P$. sanguinolentus, but it is drier, more lax, and separable from the matrix.

On fir. Strachan, Kincardineshire.

Name-rado, to shave off. Perhaps from the ease with which it is removed from the matrix. Fr. Hym. Eur. p. 578. B. E Br. n. 1808. S. Mycol. Scot. n. 766.-Pers. Obs. 2. p. I4.

116. P. vaporarius Fr.-Effused, innate, the white floccose mycelium creeping into the wood. Pores large, angular, palewhite, crowded into a continuous, firm, persistent stratum.

On dead branches. Very common. Jan.-Dec.

Extremely variable. Name-vaporarium, a stove. Perhaps first found in hothouse. Fr. Hym. Eur. p. 579. Berk. Out. p. 252. C. Hbk. n. 815. S. Mycol. Scot. n. 767.-Pers. Myc. Eur. p. 106.

Var. secernibilis B. \& Br.-Shining white, honey-colour when dried, separable.

On fir-leaves under moss. Autumn. Forres. Name-from its being separable. B. \& Br. n. 1022. S. Mycol. Scot. n. 767 .

117. P. Gordoniensis B. \& Br.-Persistently shining white, effused, superficial, membranaceous, very thin but separable, margin shortly fringed. Pores minute, unequal, angular, dissepiments very thin, fimbriato-toothed.

An extremely delicate species, and not in the slightest degree innate. The margin remains snow-white, and the pores themselves change colour only very slightly in drying.

On fir poles. Aboyne.

Name-after Marchioness of Huntly. B. E Br.n. I023. C. Hbk. n. 813. S. Mycol. Scot. n. 768. Fr. Hym. Eur. p. 579.

118. P. Vaillantii Fr.-White, thin, the free mycelium resulting in root-like ribs which are somewhat united by a membrane. Pores now and then crowded together, curt, rather large, thin, unequal. 
Polyporus. It occurs in innumerable more or less imperfect stages of development. Var. Mycelium simply membranaceous.

On dead wood. Rare. April.

Name-after Vaillant. Fr. Hym. Eur. p. 579. Berk. Out. p. 252. C. Hbk. n. 8rg. S. Mycol. Scot. n. 769.-Sow. t. 326.

119. P. farinellus Fr.-White, widely effused, thin, mycelium naked, flocculoso-pulverulent, not woven. Pores thin, continuous, unequal, somewhat flexuous, intricate.

Fugacious to the touch. Of the consistence of Thelaphora sambuci.

On beech. Aboyne.

Name-farina, meal. From its pulverulent nature. Fr. Hym. Eur. p. 579. B. \& Br.n. I292. S. Mycol. Scot. n. 770.

120. P. hymenocystis B. \& Br.-Snow-white, arachnoid beneath and at the margin. Pores large; the scarious dissepiments collapsing, at length pallid.

A very curious species.

On dead wood. Glamis, I 875 .

Name- $\dot{v} \mu \nu$, membrane; $\kappa \dot{\sigma} \sigma \iota s$, bladder. From the peculiar nature of the dissepiments. B. \& Br. n. r8ro bis. S. Mycol. Scot. n. 775 .

$$
\text { ********* Pores white, superficial, \&oc. }
$$

121. P. blepharistoma B. \& Br. - Wholly resupinate, snowwhite, mycelium arachnoid, somewhat mealy. Pores small, dissepiments thin, margin ciliato-dentate.

Very thin and delicate; the ciliato-dentate margin of the pores very elegant.

On dead wood. Glamis, I874. Nov.

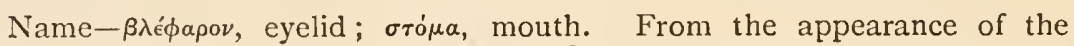
pores. B. \& Br.n. I434. S. Mycol. Scot. n. 77 I.

122. P. reticulatus Fr. - White, orbicular, thin, fugacious, radiating like flax at the floccose margin. Pores distant, cupshaped.

On rotten wood. Glamis, I874. Forres. April-Sept.

Extremely delicate and beautiful. Name-rete, a net. From the network of pores. Fr. Hym. Eur. p. 580. Icon. t. rgo. f. 3. B. E Br.n. 1810. S. Mycol. Scot. n. 772.-Pers. Syn. p. $5^{8} 4$.

\section{Species of uncertain affinity.}

123. P. bathyporus Rostk.- "Effused, white, the thin circumference flaxy. Pores rather large, cyathiform, toothed." 
The description does not agree well with the figure. According to the fig. Polyporus. it wanders over beech-branches, and is stratose (the stratum of the second season fuscous-ferruginous), smooth at the margin, fuscous in the middle, livid at the circumference.

On dead oak-branches. Coed Coch, 1873, Sic. Very like resupinate form

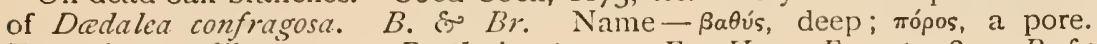
From the cup-like pores. Rostk. iv. t. 59. Fr. Hym. Eur. p. 580. B. E Br. 2.1807 .

124. P. hybridus B. \& Br.-White; mycelium thick, forming a dense membrane or creeping branched strings; hymenium breaking up into areæ. Pores long, slender, minute.

The dry-rot of oak-built vessels. On oak, in ships, \&c. According to Fries it is a monstrous form (perhaps of $P$. destructor), originating from its close situation. Name-hybridus, hybrid. Berk. Out. p. xvii. C. Hbk. n. 820. S. Mycol. Scot. n. 773. Fr. Hym. Eur. p. 581.-Sozu. t. 289, t. $3^{87}$. f. 6 .

\section{Genus XXV.-Trametes (trama, the generic distinction depending on the trama).}

Pores somewhat round, obtuse, entire, often unequal in depth and not forming a heterogeneous stratum, immersed at the base in the flesh of the pileus, and hence the trama is continuous with the flesh of the pileus and similar to it. Growing on wood, woody or corky, becoming hard, but not stratose, commonly sweet-scented.

A genus intermediate between the Dadalea and Polypori, the limits of which are not yet duly ascertained. Fr. Hym. Eur. p. $58 \mathrm{I}$.

I. Apodes ( $a, \pi$ ov́s, a foot. Stemless). Pileus dimidiate, sessile.

* Substance coloured.

** Substance white.

II. Resupinati. Pileus resupinate.

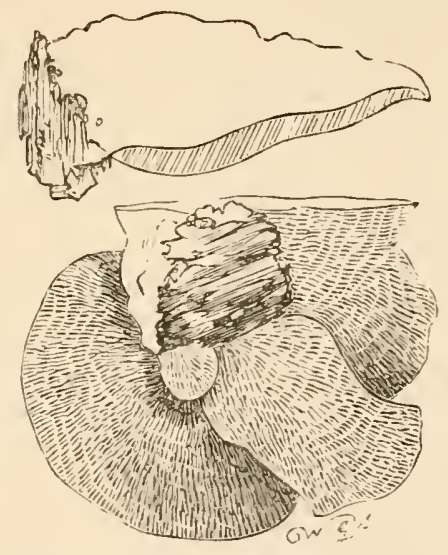

LXVIII. Trametes gibbosa. Onefourth natural size.

I.-Apodes. Pileus dimidiate, sessile. * Substance coloured.

1. T. pini Fr.-Pileus ferruginous-fuscous then blackish, internally tawny-ferruginous, corky-woody, very hard, pulvinate, 
Trametes. concentrically sulcate, rimoso-rugged, rough. Pores large, somewhat round or oblong, yellow-brick-red.

Perennial, but without distinct strata. Odour weak.

On living pine. Rare.

Name-pinus, pine. Fr. Hym. Eur. p. 582. Berk. Out. p. 253. C. Hbk. n. 821. S. Mycol. Scot. n. $776 .-$ Brot. Kl. Bor. t. 380 . Rostk. $t .50$.

\section{** Substance white.}

2. T. gibbosa Fr.-Everywhere whitish. Pileus corky, compact, villous, obsoletely zoned, extended behind, gibbous. Pores linear, straight, equal.

Large, thick, margin obtuse.

On poplar, gate-posts, stumps, \&c. Rare.

Zones convex and tuberculated; beautifully velvety; when old cinereous and green from minute Algre. M.F.B. Name-gibbus, gibbous. Fr. Hym. Eur. p. 583. Berk. Out. p. 253. C. Hbk. 12. 824. Fl. Dan. t. I964. Hussey ii. t. 4.-Pers. Syn. p. 501. B. sinuosus Sow. t. 194 var.

3. T. Bulliardi Fr.-Pileus white becoming fuscous, at length zoned, corky, becoming plane, even, smooth. Pores somewhat round, deep, unequal, pallid then rufescent.

It becomes at length fuscous internally. Odour fragrant.

On dead wood. Bathampton. Glamis. Oct.

Berkeley is inclined to regard it as a species of Dadalea. Name-after Bulliard. Fr. Hym. Eur. p. 584. B. \&o Br. n. 1293. S. Mycol. Scot. p. +12. - Bull. t. 3 IO.

4. T. suaveolens Fr.-Pileus white, corky, soft, pulvinate, villous, zoneless. Pores round, rather large, obtuse, white becoming fuscous.

Odour fragrant, of anise.

On willow, lime, \&c. Uncommon.

Spores white, oval or pip-shaped, $9 \times 4$ mk. W.G.S. Name-suavis, sweet. Siveet-scented. Fr. Hym. Eur. p. $5^{84}$. Berk. Out. p. 253. C. Hbk. n. 822. S. Mycol. Scot. n. 777. Hussey i. t. 43. Krombh. t. 4. f. 25. Fl. Dan. t. 1849. Bot. Zeit. 1859. t. II. f. 23. Harz. t. 49.-Linn. Sow, t. 228. Tratt. Austr. f. 4. Sterb. t. 27. D.

5. T. odora Fr.-Pileus pallid, corky, elastic, uneven, becoming smooth, zoneless. Pores minute, round, equal, whitish-ochraceous.

Odour fragrant.

On willow. Rare. 
Very nearly related to $T$. suavcolens. M.F.B. Spores white, oval or pip- Trametes. shaped, $3 \times 5$ mk. W.G.S. Name-odor, scent. Fr. Hym. Eur. p. 584. Berk. Out. p. 253. C. Hbk. n. 823.-Sommerf. Bolt.t. I62.

6. T. inodora Fr. - Shining white. Pileus corky, firm, becoming smooth, zoneless. Pores minute, round, entire, not changing colour.

Very like $T$. suaveolens, \&c., but smaller, firmer, always white (pores not becoming fuscous); distinguished by its want of odour.

On old mossy beech-stump. Stoke Poges.

Pores colourless, slightly angular, about $\mathrm{T}^{\frac{1}{10}} \mathrm{in}$. wide, nearly $1 / 4 \mathrm{in}$. long, not the least linear. Externally tomentose, white with a very slight tinge of pink at the base. As in Dadalea latissima, the texture radiates from a central point, and is of a pure white. $B$. $\mathcal{E} B r$. Name-inodorus, scentless. Fr. Hym. Eur. p. 584. Monogr. ii. p. 273. Icon. t. I9r. f. I. B. E Br. n. I570.

\section{II.-Resupinati. Pileus resupinate.}

7. T. mollis Fr.-Resupinate, determinate, somewhat membranaceous, pallid-wood-colour, at length becoming fuscous, umber at the margin, which is at length revolute and pubescent beneath. Pores large, unequal and torn.

A very distinct species, at length becoming black, adnate behind in the centre. Pores irregular, but not flexuoso-labyrinthine.

On dead wood, especially beech. Common. Jan.-Dec.'

Dissepiments rigid. Name-mollis, soft. Fr. Hym. Eur. p. 585. S. Mycol. Scot. $n$. 778. Dædalea Sommerf. Polyporus cervinus P. Berk. Out. p. 247. C. Hbk.n. 787 .

8. T. Terrei B. \& Br.-Resupinate, broad, somewhat orbicular, pulvinate, substance corky and white. Pores angular, here and there sinuate, pallid.

About 3 in. across, $x$ in. thick in the centre. Substance radiating from a central point, zoneless. Pores about $\frac{1}{y^{\prime}}$ in. across, angular in the centre, sinuated towards the edge. Inodorous. Habit that of Dadalea latissima.

On beech. Stoke Poges.

Name-after Michael Terry. B. \& Br.n. I57I.

9. T. serpens Fr.-White, arid, closely adnate, at first erumpent, in the form of a tubercle, orbicular, then confluent, the determinate circumference pubescent. Pores somewhat round and angular, unequal, obtuse.

Colour at length becoming pale. A very distinct species analogous with Radulum orbiculare.

On privet. Rare. Oct. 
Pores rather large, $\frac{1}{2} \sigma$ in. broad. $B$. \& $B r$. Spores oval, white, $14 \times 7 \mathrm{mk}$. W.G.S. Name-serpens, creeping. Fr. Hym. Eur. p. 586. Icon. t. I82. f. 3. Polyporus Stephensii B. \& Br. n. 356. Berk. Out. p. 252. C. Hbk. n. 8I8. Saund. \& Sm. t. 45. f. 8-12.

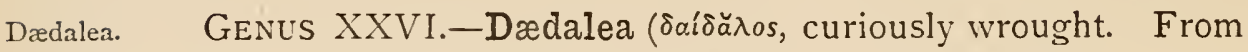
the elaborate hymenium). Pers. Syn. p. 449.

Pores firm, when fully grown sinuous, labyrinthine; in all other respects agreeing with Trametes.

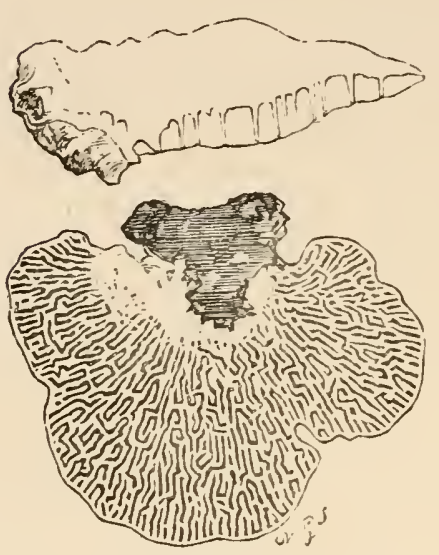

LXIX. Dadalea quercina. Onefourth natural size. Growing on wood, becoming hard, the floccose substance descending unchanged into the trama. Fr. Hym. Eur.p. 586.

* Corky-zoody, dimidiate, sessile.

** Coriaceous, dimidiate, sessile. *** Resupinate.

* Corky-woody, dimidiate, sessile.

1. D. quercina Pers.-Pale woodcolour. Pileus corky, rugulose, uneven, zoneless, rather smooth, of the same colour internally, at first porous; the pores then take the form of sinuses which are somewhat contorted or lamellose, becoming at last labyrinthine, edge obtuse.

There are many varieties-effuso-reflexed: Schaff. $t .23 \mathrm{I}$; wholly resupinate: Bull. t. 352.f. F. Pers. Myc. Eur. t. I8.f. I.

On dead oak. Frequent. June-Nov.

Perennial. Pileus $\mathrm{I} 2.5-\mathrm{I}_{5}$ cent. (5-6 in.) broad. Pores $2 \mathrm{~mm}$. (I lin.) or more broad. Sometimes resupinate or decurrent and the partitions elongated into tooth-like processes. 21I.F.B. Name-quercus, oak. Pirs. Syn. p. 500. Fr. Hym. Eur. p. 586 . Berk. Out. p. 254. t. 19. f. 5. C. Hbk. n. 825. S. Mycol. Scot. n. 779. Grev. t. 238. Krombh. t. 5. f. r, 2. Bail. t. 3r.-Sow. t. 18r. Bolt. t. 73. Bull. t. 352, 442. f. I. Vent. t. 60. f. 1, 2 (var.)

2. D. aurea Fr. Golden.-Pileus 5 cent. ( 2 in.) broad, corkycoriaceous, gibbous, veliety, somewhat zoned, unicolorous, internally, as well as the hymenium which is porous then narrowly sinuato-labyrinthine, light yellow.

Pileus triangular, margin swollen.

On dead oak. Hereford.

Imbricated, the veins for the most part straight and radiating. $B . \& B$. 
Name-aurum, gold. Fr. Hym. Eur. p. 587. B. \& Br. n. 1892.-Butt. t. Dædalea. 35. f. F.

3. D. confragosa Pers.-Pileus unicolorous, brick-red-fuscous, internally wood-colour, becoming ferruginous, corky, slightly convex, rough, somewhat zoned; sinuses porous then narrowly labyrinthine and torn, cinereous-pruinose then rufous-fuscous.

On willow, service, \&c. Rare.

Name-confragus, rough, rugged. Pers. Syn. p. 50r. Fr. Hym. Eur.p. 587. Berk. Out. p. 25t. C. Hbk. n. 826.-Bolt. t. 160. Bull. t. 491. f. I. Sozw. t. 193 .

4. D. cinerea Fr.-Pileus $4-7.5$ cent. ( $1 / 2-3$ in.) broad, cinereous, corky-woody, thick, somewhat undulated, zoned, tomentose. Pores minute, obtuse, quite entire, some round, some very long, labyrinthiform, flexuous, intricate, white or cinereous.

Perennial, stratose, allied however to D. unicolor.

On trunks. Penzance.

The thick substance separates this from every form of $D$. unicolor, also the inciso-strigose surface of the pileus. $B$. E Br. Name-cinereus, ash-colour. Fr. Hym. Eur. p. 583. Syst. IIyc. i. p. 336. Icon. t. 182. f. 2. B. \& Br. n. 1968 .

$$
\text { ** Coriaceous, dimidiate, sessile. }
$$

5. D. unicolor Fr.-Pileus cinereous, with zones of the same colour, coriaceous, villoso-strigose; sinuses labyrinthiform, flexuous, intricate, acute, at length torn into teeth.

Commonly imbricated, fuliginous when damp, whitish-grey when dry. Hymenium whitish-cinereous, sometimes fuscous. There are two forms: one thicker, margin whitish, dissepiments firmer, distant, forming more entire sinuses; the other thinner, broader, the sinuses narrower, more torn. Bull. t. 50I. f. 3. represents a remarkable variety (?) rufescent with very minute sinuses.

On stumps, especially birch. Common. July-Oct.

Pileus 5-Io cent. $(2-4$ in.) broad. Often green from minute $A \lg \mathscr{C}$. M.F.B. Name-unus, one; color, colour. Unicolorous. Fr. Hym. Eur. p. 588. Berk. Out. p. 254. C. Hbk.n.827. S. Mycol. Scot.n.780.-Bull. t. 50r. f. 3. Bolt. t. I63. Soiv. $t .325$.

*** Resupinate.

6. D. latissima Fr.-Pale wood-colour, effused, 5 in.-2 ft. broad, corky-woody, thick, undulated, zoned within; sinuses narrow, distant, somewhat round and very long, flexuous.

The structure is very peculiar, radiating from the base to the surface, with parallel filaments.

VOL. II. 
Dædalea. On dead wood. Rare.

Naine-latus, broad. Very broad. Fr. Hym. Eur.p. 589. Syst. Myc. i. p. 340. Berk. Out. p. 254. C. Hbk. n. 828. S. Mycol. Scot. n. $78 \mathrm{r}$.

7. D. vermicularis Pers. - Flesh-colour-rufescent, broadly effused, thin, becoming even; sinuses short, attenuated at both ends, flexuous, poriform at the margin.

It has much in common with $D$. latissima, but is much thinner, ro-r 5 cent. (4-6 in.) long, 5 cent. ( 2 in.) broad. Adhering to the soil by root-like fibres.

On the ground.

Berkeley refers the figure of Sowerby to $D$. latissima. Name-vermis, a worm. From the peculiar colour. Pers. Myc. Eur. 3. p. 2. Fr. Hym. Eur. p. 589. Sou. t. 424 .

\section{Species of uncertain affinity.}

8. D. ferruginea Schum.-Pileus light-yellow-ferruginous, white-villous when young and at the margin, internally fleshcolour, coriaceous, effuso-reflexed, zoned; hymenium porous then narrowly labyrinthiform, tawny.

Imbricato-connate. It seems nearest to $D$. unicolor.

On dead wood. Strachan, Kincardineshire.

Name-ferrum, iron. Ferruginous. Schum.-Fr. Hym. Eur. p. $5^{89}$. S. Mycol. Scot. n. 782. Fl. Dan. t. 2029.

Hexagona. GenUs XXY'II.-Hexagona (hexagonum, a six-sided figure; from the form of the pores). Poll. Pl. nov. p. 35. Epicr. i. p. 496.

Hymenophore descending and forming a trama of the same colour as the pileus and similar to it. Pores at the very first dilated into hexagonal, regular, woody-hard alveoli, the dividing walls firm, never torn. Dimidiate, sessile, growing on wood, corky-woody, persistent, but not growing again to form strata.

A very natural genus, easily recognised. The essential feature consists in the depressions being equally wide in the earliest stage of growth, whereas in the Polypori the pores, which are minute when young, are gradually developed and clilated. Fr. Hym. Eur.p. 589 .

No British species. 
Hymenium reticulato-cellular, or alveolate. Alveoli radiating, formed of the densely anastomosing gills, elongated. Spores white (in pairs?). Dimidiate, somerohat stipitate, fleshy, pliant, anmual, growing on wood, differing in entire appearance and structure from the preceding genera, wherefore they were formerly referred not to Polypori, but to Cantharelli or Merulii. Fr. Hy'm. Eur.p. 590.

No British species.

Genus XXIX.-Merulius. Fr. Syst. Myc. i. p. 326.

Hymenophore formed from a woven mucedinous mycelium, covered with the waxy-soft, continuous hymenium which is reticulated on the surface with obtuse folds, imperfectly porous, at length gyrose and obsoletely toothed. Growing on wood, soft, mucedinous, at the first at least resupinate. Fr. Hym. Eur. p. 59I.

I. LEPTOSPORI ( $\lambda \epsilon \pi \tau o ́ s$, fine, slight ; mópos, a pore. From the shallow pore-like folds). Hymenium naked or obsoletely pruinose with the white spores.

* Pileus effuso-reflexed, circumference determinate.

** Resupinato-effused, faxy-membranaceous, separating, Maxy beneath and at the circumference.

*** Crustoso-adnate, somewhat flaxy at the circunference.

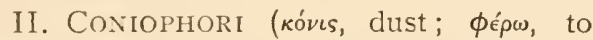
bear). Hymenium pulverulent with the ferruginous spores. All destructive.

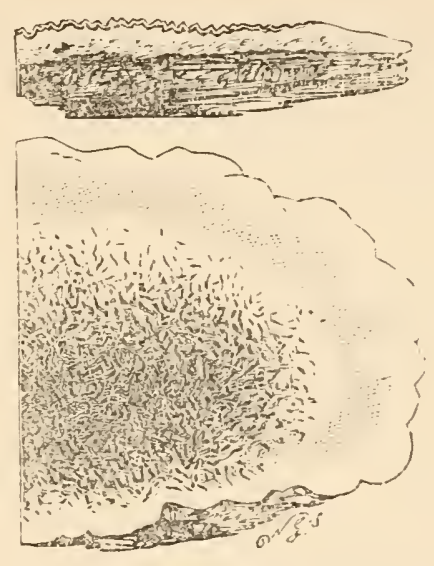

LXX. Merulius lachrymans. Onethird natural size.

\section{I.-Leptospori. Hymenium naked, \&c. \\ * Pileus effuso-reflexed, circumference determinate.}

1. M. tremellosus Schrad.-White, resupinate then free or reflexed, fleshy-tremellose, tomentose, margin dentato-radiate. Folds porous, various, ruddy.

Sporting in form, becoming pale in hidden places, but easily recognised by its gelatinoso-cartilaginous flesh. 
Merulius. On decayed trees, birch, \&c. Rare. Sept.-Feb.

Sometimes the edge is beautifully tinged with pink. M.Z.B. Spores cylindrical, curved, hyaline, $4 \times \mathrm{x} \mathrm{mk}$. $K$. Name-tremo, to tremble. From the substance approaching Tremellu. Schrad.-Fr. Hym. Eur. p. 591. Berk. Out. p. 255. C. Hbk. n. 829. S. Mycol. Scot.n. 783. Fl. Dan.t. 1553. 776. f. т. Hussey i. t. Iо. Kl. Bor. t. 460.

2. M. aurantiacus Klotsch.-Pileus 2.5 cent. (I in.) broad, between yellow and dirty white, here and there cinereous, tough, fleshy-coriaceous, effuso-reflexed, tomentose, zoned. Folds minute, somewhat poriform, dull orange.

Zones obsolete, hirsuto-tomentose.

On dead beech. Rare. May.

Allied to M. lachrymans. MI.F.B. Name-aurum, gold. Orange-yellow. Kl. in Berk. Eng. Fl. v. p. I28. Berk. Out. p. 256 . C. Hbk. n. 832 . S. Ilycol. Scot. n. 784. Hr. Hym. Eur. p. 59I.

3. M. corium Fr.-White, resupinato-effused, 5-7.5 cent. (2-3 in.) and more long, and often equally broad, soft, somewhat of the consistence of paper, reflexed at the circumference which is at length free, villous beneath; hymenizm reticulato-porous, fleshcolour or pale tan.

Remarkable, variable in form and colour, sometimes short and reflexed, sometimes broadly expanded.

On dead wood. Common. March-Dec.

Spores oval, vivid orange, $4 \times 5 \mathrm{mk}$. W.G.S. Name-corium, skin, leather. Fr. Hym. Eur. p. 591. Elench. p. 58. Berk. Out. p. 255. C. Hbk. n. 830. S. Mycol. Scot. n. 785. Grev. t. I 47.-Bull. t. 402 . Sow. t. 349.

** Resupinato-effused, flaxy-membranaceous, Eoc.

4. M. læticolor B. \& Br. - Bright-orange, wholly effused, adnate; margin tomentose, white; hymenium even then plicatorugose ; folds distant.

On sawdust and leaves. King's Lynn.

Name-latus, bright; color, colour. B. \& Br. n. I68r.

5. M. himantioides Fr.-Lilac, effused, silky, very soft, fibroussilky beneath, circumference flaxy. Folds porous then gyrose, dingy yellow then somewhat olivaceous.

Like M. lachrymans, but thinner and not pulverulent.

On fir wood and on club-mosses. Rare. Sept.

Name-imás, a strap or thong; eíos, appearance. From the thong-like 
folds. Fr. Hym. Fur.p. 592. Icon. t. x93.f. x. Br. in Bath Trans. 1870, Merulius. p. 84. C. Hbk. n. 83r. S. Mycol. Scot. n. 786. Pers. Myc. Eur. t. I4. f. 3, 4. B. arboreus Sow. t. 346 ?

6. M. molluscus Fr.-White, effused, thin, soft, membranaceous, margin flaxy. Folds poroso-gyrose, flesh-colour.

It varies with the pileus shortly reflexed and then the hymenium is not reticulated, but at the first gyroso-dentate.

On fir-branches. Uncommon. Sept.-Feb.

Hymenium dark brown when old. M.F.B. Name-molluscus, soft. Fr. Hym. Eur. p. 592. Icon. t. 193. f. 2. Berk. Out. p. 255. C. Hbk.n.833. S. Mycol. Scot. n. 787 . Pers. Myc. Eur. 2. t. I4.f. I, 2.

\section{*** Crustoso-adnate, circumference somewhat flaxy.}

7. M. porinoides Fr.-Crustaceo-adnate, thin, the flaxy circumference white. Folds poriform, distant, light yellow-dingy.

In respect of the hymenium it resembles the preceding rather than the following species.

On dead wood or on ground. Rare.

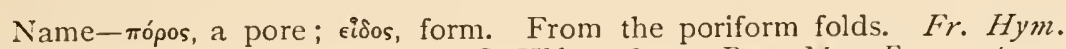
Eur. p. 593. Berk. Out. p. 255. C. Hbk. n. 834. Pers. Myc. Eur. 2. t. 14. f. 7 .

8. M. rufus Pers.-Red-flesh-colour, crustaceo-adnate, waxysoft, smooth, circumference somewhat naked; hymenium equally porous, of the same colour.

The habit is that of Polyporus, but it is distinct in its waxy-soft nature. Often immersed in the wood.

On dead oak. Uncommon. Oct.

It has a very polyporoid appearance, M.尹.B. Name-rufus, reddish. Pers. Myc. Eur. 2. t. 16.f. r, 2. Fr. Hym. Eur. p. 593. Berk. Out. p. 255. C. Hbk.n. 835. S. Mycol. Scot. n. 788 .

9. M. serpens Tode.-Pallid becoming red, crustaceo-adnate, thin, becoming smooth, the flaxy circumference white. Folds at first in the form of wrinkles, then porous, angular, entire.

On dead fir. Rare. Oct.

Not separable like $M$. corium. M.F.B. Name-serpo, to creep. Creeping. Tode.-Fr. Hym. Eur. p. 593. Icon. t. 193.f. 3. Berk. Out. p. 255. C. Hbk. n. 836. S. Mycol. Scot. n. 789 .

10. M. pallens Berk.-Pale-reddish, adnate, fleshy, somewhat gelatinous, thin, inseparable; margin indeterminate. Folds poriform.

Pores minute. 
Merulius. On fir and oak. Rare. Oct.-Dec.

Name-palleo, to be pale. Berk. Out.p. 256. C. Hbk.n.837. S. Mycol. Scot. n. 790. Fr. Hym. Eur. p. 593.

11. M. Carmichaelianus Berk.-White, extremely thin, forming effused, entirely resupinate, irregular, interrupted, confluent patches. Folds forming regular, angular reticulations; dull brown when dry.

Forming a mere pellicle, with minute, often hexagonal, extremely shallow pores, like the cells of a honeycomb but quite superficial.

On bark. Appin.

Name-after Carmichael. Berk. Out.p. 256. C. Hbk. n. 838. S. Mycol. Scot.n. 79r. Fr. Hym. Eur. p. 593.-Grev. t. 224.

II.-Coniophori. Hymenium pulverulent, \&c.

12. M. lachrymans Fr.-Light-yellow-ferruginous, spongyfleshy, slightly moist, spider-web-velvety beneath, margin swollen, tomentose, white. Folds large, porous and gyroso-toothed.

Exuding watery drops when in fullest vigour. Commonly in the form of a placenta, but also effuso-reflexed, nay, from a medial placenta stalked tubercles producing small pilei arise. Hymenium exceedingly changeable, sometimes like that of Hydnum.

On dressed wood, \&c. Very common.

The dry-rot of houses. Often covering a large surface of the wood. Spores oval, rich orange brown, $9 \times 6 \mathrm{mk}$. IV.G.S.; ellipsoid, somewhat yellow, ro$12 \times 5-6 \mathrm{mk} . K$. Name-lachryma, a tear. From the watery drops. Fr. Hym. Eur. p. 594. Sv. ätl. Sv. t. 70. Berk. Out. p. 256. C. Hbk. n. 839. S. Mycol. Scot. n. 792. Harz. t.77. Hussey i. t. 3. Fl. Dan.t. 2026. Krombh. t. 46. f. 1-2. Sozv. t. Ir3.-Wulf in Facqu. Coll. t. 8. f. 2.

* M. pulverulentus Fr.-Very broad, membranaceous, becoming even, zoned, arid, spider-web-velvety beneath, gradually decaying from the centre towards the circumference. Folds marginal, somewhat reticulated, tawny.

Of many colours. Singular from the peculiar way in which the hymenium recedes from the centre. Strachan, Kincardineshire. Name-pulvis, dust. Pulverulent. Fr. Hy'm. Eur. p. 594. S. Mycol. Scot. n. 792.

Genus XXX.-Porothelium ( $\pi \delta \rho o s$, a pore; $\theta \eta \lambda \eta \dot{\eta}$, a teat. From the porous spines). Fr. Obs. 2. p. 272.

Whole fungus composed of mycelium, expanded resupinately, somewhat membranaceous, producing papillce which are at the 
first distinct (and closed), soon opened in the form of pores, at Porothelength elongated and tubular. A genus very distinct from the lium. preceting ones, in many respects anaiogous with Fistulina. Fr. Hym. Eur. p. 595.

1. P. Friesii Mont.-White, somewhat tan-colour, effused, confluent, focculoso-membranaceous, circumference simple. Warts containing the pores immersed, yellowish, at length opening in pitcher-shape.

On dead pine. Rare. Nov.-Feb.

Name-after Elias Fries. Montagn. Ann. Sc. Nat. 1836, 7un. n. 39. Fr. Hym. Eur. p. 595. Berk. Out. p. 257. C. Hbk. n. 840. S. Mycol. Scot. 11. 793.
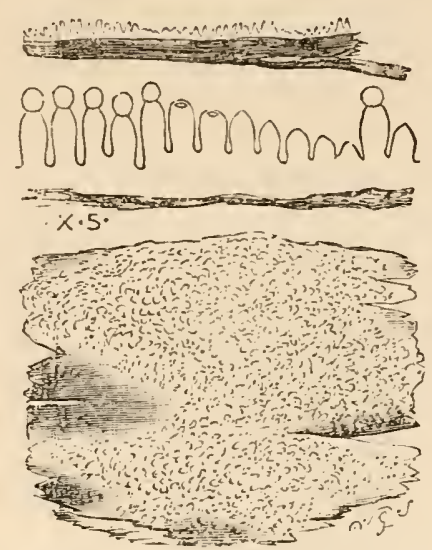

2. P. Stevensoni B. \& Br.-Sub- LXXI. Porothelium Stevensoni. stance rather thick, gelatinous, margin rather coarsely hispid, at length Natural size. Section five times natural size.

more or less denuded. Warts of the hymenium distinct, interstices very smooth, bearing at the apex a limpid, diaphanous, yellow globule.

On old pine rail. Glamis, I877-1886. Spring, autumn.

Almost white when fresh, becoming yellowish when old. The limpid globule is at first pale. When full grown the papilla is from four to five times as long as the diameter of the globule. The mycelium imparts a sweet scent to the wood. Found in greatest perfection on the under side of very old pine rail lying on the ground. Name-after Rev. John Stevenson. B. E Br. $n$. 1683. S. M Lycol. Scot. n. 794 .

3. P. Keithii B. \& Br.-Narrowly adnate, slightly umbercolour; circumference very thin, at first somewhat gelatinous. Warts short, at length collapsed, gelatinous in the centre.

On dead fir. Sanquhar. Dunphail. Glamis. April.

Name-after Rev. Dr Keith. B. E Br. n. r684. S. Mycol. Scot. n. 795.

4. P. confusum B. \& Br.-Narrowly adnate, pallid, margin very thin, arachnoid, substance at first floccoso-pulverulent. Warts very small.

On fir sticks. Glentanner. Leighwood. Glamis. Pitoulish, Inverness-shire. June-Sept.

Name-confundo, to confuse. From having been confounded with a species in another genus. $B$. \& Br. n. 1685. S. Mycol. Scot. n. 796. 
Solenia. Genus XXXI.-Solenia ( $\sigma \omega \lambda \eta^{\prime} \nu$, a pipe). Hoffm. Deutschl. Fl.

Receptacle none. Tubes membranaceous, somewhat cylindrical,

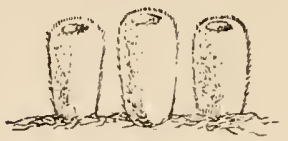

$x \cdot 20$

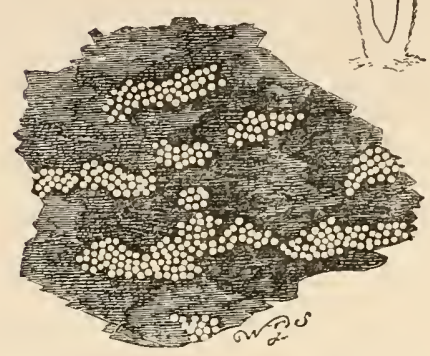

$L X X I I$. Solenia ochracea. Natural size. Section twenty times natural size. turbinate, distinct and free from one another, definitely facing the ground, mouth narrozed, in which respect they differ from the Cyphella. Fr. Hym. Eur. p. 595 .

Most nearly allied to Cyphella.

1. S. ochracea Hoffm.-Ochraceous, white internally, scattered, clavato-cylindrical, tomentose.

On dead wood. Uncommon. Aug. -Dec.

Spores subglobose, $6 \times 8 \mathrm{mk}$. $W . G . S$. Name-colour of ochre. Hoffm. D. Fl. ii. t. 8. f. 2. Fr. Hym. Eur. p. 596. Br. Bath Trans. I870, p. 90. C. Hbk. n. 957. S. Mycol. Scot. $n \cdot 797$. 


\section{ORDER III.-HYDNEI.}

Hymenium inferior or amphigenous, from the first figurate, and definitely but variously protuberant in the form of persistent spines, teeth, tubercles, crests, papillæ. Sporophore sometimes single-spored. The greater part are resupinate and effused, and hence they are inferior to the Agaricini, which are commonly circular on a central stem, and to the Polyporei, which are most frequently dimidiate. Fr. Hym. Eur.p. 598.

Genus XXXII.-Hydnum ( $\tilde{\delta} \delta$ vov, the Greek name for a kind Hydnum. of edible fungus). Linn. Gen. Plant.

Hymenium inferior, aculeate; spines awl-shaped, distinct at the base. The central genus of the order, various, analogous with the Polypori. Fr. Hym. Eur. p. 598.

I. Mesopus ( $\mu \epsilon \sigma o ́ s$, middle; $\pi$ oús, a foot). Entire, simple, with a central stem. All growing on the ground and chiefly in pine woods.

+ Carnosa. Pileus fleshy, somewhat fragile. Most of them edible.

* Spines changing colour, pileus scaly or tomentose.

** Spines changing colour, pileus even, smooth.

*** Spines unchangeable, unicolorous, whitish.

t† Lignosa. Pileus corky or coriaceous, tough.

* Spines changing colour, and, as well as the spores, somerwhat fuscous.

** Spines changing colour, and, as well as the spores, ferruginous. ish.

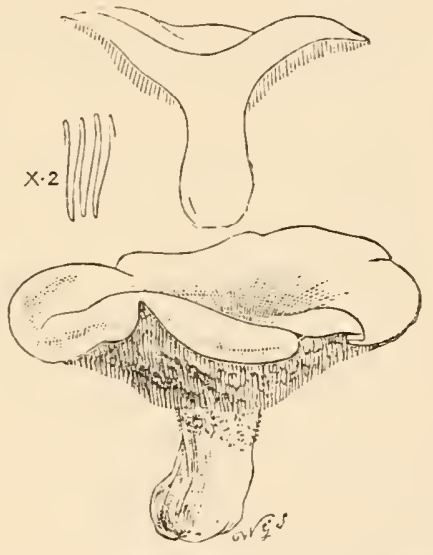

LXXIII. Hydnum repandum. One-third natural size. Section twice natural size.

II. Pleuropus ( $\pi \lambda e^{\prime}$ póv, the side; $\pi$ ov́s, a foot). Somewhat dimidiate, stem lateral.

III. MERISMA ( $\mu \in \rho i \zeta \omega$, to divide). Very much branched or tuberculiform and immarginate.

* Very much branched.

** Simple, tuberculiform, immarginate. 
Hydnum. IV. Apus ( $\dot{a}, \pi$ rov́s, a foot. Stemless). Pileus sessile, dimidiate, marginate, often effuso-reflexed.

* Pileus fleshy, soft.

** Crespitose, pilei imbricated, commonly pliant, tough. Very distinguished.

*** Simple, pileus coriaceous or corky.

**** Pileus membranaceous.

V. Resupinatr. Pileus none. Absolutely resupinate, with straight or oblique spines according to their situation.

* Spines fuscous, ferruginous.

** Spines yellowish, green.

*** Spines flesh-colour, lilac, rufescent.

**** Spines white or light-yellowish when old.

I.-Mesopus. Entire, simple, with a central stem.

+ Pileus fleshy, somewhat fragile.

* Spines changing colour, pileus scaly or tomentose.

1. H. imbricatum Linn.-Pileus about ro cent. (4 in.) broad, umber, zoneless, fleshy, rather plane, somewhat umbilicate, floccose, tessulato-scaly; flesh dingy whitish. Stem curt, 2.5-7.5 cent. ( $1-3$ in.) long, $2.5-5$ cent. ( $1-2$ in.) thick, even. Spines 8-12 $\mathrm{mm}$. (4-6 lin.) long, decurrent, cinereous-white.

There are two forms: one with the pileus plane and with thick persistent scales, another with the pileus somewhat infundibuliform, and with thinner, at length separating scales.

In pine woods. Rare. Sept.-Nov.

Often abundant where it occurs. Edible but bitter. Spores spherical, subhyaline, $3 \mathrm{mk} . K_{\text {. }} 6 \times 5 \mathrm{mk}$. IV.G.S. Name-imbrex, a tile. Imbricated. Linn. Suec. n. 1257. Fr. Hym. Eur. p. 598. Sv. ätl. Sv. t. 33. Berk. Out. p. 257. C. Hbk. 17. 8+2. S. Myycol. Scot. 11. 798. Schaff. t. I40. Fl. Dan.t. г76, г 500. Sow. t. 73. Grev. t. 71. Barla t. 38. f. I-4. Harz. t. $3^{6 .}$ Kl. Bor. t. 462. Bail. t. 29.-Nees Syst. f. 240.

2. H. squamosum Schæff. - Pileus rufous-fuscous, fleshy, irregular, depressed, smooth, breaking up into irregular scales; flesh whitish. Stem curt, attenuated downwards, white. Spines grey-fuscous, whitish at the apex.

Smaller than $H$. imbricatum, rigid. Pileus even when young.

On the ground. Fungus Show, South Kensington, i873. Oct. Name-squaina, a scale. Schaff. t. 273. Fr. Hym. Eur. p. 598. B. \& Br. n. 1435 .

3. H. scabrosum Fr.-Pileus about ro cent. (4 in.) broad, umber-ferruginous, compactly fleshy, at first turbinate, then plane above, very convex beneath, at first tomentose, then rough with flocci which are fasciculate in the form of minute crowded 
squamules, slightly repand at the margin; flesh very thick, Hydnum. white, descending into the stem. Stem very curt, 2.5 cent. ( $\mathrm{I}$ in.) long, and equally thick, round or compressed, dotted with the rudiments of spines decurrent upon it, cinereous, attenuated downwards, rounded and blackish at the base. Spines $8 \mathrm{~mm}$. (4 lin.) long, equal, awl-shaped, fuscous-ferruginous, whitish at the apex, at first sight grey-fuscous.

Very fleshy, compact, obese.

In pine wood. Forres, 1879. Sept.

Name-scabrosus, rough. Fr. Hym. Eur. p. 599. Monogr. ii. p. 273. S. Mycol. Scot. Supp. Scot. Nat. 1881, p. 37. Schaff. t. 27 I.

** Spines changing colour, pileus even, smooth.

4. H. lævigatum Sw.-Pileus IO-I 5 cent. (4-6 in.) broad, umber, fleshy, compact, firm, regular, plane, even, very smooth, margin circinate (not repand); flesh whitish, compact, but by no means fibrous, soft when fresh, pliant when dry. Stem short, thick, even, pallid fuscous. Spines thin, pallid fuscous.

Its size is that of $H$. imbricatum, but it occurs twice as large, with the pileus minutely rimuloso-rivulose, by no means scaly. The stem varies curt and unequal or longer and equal. Quite distinct from H. fragile.

In pine woods. Rannoch. Aug.-Oct.

Spores globose, verrucose, pale lemon-yellow, $7 \mathrm{mk}$. Q. Name-laris, even. Swartz. Let. Akad. Handl. 1810, p. 243. Fr. H'm. Eur. p. 599. Monogr. ii. p. 275. Sv. ätl. Sv. t. 8I. S. Mlycol. Scot. n. 799.

5. H. fragile Fr.-Pileus at first pallid, soon cinereous or brickrufescent, somewhat zoned towards the margin, fleshy, fragile, unequal, surface at first pubescent, then becoming smooth, commonly even but here and there minutely squamulose and pitted (slightly wrinkled), margin undulated and lobed; flesh grey, somewhat zoned. Stem stout, unequal, smooth, cinereous. Spines scarcely decurrent, very much elongated, slender, fragile, whitish then grey.

Very changeable. Stem sometimes short and thick, sometimes elongated. Specimens occur with the stem 7.5 cent. ( 3 in.) long, so cent. (4 in.) thick, and the pileus more than 30 cent. ( 12 in.) broad. Quite distinct from $H$. lavigatum in its soft substance, in the pileus being at first pubescent, \&c.

In pine woods and among heath. Rare. Sept.-Nov.

Name-fragilis, fragile. Fr. Hym. Eur. p. 599. Monogr. ii. p. 275. Sv. ätl. Sv. t. 89. B. \& Br. n. 1024, I366. C. Hbk. n. 843. S. .1yycol. Scot. n. 800. Berg. Pyr. t. 16. Paul. t. 34. 
6. H. repandum Linn.-Pileus 5-I 5 cent. (2-6 in.) broad, pallid, \&c., fleshy, fragile, somewhat repand, rather smooth. Stem 5-12.5 cent. ( $2-5$ in.) long, I-4 cent. ( $1 / 2-11 / 2$ in.) thick, irregularly shaped, pallid. Spines $8 \mathrm{~mm}$. (4 lin.) long, unequal, of the same colour.

The colour varies whitish, yellow, somewhat flesh-colour, unchangeable. Pileus sometimes floccoso-pruinose.

In woods. Common. Aug.-Nov.

Margin of pileus more or less arched. M.F.B. Spores white or with a suggestion of yellow, round with an obtuse apiculus at one end, $5 \mathrm{mk}$. IV.G.S. Edible. One of the most delicious. Requires about four hours' slow cooking. Name-ripandus, repand. Linn. Suec. n. 1258. Fr. Hym. Eur. p. 60r. Sv. ätl. Si. t. 15. Berk. Out. p. 258. t. 17. f. 2. C. Hbk. n. 844. S. Mycol. Scot. n. 8or. Schreff. t. 318. Bull. t. 172. Sow. t. 176. Fl. Dan.t. 310. Vittad. t. 25. f. 2. Krombh. t. 50. f. r-9. Vent. t. 27. f. 24. f. 4-6. Barla t. 32. f. I-9. Grev. t. 44. Hussey i. t. 16. Harz. t. 23, \&c.

* H. rufescens Pers. Rufescent. -Pileus $5-7.5$ cent. (2-3 in.) broad, thin, somewhat regular, pubescent. Stem 2.5-7.5 cent. (I-3 in.) long, commonly thin, somewhat equal. Spines regular.

In woods. Frequent. Aug.-Nov. Pers. Syn.p. 555. Berk. Out., C. Hbk., S. Mycol. Scot. as quoted above. Bolt. t. 89 .

†† Lignosa. Pileus corky or coriaceous, tough.

* Spines changing colour, and, as well as the spores, somewhat fuscous.

7. H. compactum Pers.-Pileus $2.5-15$ cent. ( $1-6$ in.) broad, olivaceous-cinereous or fuscous, corky, compact, undulated and tuberculose in becoming confluent, zoneless, commonly wrapped round with whitish down, internally variegated azure-blue. Stem very short, 2.5 cent. ( $\mathrm{I}$ in.) and more long, irregularly shaped, tawny inclining to fuscous. Spines $2-4 \mathrm{~mm}$. ( $\mathrm{I}-2 \mathrm{lin}$.) long, fuscous, pallid at the apex.

Irregularly shaped, somewhat sessile, often forming a shapeless crust.

In fir woods and on heaths. Rare. Sept.-Nor.

Name-compactus, compact. Pers. Syn. p. 556, partly. Fr. Hym. Eur.p. 603. Berk. Out. p. 258. B. \& Br. n. I367. C. Hbk. n. 845. S. Mycol. Scot. n. 802. Krombh.t. 50. f. 12. Strauss Sturm. 33. t. 6. -Schreff. t. I46 excluding $f .4,7$.

8. H. aurantiacum Alb. \& Schw.-Pileus $2.5-12.5$ cent. (I-5 in.) broad, orange, corky, compact, turbinato-dilated, with small 
clevations, zoneless, often covered over with whitish down, zoncd Hydnum. internally. Stem short, $\mathrm{I}-5$ cent. $(1 / 2-2$ in.) long, $\mathrm{I}-2.5$ cent. $(1 / 2-1$ in.) thick, orange. Spines $2-4 \mathrm{~mm}$. ( $\mathrm{I}-2$ lin.) long, whitish becoming fuscous.

Inodorous, firm.

In pine woods. Grantown. Sept.-Nov.

Name-aurum, gold. Orange-yellow. A. \& S. p. 265. Fir. Hym. Eur. p. 603. B. \& Br. n. 1368. S. ilycol. Scot.n. 803. Fl. Dan. t. 1439. Batsch f. 222 (bad).

9. H. ferrugineum Fr.-Pileus 2.5-IO cent. ( $\mathrm{I}-4$ in.) broad, obconic or when more fully grown flattened, even depressed, spongy-corky, soft, at first covered over with whitish down which exudes blood-red drops in the depressions, then more even and internally fernginous. Stem firm, $4-7.5$ cent. (I $1 / 2-3$ in.) long, unequal, fuscous-ferruginous. Spines awl-shaped, equal, fuscousferruginous.

Gregarious but not confluent. Spongy-soft when young, corky and juiceless when full grown.

In fir wood. Rothiemurchus. Aug.-Oct.

Name-ferrum, iron. Ferruginous. Fr. Hym. Eur. p. 603. Icon.t. 4. B. E Br.n. 1369. S. Mycol. Scot.n. 804. Krombh. t. 50. f. Iо, I I. Bull. t. 409 (var.)

** Spines changing colour, and, as well as the spores, ferruginous.

10. H. scrobiculatum Fr.-Ferruginous. Pileus 2.5-5 cent. ( I-2 in.) and more broad, corky-coriaceous, clavate then plano-infundibuliform, pubescent, disc slightly pitted, scaly, zoned within. Stem very short, $12 \mathrm{~mm}$. ( $1 / 2 \mathrm{in}$.) or a little more long, 6-8 mm. (3-4 lin.) thick, equal, smooth, often rooted. Spines very short, slightly decurrent, thin, fragile, of the same colour as the pileus, and at length becoming fuscous.

Gregarious, often growing into each other. Pileus becoming pale when dry.

In fir woods. Minstead, Lyndhurst. Rothiemurchus, \&c. Aug.-Nov.

Name-scrobis, a trench. From the slightly pitted disc. Fr. Hym. Eur. p. 604. Icon. t. 5. f. I. B. E Br. n. 1294. S. Mycol. Scot. n. 805. Wich. Gen. t. 72. f. 7.-Bull. t. 156 .

11. H. zonatum Batsch.-Ferruginous. Pileus $2.5-5$ cent. (I-2 in.) broad, equally coriaceous, thin, expanded, somewhat infundibuliform, zoned, becoming smooth, radiato-rugose, the paler 
Hydnum. margin sterile beneath. Stem $12-18 \mathrm{~mm}$. (1/2-3/4 in.) long, 4-6 mm. $(2-3$ lin.) thick, slender, somewhat equal, floccose, base tuberous. Spines $2-3 \mathrm{~mm}$. ( $\mathrm{I}-\mathrm{I} 1 / 2 \mathrm{lin}$.) long, slender, pallid then ferruginous.

Very like $H$. scrobiculatum.

In fir woods. Rare. Aug.-Oct.

Name-zona, a zone. Zoned. Batsch f. 224. Fr. Hym. Eur. p. 605. Berk. Out. p. ${ }_{258}$ C. Hbk. n. ${ }_{4} 6$. S. Mycol. Scot. n. 806 . Nees Syst.f. $2,4^{2}$.

\section{*** Spines unchangeable and spores whitish.}

12. H. nigrum Fr.-Pileus azure-blue-black, zoneless, but with a white margin when in fullest vigour, corky-rigid, club-shaped when young, then turbinate, at length flattened, plano-depressed, tubercular, tomentose, black internally. Stem 2.5 cent. (I in.) long, stout, often rooting, unequal, black, tomentose at the base, internally of the same colour. Spines awl-shaped, thin, rather short, white.

Crespitose, rarely scattered, growing into each other in various forms. Inodorous. It differs from all others in being internally black.

In pine woods. Street, Somerset.

Sometimes zoned, as in the fig. of Fries. Spores round, papillose, $4 \mathrm{mk}$. IV.G.S. Name-niger, black. Fr. Hym. Eur. p. 605. Icon. t. 5. f. 2. B. E०Br.n. г296. Seem. Fonm. 1868, p. 334. Bath Trans. 1870, p. 86. C. Hbk. n. 847 . B. pileus olivaceous-cinereous. Batsch f. 223 .

13. H. graveolens Delast.-Pileus 2.5 cent. ( $\mathrm{I}$ in.) and more broad, black-fuscous, internally fuscous, margin whitish, coriaceous, thin, soft, zoneless, rugose, smooth; flesh of the same colour but paler. Stem 2.5 cent. (I in.) or a little more long, scarcely $2 \mathrm{~mm}$. (I lin.) thick, tough, very slender, equal, smooth, even polished, fuscous-black. Spines curt, decurrent, grey.

The pileus when dry becomes cinereous. It differs remarkably from neighbouring species in its softer, thin substance, and in its odour which is almost that of Melilot. Commonly densely gregarious or cæspitose, but not growing into each other.

In fir woods. Rare. Sept.-Nor.

Retaining its scent for years. Name-graveolens (gravis-oleo), strong-smelling. Delast.-Fr. Hym. Eur. p. 605. Icon. t. 6. f. r. Berk. Out. p. $25^{8}$. C. Hbk.n.843. S. Ilycol. Scot.n. 807.

14. H. molaleucum Fr.-Pileus black, coriaceous, thin, rigid, irregular, striate, with little elevations at the disc, margin white. Stem slencler, smooth, black. Spines white.

Inodorous. Pileus plane. 
In fir woods. Ascot. Forres. Sept.

Hydnum.

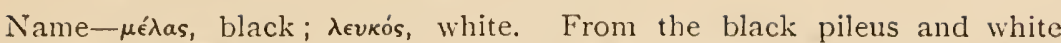
spines. Fr. Hym. Eur. p. 606. B. \& Br. n. 1295. S. Mycol. Scot. Supp. Scot. Nat. 1881, p. 38.-Schaff.t. 272.

15. H. cyathiforme Schæff. - Pileus pale cinereous, margin white, coriaceous, thin, plano-infundibuliform, zoned, disc somewhat tomentose. Stem slender, smooth, pale cinereous. Spines white.

Small, commonly growing into each other.

On fir wood. Ascot. Rothiemurchus. Sept.-Oct.

Spores globular, rough or papillated, $3 \mathrm{mk}$. W.G.S. Name-cyathus, a cup ; forma, form. Schaff. t. 139. Fr. Hym. Eur. p. 6o6. S. Mycol. Scot. n. 808. Fl. Dan. t. 1020.f. 2. H. tomentosum B. \& Br.n. 1025. C. Hbk. n. 849. Hars. t. 3. a. Seem. Fourn. $\mathrm{x} 868, t .76$.

\section{II.-Pleuropus. Somewhat dimidiate, stem lateral.}

16. $\mathrm{H}$. auriscalpium Linn.-Pileus $12-18 \mathrm{~mm}$. ( $1 / 2-3 / 4$ in.) broad, date-brown then blackish, dimidiate, coriaceous, reniform, hairy. Stem slender, 5-7.5 cent. (2-3 in.) long, I-3 mm. (1/2-I $1 / 2$ lin.) thick, vertical, rooted, hairy, of the same colour as the pileus. Spines 4-6 mm. (2-3 lin.) long, tough, date-brown.

The pileus sometimes appears entire with lobes all round.

On fir-cones and among fir-leaves. Frequent. Aug.-Nov.

Name-auriscalpium, an ear-pick. From its shape. Linn. Suec. n. r260. Fr. Hym. Eur.p. 607. Berk. Out.p. 258. C. Hbk. n. 850. S. Mycol. Scot.n. 809. Schaff. t. 143. Bull. t. 48r. f. 3. Fl. Dan. t. 10zo.f. r. Curt. Lond. t. 190. Bolt. t. 90. Grev. t. 196. Sow. t. 267 . Krombh. t. 50. f. I5-17.

III.-Merisma. Very much branched or tuberculiform, \&c.

$$
\text { * Very much branched. }
$$

17. H. coralloides Scop.-Very much branched, shining white, at length yellowish, wholly broken up into attenuated intricate branches; primary branches $12 \mathrm{~mm}$. ( $1 / 2 \mathrm{in}$.) and more thick, ultimate ones $2 \mathrm{~mm}$. (I lin.) and less. Spines 6-8 mm. (3-4 lin.) long, unilateral, awl-shaped, entire.

On decayed fir, beech, ash, \&ic. Rare.

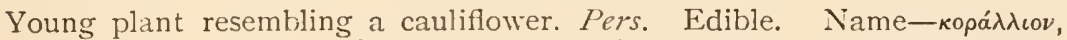
coral; ei̊os, appearance. Coral-like. Scop. Cam. 2. p. 472. Fr. Hym. Eur. p. 667. Su. ätl. Sü.t. 34. Berk. Ont. p. 259. C. Hbk. 11. 85x. Schaff.t. I42. Sow. t. 252. Krombh. t. 51.f. 4-7.-Bull. t. 390. 
18. H. erinaceum Bull.-Pileus 20 cent. (8 in.) and more broad, often much less, white, becoming yellow, fleshy, elastictough, pendulous, tubercular, immarginate, torn into fibrils above. Spines very long, $4-6$ cent. ( $1 \frac{1}{2}-21 / 2$ in.), straight, equal, pendulous.

Striking, changeable in form, in the form of a heart when most perfect, often with the rudiment of a lateral stem. Internally as if latticed in a branched manner.

On trunks of oak, beech, \&c. Rare.

Spores white, plain, $5 \times 6 \mathrm{mk}$. IV.G.S. Name-crinaceus, a hedgehog. From its appearance. Bull. t. 34. Fr. Hym. Eur. p. 608. Berk. Out. p. 259. C. Hbk. 11.852. Vittad. t. 26. Krombh. t. 5r.f. I-3.

19. H. caput-Medusæ Bull.-White, then fuliginous-cinereous, fleshy, tuberculiform, somewhat stipitate. Spines on upper surface distorted, the lower ones long, straight.

Large. The trunk is dilated into a pileus, which is covered over with slender spines on all sides.

On trunks. Rare.

Name-Medusa's head. Bull. t. 4r2. Fr. Hym. Eur. p. 608. Berk. Out. p. 259. C. Hbk.n.853.

\section{IV.-Apus. Pileus sessile, dimidiate, \&c.}

$$
\text { * Pileus Aleshy, soft. }
$$

20. H. cirrhatum Pers.-Pileus pallid, fleshy, expanded, fibrilloso-curled above with scattered decumbent abortive spines, the fimbriate margin incurved. Spines very long, $10-16 \mathrm{~mm}$. (5-8 lin.), slightly tough, equal.

Simple or imbricated. Varying white, light yellowish, rufescent.

On a beech-tree. Epping Forest.

Name-cirrus, a curl, lock of hair. Pileus curled. Pers. Syn. p. 558. Fr. Hym. Eur. p. 6og. Sv. ätl. Sv.t.71.f. x. B. \& Br.n. r37o. Fl. Dan. t. I789. f. 2 .

21. H. diversidens Fr.-Pileus 5 cent. ( 2 in.) broad, white fleshy, thick, substipitate, very irregularly shaped, densely beset above with erect, varionsly shaped, incised teeth, clothed at the entire margin with club-shaped spines, and beneath with entire awl-shaped regular spines.

Colour almost that of repandum. Singular from having spines of three kinds. Allied to $H$. cirrhatum, but not cæspitose, more irregularly shaped, here and there lobed. 
On beech and hornbeam. Guildford. Epping Forest. Oct. Hydnum.

Name-diversus; dens, a tooth. With teeth and spines of different shapes. Fr. Hym. Eur. p. 609. Sv. ätl. Sv. t. 71.f. 2. Grevillea, vol. xiii. p. 49. Krombh. t. 5I. f. 8-12.

** Caspitose, pilei imbricated, Soc.

No British species.

\section{*** Simple, pileus coriaceous or corky.}

22. H. ochraceum Pers. - Pilei $2.5-7.5$ cent. ( $\mathrm{I}-3$ in.) broad, ochraceous, effuso-reflexed, coriaceous, thin, zoned. Spines very small, ochraceous-flesh-colour.

Very small, sometimes wholly resupinate.

On dead branches. Common. Nov.

Easily removed from the matrix. M.F.B. Name-ochraceus, ochrey-yellow. Pers. Syn. p. 559. Fr. Hym. Eur. p. 612. Syst. Myc. i. p. 4I4. Berk. Out.p. 259. C. Hbk. n. 855. S. Mycol. Scot.n. 810.-Sow. t. I5.

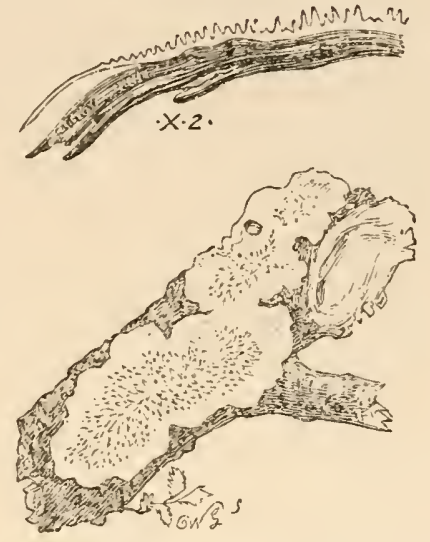

LXXIV. Hyduum ochraceum. Natural size. Section twice natural size.

**** Pileus membranaceous.

No British species.

$$
\begin{aligned}
& \text { V.-Resupinati. Pileus none, \&c. } \\
& \text { * Spines fuscous, fermginous. }
\end{aligned}
$$

23. H. squalinum Fr.-Subiculum pale wood-colour, coric ceous, firm, adnate. Spines crowded, 4-6 mm. (2-3 lin.) and more long, stout, compressed, entire, at length becoming fuscous.

Rather large, firmer than the rest, villous becoming smooth, variable in stature and colour, abnormal, here and there with the connate teeth of Irpex, and at the same time allied to Radulum.

On trunks, especially beech.

Admitted on the authority of Ray and Bolton. Name-squalus, a shark. From the strong spines like shark's teeth. Fr. Hym. Eur. p. 612. Syst. Myc. i. p. 420. Berk. Out. p. 259. C. Hbk. n. 856. Ray Syn. t. r. f. 5.Bolt. t. 74 .

VOL. II. 
Hydnum. 24. H. membranaceum Bull.-Subiculum tawny-fernginons, effused, waxy-membranaceous, agglutinated, smooth. Spines awl-shaped, crowded, equal, acute, of the same colour as the subiculum.

It varies yellowish and thinner.

On fallen sticks. Frequent.

Name--membrana, a membrane. Bull. t. 48r. f. r. Fr. Hym. Eur. p. 613. Berk. Out. p. 260. C. Hbk.n. 857. Sow. t. 327 .

25. H. Weinmanni Fr.-Subiculum faren-grey, effused, waxymembranaceous, agglutinated, smooth. Spines minute, acute, somewhat distant, equal.

Becoming cinereous when dry.

On fallen branches. Bristol.

Name-after Weinmann. Fr. Hym. Eur. p. 613. Berk. Out.p. 260. C. Hbk.n. 858. Pers. Myc. Eur. t. 22. f. 2 ?

26. H. crinale Fr.-Subiculum nmber, effused, villoso-interwoven, thin. Spines long, crowded, equal, very slender, umber.

Unicolorous. The spines are almost like hairs.

On dead wood. Rare. Essex.

Remarkable for the long dark rufous-brown spines which shine as if varnished. M.F.B. Name-crinis, hair. From the hair-like spines. Fr. Hym. Eur. p. 6r3. H. fuscum Berk. Out. p. 260. C. Hbk. n. 859.-Pers. Myc. Eur. t. 17.f. 3 .

27. H. ferruginosum Fr.-Subiculum tawny-fermiginous, effused, $5-7.5$ cent. (2-3 in.) long, tomentose. Spines crowded, conico-awl-shaped, acute, tawny-fernuginous.

The spines are straight and equal or oblique and somewhat compressed according to situation.

On decayed wood. Uncommon.

Separable from the matrix, almost mucedinous when fully developed. M.F.B. Name-ferrum, iron. Ferruginous. Fr. Hym. Eur. p. 6i3. Syst. Myc. i. p. 4 I6. Berk. Out. p. 260. C. Hbk. n. 860. S. Mycol. Scot.n. 8I I. -Schrad. Spic. t. 4. f. 2. Nees Syst. f. 248.

28. H. variecolor Fr.-Subiculum white, effused, adnate, forming a furfuraceous crust. Spines crowded, conical, short, unequal, minute, somewhat fuscous.

Like $H$. farinaceum. Spines commonly adpressed.

On dead stumps. Rare. 
Name-varius, color. From the colours. Fr. Hym. Eur.p. 6r3. Berk. Hydnum. Out.p. 260. C. Hbk. n. $86 \mathrm{r}$.

** Spines yellowish, green.

29. H. aureum Fr.-Subiculum golden, determinate, somewhat cartilaginous, continuous, smooth, radiate in the form of teeth at the circumference. Spines awl-shaped, equal, of the same colour as the subiculum.

Distinguished, analogous with Phlebia radiata, remarkable moreover for the mycelium permeating the wood and giving rise to a distinctly defined yellowflesh-coloured spot.

On dead branches. Penzance.

With a merulioid aspect. $B \& B$ Br. Name-aurum, gold. Fr. Hym. Eur. p. 6rз. B. \& $B r . n$. 1970 .

30. H. denticulatum Pers.-Light-yellow-ochraceous, shining, longitudinally effused, somewhat fleshy, subiculum thin, smooth, somewhat mealy. Spines crowded, equal, slightly toothed at the margin.

Colour bright yellowish almost between light-yellow and egg-yellow.

On rotten wood. Penzance.

Name-dens, a tooth. From the slightly toothed spines. Pers. Myc. Eur. 2. p. 181. Fr. Hym. Eur. p. 614. B. \& Br.n. 197 I.

31. H. alutaceum Fr.-Subiculum pallid-ochraceous, longitudinally effused, $7 \cdot 5-12.5$ cent. (3-5 in.) long, crustose, adnate, smooth, circumference naked. Spines minute, crowded, equal, acute.

In colour like Grandinia granulosa, but wholly distinct.

On dead wood. Rare.

Name-aluta, tanned leather. From the colour. Fr. Hym. Eur. p. 6i4. Syst. Myc. i. p. 417. Berk. Out.p. 260. C. Hbk. n. 862.

32. H. sordidum Weinm.-Dingy yellowish, broadly effused, thin, easily separating, mucid, at the circumference gyroso-porous, sulphur-yellow. Spines very crowded, compressed, incised, rather acute.

In the form of Merulius at the circumference, spines somewhat gelatinous, appearing as if composed of several growing together, smooth.

On dead wood. Stoke Poges. Nov.

Name-sordidus, dirty, dingy. Of colour. Weinm. Ross. p. 370. Fr. Hym. Eur. p. 6i4. B. \&o Br.n. 688.

33. H. limonicolor B. \& Br.-Adnate, bright lemon-yellow. 
Hydnum. Spines crowded, acute, short; mycelium shining white, scanty or obsolete.

On stone buried among pine-leaves. Glamis, I876. Oct.

Name-lemon-colour. Citrus Limonum. B. \& Br. n. 1686. S. Mycol. Scot. n. 812.

34. H. spathulatum Fr.-Subiculum whitish-yellowish, effused, membranaceous, separable, circumference fimbriated. Spines spathulate, oblique, orange.

Membrane villous beneath.

On dead wood. Rare. Jan.

Name-spatha, a spatula. Spoon-shaped. Fr. Hym. Eur. p. 6r4. Berk. Out. p. 26r. C. Hbk. n. 863. S. Mycol. Scot. n. 813. Schwein. Car. n. 993.

35. H. multiforme B. \& Br--Ochrey-white, at first even, resembling a Corticium, at length here and there fertile. Spines very acute, crowded, becoming pallid and fimbriate; texture floccoso-mealy.

Very variable, sometimes almost towy, with the margin inflexed.

On dead wood. Glamis, I877.

Name-multus, many; forma, form. Of many forms. B. \& Br. n. I687. S. Mycol. Scot. n. $8 \mathrm{r} 4$.

36. H. anomalum B. \& Br.-Pallid light yellow; stratum thin, gelatinous; teeth in the form of granules, then stipitate and obtusely divided upwards.

Substance of teeth tough, with large ovate or globose vesicles immersed in it. Near to Fries's genus Mucronella.

In the inside of very rotten ash-tree. Langridge, Somersetshire. March.

Spores globose, shortly pedicellate. $B$. \& $B r$. Name-àvẃuados, irregular. B. \& Br. $n .143^{8}$, with fig.

37. H. melleum B. \& Br.-Honey-colour, effused, thin, margin delicately flaxy; subiculum and teeth, which are acute and sometimes divided at the apex, pulverulent downwards, naked at the middle.

On broken rails on the ground. Coed Coch, 1873 .

Name-mel, honey. Honey-colour. B. \& Br. n. г 436 .

38. H. sepultum B. \& Br.-Wholly resupinate, golden, margin white. Spines acute, medium-sized. 
Forming little scattered patches. Sept.

On stones buried among pine-leaves. Glamis, 1876. Forres. Name-sepelio, to bury. Buried. B. \& Br. n. I8I3. S. Mycol. Scot. n. 820.

$$
\text { ** Spines flesh-colour, lilac, rufescent. }
$$

39. H. udum Fr.-Subiculum flesh-colour then watery-yellowish, effused, thin, somewhat gelatinous, agglutinated, smooth. Spines crowded, unequal, 2-3-forked and fimbriated, of the same colour as the subiculum.

Very long and broad. Not separable from the wood. Allied to H. membranaceum.

On dead branches. Frequent. Oct.

Forming elongated patches ro-12.5 cent. (4-5 in.) long. M.F.B. Nameudus, moist. Fr. Hym. Eur. p. 615. Syst. Myc. i. p. 422. Berk. Out. p. 26I. t. I7.f. 3. C. Hbk. n. 864. S. Mycol. Scot. n. 815.

40. H. bicolor Alb. \& Schw.-SubicuIum white, widely effused, 20 cent. (8 in.) and more, tomentose, adpressed, thin. Spines minute, curt, I m. ( $1 / 2$ lin.) long, white-villons, naked at the apex, acute, rufous-date-brown.

On bramble. Batheaston. March.

Name-bis, color. Of two colours. A. \& S. p. 270. Fr. Hym. Eur. p. 6I5. Syst. Myc. i. p. 417. B. \& Br. n. 1297 .

\section{**** Spines white, or light yellowish when old.}

41. H. nodulosum Fr.-Whitish, very broadly effused, crustaceous, closely adnate, smooth, even and at the same time nodulose. Spines very long, on the even part depressed and adnate to the wood, on the lower side of the nodules free and pendulous.

The nodules which vary in size are sterile above, even and smooth, pallid yellowish, but furnished with spines on the side facing the ground.

On fir stumps. Glamis, 1876. Oct.

Name-nodus, a knot. Nodulose. Fr. Hym. Eur. p. 6r6. S. Mycol. Scot. n. 816.-H. macrodon Fr. Monogr. ii. p. 279, not Pers. Pers. Myc. Eur. 2. t. 2, 22, f. I.

42. H. Stevensoni B. \& Br.-White, effused, mealy beneath, here and there flaxy. Spines cylindrical obtuse or truncate, sometimes compressed, pulverulent at the apex. 
Hydnum. On dead wood. Glamis, i874. March.

Name-after Rev. John Stevenson. B. \& Br. n. 1437. S. Mycol. Scot. n. 817.

43. H. niveum Pers. - Shining white. Subiculum effused, 5-7.5 cent. ( $2-3$ in.) and more long, thin, membranaceous, adnate, circumference flaxy. Spines crowded, curt, short, equal, smooth.

B. fmbriatum circumference fibrilloso-fimbriate.

On dead wood. Uncommon. April-Nov.

Name-nix, snow. Snow-white. Pers. Disp.t. 4. f. 6, 7. Fr. Hym. Eur. p. 6i6. Syst. Myc. i. p. 419. Berk. Out. p. 26I. C. Hbk. n. 865. S. Mycol. Scot. n. 818. Nees Syst.f. 246.

44. H. farinaceum Pers.-White. Subiculum effused, indeterminate, closely adnate, mealy crustose, circumference somewhat flocculose. Spines thin, somewhat distant, very acute, quite entire.

It varies yellowish.

On dead wood. Frequent. Oct.-Nov.

Forming thin effused patches, resembling scattered meal. M.F.B. Name - farina, meal. Pers. Syn. p. 562. Fr. Hym. Eur. p. 6i6. Syst. Myc. i. p. 419. Berk. Out. p. 261. C. Hbk. n. 866. S. Mycol. Scot. n. 819.-Fl. Dan. t. 1375 .

45. H. argutum Fr.-White. Subiculum effused, in scattered patches, tomentoso-interwoven, adnate. Spines acute, awlshaped, unequal, under a lens serrated or slightly toothed at the sides.

On wood and bark. Bodelwyddan. Twycross. Sept.

Distinguished by its spongy subiculum, which consists of rather strong perpendicular threads. $B$. \& Br. Name-argutus, acute. Of the spines. Fr. Hym. Eur. p. 616. B. E Br.n. 1026. C. Hbk. n. 867.-Roth. Ust. Ann. I. t. I. f. $5 \mathrm{~s}$.

46. H. stipatum Fr. - Whitish. Subiculum very widely effused, flocculoso-furfuraceous, forming an adnate crust. Spines crowded, in the form of granules, rather obtuse and slightly toothed.

The circumference is sterile or covered with spines. It varies in colour, isabelline or light yellowish.

On rotten wood. Carlisle.

Name-stipatus, crowded. Of the spines. Fr. Hym. Eur. p. 617. Grevillea, vol. xii. p. 98. 
Genus XXXIII.-Hericium Pers. Comm. Clav. p. 23. partly. Hericium. Fr. Syst. Orb. Veget. p. 88 .

Fleshy, club-shaped, in place of a pileus divided at the apex into spines, which are extended upwards, not inferior and facing the ground. Growing on trunks.

An anomalous genus, resembling Clavarice, hymenium amphigenous, but undoubtedly nearest to Hydna. Fr. Hym. Eur.p. 617.

No British species.

GENus XXXIV.-Tremellodon (Tremella, a gelatinous genus of fungi; óoovs, a tooth). Pers. Myc. Eur. p. 172.

Tremellodon.

Gelatinous, pileate, aculeate below; spines awl-shaped, equal. Fr. Hym. Eur. p. 6i 8.

1. T. gelatinosum Pers.-Pileus glaucous-fuscous, gelatinous, tremulous, dimidiate, somewhat stipitate, covered with small pimples. Spines soft, glaucous.

Extremely variable in form, stipitate (on the ground) and sessile.

On fir, trunks and sawdust. Rare. Sept.-Oct.

Of a soft gelatinous consistence approaching that of a Tremella. Pileus fan-shaped, or rounded in front, attenuated behind so as to make a short spurious stem. In an early stage it is decurrent at the point of attachment. The surface is of a bistrebrown, uneven with frequent depressions, and rough at first with little points, but

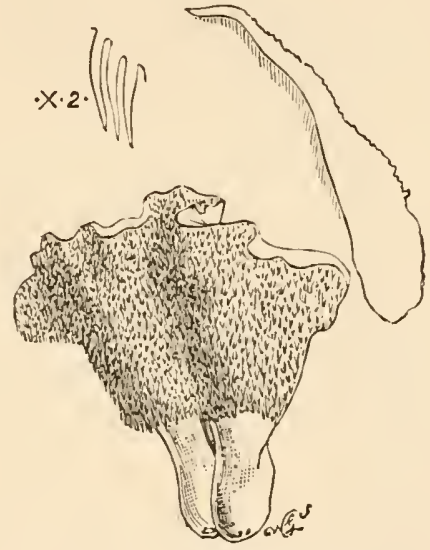

$L X X V$. Tremellodon gelatino. sum. One-third natural size. Section twice natural size. at length nearly smooth. The hymenium is either pure white or shaded with a delicate blue tint, the spines straight, of moderate length, and very delicate. The plant shrinks much in drying. $M . \mathcal{F} . B$. Of singular beauty, almost translucent with steel-blue tints shading into violet, while the spines are of a pure soft white. Spores round, somewhat irregular, white, $2 \mathrm{mk}$. W.G.S. Name-gelatina, jelly. Gelatinous. Pers. Scop. Carn. 2. p. 472. Fr. Hym. Eur. p.618. S. Mycol. Scot. Supp. Scot. Nat. 1885, p. 75. Hydnum gelatinosum Berk. Out. p. 259. C. Hbk. n. 854. Srhreff. t. 144. Facqu. Austr. t. 239. Krombh. t. 50. f. 18-22.-Fl. Lan. t. 717. Var. with pines throughout Facqu. Misc. i. t. 9. 
Sistotrema. Genus XXXV.-Sistotrema (sisto, to place; $\tau \rho \hat{\eta} \mu a$, a pore. From the arrangement of the pores). Pers.-Fr. Syst. Myc. i. p. 426.

Fleshy, with an inferior hymenium spread over teeth resembling broken gills. Gills somewhat waxy, irregularly arranged

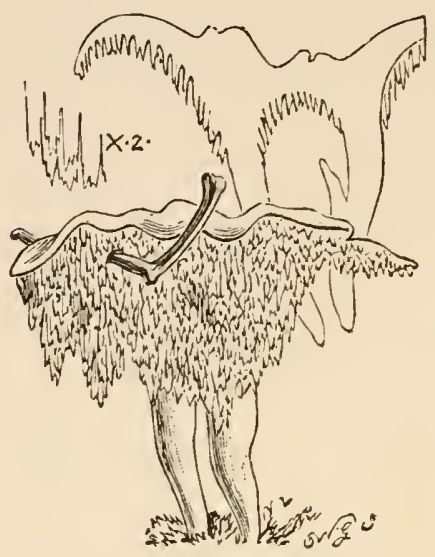

LXXVI. Sistotrema confunens. Natural size. Section twice natural size. (not radiating), distinct, bent, easily rubbed off from the pileus. Sporophores 4-spored, spores oval. Irregular in form or dimidiate.

A genus nearest to Irpex, but clearly distinct by reason of the gilllike, irregularly arranged, distinct, non-concatenate teeth, and by the fleshy substance. Fr. Hym. Eur.p. 618.

1. S. confluens Pers. - Entire, shining white. Pileus $\mathrm{I}-2.5$ cent. ( $\mathrm{x} / 2-\mathrm{r}$ in.) broad, fleshy, irregular, horizontal, villous. Stem 2.5 cent. (I in.) and less long, somewhat excentric. Gills (tooth - like plates) flexuous, changeable in form.

Simple, but cæspitose and growing into each other.

On the ground and sticks. Uncommon. Autumn.

At length yellowish or tinged with brown. Tooth-like plates of the hymenium entire or jagged. Grev. Name-confuo, to flow together. Confluent. Pers. Syn. p. 551. Fr. Hym. Eur. p. 6rg. Syst. Myc. i. p. 426. Berk. Out. p. 262. C. Hbk. n. 869. S. Mycol. Scot.n.821. Grev. t. 248. -Bull.t. 453.f. 1. Sow. t. II2.

Irpex. Genus XXXVI.-Irpex (irpex, a harrow). Fr. Elench. p. I42.

Hymenium inferior, toothed from the first. Teeth firm, somewhat coriaceous, acute, concrete with the pileus, arranged in rows or like network, connected at the base by folds, which are gill-like (in sessile species) or resemble honeycomb (in resupinate ones). Sporophores 4-spored. Growing on wood, somewhat sessile or resupinate, approaching Lenzites and Dadalece. Fr. Hym. Eur. p. 619. 
* Stipitate.

** Pendulous with the pileus extended behind.

*** Sessile or effuso-reftexed, marginate.

**** Resupinate.

$$
\text { * Stipitate. }
$$

No British species.

\section{** Pendulous with the pileus extended behind.}

\section{I. pendulus Fr. - Pilei light} yellow, extended behind, pendulous, membranaceous, plicate, adpressedly squamuloso-pilose. Teeth in rows, large, incised, shining white.

Membrane of the pileus elastic, but when extended it contracts again. Its characters are wholly those of the genus, but it is not allied to any other plant among the $H y d n a$. It is nearly allied to Cyphella, more remotely to Trogia, and might almost be regarded as the type of a separate genus.

On pine. Rare. Castle Semple (Edin. Herbarium). Menmuir.

Name - pendo, to hang. Pendulous. Fr. Hym. Eur. p. 620. Berk. Out. p. 262. C. Hbk. n. 870. S. Mycol. Scot. n. 822. -Alb. \& Schw. p. 26 r. t. 6. f. 7.

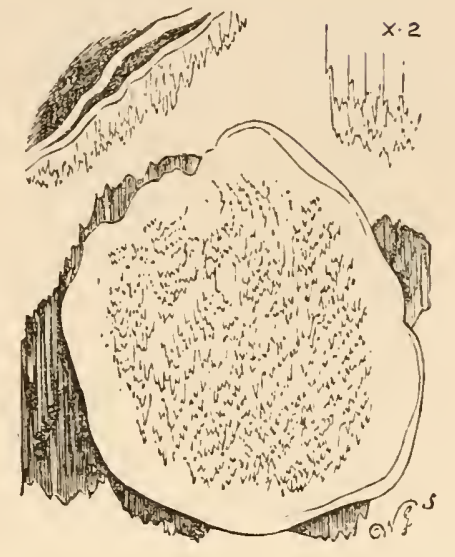

LXXVII. Irpex obliquus. Nat. ural size. Section twice natural size.

*** Sessile or effuso-reflexed, marginate.

2. I. fusco-violaceus Fr.-Pileus 5 cent. (2 in.) long, more than 2.5 cent. ( $\mathrm{I}$ in.) broad, white inclining to hoary, effusoreflexed, coriaceous, silky, zoned. Teeth in rows in the form of plates, fuscous-violaceous, incised at the apex.

It differs certainly from Polyporus abietinus. It is marked with a few depressed, concentrically sulcate zones of the same colour. Margin deflexed, often repand. Often wholly effused.

On pine trunks. Rare. Leigh Woods.

Name-From the colour of the teeth. Fr. Hym. Eur. p. 620. Elench.p. 144. Br. Bath. Trans. 1870, p. 87. C. Hbk. n. 873. Kl. Bor. t. 536.Willd. Bot. Mag. iv. t. 2. f. 5 .

\section{**** Resupinate.}

3. I. Johnstoni Berk.-Resupinate, 5 cent. ( 2 in.) long, pure white, coriaceo-membranaceous, separable from the matrix, cir- 
Irpex. cumference naked. Teeth compressed, unequal, arranged in rows.

Effused, with the margin reflexed all round, and the teeth exactly resem. bling those of many true species of Hydnum, but upon minute inspection they will be found to be seated upon fine folds.

On dead beech. Berwick.

Name-after Dr George Johnstone. Berk. Out. p. 262. C. Hbk. n. 87r. S. Mycol. Scot. n. 823. Fr. Hym. Eur. p. 621. Irpex lacteus Eng. Fl. v. p. $16 \mathrm{I}$.

4. I. spathulatus Fr.-Shining white, effused, membranaceous, at first flaxy, at length becoming smooth. Teeth spathulate, equal, entire, reticulato-connected with obsolete veins.

Very distinct, never porous. Here and there yellowish when dry.

On larch. Wallington, Northumberland. Nov.

Name-spatha, a spatula. From the spoon-shaped teeth. Fr. Hym. Eur. p. 622. B. \& Br. n. 1815. -Schrad. Spic. t. 4. f. 3 .

5. I. obliquus Fr.-White inclining to pale, effused, forming an adnate crust, circumference flaxy. Teeth extended from a base resembling honeycomb, compressed, unequal, incised, oblique.

At first abundantly porous, but toothed from the first, at length quite as in Hydna.

On stumps and dead branches. Uncommon. Nov.-Feb.

Name-obliquus, oblique. From the teeth. Fr. Hym. Eur. p. 622. Berk. Out. p. 262. C. Hbk. n. 872. S. Mycol. Scot. n. 824.-Bolt. t. 167. $f$. $\mathrm{r}$.

6. I. deformis Fr.-White, effused, crustaceous, thin, circumference pubescent, somewhat flaxy. Teeth extended in awl-shape from a minutely porous base, thin, somewhat digitato-incised.

It approaches the Polypori.

On wood. Strachan, Kincardineshire.

Name-deformis, misshapen. Fr. Hym. Eur. p. 622. S. Mycol. Scot. n. 825 .

7. I. carneus Fr.-Reddish, effused, $2.5-7.5$ cent. ( $1-3$ in.) long, cartilaginous-gelatinous, membranaceous, adnate. Teeth obtuse and awl-shaped, entire, united at the base.

It inclines to Radula and Phlebice.

On wood. Penzance.

When perfect it is a true Irpex. B. \& Br. Name-caro, flesh. Fleshcolour. Fr. Hym. Eur. p. 622. B. \& Br. n. 1972. 
Genus XXXVII.-Radulum (from the root-like appearance of Radulum. the processes of the hymenium). Fr. Elench. p. I48.

Hymenium amphigenous, tubercular. Tubercles rude, irregularly shaped, commonly elongate, obtuse, waxy (except in $R$. aterrimum), irregularly arranged, distinct. Sporophores 4-spored, occurring not only on the tubercles, but also on the even parts of the hymenium. Growing on wood, resupinato-effused, often bursting through the bark. Fr. Hym. Eur. p. 622.

* Denuded, very variable.

** Innate, removing the bark.

* Denuded, very variable.

1. R. orbiculare Fr. - A. First season's growth, white then yellowish, orbicular, confluent, circumference flaxy. Tubercles elongated, somewhat round, scattered or fasciculate.

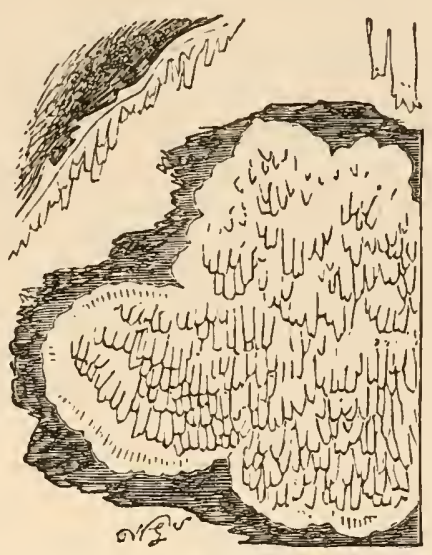

$L X X V I I I$. Radulum quercinum. Natural size. B. Second season's growth, vernal, flesh-colour, waxy-fleshy, smooth. Tubercles softer, shorter, as if rubbed away.

Entirely changeable in form, but very distinct. The tubercles vary flexuous.

On dead bark, birch, cherry, \&c. Frequent. Oct.

$5-7.5$ cent. (2-3 in.) broad, quite membranaceous or above $4 \mathrm{~mm}$. (2 lin.) thick. M.F.B. Name-orbiculus, a small disc. Orbicular, round. Fr. Hym. Eur. p. 623. Berk. Out. p. 263. C. Hbk. n. 874. S. Mycol. Scot. n. 826. Grev. t. 278.

2. $\mathbf{R}$. quercinum Fr. -White then pallid, $5-7.5$ cent. (2-3 in.), somewhat round then broadly confluent, innate, crustaceous, becoming sinooth. Tubercles round, stout, obtuse, scattered or fasciculate, irregularly shaped, floccoso-villous at the apex.

Rude, changeable in form, often confounded with Hydnum squalinum and H. variecolor.

On dead oak. Rare. Dec.

Name-quercus, oak. Growing on oak. Fr. Hym. Eur. p. 623. Syst. Myc. i. p. 423. Berk. Out.p. 263. C. Hbk. n. 875. S. Mycol. Scot. n. 827. -Ray Syn. t. I. f. 4 . 
Radulum. 3. R. tomentosum Fr.-White inclining to pale, effused, innate, rather thick, circumference swollen, erect, tomentose. Tubercles short, crowded together, angular, obtuse, smooth, confluent. ous.

When dry pale wood-colour, the tomentum sometimes becoming ferrugin-

On Pyrus aucuparia. Menmuir, Forfarsh. New Pitsligo, Aberdeensh.

Name-tomentum, down. Downy. Fr. Hym. Eur. p. 624. B. Eo Br.n. I439. S. Mycol. Scot.n. 828.

4. R. deglubens B. \& Br.-Orbicular, $8 \mathrm{~mm}$. ( $1 / 3$ in.) across, ferruginous, somewhat diaphanous. Tubercles erect, somewhat cylindrical, irregular, scattered; interstices even, pulverulent with the white spores.

On ash. Sanquhar, Moraysh. New Pitsligo, Aberdeensh. Jan. Name-deglubo, to peel off. Peeling off. B. \& Br.n. 1440. S. Mycol. Scot. n. 829.

5. R. corallinum B. \& Br.-Effused, white; subiculum shining, very thin, pelliculose. Tubercles fasciculate (fascicles $6 \mathrm{~mm}$., $1 / 4$ in. or more across), divided downwards, obtuse, coralloid.

Effused for 7.5 cent. ( 3 in.) over branches partially covered with lichens.

On oak branches. Glamis, I874. Sept.

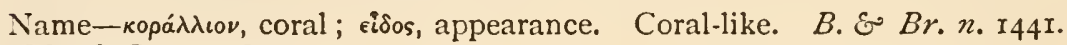
S. Mycol. Scot. n. 830.

6. R. epileucum B. \& Br.-Effused for several inches, ochreywhite, wholly resupinate; subiculum snow-white, covered by a waxy stratum. Tubercles scattered, cylindrical, under a lens fimbriated at the apex, deciduous.

Tubercles falling out and showing the white mealy subiculum, round which is an annular depression.

On decorticated wood. Glamis, 1874. Aug. 83 I.

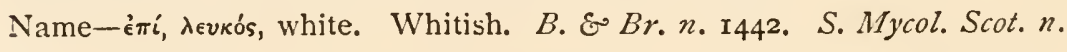
** Innate, removing the bark.

7. R. fagineum Fr.-White, becoming pale, innate, removing the bark, smooth. Tubercles elongated, round, various, obtuse, entire.

Surrounding decorticated branches like stalactite. 
On dead beech. Epping Forest. Feb.-March.

Radulum.

Name-fagus, beech. Growing on beech. Fr. Hym. Eur. p. 624. C. Hbk. n. 876.-Pers.

8. R. aterrimum Fr.-Black, innate, removing the bark, strigose. Tubercles elongated, distant, large, irregularly shaped, somewhat compressed, black.

Hymenium not continuous.

On branches. Kensington Gardens.

Berkeley now regards Hydnum erectum Soz. Herb. as identical. Nameater, black. Very black. Fr. Hym. Eur. p. 624. B. \& Br. n. 1814, 1573.

Genus XXXVIII.-Phlebia ( $\phi \lambda \epsilon \in \psi$, a vein, from the veiny appear- Phlebia. ance of the hymenium). Fr. Syst. Myc. i. p. 426.

Hymenium amphigenous, waxy-soft, smooth, continuous, from the first wrinkled into crests; covered with wrinkles which are crowded, interrupted, persistent, quite entire at the edge, everywhere bearing spores. Resupinato-effused, somewhat gelatinous - waxy when moist, cartilaginous when dry. Fr. Hym. Eur. p. 624.

1. P. merismoides Fr. - Fleshcolour then livid, villous and white beneath, orange-strigose at the circumference, effused, even or slightly branched in becoming incrusted. Wrinkles simple, straight, crowded.

The wrinkles are never porous or reticulate.

On stumps and branches. Rare. Sept.-Feb.

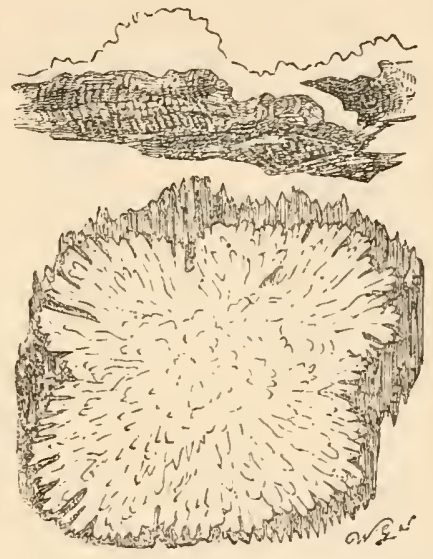

LXXIXY. Phlebia merismoides. Natural size.

Often running over mosses. Thin, tremelloid when fresh. M.7.B. 5-7.5

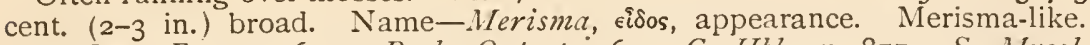
Fr. Hym. Eur. p. 624. Berk. Out. p. 263. C. Hbk. n. 877. S. Mycol. Scot.p. 156. Grev. t. 280. Huss. ii. t. 44.

2. P. radiata Fr.-Red-flesh-colour, $2.5-7.5$ cent. ( $1-3$ in.) across, somewhat round, equal, smooth on both sides, circumference radiate in the form of teeth. Folds straight, radiating in rows. 
Phlebia. Thinner and brighter-coloured than the rest.

On dead wood. Rare. Nov.

Almost orange. M.F.B. Spores curved, hyaline, $4-5 \times \mathrm{I}-\mathrm{I} .5 \mathrm{mk} . K$. Name-radiatus, rayed. From the folds. Fr. Hym. Eur. p. 625. Syst. Myc. i. p. 427. Berk. Out. p. 263. C. Hbk. n. 878. S. Mycol. Scot. p. 156. -Sow. t. 291 .

3. P. contorta Fr.-Rufous then fuscous, effused, slightly firm, smooth on both sides, circumference indeterminate. Folds here and there conglomerated, or slightly branched, somewhat flexuous, irregularly arranged.

Very much allied to $P$. radiata.

On decayed wood. Rare.

Name-contorqueo, to twist. Contorted. Of the more intricate folds. Fr. Hym. Eur. p. 625. Syst. Myc. i. p. 427. Berk. Out.p. 264. C. Hbk. n. 879. -Pers. Myc. Eur. 2. t. I8. f. 5 .

4. P. vaga Fr.-Dingy yellowish, effused, 5 cent. (2 in.) and more, adnate, circumference flaxy-fibrillose. Hymenium yellowish-grey, gradually formed by the union of creeping intricate wrinkles, which when perfect terminate in a granulose papilla.

The hymenium in perfect specimens is wholly that of the genus, waxy, but the wrinkles are at length densely granulose with papillæ.

On dead wood. Common.

Arachnoid at first, then traversed with intricate, fructifying veins rather than wrinkles, which multiply rapidly and form an intricate mass. M.F.B. Name-vagus, wandering. From the peculiar mode of formation of the hymenium. Fr. Hym. Eur. p. 625. Syst. Myc. i. p. 428. Berk. Out. p. 264. C. Hbk. n. 880. S. Mycol. Scot.p. 156 .

5. P. lirellosa Pers. - Umber-grey, resupinate, free at the margin. Sinuses very small, linear, intermixed with pores.

The sinuses at first sight assume the appearance of small cracks, but, when examined under a lens, many of them appear forked, others simple, some poriform.

\section{Habitat not recorded. Penzance.}

Found by Persoon on dried branch of black poplar. or furrow. From the appearance of the small sinuses. Eur. iii. p. 2. t. 17. f. 2, 3. Phlebia B. \& Br. n. 1973.

Name-lira, a ridge Dædalea Pers. Myc. 
Genus XXXIX.-Grandinia (grando, hail. From the granular Grandinia. character of the hymenium). Fr. Gen. Hymenom.

Hymenium amphigenous, continuous, waxy, warty with papillæ or rather granulose; granules globose or hemispherical, entire, obtuse or hollowed out at the apex, crowded, regular, smooth, persistent. Crustaceous, effiused, soft, improperly referred on account of their equal and persistent papilla to the Thelephoræ, from which they are distinguished by their polished granules. Fr. Hym. Eur. p. 625.

1. G. granulosa Fr.-Tan-colour, waxy, broadly effused, agglutinated, circumference determinate, smooth; hymenium equal, continuous. Granules hemispherical, equal, crowded.

On dead branches. Common. Oct.-Feb.

Forming a thin adnate stratum. M.F.B. Name-granum, a smail seed. Granular. Fr. Hym. Eur. p. 626. Berk. Out.p. 264. n. 832.-Pers. Syn. p. 576.

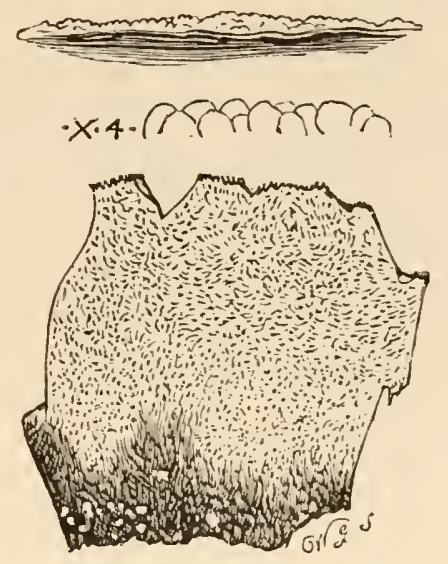

$L X X X$. Grandinia granulosa. Natural size. Section four times natural size.

2. G. mucida Fr. -Pale yellowish, waxy-mucid, effused, somewhat innate, circumference determinate, somewhat radiate; hymenium continuous. Granules crowded, large, unequal, hemispherical, soft.

Somewhat gelatinous when moist, corrugated when dry.

On rotting pine. Glamis, I877. Nay-Nov.

Name-mucidus, mucid. Fr. Hym. Eur.p. 626. B. \& Br.n. i6gг. S. Mycol. Scot. n. 833 .

3. G. ocellata Fr.-Livid, waxy, broadly effused, agglutinated, the indeterminate circumference sterile; hymenium unequal, continuous. Granules crowded, somewhat conical, obtuse, equal, of the same colour.

Unchanged when dry, not cracked, sterile in some places. The granules terminate in a very delicate whitish apiculus, and on this sinking in the apex is hollowed out forming as it were a small eye.

On dead trunks. Bodelwyddan. Coed Coch. Aug.-Sept. 
Grandinia. Name-ocellus, a little eye. From the eyelet at the apex of the granules Fr. Hym. Eur. p. 626. B. E Br. n. 1027. C. Hbk. n.883.

4. G. papillosa Fr.-Milk-white, yellowish beneath, membranaceous, somewhat round, separating when entire, smooth beneath, circumference furfuraceous; hymenium very much cracked. Granules minute, crowded, somewhat spherical, equal.

On sticks. Rare.

Name-papilla, a teat. From the granules. Fr. Hym. Eur.p. 626. B. E Br. n. 282. C. Hbk. n. 881. S. Mycol. Scot. n. 834 .

5. G. crustosa Fr.-White, floccoso-mealy, irregularly effused, crustaceous, adnate. Granules somewhat round, crowded, obtuse, of the same colour at the apex.

On Polyporus versicolor. Dun, 1874. Feb.

Name-crusta, a crust. Crustaceous. Fr. Hym. Eur.p. 627. B. \& Br. n. 1.443. S. Mycol. Scot. n. 835.-Pers. Syn. p. 562. Nees Syst. f. 247. Var. lignorum A. \& S. Often yellowish, granules unequal, often hollowed out at the apex. On rotting pine. Glamis, 1877. May. B. \& Br.n. 1690. S. Wycol. Scot. n. 835. Fr. Hym. Eur. p. 627.

Genus XL.-Odontia (ỏooús, a tooth). Fr. Gen. Hymen.

Hymenium composed of interwoven fibres, which form papillose, rarely spine-shaped warts, with
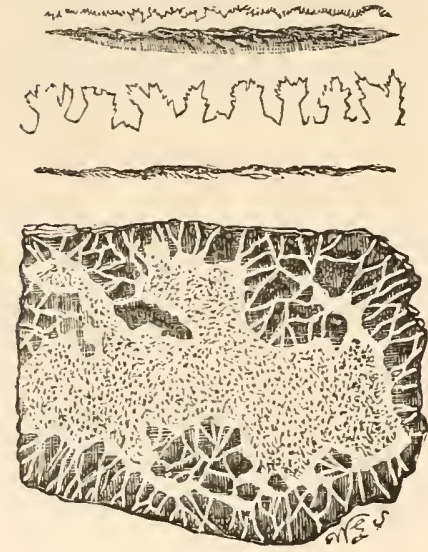

LXXXI. Odontia fimbriata.

Natural size. a multifid crest or pencilled at the apex. Resupinato-effused, arid and not waxy like the preceding, tending more towards Hydna. Fr. Hym. Eur. p. 627.

1. O. barba-Jovis Fr.-White then yellowish, flaxy-membranaceous, effused, equal. Warts at first papillose then conical, almost $4 \mathrm{~mm}$. (2 lin.) long, with an orange fringe at the apex.

The only species in which the warts resemble spines. Subiculum expanded to 20 cent. (I2 in.) and more.

On decayed wood. Epping Forest.

Sowerby's figure seems to represent the true plant, but the specimens in his herbarium are Radulum quercinum. B. \& Br. Name-Jove's beard. Fr. 
Hym. Eur. p. 627. Syst. Myc. i. p. 421. B. \&o Br. n. 1299.-Hydnum Odontia. With. -Sozv. t. 328 . Bull. t. 48 r. f. 2.

2. O. fimbriata Pers.-Pallid, effused, membranaceous, separating, traversed by root-like ribs, circumference fibrilloso-fringed. Warts minute, in the form of granules, multifid at the apex, mefescent.

Elegant. The type of the genus.

On dead wood. Uncommon. Sept.-Oct.

Frequently tinged with lilac. M.F.B. Name-fimbria, a fringe. From the fringed circumference. Pers. Obs. i. p. 88. Fr. Hym. Eur. p. 627. Berk. Out. p. 264. C. Hbk.n. 884. S. Mycol. Scot.n. 836 .

Genus XLI.-Kneiffia (after Kneif, a promising mycologist Kneiffia. of Baden, who died young). Fr. Gen. Hymen.

Hymenizm amphigenous, continuous, united, but incomplete (imperfect), similar (to the hymenophore), destitute of granules and warts, strigose and roughened with rigid, scattered or fasciculate bristles. Sporophores single-spored; spores elliptic. Laxly fleshy, soft, when dry collapsing and becoming flocculose. Swelling out of chinks in the bark of trees into various forms, hemisphericalin its most perfect state. Fr. Hym. Eur.p. 628.

1. K. setigera Fr.-Milk-white, irregularly effused, thick, fleshy, undulated, flocculose within, silky beneath, beset with scattered hyaline bristles.

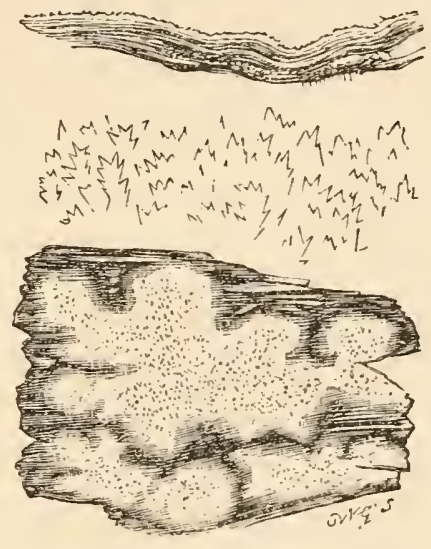

LXXXII. Kneiffa setigera. Natural size.

Of no constant form, but certainly a typical plant, not a degenerate condition of any other, and the type of a most distinct genus, in its substance and white colour comparable only with Corticium serum, but differing in the fructification. 'The bristles are rigid, equal, not to be compared with those of Auricularini. The largest specimens are of the size of an apple, but commonly thin, effused, often incrusting Spharia.

On dead wood. Uncommon. April.

Somewhat resembling Grandinia granulosa in general appearance. M.F.B. Spores elliptic, II-I4 mk. B. \& Br. Name-seta, a bristle; gero, to carry.

VOL. II. 
Kneiffia. Bristly. Fr. Hym. Eur. p. 628. Elench. p. 208. Berk. Out. p. 265. B. \& Br. n. 1299*.t. I8.f. I. C. Hbk.n.885. S. Mycol. Scot. n. 837 .

2. K. subgelatinosa B. \& Br.-Yellowish then cream-colour, thin. Granules minute, somewhat gelatinous, fringed at the apex.

Accompanied by a green $A \lg a$, which penetrates the tissue of the fungus.

On stumps of fir. Glamis, 1874. April.

Name-sub, gelatinosus, somewhat gelatinous. $B$. \& Br. n. 1444. $S$. Mycol. Scot. n. 838 .

Mucronella. Genus XLII.-Mucronella (mucro, a sharp point ; dim.)

Receptacle none. Spines awl-shaped, simple, acute, smooth, definitely facing the ground. Small, growing on wood. Fr. Hym. Eur. p. 629.

No British species. 


\section{ORDER IV.-THELEPHOREI.}

Hymenium inferior or amphigenous, coriaceous or waxy, even, rarely ribbed or papillose. Sporophores 4-spored. The beginning of a new series with the hymenium not figurate.

The hymenium is commonly said to be papillose, but these (so-called) papillæ are for the most part spurious or accidental, generally arising from incrusted Sphceria, and disappearing when the fungus grows on an even surface. Thus also the occasional papillæ in Stereum rubiginosum, hirsutum, \&c., arise from the rough surface on which they grow. In a few species papillae are present when they are in full vigour, but these collapse when the plant dries. Fr. Hym. Eur. p. 629.

\section{Genus XLIII.-Craterellus (crater, a bowl). Fr. Gen. Hymen.}

Hymenium waxy-membranaceous, distinct, but adnate to the hymenophore, definitely inferior, continuous, smooth, even or rugose. Spores white. Growing on the ground, fleshy or membranaceous, furmished with an entire pileus, stipitate, autumnal, allied to Cantharelli. Fr. Hym. Eur.p. 630.

* Tubaform, pervious to the base of the stem.

** Infundibuliform, stem stuffed.

*** Irregularly shaped, pileus and stem fleshy.

* Tubaform, pervious to the base of the stem.

1. C. lutescens Fr.--Pileus 2.5-10 cent. (I-4 in.) broad, fuscous, somewhat membranaceous, tubæform, soon pervious, undulated, flocculose. Stem about 5 cent. ( 2 in.) long, hol-

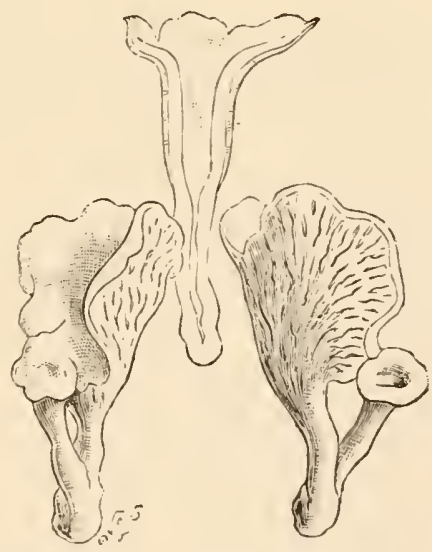

LXXXIII. Craterellus luctescens. One-half natural size. low, smooth, yellow. Hymenium yellow, \&c., remotely ribbed, even then rugose with interwoven veins. 
Craterellus. Odour strong, spirituous. Hymenium yellow, inclining to reddish, orange, and bluish - grey. Formerly confounded with Cantharellus tubaformis (lutescens).

In moist woods. Rare.

Name-yellowish. Fr. Hym. Eur. p. 630. Berk. Out. p. 265. C. Hbk. n. 886. S. Mycol. Scot. n. 839.-Schaff. t. 157. Bolt. t. 105. f. 2. Pers. Myc. Eur. 2. t. I3. f. I.

2. C. cornucopioides Pers.-Pileus blackish-fuliginous, somewhat membranaceous, tubæform, pervious, squamulose. Stem hollow, smooth, black. Hymenium even, at length slightly wrinkled, cinereous.

Very variable in size. Very like Canth. cinereus, but differing in the structure of the hymenium.

In woods. Uncommon. Sept.

Distinguished from Canth. cinereus by the spores. In this moreover the sporophores are forked above, and the spicules long and often less than four in number; in Canth. cinereus the sporophores are obtuse, and the spicules four. $B$. \& $B r$.

Pileus 7.5 cent. ( 3 in.) or more broad. More or less tufted. M.F.B. Spores Io $\times 4 \mathrm{mk}$. $B$. \& $B r$.; ellipsoid, hyaline, $12-I_{4} \times 7-8 \mathrm{mk}$. $K$. Name-cornu copice, horn of plenty. From its shape. Pers. Myc. Eur. 2. p. 5. Fr. Hym. Eur. p. 631. Berk. Out. p. 266. t. 19. f. 6. B. \& Br.n. Ir39*. C. Hbk.n. 887. S. Mycol. Scot. n. 840. Schnizl. Sturm. 31. t. 5. Hussey ii. t. 37.Krombh. t. 46. f. ro-13. Fl. Dan. t. 588, 1260. Bolt. t. Iо3. Sow. t. 74. Scheff. t. $165,166$.

\section{** Infundibuliform, stem stuffed.}

3. C. sinuosus Fr.-Pileus 2.5 cent. (I in.) broad, fuscous-grey, slightly fleshy, infundibuliform, undulated and floccose. Stem 2.5 cent. ( 1 in.) and more long, stuffed, pallid cinercous. Hymenium at length with interwoven wrinkles, pallid cinereous.

Strong-smelling, "moschatus" (Secr.) Hymenium like that of $\mathrm{Cr}$. lutescens.

In mixed woods. Frequent. Sept.-Nov.

Name-sinus, a curve. Sinuous, undulated. Fr. Hym. Eur. p. 631 . Berk. Out. p. 266. C. Hbk. n. 888. S. Mycol. Scot. n. 841.-Vaillant Par. t. II. f. II-I3.

4. C. crispus Fr.-Pileus fuliginous becoming fuscous, fleshymembranaceous, somewhat pervious, crisped. Stem stuffed at the base, pallid. Hymenium even, pallid.

Commonly confounded with Thelephora undulata.

In mixed woods. Frequent. Oct.-Nov.

This and C. sinuosus are so near that probably they are one species. Name 
-crispa, a curl. Crisped. Fr. Hym. Eur. p. 63r. Berk. Out.p. 266. C. Craterellus. Hbk. n. 889. S. Mycol. Scot. n. 8,2.-Sow. t. 75. Hussey ii. t. I8.

*** Irregularly shaped, pileus and stem fleshy.

5. C. clavatus Fr.-Pileus 5 cent. ( 2 in.) broad, somewhat light yellowish, fleshy, turbinate, truncate or depressed, flexuous, unpolished, attenuated into the solid stem; flesh thick, white. Hymenium even, then corrugated, purplish then changing colour.

Solitary or cæspitose, occasionally branched. The hymenium is whitepruinose with the spores, not separate, violaceous-flesh-colour passing into fuliginous or umber; hence the following forms are distinct: A. violaceous then date-brown. B. flesh-colour.-Schaff. t. I64. Schmid. Ic. 2. t. 60. C. purplish. Schaff.t. 276. D. umber.-Wulf. in Facq. Coll. ii. t. 12. f. 3 .

In beech wood. Bisham, Berks.

Name-clavis, a club. Club-shaped. Fr. Hym. Eur.p. 632. Sv. ätl. Sv. t. 91. B. \& Br. n. I445.-Krombh. t. 45 . f. I3-17.

Genus XLIV.-Thelephora ( $\theta \eta \lambda \dot{\eta}$, a teat; $\phi \epsilon ́ \rho \omega$, to bear). Ehrh. Fr. Gen. Hymen.

Hymenium inferior or amphigenous, continuous with the hymenophore and similar to it, even or ribbed, without an intermediate stratum. Sporophores 4-spored. Coriaceous, destitute of a cuticle, very varied in form (pileate, clavate, resupinate), growing on the ground. Fr. Hym. Eur. p. 633.

* Erect, pileus entire or divided into branches.

** Pileate, dimidiate, horizontal, somewhat sessile or effuso-reflexed.

*** Resupinate, for the most part incrusting, wherefore the forms are warious.

\section{* Erect, pileus entire or divided into branches.}

1. T. Sowerbeii B. \& Br.-Snowwhite, at length changing colour, here and there dingy yellow. Pileus coriaceous, entire, infundibuliform,

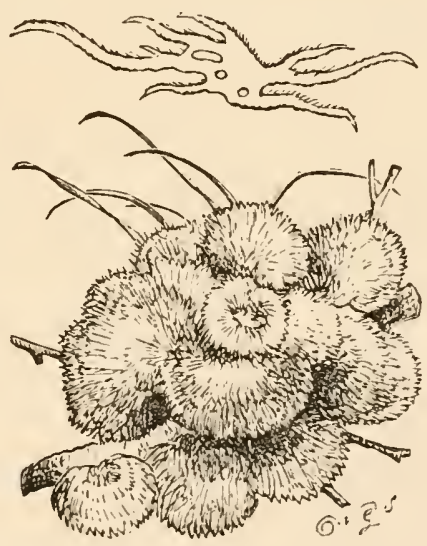

LXXXIV. Thelephora laciniata. One-third natural size.

rough with radiating processes projecting from the surface. $\mathbf{H y -}$ menium smooth (not bristly). 
Thelephora. The true plant of Sowerby, whose figure is very faithful though evidently taken from discoloured specimens.

On the ground. Rare.

Name-after Sowerby. B. \& Br.n. 1027. Berk. Out. p. 266. C. Hbk. n. 89o. Fr. Hym. Eur. p. 633.-Sow. t. 155.

2. T. multizonata B. \& Br.-Pileus bright rufous-flesh-colour above, many-zoned, multiplex, infundibuliform, formed from various confluent lobes and stems, margin lobed and crenulate. Hymenium slightly ribbed, smooth, paler.

Forming a dense mass, of a beautiful reddish tint; flesh and stem zoned within. Quite distinct from Sowerby's plant.

On the ground. Rare.

Name-multus, many; zona, a zone. $B$. E Br. n. 1028. t. 13. f. 4. C. Hbk. n. 89r. Fr. Hym. Eur. p. 633 .

3. T. undulata Fr.-Pallid. Pileus I-2.5 cent. ( $1 / 2-1$ in.) broad, coriaceo-membranaceous, depressed, even, slightly smooth, margin entire and undulated. Stem curt, $12 \mathrm{~mm}$. ( $1 / 2 \mathrm{in}$.) long, villous. Hymenium ribbed, slightly bristly. form.

Pileus central, entire, very thin, almost diaphanous and plano-infundibuli-

On the ground. Coed Coch, I878. Oct.

Spores ellipsoid, $4-5 \times 2-2 \frac{1}{2} \mathrm{mk}$. $K$. Name-unda, a wave. Undulated. Fr. Hym. Eur. p. 633. B. E Br. n. I816.-Schceff.t. 278 near it but perhaps distinct.

4. T. caryophyllea Pers.-Fuscous-purple. Pileus somewhat coriaceous, depressed, fibrous-torn, margin sometimes incised, sometimes divided into a few linear branches. Stem short. Hymenium rather even, smooth.

Inodorous.

On the ground about roots, especially fir. Rare.

It assumes every form, from that of a perfect cup with a central stem to a much and irregularly branched frond. M.F.B. Spores $6 \times 5$ mk. WV.G.S. : sphæroid, tuberculate, fuscous, about $8 \mathrm{mk} . K$. Name-from its likeness to a carnation (Dianthus caryophyllus). Pers. Syn. p. 565. Fr. Hym. Eur. p. 634. Berk. Out. p. 267. C. Hbk. n. 894. S. Mycol. Scot. n. 843. Saund. Eo Sm. t. 41. f. 2.-Schaff. t. 325. Schnizl. t. 6.

5. T. tuberosa Fr.-Pallid then rufescent. Pileus somewhat coriaceous, divided to the bulbous stem into compressed branches which are arranged in an infundibuliform manner. Hymenium inferior, smooth. 
On the ground. Rare. Foxhall, Edinburgh. Moncreiffe. Thelephora.

Scattered, subcoriaceous, about 2.5 cent. (I in.) high; pileus about twothirds of the height of the entire plant, variously divided into compressed, acute or obtuse branches. The main branches are given off from the same point, and are disposed in a circular manner, leaving the centre free, and somewhat infundibuliform; stem nearly cylindrical, obscurely furrowed, or lacunose, bulbous at the base. Hymenium covering the whole plant except the stem. Spores oval, numerous. Grev. Name-tuber, a tuber. Tuberous. Fr. Hym. Eur. p. 634. Berk. Out. p. 267. C. Hbk.n.892. S. Mycol. Scot. n. 84t.-Grev. t. $\mathrm{I}_{7} 8$.

6. T. anthocephala Fr. - Somewhat ferruginous, becoming fuscous. Pileus coriaceous-soft, pubescent, divided to the equal villous stem into flaps which are dilated upwards and fringed and whitish at the apex, or divided into irregular branched erect branches. Hymenium even.

Extremely variable, inodorous.

On the ground in woods. Uncommon.

Branches spreading upwards into greyish or purplish-brown, strongly streaked branchlets, disposed frequently like the petals of a pink, their apices dilated, pale and generally fimbriated. Very variable as to the form of the bleached laciniæ (flaps). Sometimes regular as in Bulliard's fig. M.F.B. Name - ăv $\theta_{0 s}$, a flower; $\kappa є \phi a ̆ \lambda \eta$. the head. From its resemblance to a flower. Fr. Hym. Eur. p. 634. Berk. Out.p. 267. t. I7.f. 4. C. Hbk. n. 893. S. Mycol. Scot. n. 845.-Bull. t. 452. f. I.-B. Th. digitata Fr. Sow. t. 156. Berk. Out. t. I7.f. 4 .

7. T. clavularis Fr.-Rufous-fuscous. Coriaceous, soft, irregularly branched, branches round, attenuated, even, smooth, delicately pruinose; apices acute, pubescent, whitish. Stem somewhat tuberous.

Smaller and thinner than neighbouring species, inodorous.

On the ground. Wallington, Northumberland.

Name-clavula, a small nail. From the shape of its branches. Fr. Hym. Eur. p. 634. B. \& Br.n. 1575 .

8. T. palmata Fr.-The whole $2.5-5$ cent. (I-2 in.) high, fuscous-purple, coriaceous-soft, erect, very much branched, pubescent, the simple base stem-like; branches palmate, flattened, even, somewhat fastigiate, fringed and whitish at the apex.

Odour fœtid. Becoming ferruginous when dry. The lobes are wedgeshaped, occasionally arranged in the form of small infundibuliform pilei.

On the ground in woods. Frequent. Aug.-Nov.

Forming a dense cluster, $2.5-7.5$ cent. ( $\mathrm{I}-3$ in.) thick. Smell shortly after being gathered corpse-like. Spores subsphæroid, slightly fuscous, tuberculate, $8-12 \mathrm{mk} . K$. Name-palma, the palm. From the branches resembling 
Thelephora. a palmate leaf. Fr. Hym. Eur. p. 634. Berk. Out. p. 267. C. Hbk.n.895. S. Mycol. Scot. n. 846. Holmsk. Ot. i. p. 106. t. 10. Nees f. 151.-Grev. $t$. 46. Krombh. t. 54.f. $24-25$.

\section{** Pileate, dimidiate, horizontal, Eoc.}

9. T. intybacea Pers. - Cæspitose, whitish then rufousferruginous, at length fuliginous, soft. Stems somewhat lateral, growing into each other. Pileoli imbricated, fibrous, dilated at the margin, at first white-fringed, then entire and of the same colour. Hymenium inferior, papillose, somewhat floccose.

Tufts sometimes central and obconic, sometimes lateral with somewhat triangular pileoli.

On the ground in Scotch fir wood. Glamis, 1875 .

Name-from its likeness to succory (Cichorium intybus). Pers. Syn. $p$. 567. Fr. Hym. Eur. p. 635. B. \& Br. n. I576. S. Mycol. Scot. n. 847. Bull. t. 483. f. $6,7, t .278$.

10. T. terrestris Ehrb.-Cæspitose, $2.5-5$ cent. ( $1-2$ in.) broad, fuscous, becoming black, soft. Pileoli imbricated, becoming plane, fibrous-strigose, zoneless, extended into a somewhat lateral stem, margin similar. Hymenium inferior, radiato-rugose.

Smaller than $T$. intybacea. The stems when confluent become also central; sometimes the pilei are laciniate, scaly, merismoid.

In fir woods. Uncommon.

Name-terra, the earth. Growing on the ground. Ehrb. Cr. n. I79. Fr. Hym. Eur. p. 635. Berk. Out. p. 267. C. Hbk. n. 896. S. Mycol. Scot. n. 848. Nees Syst.f. 251. Batschf. I21. Kl. Bor. t. 473.

11. T. laciniata Pers.-Fermginous-fuscous, coriaceous-soft, incrusting. Pilei somewhat imbricated, effuso-reflexed, fibrousscaly; margin fibrous-fringed, at first whitish. Hymenium inferior, papillose, flocculose.

Perennial, growing again in strata.

On stumps, chiefly Scotch fir. Common. Aug.-Nov.

Larger than $T$. terrestris. The fibres being adnate form little ridges rather than scales. $M . \mathcal{F} . B$. Spores angulato-sphæeroid, tuberculate, somewhat fuscous, 6-9 mk. $K$. Name-lacinia, a flap. From the shape of the pilei. Pers. Syn. p. 567. Fr. Hym. Eur. p. 636. Berk. Out. p. 268. C. Hbk. n. 899. S. Mycol. Scot. n. 849.-Bolt. t. I73. Sow. t. 213. Fl. Dan. t. II98, 949.

12. T. biennis Fr.-Cinereous-fuscous, coriaceous-soft, broadly incrusting. Pilei at length narrowly reflexed, tomentose, circumference fringed. Hymenium somewhat resupinate, smooth, very slightly bristly, plicate at the base. 
It corresponds with $T$. terrestris, but is more vigorous in growth, thinner, Thelephora. broader, not striate beneath. Biennial, not growing again.

On the ground, incrusting stones, \&c. Rare.

Name-biennis, lasting two years. Fr. Hym. Eur.p. 636. Berk. Out. p. 268. C. Hbk. n. 900. S. Mycol. Scot. n. 850.-Bull. t. 436. f. 2.

13. T. mollissima Pers.-Scarcely 2.5 cent. ( $\mathrm{I}$ in.) long, fleshysoft, incrusting. Pilei whitish, effuso-reflexed, forming flaps, somewhat tomentose. Hymenium inferior, smooth, even, fuscouspurple.

Soft to the touch.

On the ground in woods. Frequent. Oct.

Sometimes quite effused, sometimes assuming the form of $T$. palmata. M.F.B. Name-mollis, soft. Very soft. Pers. Syn.p. 572. Berk. Out.p. 268. t. I7.f. 5. C. Hbk. n. 898. S. Mycol. Scot.n. 85 I.

\section{** Resupinate, for the most part incrusting, E*c.}

14. T. cristata Fr.-Pallid, incrusting, slightly tough, passing into branches or ascending flaps, the apices somewhat awl-shaped or fringed. Hymenium papillose on even patches and on the sides of the branches.

Not flaxy when young. No form constant. The primary and typical condition, on the under surface of beech-leaves, is even, hyaline-fuscous, adpressed at the circumference, fibrillose. It varies with few, obconic, penicillate branches.

On the ground in woods among mosses. Frequent.

Name-crista, a crest. Crested. Fr. Hym. Eur. p. 637. Berk. Out. p. 268. C. Hbk. n. 897. S. Nyycol. Scot. n. 852. Fl. Dan. t. 2272.-Bull. t. 415.f. 1. Sow. t. I58. - Fungh. Linn. v. t. 7.f. 2.

15. T. fastidiosa Fr.-Shining white, effused, soft, shapeless, growing into each other by incrusting, passing into plate-like branches. Hymenium inferior, papillose, rufescent.

In its fœtid odour it agrees with $T$. palmata. The tufts are at first without distinct form, confluent mutually and with neighbouring bodies in a circle of as much as 30 cent. (I 2 in.) wide.

On the ground. Uncommon.

Looks at first sight like some mycelium. M.F.B. Name-fastidiosus, disgusting. From the odour. Fr. Hym. Eur. p. 637. Berk. Out.p. 268. C. Hbk. n. gor. Saund. E Sm.t. 4I.f. I.

16. T. sebacea Pers.-Whitish, effused, fleshy-waxy, becoming hard, changeable in form by incrusting, tubercular or resembling stalactite, circumference similar. Hymenium collapsing, flocculoso-pruinose. 
Thelephora. Circumference not penicillate.

On stumps, logs, grass, \&c. Common. Jan.-Oct.

Name-seba, tallow. From its consistence. Pers. Syn. p. 577. Fr. Hym. Eur. p. 637. Berk. Out. p. xvii. t. 17. f. 6. C. Hbk. n. 904. S. Mycol. Scot. n. 853. Letell. t. 607.f. 3.-Pers. Clavef. t. 4. f. 4. Fl. Dan. t. 1302. f. 2.

17. T. crustacea Schum. - Fuscons-umber, broadly effused, somewhat fleshy, undulated and tubercular, the similar circumference white-floccose. Hymenium papillose, slightly bristly.

On the ground. Burnham.

Name-crusta, a crust. Crustaceous. Schum. Sall. p. 396. Fr. Hym. Eur. p. 637. B. Eo Br.n. I577. Fl. Dan. t. I851.f. 2.

18. T. cæsia Pers.-Cinereous-bluish-grey, effused, determinate, soft, continuous. Hymenium even, slightly bristly.

A very thin, even, grey-cinereous form approaching this has occurred on sterile heathy ground.

On stumps and the ground. Frequent. Nov.

The surface is sometimes quite smooth. With its quaternate spores it is a pretty opaque object under the microscope. M.F.B. Name-casius, bluishgrey. Pers. Obs. Myc. i. t. 3. f. 6. Fr. Hym. Eur. p. 638. Berk. Out. p. 268. C. Hbk. n. 903. S. Mijcol. Scot. n. 854. Nees Syst.f. 254.

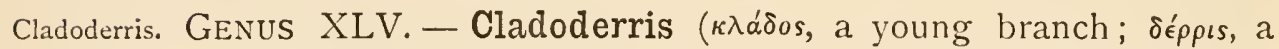
leathern coat. From its coriaceous and branched structure). Pers.

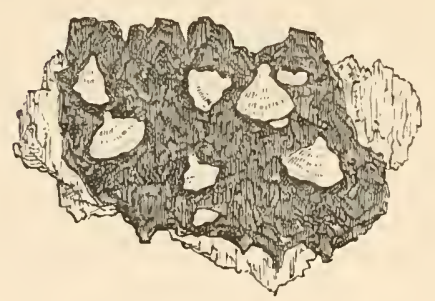

Coriaceous; hymenium woody, radiated on branched ribs, persistent, at length roughened with warts. Fr. Sum. Veg. Scan. p. 332.

1. C. minima B. \& Br.-White, 4-6 mm. (2-3 lin.) across, flabelliform, springing from a stem-like or obsolete base, resupinate. Pileus

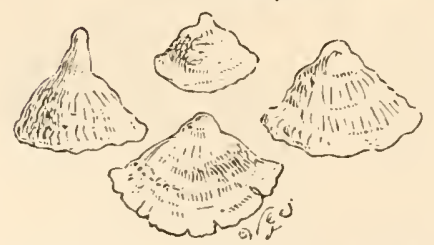

LXXXV. Cladoderris minima. Natural size. Section three times natural size. tomentose. Hymenium radiated on branched ribs.

Though small it has exactly the structure of the exotic species.

On birch. Glamis, 1876. Dec.

Name-minimus, least. Very small. $B$. \& Br. n. 1692. S. Mycol. Scot. n. 855 . 
Genus XLVI.-Stereum ( $\sigma \tau \epsilon \rho \epsilon \delta s$, hard). (Pers.) Fr. Epicr. Stereum. p. 545 .

Hymenium definitely inferior, coriaceous, separated from the fibrous-coated pileus by an intermediate fibrillose stratum, even, remaining unchanged. Sporophores 4-spored; spores minute, roundishovate. Coriaceous or woody, mostly perennial, somewhat zoned, entire, definite in form. Fr. Hym. Eur. p. 638 .

I. Merisma ( $\mu \in \rho i \zeta \omega$, to divide). Pilei very numerous, ascending, imbricated in a free tuft.

II. ApUs ( $(\dot{\alpha}, \pi$ ov́s, a foot). Pileus sessile, at first resupinate, then commonly pileatoreflexed or adnate behind, coriaceous, marginate.

* Hymenium smooth.

** Hymenium simple, slightly bristly or velvety.

*** Woody, perennial, scarcely reflexed, but marginate, the hymenium stratose by confuent pilei, at the first pruinose.

**** Rigid, the simple hymcnium pruinose.

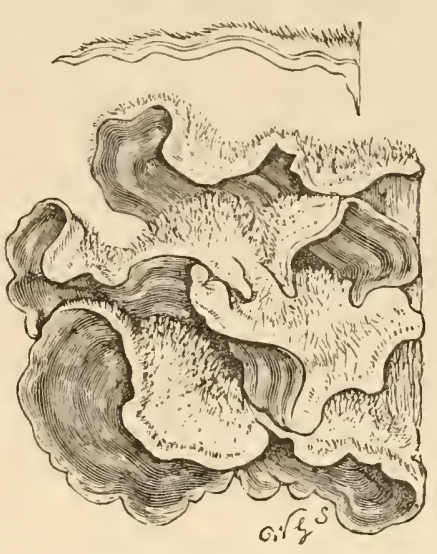

LXXXVI. Stereum hirsutum. Natural size.

III. Resupinata. Crustaceo-adnate, indeterminate, without a distinct pileus, but at length admitting of being detached entire like a piece of leather. Circumference not flaxy. Incrusting wood. (Species of Subdivision II. (Apus) occur in a resupinate state, but being limited (marginate) are from the first distinct.)

* True species, coriaceous.

** Imperfect, crustaceo-adnate, sterile.

\section{I.-MERISMA.}

No British species.

II.-Apus. Pileus sessile, at first resupinate, \&c.

* Hymenizm smooth.

1. S. ochroleucum Fr.-Pileus hoary, coriaceous-membranaceous, free, expanded, flaccid, silky, zoned. Hymenium even, smooth, yellowish (or in var. grey).

Commonly large, with zones of the same colour or fuscous. Coating of the pileus here and there separating.

On wood. Glamis, 1874. Jan.

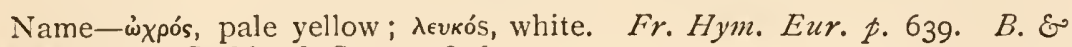
Br.n. 1818. S. Mycol. Scot. n. 856 . 
Stereum. 2. S. purpureum Pers.-Coriaceous-soft. Pileus pallid or whitish, effuso-reflexed, somewhat imbricated, zoned, villosotomentose. Hymenium naked, even, smooth, purplish. Dec.

On dead wood, especially fir and poplar. Common. May-

Varying greatly in colour, whitish, yellowish, pallid-lilac, \&c., with frequently a black zone near the margin. M.F.B. Name-purpureus, purple. Pers. Obs. Myc. 2. p. 92. Fr. Hym. Eur. p. 639. Berk. Out. p. 270. C. Hbk. n. 910. S. Mycol. Scot. n. 857. Hussey i. t. 20.-Bull. t. 483 . Sow. t. 388. f. 1 .

3. S. vorticosum Fr.-Pileus pallid, margin of the same colour, coriaceous, effuso-reflexed, obscurely zoned, strigosohirsute. Hymenium somewhat ribbed, smooth, purplish.

Exactly intermediate between $S$. purpureum and $S$. hirsutum; the colour is that of the former, the coating and entire structure as in the latter. It resembles Auricularice in the widely ribbed hymenium.

On beech. Menmuir, Forfarshire.

Name-vorticosus, full of eddies. From the ribbed hymenium. Fr. Hym. Eur. p. 639. B. E Br.n. I578. S. Mycol. Scot. n. $85^{8}$. Bull. t. 483. f. I5. Bolt. t. 82. f. D?

4. S. hirsutum Fr.-Coriaceous, stiff. Pileus somewhat zoned, inclining to pale, effused and reflexed, strigoso-hirsute, margin rather obtuse, yellow. Hymenium even, smooth, naked, juiceless, yellowish, varying in colour.

There are many varieties, even persistently resupinate. The down which covers it is yellowish, pallid or grey.

On stumps, \&c. Very common. Jan.-Dec.

Name-hirtus, hairy. Fr. Hym. Eur. p. 639. Berk. Out.p. 270. t. 17.f. 7. C. Hbk. n. 9 II. S. Mycol. Scot. n. 859. Hussey i. t. 58. Theleph. Fr. Syst. Myc. i. p. 439.-Bull.t. 274. Sow. t. 27. Fl. Dan. t. 1199. Michel. t. 66. f. 2 .

5. S. spadiceum Fr.-Coriaceous. Pilei somewhat ferruginous, effuso-reflexed, villous, the rather obtuse margin white. Hymenium even, smooth, inclining to fuscous, bleeding if bruised when fresh.

The colour varies in intensity. Intermediate stratum white. Very distinct from $S$, sanguinolentum.

On stumps and branches, chiefly ash and oak. Common. Oct.-Dec.

Name-spadix, date-brown. Fr. Hym. Eur. p. 640. Berk. Out.p. 270. C. Hbk. n. 912. S. Mycol. Scot. n. 860. Fl. Dan. t. 1619. f. I. Bull. t. 483. f. 5 . 
6. S. sanguinolentum Fr.-Coriaceous, thin. Pileus pallid, Stereum. effused and reflexed, adpressedly silky, somewhat striate, the acute margin white. Hymenium even, smooth, cinereous inclining to fuscous, bleeding when touched, pruinose when old.

It must not be confounded with S. rugosum. It is distinguished by its thin substance, by the pileus being adpressedly silky and somewhat striate, by the hymenium never being yellowish, \&c.

On wood, chiefly pine. Common. June-Nov.

Name-singuis, blood. Bleeding. Fr. Hym. Eur. p. 640. Berk. Out. p. 271. C. Hbk. n. 9i3. S. Mycol. Scot. n. 86I. Theleph. Fr. Elench. n. 178. Grev. t. 225. Kl. Bor. t. $3^{81 .}$

** Hymenium simple, slightly bristly or velvety.

7. S. rubiginosum Fr.-Coriaceous-rigid. Pileus rubiginous, effuso-reflexed, somewhat fasciate, velvety, becoming smooth and date-brown, the intermediate stratum tawny-ferruginous. Hymenium ferruginous, velvety with small bristles.

Margin paler when young.

On stumps, \&c. Common. July-Nov.

Spores cylindrical, curved. Fr. Name-rubigo, rust. Fr. Hym. Eur. p. 6+1. Hymenochæte Berk. Out. p. 27 I. C. Hbk.n. 9r6. S. Mycol. Scot. n. 866. Theleph. Fr. Syst. Myc. i. p. 436. Fl. Dan. t. I6Ig. f. 2. Sow. t. 26 (the under side downy).

8. S. tabacinum Fr.-Coriaceous, thin, flaccid. Pileus somewhat ferruginous, the margin, and intermediate stratum which is composed of filaments, golden, effused, reflexed, silky, at length becoming smooth. Hymenium paler, pubescent with small bristles.

The hymenium varies in colour. Very widely effused.

On fallen branches. Rare.

Spores elongated, slightly curved, hyaline, 3-5 $\times$ I mk. $K$. Nametabacum, tobacco. From the colour. Fr. Hym. Eur. p. 64I. Hymenochrte Berk. Out. p. 27I. C. Hbk. n. 917. Theleph. Fr. Syst. Myc. i. p. 437. -Sow. t. 25. Bolt. t. 174.

9. S. rufo-hispidum Stev.-Pallid fawn-colour, rigid, margin obtuse, raised, hispid with rufous bristles.

A very distinct species.

On bark of yew. Craig-y-barns, Dunkeld. Sept.

Name-from the rufous bristles. Hymenochæte Stevensoni B. \& Br. n. I817. S. Mycol. Scot. n. 868. 
Stereum. 10. S. avellanum Fr.-Coriaceous, hard. Pileus dingy, effused and, as well as the obtuse, free, narrowly reflexed, date-brown margin, villous. Hymenium even, velvety then pruinate and becoming smooth, pale-ferruginous (here and there bleeding).

In many respects it approaches $S$. rugosum, but is certainly very different. Colour not yellowish.

On bark and wood, especially hazel. Appin.

Name-Corylus avellana, hazel. Fr. Hym. Eur. p. 6ł2. S. Mycol. Scot. n. 862. Theleph. Fr. Syst. Myc. i. p. 442. Berk. Eng. Fl. v. p. r $\epsilon_{7}$.

*** Woody, perennial, scarcely reflexed, but marginate, Eoc.

11. S. frustulosum Fr.-Date-brown-blackish, woody, resupinate, tubercular, crowded and as if confluent, then broken up into fragments, smooth beneath and at the obsoletely marginate circumference. Hymenium convex, cimamon becoming pale, pruinose.

Easily distinguished by the colours, and by its thick, very hard, woody substance. Hymenium when perfect facing the ground, at first pruinate, when fertile pulverulent with the cinnamon spores; when turned to the light it becomes sterile, pale, denuded.

On hard oak wood. South of England.

Spores ellipsoid-sphæroid, hyaline $4-5 \times 3-4 \mathrm{mk}$. $K$. Name-frustum, a piece. From its being broken up into fragments. Fr. Hym. Eur. p. 643. B. \& Br.n. 1300. Theleph. Fr. Syst. Myc. i. p. 445. Elench. p. 191.

**** Rigid, the simple hymenium pruinose.

12. S. rugosum Fr.-Corky, rigid. Pileus date-brown, effused and shortly reflexed, obtusely marginate, at length smooth. Hymenium unpolished, pruinose, somewhat bleeding when bruised.

A. Hymenium yellowish. B. Hymenium cinereous-livid. Varying very much, even cup-shaped.

On stumps, \&c. Very common. Jan.-Dec.

Name-ruga, a wrinkle. Fr. Hym. Eur. p. 643. Berk. Out. p. 27I. C. Hbk. n. 9r4. S. Mycol. Scot. n. 863 .

Var. lauro-cerasi Berk. On laurel. S. Mycol. Scot. n. 863. Theleph. Berk. Eng. Fl. v. p. I73.

13. S. pini Fr. - Pallid, coriaceo-cartilaginous, resupinate, adnate in the form of a shield, somewhat marginate, smooth beneath, at length bullate. Hymenium purplish-flesh-colour, becoming fuscous, pruinose.

The primary shields are minute, crowded, but already free, never agglutinated or waxy. 
On bark of Scotch fir. Glamis. Aviemore.

Stereım.

Name-pinus, pine. Fr. Hym. Eur.p. 643. B. \& Br.n. 1579. S. Mycol. Scot. 12.864 .

14. S. rufum Fr.-Rufous, becoming fuscous, coriaceo-cartilaginous, erumpent, tuberculiform then somezuhat round, marginate, smooth beneath. Hymenium grey-pruinose, at length bullatetubercular.

Wholly immarginate when young.

On dead pine and ash. Glamis, i874. Sept.-March.

Name-rufus, rufous. Fr. Hym. Eur.p. 64t. Elench.p. 187. B. \& Br. n. 1580. S. Mycol. Scot. n. 865.-Sow. t. 338. f. 2.

III.-Resupinata. Crustaceo-adnate, indeterminate, \&c.

* True species, coriaceous.

15. S. stratosum B. \& Br.-Effused, bright ochraceous-white, smooth, becoming yellow, here and there wrinkled.

Substance pallid, stratose, the strata at length broken up.

Habitat not recorded. Penzance.

Name-stratum. Stratose. B. \& Br.n. 2027.

* Imperfect, crustaceo-adnate, sterile.

16. S. acerinum (Theleph. acerina Pers.)-Crustaceo-adnate, even, smooth, white.

Effused like the crust of a lichen. It must be sought for in a perfect condition on fallen trunks. When young it is continuous and somewhat pruinose. Name-acer, maple. Pers. Syn. p. 581. Fr. Hym. Eur. p. 645. Syst. Myc. i.p. 453. Berk. Out.p. 271. C. Hbk.n.915.

Genus XLVII.-Auricularia (auricula, the ear). Bull. Auricularia. Champ. p. 277. sp. I.-Fr. Epicr. p. 555.

Hymenium definitely inferior, remotely and irregularly costatoplicate, swelling and becoming gelatinous and tremulous when moist, collapsing (and coriaceous Epiir.) when dry. Habit exactly that of Stereum.

Intermediate between Thelephorei and Tremellini; nearest in affinity to the former, when dry scarcely to be distinguished from Stereum; departing from the Tremelle in the coriaceous pileus. Fr. Hym. Eur. p. 645. 
Auricularia. 1. A. mesenterica Fr.-Pilei fuscous-cinereous, resupinate then reflexed, entire, villous, fasciato-zoned. Hymenium costato-plicate, fuscous-violaceous.

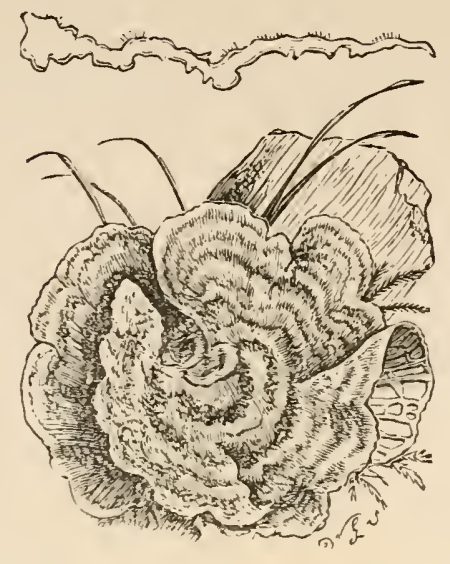

LXXXVII. Auricularia mesen. terica. One-third natural size.

\section{On stems of trees. Frequent.}

$5-7.5$ cent. $(2-3$ in.) broad, gelatinous in wet weather, hard and cartilaginous when dry, reviving with wet. Hymenium powdered with a beautiful bloom. M.F.B. Spores white, $7 \times 4$ mk. W.G.S. Name$\mu \epsilon \sigma \in \operatorname{v\tau } \rho_{\rho} o \nu$, the mesentery. Fr. Hym. Eur. p. 646. Berk. Out. p. 272. C. Hbk. n. 919.-Sow. t. 290. Hussey ii. t. 6. Bolt. t. 172. Bull. t. 290. Michel. t. 66. f. 4 .

2. A. lobata Sommerf.-As much as 17.5 cent. ( 7 in.) long, $5-12.5$ cent. (2-5 in.) broad, $2-4 \mathrm{~mm}$. ( $\mathrm{I}-2$ lin.) thick. Pileus fuscous - whitish, effuso-reflexed, lobed, variegated with strigoso - tomentose, velvety and smooth zones. Hymenium fuscouslivid, reticulato-ribbed with distant folds.

Very much allied to $A$. mesenterica.

On bark of trees. Uncommon.

Name-lobatus, lobed. Sommerf. in Mag. Nat. Vidensk. 1827, with fig. Fr. Hym. Eur. p. 646. Elench. ii. p. 34. Berk. Out. p. 272. t. 18. f. r. C. $H b k . n .920$.

Corticium. Genus XLVIII.-Corticium (cortex, bark). Fr. Epicr. p. 556.

Hymenium amphigenous, even or tubercular, springing immediately from the mycelium without an intermediate stratum; in typical species fertile and swelling when moist, fleshy-soft, contracted and hence commonly cracked when dry, or the whole breaking up. There are other species added to the genus with the hymenium arid and incrusting. Sporophores 4-spored, rarely single-spored. Resupinate, growing on wood, often sterile. Fr. Hym. Eur. p. 646.

I. Lomantia ( $\lambda \hat{\omega} \mu \alpha$, a fringe). Resupinate, but free at the circumference, determinate, marginate, commonly cup-shaped then expanded.

II. Himantił (i $\mu a ́ s$, a strap). Resupinate, effused, immarginate, clothed with flaxy fibrils or strigosely hairy at the circumference and beneath. Often sterile, fibrillose (mycelia). In their perfect state they are furnished with a remarkably well developed, waxy-soft hymenium. 
* Iycelium and circumforence white.

* Mycelium and circumference coloured.

Corticium

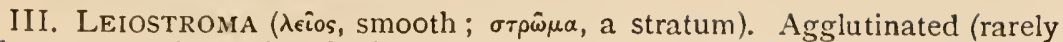
when mature becoming free), without a strigose or fibrillose circumference. For the mycelium passes at once into the hymenium which is agglutinated to the substratum, but this (the hymenium) occurs of two kinds, one thicker, waxy-soft, fertile; the other thin and sterile. The most of the species are undistinguished in appearance.

* Waxy, when fertile facing the ground, uniform, rimose when dry.

** Amphigenous, turning rigid, circumference at first vory thinly floccose and radiating, soon naked.

*** Amphigenous, at the very first hardened, somewhat grumous, circumference always naked.

**** Amphigenous, very thin, innate, removing the bark.

***** Less known species, doubtful.

Subgenus I. CONIOPHORA (кóvis, dust; $\phi \epsilon ́ p \omega$, to bear). Pers. Myc. Eur. i. p. I53. Fleshy, undulate and tubercular, rarely membranaceous, becoming even; hymenium smooth, pulverulent with the spores; in other respects agreeing with Corticizm.

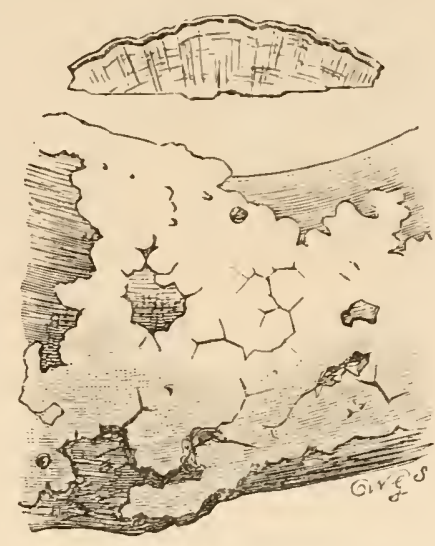

LXXXVIII. Corticiun sambuci. Natural size. Growing on wood, analogous to the group Coniophori of Merulius.

Subgenus II. Hypochnus (imo and $\chi \nu 0 v \hat{s}$, the first down on the chin). Fr. Obs. ii. p. 278. Breaking up and becoming floccose or furnished with a tomentose, somewhat pulverulent hymenium.

* Breaking up and becoming floccose.

** Hymenium tomentose, somewhat pulverulent.

\section{I.-Lomantia. Resupinate, but free at the circumference, \&c.}

1. C. evolvens Fr.-Resupinate, marginate or effuso-reflexed, soft, flocculose with whitish down beneath, zoneless. Hymenium naked, smooth, somewhat wrinkled, fuscous becoming pale fuscous, divided in cracks when dry.

So polymorphous in stature and form, that at first sight the different forms seem scarcely allied. It varies when smaller cup-shaped, marginato-reflexed; wholly resupinate, broadly effused, immarginate. It is distinguished by the hymenium being soft, somewhat tubercular, very much cracked when dry, fuscous or becoming pale, and by the floccose receptacle.

\section{On dead wood, especially cherry. Frequent. Oct.-Feb.}

Name-evolio, to unroll. Fr. Hym. Eur. p. 646. B. \& Br.n. 1029. C. Hbk.n.921. S. Mycol. Scot.n. 872 .

2. C. salicinum Fr.-White-villous externally, coriaceous, soft, rigid when dry, persistently cup-shaped, adfixed at the centre.

VOL. II. 
Corticium. Hymenium rather even, naked, persistently red-blood-colour, continuous when dry.

Very elegant, entirely like a Peziza. It varies becoming smooth.

On Salix aurata. Kinrara, Morayshire. Aug.-Sept.

Berkeley considers this the same with Exidia cinnabarina B. \& C. Spores oblong, curved, hyaline, $16-18 \times 4-6$ mk. $K$. Name-salix, willow. Fr. Hym. Eur. p. 647. B. \&o Br. n. 158r. S. Mycol. Scot. n. 873 .

3. C. amorphum Fr. $-4-6 \mathrm{~mm}$. (2-3 lin.) broad, white-tomentose externally, waxy-pliant, somewhat coriaceous, cup-shaped then flattened, confluent, marginate. Hymenium erien, continuous, pale.

On silver-fir. Perth. Dunkeld. Keir. Aug.-Oct.

The substance is white and fleshy, consisting of rather coarse threads, which at the base form a close sclerotioid network. 'The hymenium consists of colourless threads, and orange-coloured clavate bodies filled with pigment. $B$. \& $B r$. There is considerable doubt whether this is a true Corticium. Fries says the habit is exactly that of Corticium of this section, but the structure of the disc is ambiguous. Berkeley, who compares it in appearance with Peziza calycina, considers it may perhaps be the type of a new genus. Name -á, морфи́, form. Without regular form. Fr. Hym. Eur. p. 648. B. \& Br. n. I582. S. Mycol. Scot. n. 874. Theleph. Fr. Elench. p. I83.

II.-Himantiæ. Resupinate, effused, immarginate, Sc.

* Mycelizm and circumference white.

4. C. giganteum Fr.-Hyaline-quhite, very broadly effused, swelling when moist, waxy, when dry cartilaginous, of the consistence of paper, free, milk-white, circumference strigoso-radiate. Hymenium even, continuous.

At the first agglutinated, but in contracting with dryness it breaks up, and does not become cracked. Smaller and less perfect forms occur.

On pine, stumps, \&c. Common. Oct.-April.

Spores ellipsoid or sphæroid-ellipsoid, hyaline, $4-5 \times 3 \mathrm{mk}$. $K$. Namegiganteus. Of very large size. Fr. Hym. Eur. p. 648. Berk. Out. p. 272. C. Hbk. n. 922. S. Mycol. Scot. n. 875.

5. C. 1acteum Fr.-Milk-zuhite, effused, membranaceous, laxly fibrillose beneath and at the circumference. Hymenium (when perfect) waxy, deeper in colour, divided by cracks when dry.

Much smaller and thinner than $C$. giganteus.

On trunks, \&c. Frequent. Nov.-Feb.

Name-lac, milk. Milk-white. Fr. Hym. Eur.p. 649. Berk. Out.p. 273. C. Hbk.n. 923. S. Mycol. Scot. n. 876.-Bonord. f. 259. 
6. C. porosum B. \& Curt.-Resupinate, milk-white, here and Corticium. there porous, margin free, reflexed.

The pores look as if little dew-drops had settled on the hymenium, which had in consequence contracted or rather retracted.

On wood. Aboyne.

Name-porosus, porous. B. \& Br.n. I82 I. S. Mycol. Scot. n. 886.

7. C. arachnoideum Berk.-Effused, delicately flaxy as is the circumference. Hymenium white, very thin, patchy.

The mycelium is as delicate as a spider's web.

On wood, lichens, \&c. Frequent. Oct.-Feb.

Name-áá $\chi \eta \eta$, a spider. From the spider-web mycelium. Berk. Out. $p$. 273. C. Hbk. n. 924. S. Mycol. Scot. n. 877. Fr. Hym. Eur. p. 649.

8. C. fœtidum B. \& Br.-Effused, resupinate, arachnoid beneath, white then ochraceous and smooth.

Not apparently a resupinate form of Thelephora fastidiosa.

On sawdust. Coed Coch.

Name-fatidus, fœetid. B. \& Br.n. I824.

9. C. læve Pers.-Effused, membranaceous, separating, villous beneath, circumference flaxy (not fibrilloso-radiate). Hymenium even, smooth, somewhat flesh-colour or livid.

On dead wood, sticks, \&c. Very common. Nov.-March.

Hymenium sometimes pure white. M.F.B. Spores ellipsoid or ovoideosphæroid, subchlorino-hyaline, 1 $2 \times 8$-1o mk. $K$. Name-levis, even. Pers. Disp. p. 3o. Fr. Hym. Eur. p. 649. Berk. Out. p. 273. C. Hbk. n. 925. S. Mycol. Scot. n. 878.-Bonord. f. 25 I.

10. C. roseum Pers.-Rose-colour, effused, adnate, circumference fringed and whitish. Hymenium pruinose, becoming pale, at length rimoso-corrugated, hardened.

Very pretty, cognate with Hyphelia rosea.

On dead wood, birch, poplar, \&c. Frequent. Oct.-Feb.

Name-rosa, a rose. Rose-coloured. Pers. Disp. p. 3I. Fr. Hym. Eur. p. 6jo. Berk. Out.p. 273. C. Hbk.n. 926. S. Mycol. Scot. n. 879.

** Mycelium and circumference coloured.

11. C. velutinum Fr.-Flesh-colour, effused, adnate, circumference strigose with straight, diverging fibres of the same colour. Hymenium thick, fleshy, even, velvety with dense small bristles. 
Corticium. Among the most distinguished species of the genus, large, firm, never opening in flocculose clefts, rarely cracked.

On dead wood. Frequent. Aug.-Feb.

Spores ellipsoid, elongated, hyaline, $8 \mathrm{mk}$. $Q$. Name-vellus, fleece. Velvety. Fr. Hym. Eur. p. 650. Berk. Out. p. 273. C. Hbk.n. 927. S. Mycol. Scot. n. 880 .

12. C. subdealbatum B. \& Br.-Shining white, effused. Hymenium pallid fawn-colour with the bristles.

On fir. Badminton, i866. Dec.

Name-sub, and dealbatus, whitened. B. \& Br. n. 1823.

13. C. lactescens Berk.-Flesh-colour, milky, agglutinated, soft, waxy, undulated, margin shortly byssoid, at length cracked, interstices silky.

Smell like that of Lactarius quietus. Milk-white, watery. Hymenium flesh-colour or pale salmon-colour.

On dead wood, willow, \&c. Frequent. Oct.-Feb.

Name-lac, milk. Milky. Berk. Out.p. 274. C. Hbk. n. 932. S. Mycol. Scot.n. 881. Fr. Hym. Eur. p. 650.

14. C. sanguineum Fr.-Blood-red, effused, adhering laxly, like spider-web beneath, circumference laxly fibrillose, flesh-colour. Hymenium even, smooth, flesh-colour.

The mycelium tinges the wood blood-red. Rarely gathered in a fertile state.

On dead pine and larch. Uncommon. Nov.-Feb.

Name-sanguis, blood. Of the colour. Fr. Hym. Eur. p. 65o. Berk. Out. p. 273. C. Hbk. n. 928. S. Mycol. Scot. n. 882.

15. C. sulphureum Fr.-Bright sulphur-yellow, effused, fibrilloso-flaxy. Hymenium (when perfect) thick, waxy-soft, cracked when dry.

The very variable mycelium is frequent, but it is rarely perfectly developed. It occurs with the hymenium tawny.

On dead wood. Frequent. Nov.-Dec.

Fries has gathered it in greatest perfection on rotting beech-leaves. Name - sulphur, brimstone. Of the colour. Fr. Hym. Eur. p. 650. Berk. Out. p. 274. C. Hbk.n. 929. S. Mycol. Scot. n. 883 .

16. C. cinnamomeum Fr.-Cinnamon, effused, irregular by becoming confluent, adpressed, fibrilloso-strigose beneath and 
at the circumference. Hymenium fleshy, soft, smooth, naked, Corticium. of the same colour, cracked when dry.

It varies dark ochraceous. When fertile it approaches $C$. velutinus.

On birch log. Glamis, 1874 . Nov.

Name-cinnamomum, cinnamon. Of the colour. Fr. Hym. Eur. p. 650. B. \& Br.n. 1584. S. Mycol. Scot. n. 884.

17. C. cæruleum Fr.-Beautiful azure-blue, somewhat round, then effused, adnate, at first tomentose, circumference flaxy and of the same colour inclining to be whitish. Hymenium waxysoft, papillose, slightly bristly becoming smooth.

On rails, dead wood, fir, \&c. Common.

Name-caruleum, azure-blue. Fr. Hym. Eur. p. 65r. Berk. Out. p. 274. C. Hbk. n. 930. S. Mycol. Scot. n. 885.-Letell. Suppl. t.630. Roth. Catal. 2. t. 9. f. 2. Sow. t. 350 .

18. C. atro-virens Fr.-Black-green, irregularly effused, tomentose beneath and at the circumference, of the same colour. Hymenium (found only as a barren cinereous pellicle).

On sticks in woods. Rare.

Name-ater, black; vireo, to be green. Fr. Hym. Eur. p. 65I. Berk. Out. p. 274. C. Hbk.n. 93 I.

III.-Leiostroma. Agglutinated (rarely when mature becoming free), \&c.

* Waxy, when fertile facing the ground, Soc.

19. C. calceum Fr.-White, effused, agglutinated, waxy, very smooth, circumference similar. Hymenium even, smooth, when dry cracked, rigid.

Very polymorphous. The colour varies clay and whitish inclining to fuscous. Hymenium sometimes broken up into minute lumps.

On pine wood. Common. Oct.-Feb.

Name-calx, lime. Chalk-white. Fr. Hym. Eur. p. 652. Berk. Out. p. 274. C. Hbk. n. 933. S. Mycol. Scot. n. 887.

20. C. puberum Fr.-White or clay-colour, broadly effused, waxy, closely adnate, indeterminate. Hymenium even, velvety with short bristles, cracked when dry.

Like $C$. calceum, differing only in the hymenium being velvety with bristles. Very thin, separable from the matrix only in small fragmerts.

On dead wood. Aboyne. Forres. Glamis. 
Corticium. Name-puber, adult. As applied to plants downy. From the hymenium. Fr. Hym. Eur. p. 652. B. Eo Br.n. 1822. S. Mycol. Scot. n. 888. Theleph. Fr. Elench. p. 215.-Bonord. f. 256 (?)

21. C. scutellare B. \& Curt.-Whitish, then slightly tan-colour, resupinate, effused, immarginate. Hymenium broken up into minute areolæ.

On Ulex. Strachan, Kincardineshire. Glamis.

Name-scutella, a salver. From its form. B. \& Br.n. 1825. S. Mycol. Scot. n. 889. Grevillea, vol. ii. p. 4 .

22. C. lividum Pers.-Changeable in colour, effused, agglutinated, waxy-soft, becoming smooth, circumference similar. Hymenium even, naked, somewhat viscid when moist, cracked when dry.

In the same specimen the colour has been observed livid-azure-blue, and fuscous-purplish.

On clead birch. Rare.

Name-lividus, livid. Pers. Obs. i. p. 38. Fr. Hym. Eur. p. 652. Berk. Out.p. 275. C. Hbk.n. 934. S. Mycol. Scot. n. 890.

23. C. ochraceum Fr.--Broadly effused, 30 cent. (I2 in.) and more, agglutinated, waxy-soft, smooth, circumference white, somewhat radiating, soon vanishing. Hymenium pallid then ochraceous, sprinkled with golden-glistening atoms, at length naked, papillose or tubercular, cracked when collapsed.

There is a remarkable variety with concentric papillæ.

On pine stumps. Uncommon. Nov.-Dec.

Name-ochraceus, ochrey-yellow. Fr. Hym. Eur. p. 652. Berk. Out. p. 275. C. Hbk. n. 935. S. Mycol. Scot. n. 891. Theleph. Fr. Syst. Myc. i. p. 446 .

$$
\text { ** Amphigenous, becoming rigid, Eoc. }
$$

24. C. quercinum Fr.-Cartilaginous-membranaceous, at first agglutinated, then adfixed in the centre, loosened on all sides, and at length involute, rigid, smooth and becoming black beneath. Hymenium continuous, flesh-colour.

It does not become cracked because it is set free in dying.

On oak branches. Very common. Aug.-April.

Name-quercus, oak. Fr. Hym. Eur. p. 653. Berk. Out. p. 275. C. Hbk. n. 936. S. Mycol. Scot. n. 892.-Nees f. 253. Grev. t. 142. Bull. t. 436. f. I. 
25. C. cinereum Fr.-Lurid, waxy becoming rigid, confluent, Corticium. agglutinated, circumference similar. Hymenium sprinkled with very thin cinereous pruina.

There are two fornis, the thicker on wood, the thinner on bark.

On dead branches. Very common. Nov.-May.

Spores oblong or elongated, cylindrical, curved, $3-5 \times \mathrm{I}$ mk. $K$. Namecinis, ashes. Ash-colour. Fr. Hym. Eur. p. 654. Berk. Out. p. 275. C. Hbk. n. 937. S. Mlycol. Scot. n. 893 .

26. C. incarnatum Fr.-Waxy, becoming rigid, agglutinated, indeterminate, circumference radiate. Hymenium persistently bright-coloured (red, orange), sprinkled with very thin, somewhat flesh-coloured pruina.

The form on wood is rather thick, undulato-papillose, when collapsed even, cracked; that on bark thinner, persistently spuriously papillose from Sphcerice being incrusted by it.

On dead pine, Ulex, broom, \&c. Very common. Aug.-March.

Spores ellipsoid or oblong-ellipsoid, often obsoletely curved, $9-12 \times 5 \mathrm{mk}$. $K$. Name-incarnatus, flesh-coloured. Fr. Hy'm. Eur. p. 654. Berk. Out. p. 275. C. Hbk. n. 938. S. Mlycol. Scot. n. 894. Fl. Dan. t. 2035. f. 2.

27. C. nudum Fr.-Flesh-colour becoming pale, waxy, becoming rigid, agglutinated, circumference determinate, smooth. Hymenium even, cracked when dry, sprinkled (under a lens) with whitish, fugacious pruina.

On dead wood. Frequent. Nov.-Feb.

Name-nudus, naked. Fr. Hym. Eur. p. 655. Berk. Out.p. 276. C. Hik. n. 939. S. klycol. Scot. n. 895 .

* C. citrinum Pers.-Agreeing entirely with C. mudum, except in the hymenium being papillose, and in the colour being bright light yellow.

On dead wood. Moncreiffe.

Name-citrus, citron. Lemon-yellow. Pers. Myc. Eur. i. p. 136(Theleph.) Fr. Hym. Eur. p. 655. B. \& Br. n. 1695.

28. C. confluens Fr.-Somewhat membranaceous, indeterminate, agglutinated, circumference radiate (not fibrillose). Hymenium even, naked, hyaline, shining whitish when dry.

Circumference adnate, very delicate.

On dead branches, ash, \&.c. Frequent.

Name-confuo, to flow together. Confluent. Fr. Hym. Eur. p. 655. Berk. Out. p. 276. C. Hbk. n. 940. S. Mycol. Scot. n. 896. 
*** Amphigenous, from the very first hardened, Eoc.

29. C. polygonium Pers.-Flesh-colour, adnate, defined, soon hardened, somewhat grumous, circumference similar. Hymenium red under the dense pruina.

On dead branches, poplar, \&c. Frequent.

Growing in little round detached patches from the ostiola of Spharice. M.F.B. Name-polygonizes, polygonal. From the shape of the tubercles which are owing to covered Spharia. Pers. Disp. 30. Fr. Hym. Eur. p. 655. Berk. Out. p. 276. C. Hbk. n. 941. S. Mycol. Scot. n. 897.-Hoffm. D. Fl. 2. $t .6$.

30. C. violaceo-lividum Fr.-Violaceous-livid, somewhat effused, adnate, hardened. Hymenium spuriously corrugated, tubercular, sprinkled with thin, whitish pruina.

Like $C$. cinereum, but allied to C. polygonium. Often growing on Spherice.

On dead wood. Glamis, I877.

Name-from the colours. Fr. Hym. Eur. p. 655. B. \& Br. n. 1696 . S. Mycol. Scot. n. 898.

31. C. maculæforme Fr.-Somewhat rose-colour, orbicular, then confluent, hardened, thin, circumference similar, smooth. Hymenium spuriously papillose, bluish-grey pruinose.

Commonly small, 2-8 mm. ( $\mathrm{r}-4$ lin.) broad.

On dead wood. Penzance.

Name-macula, a spot; forma, form. Spot-like. Fr. Hym. Eur. p. 656. B. \& Br. n. 1975. Theleph. Fr. Syst. Myc. i. p. 454. Fl. Dan. t. 1738. f. 2.

32. C. limitatum Fr.-Lurid becoming pale, roundish, closely adnate, grumous-hardened, smooth, circumference with a defined black edge. Hymenium naked.

Easily distinguished by its essential character in having a black edge.

On Cytisus. Perth.

Name-limitatus, marked off. From the defined black circumference. Fr. Hym. Eur. p. 656. B. \& Br. n. 1697. S. Mycol. Scot. n. 899.

33. C. corrugatum Fr.-Pallid cinnamon, somewhat effused, 5-7.5 cent. ( $2-3$ in.) long, closely adnate, soon grumous. Hymenium beset with fermiginous bristles, very much cracked when dry.

The bristles are wholly like those of Stereum rubiginosum, to which it is otherwise scarcely allied. It has occurred somewhat waxy.

On dead wood. Very common. Aug.-Nor. 
Name-con, and ruga, a wrinkle. Corrugated. Fr. Hym. Eur. p. 656. Corticium, Theleph. Elench. p. 224. Hymenochæte Berk. Out. p. 272. C. Hbk. n. 918. S. Mycol. Scot.n. 867.-Grev. t. 234 .

\section{**** Amphigenous, very thin, innate, removing the bark.}

34. C. comedens Fr.-Flesh-colour becoming pale, effused, innate, growing under the bark, exposed on the epidermis splitting asunder. Hymenium even, smooth, cracked when dry.

Slightly viscid when moist. Erumpent specinens of $C$. incarnatum must not be confounded with it. Distinguished from all others by its manner of growth, never formed on decorticated wood or above the bark.

On dead branches. Very common. Nov.-March.

Hymenium sometimes white. The bark forms a margin round it. M.F.B. Name-comedo, to consume. From its destroying the bark under which it grows. Fr. Hym. Eur. p. 656. Berk. Out. p. 276. C. Hbk. n. 942. S. Mycol. Scot. n. 900. Theleph. Nees Syst. f. 255. Fr. Elench.p. 219.

\section{***** Species less known, doubtful.}

35. C. aurora Berk.-Rose-colour, turning pallid, very thin, effused, agglutinated, circumference indeterminate.

On dead leaves of Carices. Batheaston.

Name-Aurora, the dawn. From the colours. Berk. Out.p. 276. C. Hbk. n. 944. Fr. Hym. Eur. p. 657 .

36. C. typhæ Fckl. - Longitudinally effused, thin, at first orbicular, white and flaxy, wholly smooth, then somewhat mealy, tan-colour.

On Typha latifolia. North Wooton, 1874.

Spores oblongo-lanceolate, multiguttate, hyaline. Fckl. Name-from the host plant. Fuckel Symb. p. 27. Fr. Hym. Eur. p. 657. Grevillea, vol. iv. p. II9.

Subgenus I.-Coniophora. Fleshy, undulated and tubercular, \&c.

37. C. puteanum Fr.-Light-yellowish-pallid, at length fuscousolivaceous, the mucedinous circumference white, roundish or effused, Acshy, fragile. Hymenium somewhat undulated, pulverulent with the fuscous-olivaceous spores.

On dead wood in cellars, \&c. Frequent. Nov.

Very fragile, $2 \mathrm{~mm}$. (I lin.) thick. It loosens itself from the trunk with age. It decays and grows black in winter, but in the following year a new plant crusts over the destroyed one. Sommerf. Sometimes dripping with moisture. 
Corticium. M.F.B. Spores sphæroid-ellipsoid, slightly fuscous, 12-10 $\times 8-9 \mathrm{mk} . K$. Name-puteanum, pertaining to a well. From its sometimes dripping. Fr. Hym. Eur. p. 657. S. Mycol. Scot. n. 901. Theleph. Schum.-Berk. Out. p. 269. C. Hbk.n. 905. Fl. Dan. t. 2035.

38. C. stabulare Fr.-Effused, flaxy when young, white, then fleshy-soft, vinous-fuscous, circumference flaxy, white. Hymenium tubercular, white-priinose, the tubercles collapsing.

Odour fœit from its habitat.

On fir wood. Perth.

Name-stabulum, a stall. From its being found in an ox-stall. Fr. Hym. Eur. p. 658. S. Mycol. Scot. n. 902.

39. C. umbrinum Fr. - Umber, effused, fleshy-soft, villous beneath, circumference short, radiating, of the same colour. Hymenium tubercular then collapsing, ferruginous-pulverulent.

A distinguished species, not very broad but confluent, not easily separated from the matrix.

On dead wood. Penzance. Hothorpe. Feb.

Spores sphæroid, punctate, $8 \mathrm{mk}$. $Q$. Name-from the umber colour, Fr. Hym. Eur. p. 658. B. \& Br. n. I974. Grevillea, vol. xi. p. I4. Theleph. Alb. Eo Schw. p. 281. $\beta$. Fr. Elench. p. I99.

40. C. laxum Fr.-About 5-7.5 cent. (2-3 in.) long, white, membranaceous, soft, adhering laxly, spider-web-tomentose beneath, circumference flaxy. Hymenium papillose, pallid then ochraceous-fermiginous, ferruginous-pulverulent.

Papillæ rather large.

On dead fir, lichens, moss, \&c. Rare. Nov.

Spores ovoid-sphæroid, punctate, spotted, ro $\mathrm{mk}$. Q. Name-laxus, loose. From its adhering laxly. Fr. Hym. Eur. p. 659. S. Mycol. Scot. n. 903. Theleph. Fr. Elench. p. 190. Berk. Out. p. 269. C. Hbk. n. 906.

41. C. byssoideum Fr.-Ochrey-white, irregularly effused, at first flaxy, at length compact at the disc, fleshy, pulverulent, light yellow, circumference flaxy, rather whitish.

Among fir-leaves, mosses, \&c. Frequent.

Name-byssus, flax. Flaxy. Fr. Hym. Eur. p. 659. S. Mycol. Scot.n. 904. Theleph. Pers. Syn. p. 577. Berk. Out. p. 269. C. Hbk. n. 902.

42. C. aridum Fr.-Membranaceous, effused, adnate, continuous, circumference whitish. Hymenium even, sulphur-yellow, then setuloso-pulveraceous, umber inclining to ferruginous. 

Nov.

On dead and decayed pine in woods and cellars. Common. Corticium.

Name-aridus, dry. Fr. Hym. Eur. p. 659. S. Mycol. Scot. n. 905. Theleph. Berk. Out. p. 269. C. Hbk. n. 907.

Subgenus II.-Hypochnus. Breaking up and becoming floccose, \&c.

* Breaking up and becoming floccose.

43. C. serum Fr.-White, broadly effused, incrusting, thin, fleshy when fresh, smooth, pruinose, then and when dried splitting open into flocci, papillæ round, crowded together, equal.

A very singular species. Papillæe regular.

On trunks. Epping. Glamis. Menmuir. Winter.

Spores sphæroid or ovoideo-ellipsoid, smooth, hyaline or chlorino-hyaiine, 9-II $\times$ 7-8 mk. $K$. Name-serus, late. Growing in winter. Fr. Hym. Eur. p. 659. B. \& Br. n. I583, 1697. S. Mlycol. Scot. n. 906. Theleph. Pers. Syn.p. 580. Fr. Elench. p. 2II.

44. C. sambuci Fr.-White, effused, somewhat innate, incrusting, surrounding branches, indeterminate, continuous when in vigour, breaking into floccules when dry.

Easily recognised from its habitat.

On dried branches of elder. Very common. Aug.-Dec.

Very difficult to separate from C. calceum by a strict definition. M.F.B. Name-sambucus, elder. Fr. Hym. Eur. p. 660. Berk. Out. p. 276. C. Hbk. n. 943. S. Mycol. Scot. n. 907.-Grev. t. 242. Letell. t. 607. f. 2.

** Hymenium tomentose, somewhat pulverulent.

45. C. olivaceum Fr.-Membranaceous, adnate, circumference fringed and whitish. Hymenium thin, dark olivaceous, tomentose with small bristles.

Broadly effused, orbicular or elongated. The colour is distinguishing and remarkably constant.

On pine wood. Uncommon.

Spores sphæroid or sphæroid-ellipsoid, very pale yellowish or slightly fus. cous, $4 \mathrm{mk} . K$; ; ovoideo-ellipsoid, nucleate, yellow, $8 \mathrm{mk}$. $Q$. Name-from the colour. Fr. Hym. Eur. p. 660. Theleph. Fr. Elench. p. 197. Berk. Out.p. 269. C. Hok. n. 908.

46. C. ferrugineum Fr.-Fernuginous, effused, adnate, everywhere tomentose. Hymenium papillose, pulveraceous.

It may be compared with Hydnum ferruginosum and Polyporus foccosus. 
Corticium. On branches. Altyre, \&c. Oct.

Name-ferrugo, iron-rust. From the rusty colour. Fr. Hym. Eur. p. 66r. B. \& Br. n. 1585. S. Mycol. Scot. n. 908.

47. C. lacunosum B. \& Br.-Broadly effused, soft, mycelium woolly-tawny, lacunose. Hymenium pulverulent.

On branches. Aboyne, I87o. Sept.

Name-lacuno, to hollow out. Full of hollows, lacunose. B. \& Br.n. r37r. S. Mycol. Scot. n. gog. Fr. Hym. Eur. p. 66r.

48. C. anthochroum Fr.-Brick-red-rose-colour, becoming pale, effused, even above, wholly broken up, floccoso-velvety, circumference flaxy, paler.

Very pretty. Without a hymeneal membrane.

On sticks, sycamore, birch. Rare. Feb.

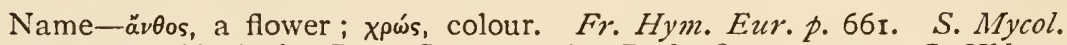
Scot. n. 9ro. Theleph. Pers. Syn. p. 576. Berk. Out. p. 270. C. Hbk.n. 909.

Cyphella.

Genus XLIX.-Cyphella ( $\kappa \bar{\nu} \phi o ́ s$, a goblet).

Fr. Syst. Myc. 2. p. 201.

Somewhat membranaceous, cup-shaped, rarely plane, adnate be-

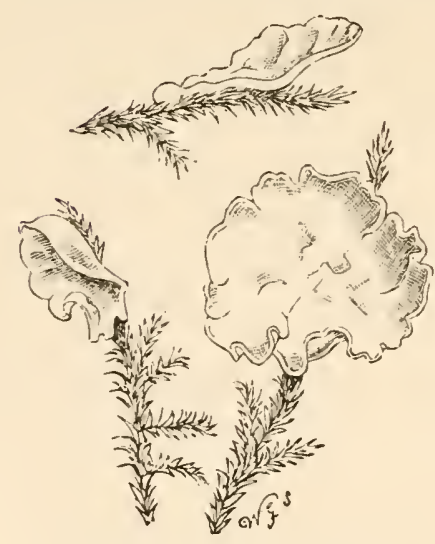

$L X X X I X$. Cyphella catilla. Natural size. hind, commonly extended in stemlike form, pendulous. Hymenium definitely inferior, similar, without the heterogeneous disc and asci of Pczize, even or at length slightly wrinkled. Sporophores 4 -spored, spores subovate.

Without doubt very near to Solenice, and removed from them by artificial characters. Fr. Hym. Eur. p. 66r.

* Lignicolce (growing on wood).

* Muscicole (growing on mosses).

*** Stipiticola (growing on stems).

**** Caulicolce and epiphylle (growing on stalks and leaves).

* Lignicola (growing on wood).

1. C. Bloxami B. \& Phill.-White, floccoso-membranaceous, disc becoming light yellow, crenato-lobed; flocci even. 
Sporophores turbinate. Spores 8-II mk. Spores terminating slightly Cyphella. branched threads.

On Ulex. Twycross.

Name-after Rev. A. Bloxam. B. E Br. n. I894.

2. C. griseo-pallida Weinm.-Pallid-grey, somewhat membranaceous, globose then campanulate, sessile, floccose externally. Hymenium even, smooth.

On dead Carex paniculata. Spye Park, Wiltshire.

Whole plant $\frac{1}{3}$ lin. diam., at first granuliform. Hymenium pale reddishgrey, border slightly undulated. M.F.B. Name-from the colour. Weinm. Ross. p. 522. Fr. Hym. Eur. p. 662. Berk. Out. p. 277. C. Hbk. n. 945.

3. C. ochroleuca B. \& Br.-Ochrey-white and villous above, membranaceous, cup-shaped, margin at length split. Hymenium even, pale ochre, brighter than the pileus.

$2 \mathrm{~mm}$. (I lin.) and more broad.

On bramble sticks. Rare.

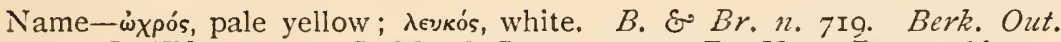
p. 277. C. Hbk. n. 948. S. Mycol. Scot. n. 91 . Fr. Hym. Eur. p. 662.

4. C. stuppea B. \& Br.-Erumpent, sessile, pezizæform, externally coarsely hispid, brownish then becoming white. Hymenium fuscous.

On broom. Menmuir, Forfarshire. March.

Name-stuppeus, made of tow. From being coarsely hispid. B. E Br. $n$. I698. S. Mycol. Scot. n. giz.

5. C. fulva B. \& Rav.-Brown-tawny, membranaceous, cupshaped, deflexed, externally tomentose.

On dead bark.

Remarkable for its deflexed mouth. Spores ovate, I7 mk. $B$. \& $B r$. Name-fulvus, tawny. B. \& Br.n. 936. C. Hbk. n. 954. Fr. Hym. Eur. p. 662 .

6. C. brunnea Phill.-Dirty-brown, sessile, cupulate, clothed near the margin with a grey pruina, margin incurved, lacerated, mouth oblique. Hymenium smooth, discoloured-brown; flesh paler, subgelatinous.

Scattered or crowded. Cups. $.5 \mathrm{~mm}$. across, $.8 \mathrm{~mm}$. high. Basidia clavate, two to four spicules; spores colourless, globose (5-6 mk.)

On bark and wood of old elder-trees. Shrewsbury. 
Cyphella. Name-brunneus, brown. Phill. Grevillea, vol. xiii. p. 49.

7. C. fraxinicola B. \& Br.-Minute, orbicular, externally snow-white, shortly villous; disc light yellow, becoming fuscous with the spores, proliferous.

On ash. Batheaston, I873. Dec.

Name-fraxinus, ash-tree; colo, to inhabit. B. \&o Br. n. 1446.

** Muscicola (growing on mosses).

8. C. muscigena Fr.-Very small, 6-1o mm. (3-5 lin.) broad, shining white, membranaceous-soft, becoming plane, somewhat dimidiate, externally silky under a lens. Hymenium slightly wrinkled.

A variable form, also stipitate, spathulate, \&c.

On moss. Uncommon. Sept.-Dec.

At first flabelliform. M.F.B. Name-muscus, moss; gigno, to bear. Growing on moss. Fr. Hym. Eur. p. 663. Berk. Out. p. 277. C. Hbk. n. 946. S. Mycol. Scot. n. 9i4. Theleph. Pers. Myc. Eur. t. 7.f. 6. Canth. lævis Fr. Syst. Myc. i. p. 324 .

9. C. galeata Fr.-Whitish, membranaceous-soft, somewhat sessile, obversely cup-shaped, then dimidiate, helmet-shaped, even, margin quite entire. Hymenium at length rufescent, slightly wrinkled.

When young entire, cup-shaped, grey when moist, snow-white when dry, then rufescent.

On mosses. Uncommon.

Name-galea, a helmet. Helmet-shaped. Fr. Hym. Eur. p. 663. Berk. Out. p. 277. C. Hbk.n.947.-Fl. Dan. t. 2027.f. I.

10. C. catilla Smith.--Somewhat membranaceous, expanded, margin crisped and undulated. Hymenium veined, $18 \mathrm{~mm} .(3 / 4$ in.) broad, grey.

Often imbricated. Allied to C. galeata.

On moss and dead leaves. King's Lynn.

Name-catillus, a small bowl. From its shape. Smith Seem. Fourn. Bot. $1873, p .337$.

11. C. muscicola Fr.-About $4 \mathrm{~mm}$. (2 lin.) broad, pale-whitish, membranaceous, somewhat sessile, persistently cup-shaped, nodding, externally slightly fibrilloso-striate, margin slightly downy, repand, torn. Hymenium even.

B. cup irregular, externally cinereous. 
On mosses. Rare.

Name-muscus, moss; colo, to inhabit. Fr. Hym. Eur.p. 663. Syst. Myc. ii. p. 202. Berk. Out. p. 277. C. Hbk. n. 949.-B. Fl. Dan. t. 2083. f. 2.

\section{*** Stipiticola (growing on stems).}

12. C. lacera Fr.-When perfect 4-6 mm. (2-3 lin.) in stature, whitish or yellow, membranaceous, cup-shaped, stipitate from the vertex being extended, pendulous, then torn into many clefts, slightly striate above with dense black fibrils. Hymenium slightly wrinkled, whitish.

On dead twigs. Rare.

Name-lacerus, torn. Fr. Hym. Eur. p. 664. Syst. Myc. ii. p. 202. Berk. Out. p. 277. C. Hbk. n. 950.-Alb. \& Schw. t. I. f. 5.

13. C. capula Fr.-Whitish, membranaceous, obliquely campanulate, extended into an oblique stem, smooth, margin sinuate, irregularly shaped. Hymenium even.

It varies yellowish.

On dead stems of herbaceous plants. Frequent.

Looks like Peziza. 11.F.B. Spores ovoid, $7 \mathrm{mk}$. Q. Name-capula, small bowls with handles. Fr. Hym. Eur. p. 664. Berk. Out.p. 278. C. Hbk. n. 951. S. Mycol. Scot. n. 915. Holmsk. ii. t. 22. Peziza Nov. Act. Hafn. i. p. 286. f. 7.-Fl. Dan. t. 1970. f. 3 seems a var.

14. C. Pimii Phill.-White or very pale yellow, cup-shaped, erect or pendent, membranaceous, pubescent, margin of cup somewhat incised. Stem rather slender, crooked, enlarged upwards.

Fasciculate. About $4 \mathrm{~mm}$. (2 lin.) high and cup $2 \mathrm{~mm}$. (r lin.) wide. Basidia cylindraceo-clavate, with sometimes only two spicules, generally four ; spores subpyriform, colourless (7-10 $\times 4 \mathrm{mk}$.)

On dead herbaceous stems in water. Dublin.

Name-after Greenwood Pim. Phill. Grevillea, vol. xiii. p. 49.

**** Caulicola and epiphylla (growing on stalks and on leaves).

15. C. pallida B. \& Br.-Cups at first orbicular, at length irregularly lobed, plane, tomentose or slightly hispid, sessile. Hymenium at length wrinkled, pallid ochraceous.

Cups $1 / 4-I$ line across, sometimes proliferous. Differs from C. Curreyi in the colour of the hymenium, which is rugose, like that of Cantharellus muscigenus, and its more irregular form. It appears also not to be erumpent, as that species often is, but is seated on the bark or wood. 
Cyphella. On old stems of Clematis vitalba.

Spores elliptic, 6-9 mk. B. \& Br. Name-pallidus, pallid. B. \& Br. $n$. I372. Rabenh. exs. n. I415. Fr. Hym. Eur. p. 664.

16. C. cuticulosa Berk.-White, diaphanous, membranaceous, at first oblong, then cup-shaped, elongated into a stem, smooth externally.

On dead grass stems. Very rare. Oct.-Feb.

Not recorded since found by Dickson. Name-cuticula, the thin external skin. From its membranaceous character. Berk. Out. p. 278. C. Hbk. n. 955. Fr. Hym. Eur. p. 665.-Dicks. Crypt. iii. t. 9. f. Ir.

17. C. Goldbachii Weinm.-White, membranaceous, cupshaped, sessile, pitcher-shaped-concave, lobed, externally villous. Hymenium even, pallid.

Minute, irregular and lobed, in which it differs from the Solenice.

On dead leaves of Aira caspitosa. Spye Park, Wilts.

Near to C. cuticulosa, from which it differs in its villous coat. $B$. \& $B r$. Name-after Goldbach. Weinm. Ross. p. 522. Fr. Hym. Eur. p. 665. Berk. Out. p. 278. C. Hbk. n. 952.-Corda Sturm t. 63.

18. C. dochmiospora B. \& Br.-Snow-white, minute, pezizæform.

Resembles externally Peziza villosa; but the hairs are not granulated.

Habitat not recorded. Batheaston, I864. Oct.

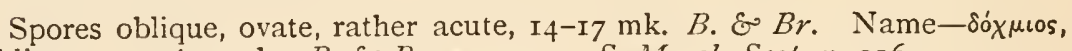
oblique; бropá, seed. B. \& Br. n. I373. S. Mycol. Scot. n. 9 I6. 


\section{ORDER V.-CLAVARIEI.}

Hymenium not distinct from the hymenophore, amphigenous. Somewhat fleshy fungi, vertical, simple or branched. Never coriaceous or incrusting as the Merismoid Thelephora which are similar in form. Fr. Hym. Eur.p. 666.

Genus L.-Sparassis ( $\sigma \pi \alpha \rho \alpha ́ \sigma \sigma \omega$, to tear in pieces). Fr. Syst. Myc. p. 464.

Fleshy, branched, with flat, leaf-like branches, composed of two plates, fertile on both sides, with 4 -spored sporophores. Very handsome. Fr. Hym. Eur. p. 666.

1. S. crispa Fr.-Whitish, very much branched; branches $2.5-5$ cent. ( $\mathrm{I}-2$ in.) broad, intricate, recurved at the apex, zoneless, serrated.

Very handsome, very large (tufts have occurred as much as I-2 ft. broad), most frequently wholly sessile, more rarely shortly stipitate.

Beside fir trees and stumps. Rare. Aug.-Oct.

Most frequently it has a tinge of pale yellow. Like a large sponge. Edible and delicious; but too rare to be of value as an article of food. Name-crispar, a curl. Crisped. Fr. Hym. Eur. p. 666. Syst. Myc. i. p. 465. Sv. ätl. Sv. t. I7. B. \& Br.n. I $139^{*}$. C. Hbk. n. 958. S. Mycol. Scot. n. 917. Kl. Bor. t. 463. Hogg \& Fohnst. t. 24. Bail. t. 27.-Wulf. in Facqu. Misc. t. I4. f. I. Krombh. t. 22. f. 2, 3. Schaff. t. 163 .

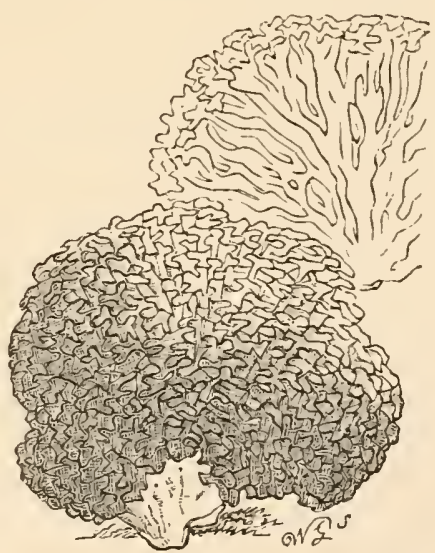

$X C$. Sparassis crispa. Onefifth natural size. 
Clavaria.

Genus Li.-Clavaria (clava, a club). Linn.-Fr. Syst. Myc. i. p. 465.

Fleshy, branched or simple, somewhat round, without a distinct stem. Hymenium continuous, dry,

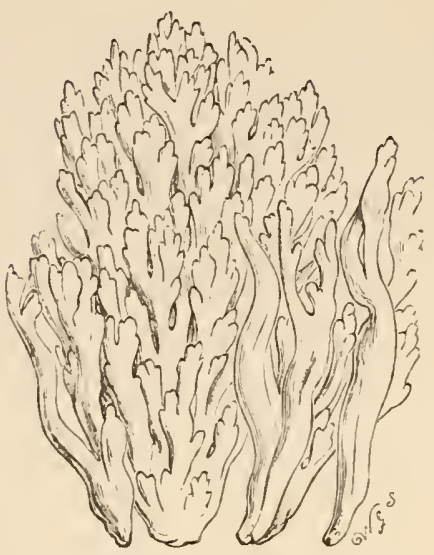

XCI. Clavaria cinerea. Onethird natural size. homogeneous. For the most part growing on the ground. Fr. Hym. Eur.p. 666.

I. RAMARIA (ramus, a branch). Holmsk. Branched, branches attenuated upwards.

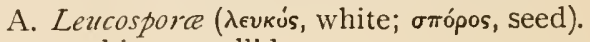
Spores white or pallid.

* Colour bright, yellow, red orviolet. On the ground.

** Colour white or grey. On the ground. *** Colour whitish or dingy. On wood.

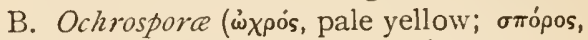
seed). Spores ochraceous or cinnamon.There are analogous species in each section which are so similar in form and colour that their figures are with difficulty distinguished. Yet they are most distinct; the Ochrosporæ spongy, tough, the majority of them bitter, and not fit to be eaten.

* Colour yellow, somewhat cinnamon, saffron. On the ground.

** Colour whitish, grey, violet. On the ground.

*** Growing on trunks.

II. SyNCORYNe ( $\sigma$ viv, together; корй́n, a club). Somewhat simple, cæspitose at the base or fasciculate.

* Reddish.

** Yellowish or white.

** Fuliginous or blackish.

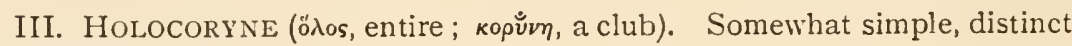
at the base.

* Colour changeable, becoming dark.

* Colour unihangeable, commonly shining white.

I.-RAmaria. Branched, branches attenuated upwards.

A. Leucosporce. Spores white or pallid.

* Colour bright, yellow, red or violet.

1. C. botrytes Pers.-Varying white, yellow, flesh-colour, 7.5 cent. ( 3 in.) and more high, but also less, fragile; trunk very thick, 2.5-5 cent. ( $1-2$ in.), unequal, very much branched. Branches swollen, unequal, somewhat wrinkled, red at the apices. 
About beech stumps. Inverary, \&c. Rare. Aug.-Oct.

Clavaria.

Spores ellipsoid, subhyaline, $12-15 \times 6$ mk. $K$. Edible. Name-ßótpvs, a cluster of grapes. From the form. Pers. Syn. p. 587. Fr. Hym. Eur. p. 667. Syst. Myc. i. p. 466. Sv. ätl. Sv. t. 35. Berk. Out.p. 278. C. Hbk. n. 959. S. Mycol. Scot. n. 9r8. Fl. Dan. t. 1303. Barla t. 40. f. I-3. Krombh. t. 53. f. I-3. Harz. t. 67. Corda Ic. v. f. 75. Quel. t. 21. f. 4. Schatf. t. 176. Wulf. in Facqu. Coll. ii. t. 13. Holmsk. ii. p. 117 with fig. Krombh. $t$. 53. $f \cdot 4$ (white).

2. C. amethystina Bull.-Violet, fragile, very much branched, equal at the base. Branches round, even, obtuse.

In grassy woods and pastures. Uncommon. Aug.-Oct.

Very variable in size. Sometimes 7.5 cent. ( 3 in.) or more high and very much branched, sometimes a few lines and nearly simple. M.F.B. Edible.

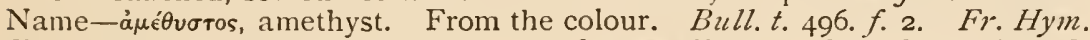
Eur. p. 667. Berk. Out. p. 279. t. 18. f. 2 small var. C. Hbk. n. 960. S. Mycol. Scot. n. 919.-Holmsk. Ot. i. p. I Io with fig., borrowed in Nees Syst. f. I5 I.

3. C. fastigiata Linn.-Scarcely exceeding 2.5 cent. (I in.) long, egg-yellow, slightly tough, cæspitose, very much branched, equal. Branches short, divaricate, branchlets fastigiate.

It varies with the apices light yellow and fuscous.

In pastures. Very common. Aug.-Oct.

Spores pale buff, irregular, $7 \mathrm{mk}$. W.G.S.; subsphæroid, $6 \mathrm{mk} . K$. Name -fastigium, the top. Reaching the top. Linn. Suec. n. 1269. Fr. Hym. Eur. p. 667. Berk. Out. p. 279. C. Hbk. n. 961. S. Mycol. Scot. n. 920. Bull. t. 358. f. D, E. Holmsk. i. p. 90 with fig. Fl. Dan. t. 836. f. 2. C. pratensis Syst. Myc. i. p. 47 I. Pers. Comm. t. 4.f. 5. Ray Syn. t. 8. f. 4.

4. C. muscoides Linn. - Yellow, slightly tough, becoming slender, twice or thrice forked, stem thin. Branchlets crescentshaped, acute.

In pastures. Frequent. Aug.-Oct.

Taller than $C$. fastigiata, solitary, less branched, dry, very smooth, except

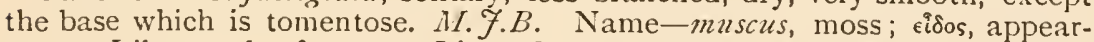
ance. Like a tuft of moss. Linn. Suec. n. I270. Fr. Hym. Eur. p. 667. Berk. Out.p. 279. C. Hbk. n. 962. S. Mycol. Scot. n. 921. Fl. Dan. t. 775. f. 2. Bull. t. 496. f. O, Z. Holmsk. i. p. 89 with fig.-Schreff. t. I73. Krombh. t. 53. f. 22, 23. Vaill. Par.t. 8.f. 4.

5. C. curta Fr.-Greenish-yellow, very small, very much branched, pressed close together. Stem none. Branches short, crowded, obtuse.

Nearest to $C$. fastigiata, but differing in stature and colour, never eggyellow as in that species.

On the ground. Coed Coch. Holme Lacy. 
Clavaria. $\quad$ Spores white. Fr. Name-curtus, curt, short. Fr. Hym. Eur. p. 668. Monogr. ii. p. 281. B. \& Br.n. I 448 .

\section{** Colour white or grey.}

6. C. coralloides Linn. - White, somewhat fragile, hollow within, trunk rather thick, repeatedly and irregularly much branched. Branches unequal, dilated upwards, branchlets crowded, acute.

Commonly cæspitose, growing into each other, unequally fastigiate. It varies with the branchlets not developed, obtuse.

In shady woods. Rare. Aug.-Oct.

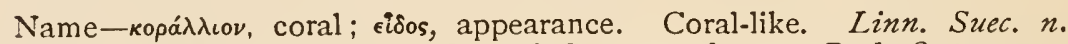
1268. Fr. Hym. Eur. p. 668. Sv. ätl. Sv. t. 92. f. 4, 5. Berk. Out. p. 279. C. Hbk. n. 963. S. Mycol. Scot. n. 922. Holmsk. i. p. II3 with fig. Sow. t. 278 . Krombh. t. $53 \cdot f \cdot 4$.

7. C. cinerea Bull.-Cinereous, fragile, stuffed, trunk somewhat thick, short, very much branched. Branches and branchlets thickened, irregularly shaped, somewhat wrinkled, rather obtuse.

The trunk varies thicker and thinner. It differs from C. grisea in the spores.

In mixed woods. Frequent. Aug.-Oct.

Spores irregular, ellipsoid-sphæroid, 8 -ro $\times 6 \mathrm{mk}$. $K$. Name-cinis, ashes. Ash-coloured. Bull. t. 354. Fr. Hym. Eur. p. 668. Berk. Out. p. 279. C. Hbk. n. 965. S. Mycol. Scot. n. 923. Grev. t. 64, 321. Letell. t. 708. f. 1. -Krombh. t. 53. f, 9, Iо.

8. C. umbrina Berk.-Pale umber, slightly branched. Branches and branchlets cylindrical, obtuse, forked.

The habit is that of $C$. fastigiata. It has not, however, the slightest tinge of yellow.

On lawns. Coed Coch. Blair Athole. Aug.-Oct.

Name-from the umber colour. Berk. Out.p. 279. t. I8. f. 4. C. Hbk. n. 96.4. S. Mycol. Scot. n. 924. Fr. Hym. Eur. p. 668.

9. C. cristata Pers.-White, very variable in stature, $2.5-5$ cent. ( $1-2$ in.) high, tough, even, stuffed. Branches dilated above, acutely incised, crested.

Somewhat cæspitose.

In mixed woods. Frequent. Aug.-Oct.

Spores angulato- or ellipsoid-sphæroid, hyaline, $8 \mathrm{mk}$. $K$. Name-crista, a crest. Crested. Pers. Syn. p. 591. Fr. Hym. Eur. p. 668. Syst. Myc. i. p. 473. Sv. ätl. Sv. t. 92. f. I-3. Berk. Out. p. 280. C. Hbk. n. 966. S. 
Mycol. Scot. n. 925. Fl. Dan. t. 1304. f. 2. Grev. t. 190. Krombh. t. 53. Clavaria. f. 12, 13.-Holmsk. i. p. 92 with fig. Scheff.t. 170. Pers. Comm. t. 2. f. 4 .

10. C. rugosa Bull.-White, tough, simple or sparingly branched, thickened upwards, wrinkled. Branches irregularly shaped, obtuse.

Very variable in form, sometimes wholly simple, club-shaped, sometimes divided into $2-4$ variously unequal branches.

In woods and pastures. Very common. Aug.-Nov.

Spores angulato-sphæroid, 8-10 mk. $K$. Name-ruga, a wrinkle. Bull. t. 448.f. 2. Fr. Hym. Eur. p. 669. Syst. Myc. i. p. 473. Berk. Out. p. 280. t. 18.f. 3. C. Hbk. n. 967. S. Mycol. Scot. n. 926. Fl. Dan. t. 1301. Grev. t. 328.-Schaff. t. 291. Bolt. t. I15. Sow. t. 278 lower fig. Vaill. Par.t. 8.f. 2. Quel. t. 20.f. 5 slender, even, furnished with short irregular branches from the base, perhaps a distinct species.

11. C. Krombholzii Fr.-Shining white, fragile, cæspitose, even, sparingly branched. Branches somezuhat compressed, obtuse.

Like $C$. rugosa, but fragile and even. Varying in stature.

In old pastures. Glamis. Moncreiffe. Sept.

Name-after Krombholz. Fr. Hym. Eur. p. 669. B. \&o Br. n. 1586. S. Mycol. Scot. n. 927. - Krombh. t. 53. f. 15, 16, 18-20. Bull. t. 496. f. 3 .

12. C. Kunzei Fr.-Shining white, tufts $4-5$ cent. ( $1 / 2-2$ in.) high, 2.5 cent. ( $\mathrm{I}$ in.) broad, somewhat fragile, very much branched from the thin, cæspitose base. Branches elongated, crowded, repeatedly forked, fastigiate, even, equal, axils compressed.

In woods. Rare. Sept.

Name-after Kunze. Fr. Hym. Eur.p. 669. Syst. Myc. i. p. 474. Berk. Out. p. 280. C. Hbk. n. 968. S. Mycol. Scot. n. 928.-Bull. t. 358. f. I.

\section{*** Colour whitish or dingy.}

13. C. pyxidata Pers. - Pallid then tan-colour, somewhat rufescent, tufts as much as 10-I2.5 cent. ( $4-5$ in.) high, trunk thin, smooth, branched. Branches and branchlets all hollowed out in cup-shape at the apex, cups radiate in a proliferous manner at the margin.

The most distinct of the genus, white-spored. Branchlets obconic and even, the cups again and again proliferous in a whorled manner, the terminal ones toothed.

On the ground. Penzance.

Name-pyxis, a small box. Pyxidate. Pers. Comm.t. ז.f. r. Fr. Hym. Eur. p. 669. B. \& Br. n. 1976. Fl. Dan. t. 1304.f. I. 
* Colour yellow, somewhat cinnamon, saffron.

14. C. aurea Schæff.-Trunk thick, elastic, pale, divided into stout, tense and straight, very dichotomously branched, round, obtuse, somewhat toothed, yellow branches.

Large, 7.5-10 cent. (3-4 in.) high, elastic, soft, not pure yellow.

In mixed woods. Rare. Aug.-Oct.

Spores ellipsoid, to-I4 $\times 5-6 \mathrm{mk} . K$. Name-aurum, gold. Yellow. Scheff. t. 287 \& 285. Fr. Hym. Eur. p. 670. Berk. Out. p. 280. C. Hbk. n. 969. S. Mycol. Scot. n. 929.-Bull. t. 222. Krombh. t. 53.f.7.

15. C. formosa Pers.-Trunk thick, 2.5 cent. ( $\mathrm{I}$ in.) and more, whitish, elastic. Branches very much branched, elongated, orange-rose-colour, branchlets obtuse, light yellowish.

Variable.

In woods. Rare.

Spores elongated oval, covered with papillæ, $\mathrm{x} 6 \times 8 \mathrm{mk}$. W.G.S. Nameformosus, finely formed, beautiful. Pers. Ic. Eo descr. t. 3. f. 5. Fr. Hym. Eur. p. 671. Syst. Myc. i. p. 466. B. \& Br. n. то3т. C. Hbk. n. 970. Krombh. t. 54. f. 21, 22. Holmsk. i. n. 13 with fig. Corda Ic. iii. f. 136.-Harz. t. 7 lower fig. Batsch f. 48.

16. C. spinulosa Pers.-Trunk short, rather thick 2.5 cent., I in.), pallid. Branches elongated, crowded, tense and straight, attenuated, somewhat cinnamon (fuliginous-date-brown: Pers.), of the same colour at the apex.

More distinct than C. aurea and formosa.

In pine woods. Coed Coch.

Name-spinulosus, spined. From the appearance of the branches. Pers. Obs. 2. t. 3. f. x. Fr. Hym. Eur. p. 671. Syst. Myc. i. p. 468. B. \& Br. n. I302. - Krombh. t. 53. f. 8.

17. C. abietina Pers.-Height 5-7.5 cent. (2-3 in.) Ochraceous, trunk short, rather thick ( $8 \mathrm{~mm} ., 4$ lin.), white-tomentose, very much branched. Branches crowded, longitudinally wrinkled when dry, branchlets tense and straight, acute.

Becoming green when rubbed. Taste bitter.

Under spruce fir. Common. Aug.-Oct.

Spores oval, greenish-yellow, $5 \times 4$ mk. W.G.S.; subellipsoid, 8-1o $\times 4-6$ mk. K. Name-abies, fir. Pers. Comm.p. 46 (var.) Fr. Hym. Eur. p. 67I. Syst. Myc. i. p. 469. Berk. Out. p. 280. C. Hbk. n. 97I. S. Mycol. Scot. n. 930. Grev. t. II7. Fl. Dan. t. 2030. f. 2. 
18. C. flaccida Fr.-Ochraceous, $2.5-4$ cent. ( $1-1 \frac{1}{2}$ in.) long, Clavaria. thin, very much branched, flaccid. Stem thin, $2 \mathrm{~mm}$. (I lin.) thick, very short, smooth. Branches crowded, even, unequal, converging, acute.

Allied to $C$. abietina, but much thinner. It is smooth in itself, but the mycelium is floccose, creeping over leaves.

Among moss in wood. Rare.

Spores ellipsoid-sphæroid, $4-5 \times 3 \mathrm{mk} . K$. Name-faccidus, flaccid. Fr. Hym. Eur.p.671. Berk. Out. p. 280. C. Hbk.n. 972.

19. C. crocea Pers.-Suffron-yellow, minute, thin, stem naked, pallid. Branches and branchlets similar, somewhat forked.

According to the fig. it is wholly distinct. Spores unknown.

On waste ground. Wraxall, Somerset. Glamis. Sept.

Name-crocus, saffron. Saffron-yellow. Pers. Ic. \&o descr. $t$. II. $f .6$. Berk. Out. p. 280. C. Hbk. n. 973. S. Mycol. Scot. n. 93I.

\section{* Colour whitish, grey, violet.}

20. C. grisea Pers.-Firm. Trunk 4 cent. ( $1 / 2$ in.) long, 2.5 cent. (I in.) thick, whitish. Branches 7.5 cent. (3 in.) long, attenuated, somewhat wrinkled, and as well as the unequal, obtuse branchlets, fuliginous-cinereous.

In its exceedingly variable form it is with difficulty distinguished from $C$. cinerea, but is clearly distinct from its rufous-brown spores.

In woods. Rare. Sept.

Name-griscus, grey. Pers. Comm. p. 44. Fr. Hym. Eur. p. 672. Syst. Myc. i. p. 468. Berk. Out. p. 28I. C. Hbk. n. 974. S. Mycol. Scot.n. 932.

21. C. condensata Fr.-Tan-rufescent, tufts very dense, 7.5-10 cent. (3-4 in.) high, and without a common trunk, very much branched from the base, smooth, unchangeable when bruised. Branches tense and straight, crozuded in a parallel manner, even, fastigiate at the apex, twice or thrice toothed, yellow.

Mycelium white, membranaceous, creeping among leaves.

On the ground under trees. West Farleigh, I874.

Spores ellipsoid, $9 \mathrm{mk}$. $K$. Name-condenso, to press close together. From the manner in which the branches are close together. Fr. Hym. Eur. p. 672. B. \& Br.n. I $^{8} 7$. -Schaff. $t$. I 77 (departing in its reddish colour).

*** Growing on trunks.

22. C. stricta Pers.-Yellowish-pallid, becoming fuscous when 
Clavaria. bruised, trunk about $6 \mathrm{~mm}$. (3 lin.) long and thick, very much branched. Branches and branchlets tense and straight, even, crowded and adpressed, acute.

Mycelium most frequently fibrillose, naked.

In woods. Uncommon. Aug.-Oct.

Spores dark cinnamon. Fr.; creamy-yellow, $4 \times 6 \mathrm{mk}$. W.G.S. Namestringo, to draw tight. Tense and straight. Pers. Comm. p. 45. t. 4. f. I. Fr. Hym. Eur. p. 673. Berk. Out. p. 281. t. 18. f. 5. C. Hbk. n. 975. S. Mycol. Scot. n. 933. Fl. Dan. t. I302.f. I. Krombh. t. 54. f. 23.

23. C. crispula Fr.-Entire height $2.5-7.5$ cent. (I-3 in.) Tan then ochraceous, very much branched, trunk thin, with villous rootlets. Branches flexuous, multifid, branchlets of the same colour, divaricate.

Protean but quite distinct.

At the base of trees, ash. Rare.

Spores creamy-yellow, $3 \times 5$ mk. W.G.S. Name-crispulus, slightly curled. Fr. Hym. Eur. p. 673. Syst. Myc. i. p. 470. Berk. Out. p. 28r. C. Hbk.n. 976.-Bull. t. 358. f. r. a, b. Ehrenb. Nov. Act. Nat. Cur. x.t. I4.

II.-Syncoryne. Somewhat simple, cæspitose at the base, \&c. * Reddish.

24. C. purpurea Fr. - Purple, cæspitose. Clubs elongated, generally 7.5 cent. ( 3 in.) long, hollow then compressed, simple, acute.

Very remarkable. When solitary it is more drawn out and decumbent. Fragile.

In grassy places. Rare. Aug.-Oct.

Name-from the colour. Fr. Hym. Eur. p. 674. Syst. Myc. i. p. 480. Berk. Out. p. 281. C. Hbk. n. 977. S. Mycol. Scot. n. 934. Fl. Dan.t. 837.f. 2 .

25. C. rufa Fl. Dan.-Rufous, 4 cent. ( $1 \frac{1}{2}$ in.) long, $4 \mathrm{~mm}$. (2 lin.) thick. Clubs stuffed, thickened, somewhat bifid, acute.

Cæspitose.

On the ground. Rannoch. The Burn, Forfarshire.

Name-rufus, reddish. Fl. Dan. t. 775. f. I. Fr. Hym. Eur. p. 674. Syst. Myc. i. p. 480. S. Mycol. Scot. n. 935.

26. C. rosea Fr.-Rose-colour, 4 cent. ( $1 \frac{1}{2}$ in.) long, somewhat fasciculate, fragile. Clubs stuffed, at length becoming yellow at the apex, attenuated downwards, whitish. 
Elegant. No distinct stem, but the club is narrowed at the base.

In pastures and among moss. Rare.

Name-from the colour. Fr. Hym. Eur. p. 674. Syst. Myc. i. p. 482. Berk. Out. p. 28r. C. Hbk. n. 978. S. Mycol. Scot. n. 936.-Sv. Bot. t. $55^{8}$. B. attenuata Fr. Obs. 2. t. 5. f. 2. Krombh. t. 53. f. 2 I.

\section{* Yellowish or white.}

27. C. fusiformis Sow. - Yellow, cæspitoso-connate, slightly firm, soon hollow. Clubs somewhat fusiform, simple and toothed, even, attenuated to the base which is of the same colour.

Taller than $C$. inequalis, more connate, at length becoming fuscous at the apex. Both vary unequal, not very different.

In woods, pastures, \&c. Common.

Name-fusus, a spindle; forma, form. Spindle-shaped. Sow.t. 234. Fr. Hym. Eur. p. 674. Berk. Out. p. 281. C. Hbk. n. 979. S. Mycol. Scot. n. 937. Bolt. $t$. I 10. Var. with the irregularly shaped clubs toothed: Sow. $t$. 235. .

28. C. ceranoides Pers.-Height 7.5 cent. ( 3 in.) Yellow, fasciculate, unequal, slightly divided above, apex brown.

Very cæspitose. Clubs attenuated downwards, curved, somewhat ventricose.

In woods. Rare. Nov.

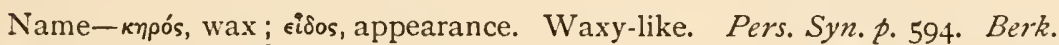
Out. p. 282. C. Hbk. n. 980. Fr. Syst. Myc. i. p. 481. Hym. Eur. p. 674 under $\mathrm{C}$. fusiformis.

29. C. inæqualis Fl. Dan.-Yellow, gregarious, somewhat fasciculate, fragile, stuffed. Clubs variable, simple or forked, continuous downwards, of the same colour.

Very changeable in form, clavate and cylindrical. Distinguished from $C$. fusiformis chiefly by its irregularity. Tufts less dense.

In woods and pastures. Very common. Aug.-Oct.

2.5-7.5 cent. ( $1-3$ in.) high. Compressed, angular or channelled, often bifid and variously cut and jagged at the apex, nore or less ventricose in the centre. Grev. Spores white, I I $\times 5 \mathrm{mk}$. W.G.S. Name-incuqualis, unequal. Fl. Dan. t. 873.f. r. Fr. Hym. Eur. p. 674. Syst. Myc. i. p. 48ז. Berk. Out. p. 282. C. Hbk. n. 981. S. Mycol. Scot. n. 938. Fl. Bat. t. 814. f. 1. Hussey i. t. 18.-Bull. t. 264. Sow. t. 253 partly. Pers. Comm. t. I. f. 3. Grev. t. 37. Fl. Dan. t. I783.f. 2. Sv. Bot. t. 504.f. 4.

Var. aurantiaca Pers. Somewhat wrinkled and compressed. Krombh.t. 53. f. 19, 20. Vaill. t. 7.f.5.

30. C. argillacea Fr.-Height $\mathrm{I}-2.5$ cent. $(1 / 2-\mathrm{I}$ in.) Pallidclay-colour, fasciculate, fragile. Clubs simple, variable. Stem yellow-shining. 
Clavaria. Constantly thickened upwards.

In woods and moss. Frequent. Aug.-Oct.

There is a variety with a white stem. The plant, moreover, is either dilated or cylindrical. The stem in this species is more distinct from the pileus than is consistent with the generic character. M.F.B. Name-argilla, clay. Claycoloured. A. clavata, clubs somewhat compressed. Fr. Hym. Eur. p. 675. Syst. Myc. i. p. 482. Berk. Out. p. 282. C. Hbk. n. 982. S. Mycol. Scot. n. 939. Fr. Obs. t. 5. f. 3. Schmied. Ic. t. 15. Fl. Dan.t. 1852. f. 2. Fl. Bat. t. 814. f. 2. Harz. t. 7. f. т-7. B. Clubs cylindrical, attenuated. Pers. Comm. t. r. f. 4. Fl. Dan. t. Ig66. f. 2.

31. C. vermicularis Scop.-Shining white, cæspitose, fragile.

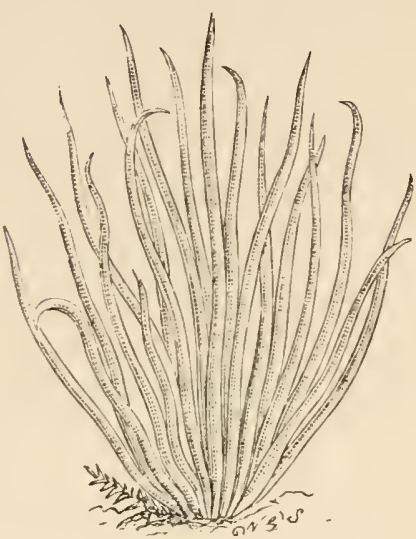

XCII. Clavaria vermicularis. One-half natural size. Clubs stuffed, simple, cylindrical, awlshaped.

Often flexuous or incurved. Of the thickness of a pigeon's quill.

On lawns. Very common. Sept.

Looks like a little bundle of candles. M.F.B. Name-vermis, a worm. Flexuous. Scop.-Fr. Hym. Eur. p. 675. Syst. Myc. i. p. 484. Berk. Out. p. 282. C. Hbk. n. 984. S. Mycol. Scot. n. 940. Swartz in Vet. Ak. Handl. г81 . t. 6. f. 2. Fl. Dan. t. 1966. f. r, 775.f. 2. Mich. t. 87.f. 2 .

32. C. fragilis Holmsk - Commonly white, sometimes yellowish, fasciculate, very fragile, attenuated and white downwards. Clubs hollow, rather obtuse, variable.

Distinguished by its white base, \&c., from the three preceding species. 2.57.5 cent. ( $\mathrm{I}-3$ in.) long, occasionally forked, when young stuffed, round, tense and straight, then hollow, compressed, twisted, often wrinkled.

In pastures, \&c. Common. Aug.-Oct.

Name-fragilis, fragile. Holmsk. i. p. 7 with fig. Fr. Hym. Eur. p. 675. Syst. Myc. i. p. 484. Berk. Out. p. 283. C. Hbk.n. 985. S. Mycol. Scot.n. 941. A. club swollen, thickened. Bull. t. 463. f. I. Sow. t. 9o. Mich. $t$. 87.f. ro. Vaill. t. 7.f. 5. B. more slender, cylindrical, somewhat attenuated. Sow. t. 232. Fl. Dan. t. 775.f. 2. Barla t. 41.f. I4-16. Mich. t. 87. f. I3. C. Cl. gracilis Pers. thin, gregarious, acute. Bolt. t. III. f. I. Mich. t. 87.f. 6, perhaps a distinct species.

*** Fuliginous or blackish.

33. C. fumosa Pers. - Fuliginous, fasciculate, fistulose, fragile. Clubs even, tense and straight, somewhat compressed.

It differs from C. fragilis only in the colour.

In pastures, \&c., uncommon. Aug.-Sept. 
Name-fumus, smoke. Smoke-coloured. Pers. Comm. p. 76. Fr. Hym. Clavaria. Eur. p. 676. B. \& Br. n. I303. C. Hbk. n. 986. S. Mycol. Scot. n. 942. Krombh. t. 53.f. 18.

III.-Holocoryne. Somewhat simple, separate at the base.

* Colour changeaóle, becoming dark.

34. C. pistillaris Linn.-Light yellow then rufescent, simple, large, fleshy, stuffed, obovato-clavate, obtuse.

In woods among fern. Uncommon. Sept.

15-30 cent. (6-12 in.) long. Dingy brown in decay. M.F.B. Spores white, ro $\times 5$ mk. W.G.S.; ellipsoid, hyaline, Io-I $\times 5^{-6} \mathrm{mk} . K$. Namepistillum, a pestle. Pestle-shaped. Linn. Suec. n. 1246. Fr. Hym. Eur. p. 676. Berk. Out. p. 283. C. Hbk. n. 987. S. Mycol. Scot. n. 943. Bull. t. 244. Sow. t. 277. Hussey i. t. 62. Fl. Dan. t. 1255. Holmsk. p. 12 with fig. Sv. Bot. t. 504. f. I. Krombh. t. 54. f. I-I I. Ventur. t. 4 I. f. I-2. Corda Sturm. ii. t. $5^{8}$ and Icon. v.f. 76. Quel. t. 21. f. 2. Forms departing from the type: Schaff. t. 290. Kl. Bor. t. 395, slender, attenuated upwards. -Pers. Myc. Eur. t. I5. f. I veined at the apex; perhaps distinct.-Chev. Par. t. 8.f. 2. Var. alba Batt. t. 3. A.

35. C. ligula Fr.-Yellowish when young, pallid-rufescent when full grown, simple, gregarious, spongy-fleshy, elongato-clavate, obtuse, villous at the base.

Smaller and softer than $C$. pistillaris.

In woods. Strachan, Kincardineshire.

Name-ligula, a small tongue, strap. From its shape. Fr. Hym. Eur.p. 676. B. E0 Br.n. 1820. S. Mycol. Scot. n. 944. A. young, Schmied. Ic. $t$. 5 upper fig. Fl. Dan. t. 837. - Wulf. in Facqu. Misc. ii. t. 2. f. 2. Sv. Bot. t. 504. f. 3. B. old,-Schaff. t. I7 I. Krombh. t. 54.f. 12.

36. C. contorta Holmsk.-Watery yellowish, 2.5 cent. (I in.) long, about 6-8 mm. (3-4 lin.) thick, simple, erumpent, stuffed, spongy-fleshy, soft to the touch, somewhat twisted, wrinkled obtuse, pruinose.

Among the most distinguished, growing in winter. Almost spongy after rain. Sometimes spathulate, compressed, sometimes swollen and somewhat twisted. More or less irregularly curved. Solitary or cæspitose.

On fallen branches. Rare. Sept.

Easily known by its erumpent habit. Name-contorqueo, to twist. Twisted. Holmsk. Ot. i. p. 29 with fig. Fr. Hym. Eur. p. 677. Syst. Myc. i. p. 478. Berk. Out. p. 283. C. Hbk. n. 988. S. llycol. Scot. n. 945.-Fl. Dan.t. 1852 .

37. C. fistulosa Fr.-Light yellowish then rufescent, simple, slender, very long, tense and straight, fistulose, rather obtuse; root short, villous. 
Clavaria. Too nearly allied to C. juncea. Fr. Hym. Eur. p. 677. Fl. Dan. t. 1256, I 100. $f .3$. Holmsk. i. p. I5 with figure. Krombh. t. 5. f. I9.

* C. Ardenia Sow.-Ferruginous then date brown, simple, very long, more than 20 cent. ( 8 in.), thickened upwards, hollow, obtuse or hollowed out at the apex, tomentose at the base, not rooting.

The apex is acute when young, then obtuse, \&c.

On fallen branches. Rare.

Var. Ardenia only is British. Name-after Lady Arden. Sow. t. 215. Fr. Hym. Eur. p. 677. Syst. Myc. i. p. 478. Berk. Out. p. 283. C. Hbk. n. 989. S. Mycol. Scot. n. 946.

38. C. juncea Fr.-Pallid then rufescent, $5-12.5$ cent. (2-5 in.) long, thin, filiform, flaccid, fistulose, acute, the creeping base fibrillose.

Gregarious. Its affinity with Typhule is very close. The root is never sclerotioid at the base, stem not distinct. Var. vivipara, fibrillose at the sides. Bull. t. 463. f. $H$.

In woods among leaves. Uncommon. Sept.

Name-juncus, a rush. Fr. Hym. Eur. p. 677. Syst. Myc. i. p. 479. Berk. Out. p. 283. C. Hbk. n. 990. S. Mycol. Scot. n. 947.-Fl. Dan. t. 1257. Mich. t. 87.f. 7 .

39. C. tuberosa Sow.-Yellowish, cæspitose, simple, tough, even, linear, tuberous and rooting at the base.

On birch. Very rare. Dunphail, Morayshire. Nov.

Root a thick, strigose, subglobose tuber, giving out two or three simple linear subacute receptacles from the same base. M.F.B. Not recorded since the time of Sowerby till gathered at Dunphail by Dr Keith. Spores ellipsoid, comma-shaped, punctate, Io mk. $Q$. Name-tuber, a tuber. Tuberousrooted. Sow. t. I99. B. \& Br. n. I 448. S. Mycol. Scot. n. 948. Calocera Fr. Hym. Eur. p. 080. Berk. Out.p. 284. C. Hbk. n. 994.

* Colour unchangeable, commonly shining white.

40. C. canaliculata Fr.-Shining white, 7.5 cent. (3 in.) long, solitary, fistulose, slightly tough, very smooth, not rooting, at length compressed, channelled or splitting longitudinally.

Sometimes in pairs.

On the ground. Coed Coch.

Name-canaliculus, a small channel. Marked with channels. Fr. Hym. Eur. p. 678. B. \& Br. n. 1895. Quel. t. 21. f. т. -Bull. t. 496. f. L. M.

41. C. tenuipes B. \& Br.-Pallid clay-colour. Club inflated, wrinkled. Stem slender, flexuous, somewhat distinct from the club. 
Not exceeding 2.5 cent. ( $\mathrm{r}$ in.) in height. Head swollen, obovate, about 12 Clavaria. $\mathrm{mm}$. ( $1 / 2$ in.) high, rarely confluent with the stem.

On bare heathy ground. Sherwood Forest. Nov.

Name-tenuis, thin; pes, a foot. Thin-stemmed. B. \& Br.n. 369. t. 9. f. 2. Out. p. 282. C. Hbk. n. 983. Fr. Hym. Eur. p. 678.

42. C. incarnata Weinm.-Flesh-colour, white-pruinose, internally purple, varying $12 \mathrm{~mm} .-4$ cent. ( $1 / 2-\mathrm{I} / 2 \mathrm{in}$.) long, quite simple, solid, cylindrical.

Gregarious.

On the ground. Terrington, Norfolk.

Name-incarnatus, flesh-coloured. Weinm. p. 5ro. Fr. Hym. Eur. p. 678. Grevillea, vol. viii. $p .98$.

43. C. acuta Sow.-White, $2.5-7.5$ cent. ( $I-3$ in.) high, quite simple, tense and straight. Club small, distinct, sharp-pointed, pruinose. Stem cylindrical, equal.

On soil in garden pots. Rare.

Name-acutus, acute. Sharp-pointed. Sow. t. 333. Berk. Out. p. 283. C. Hbk.n. 991. Fr. Hym. Eur. p. 679. Syst. Mfyc. i. p. 485.

44. C. uncialis Grev.-Pale white, quite simple, stuffed, tough, tense and straight, obtuse, smooth. Stem continuous, attenuated.

Varying in size, but scarcely exceeding 2.5 cent. ( $\mathrm{I}$ in.)

On dead stems of herbaceous plants, \&c. Uncommon. May.

Name-uncia, an inch. Grev. t. 98. Fr. Hym. Eur. p. 679. Elench. p. 232. Berk. Out. p. 284. C. Hbk. n. 992. S. Mycol. Scot. n. 949.

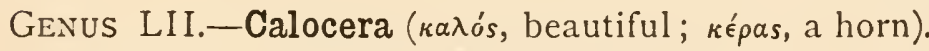

Calocera.

Fr. Syst. Myc. i. p. 485.

Gelatinoso-cartilaginous, horny when dry, vertical, somewhat cylindrical, simple or branched, viscid, without a distinct stem. Hymenium amphigenous; sporophores bifurcate; spores oblong, curved.

Intermediate between the Clavariei and Tremellini. Fr. Hym. Eur. p. 679.

\footnotetext{
* Branched.

** Caspitose.

*** Simple, distinct.
} 
1. C. viscosa Fr.-Golden-egg-yellow, 2.5 cent. (I in.) and more high, branched, tough, rooted, even, linear. Branches round or com-

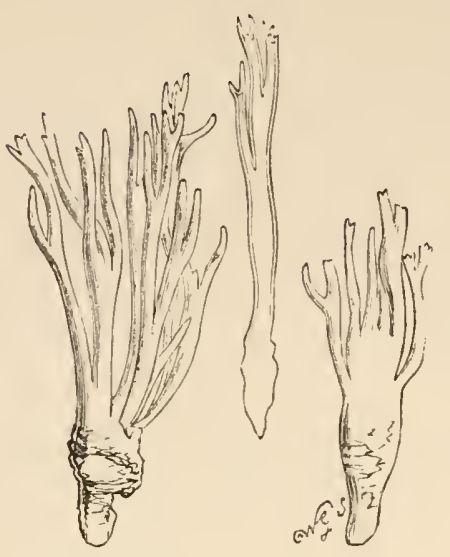

XCIII. Calocera riscosa. Onehalf natural size. pressed, tense and straight, repeatedly dichotomous.

The long root paler.

On stumps, chiefly pine. Very common. July-Dec.

Spores white. Fr.; hyaline, ellipsoid oblong, mostly slightly curved, 8 -Io $\times 4 \mathrm{mk}$. $K$. Name-viscus, bird-lime. Viscous. Fr. Hym. Eur. p. 68o. Syst. Myc. i. p. 486. Berk. Out. p. 284. C. Hbk. n. 993. S. Mycol. Scot. n. 950. Bonord. f. 257.Pers. Comm. t. I. f. 5. Schaff. t. I74. Quel. t. 2I.f. 5.

2. C. palmata Fr.-Orange-yellow, branched, tremelloso-tough, compressed, dilated upwards, divided.

Branchlets somewhat round, divaricate, obtuse.

Nearest to $C$. cornea.

On wood. Twycross.

Name-palma, the palm. From the branchlets resembling a palmate leaf. Fr. Hym. Eur. p. 680. Grevillea, vol. v. p. II.

\section{** Caspitose.}

3. C. cornea Fr.-Yellow-orange, 4-10 mm. (2-5 lin.) and more high, cæspitose, rooted, even, viscous. Clubs small, curt, awlshaped, connate at the base.

On dead wood, oak and beech. Frequent.

Name-cornu, a horn. Horny. Fr. Hym. Eur.p. 680. Syst. Myc. i. p. 486. Berk. Out. p. 284. C. Hbk. n. 995. S. Mycol. Scot. n. 951.-Batsch f. 161. Fl. Dan. t. 1305. f. 2. Sow. t. 40. Bull. t. $463 . f .4$.

4. C. corticalis Fr.-Pallid-flesh-colour, cæspitose, erumpent, soft, pellucid. Clubs small, awl-shaped, somewhat distinct.

Elegant, delicate, smaller than the rest, scarcely $2 \mathrm{~mm}$. (I lin.) long.

On dead bark. Penzance.

Name-cortex, bark. Growing on bark. Fr. Hym. Eur. p. 68o. Elench. p. 233. B. \& Br. n. 1977.-Batsch f. I62? 
5. C. stricta Fr.-Yeilow, simple, solitary, elongated, blunt at the base, linear, even when dry.

A. truncorum, I2 mm. -2.5 cent. (1/2-I in.) long, the base girt with white delicate down. B. epiphylla, 5-7.5 cent. $(2-3$ in.) high, the base naked and bluntly rooted.

On ash. Belvoir Castle. Oct.

Name-stringo, to draw tight. Tense and straight. Fr. Hym. Eur. p. 68o. A. B. \& Br. n. 1032. C. Hbk. n. 996.-Bonord. f. 255.

6. C. striata Fr.-Yellow, simple, solitary, tough, lanceolate, acute, striate when dry.

Commonly taken for a form of $C$. cornea, but distinct.

On prostrate trunks. Batheaston.

Spores $8 \times 6 \mathrm{mk}$. B. \& Br. Name-stria, a furrow. Striate. Fr. Hym. Eur. p. 681. B. \& Br. n. Ir40. C. Hbk. n. 997.-Hoffm. Germ. t. 7. f. r.

7. C. glossoides Fr.-Light-yellow, I $2 \mathrm{~mm}$. ( $\mathrm{t} / 2 \mathrm{in}$.) long, simple, solitary, somewhat tremellose. Club small, thickened, obtuse, compressed. Stem round.

On decayed oak and stumps. Leighwood, Bristol.

Composed of erect forked flocci. Spores oblong, oblique, somewhat incurved, attached by a short pedicel. $B$. $\mathcal{\sigma} B r$. Name- $-\gamma \lambda \hat{\omega} \sigma \sigma \alpha$, the tongue;

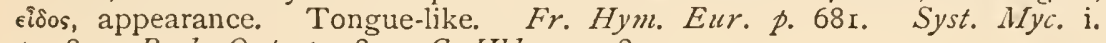
p. 487. Berk. Out. p. 284. C. Hbk. n. 998.

Genus LIII.-Pterula. Fr. in Linn. I830. p. 53 I.

Cartilaginous, filiform, arid, equal, without a distinct stem. Hymenium pubescent then becoming smooth, with 4-spored sporophores (Léveill.) Fr. Hym. Eur.p. 681.

Some species are simple, others much branched.

1. P. subulata Fr.-Height 4 cent. ( $1 / 2$ in.), very densely crowded, tense and straight, equal except at the attenuated base, sparingly branched. Branches growing into each other, whitishcinereous, multifid at the apex, awl-shaped, smooth, becoming yellow.

Tough. Not thicker than a fine thread.

On wood. Burnham Beeches, I874.

Name-subulu, an awl. Awl-shaped. Fr. Hym. Eur.p. 682. Syst. Myc. iii. p. 286. Linn. 1830. t. II. f. 4. B. \& Br. n. 1588 . 
Pterula. 2. P. multifida Fr. - Height $2.5-5$ cent. ( $1-2$ in.), at the first pallid whitish then (especially when dried), dirty pale yellowish, very much branched, very delicate, flaccid but slightly tough. Branches tense and straight, not much thicker than a hair, heaped as if swept together, somewhat fastigiate, spear-shaped at the apex, of the same colour.

On dead branches. Sept.

Name-multus, many; findo, to cleave. From the multitude of branches into which it is cleft. Fr. Hym. Eur. p. 682. Monogr. ii. p. 282. B. \& Br.n. I304.

Typhula. Genus LIV.-Typhula (Typha, the Reed-mace, which it somewhat resembles in miniature. Berk.) Pers.-Fr. Epicr. p. 584.

Minute tender fungi with a filiform stem, which is either heterogeneous and distinct from the linear club, or springs from a sclerotioid hybernaculum. Hymenium waxy, sporophores forked, spicules elongated. Growing on plants. Fr. Hym. Eur. p. 682.

I. Phacorrhize (фakós, a lentil; $\dot{\rho}(\xi \xi a$, a root, from the sclerotioid root). Springing from sclerotioid hybernacula.

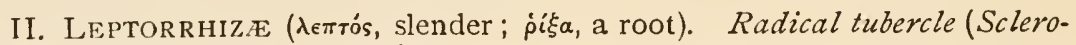
tium) not discovered or azvanting.

I.-PhacorrhizÆ. Springing from sclerotioid hybernacula.

1. T. erythropus Fr.-Simple, club

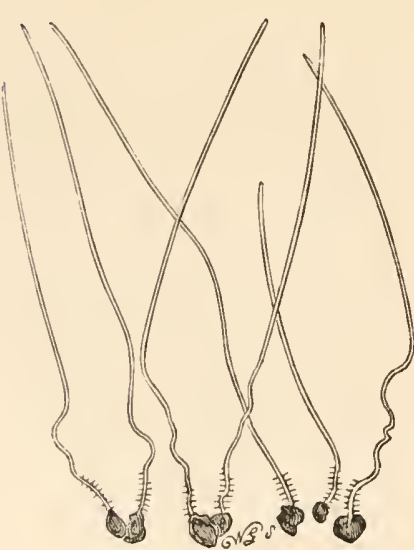

XCIV. Typhula phacorrhiza.

One-half natural size. 4-6 mm. (2-3 lin.) long, white, linear, cylindrical, smooth; stem elongated, I $2 \mathrm{~mm}$. ( $1 / 2 \mathrm{in}$.), filiform, reddishblack, hybernaculum depressed, blackish.

The hybernaculum (sometimes awanting) is Sclerotium scutellatum.

On dead stems of herbaceous plants. Common. Autumn.

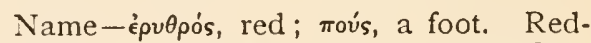
stemmed. Fr. Hym. Eur. p. 683. Syst. Myc. i. p. 495. Berk. Out.p. 284. C. Hbk. n. 999. S. Mycol. Scot. n. 952. Fl. Dan. t. 2030.-Bolt. t. II2. Grev. t. 43 .

2. T. phacorrhiza Fr.-Pallid, be- 
coming somewhat fuscous below, simple, elongated, filiform, Typhula. smooth; hybernaculum compressed, pallid then fuscous.

The hybernaculum is Sclerotium scutellatum. By most recent authors it has been joined with Clavaria juncea, but the best authorities keep them distinct. Cl. juncea Leveill. in Ann. Sc. Nat. I843, t. 7.f. I seems a var. of this.

On dead herbaceous stems, leaves, \&c. Uncommon. Oct.

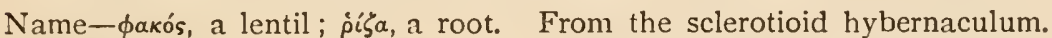
Fr. Hym. Eur. p. 683. Berk. Out.p.284. C. Hbk.n. 1002. S. Mycol. Scot.n. 953. Schnizl. Sturm 31. t. 12. Reich. in Schr. Naturf. Freund. Berl. i. $t$. 9.f. 4. Sow. t. 233.

3. T. incarnata Lasch.-Whitish, flesh-colour upwards, simple, filiform, cylindrical, attenuated into a continuous stem and hairy downwards; hybernaculum compressed, fuscous.

Very much allied to $T$. phacorrhiza.

On dead herbaceous stems. Uncommon.

Name-incarnatus, flesh-coloured. Lasch.-Fr. Hym. Eur.p. 683. Berk. Out. p. 285. C. Hbk.n. roor. S. Mycol. Scot. n. 954.-Grev. t. 93 .

4. T. gyrans Fr.-White, simple, very slender, somewhat cylindrical; stem thin, pubescent; hybernaculum pallid, becoming fuscous.

The hybernaculum is Sclerotium complanatum.

On straw, \&c. Uncommon.

Name-gyro, to turn in a circle or make circular. From the somewhat cylindrical head. Fr. Hym. Eur. p. 684. Br. Bath Trans. 1870, p.92. C. Hbk. n. I000. S. Mycol. Scot. n. 955.-Batsch f. 164.

5. T. muscicola Fr.-Simple, filiform, club white, cylindrical, obtuse, attenuated into a thin, smooth stem; hybernaculum even, pallid.

Distinctly stipitate, $5-7.5$ cent. (2-3 in.) high.

On the larger mosses. Uncommon.

Name-muscus, moss; colo, to inhabit. Fr. Hym. Eur. p. 684. Ber Out. p. 285. C. Hbk. n. $1003 .-$ Pers. Obs. 2. t. 3.f. 2.

II.-LeptorRhizÆ.-Radical tubercle not discovered, \&c.

6. T. Grevillei Fr.-White, simple, club thickened, obtuse; stem capillary, pilose.

Doubtless a form of $T$. gyrans, wanting the tubercle.

VOL. II. 
Typhula. On dead leaves, \&c. Frequent. Oct.

Name-after Greville. Fr. Hym. Eur. p. 685. Berk. Out. p. 285. C. Hbk.n. roo4. S. Mycol. Scot.n. 956 . Grev. t. 49.

7. T. gracillima White.-White; stem very slender, curved, smooth, club elongated.

On various herbaceous plants. Perth.

Name-gracilis, slender. Very slender. White.-B. \& Br.n. r6g9. S. Mycol. Scot. n. 957 .

8. T. filiformis Fr.-Club whitish, thickened, smooth; stem somewhat branched, decumbent, date-brown.

Among dead leaves. Rare.

Name-filum, a thread; forma, form. Thread-like. Fr. Hym. Eur. p. 685. Berk. Out. p. 285. C. Hbk. n. 1005.-Bull. t. 448. f. I. Sow. t. 387. f. 4 .

9. T. gracilis Berk. \& Desm.-Club pallid, simple or forked, acute, rough with spores and little prominent bristles; stem short, distinct, smooth or bristly.

$2 \mathrm{~mm}$. (x lin.) or more high. Rugged with the fruit-bearing cells, which are frosted with the spores, and interspersed sometimes with short bristles, of which some of the upper ones support a small spore; tips often acuminate and then nearly barren. Very near to Isaria.

On putrid leaves. Uncommon.

Spores elliptic, having a sparkling appearance under a lens. $B$. \& $B r$; sphæroid or sphæroid-ellipsoid, 8-ro mk. $K$. Name-gracilis, slender. Berk. Out. p. 285. B. E Br. n. 84. t. 8. f. 1. C. Hbk. n. 1006. Fr. Hym. Eur. p. 686.

10. T. translucens B. \& Br.-Minute, white, pellucid; stem short, thickened upwards; head irregular, somewhat obovate.

Resembling somewhat a prematurely dried Myxogast, but a true Hymenomycete.

On the ground. Glamis, I875. Oct.

Name-transluceo, to be transparent. Translucent. B. \& Br. n. 1589 . S. Mycol. Scot. n. $95^{8}$. 
Genus LV.-Pistillaria (pistillum, a pestle. From the form). Pistillaria. Fr. Syst. Myc. i. p. 496.

Very small, with a turgid club, which is either sessile, or. attenuated into a short continuous stem, hardened when dry Substance somewhat cellular. Sporophores simple or forked. Fr. Hym. Eur.p. 686.

1. P. micans Fr:-Glistening-rosecolour, scarcely exceeding $2 \mathrm{~mm}$. (I lin.) high, obovate, obtuse; stem short, attenuated, and, as well as the oval spores, white.

Smooth, but somewhat pruinose.

On dead thistles. Rare.

Spores ovoid-ellipsoid, 9-1o $\times$ 5-6 mk. $K$. Name-mico, to glisten. Fr. Hym. Eur. p. 686. Berk. Out. p. 285. C. Hbk. n. 1007.-Hoffm. Germ. t. 7. f. 2. Ehrenb. Ber. t. 3. f. 2.
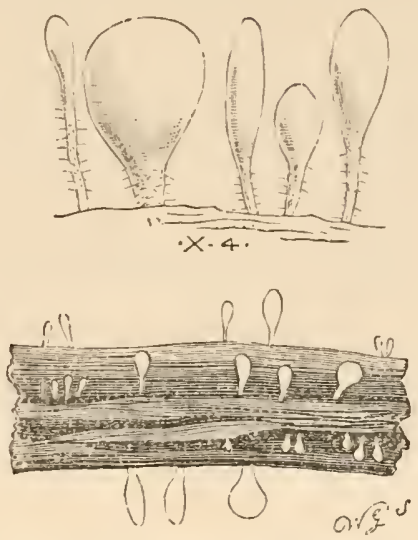

XCV. Pistillaria pubenula.

Natural size. Section four times natural size.

2. P. culmigena Fr.-Hyaline-pellucid, ovato-clavate, obtuse; stem distinct, very short.

Small, soft when fresh, hardened when dry, sclerotioid.

On stalks of grass. Frequent. Jan.

Name-culmus, a haulm; gigno, to bear. Growing on stalks. Fr. Hym. Eur. p. 687. Montagn. Ann. Sc. Nat. 1836, t. 12. f. 2. Berk. Out. p. 285. C. Hbk. n. 1008 .

3. P. quisquiliaris Fr.-Whitish, 6-S mm. (3-4 lin.) long, thickened upwards, somewhat compressed, soft when fresh, rigid when dry, attenuated at the base, smooth, somewhat stipitate.

Gregarious, here and there flattened and bifid. .

On fern stems. Common. Sept.-Oct.

Often attached to a Sclerotium. M.F.B. Spores sausage-shaped, $\mathrm{I}_{5} \mathrm{mk} . Q$. Name-quisquilice, sweepings, rubbish. Among refuse of fern. Fr. Hym. Eur. p. 687. Berk. Out. p. 286. C. Hbk. n. 1009. S. Mycol. Scot. n. 959. -Sow. t. 334. f. I.

4. P. furcata Smith.-Clubs white or yellowish, 3 cent. ( $1 / 4$ in.) high, waxy then tough, compressed, broad at the apex, attenuated downwards, generally furcate and cæspitose. 
Pistillaria. In greenhouses.

Name-furca, a fork. Forked. Worth. Smith in C. Hbk. n. Ior2.

5. P. puberula Berk.-White, scarcely $2 \mathrm{~mm}$. ( $\mathrm{I}$ lin.) high, obovate, ventricose; stem short, distinct, attenuated upwards, pellucid, fibrous, tomentose.

On dead Pteris aquilina. Rare. Sept.-Oct.

Name-pubes, first downy hair on the chin. From the tomentose stem. Berk. Out. p. 286. Eng. Fl. v. p. I81. C. Hbk. n. того. S. Mycol. Scot. n. 960. Fr. Hym. Eur. p. 688. -Sow. t. 334. f. 2.

6. P. pusilla Fr.-White, very small, $2 \mathrm{~mm}$. (I lin.) long, smooth, even, linear; stem not distinct.

On Equisetum. Weymouth.

Slightly thickened upwards, nodding when dry. M.F.B. Name-pusio, a small boy. Very small. Fr. Hym. Eur. p. 688. Syst. Myc. i. p. 498. Berk. Out. p. 286. Eng. Fl. v. p. I82. C. Hbk.n. I0Ir.

Microcera.

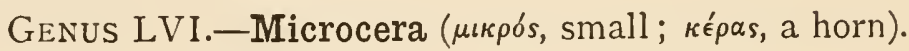

Desm. Ann. Sc. Nat. I848, p. 350.

"External veil persistent, membranaceous-floccose, breaking above into many laciniæ. Receptacle fleshy, club-shaped, formed of simple spore-bearing fibres. Spores fusiform, arcuate." Fr. Hym. Eur. p. 689.

No British species. 


\section{ORDER VI.-TREMELLINEI.}

Whole fungus homogeneous, gelatinous, shrivelling when dry, reviving when moistened, pervaded internally with branched filaments, terminating towards the surface all round in sporophores; spores somewhat reniform.

The structure of the Tremellini is admirably illustrated by Tulasne in Ann. Sc. Nat. IS53. Fr. Hym. Eur. p. 689.

\section{Genus LVII.-Tremella (tremo, to tremble). Dill.-Fr. Syst. Myc. 2. p. 2 Io.}

Tremella.

Distended with jelly when moist, tremulous, immarginate, not papillate, sporophores globose, becoming quadripartite, and sending out from each division an elongated free spicule, which terminates in a simple spore. Fr. Hym. Eur. p. 689.

I. MEsenteriformes ( $\mu \in \sigma \in \sigma^{\prime} \tau \epsilon \rho o \nu$, the mesentery). Gelatinous inclining to cartilaginous, foliaceous, naked.

II. Cerebrinæ (cerebrum, the brain). Firm then pulpy, somewhat pruinose with the spores.

III. CRUSTACEæ (crusta, a crust). Diffused, becoming plane.

IV. Tuberculiformes (tuberculum, a little tuber). Simall, somewhat erumpent.

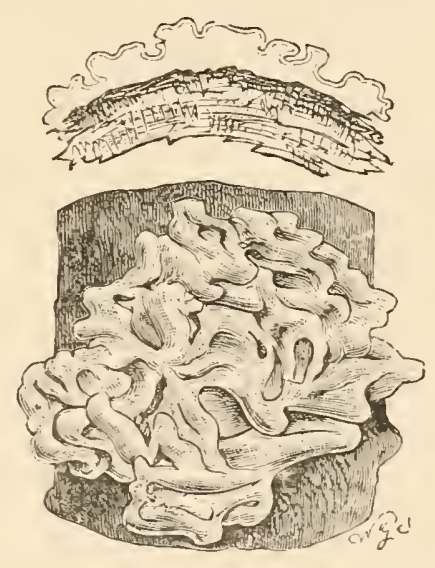

X'CVI. Tremella mesenterica. Natural size.

\section{I.-Mesenteriformes. Gelatinous, inclining to cartilaginous, \&c.}

1. T. fimbriata Pers.-Olivaceous inclining to black, cæspitose, clusters 5-7.5 cent. (2-3 in.) high and even broader, erect, corrugated; lobes flaccid, incised at the margin, undulato-fimbriate.

When soaked with water it has a dark tawny tinge. 
Tremella. On dead branches. Rare. Sowerby's Herbarium.

Name-fimbrice, a fringe. From the appearance of the lobes. Pers. Obs. 2. p. 97. Fr. Hym. Eur. p. 690 . Berk. Out. p. 286. C. Hbk. n. 1013.Bull. t. 272. Hoffm. Veg. Crypt. i. t. 7.f. I.

2. T. frondosa Fr.-Yellow inclining to pale, cæspitose, very large, even, plicate at the base; lobes gyroso-undulated.

The largest of the genus, nearest to $T$. foliacea, but thrice as large, more gyrose. There is no nucleus, and the structure is very different from that of Namatelia, wherefore it does not belong to that genus.

On roots of living trees, oak. Rare. Wothorpe, Norths. Careston, Forfarshire.

Colour a peculiar pale pinkish yellow. M.F.B. Name-frondosus, leafy. From the appearance of the lobes. Fr. Hym. Eur. p. 6go. Syst. Myc. ii. p. 212. Berk. Out. p. 286. C. Hbk. n. ior4. S. Mycol. Scot. n. 961.-Bull. t. 499.f. T.

3. T. foliacea Pers--Cimnamon-flesh-colour, cæspitose, cluster 2.5-5 cent. ( I-2 in.), even, undulated, plicate at the base.

When young it is flattened down and nestles under the bark, wrinkled, then protruding from the plane base and forming the cluster. Kickx notes a var. growing on the ground.

On stumps, logs, \&c. Frequent. Aug.-Dec.

Surface finely pubescent or granulated, the granulations pale, giving the plant a velvet-like gloss. Eng. Bot. Name-folium, a leaf. From the leafy appearance. Pers. Obs. 2. p. 98. Berk. Out. p. 287. C. Hbk. n. Ior5. S. Mycol. Scot. n. 962.-Bull. t. 406. f. A. a. Engl. Bot. t. 1452.

4. T. lutescens Pers.-Yellowish, cæspitose, small, cluster I2.5 cent. ( $1 / 2-I$ in.) broad, very soft, undulato-gyrose; lobes entire, naked.

Inclining to be fluid. Whitish when young.

On stumps, \&c. Frequent. Aug.-Feb.

Name-luteus, yellow. Yellowish. Pers. Syn. p. 622. Ic. \&o descr.p. 33 . t. 8. f. 9. Berk. Out. p. 287. C. Hbk. n. 1016. S. Mycol. Scot. n. 963.Bull. t. 406. f. $B-D$.

II.-Cerebrinæ. Firm then pulpy, \&-c.

5. T. mesenterica Retz.-Orange, simple, ascending, toughish, changeable in form, plicato-undulate, gyrose.

There is no constant form; when full grown pulverulent with the spores.

On sticks, Ulex, broom, \&c. Very common. July-Dec. 


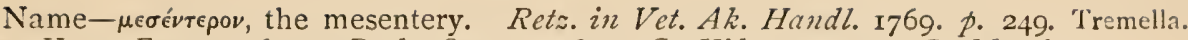
Fr. Hym. Eur. p. 691. Berk. Out. p. 287. C. Hbk. n. Ior7. S. Mycol. Scot. n. 964. Facqu. Misc. i. t. 15. Eng. Bot. t. 709. Hussey i. t. 27.Schaff. t. I68. Bull. t. I74. Hoffm. Veg. Crypt. i. t. 6. f. 4. Fl. Dan.t. 885 .

6. T. intumescens Eng. Bot.-Brown, becoming black when dry, somewhat cæspitose, rounded or conglomerate, soft, obsoletely punctate, somewhat tortuously lobed.

It is properly developed only in very damp weather, and forms numerous, rounded, soft, pulpy lobes, which are twisted and swollen, resembling the intestines of some animal.

On fallen trunks, beech, \&c. Rare.

When cut longitudinally brown vertical streaks are discernible near the surface. W.G.S. Name-intumesco, to swell up. Eng. Bot. t. I87o. Fr. Hym. Eur. p. 69r. Syst. Myc. ii. p. 215. Berk. Out. p. 288. C. Hbk.n. IO2I. S. Mycol. Scot. n. 965 .

7. T. vesicaria Eng. Bot. - Pallid, erect, frm, gelatinous within, undulated and gyrose.

On the ground. Very rare.

Spores Ir $\times 6 \mathrm{mk}$. B. \& Br. Name-vesica, a bladder. Eng. Bot. t. 245 I. Fr. Hym. Eur. p. 691. Berk. Out. p. 287. C. Hbk.n. 1018.

8. T. albida Huds.-Whitish, becoming fuscous when dry; 2.5 cent. ( $\mathrm{I}$ in.) broad, ascending, tough, expanded, undulated, somewhat gyrose, pruinose.

On dead wood. Common. Sept.-May.

Erumpent from bark. Spores oblong obtuse, curved, 2-guttate, subhyaline, I2-I $4 \times 4-5 \mathrm{mk}$. $K$. Name-albus, white. Whitish. Huds. Angl. ii. p. 565. Eng. Bot. t. 2117. Fr. Hym. Eur. p.691. Syst. Myc. ii. p. 215. Berk. Out. p. 287. C. Hbk.n. 1020. S. Mycol. Scot. n. 966.-Bull. t. 386.f. A.

\section{III.-CRUSTACEæ. Effused, flattened.}

9. T. viscosa Berk.-At first white then hyaline, effused, resupinate, undulated, somewhat viscous, the similar circumference naked.

On dead branches. Common. Jan.-Dec.

Forming a viscid stratum on the wood. Name-viscus, bird-lime. Viscous. Berk. Out. p. 288. Ann. Nat. Hist. Ser. ii. vol. xiii. t. 15. f. 4. Fr. Hym. Eur. p. 691. C. Hbk.n. 1027. S. Mycol. Scot.n.967.-Fl. Dan.t. 1851.f. I.

10. T. epigæa B. \& Br.-White, effused, gelatinous, gyrosoplicate, sprinkled with the white spores.

Spreading over the naked soil, on which it forms a thin, white, gelatinous stratum. 
Tremella On the ground. Rare. Aug.-Sept.

Name-i $\pi i$, upon; $\gamma \hat{\eta}$, the earth. B. \&o Br. n. 373. t. 9. f. 3. Berk. Out. p. 289. C. Hbk.n. Io28. S. Mycol. Scot. n. 968 .

\section{IV.-Tuberculiformes. Small, somewhat erumpent.}

11. T. violacea Relh. -Small, 6-8 mm. (3-4 lin.) broad, $2 \mathrm{~mm}$. (I lin.) thick, violaceous, becoming black when dry, erumpent, firm, somewhat compressed, gyrose.

Gregarious. The habit is that of Dacrymyces, but the structure is that of Tremella.

On trunks of pear-trees. Rare.

Name-from the colour. Relh. Cant. p. 442. Fr. Hym. Eur. p. 692. Dacrymyces Berk. Out. p. 290. C. Hbk. n. 1036. Tulasne Ann. Sc. Nat. I853, t. I2. $f .3-12$.

12. T. indecorata Sommerf. - Dingy, livid or olivaceous becoming fuscous, black fuscous when dry, $4-8 \mathrm{~mm}$. (2-4 lin.) broad, $4 \mathrm{~mm}$. (2 lin.) thick, erumpent, rounded, convex when swollen, plicate, opaque.

At first bursting through bark, firm, then plicate, connate as if with many lobes combined.

On birch, oak, willow. Rare. Oct.-Nov.

Name-indecorus, ugly. From its dingy appearance. Sommerf. Lapp. p. 306. Fr. Hym. Eur. p. 692. Berk. Out. p. 288. C. Hbk.n. 1022. S. Mycol. Scot. n. 969 .

13. T. moriformis Eng. Bot.-Black, minute, somewhat gelatinous, firm, spherical, sinuous, opaque.

Habit exactly that of the mulberry.

On dead branches. Rare. Batheaston. Dun. Forfarshire. Nov.

Interior mass translucent, violet. Staining paper violet. Name-morus, mulberry; forma, form. From its resemblance to a mulberry. Eng. Bot. $t$. 2476. Berk. Out. p. 287. C. Hbk. n. Iorg. S. Mycol. Scot. n. 970. Fr. Hym. Eur. p. 692.

14. T. tubercularia Berk. - Erumpent, somewhat stipitate, head pileate, dingy white, nearly black when dry; stem round, short.

When dry it has a peculiar semi-transparent horny appearance.

On dead branches. Frequent. Oct.-Dec.

Name-tuberculum, a tubercle. Berk. Out. p. 288. C. Hbk. n. I024. S. Mycol. Scot. n. 97r. Fr. Hym. Eur. p. 692. 
15. T. foliicola Fckl.-White above, brown below, scattered, Tremella. crowded, somewhat sessile, granular, globose, gelatinous above, hard and dry below, when dry cup-shaped.

Conidia on the apices of branched sterigmata, fusiform curved, simple, hyaline, $6 \times 2 \mathrm{mk}$.

On the lower surface of leaves of Rubus fruticosus with Phragmidium. Castle Rising, i882. March.

Name-folium, a leaf; colo, to inhabit. Fckl. Symb. Myc. p. 402. Grevillea, vol. xiii. p. 50. Sacc. Fung. Ital. n. 1024.

16. T. torta Berk.-Yellow or orange, minute, 4-6 mm. (2-3 lin.) broad, round, depressed, gyroso-tuberculate.

On dead wood, oak, \&c. Common. Oct.-Dec.

Name-torqueo, to twist. Twisted. Berk. Out. p. 288. C. Hbk. n. I025. S. Mycol. Scot. n. 972. Fr. Hym. Eur. p. 692.

17. T. versicolor Berk.-Orange, at length brown, minute, orbicular.

Tear-like, pallid when young.

On Corticium mudum. Uncommon.

Name-versicolor, changeable in colour. Berk. Out.p. 288. C. Hbk. n. I026. S. Mycol. Scot. n. 973. Fr. Hym. Eur. p. 693.

Genus LVIII.-Exidia ( $\xi^{\xi} \xi \delta \delta \omega$, to exude. Exuding from the Exidia. receptacle). Fr. Syst. Myc. ii. p. 220.

Distended with jelly when moist, tremulous, somewhat marginate, $p a$ pillose, with a gelatinous coloured stratum covering the sporophores, the spicules of which are erumpent only at their apices.

An easily recognised genus from its habit and from the papillæ. Fr. Hym. Eur. p. 693 .

I. AURICULINæ (auricula, the external ear). Pezizoid.

II. SPICUlaria (spiculum, a little point, spicule). Somewhat plane, unpolished beneath, very evidently glandular, here and there gyrose.

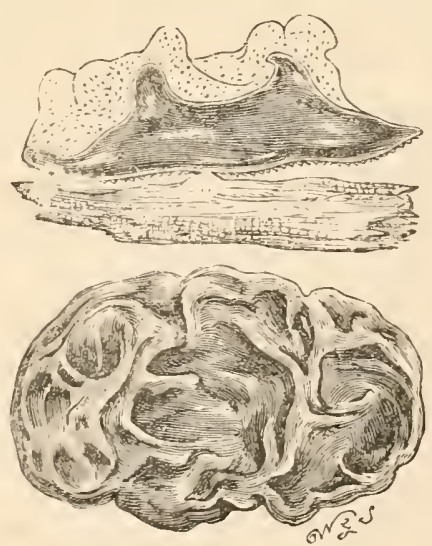

XCVII. Exidia glandulosa. Natural size. 
1. E. truncata Fr.-Scarcely reaching 2.5 cent. (I in.) in height and breadth, very black, shining, soft, distended with jelly, disc truncato-plane, glandular, at length cavernous, rough with dots beneath; stem very short.

It does not become swollen when moistened.

On lime branches. Yester Gardens. Dec.

Spores oblong, curved, chlorino-hyaline, $\mathrm{x}_{4}-16 \times 5^{-6} \mathrm{mk} . K$. Nametrunco, to maim, shorten. Cut short, truncate. Fr. Hym. Eur. p. 693 . Syst. Myc. ii. p. 224. Scot. Nat. iii. p. 20. S. Mycol. Scot. n. 974.

2. E. recisa Fr.-Fuscous-amber-colour, $I-2.5$ cent. ( $I / 2-I$ in.) broad, very soft, distended with jelly, disc truncato-plane, ribbed, papillose, somewhat repand, rough with dots beneath; stem very short, excentric, oblique.

On dead wood, willow, \&c. Common. Sept.-Oct.

Name-recido, to cut short. Shortened. Fr. Hym. Eur. p. 693. Syst. Myc. ii. p. 223. Berk. Out.p. 289. C. Hbk. n. 1029. S. Mycol. Scot. n. 975. -Dittm. Sturm i.t. 13. Eng. Bot. t. 1819.

\section{II.-SpiculariÆ. Somewhat plane, \&c.}

3. E. glandulosa Fr.-Blackish, 5-7.5 cent. (2-3 in.) broad, effused, somewhat plane, thick, undulated, studded with conical papillæ, cinereous and somewhat tomentose beneath.

Extremely variable in form and size.

On dead oak. Common. Sept.-March.

The under side feels like black crape. Sometimes truncate, sometimes pendulous. M.F.B. Known as Witch's butter. Spores oblong, curved, hyaline, I2-I $4 \times 5 \mathrm{mk} . K$. Name-glandula, glands. Full of glands. From the papillæ. Fr. Hym. Eur. p. 694. Syst. Myc. ii. p. 224. Berk. Out. p. 289. C. Hbk. n. 103o. S. Mycol. Scot. n. 976 . Hussey i. t. $4^{2 .-B u l l . t .420 . f . ~ I . ~}$ Fl. Dan. t. 884. Eng. Bot. t. 2448, 2452.

4. E. saccharina Fr.-Tawny-cimamon, effused, tubercular, gyroso-undulated, thick, sprinkled with few papillæ.

The colour is that of crystallised sugar. Papillæ minute, obtuse, vanishing.

On larch and Scotch fir. Rare. Nov.

Name-saccharon, sugar. From the colour. Fr. Hym. Eur. p. 694. Berk. Out. p. 289. C. Hbk.n. 1031. S. Mycol. Scot.n. 977. 
Genus LIX.-Hirneola (himea, a jug). Fr. Fung. Nat. p. 24. Hirneola.

Gelatinous inclining to cartilaginous, soft when moist, and tremulous but not clistended with jelly ; excipulum (cavity) cup shaped, when dry coriaceo-horny, reviving when moistened, but scarcely swelling. The hard skin which forms the hymenium superior, discoid, of a different colour from the excipulum, and when soaked for a considerable time admitting of being separated from it entire.

Sporophores not involved in jelly; spores oblong, curved.

A remarkable genus, clearly distinct alike from Auricularia and Exidia. Fr. Hym Eur. p. 695.

\section{H. auricula-Judæ Berk.-Thin,}

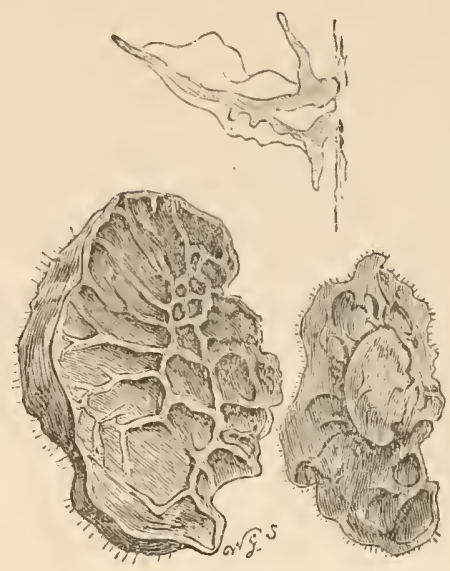

XCVIII. Hirneola auricula.Fuda. One-third natural size. concave, flexuous, at length black, venoso-plicate without and within, tomentose and olive-cinereous beneath.

On elder and elm. Frequent. March-Aug.

Plant $2.5-7.5$ cent. ( $1-3$ in.) broad. Upper substance corrugated, the plaits branching from the middle part where they are strongest and somewhat convoluted, so as to give an idea of a human ear. When the plant grows on a perpendicular stump or tree it turns upwards. Eng. Bot. Name-Jew's-ear. Berk. Out.p. 289. t. 18.f. 7. C. Hbk. 11. 1032. S. Mycol. Scot. n. 978. Fr. Hym. Eur. p. 695. Hussey i. t. 53.-Bolt. t. 107. Mich. Gen. t. 66. f. 1. B. more even. Berk. Out.t. 18.f.7. C. reddish-fuscous. Bull.t. 427.f. 2. Eng. Bot. t. 2447 .

Genus LX.-Femsjonia (from Femsjö). Fr. Summ. Femsjonia. Veg. Scand. p. 34I.

Cup-shaped, distended with firm jelly, different on the two sides, disc thick, heterogeneous, even and not glandular. Sporophores immersed, globose, the oblong spores curved. Growing on wood, erumpent, brightly coloured. Fr. Hym. Eur. p. 695.

No British species. 


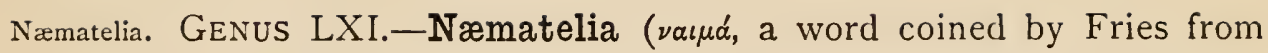
$\nu \alpha i \omega$, and applied to the gelatinous substance which surrounds the nucleus; $\epsilon^{\prime \lambda} \lambda^{\prime} \omega$, to roll or wrap round). Fr. Syst. Myc. ii. p. 227.

Solid, convex, immarginate, nucleus fleshy firm, entirely en-

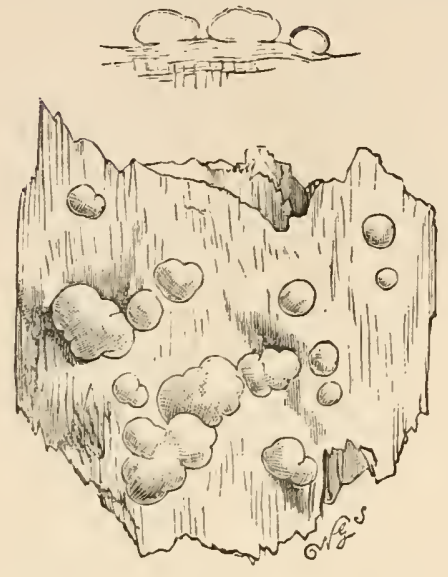

XCIX. Namatelia encephala. Natural size. veloped with a thick gelatinous stratum, which is internally fibrosofloccose, and everywhere covered with sporophores. Growing on wood, rather firm, not shrivelling when dry. Fr. Hym. Eur. p. 696.

1. N. encephala Fr.-Pallid-fleshcolour, 8-12 mm. (4-6 lin.) broad and thick, somewhat sessile, pulvinate, plicato-rugose.

Solitary or clustered. Nucleus large, hard, white.

On pine branches, chiefly Scotch fir. Frequent. Sept.-Feb.

Looks like the brain of some animal. $M . \mathcal{F} . B$. Name- $\dot{\epsilon} \nu$, within ; $\kappa \varepsilon \phi \breve{a} \lambda \dot{\eta}$. head. From its brain-like appearance. Fr. Hym. Eur. p. 696. Syst. Myc. ii. $p$. 227. Berk. Out. p. 290. C. Hbk. n. 1033. S. Mycol. Scot.n. 979.-Willd. Bot. Mag. i. t. 4. f. I4.

2. N. nucleata Fr.-Whitish then light yellow-fuscous, $2-8 \mathrm{~mm}$. (I-4 lin.) broad, sessile, becoming plane, somewhat gyrose.

On rotten wood. Rare.

Sometimes confounded with Tremella albida from which it differs in the presence of a small white nucleus. M.F.B. Name-nucleus, a kernel. Fr. Hym. Eur. p. 696. Syst. Mlyc. ii. p. 228. Berk. Out. p. 290. C. Hbk. n. IO34.

3. N. virescens Corda.-Greenish, sessile, somewhat orbicular, depressed, gyroso-tubercular.

On branches of Ulex, \&c. Common. Jan.-Dec.

Name-vireo, to be green. Corda Ic. iii. f. go. Fr. Hym. Eur. p. 696. Berk. Out. p. 290. C. Hbk. n. 1035. S. Hycol. Scot. n. 980.-Fl. Dan. t. I857. f. I. 
Genus LXII.-Guepinia (after Guepin). Fr. Elench. ii. p. 30. Guepinia.

Gelatinous inclining to cartilaginous, free, different on the two sides, variable in form, substipitate; hymenium confined to one side; sporophores linear, long-forked, 2 spored; spores curved. Fr. Hym. Eur.p. 697.

1. G. peziza Tul.-Yellow, cupshaped, somewhat sessile, smooth on both sides, adnate behind; stem slender.

Very remarkable in having the hymenium on the upper side.

On wood. Shere.

Name-From its being like Peziza. Tul. Ann. Sc. Nat. 1853, p. 224. Fr. Hym. Eur. p. 697. Grevillea, vol. vi. p. 7 r. Pl. 97. f. $19,20$.

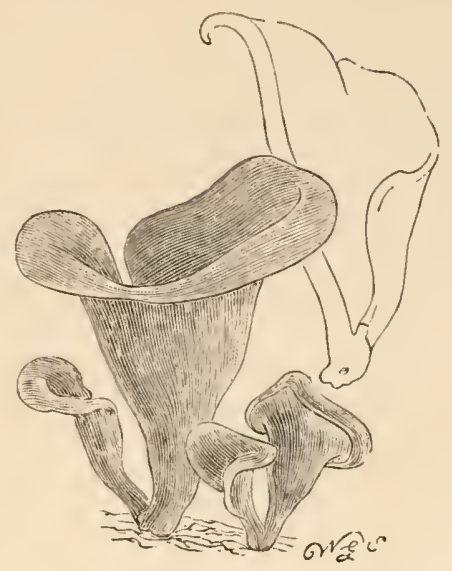

C. Guepinia helvelloides. One. half natural size.

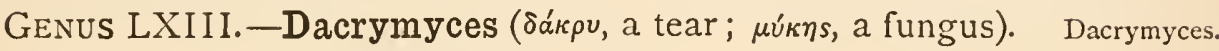
Nees Syst. p. 89.

Gelatinous, homogeneous, pervaded internally with septate fibres; conidia linked together like a necklace; sporophores clavate at the end of the filaments, bifurcate when mature; spores septate. Tul. Ann. Sc. Nat. i 853, t. I I. f. 19. t. I2. Fr. Hym. Eur. p. 697.

* Red.

** Yellowish.

*** Pallid or fuscous.

$$
\text { * Red. }
$$

1. D. macrosporus B. \& Br.Rose-colour, gelatinous, tuberculated.

Forming irregular gyrate and tuberculated masses of a rosy colour, about $6 \mathrm{~mm}$. $(1 / 4$ in.) long, parasitic on old remains of
Spheria stigma. It preserves its rosy tint when dry.

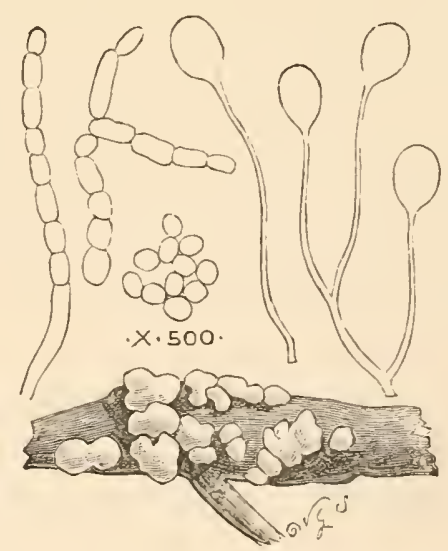

CI. Dacrymyces sebaceus. Natural size. Section five hundred times natural size. 
Dacrymyces. On dead branches. Batheaston. Dec.-March.

Primary spores oblong, 3-5 septate, 40-50 3 8-II $\mathrm{mk}$. Secondary spores

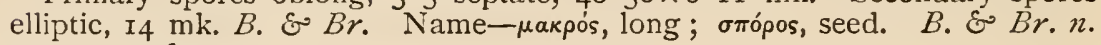
I374. t. $7 . f . \mathrm{I}$.

\section{** Yellowish.}

2. D. deliquescens Dub.- Yellowish, somewhat round, rooted, convex, immarginate, at length twisted, hyaline; spores triseptate.

At first pezizæform, even, dingy yellowish, becoming pale, yellow-fuscous when dry.

On dead wood, pine rails, \&c. Common. Jan.-Dec.

Easily distinguished from $D$. stillatus by its larger size, more cæspitose habit, and paler yellowish colour. $6-12 \mathrm{~mm}$. (1/4-1/2 in.) across. M.J.B. Spores triseptate, curved, oblong, hyaline, $12-22 \times 6 \mathrm{mk} . K$. Namedeliquesco, to dissolve. Deliquescent. Dub. Bot. Gall. p. 729. Fr. Hym. Eur. p. 698. Berk. Out. p. 290. C. Hbk.n. 1038. S. Mycol. Scot.n.981. -Bull. t. 455. f. 3. Corda Ic. ii. f. II5.

3. D. stillatus Nees.-Yellow then orange, colour persistent, 2-8 mm. (I-4 lin.) broad, somewhat round, convex, at length plicate, spores multiseptate.

Gregarious, somewnat confluent, variable in form, spherical when young, then turbinate or irregular, pezizoid, plicate, sessile or stipitate. It is readily distinguished from $D$. deliquescens by its colour being persistently bright.

On pine stumps, rails, \&c. Common. Jan.-Dec.

Spores multiseptate, subhyaline, slightly curved, ro- $22 \times 8 \mathrm{mk} . K$. Name - stillo, to drop. Nees Syst. p. 89. f. 90. Fr. Hym. Eur. p. 699. Syst. IIyc. ii. p. 230. Berk. Out. p. 291. t. 18. f. 8. C. Hbk.n. 1039. S. Mycol. Scot. n. 982. Grev. t. 159. Corda Ic. ii.f. II4?

4. D. chrysocomus Tul.-Golden, orbicular, when young spherical, immarginate, soon collapsing, pezizoid, and at length flattened, persistently even; spores multiseptate.

It agrees in its structure with $D$. stillatus. When dry it is very much contracted, somewhat horny.

On fir sticks. Rare.

Spores multiseptate, ellipsoid, pale yellow, 20-28 $\times 9$-I I mk. $K$. Name-

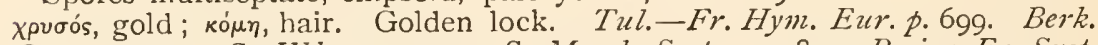
Out. p. 291. C. Hbk. n. 1о4о. S. Mycol. Scot. n. 983.-Peziza Fr. Syst. Myc. ii. p. I40. Bull. t. 376. f. 2. Sow. t. I52.

*** Pallid or fuscous.

5. D. sebaceus B. \& Br.-Whitish, somewhat round, composed 
of filaments which are variously branched and often clavate Dacrymyces. above.

Conspicuous only in rainy weather. Forming circular patches. Individual plants 4-8 mm. (2-4 lin.) broad.

On twigs of ash and maple. Bath, I868. Winter.

Spores ovato-triangular, $\mathrm{I} 4 \times 6-8 \mathrm{mk} . B$. \& $B r$. Name-sehum, tallow. From its resemblance to little spots of tallow. B. \& Br. n. I305. t. 18. f. 2. C. Hbk. n. 1037. Fr. Hym. Eur. p. 699.

6. D. succineus Fr.-Amber-colour, punctiform, somewhat gelatinous, smooth, becoming pale externally when moistened, disc darker and immarginate. does.

Gregarious, very small, rather thick, collapsing when dry as D. chrysocomus

On pine leaves. Grantown, Morayshire.

Minute, cup-shaped, stipitate, pale-yellow ; stem short, stout, black ; spores cylindrical, II $\times$ I $1 / 2 \mathrm{mk}$. The British specimens exactly accord with those from Sprée in Rabenhorst's 'Fungi Europai,' No. 680. Phillips. Namesuccinum, amber. From the colour. Fr. Hym. Eur. p. 699. S. Mycol. Scot. n. 984 .

7. D. vermiformis B. \& Br.-Grey, minute, worm-shaped. Sporophores globose; spores globose, pallid fuscous.

Sporophores I4 mk.; spores $6 \mathrm{mk}$.

On rotten wood. Batheaston. April.

Name-vermis, a worm; forma, form. B. \& Br.n. I700. t. 3. f. r. 



\section{A D D E N D A.}

THE following were unfortunately omitted from Vol. I.:-

Acetabularia, a subgenus of Agaricus, belongs to the third Acetabulaseries Dermini, and takes its place before Subgenus XIX., Pholiota.

Acetabularia (acetabulum, a vinegar cup. From the cup-like volva). Berk. Linn. Journ. xviii. p. 389 .

Universal veil distinct from the pileus; hymenophore distinct; gills free; spores pallid tawny or brown.

Analogous to Volvaria and Chiitonia.

1. A. acetabulosus Sow.-Pileus about 2.5 cent. (I in.) broad, lightbrown, convex, striate especially at the margin. Stem 5 cent. (2 in.) long, white, equal, hollow; volva nearly white. Gills free, narrow,

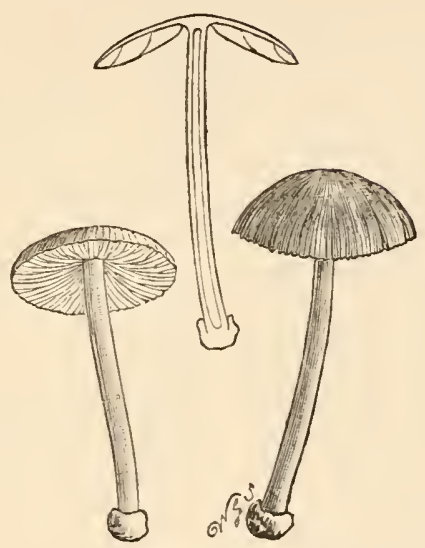

CII. Acetabularia. One-half natural size. hispid, light-brown. May.

Bank of Thames near high-water mark at Millbank, I795.

This is very like a poor specimen of $A$. congregatus, but the pileus is more plaited. The lamellæe are remarkably glandular on their sides; and instead of a bare base or foot, it stands in a little socket-like volva. Sow. The accompanying illustration is from the original specimen in the British Museum. Sowerby gives also an enlarged section of the gills, and a side of a gill showing very large cystidia. The pileus appears to be slightly split as in $A$. rimosus. Name-from the cup-like volva. Sow. t. 303. Berk. Linn. Fourn. xviii. p. 389. C. Illust. Pl. 345 .

VOL. II. 
Hiatula Hiatula holds as yet an uncertain position. From the colour of the spores, and the habit being that of Mycena, it might be

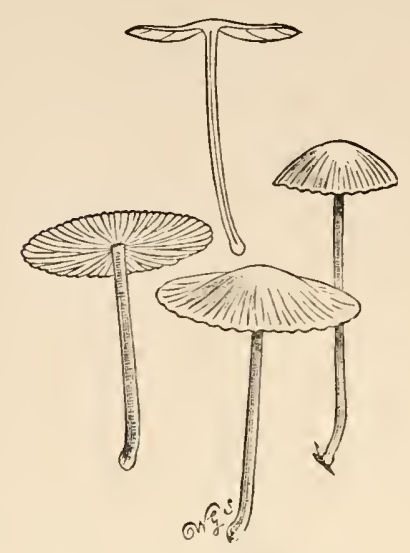

CIII. Hiatula Wynnia. Onehalf natural size. referred to the Leucospori, but the mode of growth is entirely that of the Coprini. At present it is placed next to Coprimus.

Hiatula (hio, to gape. From the manner in which the pileus splits open). Mont. Ann. Sc. Nat. IS54. Vol. i. p. 107.

Pileus very thin, without a pellicle, formed by the junction of the back of the gills, when expanded veliform and splitting open as in the most delicate Coprini, but not melting away, and the sporidia are white. Fr. Nov. Symb. Myc.p. II.

1. H. Wynniæ B. \& Br.-Shining white. Pileus 4 cent. (I $1 / 2$ in.) broad, tender, striate, pulverulent, centre darker. Stem 2.5 cent. ( 1 in.) long, $2 \mathrm{~mm}$. (I lin.) thick, slender, striate. Gills scarious, rather broad.

One specimen became darker in drying, and had a longer and thicker stem.

In a stove. Kew.

Name-after Mrs Lloyd Wynne. B. \& Br.n. 1772 . 


\section{G L O S S A R Y.}

ADNATE (adnascor, to grow to), growing into; of gills e.g. closely attached to the stem.

ADNEXED ( $a d$, to ; necto, to join), of gills attached to the stem but not adnate to it.

ADPRESSED ( $a d$, to ; premo, to press), pressed in close contact.

ERUGINOUS (arugo, rust of copper), verdigris-green.

AgGlutinated (agglutino, to cement), glued to a surface.

Alveolate (alveus, a hollow), in the form of small depressions like shallow honeycomb.

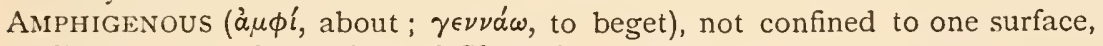
all round; e.g. hymenium of Clavaria.

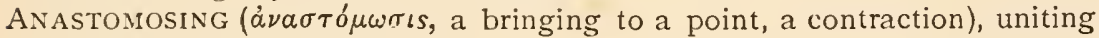
by running together irregularly.

ANNULAR (anmulus, a ring), in the form of a ring.

APICAL (apex, the top), close to the apex.

APICUlATE (apex), terminating in a small point.

APPENDICULATE (appendix, an appendage), hanging in small fragments.

Approximate ( $a d$, to; proximo, to approach), of gills which approach but do not reach the stem.

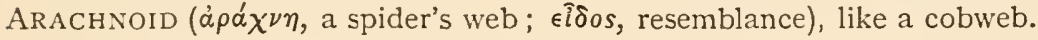

ARCUATE (arcus, a bow), bow-shaped.

Areolate (area, a plot), divided into little areas or patches.

ASCENDING (ascendo, to climb), inclining upwards.

Atomate (áropos, an atom), sprinkled with atoms.

Bullate (bulla, a bubble), furnished with a boss or stud.

CASPITOSE (crespes, a clump), growing in tufts.

CALYPTRA (calyptra, a hood), applied e.g. to the portion of the volva covering the pileus.

Campanulate (campana, a bell), bell-shaped.

Cinereous (cinis, ashes), ash-coloured.

Circinate (circino, to make round), rounded.

Clavate (clava, a club), club-shaped. 
Confervoid (Conferva, a name applied to certain of the Alga, sea-weeds; $\epsilon \hat{l} \delta$ os, form), like a Conferva; from the finely branched threads.

Connate (con, together; nascor, to be born), united by growing together.

Continuous (continuo, to unite), without a break; $e . g$. of a surface which is not cracked, or of one part which runs into another without interruption.

CORRUGATED (corrugo, to wrinkle), drawn into wrinkles or folds.

CORTICATED (cortex, bark), furnished with bark-like covering.

CoRTINA (cortina, a veil), a veil of a spider-web structure; applied to the peculiar veil of the genus Cortinarius.

Cortinate, furnished with a cortina.

Crenate (crena, a notch), notched at the edge. The notches are blunt or rounded, not sharp as in a serrated edge.

Cribrose (cribrum, a sieve), pierced with holes.

CUSPIDATE (cuspis, a point, spear), with a sharp spear-like point.

CYATHIFORM (cyathus, a cup ; forma, form), cup-shaped.

DeCURRENT (decurro, to run down), running down; e.g. of gills on the apex of the stem.

Determinate (determino, to limit), ending definitely; having a distinctly defined outline.

DiAPHANOUS ( $\delta \iota^{\prime}$, through; $\phi \alpha i \nu \omega$, to appear), of a transparent nature.

Diснотомоus ( $\delta i \chi \chi \alpha, \tau \epsilon^{\prime} \mu \nu(v$, to cut), divided into two ; regularly forked.

DIMIDIATE (dimidio, to halve), halved; e.g. of gills which reach half-way to the stem.

DiscIFORM (discus, a quoit ; forma, form), disk-shaped ; of a circular and flat form.

Dissepiments (dissepimentum, a partition), dividing walls.

DisTANT (disto, to stand apart), far apart; of gills which have a wide distance between them.

DIVARICATE (divarico, to spread asunder), separating at an obtuse angle.

ECHinulate (echinus, a hedgehog), beset with short bristles.

EFFUSED (effundo, to pour out), spread over without regular form.

EMARGINATE (e, out of; margo, the margin), of gills with a sudden curve as if scooped out at the point of attachment to the stem.

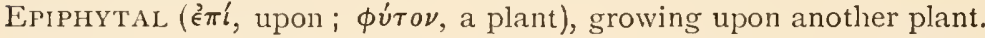

EVEN, of a surface which is quite plane as contrasted $e . g$. with one which is striate, pitted, \&c. Distinguished from smooth. A surface may not be smooth, and yet even.

FARINACEOUS (farina, meal), mealy.

FASciate ( fascia, a band or girth), zoned with coloured bands.

FASCICULATE (fascis, a bundle), growing in small bundles.

Fastigiate (fastigizm, the top), reaching the top.

Fibrillose ( $f i b r a$, a fibre), clothed with small fibres.

Fibrous, composed of fibres.

FIIIFORM ( flum, a thread; forma, form), thread-like.

Fimbriate (fimbria, a fringe), fringed.

FISSILE ( $f$ indo, to split), capable of being split.

Fistulose (fistula, a pipe), hollow in the centre like a pipe.

FLOCCI (floccus, a lock of wool), woolly locks. 
FLocCULOSE, covered with small flocci.

FREE, of gills which reach the stem but are not attached to it.

FURFURACEOUS (furfur, bran), with branny scales or scurf.

Fuscous (fuscus, dusky), brownish in colour, but dingy, not pure.

GrbBous (gibbus, hump-backed), in the form of a swelling; of a pileus e.g. which is more convex or tumid on one side than the other.

GiLLS, the plates of an Agaric on which the hymenium is situated.

GREAVED (greve, the shin-bone), of a stem clothed like a leg in armour.

Grumous (grumus, a little heap), clotted; of flesh e.g. composed of little clustered grains.

GuTTATE (gutta, a tear), marked with tear-like spots.

Gyrose ( $\gamma \hat{v} \rho \circ$ s, a circle), circling in wavy folds.

Heterogeneous ( ${ }^{\prime \prime} \tau \epsilon \rho o s$, one of two; $\gamma \in \nu \nu \alpha \dot{\omega} \omega$, to beget), of a structure which is different from adjacent ones.

Homogeneous ( $\delta \mu o ́ s$, one and the same; $\gamma \in \nu \nu a ́ \omega$, to beget), similar in structure.

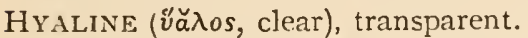

HYBERNACULUM (hiberno, to winter), applied to bodies which are the forms in which certain fungi, e.g. Typhula, pass the winter.

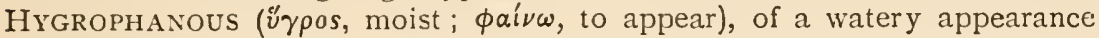
when moist and opaque when dry.

HYMENIUM ( $\dot{v} \mu \eta \dot{\nu}$, a membrane), the fruit-bearing surface; e.g. on each side of the gills of an Agaric.

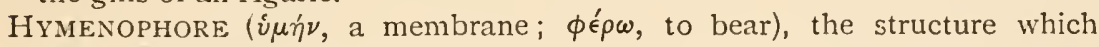
bears the lyymenium; in Agarics e.g. the under surface of the pileus to which the gills are attached.

IMMARGINATE (in, negative; margo, a margin), without a distinct border.

IMMERSED (immergo, to immerse), sunk into the matrix.

INFERIOR, of the ring of an Agaric which is far down on the stem.

INFUNDIBULIFORM (infundibulum, a funnel; forma, form), funnel-shaped.

INNATE (in, into; nascor, to be born), adhering by growing into.

INSERTED (insero, to insert), growing like a graft from its stock.

INVOLUTE (in; volvo, to roll), rolled inwards.

ISABELLINE, of the colour of soiled linen; brownish-yellow-clay.

LaCiniate (lacinia, a lappet, flap), divided into flaps.

LACUNOSE (lacuna, a pit), marked with small hollows.

LANCEOLATE (lancea, a spear), lance-shaped; tapering to both ends.

LiNEAR (linea, a line), narrow and straight.

MAMMIFORM (mamma, a breast; forma, form), breast-shaped.

MARGinate (margo, a margin), having a distinct border.

MATRIX (matrix, the womb), the substance on which a fungus grows.

MEDIAL (medium, the middle), at the middle; of the ring of an Agaric e.g. which is between superior or near the apex of the stem, and distant or far removed from the apex.

MERISMOID (Merisma, from $\mu \epsilon \rho$ i $\zeta \omega$, to divide, a generic name applied by Persoon to certain fungi with branched or laciniate pilei, now included under 
Thelephora; єî̉os, form), resembling a Merisma-i.e. having a branched or laciniate pileus.

MYCELIUM ( $\mu$ v́k $\eta s$, a fungus), spawn of fungi resulting from the germination of spores; in Agarics e.g. forming root-like threads.

OBCONIC ( $o b$; conus, a cone), inversely conical.

OBovate $(o b ;$ ovum, an egg), inversely egg-shaped.

Papillate (papilla, a nipple), furnished with one or more nipple-like elevations.

PARTIAL (pars, a part), of a veil clothing the stem and reaching to the edge of the pileus, but not extending beyond it.

Pectinate (pecten, a comb), like the teeth of a comb.

Pelliculose (pellis, skin), furnished with a pellicle or distinct skin.

Pencilled (penicillum, a painter's brush), with pencil-like hairs either on the tip or border.

Peronate (pero, a kind of high boot), sheathed; of a stem e.g. which has a covering like a legged boot.

PERvious (per, through; via, a way), forming an open tube-like passage.

Pileus (pileus, a hat), a part of the receptacle of a fungus; e.g. the cap-like head of Agarics.

Pileoli, secondary pilei ; arising from the division of a primary pileus.

Pilose (pilus, a hair), covered with hairs.

PORIFORM (porus, a pore; forma, form), in the form of pores.

POROus, furnished with pores.

Proliferous (proles, offspring; fero, to bear), applied to an organ which gives rise to secondary ones of the same kind.

Pruinose (pruina, hoar-frost), covered with frost-like bloom.

PRUNIFORM (prunus, a plum; forma, form), plum-shaped.

Pulvinate (pulvinus, a cushion), cushion-shaped.

Punctate (punctus, a point), dotted with points.

QUATERNATE (quatuor, four; nascor, to be born), arranged in groups of four.

REMOTE (removeo, to remove), of gills which do not reach the stem, but leave a free space between them and it.

RENIFORM (renes, the kidneys; forma, form), kidney-shaped.

REPAND (repando, to throw open), bent backwards.

RESUPINATE (resupino, to throw on the back), lying on the back; of an Agaric e.g. lying on the back without a stem; or of fungi spread over the matrix without any stem and with the hymenium upwards.

REVOLUTE (revolvo, to roll back), rolled backwards; of the margin of a pileus $e . g .$, the opposite of involute.

RIMOSE (rima, a crack), cracked.

RING, a part of the veil adhering in the form of a ring to the stem of an Agaric.

Rivulose (rivula, a small stream), marked with lines like rivulets.

RUBIGINOUS (rubigo, rust), rust-coloured.

RUFESCENT (rufesco, to become reddish), reddish in colour.

Rugose (ruga, a wrinkle), wrinkled. 
ScABrous (scaber, rough), rough on the surface.

SCARIOUS ( $\sigma \kappa \alpha$ ápos, a kind of sea-fish), applied to a shrivelled membrane.

Scissile (scindo, to cleave), capable of being cleft asunder; of two plates e.g. lying together, but capable of being separated.

SCLEROTIOID ( $\sigma \kappa \lambda \eta \rho o ́ s$, hard; $\epsilon \hat{i} \delta o s$, resemblance), in the form of a Sclerotium, a form assumed by the mycelium of certain fungi.

Scrobiculate (scrobis, a trench), marked with small pits.

SEPARATING (separo, to separate), becoming detached as gills from the stem, or resupinate fungi from the matrix.

Serrate (serra, a saw), with teeth like a saw.

SESsile (sedeo, to sit), seated without a stem.

SINUATE (sinus, a curve), waved; of a pileus with a wavy margin; of gills which have a sudden wave or sinus where they reach the stem.

Sмоотн, applied to a surface which is destitute of hairs, \&c. See Even.

SPATHUlate (spatha, a broad flat instrument for stirring liquids), shaped like a spatula or spoon.

SQuAmose (squama, a scale), scaly.

SQUAMULOSE, covered with small scales.

SQUARROSE (squarrosus, rough), rough with scales.

STIPITATE (stipes, a stalk), stemmed.

Stoloniferous (stolo, a sucker; fero, to bear), stolon-bearing; applied to a trailing and rooting branch.

STRIATE (stria, a furrow, flute of a column), marked with lines in the form of channels.

STRIGOSE (striga, a swath), rough with fascicles of hairs.

STUFFED, of a stem filled with substance of a different texture from its walls.

Subiculum (subiculum, an under layer), the thready mycelium forming the under layer of the plant.

SulCATE (sulcus, a furrow), marked with furrows.

SUPERIOR (super, above), the upper surface; or applied to a ring when it is near the apex of the stem.

TOMENTOSE (tomentum, wool, \&c.), downy.

TRAMA (trama, the weft or filling of a web), the substance proceeding from the hymenophore, between the plates of (central in) the gills in Agarics, and between the double membranes of which the dissepiments of the pores are composed in Polyporei.

TREMELLOID (tremo, to tremble), of the consistency of jelly.

TRUNCATE (trunco, to maim), ending abruptly as if cut short.

TUBæFORM (tuba, a trumpet; forma, form), trumpet-shaped.

TUBERCLE (tuber, a swelling), a small wart-like excrescence.

Umbilicate (umbilicus, the navel), with a central depression.

UMBONATE (umbo, the boss of a shield), with a central boss-like elevation.

UNCINATE (uncinus, a hook), hooked.

UNIVERSAL (universus, whole), of the veil or volva which entirely envelops the fungus when young.

VEIL (velum, a covering), a covering of various texture more or less completely enwrapping a fungus; occurring chiefly among the Agaricini.

VELIFORM (velum; forma, form), of a thin veil-like covering. 
VENTRICOSE (venter, the belly), swollen in the middle.

VERNICOSE (vernis, varnish), shining as if varnished.

VILLOUS (villus, a tuft of hair), downy with soft hairs.

ViRGATE (virga, a twig, stripe), streaked.

Volva (volva, a wrapper), a substance (universal veil) covering the plant; e.g. in young Amanita.

ZONED (zona, a girdle), furnished with one or more concentric circles of colour, depression, \&c. 


\section{INDEX TO VOL. II.}

\begin{tabular}{|c|c|c|c|c|c|c|}
\hline \multirow{3}{*}{\multicolumn{2}{|c|}{$\begin{array}{l}\text { ACETABULARIA Berk. } \\
\text { acetabulosus Sow. }\end{array}$}} & & Page & Boletus Dill._continu & & PAGE \\
\hline & & - & 321 & piperatus $B u l l$. & - & . 171 \\
\hline & & & 321 & pruinatus $F r$. & • & 174 \\
\hline AGARICUS $\operatorname{Lin} n$. & - & & • & $\begin{array}{l}\text { purpurens Fr. } \\
\text { radicans Pers. }\end{array}$ & $\dot{\bullet}$ & 173 \\
\hline adhosivus With. & - & & 156 & rubinus Smith & . & 173 \\
\hline filamentosus Fr. & - & & 68 & sanguineus With. & . & 170 \\
\hline glaucopus sow. & - & . & 5 & satanas Lenz. . & . & 177 \\
\hline helvelloides Bull. & - & & 136 & scaber Fr. • & - & 180 \\
\hline obscuratus Lasch. & - & & 112 & spadiceus Schceff. & - & 173 \\
\hline paradoxus Kalchbr & & - & 67 & striæpes Secr. . & - & 172 \\
\hline sublanatus Huss. & - & • & 3 & strobilaceus Scop. . & - & 18 \\
\hline tristis Krombh. & - & & 112 & subtomentosus Linn. & - & $17:$ \\
\hline turbinatus Sow. & - & . & S & sulphureus Fr. • & - & 171 \\
\hline turfosus Sow. . & & . & $16 !$ & variecolor $B . \& B r$. & - & 174 \\
\hline validus Berk. . & & - & 26 & variegatus $S w . \quad$. & - & 171 \\
\hline ARRHENIA $F r$. & - & - & 157 & viscidus $\operatorname{Lin} n$. & • & : \\
\hline AURICULARIA Bull. & - & - & $2 \pi 1$ & Calocera $F r$. & - & 301 \\
\hline lobata Somnuerf. & - & - & $27 \cdot 2$ & cornea Fr. . & - & 302 \\
\hline mesenterica $F r$. & - & • & 272 & corticalis $F r$. . & . & 302 \\
\hline & & & & glossoides $F r$. & - & \\
\hline BoletuS Dill & - & - & 166 & palmata $F r$. . & . & 30 \\
\hline æreus Bull. & - & • & 176 & striata Fr. . & - & 30 \\
\hline astivalis $F r$. . & - & - & 177 & stricta $F r$. & - & $30 \vdots$ \\
\hline alutarius $F r$. . & • & & 180 & tuberosa Fr. . & . & 300 \\
\hline arboreus Sow.. & - & . & 229 & viscosa $F r$. & - & 302 \\
\hline badius $F r . \quad$. & - & & 170 & & & \\
\hline bovinus Linn. & • & • & 170 & CANTHARELLUS Adans. & - & \\
\hline calopus Fr. & - & & • & albidus $F r$. & - & - \\
\hline carnosus Rosth: & & • & 152 & anthracophilus Lev. & - & 13 \\
\hline castaneus Bull. & 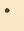 & • & 181 & aurantiacus Fr. & - & 132 \\
\hline chrysenteron $\mathrm{Fr}$. & - & • & 172 & Brownii $B . \& B r$. & - & 133 \\
\hline collinitus $F r$. & & • & 169 & carbonarius $A . \& S$. & - & 133 \\
\hline cyanescens Bull. & - & • & 181 & cibarius $F r . \quad$. & • & 132 \\
\hline edulis Bull. . & & - & 176 & cinereus $F r$. & • & - \\
\hline aus Schum. & - & - & 168 & cupulatus Fr. & - & - \\
\hline erythropus Pers. & - & $-2{ }^{2}$ & 178 & Friesii Quel. & - & 132 \\
\hline felleus Eull. . & & . & 180 & Houghtoni Phill. & - & 134 \\
\hline flavidus Fr. . & • & - & 169 & infundibuliformis $F r$. & - & 134 \\
\hline flavus With. . & & $\cdot 3$ & 168 & lobatus $F r$. & - & 137 \\
\hline fragrans Vitt. . & & . & 176 & Intescens Bull. & - & 13 \\
\hline granulatus Linn. & & . & 169 & muscigenus $F r$. & - & - \\
\hline impolitus Fr. . & & & 177 & radicosus B. \& Br. . & - & \\
\hline lariciuus Berh. & & & 179 & retirugus $F r$. & - & - \\
\hline luridus Schceff. & & & 178 & Stevensoni $B$. \& $\mathrm{Br}$. & - & 136 \\
\hline luteus Linn. . & & & 168 & tubaformis $F r$. & - & 131 \\
\hline olivaceus Schceff. & & & 175 & umbonatus $F r$. & - & 133 \\
\hline $\begin{array}{l}\text { pachypus Fr. } \\
\text { pachypus Krombh. }\end{array}$ & & & $\begin{array}{l}175 \\
. \quad 176\end{array}$ & LADODERRIS Pers. & & \\
\hline $\begin{array}{l}\text { pachypus Krombh. } \\
\text { parasiticus } B u l l .\end{array}$ & & - & - 174 & minima $B$. \& $B r$. & • & \\
\hline
\end{tabular}


Clavaria $\operatorname{Linn}$. abietina Pers. . acuta Sow. amethystina $\dot{B} u l l$. Ardenia Sow. argillacea $\mathrm{Fr}$. . aurautiaca Pers. aurea Schceff.

botrytes Pers.

canaliculata $F r$. ceranoides Pers. cinerea Bull. condensata $F r$. contorta Holmsk. coralloides Linn. crispula $F r$. cristata Pers. . crocea Pers. curta Fr.

fastigiata $\operatorname{Linn}$

fistulosa $F r$. .

flaccida $F r$.

formosa Pers. .

fragilis Holmsk.

fumosa Pers.

fusiformis Sow. gracilis Pers. .

grisea Pers.

inæqualis $F$. Dan.

incarnata Weinm.

juncea $F r$.

juncea Lev.

Kromholzii $F r$.

Kunzei $\mathrm{Fr}$.

ligula $\mathrm{Fr}$.

ruuscoides $\operatorname{Linn}$.

pistillaris Linn.

pratensis Pers.

purpurea Fr. .

pyxidata Pers.

rosea $\mathrm{Fr}$.

rufa $F l$. Dan. .

rugosa Bull.

spinulosa Pers.

stricta Pers.

tenuipes $B . \& B r$.

tuberosa Sow.

umbrina Berk.

uncialis Grev.

vermicularis Scop.

Corticium Fr.

amorphum $\mathrm{Fr}$.

anthochroum $\mathrm{Fr}$.

arachnoideum Berk.

aridum $F r$.

atrovirens $F r$.

byssoideum $\mathrm{Fr}$.

cæruleum $F r$.

calceum $\mathrm{Fr}$.

cinereum Fr.

cinnamomeuin $\mathrm{Fr}$.

citrinum Pers.

comedens Fr.

confluens Fr. .

corrugatum $\mathrm{Fr}$.
evolvens $\mathrm{Fr}$.
PAG

290

294

301

291

300

297

297

294

290

300

297

292

295

299

292

296

292

295

$\therefore 91$

291

299

295

294

298

298

297

208

295

297

301

300

305

293

293

299

291

299

291

296

293

296

296

293

294

295

300

300

292

301

298

272

274

284

275

282

277

281

282
Corticium Fr.-contiuued.

PAGE

ferrugineum $\mathrm{Fr}$. . . . . 283

fotidum $B . \& B r$. . . . . 275

giganteum $\mathrm{Fr}$. • . . . . 274

incarnatum $\mathrm{Fr}$. $\quad$ • $\quad$ • $\quad$ • $\quad 279$

lactescens Berk. . . . . . 276

lacteum Fr. . . . . 274

lacunosum $B . \& B r$. $\quad 284$

læve Pers. . . . . . 275

laxum $\mathrm{Fr}$.

limitatum $\mathrm{Fr}$.

lividum Pers. . $\quad . \quad$ : $\quad . \quad 278$

maculæforme $\mathrm{Fr}$. • . • . . 280

nudum Fr. . . . . . 279

ochraceum Fr. . . . . 278

olivaceum Fr. $\quad$. $\quad$. . . . 283

polygonium Pers. • . . 280

porosum B. \& Curt. $\quad$. . $\quad$. 275

puberum Fr. . • • . 277

puteanum $F r$. $\quad . \quad$. . . 281

quercinum $\mathrm{Fr}$. $\quad \cdot \quad \cdot \quad . \quad 278$

roseum Pers. . . . . . 275

salicinum Fr. . . . . . . 273

sambuci $F r . \quad$ • $\quad . \quad$ • . . 283

sanguineum Fr. . . . . . . 276

scutellare B. \& Curt. . . . 278

serum Fr. $\quad . \quad 253$

stabulare Fr. . . . . . . 282

subdealbatum $B$. \& $B r$. . . . 276

sulphureum Fr. . . . 276

typhæ Fchl. • • : $\quad$ • $\quad .281$

umbrinum Fr. . . . 282

velutinum $\mathrm{Fr}$. $\quad . \quad$. $\quad . \quad .275$

violaceo-lividum $F r . \quad$. . . 280

Cortinarius Fr. . . . . . 1

acutus $F r . \quad$. $\quad . \quad$. $\quad . \quad$. 61

albo-violaceus Fr. • • . . . 24

anfractus $F r$. . $\quad$ • $\quad$ • $\quad$ • $\quad$ - 7

anomalus $F r$. . . . . . 32

anthracinus $\mathrm{Fr}$. $\quad$ • $\quad$. $\quad$. $\quad$ - 34

arenatus Fr. • • • • • $\quad \cdot 28$

argentatus $\mathrm{Fr} . \quad$ • $\quad$ • $\quad$ • $\quad$ • 22

armeniacus $\mathrm{Fr} . \quad \cdot \quad \cdot \quad \cdot \quad \cdot 52$

armillatus $\mathrm{Fr}$. $\quad$ • $\quad$ • $\quad$ • $\quad$ • 43

arvinaceus $\mathrm{Fr}$. $\quad$ • $\quad \cdot \quad \cdot \quad \cdot 17$

bivelus $F r$. • • • • • • 38

bolaris $F r . \quad . \quad$. $\quad . \quad$. $\quad$. 26

bulbosus $F r$. • $\quad$ • $\quad$ • $\quad$ • $\quad$ • 39

Bulliardi Fr. . $\quad$ - $\quad$ - $\quad$. $\quad 26$

cærulescens $\mathrm{Fr}$.

ccerulescens Saund. \& Sm. $\quad . \quad 14$

callisteus $\mathrm{Fr}$. . • . • • . 26

calochrous $\mathrm{Fr} \quad$. $\quad$. $\quad . \quad$. 9

camphoratus $F r$. . . . . . 24

camurus Fr. . $\quad$ • $\quad$. $\quad$ • $\quad$. 30

caninus Fr. $\quad . \quad .31$

castaneus Fr. . $\quad$. $\quad$. $\quad$ • $\quad$. 55

cinnabarinus $\mathrm{Fr}$. . . . . 33

ciunamomeus $\mathrm{Fr}$. . $\quad$. . $\quad$. 35

claricolor Fr. . . . . . . 3

collinitus Fr. . $\quad$ • $\quad$ • . $\quad$. 17

colus Fr. $\quad$ • . $\quad . \quad$ • $\quad$. 56

cotoneus Fr. . . . . . . 36

croceo-cæruleus Fr. $\quad$ • . $\quad$ • 15

cumatilis $\mathrm{Fr}$. . $\quad$. $\quad$ • . 13

cyanites Fr. • . . . . . $\quad$ • 23

cyanopus Fr. . $\quad$. $\quad$. $\quad . \quad$. 5

decipiens $F r$. . $\quad . \quad$. $\quad$ • $\quad$. 59 
Cortinarius $F r$-continued.

decolorans $F r$.

decoloratus $\mathrm{Fr}$.

decumbens $F r$.

delibutus $F r$. .

detonsus Fr. .

diabolicus $F r$.

dibaphus Fr. .

dilutus $F r$.

duracinus $F r$. .

elatior Fr.

erythrinus $\mathrm{Fr}$.

evermius $F r$.

fasciatus $F r$. .

finitimus Weimm.

flabellus $F r$.

flexipes $F r$.

fulgeus $\mathrm{Fr}$.

fulmineus $\mathrm{Fr}$.

gentilis $F r$.

germanus $F r$.

glaucopus $F r$.

grallipes $\mathrm{Fr}$.

hæmatochelis $F r$.

helvelloides $\mathrm{Fr}$.

helvolus $\mathrm{Fr}$.

hemitrichus Fr.

iliopodius $F r$.

illibatus $F r$.

imbutus $F r$.

impennis Fr.

incisus $\mathrm{Fr}$.

infucatus $F r$.

jubarinus $F r$. .

Junghuhnii $F r$.

largus Fr.

leucopus $F r$.

licinipes $F r$.

limonius $F r$. .

livido-ochraceus Berk.

macropus $F r$.

miltinus $F r$.

milvinus $F r$. .

mucifluus Fr. .

multiformis $F r$.

myrtillinus $F r$.

napus $F r$.

obtusus Fr.

ochroleucus $F r$.

orellanus Fr. .

orichalceus Batsch .

paleaceus $F r$.

papulosus $F r$.

penicillatus $F r$.

periscelis $F r$. .

pholideus Fr.

plumiger $F r$.

pluvius Fr.

porphyropus $F r$.

prasinus $F r$.

priviguus $F r$. .

psammocephalus $\dot{F r}$.

punctatus $\mathrm{Fr}$.

purpurascens $\mathrm{Fr}$.

quadricolor Fr.

raphanoides $F r$.

Reedii Berk.

redimitus $F r$.
PAG 15

14

30

60

53

18

59

42

62
Cortinarius Fr.-continued. renidens $\mathrm{Fr}$.

Riederi $F r$

rigens $\mathrm{Fr}$.

russus $F r$.

saginus $F r$

salor Fr.

sanguineus $F r$.

saturninus $F r$.

scanders $F$

scaurus Fr. $\bullet \cdot \cdot{ }^{\circ} \cdot{ }^{\circ}$

scutulatus $F r$. $\quad$. $\quad$. $\quad$. $\quad$. 42

sebaceus Fr. 4

spilomeus $\mathrm{Fr}$. . . . . 33

stemmatus $\mathrm{Fr}$. $\quad . \quad$. $\quad . \quad . \quad 50$

stillatitius $\mathrm{Fr}$. 21

subferrugineus $\mathrm{Fr} . \quad{ }^{\circ} \quad{ }^{\circ} \quad . \quad 52$

sublanatus $F r$..$\quad .27$

subpurpurascens Fr. $\quad$. $\quad$ • 10

tabularis $\mathrm{Fr}$. . . . . 30

talus Fr. $\quad . \quad$. $\quad . \quad$. $\quad .8$

tophaceus Fr. $\quad . \quad$. $\quad 25$

torvus $F r . \quad$ • . . . . . . 40

traganus Fr. . $\quad \cdot \quad \cdot \quad . \quad$. 24

trifornis $F r$. . . . . . . 47

triumphans $F r$..$\quad \cdot \quad \cdot \quad \cdot 2$

turbinatus Fr. $\quad$ • $\quad$ • $\quad$ • $\quad$. 11

turmalis $\mathrm{Fr}$. . $\quad . \quad \cdot \quad \cdot \quad \cdot \quad \cdot 3$

uliginosus Berk. • • . . 35

uraceus Fr. • • • • • $\quad$ • 57

urbicus Fr. $\quad$ • $\quad$ • $\quad$ • $\quad$ • $\quad$. 39

varius $F r$. . . . . . $\quad$. 4

venetus Fr. • • • • • • •

violaceus $F r . . \quad$. $\quad$. $\quad$. $\quad$. 23

Craterellus Fr. . . . . . 259

elavatus Fr. . . . . . . . 261

cornucopioides Pers. . . . . 260

crispus Fr. . . . . . $\quad$. 260

lutescens Fr. . . . . . 259

sinuosus Fr. . $\quad$. $\quad$. $\quad$. $\quad$. 260

Cyphella Fr. . . • . . 284

Bloxami B. \& Phill. $\quad$ • $\quad$. 284

brumnea Phill. . . . . . 285

capula Fr. • . . . . . . 287

catilla Smith . . . . . 286

cuticulosa Berk. . . . . . 288

dochmiospora $B$. \& $B r$. . . $28 s$

fraxinicola $B . \& B r$. . . . 286

fulva $B$. \& Rav. . . . . 285

galeata $\mathrm{Fr}$. . . . . . 286

Goldbachiı Weinm. . . . 2ss

griseo-pallida Weinm. . . . . 2S5

lacera Fr. • • . . . . 287

muscicola Fr. $\quad$ • $\quad$ • $\quad$. $\quad$. 286

muscigena $F r$. . . . . . 286

ochroleuca $B . \& \mathrm{Er}$. . . . 285

pallida $B . \& B r . \quad$ • $\quad$. $\quad . \quad .287$

Pimii Phill. . . . . . . 287

stuppea $B . \& B r . \quad$ * $\quad$ • $\quad$ • 285

DACRymyces Nees . . . . 317

chry socomus $T u l$. . . . . . 318

deliquescens $D u b$. . . . . . 318

macrosporus B. \& Br. . $\quad$. $\quad$. 317

sebaceus $B$. \& $B r$. . . . $\quad$. 318

stillatus Nees . . . . 318

succineus Fr. . $\quad . \quad$. $\quad . \quad .319$

vermiformis $\ddot{B} . \& \dot{B r}$. $\quad . \quad \therefore 319$ 
D fadalea Pers

aurea $F r$.

cinerea $F r$.

confragosa Pers.

ferruginea Schum.

latissima $F r$. .

quercina Pers.

unicolor $\mathrm{Fr}$.

vermicularis Pers.

ExIDIA $F r$.

glandulosa $F r$.

recisa $\mathrm{Fr}$.

sacchariua $F r$.

truncata Fr.

Favolus $F$

Femsjonia $\mathrm{Fr}$.

Fistulina Bull. hepatica Fr.

Gomphidius $F r$.

glutinosus $\mathrm{Fr}$.

gracilis $B . \& B r$.

rosells $\mathrm{Fr}$.

stillatus Strauss

viscidus $F r$.

Grandinia Fr. . crustosa Fr. granulosa $F r$.

mucida $F r$.

ocellata Fr.

papillosa $F r$.

Guepinia $F r$. peziza $T u l$.

Hericium Pers.

Hexagona Poll.

Hiatula $F r$.

Wynuiæ $B$. \& $B r$.

Hirneola $F r$.

auricula-Judæ Berk.

Hydxum Linn.

alutaceum $F r$.

anomalum $B$. \& $B r$.

argutum $F r$.

aurantiacum $\dot{A} l b . \dot{\&} \operatorname{Sch} \dot{w}$

aureum $F r$.

auriscalpium $\dot{L}$ inn.

bicolor Alb. \& Schw

caput-Medusæ Bull.

cirrhatum Pers.

compactum Pers.

coralloides Scop.

crinale $\mathrm{Fr}$.

cyathiforme Schaff.

denticulatum Pers.

diversidens $F r$.

erinaceum Bull.

farinaceum Pers.
Page

224

224

$2 \cdot 25$

225

$2 ? 6$

225

224

225

- 226

313

314

314

314

34

227

315

183 183

63

63

64

64

65

64

255

256

255

255

255

256

317

317

247

226

322

322

315

315

233

243

244

246

$\mathbf{2 3 6}$

213

239

245

240

240

236

239

242

239

243

240

240

246
Hydnum Linn.-continued.

ferruginenm $F r$.

ferruginosum $\mathrm{Fr}$. . . . . . 242

fragile $F r . \quad . \quad \cdot \quad \cdot \quad . \quad \cdot 235$

fuscum Berk. . . . . . . 242

gelatinosum Pers. . . . .247

graveolens Delast. . . . . 238

imbricatum Linn. . $\quad . \quad$. $\quad .234$

lævigatum $S w . \quad . \quad 235$

limonicolor $B . \& B r$. $\quad$. $\quad$. 243

macrodon Fr. . . $\quad 245$

melaleucum $F r . \quad \cdot \quad \cdot \quad \cdot \quad \cdot 238$

nelleum $B . \& \mathrm{Br}$. . $\quad 244$

menturanaceum Bull. : . $\quad$. 242

multiforme B. \& Br. . . . 244

nigrum $F r . \quad . \quad . \quad$. $\quad . \quad .238$

niveum Pers. . . . . . 246

nodulosum $F r$. $\quad . \quad$ • $\quad$. 245

ochraceum Pers. . . . . . 211

repanduns Linn. . • • . . 236

rutescens Pers. . . . . . 236

scabrosum Fr. • • . . . . 234

scrobiculatum $\mathrm{Fr}$. $\quad . \quad$. 237

sepultum $B . \& B r$. $\quad$. $\quad$. $\quad 244$

sordidum Weinm. . $\quad . \quad$. $\quad .243$

spathulatum $\mathrm{Fr}$. . . . . . 244

squalinum Fr. $\quad . \quad$. $\quad . \quad$. 241

squamosum Scheff. $\quad . \quad$. 234

Stevensoni $B . \& B$ Br. $\quad$. $\quad$ • $\quad$. 245

stipatum $\mathrm{Fr}$. . . . . . 246

tomentosum B. \& Br. $\quad$ - $\quad$ - 239

udum Fr. • . . . . . 245

variecolor Fr. $\quad$. $\quad$. $\quad$. $\quad$. 242

Weinmanni Fr. • • . . . 242

zonatum Batsch . . . . 237

Hygrophorus Fr. . . . . 70

agathosmus Fr. . . . . 76

artustivus $\mathrm{Fr}$. $\quad . \quad$ • $\quad$. 73

calyptræformis $B . \& B r$. $\quad$. $\quad$. 89

caplinus $F r$. . . . . . . 77

cerareus Fr. . . . . . . $\quad .86$

cerasinus Berk. . . . . $\quad 76$

chlorophanus Fr. . . . . . 90

chrysodon Fr. • . • . $\quad 71$

cinereus Fr. . $\quad \cdot \quad \cdot \quad \cdot \quad 79$

Clarkii $B . \& B r . \quad$ \& $\quad$. $\quad$ • $\quad$. 82

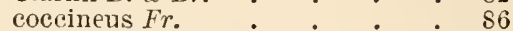

Culemannianus Blox. . . . 84

conieus Fr. • • • $\quad . \quad$. 89

cossus Fr. $. \quad . \quad . \quad 72$

discoidens $\mathrm{Fr} . \quad$. $\quad . \quad$. $\quad$. 74

distans Berk. . . . . . 81

eburueus Fr. . . . . . . 71

erubescens $F r . \quad . \quad . \quad . \quad$. 73

foetens Phill. . $\quad . \quad$. $\quad . \quad$. 79

fornicatus $F r$. $\quad . \quad$. . $\quad$. 81

fuscu-albus $\mathrm{Fr}$. $\quad . \quad$. $\quad . \quad$. 76

glauco-nitens $F r$. . . . . . 91

glutinifer Fr. $\quad$. $\quad$ • . . . 73

Houghtoni $B . \& B r . \quad$ * $\quad$. $\quad$. $\$ 4$

hypothejus $F r$. . . . . $\quad$. 75

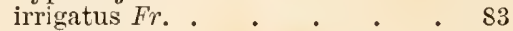

lacinus Fr. . . . . . $\quad$. 83

letus Fr. $\quad \cdot \quad \cdot \quad \cdot \quad \cdot \quad$ : $\quad$ : 55

leporinus Fr. . $\quad$. $\quad$. $\quad$. $\quad$. 78

lumacinus $\mathrm{Fr}$. $\quad \cdot \quad \cdot \quad \cdot \quad \cdot \quad 74$

livido-albus Fr. . . . . $\quad$ • 77

mesotephrus $\dot{B} . \& \dot{B} r . \quad \cdot \quad \cdot \quad \cdot \quad 77$ 
HygRophoRus Fr.-continued. metapodius $\mathrm{Fr}$.

micaceus $B . \& B r$.

ininiatus $\mathrm{Fr}$. .

mollis $B$. \& $B r$.

mueronellus $\mathrm{Fr}$.

murinaceus Fr.

nemoreus $F r$.

nitratus $F r$.

niveus $F r$.

obrusseus $\mathrm{Fr}$.

olivaceo-albus $\mathrm{Fr}$.

ovinus $F r$.

pallidus $\dot{B}$. \& $B r$.

penarius $F r$. .

pratensis Fr. .

psittacinus Fr.

pulverulentus $B . \& B r$.

puniceus $F r$.

russo-coriaceus $B . \& \mathrm{Br}$.

sciophanus $F r$.

subradiatus $\mathrm{Fr}$.

turundus $F r$.

unguinosus $F r$.

virgineus $F r$.

vitellinus $F r$.

HYMENOCH ETE Lev.

corrugata Berk.

rubiginosa Lev.

Sterensoni B. \& Br.

tabacina Lev.

IRPEx $F r$.

carneus $\mathrm{Fr}$.

deformis $\mathrm{Fr}$.

fusco-violaceus $F r$.

Johnstoni Berk.

lacteus Eng. Fl.

obliquus Fr.

pendulus $F r$.

spathulatus $F r$.

KNeIFfia $F r$.

setigera $\mathrm{Fr}$.

subgelatinosa $\mathrm{B}$. $\& \mathrm{Br}$.

LACTARIUS Fr.

acris $F r$.

blennius $\mathrm{Fr}$.

camphoratus $\mathrm{Fr}$.

capsicum Schulz.

chrysorheus $\mathrm{Fr}$.

cilicioides $\mathrm{Fr}$.

circellatus $\mathrm{Fr}$.

controversus $\mathrm{Fr}$.

cyithula Fr.

deliciosus $F r$.

exsuccus Shith

flexuosus $\mathrm{Fr}$.

fuliginosus $F r$.

glyciosinus Fr.

helvus $F r$.

hysginus $F r$.

ichoratus $\mathrm{Fr}$. .

insulsus $F r$.

lilacinus Lasch
Page | Lactarius Fr.-continued.

111ammosus $F r$.

margine-tomentoso $B . \& \mathrm{Br}$.

Page

minimus Smith

mitissimus Fr.

obnubilus Lasch 112

pallidus Fr. • • • • • 104

pallidus Saund. \& Sin. . . . 105

pargamenus Fr. •. • .

picinus Fr. $\quad . \quad \cdot \quad \cdot \quad \cdot 109$

piperatus $\mathrm{Fr}$. . . . . 102

jubescens $F r$. $\quad . \quad$ • . $\quad .95$

lyrogalus $F r$. .

quietus Fr. . . . 104

roseo-zonatus Post. . . 99

rufus Fr. $\quad$. $\quad . \quad$ • 106

scoticus $B . \& B r . \quad . \quad . \quad \cdot 103$

scrobiculatus $F r$. $\quad$ • $\quad$ • $\quad$ • $\quad$ • 93

serifluus Fr. . . . . . . 110

squalidus Fr. . $\quad$ • $\quad . \quad . \quad . \quad 100$

subdulcis $F r$. . . . . . 111

Terrei $B . \& B r . \quad$. $\quad$ • . . 111

theingalus $\mathrm{Fr}$. 105

torminosus $F r$.

trivialis $F r$. $\quad . \quad \cdot \quad \cdot \quad \cdot 98$

turpis Fr. • • • •

uvidus Fr. $\quad . \quad$. $\quad . \quad$ • $\quad . \quad 98$

vellereus $F r$.

vietus $\mathrm{Fr}$. $\quad \bullet \quad \cdot \quad \cdot \quad \cdot 105$

volenutus $F r$. . $\quad . \quad 109$

zonarius Fr. $\quad$ • $\quad$ • $\quad$ • $\quad$ • $\quad$ • 96

Lentinus $\mathrm{Fr}$. • • • • • • • 153

adhærens Fr. • • • . . 156

cochleatus $\mathrm{Fr} . \quad$. $\quad . \quad$ • $\quad$. 156

Dunalii Fr. • • • • 154

fimbriatus Curr. • • • • • 157

flabelliformis $\mathrm{Fr}$. . . . . 158

leontopodius Schulz. . . 155

lepideus $F r$. . . 155

pulverulentus Fr. . . . . . 155

resinaceus $F r$. $. \quad . \quad .156$

scoticus B. \& Br. . . . . . 157

tigrinus $\mathrm{Fr} . \quad$ • $\quad$ • $\quad$. $\quad$ • 154

vulpinus $\mathrm{Fr}$. • . . . . $\quad$ • 157

LENZITES $F r$. . . . . . 163

abietina $F r$. . . . . . 165

betulina Fr. . . . . . 163

flaccida Fr. $\quad$. $\quad$. $\quad$. $\quad$. $\quad .164$

siepiaria $\mathrm{Fr}$. . . $\quad$ • $\quad$. $\quad$. 164

Marasmius Fr. • . • . 139

alliaceus $F r$. . . . . . 148

amadelphus $F r$.

androsaceus $\mathrm{Fr}$. . $\quad . \quad$ • $\quad$. 150

angulatus $B$. \& $\mathrm{Br}$. . $\quad . \quad 147$

archy'ropus $F r . \quad$. $\quad$ • $\quad$. 145

Broomei Berk. $\quad . \quad$. $\quad$ • 153

calopus Fr. . . . . . . . 146

caulicinalis $F r . \quad \quad \cdot \quad \cdot \quad \cdot \quad \cdot 149$

Curreyi B. \& $\mathrm{Br}$. . . . 151

elichloe Fr. . $\quad$ • $\quad$ • $\quad$. 152

epiphyllus $\mathrm{Fr}$. $\quad$ • $\quad$ • . . 152

erythropus Fr. $\quad . \quad$. $\quad . \quad$. 144

foetidus $\mathrm{Fr}$. . . . 147

fusco-purpureus Fr. . . . 143

gramineus Lev. . . . . 152

graminum Berk. $\quad . \quad$ • $\quad . \quad$. 150 
Marasmus Fr.-continued. Hudsoni $\mathrm{Fr}$. impudicus $\mathrm{Fr}$. insititius $F r$. languidus $F r$. . oreades Fr. perforans $F r$. . peronatus $F r$. . porreus $F r$. ramealis $F r$. rotula Fr. saccharinus $F r$. scorodonius $\mathrm{Fr}$. scorteus Fr. splachnoides $\overrightarrow{F r}$. spodoleucus Berk. Stephensii Berk.

terginus $F r$.

torquescens Quel. urens $F r$.

Vaillantii $F r$.

varicosus $F r$.

Wynuei $B . \& B r$.

Merulius $F r$.

aurantiacus Klotsch

Carmichaelianus Berk.

corium $\mathrm{Fr}$.

himantioides $F r$.

lachrymaus $F r$.

læticulor $B$. \& $\mathrm{Br}$.

molluscus Fr. .

pallens Berk.

porinoides $F r$.

pulverulentus $F r$.

rufus Pers.

serpens Tode. .

tremellosus Schrad.

Microcera Desm.

Mucronella $F r$.

NEMATElia Fr. . encepliala $F r$. nucleata $\mathrm{Fr}$. virescens Corda

Nyctalis $F r$. asterophora $\mathrm{Fr}$. caliginosa Smith parasitica $F r$. .

Odontia $F r$.

barba-Jovis Fr.

fimbriata Pers.

Panus Fr.

conchatus $F r$.

farinaceus Schum.

patellaris $F r$.

Stevensoni $B . \& B r$.

stipticus $F r$.

torulosus Fr.

Paxillus Fr.

atro-tomentosus $\mathrm{Fr}$. fagi $B . \& B r$.

giganteus $F r$.
Page
Paxilues Fr.-continued. involutus $F r$. . lepista $F r$. leptopus $F r$. panæolus $F r$. panuoides Fr. $\quad \cdot \quad 69$ paradoxus Bert. . . . . . 67 spilomæolus $F r$. $\quad$ • $\quad$ • $\quad$ • 67

Phlebia Fr. . . . . . 253

contorta Fr. . • . . . 254

lirellosa Pers. . . . . . . 254

merisnoides Fr. . . . . 253

radiata Fr. . . . . . 253

vaga Fr. . . . . . . . 254

Pistillaria $\mathrm{Fr}$. $\quad$. . . 307

culmigena Fr. $\quad . \quad$. $\quad .307$

furcata Srith. . . . . 307

Inicans Fr. . . . . . 307

quisquiliaris $F r$. $\quad . \quad$. $\quad . \quad 307$

puberula Berk. . . . . 308

pusilla Fr. $\quad$. $\quad . \quad$. $\quad . \quad 308$

Polyporus Fr. . . . . . 183

abietinus Fr. . . . . . 211

acauthoides Fr. $\quad . \quad$ : $\quad . \quad$. 195

adiposus $B . \& B r$. . . . . 201

adustus Fr. . . . . $\quad .200$

alligatus $F r$. . . . . . 195

alutaceus Fr. $\quad . \quad$. $\quad$. $\quad . \quad 197$

amorphus Fr. • . . . 201

aneirinus Sommerf. $\quad$. $\quad$. 214

annosus Fr. . . . . . 208

applanatus $F r . \quad$ • $\quad$ • $\quad$. 204

armeniacis Berk: •. • . 215

bathyporus Rostk. . . . . 220

betuliuus Fr. . • • . . . 203

blepharistuma $B . \& \mathrm{Br}$. $\quad$. $\quad 220$

bombycinus Fr. . . . . 214

borealis Fr. . . . . . . 202

brumalis Fr. . . . . . . 188

cæ-ius Fr. $\quad$. $\quad$ • . . . . 198

callosus Fr. . . . . . $\quad$. 217

carneus Nees . • . . . 208

cerebrinus $\mathrm{B} . \& \mathrm{Br}$. $\quad$. $\quad$. 197

cervinus Pers. . . . . 223

chionens Fr. . $\quad$. $\quad$ • $\quad$. $\quad$. 197

cinctus Berk. $\quad$. . . . . 215

collabefactus $B . \& B r . \quad$ * $\quad .218$

conchatus Fr. $\quad$. . . . . 206

connatus Fr. . $\quad$ • . . . $\quad$. 207

contiguus $\mathrm{Fr}$. $\quad$. $\quad$. $\quad$. $\quad$. 212

crispus Fr. . . . . . . 200

cristatus Fr. . . . . . . 191

cryptarum Fr. . . . . $\quad$. 209

cuticularis Fr. . . . . 202

cytisinus Berk. . . . . . 207

destructor Fr. $\quad$. $\quad . \quad$. $\quad . \quad 199$

dryadeus Fr. . . . . . . 202

elegans Fr. . . . . . 192

epileucus Fr. • . . . . . 196

fariuellus $F r$. $\quad$ • $\quad$. $\quad$. $\quad .220$

ferruginosus $F r$. . . . $\quad$. 212

fibula Fr. $\quad . \quad$. $\quad . \quad$. 210

floccipes Rostk. - . . . 188

fomentarius $F r$. $\quad$. $\quad$. $\quad . \quad$. 204

fragilis $F r . \quad$. $\quad$ • $\quad$ • $\quad$ • $\quad$. 198

fraxineus $F r . \cdot \quad \cdot \quad \cdot \quad \cdot \quad \cdot \quad 207$ 
Polyporus Fr.-continued. frondosus $\mathrm{Fr}$. fulvus $F r$.

funosus $F r$.

fusciululus $F r$.

giganteus $\mathrm{Fr}$.

Gordoniensis $\dot{B} . \& \dot{B} r$

gossypinus Lev.

Herbergii Rostl.

heteroclitus $F r$.

hirsutus $F r$.

hispidus $F r$.

hyloridus $B$. \& $B r$.

hymenocystis $B$. \& $B r$.

igniarius Fr.

incaruatus $F r$.

intybaceus $F r$.

Keithii $B$. \& $B r$.

lacteus $\mathrm{Fr}$.

Læstadii Fr. \& Bert.

lentus Berk.

leptocephalus $F r$.

leucomelas $F r$.

lucidus $F r$.

medulla-pan is $F r$.

melanouus $F r$.

mirans $F r$.

Michelii $F r$.

mollis $F r$.

molluscus $F r$.

mucidus $F r$.

nidulans $\mathrm{Fr}$.

nigricans $F r$.

nitidus $\mathrm{Fr}$.

nummularius $F 0^{\circ}$.

obducens Pers.

pallescens $F r$.

pectinatus Kiotsch

perennis $\mathrm{Fr}$.

petaloides $F r$.

picipes $\mathrm{Fr}^{\circ}$.

polymorphus Rostk.

populinns $F r$.

purpureus $F r$.

quercinus $F r$.

radiatus $F r$.

radula $F r$.

ramentaceus $\dot{B} \& \dot{B} r$.

Rennyi $\mathrm{B}$. \& $\mathrm{Br}$.

reticulatus $F r$.

rhodellus $\mathrm{Fr}$. .

ribis $F r$.

roseus $F r$.

Rosthovii $F r$.

rufescens $F r$.

rufus $F r$.

rutilans $F r$.

rutilans Saund. \& S

salicinus $F r$.

salignus $F r$.

sanguinolentus $F r$.

Schweinizii $\mathrm{Fr}$.

secernibilis $B . \& \mathrm{Br}$.

spumens $F r$.

squamosus $F r$.

Stephensii B. \& Br

subfusco-flavidus Rostl:

subgelatinosus $B$. \& $B r$.
Page

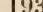

205

200

$18 \mathrm{~S}$

194

199

219

209

195

196

210

201

221

$2 \div 0$

205

213

193

201

197

214

187

188

187

193

216

190

213

190

198

218

217

199

204

214

192

217

197

205

189

192

191

209

208

212

203

209

219

214

215

220

213

206

206

191

189

213

199

199

206

196

218

189

219

202

190

224

215

216
Polyporus Fr.-continued. sulphtureus $F r$. terrestris $\mathrm{Fr}$. . trabeus Rostk. ulmarius $\mathrm{Fr}$. umbellatus $F r$. umbrinus $\mathrm{Fr}$.

Vaillantii $\mathrm{Fr}$.

vaporarius $F r$.

variegatus Secr.

varius $F r$

vegetus $F r$.

velutinus $F r$.

versicolor $F r$.

iolaceus Fr. • • • • • . 212

viridans Berk. $\quad$. $\quad$. $\quad$. . . 216

vitrells $F r$. . . . . . 217

vulgaris $F r . \quad . \quad \cdot \quad \cdot \quad \cdot 218$

Wynnize $B . \& B r$. . . . . 211

Porothelium Fr.

Friesii Mont.

Keithii $B . \& \mathrm{Br}$. $\quad \cdot \quad \cdot \quad \cdot \quad \cdot 231$

Stevensoni B. \& Br. . . $\quad$. 231

PTERUla Fr. . . . . . 303

unltifida Fr. . $\quad$. $\quad . \quad$. $\quad .304$

subulata Fr. . . . . . . $\quad$. 303

Radulum Fr. . . . . . 251

aterrimum $\mathrm{Fr}$. • . . . 253

corallinum $B . \& \mathrm{Br}^{\circ} \quad \bullet^{\circ} \quad{ }^{\circ} \quad \cdot 252$

deglubens $B$. \& $B r$.

epileucum $B$. \& $B r$. $\quad: \quad: 252$

erectum Sow. . . . . 253

fagineum $F r$. $\quad . \quad \cdot \quad . \quad .252$

orbiculare $\mathrm{Fr}$.. .251

quercium Fr. $\quad . \quad . \quad . \quad 251$

tomentosum Fr. . . . . . 252

Russula Pers. . . . . . 113

adusta $F r . \quad$. $\quad . \quad$. $\quad . \quad$. 114

alutacea Fr. . . . . . . 129

aurata Fr. . .

chamæleontina $\mathrm{Fr} . \quad . \quad . \quad .130$

consobrina $\mathrm{Fr}$. • • • • • 123

cutefracta Cle. . . . . 121

cyanoxantha Fr. . . . . . 122

decolorans Fr. . . . . . 128

delica Fr. . . . 115

deprallens Fr. . $\quad . \quad$. $\quad . \quad 117$

diimeia Che. . • . . 118

Du Portii Phill. : . . . $\quad$. 119

elephantina $\mathrm{Fr}$. • • • • • • 115

emetica Fr. . . . $\quad$. $\quad .125$

fellea $F r$. . . . . 124

fœtens $F r . \quad$. $\quad$. $\quad$. $\quad$. $\quad$. 124

fragilis $F r$. . . . . . . . 126

furcata $F r . \quad$. $\quad . \quad$. $\quad$. 116

galochroa Fr. . . . . . . 123

lieterophylla $\mathrm{Fr}$. . . . . . 123

integra Fr. . . . . . 127

lactea Fr. . . . . . . . 118

lepida $\mathrm{Fr}$.

Linnæi Fr. . . . . . . 120

lutea Fr. . . . 129

nauseosa Fr. . . . . . . 130

nigricans $F r$. $\quad . \quad$. $\quad$. $\quad$. 114 
Russula Pers.-contiuued. nitida $F r$.

ochrolenca $F r$.

olivacea $F r$.

pectinata $F r$.

Queletii Fr.

rosacea $F r$.

rubra Fr.

sanguinea $\mathrm{Fr}$.

sardonia $F r$.

semicrema $F r$.

sororia Larbr.

subfotens Smith

vesca Fr.

veternosa $\mathrm{Fr}$.

virescens $F r$.

vitellina $F r$.

xerampelina $F r$.

SchizophylluM $F r$. commune $F r$.

Sistotrema Pers. confluens Pers.

Solenia Hoffm. . ochracea Hoffm.

Sparaseis Fr. . crispa $F r$.

Stereum Pers. . acerinum Pers. avellanum $F r$.

frustulosum $F r$. hirsutum $F r$.

lauro-cerasi Berk. ochroleucum $\mathrm{Fr}$.

pini $F r$.

yurpureum Pers.

rubiginosum $\mathrm{Fr}$.

rufo-hispidum Stev.

rufum Fr.

rugosum Fr.

sanguinolentum $F r^{\circ}$.

spadicenm $\mathrm{Fr}$.

stratosum $B . \& B r$.

tabacinum $F r$.

vorticosum Fr.

Strobilomyces Berk. strobilaceus Berk. .

Thelephora Ehrb. anthocephala $F r$.

bienuis Fr.

cæsia Pers.

caryophyllea Pers. .

clavularis $F r$.

cristata $\mathrm{Fr}$

crustacea Schum.

digitata $\mathrm{Fr}$.

fastidiosa $F r$.
PAGE

129

126

121

126

125

117

120

116

117

115

124

124

122

127

119

130

121

162

162

$24 \mathrm{~S}$

248

232

232

289

289

267

271

270

270

$26 \mathrm{~S}$

270

257

270

268

269

269

271

270

269

$26 \mathrm{~S}$

271

269

$26 \mathrm{~S}$

182

- 152

261

263

264

266

262

263

265

266

263

265
Thelephora Ehrb.-continued. intybacea Pers.

laciniata Pers.

mollissima Pers.

multizonata $B . \& \dot{B}$. $: \quad: \quad 262$

palmata $F r$.

sebacea Pers.

Sowerbeii $B$.

tuberosa Fr. . . • . . . 262

terrestris Ehrb. . . . . 264

undulata Fr. . . . . . $\quad$. 262

Trametes Fr. • . . . . . 221

Bulliardi Fr. . . . . . $\quad 222$

gibbosa Fr. $\quad$. $\quad$ • . . . . 222

inodora $\mathrm{Fr}$. . • • • . . 223

mollis Fr. • . . . • . 223

odora Fr. $\quad . \quad$ • . . . . 222

piniFr. . . . . . . . $\quad$. 221

serpens Fr. . • • • 223

suaveolens $\mathrm{Fr}$. $\quad$ • $\quad$ • . . 222

Terrei $B . \& B r . \quad$ • $\quad$ • $\quad$ • $\quad$ • 223

Tremella Dill. . . . . 309

albida Huds. . . . . . . 311

epigæa $B . \& B r . \quad$ • $\quad$ - . $\quad$. 311

fimbriata Pers. . . . . $\quad$. 309

foliacea Pers. . $\quad$ • $\quad$. $\quad$ • $\quad$ • 310

foliicola Fckl. . . . . . 313

frondosa $F r$. . $\quad . \quad$. $\quad$ • $\quad$ - 310

indecorata Sommerf. $\quad$. $\quad$ • $\quad$. 312

intumescens Eng. Bot. . . . . 311

lutescens Pers. . . . . 310

mesenterica Retz. . . . . 310

moriformis Eng. Bot. . . . 312

torta Berk. . . . . . . . 313

tubercularia Berk. . . . . 312

versicolor Berk. . . . . . $\quad$. 313

vesicaria Eng. Bot. . . . . 311

violacea Relh. . . . . . 312

viscosa Berk. . . . . . . 311

Tremellodon Pers. . . . . 247

gelatinosum Pers. . . . $\quad$. 247

Trogia Fr. $\quad$. $\quad . \quad$. $\quad .162$

crispa Fr. $\quad$. $\quad$ • $\quad$ • $\quad$ • 162

Typhula Pers. • . . . . 304

erythropus Fr. • . . . 304

filiformis $F r$. . . . . $\quad$. 306

Grevillei Fr. • • 305

gracilis Bert. \& Desm. . . 306

gracillima White . • . . 306

gyrans Fr. $\quad . \quad$. $\quad . \quad$ • $\quad .305$

incarnata Lasch . . • . 305

muscicola Fr. $\quad$. $\quad$ • $\quad$. $\quad$ - 305

phacorrhiza $\mathrm{Fr}$. • • • • 304

translucens $B . \& B r$. . . $\quad$ • 306

Xerotus Fr. • . • • • . 161

degener Fr. $\quad$ • $\quad$ • $\quad$ • $\quad$ • $\quad$ • 161 
2392 


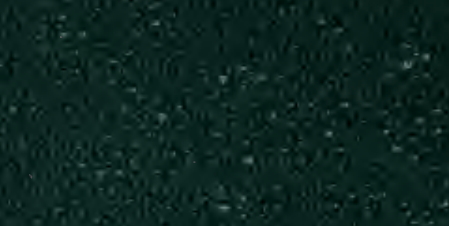

and

6 (6)

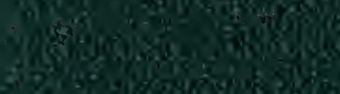

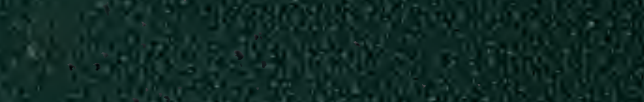

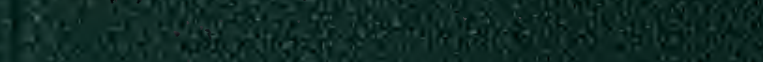

Uf

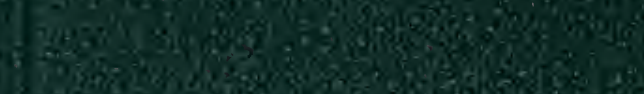

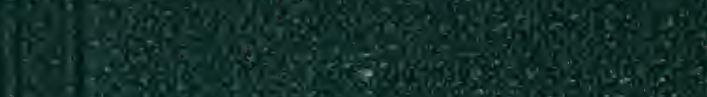

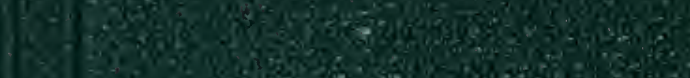

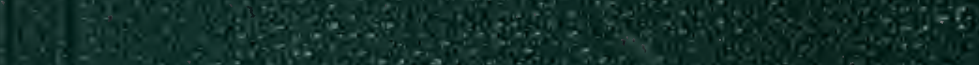

3.

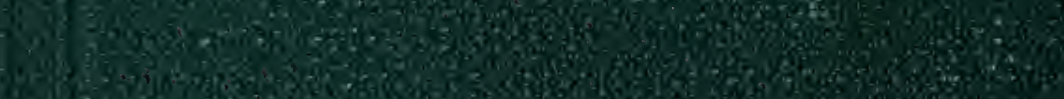

6.12.

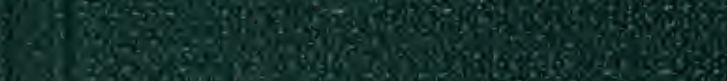

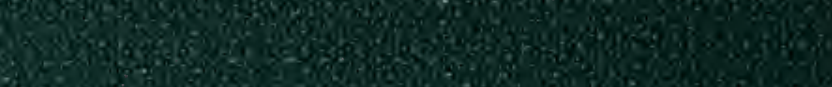

bist

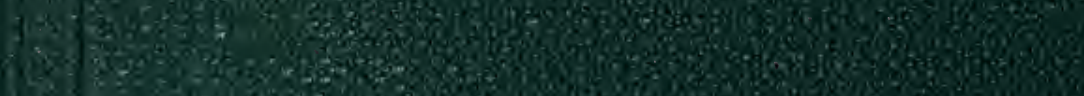

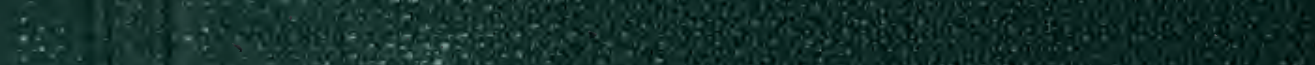

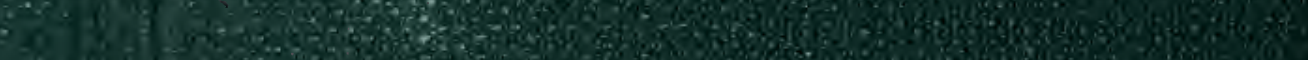

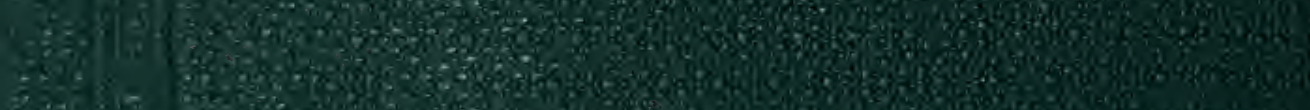

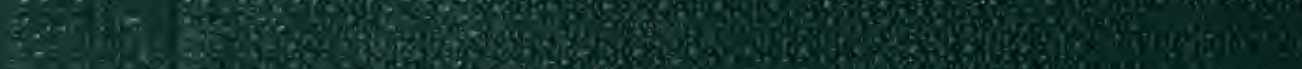

is

if 